\begin{abstract}
SANTOS
a relação entre o porto e a cidade e sua (re)valorização no território macrometropolitano de São Paulo
\end{abstract}

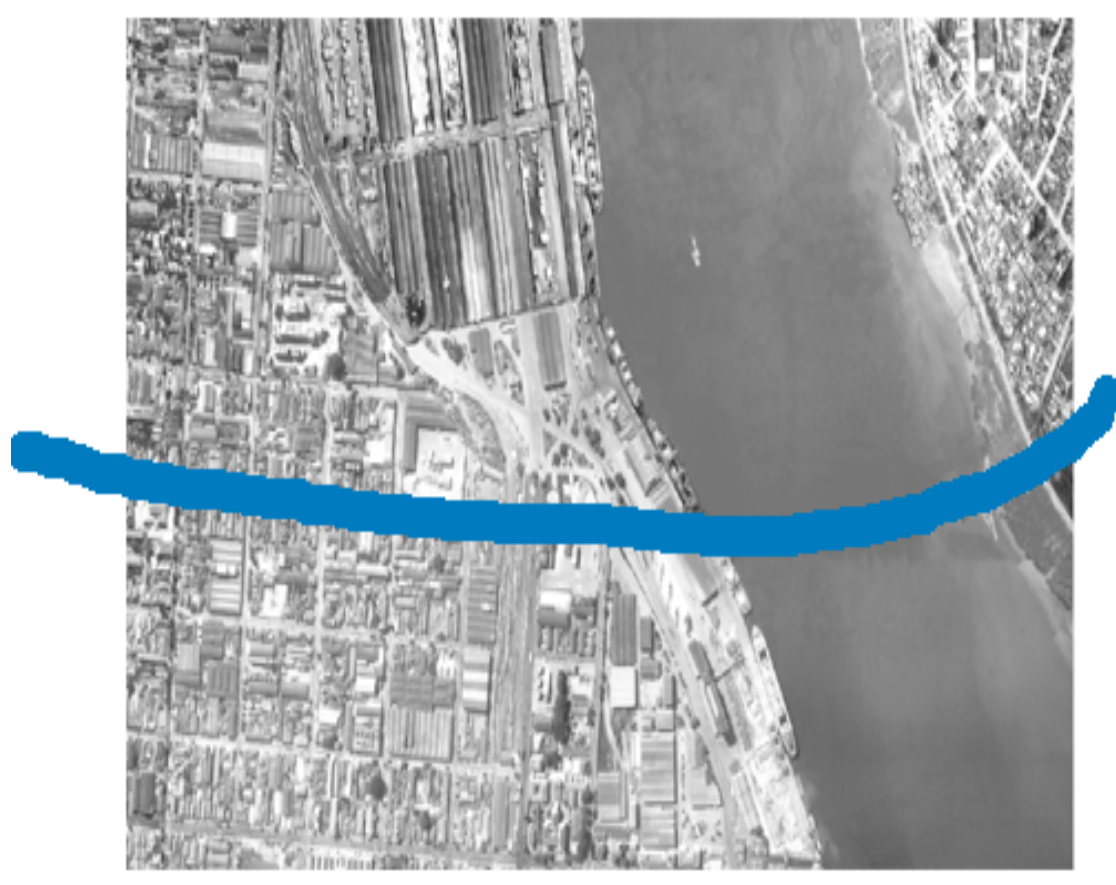

PEDRO MANUEL RIVABEN DE SALES

FACULDADE DE ARQUITETURA E URBANISMO UNIVERSIDADE DE SÃO PAULO 


\section{SANTOS \\ a relação entre o porto e a cidade e sua (re)valorização no território macrometropolitano de São Paulo}

Pedro Mauel Rivaben de Sales

TESE SUBMETIDA À FACULDADE DE ARQUITETURA E URBANISMO DA UNIVERSIDADE DE SÃO PAULO COMO PARTE DOS REQUISITOS PRA A OBTENÇÃO DO GRAU DE DOUTOR

Orientador: Prof. Dr. Sylvio Barros Sawaya 


\section{AGRADECIMENTOS}

Embora, em grande medida, um esforço solitário, o trabalho de feitura de uma tese não se realizaria sem o envolvimento direto ou menos direto, voluntário ou não, de muitas pessoas. E a todas elas, pela compreensão e estímulo, o meu mais reconhecido agradecimento. Porém, pela importante participação que tiveram neste período de estudos não posso deixar de registrar, carinhosamente, os seguintes agradecimentos.

Muito especialmente, agradeço a sabedoria e o "fair-play" com que meu orientador, o arquiteto, professor e amigo Sylvio de Barros Sawaya tem sabido, lidar — há pelo menos quinze anos-com minhas pretensões, ensinando-me, sempre, a valorizar a Arquitetura e o Projeto. As reuniões com o grupo de sues orientandos permitiram interessantes discussões.

Agradeço aos professores Joan Busquets i Grao e Xavier Eizaguirre Goicotchea, que supervisionaram meu estágio de pesquisa junto ao Departament d'Urbanisme I Ordenació del Territori da Escola Técnica Superior de Arquitectura de Barcelona da Universitat Politécnica de Catalunya, onde pude entrar em contato com as idéias e experiências acerca do projeto para a cidade contemporânea.

José Cláudio Gomes, Joaquim Guedes, Ana Lanna, M. Lúcia Gitahy, J. L. Ronca, Carlos E. Zahn, Regina Meyer, Philip Gunn, professores da FAU, e J. Parcerisa, S. Bel e M. T. Capell, da UPC, nas aulas ou na banca de qualificação, ensejaram-me a possibilidade de ajustar, com seus ensinamentos e críticas, os rumos iniciais desta pesquisa.

Gostaria também de lembrar o nome dos professores e amigos —Cláudio Manetti, Luiz de Pinedo, Célia R. Paes, Paulo Bastos, Cássia Magaldi e Fernando Almeida - com os quais, repartindo a responsabilidade de disciplinas e bancas, pude discutir e, talvez, melhorar algumas idéias sobre a arquitetura e o urbanismo. Neste sentido, devo também agradecer aos meus alunos da FAU de Santos e da Anhembi Morumbi: particularmente aqueles que, participando dessa discussão e envolvendo-se com os temas da questão portuária contribuiram com importantes informações e questionamentos.

Agradeço aos arquitetos André Franco e Renata Cioffi, que ajudaram no levantamento inicial de material sobre a cidade e o porto de Santos, e, especialmente, à arquiteta Beatriz Godinho de Andrade que colaborou dedicadamente no recolhimento e tratamento gráfico de material fundamental para a conclusão da pesquisa. Gisele e Marcus Paulo trouxeram fotos aéreas e Jameson Miguel editou, pacientemente, este trabalho.

L. Rios, J. M. Carriço, F. Gazal, N. Gonçalves, os bibliotecários da FAU, do Museu do Porto, da Fundação Arquivo e Memória de Santos, do Núcleo de Memória da Unicamp e do Centro Edgard Leuenroth possibiltaram dados e informações valiosas. 
Os colegas do DPH partciparam, solidários, no dia-a-dia. Walter Pires facilitou-me informações e livros.

Renato, Guilherme, Paulo, Chico, Beda e Bartira, presenças fraternais. Ema e Cláudia "in memorian".

Cidinha, Isa, Diná, Maria José, Maria Salgado, D. Dirce, Débora, Roseli e Margarida Buil representam o espaço acadêmico a mim oferecido pela FAUSP, FAUS, Anhembi-Morumbi e UPC.

Finalmente devo registrar que esta pesquisa teve suporte financeiro de bolsas de estudo e de capacitação docente a mim concedidas, respectivamente, pelo $\mathrm{CNPq}$ - que me possibilitou o estágio de estudos em Barcelona-e pela Universidade Católica de Santos, que foi de grande valia para o término deste trabalho. A Universidade Anhembi-Morumbi, através da Coordenação do curso de Arquitetura, facilitou-me o serviço de cópias da tese. 
Marta compartilhou intensamente tudo, todos os momentos, nossos pais e irmãos, mesmo na ausência do conívio, deram estímulo e apoio decidico e animado Felipe e Marcela, presente e futuro bonitos

A eles dedico este trabalho 


\section{Resumo da tese}

Enfatizando os aspectos que dizem respeito à relação física e funcional que a cidade de Santos estabelece com seu porto, este estudo tem como como objetivo discutir sua (re)valorização no território macrometropolitano de São Paulo. O estudo teórico das transformações urbanas decorrentes do fenômeno de passagem da "aglomeração" (espaço circunscrito e contínuo) à "rede" (espaço descontínuo e não homogêneo), evidencia a importância da dimensão local frente à global e serve para verificar as respostas que o urbanismo contemporâneo oferece a este novo quadro. $O$ exame das condições, fatores, estrutura e tendências do desenvolvimento territorial do eixo Santos-São PauloCampinas procura problematizar o modelo de desenvolvimento urbano santista. Pelo confronto entre as tipologias da expansão portuária e aconfiguração dos sistemas de lugares que definem a estrutura urbana de Santos a cada etapa de seu crescimento, busca-se identificar suas contradições e conflitos. A partir das compatibilidades e incompatibilidades, das pendências e potencialidades que se possa flagrar entre as lógicas portuárias, territoriais e urbanas, traça-se diretrizes para uma nova relação cidade/porto, entendida como "infraestrutura" necessária para suportar processos de (re)ativação econômica e social da cidade de Santos.

\section{Abstract}

The aim of this work is to bring forth the importance of the city of Santos in the macro-metropolitan territorial realm of the State of São Paulo, Brazil. This interpretation will emphasize a new relation established between the city of Santos and its port. The theoretical study outlines the impacts related to recent transformations observed in the form of urban tissues: from aglomeration (circumscribed, continuous space) to network (non-homogeneous, non-continuous space). This approach analyzes the contraposition of local versus global dimensions and relations as it is used as background to check the responses which contemporary Urbanism is offering nowadays regarding this new framework. The study of conditions, factors and new trends of territorial transformations in the Santos-São Paulo-Campinas axis is an attempt to compare and debate the different urban development models adopted in the city of Santos so far The cross-analysis of typological characteristics of the port expansion and the system of "places" which defines the city's structure seeks to identify the specific approaches related to each model as well as their contradictions. From capabilities to incompatibilities, through new trends and possibilities of portuary and territorial structure and their urban logic, guidelines are proposed to the future urban development of Santos. These transformatins will be the infrastructural support to reactivate the status of the city of Santos in the macro-metropolitan realm. 


\section{ÍNDICE}

Introdução

Capítulo $1 . \quad 9$

Da aglomeração à rede: estratégias de projeto
1.1. A nova geografia do território

1.2. A cidade contemporânea e a necessidade de novos conceitos 17

Capítulo 2.

Santos, São Paulo, Campinas...e os processos de valorização territorial

2.1. (Geo)morfologia da macrometrópole

2.2. As representações do território e suas transformações 41

2.3. A estrutura macrometropolitana 66

2.4. Santos e Campinas 76

Capítulo 3.

A construção e expansão do porto de Santos
3.1.O porto moderno

3.2. As mutações da relação porto/cidade 113

Capítulo $4 . \quad 125$

O porto e os modelos de crescimento da cidade de Santos

4.1. Santos, antes do porto moderno 126

4.2 As formas de crescimento urbano de Santos 134

$\begin{array}{ll}\text { 4.3.O porto e os sistemas intra-urbanos } & 149\end{array}$

Capítulo 5

Uma síntese como possibilidade

5.2. Hipóteses de uma nova relação porto-cidade:

Conclusão

Apêndice

Estudos de caso de reconversão urbanística de áreas portuárias

1. Infra-estrutura portuária e a cidade:

as características dos projetos em curso $\quad 211$

2. Barcelona $\quad 214$

3. Roterdã 239

$\begin{array}{ll}\text { Bibliografia } & 271\end{array}$ 


\section{INTRODUÇÃO}

Pode-se lembrar, através de Milton Santos, que no Brasil, os investimentos em infra-estrutura, em um primeiro momento, foram feitos pelo capital privado, "que arcava com uma parcela de responsabilidade na implantação das economias de aglomeração indispensáveis ao funcionamento da máquina econômica e do organismo social" ". Em uma fase de transição, o poder público, assumindo cada vez mais essa responsabilidade, passa também, através das obras públicas, a beneficiar grande número de empresas e parcela considerável da população. Em um período mais recente o Estado, em nome do incremento da capacidade de exportação, do aumento do produto interno produto, etc., centralizando os investimentos, tende a dar suporte e fortalecer apenas os sistemas gerais de produção, interessados fundamentalmente às empresas hegemônicas. Seguindo o raciocínio dentro de uma visão que sofreria revisão em face do fenômeno do aumento exponencial da fluidez do território-, Santos reconhecia a existência dentro do sistema urbano de duas redes: uma voltada para as tarefas de exportação e importação, "tributária de um modelo orientado por fora" e outra mais voltada ao "consumo interno e às tarefas indispensáveis a provê-lo".

"O sistema urbano voltado para o exterior seria o principal utilizador das grandes vias e meios de transporte, exigindo até mesmo, em certos casos, a construção de rotas e dutos exclusivos (ou quase), como a ferrovia do aço ou a estrada da soja. Se algumas aglomerações (portos, nós de circulação, cidades-entreposto) eram praticamente exclusivas do sub-sistema exportador, a rede urbana como um todo seria utilizada indiferentemente por ambos os subsistemas. Em muitas cidades, os dois sistemas se encontrariam, utilizando-se dos mesmos objetos, ainda que gerando relações diferentes"2.

Se, no Brasil, desde os anos 50, recursos públicos foram "orientados" prioritariamente no sentido de atender as exigências das condições gerais de produção, a modernização do território resultante, antes seletiva e concentrada em poucos pontos, tende, pelas inovações do setor de comunicações e transportes, a difundir-se de forma mais rápida e mais ampla, trazendo como consequência a difusão territorial das externalidades requeridas para a localização de funções urbanas, antes concentradas em torno das grandes cidades. No entanto, ainda segundo Santos, isto também implica que só as grandes corporações podem usar na totalidade do território as novas condições infra-estruturais (materiais e sociais).

Particularmente interessado à infra-estrutura portuária, poder-se-ia indagar se será este processo de dissociação entre os "sistemas urbanos" e "redes 
infra-estruturais" uma resultante específica da conjuntura econômicapolítica nacional, ou mesmo de países em desenvolvimento? Ou, antes, na medida em que essa infra-estrutura representa um dos suportes fundamentais das relações do comércio internacional, aquela dissociação reflete decisões políticas (como "questão nacional") e transformações tecnológicas que se impõem em escala mundial, atinentes como são justamente às novas condições e determinações globalizadas? E, sendo afirmativa ${ }^{3}$ a resposta a essa indagação, não constituiria a infra-estrutura portuária contemporânea, por suas exigências em termos técnicos e econômicos, e logo, pela sua dissociação física e funcional, bem como por sua separação institucional em relação às cidades, cada vez menos um "capital fixo social", ou "urbano"? E para tentar avançar nesta resposta, talvez houvesse que se perguntar se a infra-estrutura portuária, reconhecida sua natureza técnica e funcional específica, já terá representado esta condição?

O argumento para reconhecer esta condição "social", "coletiva" ou "urbana" da infra-estrutura portuária funda-se no fato de que durante um grande tempo as relações entre essa e a cidade constituiram um sistema basedado na imbricação e complementariedade de suas diferentes funções — formando "praças" de intercâmbio, de valorização e de produção abertas ao comércio marítimo- Em outras palavras, o porto além de constituir elemento de valorização territorial, ou seja elemento que permite à cidade inserir-se na cadeia que articula econômica e espacialmente um mercado de produtos, ao mesmo tempo, ao articular um mercado de fatores (solo, capital, trabalho) gera também economias externas, que derivam de efeitos de sinergia, como as economias de aglomeração, de urbanização, de diversificação, "produzindo" a cidade. Hoje, dadas as mutações da atividade portuária face às crescentes exigências de racionalidade e produtividade, fluidez e mobilidade, impostas pela industrialização e enfatizadas por estratégias econômicas globais e, inerente a elas, pela dispersão dos centros de decisão, o porto torna-se cada vez mais uma entidade distinta, quando não distante da cidade, na medida em que passa a constituir um simples elo na cadeia logística de transporte, sobre a qual nem ele (porto) nem a cidade, ou a região, têm mais controle. ${ }^{4}$

Por Hoyle (1988), pode-se observar que, particularmente intensa nas décadas de 1970 e 1980, a evolução das tecnologias marítimas (terminais especializados de carga, conteneirização $0^{5}$ e métodos ro-ro ${ }^{6}$ ) tiveram o efeito de enfraquecer, quando não de romper, os tradicionalmente fortes laços funcionais que existiam entre a cidade o porto: "o porto moderno funciona antes como uma porta que como um centro de atividades" . Por outro lado, a necessidade de águas profundas para a operação dos cada vez maiores navios e de grandes espaços livres para a movimentação, aliada à exigência de aticulação direta com os sistemas nacionais (ou mesmo continentais) de transportes, explica o processo mais ou menos generalizado do abandono 
físico dos antigos sítios portuários, em grande parte, originalmente localizados em posições urbanas centrais.

E assim, o tema dos projetos de tranformação de antigas áreas portuárias, bem como ferroviárias e industriais, tornadas obsoletas ou sub-utilizadas pelos processos de inovações nas tecnologias de transporte ou de produção, têm sido, desde pelo menos os meados da década de 80 uma das principais pautas do urbanismo contemporâneo. É que, coincidindo com as crises urbanas iniciadas na década de 70 (questão energética, nova divisão internacional do trabalho, desindustrialização etc), o esvaziamento dessas áreas, repita-se, não só portuárias, iria propiciar verdadeiras "oportunidades" para a atualização e revalorização da cidade contemporânea. Portanto, neste sentido poder-se-ia dizer que o porto, ou melhor, a transformação das áreas portuárias, volta a "produzir" positivamente a cidade.

*** $*$

Em face deste quadro, o presente trabalho pretende responder "porque" e "como" se pode e se deve pensar um projeto de reconversão urbanística do porto de Santos. E desde logo, em nome da coerência teórica desta idéia, haveria que se responder "para que" e "onde" (ou seja para que parte ou partes da área portuária) tal hipótese se mostra válida.

De antemão pode-se afirmar que sómente uma interpretação mais ampla dos processos territoriais e urbanos pode evitar o reducionismo que conduz ao (des)entendimento do projeto de transformação daquelas áreas, tornadas vacantes ou, pelo meno redundantes, como ocupação de um "vazio urbano". Tal opção interpretativa justifica-se ainda mais pelo fato de que, aparentemente, a quase totalidade das áreas portuárias de Santos se mantém (ao menos potencialmente) em operação. No entanto, esta aparente contradição nos termos da própria hipótese — reconversão de áreas "produtivas": contradição ainda maior se considerada o "desperdício" e o custo social que representa o fenômeno da obsolescência forçada das infraestruturas- é o princípio que move esta investigação e assim estabelece seus rumos de indagação. Neste sentido, se "as descrições territoriais não são independentes das intenções e linguagens projetuais que se encontram por trás delas"», o caminho desta investigação deve passar de modo dominante pela verificação das seguintes questões:

- $\quad$ interpretação do modelo territorial "preparado" pela infra-estrutura portuária através da verificação da hipótese que atribui os papéis que a cidade de Santos passa a desempenhar neste modelo e suas mudanças, enquanto lugar de transição/ruptura da circulação de produtos e bens e de convergência/concentração de fatores de urbanização;

- $\quad$ revelar em que medida e por quais mecanismos as operações de construção e transformação da infra-estrutura portuária multiplicaram 
seus efeitos, produzindo "marcas" permanentes no crescimento da cidade;

- $\quad$ explicitar as contradições e conflitos urbanos decorrentes da relação porto/cidade, como "material" para a construção de hipóteses alternativas a essa mesma relação.

Portanto, é na possibilidade de intersecção das lógicas, ritmos e condicionantes próprios às escalas territoriais e urbanas (embora frequentemente tratadas de forma independente e contraditória) onde se funda a perspectiva analítica e propositiva destas indagações. Mesmo porque, uma sumária caracterização do problema de constituição dos setores portuários urbanos, talvez seja suficiente para mostrar que, quando se tematiza a relação entre as grandes infra-estruturas de transportes e cidade, desde o ponto de vista da construção do espaço, tanto sob os aspectos físicoformais, quanto naqueles referentes aos processos através do qual o mesmo se transforma, há que se reconhecer, antes de mais nada, a imbricação de duas lógicas. A que se refere aos imperativos da produção do espaço urbano e aquela decorrente do papel territorial desempenhado pelas infra-estruturas e que, portanto, remete-se - particularmente fortes no caso de Santos- às exigências e decisões de ordem diversa e de origem exógena à cidade. Neste sentido, a história do processo de construção da relação entre o porto e a cidade é a história de uma difícil conciliação que, se em certos momentos, desde uma possível sinergia que possa estabelecer-se entre aquelas lógicas, gera novas e potentes dinâmicas urbanas, em outros, traduz-se em fenômenos de autonomia e divisão espacial, comprometendo, pela própria inércia das "marcas infra-estruturais" impressas no tecido físico e social, as formas de evolução da cidade.

***

O porto (ao menos em sua versão moderna) é, em grande medida, infraestrutura cuja forma e caráter foram estabelecidas pelo desenvolvimento econômico e tecnológico do século XIX. A importância dada aos deslocamento das mercadorias e pessoas, possibilitando articular os lugares com regiões cada vez mais vastas, remete-se aos processos de modernização do século XIX, e traduzir-se-ia materialmente na articulação "funcional" de espaços, construções, maquinarias e redes. Segundo Bonillo (1991, 10), o porto constituiu, assim, "um laboratório experimental das categorias e lógicas do espaço moderno", onde os imperativos de racionalidade e produtividade capitalistas reorganizam as relações de trabalho e a partir do qual articulam tanto um mercado de produtos (ao "iniciar um processo de integração espacial e econômica dos elementos da cadeia de circulação de mercadorias"), quanto um mercado de fatores "produtores" da cidade (capital, trabalho e solo). 
Consequentemente, correspondendo aos investimentos de capital de ponta a seu modo e seu tempo comprometidos com os avanços econômicos e tecnológicos, e que, por isto mesmo, procuram assegurar, por mecanismos de controle, a apropriação dos efeitos multiplicadores gerados, as infraestruturas acabam estabelecendo características de inércia no crescimento da cidade, particularmente por sua associação com a criação do solo, a edificação e a localização induzida das atividades. No entanto, ainda que as infra-estruturas tenham legado marcas físicas "inerciais" que condicionam a transformação do espaço urbano e terrritorial, sua "capacidade" de "produzir" esse mesmo espaço (isto é, mantê-lo ativo no ciclo de "produções" e "consumos"), não constitui fenômeno permanente. A condição para que a infra-estrutura seja meio de produção do espaço verdadeiro capital fixo--, de modo que a espiral de consumo e produção permaneça no tempo, supõe, de acordo com Ordoñez e Solá-Morales (1977, p.66), "a capitalização de setores econômicos que estejam comprometidos por suas conexões técnicas e funcionais com alternativas de crescimento urbano ordenadas"; alternativas essas tomadas como um marco físico e jurídico capaz de dar suporte às iniciativas dos diversos operadores. Nesta linha de raciocínio, a não correspondência que possa existir entre os elementos infra-estruturais e as "necessidades" econômicas e sociais geraria tensões e desequilíbrios e acabaria comprometendo a própria "fixidez" do capital representado pelos primeiros. Ainda que esse "marco físico e jurídico" (ou seja, o "plano" ) deixa de ter, como se verá, contornos precisos pela própria "imprevisibilidade" das necessidades econômicas e sociais, que multiplicam-se e fragmentam-se segundo os interesses da diversidade de atores, como sucede na cidade contemporânea (ou melhor, à escala alargada do território), não se pode deixar de entender a infra-estrutura através dos vínculos técnicos e de gestão que possa ter com alternativas de crescimento urbano que suponham a "socialização capitalista" crescimento. Neste sentido, a "dimensão" ou "propriedade" social da infraestrutura como capital fixo implica na dialética "desenvolvimento (produção, fatores de crescimento, etc) e "utilidade (dimensão coletiva do "consumo", "valor de uso").

$* * *$

Buscando evidenciar os momentos importantes da dinâmica espacial que associa iniciativas de construção da infra-estrutura portuária, processos de desenvolvimento do território e formas de crescimento urbano da cidade de Santos — no sentido de flagrar alternativas a essa mesma dinâmica- a pesquisa realizada pautou-se por três níveis de objetivos :

- reconstituir uma "história" de projetos que vinculam mais diretamente porto e cidade: daí a importância da iconografia e do desenho como processo de restituição e método de análise" ; 
- testar hipóteses que possam servir para interpretar a relação cidade/ porto como espaço privilegiado de imbricação das lógicas territoriais e urbanas;

- fornecer elementos para o "projeto", entendido como hipótese que suscita questões e revela alternativas.

Deste modo, este trabalho organiza-se segundo cinco capítulos e apêndice. No capítulo 1, a reflexão sobre a cidade e o território contemporâneo reúne aportes teóricos que possam permitir criar um marco de referência para o caminho analítico. A partir da leitura "geográfica" do fenômeno da passagem da "aglomeração" (espaço circunscrito e contínuo) à "rede" (espaço descontínuo e não homogêneo) - leitura essa que lança mão de teorias elaboradas por Dematteis e Santos-, busca-se verificar as tendências recentes dos processos e formas de "valorização territorial", entendida enquanto atribuição de valor econômico às condições locais, dadas, herdadas ou produzidas, através de sua interação com contextos mais amplos. Na medida em que a cidade passa, cada vez mais, a ser modelada pelos diversos fluxos que a atravessam e que a conectam com outros fragmentos urbanos distantes, procura-se evidenciar o papel do "contingente", da dimensão local, como "recurso" a partir do qual montar estratégias contemporâneas de desenvolvimento urbano. E, dentro deste marco conceitual procura-se examinar a pertinência da afirmação do "projeto urbano" sobre o "plano geral", como instrumento de intervenção na cidade. Neste sentido, a verificação dos novos conceitos que o urbanismo (particularmente o de extração latino-européia) lançou mão para colher o sentido da mudança far-se-á através da análise da importância (enfatizada por Secchi, Solá-Morales, entre outros) da morfologia urbana, suas "regras" e identidade, como argumento sobre o qual construir estratégias analíticas e projetuais. Da reunião desses pontos de vista (geográficos e urbanísticos), emerge a pertinência disciplinar, teórica e prática, dos conceitos de "nó" (enquanto ponto de articulação do sistema de redes, materiais e imateriais, e seus processos "trans-escalares") e de "lugar" (especificidade material como produto da história em um longo processo de acumulação de estratos sobre um território caracterizado) e, logo, a necessidade, particularmente importante no estudo das infra-estruturas, da consideração de duas relações, expressas "graficamente" por Dematteis, como "horizontais" e "verticais"12.

O capítulo 2, mais "horizontal" —no sentido em que indaga as inter-relações que a "situação" santista mantém com escalas diversas-, trata de caracterizar as condições e fatores "territoriais" de formação e transformação da Macrometrópole de São Paulo, na medida em que essa escala "macroregional" (compreendendo o espaço de extravazamento das funções metropolitanas antes concentradas na capital) conforma o contexto mais denso das "trocas" de Santos e seu porto. A partir da descrição das variáveis geo-morfologia, rede de infra-estruturas, sistema de cidades e 
localização das atividades, busca-se verificar a "posição" da cidade Santos no modelo territorial macrometropolitano e suas mudanças. O "material" desta análise é "fornecido" principalmente pelas "imagens" ou "representações territoriais" elaboradas pelos vários estudos e planos regionais.

Já o capítulo 3, um "intermezzo" monográfico, trata o porto não como elemento do processo produtivo e da cadeia de transportes, mas, sobretudo (embora obviamente condicionado por esta condição), como entidade física, como produto técnico e social. Esta parte do trabalho busca identificar as características físico-formais das diferentes tipologias da "expansão portuária". A partir de sua "confrontação" com os modelos gerais de crescimento da cidade (estudado no capítulo 4), procura-se evidenciar as contradições e conflitos que se manifestam entre essas mesmas tipologias entendidas como "signo" da crescente autonomia física e funcional do aparelho portuário- e a forma e o uso do espaço urbano. Assim, o contraste entre as duas "lógicas" de construção do espaço, a portuária e a propriamente urbana, deve flagrar os efeitos "resultantes" sobre o sistema ambiental, a rede viária e os grandes eixos estruturadores, as territorialidades (que definem e social e espacialmente cada parte das cidades), as centralidades e os setores de desenvolvimento econômico e urbano da metrópole santista. Para tanto, enfatizar-se-á o aspecto físico-formal da questão, verificando-se as "marcas" que o porto legou à estruturação e configuração dos espaços e usos da cidade de Santos, e, inversamente, as eventuais implicações urbanas no desenvolvimento portuário.

O capítulo 5, como esforço de "síntese" das tensões históricas que permeiam a relação porto-cidade, intenta fornecer elementos para a interpretação projetual dessa mesma relação. Ou seja, procura-se caracterizar os problemas, as questões fundamentais e também, as potencialidades latentes nessa mesma relação no sentido de se identificar pautas de transformação urbana coerentes e comprometidas com a definição de um novo papel que o porto e a cidade de Santos possam vir a desempenhar no território macrometropolitano.

Por último, embora em "Apêndice" mas não menos importante, estuda-se casos de reconversão urbanística de áreas portuárias, notadamente em Barcelona e Roterdã, com o objetivo de se verificar as regularidades que se possa evidenciar com o caso santista, enquanto possibilidade de se estabelecer para esse um marco de referência analítico e projetual.

'M. Santos A urbanização brasileira, p.110

${ }^{2}$ Ibid, p.114

${ }^{3}$ Poder-se-ia apenas para ilustrar um caso de dissociação entre as redes de fluxos comerciais arrolar o exemplo da França, onde através da lei "Laval" de 1965, o sistema portuário, tradicionalmente controlado pelas instâncias locais, passa a ser gerido pelo poder central na 
medida em que se converte em questão nacional que sobreleva o poder de mando das cidades ou da região. Porém este não constitui um padrão fixo: nem sempre os portos são entidades centralizadas nas mãos do governo central. Em alguns casos ou são dirigidos por colegiados, ou até constituem propriedade de municípios, como por exemplo, em Roterdã e Hamburgo. (vide Apêndice e AIVP. "Ciudades y puertos, mutación y recomposición”, 1998)

${ }^{4}$ A. Vigarié, "Villes portuaires et changements economiques" in AIVP. Op. cit

${ }^{5}$ Conteinerização — tecnologia surgida em 1956 nos Estados Unidos— refere-se à unitização de cargas acondicionadas em um mesmo volume que foi padronizado pelo modelo de cofres metálicos de 20 e 40 pés. A não necessidade de ruptura e armazenagem de cargas —atividade antes realizada dentro das áreas portuárias - reformulou completamente o conceito de transportes na medida que possibilita a entrega porta a porta: Isto implica não só maiores disponibilidade de áreas portuárias desimpedidas e conectadas diretamente aos sistemas territoriais de transporte como o desenvolimento de toda uma logística da parte terrestre, que se mostra tão importante quanto a marítima

' Ro-ro é a breviatura de "roll on-roll off", e denota um tipo de operação portuária onde a carga é levada/tirada diretamente do interior dos navios através de sistemas sobre rodas.

${ }^{7}$ B. S. Hoyle, "Development dynamics at the port city interface" in Revitalising the waterfronts, 1988, p.3

${ }^{8}$ A. Font. "Anatomía de una Metrópoli discontinua: la Barcelona Metropolitana” in Papers. Regió Metropolitana de Barcelona, $n^{\circ}$. 26, 1997, p. 3

${ }^{9} \mathrm{O}$ plano no sentido da ideologia segundo a qual se pretendia prever e controlar as variáveis globais do crescimento urbano e da ordenação territorial

${ }^{10}$ Que não se confunda os conceitos de socialização objetiva e justiça social: hoje como no passado são independentes entre si e em certos casos contrapostos (G. Dematteis, La scomposizione metropolitana, in La cittá del mondo.., 1988, p.38)

" Guia de referência iconográfia acompanhará o presente volume

${ }^{12}$ G. Dematteis, Il progetto implicito, 1995 e Contesti e situazioni territoriali in Piemonte in Urbanistica $\mathrm{n}^{\circ}$ 96, outubro 1989. Por ora talvez seja suficiente notar que tais conceitos diferem diametralmente daqueles utilizados por Santos $(1994,16)$, onde "as horizontalidades serão os domínios da contiguidade, daqueles vizinho reunidos por uma comunidade territorial, enquanto as verticalidades seriam formadas por pontos distantes uns dos outros, ligados por todas as formas e processos sociais". 


\section{Capítulo 1}

\section{DA AGLOMERAÇÃO À REDE: ESTRATÉGIAS DE PROJETO}

\subsection{A nova geografia do território}

Desde a visão econômica dos problemas territoriais, a explicação do "peso" específico que as grandes infra-estruturas de transporte têm na ordenação espacial dos assentamentos produtivos e residenciais vem dada pela associação sobretudo de dois fatores: diferenciais de acessibilidade e "indivisibilidade dos investimentos. O primeiro diz respeito aos graus de interconexão de um ponto territorial à rede de transportes; o segundo referese ao fato de que "os processos de produção possuem um umbral (ou limiar), mínimo", abaixo do qual não é possível, em função de sua própria economia interna ou de escala, dividí-1o² .

A partir destes conceitos, pode-se observar que em um primeiro momento o território poderia ser considerado "plano e homogêneo" (ou seja teóricamente acessível em todos seus pontos através de uma rede de caminhos mais ou menos precários). Em um momento posterior, ao aumentar as necessidades de circulação ou tráfego, a indivisibilidade na construção da infra-estrutura de transportes, ou na prestação de serviços (para diminuir os custos de transporte), teria como efeito o fato de que, na medida que os investimentos não podem ser distribuídos de forma geral, a escassez de recursos e a seletividade de sua aplicação hierarquizariam os pontos do território, menos em função da distância entre eles que da posição que passam a assumir no esquema que representa a rede de transportes ${ }^{3}$. Essa "posição", portanto, corresponde sobretudo aos tempos e custos relativos ao movimento.

O diferencial de acessibilidade (pela concentração de investimentos em apenas algumas das interconexões), redundando em imperfeita mobilidade de pessoas ou coisas, acabaria produzindo fenômenos de concentração espacial também diferenciados (pelas vantagens locacionais de produção e distribuição proporcionadas pela economia de aglomeração que, por sua vez, aumentaria as possibilidades de obter economias de escala, reduzindo custos, subdividindo o processo produtivo, aumentando a produtividade). E, principalmente, nos países subdesenvolvidos, a espiral deste processo tende a crescer na medida em que os novos investimentos dar-se-iam, seletivamente, em lugares já previamente beneficiados pelas primeiras inversões capitalistas, segundo o fenômeno da "concentração cumulativa".

De acordo com M. Santos ${ }^{4}$, o fator Estado quando funciona "como suporte dos monopólios, pela concentração das infra-estruturas" age como elemento 
de concentração econômica e demográfica, reforçando em cadeia o processo cumulativo. De onde se pode inferir, por oposição, que a difusão das infraestruturas constitui fator (necessário, embora não suficiente) de desconcentração e equilíbrio territorial. De fato, combinado com outras alternativas (densidade da estrutura social, situação geográfica, aglomeração e concentração espacial da população), o investimento em infra-estrutura pode representar forte impulso aos processos de desenvolvimento regional. Particularmente pela capacidade que a integração das infra-estruturas tem em dotar de maior acessibilidade o território, fazendo diminuir o grau de marginalidade das regiões e "contribuindo de forma importante com a coesão econômica e social assim como com a diminuição dos desequilíbrios territoriais" ${ }^{5}$. Porém, como observa Izquierdo ${ }^{6}$, o paradigma político dos anos 50/60, que se baseava em uma possível relação causal transportedesenvolvimento regional, entra em crise com a evidência de que os efeitos das infra-estruturas podem ser contrários aos desejados, dependendo portanto de verificações de cada caso. Particularmente interessante para a análise do caso santista (como se verá no capítulo 2), o efeito perverso dessa relação pode ser ilustrado pela experiência da "Estrada do Sol" italiana que, ligando as regiões norte e sul, acabaria evidenciando o "efeito de sucção que podem provocar as áreas mais desenvolvidas sobre as mais atrasadas" ${ }^{7}$.

\section{O modelo em rede}

A superação das barreiras espaciais mediante as contínuas e sucessivas ondas de inovação tecnológica é um fenômeno que sempre teve enorme relevo no quadro da dinâmica histórica do capitalismo ${ }^{8}$. Buscando, no dizer de Marx, "anular o espaço mediante o tempo", na medida em que o capital necessita da criação de condições físicas que facilitem o comércio ${ }^{\circ}$, vêm se produzindo, desde pelo menos o século XVI, as revoluções no campo dos transportes e da comunicação. Tendo como marco a imagem da "global village" macluhiana dos anos 60, o que se pode afirmar é que o ulterior conjunto de inovações neste campo, acabaram reduzindo drasticamente os tempos e os custos do "movimento".

Neste sentido, pode-se observar que a condição "ordenadora/ vertebradora" das grandes infra-estruturas de transporte e comunicação ganha, desde sua maior difusão e socialização, associadas às inovações do processo produtivo, uma nova escala e sentido, à medida que confere suporte material aos fenômenos de dispersão e descontinuidade de alguma variáveis. Fenômenos esses que marcam o processo contemporâneo de organização do território e redefinem o papel de "centralidade" exercido pelas grandes cidades.

Se, de maneira geral, na metrópole industrial o "custo do transporte constituía o fator que criava monopólio natural das cidades sobre as áreas de influência contíguas, dado o aumento generalizado da fluidez do 
território, graças aos progressos nos transportes, nas comunicações e na produção e uso das informações, mesmo nos países subdesenvolvidos, as relações de interação e de troca se configuram segundo escalas que superam amplamente os limites regionais e mesmo nacionais. E dada a consequente maior mobilidade adquirida pelo capital produtivo e financeiro (que, na verdade, rearticula-se em uma dimensão geográfica transnacional), outras vantagens locacionais ${ }^{10}$ despontam, talvez, como fatores muito mais decisivos para a localização das atividades econômicas que a "distância e, também, que seu corolário, a "aglomeração . Isto porque as inovações tecnológicas do processo produtivo industrial, baseadas na circulação ampla das informações (que reduz o atrito da distância), na informatização e na automação (que redimensionam as necessidades da economia de escala), criam as condições que permitem às atividades econômicas "aproveitar" (também em relação aos problemas decorrentes das deseconomias de aglomeração) a difusão das infra-estruturas territoriais como suporte do processo de sua desconcentração espacial.

Portanto, como assinala Russo", "os fluxos de trocas comerciais, de mercadorias, de informação, que se davam essencialmente no interior das áreas urbanas, tendem a superar os limites regionais e nacionais", rompendo, como já se observou, o monopólio da cidade sobre sua tradicional área de influência. Os campos de externalidade já não se referem a um espaço contínuo e homogêneo (posição geográfica), mas configurando-se como redes, "articuladas em centros e sistemas urbanos pequenos e grandes, sobre extensões territoriais tendencialmente nacionais e internacionais" remetem à noção de um espaço descontínuo e não homegêneo (posição relacional), "caracterizado pela sobreposição e entrecruzamento das diversas redes de relações econômicas, culturais e políticas que passam por cada lugar"’3. Daí M. Santos $(1994,15)$ escrever que "a interdependência universal dos lugares é a nova realidade do território".

Desta maneira, se a representação clássica da cidade tomava-a como espaço central, aglomerado e circunscrito, hoje, com a perda da estabilidade e continuidade dos processos, coloca-se em tela o problema de um espaço multidimensional, de "regiões" entre si não conexas, de tal maneira que se pode falar do "ambiente como contingência e do mundo como rede ${ }^{14}$. Segundo Dematteis:

Uma organização reticular do espaço, como descrição de tendências e como objetivo de políticas territoriais pós-industriais, responde bem aos requisitos do modelo de auto-organização que (...) oferece a interpretação mais satisfatória dos processos de desenvolvimento local (...) A ordem reticular se apresenta como mais repetitiva e menos deterministicamente estruturada que aquela hierárquica-central e, por isto, mais flexível, mais livre, 
mais aberta à ações criadoras da contingência local, mais suscetível de diversificação e de complexidade (...) pela interação com o ambiente"15.

Ampliadas as bases do processo de valorização territorial, pela extensão aos sistemas urbanos menores dos campos de externalidade antes formados concentricamente em torno das maiores cidades, o fator de desenvolvimento, inércia ou decadência de uma cidade vem dado pelas condições de interação de certas contingências locais (conformando um determinado umbral ou "massa crítica" de recursos locais) com os outros nós das redes (a partir da recíproca "especialização" destes pontos). No entanto, ainda que menos deterministicamente estruturado, o sistema em rede não anula as escalas hierárquicas mas tende a simplificá-las, fundando-as basicamente em dois níveis. Um nível metropolitano que, inserido diretamente na rede dos intercâmbios internacionais (capitais, mercadorias, informação, etc), controla e orienta o segundo, configurado pela rede urbana regional ${ }^{16}$, mais voltado às tarefas técnicas da produção ${ }^{17}$. Neste quadro, porém, as relações de interação e dependência entre os dois níveis alteram-se ${ }^{18}$, ao não necessariamente estabelecerem-se entre áreas geograficamente vizinhas. Ainda que a dependência hierárquica entre o nível metropolitano e aquele dos sistemas urbanos menores permaneça, e talvez se reforce, essa dependência baseia-se mais em diferenças "qualitativas" (especialização, natureza das trocas) que "quantitativas" (proximidade de centros, dimensão da concentração urbana).

Por outro lado, deve-se observar, como o faz Santos ${ }^{19}$, que sómente as grandes corporações constituem empresas cuja ação espacial, não necessitando da continuidade espacial (pois operando eminentemente no nível político-decisional), é capaz de utilizar plenamente as novas condições de dilatação dos sistemas infra-estruturais e produtivos, regulando o território em seu equipamento e uso. E aí, talvez, evidencia-se, do ponto de vista espacial, a principal transformação das grandes cidades contemporâneas: a perda da conotação territorial dos sistemas urbanos. Pois, as redes das diversas funções centrais (comando financeiro, trocas comerciais, informações e inovações, etc) tendem a ter cada uma sua própria geografia diferente, definida pela "presença das grandes empresas em lugares estratégicos do espaço total, (em) pontos escolhidos por elas mesmas, dos quais exerce sua ação sobre outros pontos ou zonas, diretamente ou por intermédio de outras firmas". Neste sentido é que Santos ${ }^{20}$ distingue o espaço da técnica (forma) e o espaço da política (norma).

Ao lado da desconcentração e fragmentação da produção, construídas sobre sistemas de interdependência a escala mais amplas que a da vizinhança geográfica, assiste-se nas grandes metrópoles a "uma perda de coesão da 
comunidade com uma base territorial definida, decomposta em tantos fragmentos quantos são as redes de "funções centrais" que a atravessam" " e que, interessadas a uma ordem superior que se manifesta e opera a nível mundial, põem em crise os interesses econômicos e culturais anteriormente identificados "espacialmente" com a cidade (ou a menos com os imperativos e orientações das elites locais). A cidade passa a ser vista como simples suporte físico e infra-estrutural de atividades "globalizadas", largamente dependentes de outras escalas espaciais e de "velocidades" diversas (como, por exemplo a correspondente à transformação da sociedade e cultura locais e aquela referente às decisões econômicas e tecnológicas e suas mudanças).

\section{O modelo em rede e o papel das cidades}

Nas fases em que a acumulação capitalista dependia principalmente das economias de aglomeração e da urbanização concentrada, os processos de organização espacial puderam ser explicados a partir de conceitos e modelos fundados sobre a coincidência entre sistemas urbanos e sistemas

produtivos (teoria da localização, polaridades, sistemas de cidades, eixos de crescimento, base econômica, etc.). Nestes modelos, a metrópole moderna clássica, como centro de convergência dos principais circuitos regionais, nacionais e internacionais, era também o centro de âmbitos territoriais bem definidos, baseados sobre a distância dos centros e sobre hipóteses de gradiente centro-periferia. Na medida em que a distância física não é mais determinante, o "centro", no sentido físico-espacial, perde seus contornos precisos. É o que a passagem da rede urbana hierarquizada (a "árvore" de Christaller) ou polarizada (a "estrela" de Perroux") para uma rede interconexa indica, ou seja, que a "centralidade" se encontra distribuída entre os nós da rede, dependente da nova divisão internacional do trabalho (especialização) e da interconexão "setorial" da cada ponto com os outros pontos. E na medida em que a interconexão em redes setoriais prevalece sobre a relação de interdependência que ligava os pontos do território segundo âmbitos territoriais bem definidos, os fatores estratégicos de desenvolvimento urbano contemporâneo remetem-se e referenciam-se, como se observou, à outras escalas e "velocidades", tornando-se cada vez menos dedutíveis dos "mecanismos" de funcionamento da cidade, assentados como eram nas variáveis de proximidade (centros regionais de Christaller) e de polarização/irradiação (pólos industriais de Perroux).

O modelo teórico que busca apreender o fenômeno da passagem da "aglomeração à rede" apóia-se basicamente em dois pontos. O primeiro ponto, vale repetir, implica no reconhecimento de que "centralidade" encontra-se distribuída entre os nós da rede, de acordo com a própria especialização e interação desses nós ${ }^{22}$. Portanto, "centralidade" significa pertencer a algumas das diversas redes, hierarquizadas como são, segundo dois níveis que coexistem $— o$ metropolitano, de alcance internacional, e o 
local, de âmbito regional-. O segundo ponto diz respeito à localização das atividades, que se produz agora de maneira individual e fragmentária em um território cada vez mais "auto-organizado" e interdependente. Observa-se aí, portanto, a passagem de um esquema fundado na unicidade do pólo regional dominante a um reticular, onde o pólo perde sua preeminência absoluta em favor de nodalidades periféricas, em um cenário de complementariedade e competição entre os termos.

No entanto, a uma economia sempre mais internacional e global não corresponde uma crescente homogeneidade territorial: os "nós" centrais das redes - as ditas cidades mundiais-, em vez de se difundirem e dissolverem à escala da "aldeia global", aumentam seu poder de controle e comando. Como mostra Sassen $(1998,153)$, "a dispersão territorial das atividades econômicas, das quais a globalização é uma das formas, contribui para o crescimento das funções e operações centralizadas". Isto na medida que seria inerente à lógica do terciário ou quaternário (serviços especializados), a superconcentração das atividades em certas cidades centrais. A questão da escala e da complexidade das transações internacionais (e mesmo regionais), bem como o papel da prestação de serviços na organização industrial, territorialmente dispersa, torna aquela concentração, por mais elevados que sejam os custos, "um arranjo indispensável" frente ao fator tempo das decisões, pois a complexidade e a inovação na produção dos serviços especializados requerem aportes múltiplos, frequentes e também especializados: "a característica particular da produção explica a centralização do gerenciamento e da prestação de serviços, que alimentou a prosperidade econômica ocorrida no início e em meados da década de 1980, nas grandes cidades". Esta lógica, segundo ela, explica a aglomeração e "as condições fundamentais para a renovada centralidade das cidades, nas economias avançadas". Porém, este fenômeno não ficaria restrito às capitais mundiais: a globalização da atividade econômica, os grandes volumes das transações e as mudanças da tecnologia, que neutralizam as distâncias, acaba impondo esta mesma lógica, ainda que em escalas diversas, a centros regionais. Portanto as grandes cidades, independente do nível de desenvolvimento dos contextos regionais em que se inserem, passsam a desempenhar papel tanto de "nós" de redes, tecnológica e/ou financeiramente especializadas, quanto de cabeças de ponte do capital internacional nos mercados regionais ${ }^{23}$. Isto acabaria levando à gradativa especialização funcional das cidades, que passam a concentrar atividades específicas: centro financeiro, indústria moderna, pesquisa, distribuição, etc.

No entanto deve-se observar que, neste novo quadro territorial, de um lado, o "urbano" já não coincide "com a cidade densa, nem com os limites municipais, nem tampouco, com as aglomerações metropolitanas típicas do modelo fordista" ${ }^{24}$, mas é, antes de mais nada, sistema de cidades. E que, por outro lado, um nó, uma cidade da rede, poderia ter três posições 
possíveis: "ser um ponto de recepção e emissão dos fluxos, estar "sobre" os fluxos, mas sem potencial suficiente para investir, ou estar à margem da rede" ${ }^{25}$. Por força disto, desponta um cenário de grande competição em nível nacional e internacional entre localidades, regiões e estados, no sentido de se criarem condições de atrativilidade e "conservação" do capital (de um lado, cada vez mais "volúvel" e, por outro, em grande parte, crescentemente centralizado pelas grandes corporações).

A competição em nível nacional e internacional, tendendo a "erodir o relativo monopólio que uma cidade exercia sobre sua área de gravitação e influência"26, traz como consequência a necessidade de cada cidade buscar uma específica colocação dentro da rede urbana. Daí a hipótese, defendida por alguns estudiosos, sobre a necessidade de cada cidade definir estratégias diferenciadas no sentido de assegurar qualquer tipo de vantagem comparativa nas "relações de rede", atrair investimentos e, assim, consequentemente, buscar melhorar sua própria posição na rede. Isto faz, por exemplo com que A. Font ${ }^{27}$, observe que nos processos de crescimento e organização territorial contemporâneos, ao lado da tendência à homegeneização (derivada dos processos gerais de globalização que afetam os sistemas produtivos, comportamentos, forma dos artefatos), emerja, de forma aparentemente oposta ou contraditória, a afirmação "da especificidade e da diferença, do decisivo papel do local como mecanismo de reação e defesa, mas também, de definição e afirmação frente a um mundo aparentemente cada vez mais igual; como ativo para oferecer uma especificidade e para atrair ou conquistar recursos produtivos, financeiros ou de representação institucional". Nesta perspectiva, de um lado, a atenção recai sobre os aspectos estruturais de grande escala ("discussão habitual do projeto metropolitano" -infra-estruturas viárias e de transporte, enclaves de atividades inovadoras, reservas de espaços naturais, etc), de outro, volta-se, com mais força, aos processos mais difusos pelo território, "configuradores dos tecidos metropolitanos, responsáveis pela qualidade urbana e pelos códigos genéticos de sua transformação" 28 .

Para Dematteis, no interior dos modelos de passagem de uma rede hierárquica a uma rede interconexa (ou que levaria à "decomposição metropolitana", isto é, à distribuição da centralidade entre os "nós" da rede, de acordo com sua especialização e interação), poder-se-ia identificar uma representação que se propõe como "projeto implícito", o qual, sem ignorar a potente ação das redes globais, reintroduz a autonomia e a importância da dimensão do local, enquanto valorização de seus próprios recursos, potencialidades e vocações: “...os nós locais não serão simples "partes" da rede ( ou seja não constituem sub-sistema cujas propriedades são redutíveis àquelas do sitema global) e rede global não será a simples soma dos locais que a compõem. Não só o local não poderá existir sem o global, mas também este último dependerá da ação dos diversos sistemas locais" ${ }^{29}$. 
Assim é que se "as grandes cidades oferecem externalidades ambientais derivadas da acumulação histórica de recursos culturais e de capital fixo social e da intensidade das relações sociais" ”o, a referência a valores específicos constituiria o campo onde se explorar novos significados e novas possibilidades para o território. Como elementos de produção de identidade dos lugares e dos espaços metropolitanos, esses valores, continuamente elaborados e transformados em valores universais, precisamente através de sua relação com as dinâmicas globais, conformariam os recursos sobre os quais se montar estratégias de desenvolvimento.

Assim quais seriam os fatores do atual processo de especialização funcional e de diferenciação hierárquica de cada "nó" urbano? Parece que, ainda que sua validade só possa ser verificada a posteriori, as "receitas" mais recentes do desenvolvimento urbano baseiam-se em três "ingredientes" fundamentais que interagem entre si: as infra-estruturas, a qualidade ambiental (ou de vida), as inovações ${ }^{31}$.

Daí talvez, ainda de acordo com Dematteis, a principal raiz da crise da cidade e do urbanismo: conciliar tensões que nascem das funções que as grandes cidades são chamadas a desempenhar. Suporte da economia, ambiente que assegure certas condições funcionais e níveis de qualidade de vida, "caldo" de cultura das inovações. E isto exigiria projetar e administrar a cidade como sistema territorial unitário, capacidade que parece negada pelo próprio desenvolvimento em curso, que antepõe os interesses locaisterritoriais àqueles setoriais-globais. De qualquer maneira, no entanto, ainda que a cidade seja tomada como grande infra-estrutura coletiva do desenvolvimento econômico ("fornecendo às empresas aquilo que não produzem, mas que é de absoluta necessidade para manterem-se competitivas" ${ }^{2}$ ), na nova ordem econômica mundial, o tradicional "espaço aglomerado e circunscrito" é insubstituível como "lugar onde uma estratificação social 'densa', com tradições e instituições civís consolidadas e 'atmosfera' intelectual específica, pode produzir as condições deste bem sempre estratégico como é a inovação" ${ }^{3}$. Neste sentido é que se pode observar que o crescimento, a estagnação ou o declínio de cada centro, enquanto nó de uma "tendencial ecumenópole reticular", depende de sua especialização, da natureza das trocas que mantém com os outros nós da rede, bem como das condições ambientais locais, entre as quais, as culturais assumem particular importância na medida em que formam o substrato da continuidade e da inovação ${ }^{34}$. 


\subsection{A cidade contemporânea e a necessidade de novos conceitos}

Na medida que as novas condições estratégicas de desenvolvimento urbano alteram-se, as exigências de requalificação da cidade trariam a necessidade de novas agregações institucionais e novos planos, já que os "grandes planos globais" acabaram ficando sob suspeição e as políticas setoriais (dados os escassos resultados obtidos pelos programas estatais em termos de habitação, equipamentos, etc) entrariam em crise: não se tratava mais de "equilibrar" o sistema, nem de "controlar" o crescimento urbano, mas sim de "atrair" e "captar" novas atividades. Mesmo porque as novas demandas, "imprevisíveis" a longo termo, tornariam os planos convencionais obstáculo ao crescimento da economia urbana e impedimento de novos empreendimentos. Antes, como resposta aos fenômenos de estabilidade do crescimento urbano e metropolitano e de difusão territorial dos assentamentos produtivos e residenciais, coloca-se a questão da especificidade de cada lugar e de cada situação, como recurso estratégico para a "atualização competitiva" da cidade. Como nota Secchi ${ }^{35}$ :

De um lado, observa-se a crescente e sempre mais aguda sensibilidade ambiental... de outro, a dimensão assumida em muitos países (certamente não só) da Europa, pelos processos de dispersão dos assentamentos, as novas formas de "paisagem" que emergem; os processos contemporâneos de relocalização de diversas atividades de produção, depósito e distribuição; a mudança nas demandas de espaço por elas requeridas; o impressionante crescimento, por exemplo, dos espaços destinados ao "depósito" de mercadorias, de autos, de pessoas e a drástica diminuição daqueles destinados à produção; a perda do papel e das funções de muitos das referências da organização territorial da cidade novecentista, de boa parte do "capital fixo social" então constituído, o seu tranformar-se, hoje, sob a forma de "áreas vazias", de indústria, prisão, caserna, escola, hospital, centro tecnológico, mercado, pátio de carga, matadouro, canal, porto, ponte abandonadas..."

Assim, a identificação do problema dos grandes vazios e interstícios urbanos, legados da cidade industrial localizados dentro dos tecidos mais densamente edificados, e a diversidade das demandas, exigências e interesses, própria à sociedade contemporânea "de minorias" e suas "várias velocidades", passam a ser tomados como temas prioritários de análise e de projeto e, invariavelmente, tratados sob uma ótica de "grão mais fino". E, perpassando todas as indagações, a questão da revalorização do espaço urbano mostra-se tema de preocupação central da análise e do projeto. No entanto, é preciso observar a existência dos vários matizes da discussão sobre a falência dos grandes planos. Tanto na academia como na prática profissional, tal discussão envolveu desde posturas teóricas mais consistentes e férteis em defesa de uma coerência urbana mais geral, até posturas meramente 
ideológicas, principalmente fundadas, banal e oportunisticamente, nas plataformas neo-liberais de defesa da "deregulation". Esta últimas, de fato, ao atender somente às exigências de qualidade dos novos e poderosos operadores, acabariam levando a controvertidos resultados em diversas cidades $^{36}$.

\section{Novos paradigma disciplinares}

O "funcionalismo científico", entendendo que a "racionalização" do território supunha a especialização funcional de suas partes, articuladas, precisamente, em função de "espaços centrais" -imagem e condição de funcionamento da cidade industrial ${ }^{37}$-, ligava essa mesma idéia de racionalização à concepção do "plano". Neste sentido, mesmo a visão mais abrangente dos problemas territoriais desde sua inter-relação com os aspectos sócio-econômicos gerais, fundava-se na possibilidade da previsão (em geral, quantitativa) das "necessidades" futuras, extrapoladas de um estado de coisas inicial. Porém, a sucessão clássica análise-previsão-planointervenção se revela impraticável na medida em que, de um lado, o comportamento de cada nó, na organização espacial em rede, é largamente imprevisível $^{38}$ (assim como é a passagem de certas funções de um nível a outro da rede). De outro lado, a sociedade contemporânea, composta por "minorias", que enfatizam a própria identidade e a própria e recíproca diferença, revela-se portadora de objetivos, necessidades e demandas com contornos incertos até pela falta de referência de sujeitos que representem o interesse geral $^{39}$. Ou seja, a estrutura social urbana "tradicionalmente representada por poucos grupos hegemônicos de caráter substancialmente homogêneo" ${ }^{40}$, fragmenta-se em uma multiplicidade de grupos e de individualismos, caracterizados por um "nomadismo" espacial, social e cultural.

Diante deste quadro social e territorial, a discussão disciplinar mais interessante foi travada em torno do que foi denominado de "terceira geração" ${ }^{41}$ dos planos urbanísticos. Se, de acordo com Secchi ${ }^{42}$, à primeira geração correspondem aqueles planos que enfrentaram os fenômenos da expansão urbana com os métodos e as técnicas da Carta de Atenas ("funcionalismo quantitativo"), levando, em grande parte dos casos, à "graves distorções na esfera da redistribuição das rendas", a segunda geração dos planos, enfatizando justamente o enfrentamento dessas mesmas distorções, iria atuar basicamente sobre a oferta dos serviços e equipamentos públicos e sobre a distribuição da propriedade. Mas, utilizando técnicas de origem racionalista (standards, zoneamento, cálculos de necessidades) e privilegiando o enfoque institucional (intervenção pública), funcional (monotemático) e quantitativo (dimensionamento), acabaria levando a soluções urbanas empobrecidas e limitadas, porque monofuncionais e parciais, deixando de lado o papel de "transformação física e social, de 
produção de novas relações entre lugar e sujeito", que se tornam cada vez mais específicas ${ }^{43}$. E, mesmo porque o crescimento urbano cessara, seria precisamente sobre a modificação de situações existentes ou de espaços interstíciais dotados de forte especificidade que os planos da terceira geração colocariam sua atenção. E neste sentido, sem o perigo de exagerar nas generalizações, o urbanismo dos anos 80 é nitidamente marcado pelos "planos desenhados", ou simplesmente por projetos ditos "especiais" ou "estratégicos", onde a atenção dada à análise morfológica e ao papel da arquitetura urbana assumem particular relevância ${ }^{44}$.

Segundo Busquets, "frente ao impasse do planejamento de corte tradicional e ao desenho urbano de puro alcance decorativo, surgem novos processos de transformação urbana e novas idéias para projetar a cidade, que em sua aplicação demonstram seu interesse conceitual e teórico" 4 . Idéias como "projeto urbano", "escala intermediária" ou "projetos do plano", valorizando a questão da preocupação com a forma urbana, tornar-se-iam referências fundamentais no processo de recuperação urbanística e relançamento econômico das cidades. Mas qual teriam sido as razões do impasse do planejamento de "corte tradicional"? O mesmo Busquets, defensor do ponto de vista de que "o desenvolvimento urbano em período de crise não é necessariamente o urbanismo da austeridade" ${ }^{46}$, responde. De um lado, a rigidez e a não "aggiornabilittá" dos planos, sua burocratização (administração de standards) ou mesmo, a "setorização" das políticas urbanas, não responderiam mais aos processos de transformação que a cidade reclamava. Por outro lado, o vazio teórico que a aplicação estereotipada da arquitetura moderna havia legado, fez perder a capacidade integradora do projeto frente às necessidades de formulação de temas centrais de desenvolvimento que necessitariam "verificação conjuntural", não excluindo, no entanto, o compromisso com a reinvidicação do plano como instrumento necessário na organização social. O urbanismo contemporâneo deveria, em suma, propor o abandono tanto da esquemática e burocrática administração de padrões e normas quanto das posteriores políticas setoriais (agentes urbanísticos privilegiados e autônomos dos processos de transformação) pela reinvidicação de um novo projeto para a cidade.

Já na concepção de Secchi, a nova forma do plano deve dar forma concreta aos fenômenos múltiplos e variados nos quais a sociedade contemporânea (reconhecida sua complexidade e diversidade de objetivos, interesses e necessidades), não deixaria de encontrar "regras dotadas de significado". Só que a apreensão e interpretação dessas mesmas "regras" já não poderiam ser dedutíveis de reflexões de caráter geral atinentes aos princípios estruturais dessa sociedade. Assim, as consequências deste estado de coisas, ou seja a multiplicação das identidades do atores e a perda da nitidez da relação público/ privado — enquanto "sinônimo de (interesse) geral e coletivo e de privado e 
particular" 4 -, em uma época na qual "os interesse gerais e coletivos tornam-se difíceis de reconhecer e na qual nenhum ator, nem mesmo a administração pública, pode ser plenamente reconhecido como sua específica portadora" ${ }^{48}$, repercutiriam dentro do campo disciplinar do urbanismo, colocando em crise o que Secchi denomina de "metáfora do telescópio" ("cannocchiale"). Resistente à idéia de que a compreensão do tempo e do espaço se dê por sucessivas aproximações ${ }^{49}$ e que o planejamento possa obedecer a convencional sequência lógica e cronológica de formulação, negociação e atuação, Secchi propõe que a época atual requer "uma forte dose de imaginação" capaz de interpretar, e não transcrever, mesmo com as poucas informações que se dispõe, os fenômenos em curso, principalmente aqueles referentes "à natureza e caráter do espaço habitável de cada lugar.

Porém, se "dentro da descontinuidade do espaço e do tempo físico, econômico, social e institucional, dos interesses, das demandas, das necessidades, dos procedimentos administrativos e de mobilização dos recursos, alguns lugares se apresentem como lugares com uma particular 'espessura' problemática"so, então, a primeira questão que se colocaria para o urbanismo contemporâneo seria a de identificar tais lugares. E isolar um número finito de "lugares problemáticos" implica reconhecer o problema do âmbito do qual é "recortado".

Os critérios de escolha destas áreas "problemáticas" ou "notáveis" como lugar da intervenção, de maneira geral não sendo mais vinculados ao plano geral, resultam muito diversificados: em alguns casos dependem de uma "reflexão" da administração sobre um sistema de áreas; em outros, da conjuntural emergência de demandas e interesses privados, ou ainda de uma "antecipação ideológica" de novas referências urbanas. Daí, que o pretendido caráter estratégico dos projetos de intervenção, com incidência à escala urbana, metropolitana ou mesmo regional (difusão de mudança e inovação, reequilíbrio de setores, etc.) ou ainda, a perspectiva da dimensão "pública" destes mesmos projetos, isto é, que faça emergir uma idéia geral da cidade, pressuponham para seu próprio (não exclusivamente financeiro, imobiliário ou publicitário) êxito, um esforço de reflexão teórica, uma teoria da cidade ${ }^{51}$, através da qual, em tese, seria possível reconhecer conceitualmente as emergências urbanas (nós estruturais geradores) e liberar projetualmente as suas potencialidades (ancorando aí, os processos de modificação da cidade).

Revela-se aí um caminho rico de possibilidades a serem exploradas ao articular projeto "público" e transformação da cidade a partir do reconhecimento de pontos estratégicos de renovação: este último conferindo legitimidade ao primeiro. Porém, agora, superando o percurso que da descrição passava à interpretação, à compreensão, à previsão e à valoração, bem como as visões idealistas da cidade e do território, a tentativa de 
identificar o caráter desses lugares é atribuída ao projeto, interpretando, desde uma visão prospectiva, calcada no reconhecimento das "coisas e dos atores", dos processos e suas regras de desenvolvimento, a especificidade desse mesmo lugar e de seu âmbito. Tais projetos (preliminares ou provisórios) constituíram na visão de Secchi, hipóteses a serem corroboradas ou falseadas na relação com os diversos grupos de interesse, com as diversas instituições, segundo critérios de justiça social e de "como fazer bem a coisa, sobre como fazer economia de recursos e de meios expressivos, sobre como usar e re-utilizar dentro de novas combinações ricas de novos significados, os "materiais" disponíveis" ${ }_{52}$, explorando as possibilidades concretas de melhoria de situações específicas ${ }^{53}$.

Deste modo, poder-se-ia observar que, seguindo a formulação de Secchi, "os problemas com os quais se defrontam, hoje, o plano e o projeto de arquitetura não podem ser reduzidos e resolvidos em termos de (sub/super) dimensionamento ${ }^{54}$, mas também não podem ser vagamente considerados como questão da qualidade contraposta à quantidade, da designação (individualização) das situações e lugares contraposta aos valores e princípios ("científicos" ou ideológicos)". ${ }^{55}$ Portanto, como sugere ainda Secchi, que "categorias conceituais seriam capazes de "colher" o sentido das mudanças, orientando novas estratégias de pesquisa e projetação que possam convergir com as exigências, as práticas sociais e as instâncias de decisão atuais" ${ }^{56}$ ?

Em primeiro lugar, como se observou, parece-me que a resposta a esta pergunta passa necessariamente pela falência do modelo "dedutivo", que encontrava na sequência análise-previsão-plano-intervenção sua "ilusão de controlar as variáveis estratégicas de desenvolvimento urbano" ${ }^{97}$.

Em segundo lugar, corolário da primeira, deve-se considerar a questão do deslocamento da ênfase analítica do urbanismo, no sentido de que o insucesso teórico e técnico dos planos anteriores em explicar e organizar as novas dinâmicas urbanas e territoriais acabaria colocando sob supeição a ideologia a partir da qual a construção da cidade era concebida sobretudo como fruto de um processo de negociação entre os interesses públicos e privados. Diante de seus escassos resultados, a essa concepção contrapor-seia o conhecimento da dimensão técnica da construção urbana, recuperando um (subvalorizado) saber, tipicamente cumulativo, que diz respeito sobretudo aos aspectos físicos, "visíveis" da cidade e do território. Não (ao menos nas formulações mais interessantes) no sentido do retorno ao movimento da "city beautiful" ou à estética da cidade, mas como forma de dar resposta concreta, material, ainda que inevitavelmente parcial, às demandas sociais e à multiplicidade e complexidade de interesses e necessidades, condição essencial da sociedade contemporânea. 
E, em terceiro lugar, diretamente vinculada às primeiras, a resposta deve ser procurada na necessidade de um novo entendimento que se poderia ter da cidade. E talvez, esta discussão passe, de modo dominante pela verificação dos termos em que resume de maneira clara Bohigas ${ }^{58}$ : Ou seja, a oposição entre o "conceito de cidade como sistema ideal unitário e o conceito de cidade como soma conflitiva de fragmentos reais". Ao primeiro, isto é, a cidade como "grande sistema coerente e racional", corresponderia a visão técnica e política dos planos gerais - "uma espécie de metafísica da totalidade"-, enquanto ao segundo ("entender a cidade a partir do elemento relativamente autônomo das formas urbanas"), caberia a visão da "cidade que constrói e se consolida através de projetos". Projetos esses, como já dito, inevitavelemente parciais. Esta aparente limitação, no entanto, pode representar sua força. Desde que sua ênfase seja colocada na capacidade resolutiva dos principais problemas ou temas pendentes da cidade, revertendo tendências e propondo novas alternativas com compromisso urbano ao permitir rearticular, com maior capacidade de verificação e justificação, espaços e edifícios, funções e símbolos. Décadas de índices e padrões quantitativos e de programas setoriais tecnocraticamente desarticulados resultaram, na maior parte das vezes, em um ambiente urbano desfigurado, descaracterizado e empobrecido. Tanto em termos do conforto e bem-estar da população como naqueles referentes à sua representação cultural coletiva.

Neste sentido, desde já poder-se-ia notar, como o faz Secchi, que a maior preocupação atual com a morfologia urbana e territorial talvez tenha muito a dever à constatação de que "as diversas partes da cidade e do território mostram possuir regras ordenadoras do espaço, de seu uso e de seu significado, invariáveis no tempo e ao suceder dos arranjos sociais e econômicos bastante distintos entre si". ${ }^{59}$ Segue que se à sociedade correspondem tempos mais rápidos de mudança, o caráter de permanência, de longa duração das formas construídas, intermediando e de certa forma condicionando tais mudanças, pode revelar tanto nas regularidades quanto nas excessões e intenções manifestas no próprio caráter físico da cidade e do território, certos argumentos sobre os quais "construir" estratégias analíticas e projetuais.

Em um sentido bastante semelhante, ao entender que as formas territoriais conformam síntese quase única das relações sociais, Solá-Morales postula que é precisamente na "identidade" dessas formas onde reside o fundamento de sua própria aternativa. Para tanto, como hipótese metodológica, haveria que individualizar e interpretar as lógicas que, sobrepostas, configuram as diversas partes e elementos da cidade e do terrritório segundo leis, razões, ritmos e condicionamentos sociais e históricos próprios a elas. Desta maneira vem, uma vez mais, proposta a superação do raciocínio baseado na “descrição estatística - projeção futura - designação funcional". E, também, a 
necessidade de discutir criticamente as macro-interpretações sócio-econômicas dos problemas urbanos e territoriais cuja visão totalizadora do território (ainda que constituindo "referência unitária para todo o conjunto"60) ressente-se, no entanto, da especificação e explicação, à escala correspondente, das opções implícitas em cada intervenção concreta. Neste sentido as formas territoriais podem e devem ser entendidas não só como "efeito", resultado das relações sócio-econômicas mas também, à medida que constituem fatos concretos, específicos e históricos, como causa, fator de definição dessas mesmas relações e, portanto, como recurso a ser (re)valorizado.

Portanto, pode-se supor, que é a partir da identidade de cada situação urbana e territorial, ou como propõe Dematteis ${ }^{61}$, da individualização de "sua estabilidade não só sob o aspecto físico-formal mas também do ponto de vista dos processos (ecológicos, sociais, culturais, institucionais)" da qual cada situação deriva e através da qual se modifica (atribuindo-lhe valor e significado)" onde desenha-se a linha de investigação mais rica de possibilidades Aí, a descrição das "regras" próprias a cada situação existente pode permitir, confrontada e mediadada com as dinâmicas globais, a interpretação de sua alternativa através do "projeto", entendido enquanto "representação mental antecipadora das mudanças" e instrumento de primeira para ordem para a mediação dos interesses do maior número possível de atores. Não se trata da defesa tecnocrática da "autonomia técnica" do projeto, pois o mesmo sem capacidade de ser socialmente suportado é meramente um desenho. Mas, como Busquets adverte, "sem um projeto ou estratégia precisa não pode haver um consenso de idéias ou um debate que contraponha os interesses mais gerais em uma cidade"62.

Neste sentido, no lugar da importância conferida às regras de interação e contratação social pelo urbanismo de décadas anteriores (e, aí, o zoneamento e o "dimensionamento", este último inclusive como valor de juízo, tinham um papel central no discurso teórico e técnico dos planos tradicionais), agora, diante do contorno incerto que assumem essas mesmas interações, cada vez mais complexas, entre indivíduo, grupo social e a constituição física do ambiente, a atenção passa a ser colocada sobre a questão da especificidade do contexto físico-formal. Isto é, a ênfase passa a recair sobre a questão do compromisso com a forma urbana e territorial, na medida em que através desse compromisso se possa garantir, justificando-o com "argumentos" públicos, não privados, as condições "especiais" próprias à cidade e ao território: permanência a longo termo, "mais-valia" coletiva (enquanto principal capital fixo social) e imagem dotada de sentido (constituindo assim, bem de interesse geral a partir do qual a sociedade ou suas diversas partes se reconhecem) ${ }^{63}$. E neste sentido o "projeto" revela sua potencialidade como instrumento que ativa o debate das idéias que se possa ter para a cidade e o território, antecipando hipóteses não só interessadas à definição formal e funcional da ação de ordenação e transformação da 
estrutura espacial, como também ao que diz respeito ao controle da apropriação dos benefícios que tal atuação possa gerar.

Portanto, o que se deve ter presente é que no lugar dos "mecanismos de funcionamento da cidade", inúteis porque teóricamente sem fundamento, a atenção disciplinar desloca-se para a capacidade de avaliar quais "combinações de contingências locais podem, em certo momento, responder razoavelmente a certas intenções e desejos dos sujeitos urbanos. Em vez de examinar um estado inicial de coisas para deduzir estados sucessivos, a análise urbanística pode constituir apenas no partir de um estado final projetado para precisá-lo melhor, para aclarar-lhe o sentido e avaliar a modalidade que permite ligá-lo com o estado atual" ${ }^{\prime 64}$.Ou seja, em vez da explicação causal, a análise deve sobretudo fornecer representações e interpretações da realidade e suas possíveis transformações.

***

Talvez o conjunto de idéias analisado acima possa ser sintetizado segundo duas idéias gerais. Por um lado, superando as tentativas "racionalizadoras" que pretendem, como alerta Morin ${ }^{65}$, abarcar a realidade dentro de um sistema pretensamente coerente ou ideal, parece ficar claro que o debate sobre a cidade contemporânea supõe antes um "diálogo" com as múltiplas "racionalidades" que a compõem e transformam. Por outro lado, tem-se que face às tendências homogeneizantes derivadas dos processos "globais", a dimensão local se afirma como especificidade e diferença, revelando o decisivo papel do contingente. Portanto, entendendo, desde M. Santos, que a nova realidade do território é a interdependência universal de todos os lugares, segue-se que a apreensão de cada situação ou objeto territorial só possa realizar-se a partir da verificação das ligações específicas que essas mesmas situações ou objetos têm, seja com os níveis territoriais superiores seja com os outros objetos territoriais coexistentes. Daí a importância, como propõe Dematteis ${ }^{66}$ da análise das "situações territoriais" como verificação da intersecção de um espaço de relações "horizontais" e de um "espaçoambiente" de relações "verticais". As primeiras, referentes às interações econômicas, culturais, sociais, que os centros urbanos mantém entre si às mais diversas escalas e que lhes conferem seu "valor" ou significado territorial. As segundas, as "verticais", referem-se aos componentes ecológicos e histórico-culturais próprios a cada lugar ou área, conferindo aos mesmo sua identidade e especificidade morfológica. Se a pertinência "prática" desssa últimas deriva dos "valores" que assumem na interações "horizontais", no entanto, não se trata de fundar em nível local as "necessidades" da nova ordem superior que se manifesta e opera como rede em um nível planetário, mas sim de, invertendo essa relação, afirmar as contingências locais, em sua diversidade e especificidade, como recurso para atração de novas atividades e ocasião para melhorar sua posição competitiva na rede das múltiplas trocas. Neste sentido, o "local" não é um "significante" disponível a receber qualquer 
"significado" nem o global pode ser confundido com a ideologia da
transformação em si mesma, compondo e recompondo os fragmentos.

"A existência e o fortalecimento das cidades que são ao mesmo tempo sistemas territoriais locais e "nós" de redes globais, livres de relações de posição e distância referentes ao território circundante, constitui um paradoxo (...). O "continuum" territorial global-local estático e hierárquico se mostra inadequado para descrever o mundo móvel e mutável da odierna rede global, enquanto reduzir tudo às tais redes, ignorando o "radicado" localmente, não permite dizer como funciona o mundo que descreve" 67 .

'M. Ribas I Piera, J. Solé I Llusá. T. Pou i Viver. Teoria de las areas metropolitanas., 1979. p. 12 ${ }^{2} \mathrm{R}$. Tamomes. "Infra-estructura: los impactos economicos e sociales" in Hacia una visión estrategica de las infraestructuras como herramienta de integración -El caso de Iberoamerica en el contexto internacional, 1995, p.3. Para o autor quatro seriam as características do gasto público com infraestruturas:

- $\quad$ indivisibilidade' —o que significa que as infra-estrutras podem ser utilizadas com distintas intensidades, desde um aparente superdimensionamento inicial que vai se diluindo até chegar à plenitude ("colmatación");

- $\quad$ insubstitibilidade' —na medida em que não é possível substituí-las por uma de mais baixo custo, já que as necessidades do aproveitamento dos potenciais previsíveis, exige um investimento crítico que não pode cair abaixo de certos níveis;

- imobilidade' - já que se requerem fortes investimentos nos quais se imobilizam recursos escassos;

- $\quad$ polivalência' —no sentido em que as infra-estrturas são utilizadas em nuemerosos processos de produção como "inputs" dos mesmos"

${ }^{3}$ B. Secchi. Analisis de las estructuras territoriales, 1968

${ }^{4}$ M. Santos. O espaço dividido, 1979, p.222

${ }^{5}$ R. Isquierdo. "Las infraestructuras de transporte como insttrumennto de integración en el contexto iberoamericano" in Hacia una visión estrategica de las infraestructuras como herramienta de integración -El caso de Iberoamerica en el contexto internacional, 1995,. p.24

${ }^{6}$ Id., Ibid.

${ }^{7}$ Id., ibid, p.4

${ }^{8}$ D Harvey,. "I luoghi all'interno del "villagio globale": riflessioni sulla condizione urbana nel capitalismo del tardo Novecento" in Vários. La cittá del mondo e il futuro delle metropoli, 1988

${ }^{9}$ M. Santos. A urbanização brasileira, 1993, p. 102

${ }^{10}$ D. Harvey. Op. cit..

Estas novas vantagens locacionais referem-se às "pequenas diferenças sobre o plano da oferta da mão de obra, da infra-estrutura, dos recursos, da normativa estatal e do regime fiscal

" M. Russo, Aree dismesse, 1998, p.115

${ }^{12}$ G. Dematteis. Apud M. Russo. Op. cit., p.115

${ }^{13}$ M. Russo, Op. cit., p. 115

${ }^{14}$ B. Secchi, “Territorio, economia e societá", in Un progetto per l' urbanistica, 1989, p.209

${ }^{15}$ G. Dematteis, apud. B. Secchi. Op. cit., p.210

${ }^{16}$ G. Dematteis. "La scomposizione metropolitana" in La cittá del mondo e il futuro delle metropoli, 1988

${ }^{17}$ M Santos,. A urbanização brasileira, 1993

${ }^{18}$ G. Dematteis, Progetto implicito, 1996, p.90

${ }^{19}$ M. Santos. Op. cit

${ }^{20}$ M. Santos. "O retorno do território" in M. Santos, M. A. A. Souza et alli, Território, globalização,fragmentação, 1994

${ }^{21}$ G. Dematteis. Op. cit., p. 36 e Progetto implicito, 1996, p.85: "O papel crescente das comunicações e dos serviços ligados às informações, na organização e no desenvolvimento das sociedades industriais avançadas, tende a reduzir cada vez mais o "atrito de distância". Debilitam- 
se assim os principais fatores que conferiam coesão territorial e portanto significado geográficoregional a fatos como a interação social e econômica, a comunidade de interesses, a capacidade de controle, a acessibilidade aos serviços, a homogeneidade sócio-cultural, etc"

${ }^{22}$ S. Sassen. (1998, p.124) comenta o "surgimento" de cidades mundiais a partir da concentração de setores dominantes em certos centros urbanos que não têm uma longa história como centro internacional de negócios e atividades bancárias ou mesmo que não disponham de uma infraestrutura construída no passado como por exemplo o caso de Miami e Toronto comparado à Nova York e Londres

${ }^{23}$ L. Bertolini e T. Spit. Cities on rails, 1998, p.37

${ }^{24}$ M. Castañer e J. Vicente, "Figueres, una area en busca de función" in A. Font. L. Calvet, E. Roca (ed.) Infraestructuras de transporte y forma urbana. Exploraciones proyectuales para la ordenación urbana de Figueres. Fundación Politècnica de Catalunya-UPB, Barcelona, 1995, p. 19

${ }^{25}$ Ibid.

${ }^{26}$ G. Dematteis. La scompozicione metropolitana, 1988., p.35

${ }^{27}$ A. Font. Anatomia de una metrópoli discontinua: la Barcelona metropolitana, in Papers $\mathrm{n}{ }^{\circ} 28$, p. 4

${ }^{28}$ Ibid, p. 9

${ }^{29}$ G. Dematteis, Progetto implicito, 1998, p. 78

${ }^{30}$ G. Dematteis, apud M. Russo, Op. cit., p.116

${ }^{31}$ G. Dematteis, La scompozicione metropolitana, 1988

${ }^{32}$ Para Harvey (1988, p. 25), tendo em vista as condições de vitalidade econômica que uma cidade possa "oferecer" para a operação das empresas no contexto urbano, evidenciam-se quatro alternativas possíveis (que se bem diversas entre sí, não seriam excludentes):

1. centro de produção, requerendo mão de obra disciplinada, de baixo custo ou mesmo, em outros casos, altamente especializada, além de massivos investimentos sobre o plano infraestrutural (transportes e comunicações, educação, pesquisa) e apoio financeiro do estado

2. centro de consumo, atendendo ao crescimento do turismo de massa e aos setores de atividades de lazer, culturais, etc, a atenção voltar-se-ia tanto para os problemas da "qualidade de vida" (incluindo o renovado interesse pelo patrimônio construído no passado) quanto para a criação de infra-estruturas (hotéis, parques, centros culturais ou esportivos, museus, etc) e a oferta de eventos (feiras, mostras, jogos, concertos, etc)

3.centro de "comando e controle" (financeiro, administrativo, etc): a indústria de escritórios requereria estratégias públicas e privadas (aeroportos, comunicação a alta velocidade, conjuntos comerciais e de escritórios, etc)

4.estratégias "institucionais", traduzidas em políticas fiscais, investimentos, etc

Também Sassen (1998, p. 56) mostra que "as zonas de produção, os centros de turismo e os grandes centros comerciais e financeiros constituem três tipos de locais para a implantação dos processos globais"

${ }^{33}$ G. Dematteis. "La scomposizione metropolitana", 1988. p.38

${ }^{34}$ G. Dematteis, Progetto implicito, 1996, p. 90

${ }^{35} \mathrm{~B}$. Secchi. "Ridurre la complessitá" in Urbanistica, p.5

${ }^{36}$ Neste quadro, a reorganização da estrutura do Estado para a promoção e gestão das novas políticas territoriais e urbanas receberam tratamento diversos segundo os diversos momentos políticos pelos quais os países passavam. Ainda que, como mostra Gasparrini (1994), a diferença das diversas linhas ideológicas tenha, de maneira geral, se esvaido, levando à certa confusão entre as atribuições público/privado, além de uma duplicação da estrutura administrativa-política. Neste sentido é paradigmático o caso da desregulamentação total promovido pelo governo de Tatcher cuja maior expressão, no bojo do lançamento das "enterprise zones"— áreas designadas sob condições fiscais e normativas especiais para estimular sua renovação— viria a redundar no projeto das Docklands de Londres sob a gestão "centralizadora" da LDDC. A grande polêmica gerada por esse projeto talvez possa ser sintetizada nos seguintes pontos:

- grande processo especulativo alimentado por aquela desregulamentação (afastando do processo inclusive as várias administrações locais)“"

- a falta de qualquer planejamento do empreendimento, o que levou a iniciativa privada a "bancar" os recursos para a infra-estrutura de transportes, deficitária como era frente ao enorme patrimônio construído posto em jogo pela própria desregulamentação;

- o controvertido resultado urbanístico e arquitetônico de toda a operação, fragmentado e desvinculado, sem qualquer coerência de conjunto.

No entanto, não obstante todos estes pontos polêmicos, o novo governo central (agora liderado pelo Labor Party) acabaria dando (sob novo registro de gestão? ou mesmo projetual?) continuidade 
à transformação das margens do Tâmisa segundo um projeto de grande escala concebido pelo arquiteto Richard Rogers.

Em outro extremo, o caso francês evidencia a "competição" política e administrativa entre diversos níveis da administração central e local. Competição essa que se expressa segundo duas iniciativas de signo diverso: os "grandes projetos" de Mitterand e os instrumentos tradicionais de Chirac, então prefeito de Paris, através das Zac (Zone d'amenagement concerté), Sdau (Schema directeur d'amenagement et urbanismo) e Pos (Plan d'ocupation de sol). No entanto, o desenvolvimento dessas linhas de atuação aparentemente contraditórias, acabariam evidenciando uma relação sinergética, sobretudo quando os grandes projetos são absorvidos por operações de requalificação de partes degradadas da cidade. No amplo projeto para o setor leste de Paris Seine Rive Gauche, por exemplo, as Zac's de Bercy e de Tolbiac, reconquistando área de ferrovia para residência e serviços diversos, integram-se à funções de altíssimo nível como a nova Biblioteca Nacional e o Ministério da Finanças, conjugando, segundo um plano de requalificação de uma das partes mais degradadas da cidade, intervenções de recomposição morfológica de tecidos consolidados com projetos de implantação de "novas centralidades". Contrariamente à experiência londrina (onde prevaleceu a lógica política ou imobiliária da imagem "espetacular" como forma de atração de investimentos internacionais), tais projetos buscam exprimir a necessária complexidade funcional e social da cidade, conciliando "as duas velocidades do território". isto é, qualidade de vida e do espaço urbano, de um lado, e, de outro, a necessidade de competição internacional. Outros exemplos de cooperação e integração entre os vários níveis governamentais podem ser constatados também na operação Kop van Zuid em Roterdã (onde o governo central responsabilizou-se pela dotação de infra-estrutura enquanto ficava a cargo da administração municipal, em parceria com a iniciativa privada, a criação de um centro de negócios internacional, conjugando esforços dentro de uma nova política territorial da Randstad — sistema metropolitano holandês composto pelas cidades de Amsterdã, Roterdã, Haya e Utrecht). Ou Barcelona, onde a implantação da estação de TAV — Trem de Alta Velocidade— em Sant Andreu/Sagrera, segundo um projeto comum do MOPT, Generalitat e Ayuntament, obedeceu mais a lógica urbana do programa das "Áreas de nova centralidade", no sentido de tirar proveito do novo fator indutor de transformação para o processo de requalificação de bairros suburbanos ou áreas deterioradas), que a estritamente territorial, cujos postuladores defendiam a tese da localização da estação junto ao novo porto e aeroporto, conferindo uma suposta corência à reordenação do sitema viário geral da metrópole.

Há que se notar neste ponto que, a partir de uma mudança de mentalidade das autoridades ferroviárias e portuárias em relação à reutilização das antigas instalações, obsoletas e em desuso, as cidades passariam a amplamente recuperar para uso urbano grandes extensões de terra central pelo desenvolvimento de projetos de áreas de nova centralidade, como exemplificam, ainda que sinalizando casos de conflito entre os diversos agentes e interesses envolvidos, a reconversão de Port Vell em Barcelona e da área Garibaldi-Reppublica em Milão. (vide P. M. R. Sales, Trabalhos Programados, 1998)

${ }^{37}$ G. Dematteis. "La scomposizione metropolitana”, 1998

${ }^{38}$ Id., Ibid.

39 Segundo B. Secchi (1989), a solução não pode mais nascer sómente dentro do processo de interação e contratação entre os diversos agentes sociais, à medida em que em uma sociedade de "minorias" o espaço da autoridade não é referível a um único pólo e a mobilidade social não é exclusivamente do tipo ascendente ou descendente. Daí a dificuldade de pensar os sujeitos coletivos como representantes e/ou demandatários de interesses gerais pois o sistema de estratificação social, fechado e fortemente hierarquizado, teria deixado de ser, após a crise dos anos 70, o principal regulador, em termos econômicos ou políticos, do sistema de interação e contratação social.

${ }^{40}$ Carlo Gasparrini. L'attualitá dell'urbanistica. Etsalibri, Milão,1994, p. 9

${ }^{41}$ Vide Campos Venutti. La terza generazione del piano

${ }^{42}$.B Secchi. "Piani della terza generazione" in Un progetto per la urbanistica, 1989, p.114

${ }^{43}$ B Secchi. "Ridurre la complessitá", in Urbanistica, p. 4

${ }^{44}$ Pode ser interessante notar que a partir da crítica ao "racionalismo" e à "modelística" dos anos anteriores, a passagem da "crítica materialista" às intervenções de reequipamento das periferias, chegando ao predomínio do "enfoque morfologista", foi realizada, de modo geral, pela mesma geração de urbanistas, tanto na Itália como na Espanha.

${ }^{45}$ Joan Busquets. Barcelona, evolución urbanística de una capital compacta, 1994 p.31

${ }^{46} \mathrm{Ibid}$

${ }^{47}$ B. Secchi, "Ridurre la complessitá" in Urbanistica no 85, p.4

${ }^{48}$ Ibid. 
${ }^{49}$ Id. "La riduzione fertile" in Urbanistica n'90, p. 4

"Do geral ao particular, do conjunto ao detalhe, da regra à excessão ... de que o conhecimento deva preceder a decisão, que a análise deva preceder ao projeto... que o plano geral deva sempre preceder ao particular, a definição da norma deva preceder a elaboração de um projeto específico" ${ }^{50}$ Id. "Ridurre la complessitá" in Urbanistica $n^{\circ} 84$, p.6

${ }^{51}$ Não no sentido tratadístico (sistematização, codificação ou generalização de princípios universais ou ideais) mas como "uma tentativa experimental de fazer corresponder antecipação dos eventos com processos inscritos no corpo urbano de maneira que possam ser guiados a objetivos de transformação desejados" (S. Crotti, Urbanistica n ${ }^{\circ}$ 89, p. 75)

${ }^{52}$ Id. "Nuove forme de razionalitá". In Urbanistica no 91

${ }^{53}$ B. Secchi. "Disegnare il piano". in Urbanistica n ${ }^{\circ} 89$, p.13; "La riduzione fertile" in Urbanistica, $\mathrm{n}^{\circ}$ 90, ${ }^{\circ} .5$; "L'eccezione e la regola" in Un progetto per l'urbanistica., 1989, p.80 e seg..

“... projetar o espaço aberto, a sua articulação, o materiais que o constituem, as relações que o conectam ou desunem-no internamente, que o ligam ou separam do espaço edificado, os modos nos quais essas mesmas relações se fazem materia -rua, ponte, calçada, linha de bonde, etc".

As "regras" apresentam-se sob "forma de reconhecíveis modalidades de partição do território, de definição e articulação de caracteres morfológicos do espaço edificado ou não, eventualmente de definições tipológicas". E se regra é relação entre objetos, os procedimentos para Secchi, indicam a relação entre sujeitos e objetos (sua produção e apropriação). Ambos remetem, "não de um modo unívoco e determinístico" à estrutura de interação social: sistemas de trocas, de conflitos, de cooperação entre grupos de interesse, entre proprietários, promotores imobiliários, construtores, entre administração e cidadãos". Desta maneira, "a regra diferencia e especifica o espaço: (...) constrói um sistema de relações possíveis, constrói imagens e representações dotados de sentido dentro das quais a sociedade ou suas partes se reconhecem".

${ }^{54}$ Fundada tanto nos princípios da "naturalidade" de algumas necessidades humanas (daí a proposição do "minimun existens", daí as "necessidades não atendidas" de grupos sociais menos privilegiados, etc.) quanto nos critérios "ótimos” da relação intensidade de uso/relações sociais (como forma de regulação da formação e distribuição da renda social) a análise quantitativa do território configura a possibilidade de "racionalidade" ordenadora do plano segundo argumentos de caráter universal

${ }^{55}$ B. Secchi. "Leccezione e la regola" in Un progetto per l'urbanistica. Op., cit., p. 79

${ }^{56}$ Ibid.

${ }^{57}$ G. Dematteis, La scompozicione metropolitana, 1988

${ }^{58} \mathrm{O}$. Bohigas. Reconstrucción de Barcelona, 1986

${ }^{59}$ B. Secchi. "Dimensionamento" in Un progetto per l'urbanistica. Op. cit., p.73.

Secchi pergunta em que medida as previsões contidas nos diversos planos tiveram implicação na atividade imobiliária (volume de construções, preço da oferta), na distribuição de renda, ou ainda no desenvolvimennto e crescimento da economia local. Antes, ele propõe que se considere a evidência da importância da extensão das área residenciais e industriais sobre as modalidades de assentamento: dispersão/concentração, homogeneidade / heterogeneidade de funções e tipos edificatórios, congruência / incongruência das relações entre as diversas partes da cidade, etc. ${ }^{60}$ Manoel Solá-Morales. "Reconeixement comarcal I ordenació del territori”, in Quaderns 1981, p.59

${ }^{61}$ Giuseppe Dematteis. "Contesti e situazioni territoriali in Piemonte. in Urbanistica n 96, 1989, p. 46

${ }_{62}$ J. Busquets. "Barcelona entre la forma y la reforma". Ayuntament de Barcelona, 1992, p.17

${ }^{63}$ Ibid..

${ }^{64}$ G. Dematteis, La scompozicione metropolitana, Ibid, p.39

${ }^{65}$ E. Morin. Introducción al pensamiento complejo, 1995, p. 102

${ }^{66}$ G. Dematteis. "Contesti e situazioni territoriali in Piemonte, in Urbanistica, no 96, 1989, p.46

${ }^{67}$ G. Dematteis. Progetto implicito, 1996, p.77 


\section{Capítulo 2 \\ SANTOS, SÃO PAULO, CAMPINAS... E OS PROCESSOS DE VALORIZAÇÃO TERRITORIAL}

Se a configuração do território puder ser entendida como formas materiais que o homem vai superpondo à natureza de maneira que se criem as condições de trabalho próprias a cada época e dado que a forma construída permanece além da duração dos processos sociais que lhe deram origem, como um legado aos tempos futuros, ao qual a sociedade tem que se adaptar ou transformar, seguese que a paisagem é, portanto, "resultado cumulativo dos tempos pregressos e do uso de novas técnicas"'. Ou seja, o território, como campo da possibilidade de ação, constrói-se e desenvolve-se através de um lenta e complexa condensação, sedimentação e estratificação de trabalho social, "vivo" e "morto".

Neste sentido, a valorização de cada um dos seus pontos —e a cidades constituem pontos privilegiados - depende da interação das condições naturalmente "dadas" ou historicamente "herdadas" —isto é, aquelas que representam legados de processos não mais vigentes—, com as condições "produzidas" a cada período histórico, como resultado das intervenções "públicas" (em sua dimensão social, coletiva) ${ }^{2}$. Condições essas de cuja "concentração" ou "distribuição" espacial, enquanto política territorial, implícita ou fatual, dependem as oportunidades que se possa ter em termos de desenvolvimento local ou regional.

Assim, buscando entender como as características "próprias" de um lugar, pré-existindo como simples fato físico ou histórico-cultural, tornam-se em dados momentos valores econômicos (ou condição suficiente para a produção de valores econômicos ou, ainda, pelo contrário, limitação e resistência ao desenvolvimento), esta parte do trabalho, trata de identificar as condições, os processos e os fenômenos históricos de valorização territorial no sentido de informar sobre o significado que o porto, como infra-estrutura, ao mesmo tempo herdada e continuamente "produzida", tem para o desenvolvimento da cidade de Santos e seu entorno metropolitano.

Isto se fará, principalmente, através da confrontação dos papéis que Santos e Campinas assumem na conformação do marco teritorial e econômico que se conhece como "Complexo Macrometropolitano Paulista", ou simplesmente Macrometrópole. Sem desconhecer, obviamente, o "peso" da refererência e da intermediação exercido pela capital-metrópole, a opção pelo estudo "cruzado" dessas duas cidades deriva da hipótese de que o rebatimento e confrontação de processos parciais e específicos de construção do território 
possa fornecer, por sua própria “complementariedade", elementos para a verificação dos fenômenos e condições de valorização e desenvolvimento territorial e suas tendências mais recentes. Para tanto serão analisadas as base geo-morfológicas deste território, as "imagens" que explicam ou representam a cada momento histórico as suas transformações, bem como os modelos de estruturação espacial, que posssam sintetizar, "metafóricamente”, as relações de polaridade, dependência, complementariedade que nele se manifestam com o fim de interpretar o papel territorial da cidade de Santos e seu "encaixe" no contexto macrometropolitano.

\section{1. (Geo)morfologia da macrometrópole}

Como síntese "útil" das taxonomias geomorfológicas adotadas para descrever o mapa do Estado de São Paulo, pode-se afirmar que o território do "complexo macro-metropolitano" assenta-se sobre ao menos três "macrocompartimentos morfoestruturais". Adotando a divisão proposta por Ross e Moroz (1997), estas grande unidades de relevos (tomadas na pespectiva de sua gênese, "onde entram elementos morfo-estruturais e morfoclimáticos”) são as seguintes:

- Cinturão Orogênico do Litoral”, que em sua vasta extensão de antigos terrenos cristalinos (desde o Uruguai até o norte da Bahia), abriga o Planalto Atlântico e suas distintas fisionomias regionais, incluida aí a Serra do Mar e os morros litorâneos

- Bacias Sedimentares Cenozóicas", onde se destacam as unidades das Planícies Litorâneas e as Bacias (de São Paulo -Tietê-, de Taubaté Médio Paraíba- e do Baixo Ribeira)

- Bacia Sedimentar do Paraná", na sua parte relativa à borda ocidental da "Depressão Periférica Paulista", que inclui a Depressão de Moji-Guaçu e a do Médio Tietê

Nesta divisão, a "área" metropolitana de São Paulo, ao irradiar-se pelo Planalto Atlântico, a partir da Bacia Sedimentar de São Paulo, abarca, além dela, porções de diversas zonas, sub-zonas e bacias (destacando-se o Planalto Paulistano que abrange mais de $60 \%$ deste território). O Litoral ${ }^{3}$ compreende tanto unidades do Planalto Atlântico (Serra do Mar e Morros Litorâneos) como as Planícies Litorâneas das Bacias Sedimentares (Santista, Bertioga, Litoral Norte). Já, as cidades do Vale do Paraíba alojam-se sobre a unidade da Depressão do Médio Paraíba — Bacia de Taubaté, embutida na porção nodeste do Planalto Atlântico—, enquanto Campinas e Sorocaba estabelecemse sobre a linha divisória entre o Planalto Atlântico (unidade Planalto de Jundaí) e a porção leste da Depressão Periférica Paulista. 


\section{A Baixada Santista}

Deixando por ora de lado o "Mapa Geomorfológico" de Ross e Moroz (1997), pode-se afirmar que a geografia física do litoral paulista compreende três grandes seções ou sub-unidades: o Litoral Norte, a Baixada Santista e o Litoral $\mathrm{Sul}^{4}$. A característica que os distingue é a relação da costa com as escarpas da serra do Mar. Essa constitui a mais maciça e contínua muralha de separação entre o litoral e os planaltos interiores existente nas costas brasileiras e, assim, com suas vertentes abruptas e escarpas assimétricas ${ }^{5}$, configura toda a fachada litorânea paulista por algumas centenas de quilômetros, margeando o Planalto Atlântico desde a região do Planalto da Bocaina, na divisa com o Estado do Rio de Janeiro, ao norte, até a região do vale do Ribeira de Iguape, ao sul.

Se na porção norte desta fachada, os frontões da serra entam em contato direto com as águas do mar (caracterizando exemplos de "costas de abrasão"), ao sul, as escarpas da serra afastam-se progressivamente da orla marítima. Assim, no Litoral Norte, os esporões rochosos da serra, avançando intercaladamente sobre o mar, recortam o litoral, com inúmeras enseadas, cabos e ilhas e encaixam, sucessivamente, pequenas praias. Na porção sul, dominantemente retilínea, as extensas planícies ou terraços litorâneos, cada vez mais amplos $(80 \mathrm{~km})$, comportam ampla área lagunar, barrada por linhas de restinga antigas, como a ilha Comprida e a de Cananéia. O setor da Baixada Santista ${ }^{6}$ apresenta-se, portanto, sob o ponto de vista fisiográfico, como a área de transição, reunindo as características dos dois outros setores de uma maneira sui-generis: aí, a serra perde sua continuidade ao se destacarem (como que desvinculados dela) alguns maciços isolados. Esses maciços, compondo originariamente um antigo "paleo-arquipélago quaternário", "afloram sob a forma de morros isolados na horizontalidade da planície (e, assim) constituem pontos de amarração para os processos de colmatagem"”, que se dão em sua parte posterior, alimentados pelas alta densidade de drenagem da serra. Neste quadro, a ilha de São Vicente, entre a grande ilha de Santo Amaro, a leste, e o litoral da Praia Grande a oeste, coloca-se como um vasto tampão "que separa as águas ocupadas por manguezais, que se desenvolvem desde as bases da Serra do Mar, e o oceano, dificultando o escoamento das águas continentais que vertem da serra e dos maciços litorâneos, como as do Jurubatuba, Quilombo, Mogi, Cubatão, Branco e Piassubuçu"». Os inumeráveis cursos d'água provenientes da serra responsáveis pelo carregamento da sedimentação fina - e os movimentos da maré —fator de "salinidade" e "turbilhonamento"- acabaram resultando em uma labiríntica rede de drenagem superficial ("delta-estuarino"), que, pela massa líquida formada ao redor da Ilha de São Vicente, evidencia a dificuldade que essa rede possui para encontrar saídas para o mar e explica os processos de assoreamento das barras. Convergindo no Largo do Caneú (braço de água 
com largura variável que atinge $2 \mathrm{~km}$ ), essa rede encontra as águas do oceano através de três barras:

- a de São Vicente (entre o morrro de Japuí e a ilha Porchat, rasa e de fundos irregulares),

- a do canal de Bertioga (entre a Ilha de Santo Amaro e os espigões da Serra do Mar, com calha estreita e pouco profunda)

- a Grande dos Santos, mais conhecida como o estuário de Santos .

Tal esquema fisiográfico daria à Baixada Santista vantagens locacionais: propicia o porto e explica o povoamento. No entanto, sua preeeminência em relação às demais áreas do litoral paulista, onde sucedem-se, particularmente em sua porção centro-norte, inúmeros ancoradouros naturais, dependeria, em grande medida, do problema de superação do obstáculo da Serra do Mar.

\section{A serra e os caminhos}

Denis $(1910,1927)$ e Mombeig $(1937,1940)$, entre outros ${ }^{10}$, destacaram o fato de existir na área imediatamente contígua à Baixada Santista uma ligeira "enseladura" topográfica (de 800m de altitude) na Serra do Mar, bem como sublinharam sua importância no estabelecimento das relações entre o litoral e o planalto. À observação de que na região santista a Serra do Mar perde altura na medida em que se afasta do litoral, há que se acrescentar o fato de que a mesma, após um trecho de paredões contínuos e relativamente maciço — que se estende desde o canal de São Sebastião até a Bertioga — apresenta, nesta área, um quadro topográfico bem mais complexo. A quebra da continuidade das suas escarpas, pelo destacamento de esporões do corpo principal, se por um lado, como observado acima, caracteriza a geografia física do litoral de Santos (dando origem à presença de maciços isolados e à subsequente sedimentação flúvio-marinha do "delta estuarino"), por outro lado, responde por um padrão de drenagem que, adaptado às direções das estruturas de falhas e fraturas, iria desenhar vales de grandes entalhamentos e assim criar, com maior ou menor facilidade, as condições de se estabelecer a comunicação litoral-planalto.

Sobre as trilhas indígenas" e com poucas variações durante séculos, a ligação litoral-planalto aproveitou-se fundamentalmente dos cursos d'água e dos vales dos rios. Até a construção do aterro do Cubatão (uma "estrada de carro", inaugurada em 1827), as viagens eram feitas em barco, navegando-se pelo rio do mesmo nome, desde o Largo do Caneú (centro de convergência dos cursos d'água na planície) até o porto fluvial no pé-da-serra e, daí, serra acima, ora utlizou-se o vale do Mogí (trilha dos Tupuniquins), ora o vale do Perequê (caminho do Padre José). Na verdade, "Perequê e Pedras chegaram a dividir as atenções, o segundo terminando por prevalecer (calçada de Lorena (1791), 
estrada da Maioridade (1844), estrada do Vergueiro (1852), caminho do Mar (1930)" "12.

Notando que estes traçados têm rampas fortíssimas e curvas tão fechadas (pois, ao utilizarem-se dos vales dos rios Perequê e Pedra, não "ladeiam" a serra), Rodrigues (1965, p.30) vai destacar as possibilidades "morfológicas" para a transposição das encostas da serra, representadas pelos vales dos rios Mogi e Cubatão. Tais vales, encaixados, pela erosão, nas camadas de xisto existentes na gigantesca muralha gnáissaca, desenvolvendo-se paralelos entre si, mas segundo sentidos opostos, oferecem — na forma de "pinças de caranguejo" quatro passagens naturais entre São Paulo e Santos; passagens essas que se dariam pelas seguintes vertentes:

- vertente direita do rio Cubatão, hoje ocupada pelo ramal MairinqueSantos da Estrada de Ferro Sorocabana;

- vertente esquerda do rio Cubatão, chamada Serra do Cubatão, hoje ocupada pela Via Anchieta;

- vertente esquerda do Rio Mogi, chamada Serra do Morrão, ocupada pela Estrada de Ferro Santos-Jundiaí;

- vertente direita do Rio Mogi, chamada Serrra do Mogi".

Se destes vales só a última vertente ainda não foi aproveitada para a transposição da serra (seria excessivamente curta para a ferrovia), o certo é que se não existisse o obstáculo representado pela Serra do mar, "a partir do porto marítimo as rotas continentais abrir-se-iam em leque para todas as direções, a retro-terra ficando articulada com as rotas marítimas por intermédio de um único ponto"»

Para Ab'Saber, estas características fisiográficas da Serra do Mar teriam que ser consideradas apenas como um dos fatores na explicação da fixação e garantia das relações entre o litoral e o planalto. Os outros fatores seriam o relevo dos Campos de Piratininga — um "dos mais suaves e individualizados da periferia do Planalto Atlântico"- e as inúmeras passagens naturais que este sítio propicia para todas as direções do hinterland. Seguindo o raciocínio do geógrafo,

de que valeria, por exemplo, um compatimento suave e individualizado de Planalto, sem acesso rápido, fácil e direto para um sítio portuário de valor? Por outro lado, que significado teria a existência de um bom porto natural na fachada costeira, em face da inexistência de espaços e áreas humanizáveis do Planalto? Ou ainda, que prioridade poderia ter a região de São Paulo, na concentração das rotas terrestres paulistas, se se repetissem, com frequência, as mesmas condições fisiográficas em áreas vizinhas ou contíguas? ${ }^{14}$. 
Porém, lembrando Caio Prado ${ }^{15}$, ou seja sua constatação da pobreza do solo em um raio de 50km em torno da cidade de São Paulo, poder-se-ia reclamar a ausência, entre os fatores arrolados na análise do geógrafo, da consideração da especificidade e potencialidade do território interior. De qualquer modo, na vertente continental, os vales e compartimentos de planalto da bacia sedimentar do alto Tietê (sobre a qual iria se estender a mancha urbanizada da metrópole de São Paulo), sendo sucessivamente aproveitados para irradiar os caminhos, tornaram os Campos de Piratininga o principal nó de amarração das rotas marítimas e das rotas terrestres. Assim acabariam possibilitando a constituição de um verdadeiro "porto-seco"16 que imporia, como se tratará logo adiante, o binômio Santos-São Paulo sobre todos os outros binômios existentes no período colonial.

\section{O Planalto Atlântico e a bacia sedimentar de São Paulo.}

Escalada a serra, a partir da cabeceira do rio das Pedras e utilizando-se também os vales do Grande, Meninos, Tamanduateí, penetra-se em outro domínio: a das "terras altas" do Planalto Atlântico que se estende, como a parte paulista de uma região fisiográfica mais ampla, aos estados vizinhos. "O modelo dominante do Planalto Atlântico constitui-se por formas de topos convexos, elevada densidade de canais de drenagem e vales profundos. É a área do "Domínio dos Mares de Morros" definidos por Ab'Saber (1970)"

Em uma primeira leitura, os grandes traços morfológicos que, de maneira geral, caracterizam o Planalto Atlântico são o paralelismo das duas serras - a do Mar e a da Mantiqueira-, e a interrupção de sua unidade "morfoestrutural" (observadas as variações fisionômicas regionais ${ }^{18}$ ) por duas bacias sedimentares (cenozóicas), que se acham como que encaixadas nele. A de São Paulo e a do Paraíba do Sul, ambas contrapondo "as formas tabulares de suas argilas e areias terciárias às formas arredondadas ou às cristas das serras que as emolduram" " O que merece ser destacado, segundo Mombeig (1957, 133), é que

a vida urbana encontra nas bacias todos os elementos propícios ao seu desenvolvimento: o espaço e a posição favorável aos grandes eixos de circulação. No vale do Paraíba, as cidades acompanham a antiga estrada do Rio de Janeiro, marcando ao mesmo tempo na planície a etapa para os viajantes que iam, com suas tropas, do litoral a Minas Gerais. Na história, São Paulo tomou o lugar de Santo André da Borda do Campo; a bacia sucedeu à região serrana. A metrópole contemporânea, cuja expansão urbana se processou graças às várzeas do Tietê e às colinas terciárias, também se acha estreitamente ligada aos planaltos. Estes a circundam por todos os lados, e condicionam-lhe as vias de acesso, quer as rodoviárias, quer as ferroviárias e mesmo as aéreas." 
Se ao sul, foram os vales dos rios que sugeriram, entre "o relevo amorreado, relativamente rebaixado" da Morraria do Embu, as passagens e os caminhos em direção à vertente oceânica, a nordeste, as estradas para o Rio de Janeiro desenvolveram-se sobre os terrenos planos da bacia sedimentar do Médio Paraíba. Ao norte, os vales encaixados nas áreas serranas ou de morros mais ou menos acidentados, favoreceram a implantação dos eixos viários, que, para além do Planalto de Jundiaí, iriam se desenvolver sobre os terrenos da Depressão Periférica Paulista e suas três grandes bacias de drenagem ${ }^{20}$.

Assim pode-se observar que se as condições geomorfológicas fizeram as entradas do Estado de São Paulo - pelo mar, pelo vale do Paraíba e por Sorocaba- convergirem sobre a capital, também os caminhos para o interior encontrariam nos Campos de Piratininga meio propício para se irradiarem. Como anotou Monbeig ${ }^{21}$ :

Uma vez transposto o escarpamento da Serrra do Mar, não há mais dificuldade séria, verdadeiramente capaz de entravar as comunicações. A construção das vias férreas irradiantes ao redor da capital não esbarrará nunca com dificuldades técnicas de importância; há nisso grandes vantagens geográficas que é necessário não desprezar se se quiser compreender a rapidez com a qual se povoou o interior".

\section{A Depressão Periférica Paulista}

A simples observação de uma carta geomorfológica de São Paulo evidencia o papel de transição que a Depressão Periférica exerce entre o Planalto Atlântico e o Planalto Ocidental Paulista: de um lado colocando-se na periferia do maciço antigo e de outro, sendo limitada pela "cuesta" da Serra de Botucatu. Ao mesmo tempo, essa observação salienta o curso de alguns rios principais (Tietê, Paranapanema, Moji-Guaçu e Pardo) que, "mantendo seu antigo traçado dirigido para NW em direção ao eixo da bacia do Rio Paraná"22, cortam a forma de arco da Depressão segundo grandes bacias de drenagem e assim caracterizam suas unidades "morfoesculturais" respectivas ${ }^{23}$. Unidades essas que, vencidas as cotas de 800 a 1200m da "cuesta", se fazem correponder aos planaltos residuais interiores, cujos espigões estabeleceram as diretrizes das comunicações do processso cafeeiro de colonização. Processo esse que, deslocando-se das terras do Vale do Paríba e valorizando o papel das bacias sedimentares e dos terrenos cristalinos dos vales do Atibaia e do Capivarí (onde o afloramento de diabásio e basaltos formava verdadeiras ilhas de "terra roxa"), iria desde a região de Campinas suceder a cultura canavieira e expandir-se, sucessivamente, a toda porção noroeste e oeste do Estado.

Situadas logo após o alinhamento de cristas das $\operatorname{serras}^{24}$ e, portanto, sobre a linha divisória que demarca a passagem dos relevos de natureza "gnaissica" do 
Planalto Atlântico para os "sedimentares" da grande Bacia do Paraná, Campinas e Sorocaba (além de Itú), guardando traços característicos de ambos esses relevos (a leste, a serraria dos Planaltos de Jundiaí e Ibiuna/São Roque e, a oeste, a topografia suave e os vales amplos da Depressão Periférica), constituiram verdadeiras "portas" das apertadas saídas do planalto e assim serviram como ponto de apoio para as comunicações, respectivamente, com o norte (Minas Gerais, Goiás e Cuiabá) e com o sul (Viamão-Rio Grande do Sul). No caso do primeiro destes eixos de comunicação, a inclinação para o norte do arco da Depressão Periférica, encontrando o rebaixamento das cuestas na altura do vale do Moji, seria aproveitada pelo caminho de penetração interior dos Guaiases, enquanto ao sul, o reforço da integração territorial dos Campos de Vacaria ao eixo Rio-São Paulo-Minas (servindo ao comércio e às estratégias de colonização e defesa), iria encontrar nos campos limpos e suaves do médio Paranapanema o território onde desenvolver seu canal de circulação com o Brasil meridional. Sobre estes eixos, em torno dos pousos, estabelecer-se-iam os principais núcleos de povoamento.

$* * *$

Ainda que composta por três domínios geo-morfológicos bastante distintos que se sucedem em uma faixa de 150/200km a partir do litoral, a entidade territorial, denominada Macrometrópole, define as bases de seu desenvolvimento econômico, precisamente a partir das relações que a ocupação antrópica, a cada período histórico, estabelece entre esses domínios, explorando de forma complementar suas especificidades e potencialidades geográficas. Suas inter-relações e articulação como sistema territorial uno remetem-se aos primeiros momentos da ação do homem sobre êle e irão se tornando mais complexas e efetivas à medida que a concentração de recursos e equipamentos irá, sucessivamente, construindo sua fluidez. As condições do relevo e drenagem ajudam a explicar a formação dos núcleos e a definição dos caminhos. Os processos territoriais que se desenvolvem, ainda que abarcando domínios geológicos, geomorfológicos e de clima distintos, fazem supor a existência (definição e permanência) de um baricentro, a partir do qual aqueles processos articulam-se e diferenciam-se, contidos em contornos mais ou menos precisos. Este baricentro — a cidade de São Paulo— explica as "margens" deste território e justifica seus limites. Constituído no entroncamento dos caminhos, a força desse baricentro decorreria particularmente de sua posição na trama de articulação do interior com o litoral, constituindo, como se observou, um verdadeiro "porto seco".

Se um certo "determinismo" geográfico (Maia, 1951), a "permanência de certas causas" (Prado, 1961), ou ainda, a "recorrência de certas soluções" (Petrone, 1965) tiraram partido do entendimento "morfológico" do espaço para a explicação dos pontos catalizadores de aglomerações, das linhas de comunicação e do desenvolvimento das atividades, particularmente evidentes 
na unidade Santos-São Paulo, por outro lado, o "uso alargado" do território revela, face às próprias condições geo-morfológicas, suas contradições, tanto em termos físicos quanto de gestão. Especificamente em relação à ocupação do solo na região da Baixada Santista, algumas das contradições, que afetam mais diretamente o tema da infra-estrutura portuária, a construção das cidades e o desenvolvimemento econômico, remetem-se, como se tratará adiante, às condições do relevo e da drenagem. 


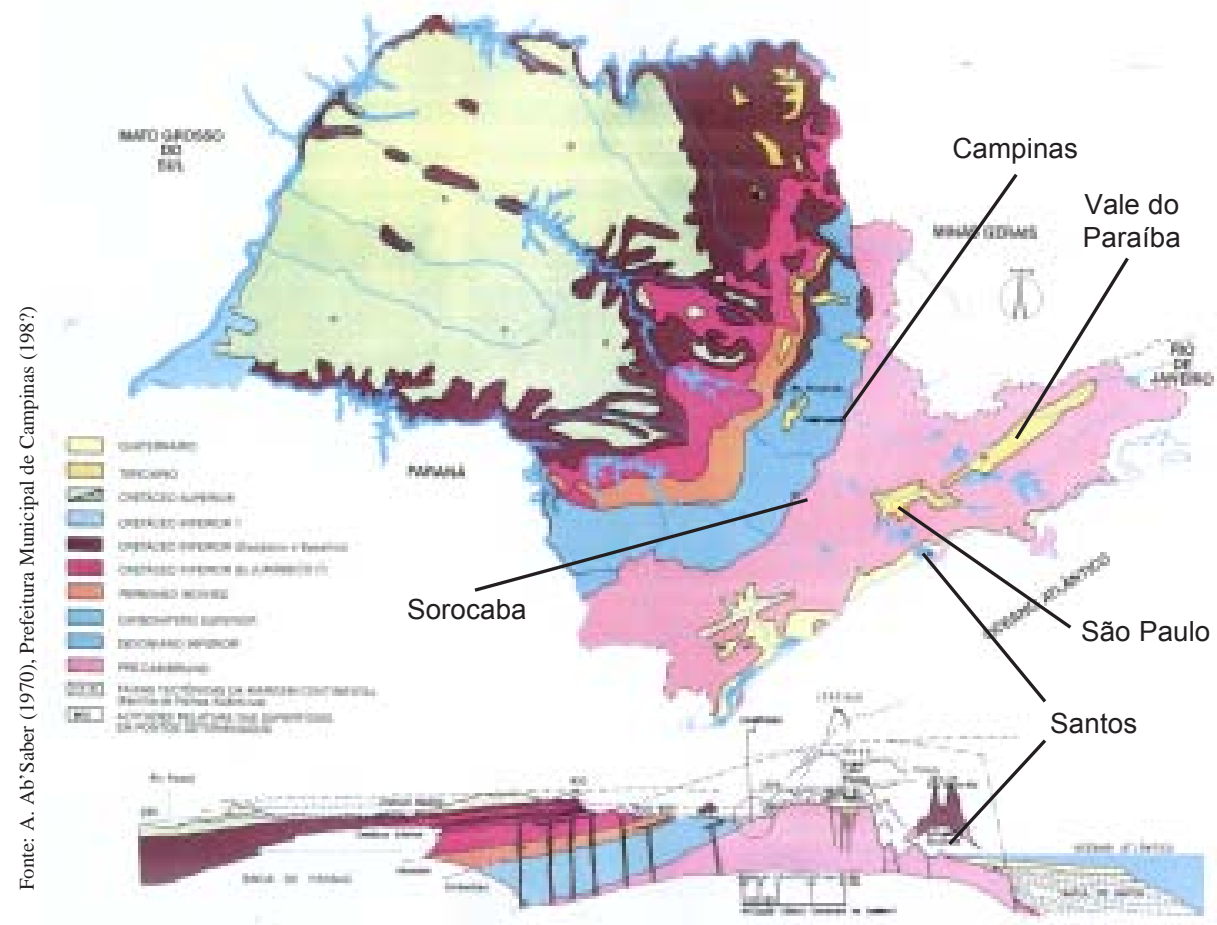

Compartimentos morfoestruturais do Estado de São Paulo: o território macrometropolitano assenta-se sobre três desses compartimentos — Planalto Atlântico (rosa), Bacias Sedimentares (amarelo/laranja) e Depressão Periférica (azul)

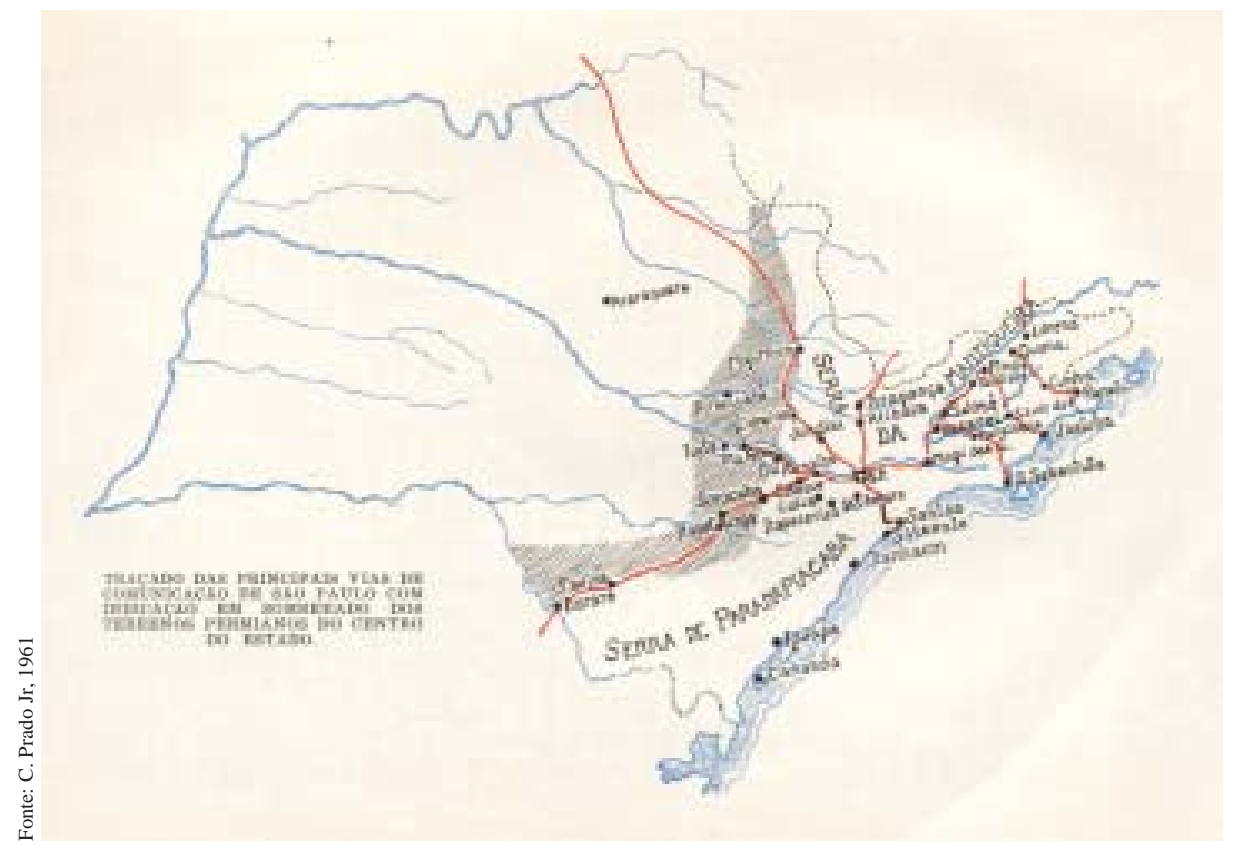

A relação entre os traçados das vias de penetração e a geomorfologia, ressaltando-se a linha do vale do Paraíba (nordeste) e o arco da Depressão Periférica que condicionam as principais diretrizes, a partir de São Paulo 
Litoral paulista:

hidrografia, relevo e cobertura vegetal. Ao norte a serra em contato com a água, ao sul, grandes extensões de áreas de restinga fazem a transição entre o planalto e o litoral. A Baixada constitui elemento de transição fisiográfica.

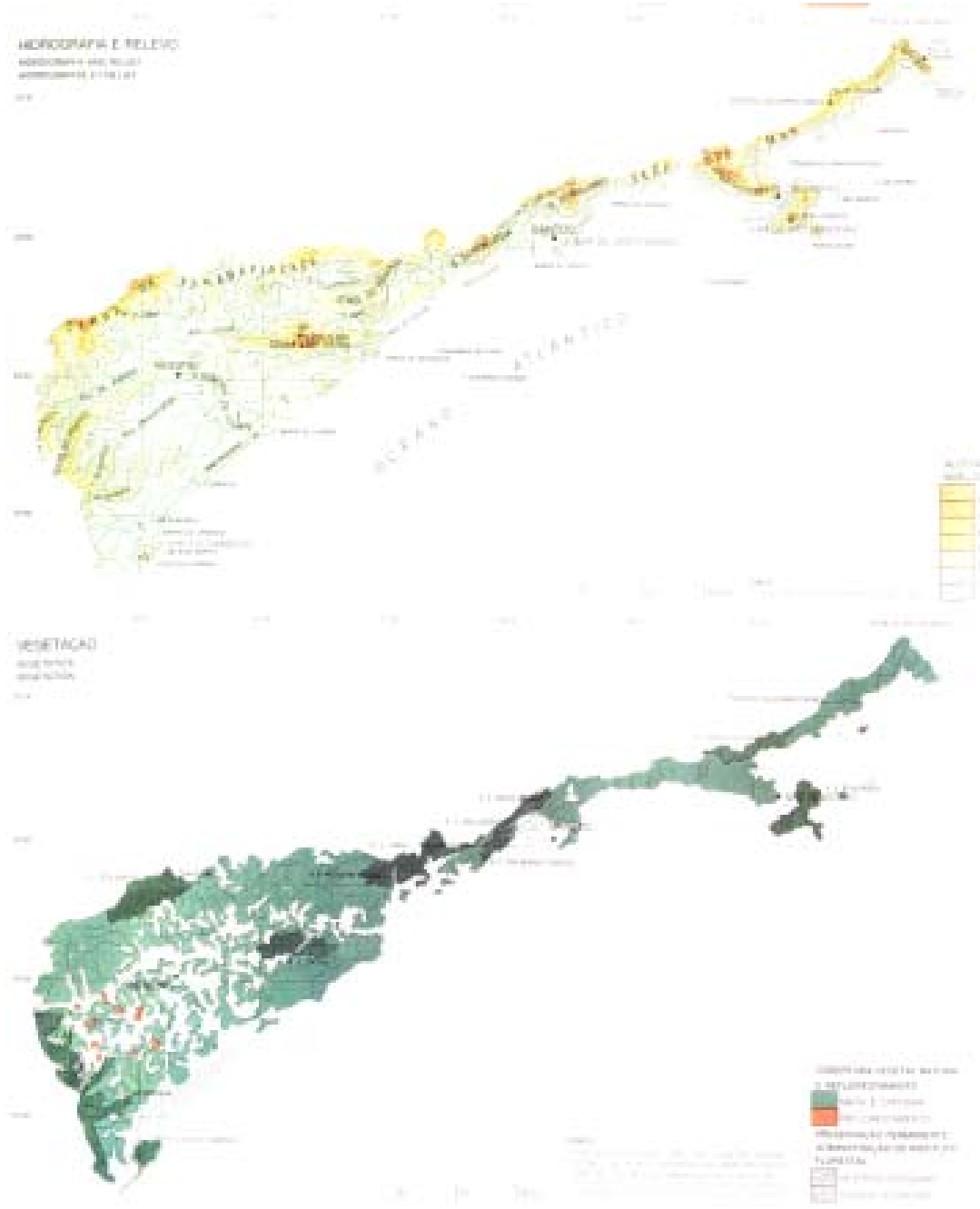

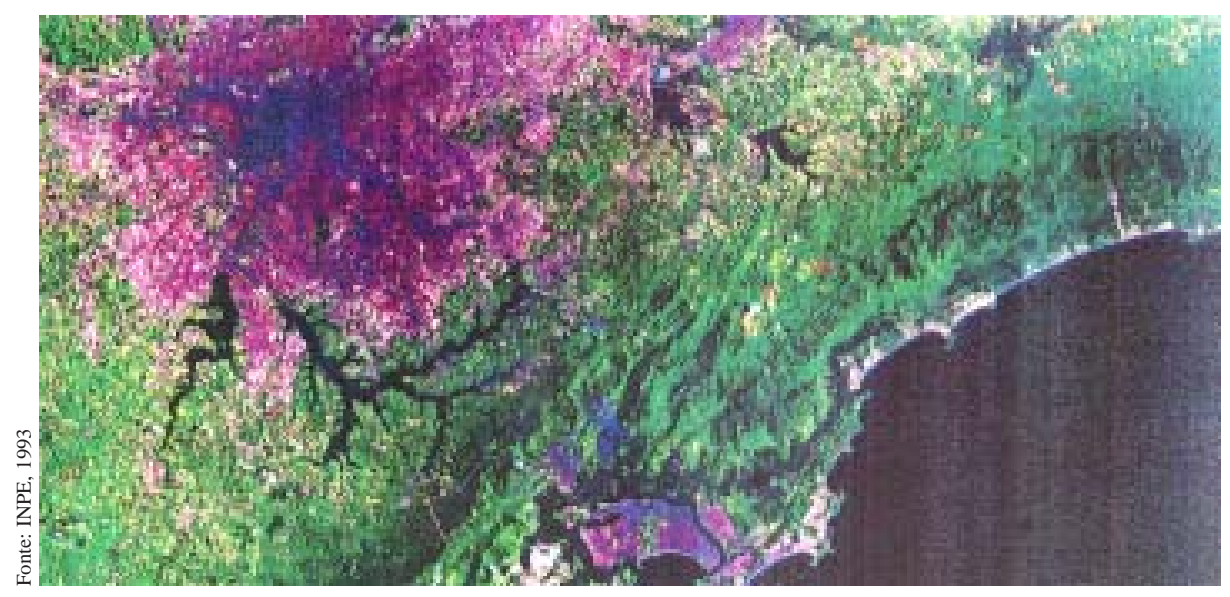

Imagem do satélite Landsat-5: a sudeste, um setor da Baixada Santista (compreeendendo as duas illhas - São Vicente e Santo Amaro - , o manguezal, além dos municípios de Cubatão, São Vicente, Santos e Bertioga). A grande mancha em tons arroxeados constitui a malha urbana da Grande São Paulo. Separando planície e planalto, as escarpas da Serra do Mar 
Vista desde o norte da ilha de São Vicente: o largo do Caneú, o estuário, os morros e a planície sedimentar
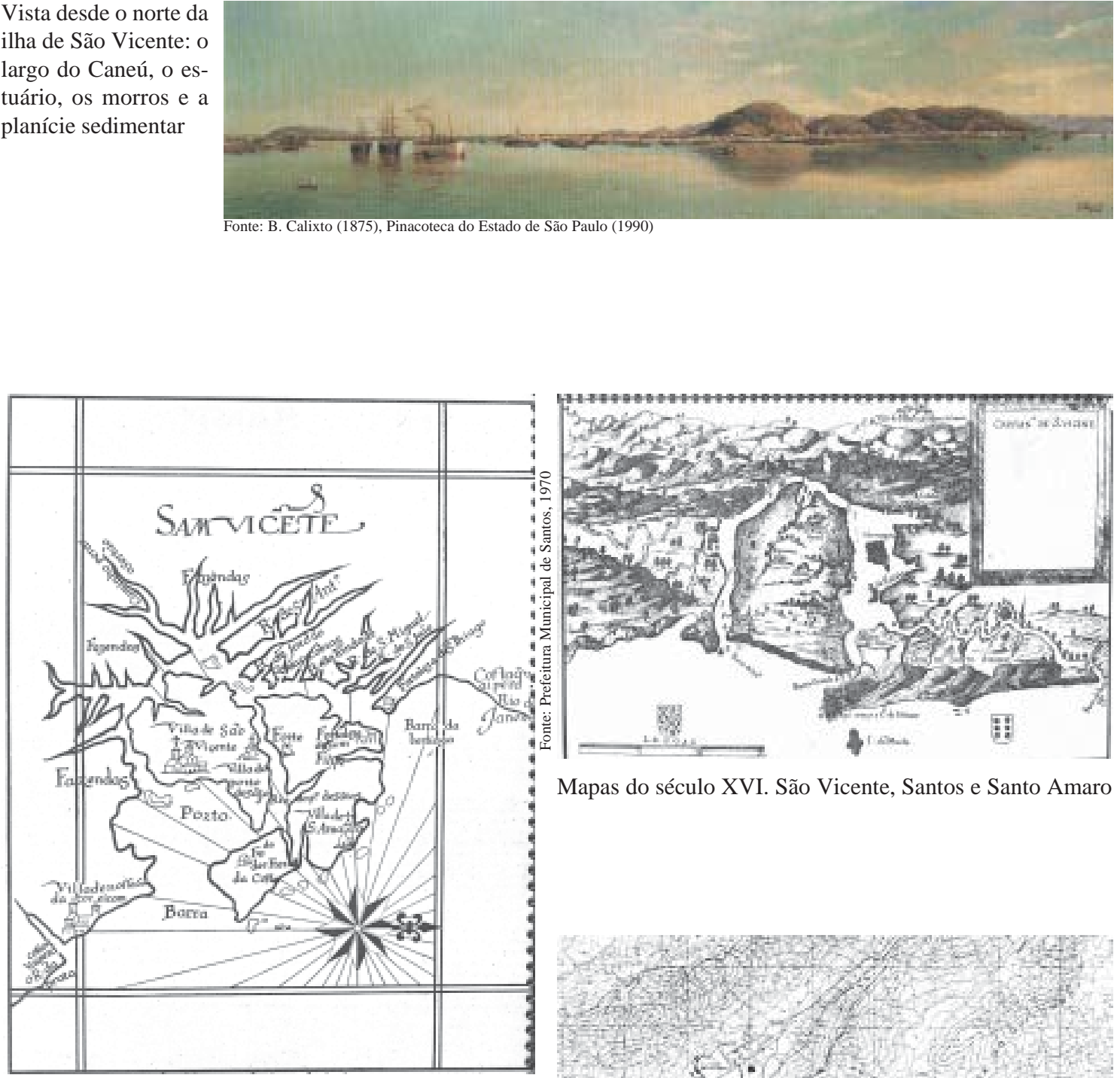

Mapas do século XVI. São Vicente, Santos e Santo Amaro

Planta do setro central da Baixada Santista: os contrafortes da serra, a rede de drenagem e a ilha de São Vicente — 병 elementos fisiográ-ficos que condicio-naram o porto, as áreas de assentamento e os caminhos para o planalto

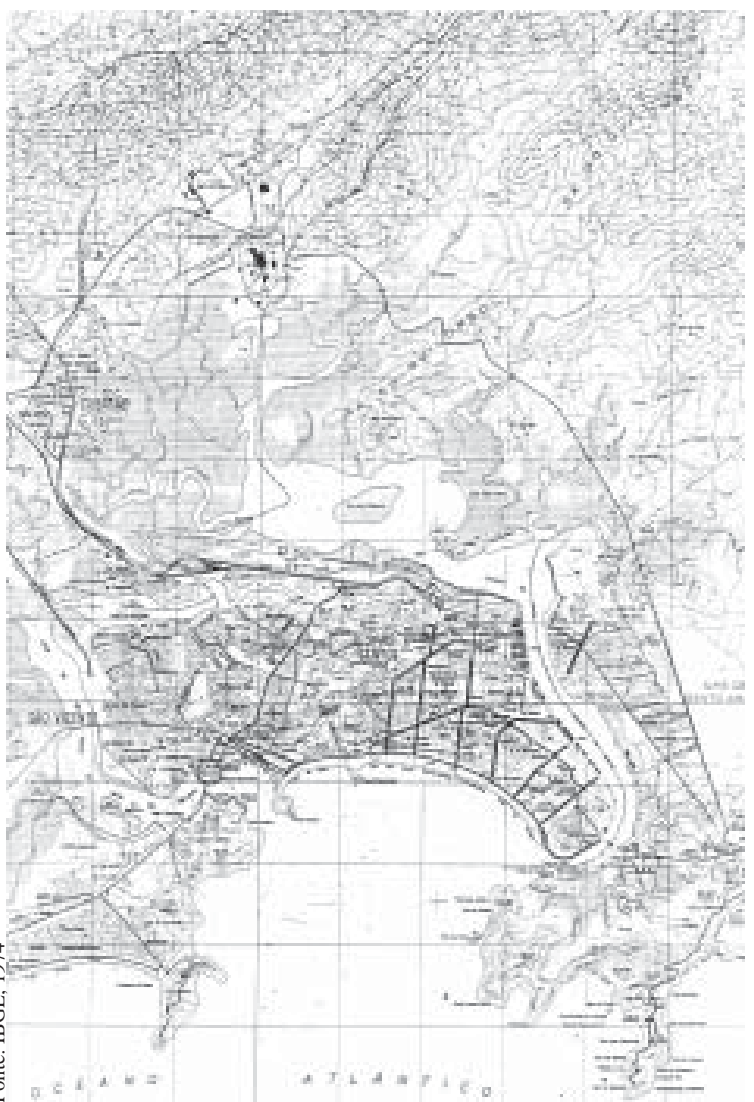




\subsection{As representações do território e suas transformações}

Se é a construção/utilização do território, e não o território em si que interessa, as imagens territoriais — representações mentais que justificam o existente ou que antecipam as mudanças de situações territoriais_-podem ajudar a compor um quadro interpretativo dos modos e das formas através das quais esse território se estrutura e se oferece, ou cria resistências, aos processos de uso e transformação. Isto é, a partir das diferentes "imagens" que representam os momentos significativos de transformação do território, pode-se tentar identificar tanto seus elementos "fortes", definidores, quanto a variação no tempo de suas inter-relações e do seus significados.

\section{$1765 / 1775$}

O reconhecido distanciamento da Capitania de São Paulo das primeira etapas da colonização, tanto em termos físicos quanto econômicos, políticos ou militares (os primeiros talvez explicando os segundos - fato que acabaria implicando na ausência de "ações" territoriais mais consistentes em termos de estabilidade), sugere tomar, como ponto de partida desta descrição, a denominada "Restauração" enquanto momento no qual, incluída nas estratégias portuguesas de povoamento e defesa, a porção paulista do território brasileiro passa a experimentar um dinamismo relativamente maior de sua base econômica e uma maior fixidez de assentamentos e infra-estruturas. Neste sentido foi concebida a missão de Mogado de Mateus:

Foi Sua magestade servido de me mandar com o governo desta Capitania, encarregando-me de procurar por todos os meyos estabelecela ao seu antigo esplendor, procurando os modos mais efficazes de acrescentar as suas povoaçõens, estender aos confins dos seus dominios, fertilizar os campos com a agricultura, estabelecer, nas terras diferentes fabricas, idear novos caminhos, penetrar incognitos sertõens, descobrir o ouro das suas minas e finalmente, fortificar as suas Praças, armar o seu Exército, fazer observar as Leys e respeitar as Justiças" 25

A relativa debilidade econômica, demográfica e política que a Capitania de São Paulo apresentou nos três primeiros séculos de colonização ${ }^{26}$, ou ainda, sua marginalização (acentuada em meados do século XVIII pela perda das zonas mineiras), não deixou de prover o território de uma infra-estrutura, que, se bem igualmente frágil, no entanto, serviria para suportar a política de dinamização (agrícola e sobretudo militar) ${ }^{27}$, estabelecida pela Coroa e que deveria ser levada a cabo, não sem dificuldades, pelo Morgado de Mateus. A Capitania" ${ }^{28}$, para ele, "morta" e que lhe caberia tirar das "cinzas que já não existem", contava com "uma população de cerca de 60.000 almas, distribuída em uma cidade, 18 vilas, 9 aldeias de índios e 38 freguesias, ou dispersa "pelos matos", vivendo da lavoura de subsistência ou de suas atividades 
mercantis nas rotas do Viamão (1740) ou do Cuiabá (1725)"²9, e talvez, menos, do Rio de Janeiro (1720).

Embora as principais ações territoriais de colonização do período tivessem natureza e objetivos fundamentalmente militares (expedições para o Iguatemi/ Mato Grosso, Tibagi/Paraná, Viamão/Rio Grande), reconhecia-se que era preciso congregar os colonos "o mais que se puder, em Povoações Civís, fundando-se de novo, e acrescentando aquela que já temos, por que sem isso não pode haver comércio nem riqueza permanente." ${ }^{30}$. Assim novas povoações (Guaratuba, Sabaúna, Lages, Faxina, Apiaí, Piracicaba, Caraguatatuba, Paraibuna, Campinas, etc.), viriam sobrepor-se à precária rede urbana existente, ao mesmo tempo que antigos e novos núcleos eram promovidos à posição de vilas. Ambas ações visando fortalecer os rumos estratégicos para a defesa e a expansão da capitania. Baseada no mapa de 1792, elaborado por ordem do Governador Bernardo José de Lorena, Bellotto $(1979,198)$ sugere, a grosso modo, os seguintes vetores de colonização: para o sul (defesa e integração do caminho de Viamão), para o norte (Minas Gerais e Goiás, passando Por Moji-Guaçu e Atibaia), para o Rio de Janeiro (pelo Vale do Paraíba atingindo o litoral junto ao porto de São Sebastião) e na direção Tietê-Paraná (onde Campinas e Piracicaba aparecem como pontos de apoio das expedição para o Iguatemi).

Quanto ao caminho para Santos, ainda que representasse alguma importância em termos militares, refletida nas insistentes preocupações do Morgado ${ }^{31}$, haveria que se esperar o governo de Lorena (1788/1797) e o fortalecimento da economia açucareira para que hovesse condições propícias ("recursos e gente capacitada") para sua melhoria. Neste sentido, com respeito ao porto de Santos, à abertura do Caminho Novo para as minas e ao consequente monopólio exercido pelo Rio de Janeiro, desviando o ouro de Minas e Goiás, (além do fato de Santos ter perdido, para São Paulo, o "cofre" e a Provedoria, e de seu porto não dispor de produção suficiente para carregar o retorno dos navios — reflexo da pobreza da Capitania), iria juntar-se o problema das ligações viárias com o planalto. O desempenho do porto, que, então, passava por sua fase de maior decadência, viria como consequência de nova uma política de exportação e de redefinição da base econômica e territorial paulista.

\section{0/1850: O quadrilátero do açúcar e o litoral}

Desde o final do século XVIII até a primeira metade do século XIX, todas as áreas em que se poderia dividir geograficamente a Capitania de São Paulo, com excessão da Capital e da parte sul do Litoral (incluindo aí Santos), desenvolveram centros produtores de açúcar e/ou aguardente: no Litoral, sua porção norte; "serra acima", no Vale do Paraíba, o caminho para o Rio de Janeiro (embora centros açucareiros de pouca expressão, se confrontados com a "precoce" vocação cafeeira da área) e, no Oeste, a área compreendida no 
chamado "Quadrilátero do açúcar", formado pelas cidade de Sorocaba, Piracicaba, Mogi-Guaçu e Jundiaî́32.

Se o êxito dos primeiros, isto é, dos centros localizados, principalmente, em Ubatuba e São Sebastião, bem como, em menor medida, daqueles localizados no vale do Paraíba, esteve, de certa maniera, condicionado pelas restrições (e contínuas liberações) das exportações para o Rio de Janeiro, o fortalecimento do "quadrilátero" deveu-se, justamente, ao favorecimento do comércio com Santos, eleito, em 1789, por determinação do Governador Bernardo José de Lorena, porto exclusivo para a exportação "direta" para o Reino ${ }^{33}$. Se antes a produção poderia escoar também por São Sebastião e Ubatuba, (e ainda por Parati e Angra dos Reis, todos esses portos ligados por caminhos, respectivamente a Jacareí, Taubaté e Guaratinguetá), o certo é que o governo de Lorena, faria decrescer o número de engenhos de São Sebastião e Ubatuba, levando aquelas vilas à decadência ${ }^{34}$.

Em 1791, como consequência de sua política de exportação, que visava fazer convergir para Santos toda a exportação da Capitania e proteger a agricultura "serra acima", Bernardo de Lorena entrega para a circulação, "obra notável para a época", um caminho calçado "com largura para poderem passar tropas de Bestas encontradas sem pararem" ${ }^{35}$. No entanto, a estrada de terra (aterrados e pontes) do Cubatão até Santos teria que esperar até 1827, coincidindo com a exportação cada vez maior do açúcar. Mas, de qualquer maneira, apesar dos insistentes problemas de conservação dos caminhos e ainda que até 1852 (data de referência de consolidação da Estrada da Maioridade, inaugurada em 1846) a estrada não suportasse o trânsito de carros, a viagem de São Paulo a Santos podia ser feita em 2 ou 3 dias. Quanto á estradas de "serra acima", principalmente aquelas de ligação do "quadrilátero" com São Paulo os viajantes, que nunca deixaram de registrar os problemas da estrada para Santos, rararamente se referem a seu mau estado.

Portanto, ao lado do reconhecimento da boa qualidade das terras de Campinas, Jundiaí e Itu para o plantio da cana e, logo, do incentivo para os fazendeiros do oeste, e objetivando a integração da economia do planalto ao mercado mundial, passa a aparecer com contundência nas preocupações administrativas da Capitania, o problema das comunicações viárias em geral, e do porto de Santos com o planalto, em particular ${ }^{36}$. Na verdade, as estradas do planalto aproveitariam, com algumas modificações, caminhos já esboçados desde os tempos dos bandeirantes, e que, naturalmente menos problemáticos que a "descida" da serra, em termos de adequação à topografia, já haviam sido relativamente melhorados pelo govermo do Morgado de Mateus. Assim, as principais rotas do açucar seguiam sendo a de Goiás (saindo de São Paulo, passando por Jundiaí, Campinas, Mogi-Mirim, Mogi-Guaçu, para depois seguir para Franca e Goiás), a que atinge Tietê e Porto Feliz (com desvio para Piracicaba), a do Sul, em direção a Sorocaba, e a do Rio de Janeiro ${ }^{37}$. 
Durante o governo de Oeynhausen (1819-1825), tendo em vista "regular a conservação" das estradas, foi estabelecida a classificação de sete estradas, conforme se pode observar no Mappa Chorographico da Provincia de São Paulo de 1837 de Daniel Pedro Muller ${ }^{38}$. Dadas as mencionadas medidas restritivas tomadas em relação aos demais portos do litoral paulista, todas estas estradas (com excessão de uma) convergiriam naturalmente para São Paulo, capital da Provincia e ponto de articulação com o porto de exportação de Santos. Ambas cidades, beneficiadas por aquelas mesmas medidas, refletiriam nas transformações do núcleo urbano o incremento da produção e dos transportes. E Santos passaria assim a constituir a principal "porta de entrada do território paulista. Pois em relação às outras duas "entradas" da província, ao norte, os núcleos urbanos do caminho para o Rio de Janeiro, teriam que esperar o café em 1830 para desenvolverem-se ${ }^{39}$, ainda assim, (re)articulados, mais uma vez, antes com os portos fluminenses que com Santos e São Paulo. E, ao sul, Sorocaba, apesar das tentativas de implantação de outras atividades, tinha no comércio de muares sua principal riqueza. Deste modo,

a estrada mais importante, a grande espinha dorsal de todo o systema de comunicações, era ainda, como sempre havia sido, a que partia de Santos, se dirigia à capital e d'ahi seguia para noroeste, passando pelos ricos e muito prosperos municipios de Jundiahy, Campinas, Limeira, Rio Claro, S. Carlos do Pinhal, Araraquara e Jaboticabal..."40.

Este percurso sendo, obviamente, o percurso de maior interesse dos viajantes do início do século XIX, tem nas descrições desses mesmos viajantes importante fonte de informação sobre as cidades sobre ele implantadas. Seguindo o roteiro percorrido pela maioria deles, a vila de Santos chamaria a atenção "mais pelo seu comércio, como porto de mar da província, que pela beleza de sua situação ou pela elegância de seus prédios (...) Muitas são as casa de comércio estrangeiras aí instaladas e fazendo próspero negócio" ${ }^{41}$. No entanto, apesar de ser a vila, "o entreposto de todos os objetos de exportação e importação da Província, de Goiás e de Mato-Grosso", seria "de lastimar-se que, sendo esta Villa uma das mais antigas do Brasil, colocada tão vantajosamente para o comércio, com um excelente porto, em uma das mais povoadas, e melhores províncias do Brasil, esteja ainda tão pouco adiantada"42.

De Santos, navegando-se rio acima, até Cubatão (último ponto do trânsito das tropas antes da construção do aterrado, portanto sede da alfândega), escalavase a serra, segundo Kidder, "por uma das maiores e mais caras estradas que já se construiu no Brasil" ${ }^{43}$ ), e chegava-se aos planos suavementes inclinados de São Bernardo, para, depois, atingir-se o terreno "um pouco elevado, cercado de belos e dilatados campos" ${ }^{44}$, onde situava-se a cidade de São Paulo: 
A cidade é o centro de convergência de toda a província. Muitos dentre os fazendeiros têm casas nas cidades e só permanecem algum tempo na fazenda, pois, de São Paulo podem melhor orientar a venda de suas safras, à medida que passam, serra abaixo em demanda do mercado" 45 .

A direção seguida, passando por morros e vales, de Jundiai ("importante centro comercial" de "2 ou 3 mil almas" ${ }^{46}$ ) levava a Campinas. Como atestava o alemão Tschudi ${ }^{47}$ em 1857:

Desde muito tempo Campinas se firmou como importante centro comercial de algumas comarcas distantes, tanto da Província, como também de Minas Gerais, que para ela enviam seus produtos, tais como algodão, toucinho, feijão, queijo, etc., recebendo em troca sal, ferramentas, artigos importados da Europa. Só da comarca de Franca, chegam anualmente de 500 a 700 vagões, que são enviados das cidade para Santos e Rio de Janeiro em carretas e tropas de mulas. Este comércio tomará novo incremento quando for servido por estrada de ferro. A agricultura se desenvolverá mais para o Oeste, nas regiões dos rios Piracicaba e Tietê, que passarão a enviar seus produtos para Campinas"...

\section{0/1930: cafélferrovia e o binômio Santos-São Paulo}

Se já desde 1836 o café implantara-se com relativa força no Vale do Paraíba, é no período compreendido entre 1854 e 1886 que esta lavoura atinge seu período áureo e, assim, atraindo a imigração de outros Estados ${ }^{48}$, iria induzir grande concentração demográfica que se estabeleceria em torno dos núcleos urbanos paraibenses. Entretanto "os primeiros anos do século XX revelam-se nefastos à Zona Norte. A Abolição, as crises repetidas, a abertura de novas zonas mais férteis provocam o abandono rápido dos cafezais e a queda da produção abaixo de 800.000 arrobas. Concomitantemente decresce a poulação". Segundo estatística de Daniel Pedro Miller ${ }^{49}$, em 1836 o Vale do Paraíba seria o responsável por $88 \%$ da produção cafeeira, enquanto o centrooeste respondia apenas por $12 \%$. Já em 1886, ou seja, em plena era ferroviária, equilibram-se as porcentagens com a região de Campinas produzindo 29\% da Província e o Vale do Paraíaba, 20\% (quantia que cairia para $4 \%$ em 1920). Subsequente, outras áreas entram em jogo, como a Mogiana, que então participaria com 21\%, e a Paulista, com 23\% da produção total de São Paulo ${ }^{50}$.

Esta nova organização espacial da lavoura cafeeira só foi possível pelo desenvolvimento ferroviário que, concretamente deflagrado ${ }^{51}$ com a inauguração, em 1867, da linha de Santos a Jundiaí, através de concessão à empresa de capital inglês, São Paulo Railway Co., acabaria impondo uma nova ordem política e espacial ao território, elegendo os interreses prioritários do eixo Santos-São Paulo-Campinas. Ainda que a produção do Vale do 
Paraíba, como se viu, fosse então superior ao de outras regiões, seu escoamento dava-se, ainda, muito mais pelos portos do litoral Norte e do Rio de Janeiro: o suporte ferroviário para esta produção, embora antecedendo a linha inglesa, acabaria esbarrando na instabilidade das relações entre São Paulo e Minas, nos problemas técnicos de diferenças de bitolas e, sobretudo, no próprio declínio da produção da região.

Em relação ao desenvolvimento do café rumo ao oeste paulista, o estado precário das estradas e, especificamente, a difícil descida da serra do Mar, bem como a dificuldade de se plantar "além" de Campinas representava grande obstáculo. Neste sentido, como observava A. Pinto (1903, p.26):

Era pois natural que o primeiro caminho de ferro a construir-se na Província viesse a ligar seu principal porto de mar (Santos) à capital e aos centros mais importantes de produção, que eram então os municípios de São Carlos (atual Campinas), Constituição (atual Piracicaba), Itu e Porto Feliz .

A "naturalidade" a que se refere Pinto, beneficiada e estimulada por amplas concessões de favores por parte dos governos, central e provincial (garantia de juros, privilégio de zona na extensão de 5 léguas $-31 \mathrm{~km}$ — para cada lado da estrada, isenção de direitos de importação, direito de desapropriação dos terrenos necessários, direito de exploração de minas encontradas na zona, etc) e "justificada" pela escassez de recursos e capitais públicos, acabaria convertendo-se na única regra da vertiginosa proliferação das estradas de ferro, que se daria, portanto, à revelia, mesmo porque não os havia, de qualquer plano geral ${ }^{52}$. Desta maneira, a "naturalidade" do desenvolvimento ferroviário levaria a uma estruturação da malha na qual a São Paulo Railway (que por isto mesmo abriria mão de seus direitos de extensão da linha de Jundiaí a Rio Claro ${ }^{53}$ ) estava "fadada a ser a chave de todas as comunicações com o interior - a construção das linhas que se lhes seguiram se foi operando aos pedaços, ao puro arbítrio das localidades mais aproximadas do ponto a que chega o melhoramento" ${ }^{54}$. No entanto, para o mesmo autor, apesar da ausência de um princípio geral de organização, o resultado final acabaria sendo bem delineado: "com bem poucas modificações seria o próprio que conviria traçar hoje sobre o mapa do Estado..." ${ }^{55}$. Suportada pela rigidez do monopólio da articulação viária do planalto com o porto de Santos, tinha-se como certo que

a linha Santos a Jundiaí é, como se sabe, o tronco principal de todo o sitema ferroviário do Estado, o caminho mais direto entre as regiões agrícolas do interior e o seu grande mercado de exportação, o que goza do privilégio de passar pela capital, que além da sede de Governo, é o centro da população, comércio e indústria mais importante do Estado" ${ }^{\prime 56}$. 
Porém, este "escouadouro natural", que acabaria impondo definitivamente o binômio Santos-São Paulo sobre todos os outros que ainda operavam na ligação planalto-litoral ${ }^{57}$, foi sucessivamente questionado através de projetos alternativos. Isto muito se deveu às constantes e contínuas deficiências apresentadas pelo serviço da companhia inglesa, além dos elevados preços e taxas que a mesma impunha para o transporte até o porto de Santos. Ainda que todos esses projetos tenham fracassado pelas mais diversas razões (a principal delas tavez tenha sido a financeira, na medida em que o principal centro financeiro era justamente o ingles, evidentemente desinteressado na, senão contrário mesmo à, quebra do monopólio da companhia inglesa), parece importante recuperar sua história na medida que ajudam, evidenciando hipóteses de estruturação do sistema de comunicações e transportes, a colocar luz não só sobre as possibilidades de modelos territoriais alternativos ${ }^{58}$, como também as resistências interpostas à sua realização. No entanto, ainda que projetos de um novo porto em São Sebastião tenham sido sucessivamente retomados em outras épocas, assim como o foi o problema da ligação com o planalto (só realizado em 1938 pela linha Mairinque-Santos da Sorocabana), o fato é que, sendo "a linha da São Paulo Railway conjuntamente com as Docas de Santos "o "factor" que controlla a rede de transportes de São Paulo", o território paulista encontrava na cidade de São Paulo "o centro receptor e distribuidor da volumosa importação entrada pelo porto de Santos, o qual pode ser cognominado a estação maritma de S. Paulo"s9.

Se a cidade de São Paulo tornava-se o centro de toda a vida do Estado, Santos, apesar de todo o debate em torno da geografia portuária paulista, tendo realizado as obras de saneamento do início do século reforçava, em grande parte através da força política monopolista da Compania Docas, a extensão e o aparelhamento do porto, convertendo-se na segunda mais importante e populosa cidade do Estado. Nesta configuração territorial, além do papel dominante dessas duas cidades, Campinas, segundo Matos, (1981, 158) despontava como "grande nó de comunicações que, numa carta ferroviária, aparecia como verdadeira estrela com seis radiais, reduzidas a quatro com a extinção da Funilense e do Ramal Férreo". Seu papel ${ }^{60}$ reforçava-se, se comparado a outros centros ferroviários como Jundiaí, Araraquara, Sorocaba ${ }^{61}$ e Botucatu, na medida em que a cidade constituia ponto inicial da Mogiana, fazendo com que as vinculações de toda a área "capturada" por ela (sul de Minas, Triângulo, parte do oeste miniero e Goiás) fossem sempre maiores com Campinas do que propriamente com a capital.

Mas de modo geral, em relação à configuração territorial do Estado de São Paulo, deve-se observar a estreita relação existente entre o desenvolvimento da produção de café, o crescimento da população e as ferrovias em São Paulo. No processo territorial posto em marcha pelo avanço das fronteiras agrícolas, a "seleção" das cidades, em um primeiro momento, foi condicionada pela ferrovia e pelas circunstâncias geográficas favoráveis, 
fatores que catalizaram fortemente o movimento imigratório: Porém a sobrevivência econômico-demográfica de cada uma dessas cidades à onda cafeeira dependeria, de acordo com Millet (1946, 33), de "uma espécie de ponto de equilíbrio que precisa ser atingido antes da derrocada". Ponto de equilíbrio (em termos de comunicações, escolaridade, finanças municipais, etc) que fizeram Taubaté, Jundiaí, Campinas, Piracicaba, Sorocaba, Baurú se firmarem como centros urbanos, enquanto Areias, Ubatuba, São Luiz do Paraitinga, Parnaiba, praticamente, desapareceram, despovoando-se.

1930-1970: as duas fases da industrialização e o modelo rodoviário

Se a implantação da linha Mairinque-Santos da Sorocabana pretendia marcar o fim do monopólio da São Paulo Railway no transporte ferroviário através da serra, este fato, de forma aparentemente contraditória, coincidiu com o início de um novo processo no qual a ferrovia ${ }^{62}$ começaria a perder gradativamente força como elemento estruturador do território. A já referida ausência de um plano geral ferroviário, ao sabor dos interesses imediatos do café, a perda, por parte do mesmo café, do papel de elemento dinâmico da economia, bem como o modelo concentrador de recursos e população na capital do Estado, todos estes fatores, já analisados por F. Saez ${ }^{63}$ levariam a um crescente déficit operacional das companhias ferroviárias, culminando com sua encampação pública, na década de 1950. Assim, a progressiva descapitalização do serviço ferroviário e a consequente obsolescência da malha ferroviária, dando-se por consumada a sua exploração financeira, retiram-lhe a capacidade infraestrutural que tinha em sua origem. No entanto, mesmo que a partir de 1920 não tenha havido qualquer crescimento significativo da malha ferroviária de $7.160 \mathrm{~km}$, o incipiente equipamento do território com estradas de rodagem, reservaram ainda às ferrovias um papel a desempenhar.

Neste quadro de transição, embora a melhoria da estrada para Santos tivesse representado uma preocupação constante dos governos (Estrada do Vergueiro como reconstrução da Estrada da Maioridade, seguidamente restaurada), e a rede de estradas para carros tivesse um relativamente importante papel de alimentação das ferrovias, as primeiras medidas práticas no setor rodoviário, de acordo como Reis ${ }^{64}$, tardaram a acompanhar, por falta de recursos orçamentários e de condições técnicas, os esquemas esportivos interessados ao automobilismo, que se instaurara na sociedade paulistana desde 1908. Em 1913, o Governo do Estado, no "Plano de Viação para São Paulo", destaca as obras rodoviárias, principalmente aquelas interessadas às ligações de São Paulo com Jundiaí, Sorocaba e Santos, onde se recomendava, segundo decreto de 1915, o aproveitamento do trabalho de presidários na construção das rodovias ${ }^{65}$. No governo de Washington Luiz, iniciado em 1920, dá-se, não sem dificuldades ${ }^{66}$ a execução da estrada São Paulo-Campinas, seguida pela São Paulo-São Roque e São Paulo-Itu, seguidas pelos trechos de ligação da capital com Mogi das Cruzes e Jacareí e pelo prolongamento da estrada de 
Campinas a Ribeirão Preto (236 km), iniciando-se pouco depois a pavimentação (de concreto) dos primeiros trechos da serra, para receber em 1925 a movimentação de 600 veículos diários. ${ }^{67}$

Mas é a partir de 1930 que as atividades rodoviárias no Estado de São Paulo assumem nova dimensão, administrativa e técnica. O DER (Departamento de Estradas de Rodagem), criado em 1934, propõe a construção de uma nova rodovia entre São Paulo e Santos (1939/1947, segunda pista em 1953) e outra entre São Paulo e Campinas (1940/1950, segunda pista 1961). Indicador da nova fase técnica, financeira e política, bem como do papel que o modelo rodoviário assumia no equipamento do território, tem-se o fato de que foram dispendidos "com aplausos gerais e unânimes, em apenas um quilômetro de uma moderna auto-estrada, como a Via Anchieta, uma importância igual senão maior, da que foi gasta em toda estrada S. Paulo-Campinas e que foi taxada de esbanjamento, quando de sua construção." ${ }^{68}$

As localidades e os traçados privilegiados pelas novas rodovias talvez deêm, por si, uma dimensão clara da consolidação do papel polarizador exercido pela capital que já em 1926 constituia

grande praça consumidora, (que) às funções do vasto entreposto commercial allia as de centro fabril de primeira ordem - o maior da America do Sul. Para S. Paulo convergem as materias primas destinadas a alimentar os numerosissimos estabelecimentos industriaes... de onde sahem os multiplos productos manufacurados que vão abastecer todos os mercados do paiz. Por outro lado, o armazenamento e a movimentação de todas as mercadorias, importadas ou ahi produzidas, geraram intensa vida commercial que, diariamente, cresce e avulta, attingindo proporções nunca previstas. Como consequência, surgiu em S. Paulo, o grande mercado monetário que organiza e estimula todos os emprehendimentos que despertam e fecundam a grandeza do Estado e dos estados circumvizinhos". ${ }^{69}$

Não interessando aqui aprofundar a análise do vertiginoso processo de crescimento econòmicoe demográfico metropolitano, talvez bastasse ressaltar o entendimento que à "industrialização restringida" (regime de acumulação dependente ainda dos recursos provenientes da agricultura, portanto assentada ainda sobre bases técnicas e financeiras limitadas) sucede na década de $50 \mathrm{o}$ movimento de passagem para a "indústrialização pesada" ", baseada na implantação de bens de produção e que supõe a exacerbação do crescimento das cidades, o esvaziamento do campo e a consagração do consumo industrializado. Em 1954, portanto apenas no primeiro momento daquela passagem, os estudos do S.A.G.M.A.C.S. $(1954,370)$ analisando a realidade paulistana, já dectetavam a concentração industrial polarizada na capital: 
Se devemos lamentar que a criação de São Paulo se tenha processado tumultuosamente, sem "zoning" racional de implantação industrial e residencial, sem plano de urbanismo, não podemos, no entanto, condenar a concentração das fábricas que se efetuou no ponto mais econômico, tanto do ponto de vista do abastecimento, das matérias primas e da exportação, como do ponto de vista da utilização da energia elétrica e rendimento do trabalho. O sistema de comunicações radiais permitia, ao mesmo tempo, a conquista da floresta, a penetração até o rio Paraguai, o abastecimento em mercadorias e o maior mercado internacional do café. O Estado de São Paulo, de modo geral, utilizou muito bem a primeira fase de sua expansão".

Enfatizando que a cidade de São Paulo teria atingido, "se já não ultrapassou; o tamanho que permite a uma grande capital manter-se em uma dimensão humana, sem se sobrecarregar despesas gerais e sociais extravagantes", e que, "felizmente", a única fonte de energia teria se tornado insuficiente, obrigando à reflexão e à aceitação de uma nova orientação de implantação industrial, o estudo do S.A.G.M.A.C.S. ${ }^{71}$, em nome do "aproveitamento territorial coerente e equilibrado", iria analisar o potencial de desenvolvimento de cada uma das regiões, cuja divisão, aliás, tinha sido proposta pelo próprio estudo.

Calcado na observação das cartas de população ${ }^{72}$, das ferrovias e das estradas de rodagem e tendo em vista o aproveitamento do potencial energético, o estudo decteta quatro "braços", que constituiriam "a estrutura em forma de cruz, já reconhecida como figurando a extensão de São Paulo" ‘s. Se na região do Vale do Paraíba poderia estabelecer-se uma grande e bela "cidade em forma de rosário" de 2 milhões de habitantes, onde São José dos Campos e Taubaté, as "contas grandes" do rosário, seriam as "reservas comerciais e culturais entre São Paulo e a Capital Federal" ", ao sul, um outro "braço", a princípio voltado em direção a São Caetano-Santo André, sofreria a atração da Via Anchieta antes de alcançar "Santos e seus entrepostos, a usina elétrica do Cubatão, e mais além, a refinaria de petróleo, seguida da siderúrgica de Capivarî"75. Já o "braço" noroeste, passando por Jundiaí e Campinas, atinge Piracicaba e Limeira, bifurcando-se depois na direção de Rio Claro, São Carlos, Araraquara, etc, até atingir o rio Grande. Teria uma "sorte (...) mais indecisa, ao menos na parte sul, salvo pela intensificação da produção hidroelétrica no setor de Itú e pelo aproveitamento da energia produzida pela importante usina projetada em Barra Bonita"76. E o braço oeste, por São Roque, Sorocaba e Tatuí, alcança Tietê. Seu desenvolvimento, apoiado na energia de Ituporanga, na expectativa da energia de Juquiá, e na fábrica de alumínio de São Roque, teria como orientações preferenciais a produção de material elétrico pesado (linhas de alta tensão) e o fomento da produção de cimento. As demais regiões, pela localização de importantes industrias de transformação de produtos agrícolas, de certas matérias primas industriais, etc., poderiam, desvinculadas do centro industrial da capital paulistana, ter em 
sua dependência os mercados de Goiás, Mato Grosso, Paraná e até mesmo do Paraguai e da Bolívia.

O que interessa notar é que reforçando sua opção preferencial pela "cidade em rosário" do vale do Paraíba, esta hipótese de desenvolvimento exigiria a consideração da construção de um novo porto. Não seria apenas a então insuficiência da capacidade do porto de Santos (em grande parte devido à incapacidade por parte das vias férreas e rodoviárias existentes de suportar um aumento do volume de cargas); "mas também a necessidade imperiosa de descentralização, inúmeras vezes propuganada neste relatório". Desta vez o lugar escolhido, em vez de São Sebastião (além dos custos dos trabalhos e da qualidade do abrigo, a necessidade de preservar a beleza e o patrimônio histórico seriam os fatores da objeção), deveria ser a Enseada do Flamengo. A construção de um dique contínuo de 1800m, ligando a Ponta Grossa à ilha Anchieta, o que permitiria o acesso de navios de grande tonelagem. A ligação com São Paulo dar-se-ia pela estrada de rodagem São José dos CamposCaraguatatuba. Talvez também seja interessante notar que a proposição de um porto na Enseada do Flamengo, mesmo tendo em consideração a ligação Atlântico-Pacífico, de Santos a Antofagasta, deu-se no bojo de mais um debate sobre a viabilidade portuária de São Sebastião. Dentro dos projetos da mudança da capital federal, cogitava-se, então, estabelecer a ligação direta da Mogiana Brasília-São Sebastião, através de 2000km de trilhos numa só bitola $^{77}$.

Por outro lado, o estudo do S.A.G.M.A.C.S. apontava que embora constituindo a malha mais densa do $\mathrm{Brasil}^{78}$, o transporte ferroviário dava sinais de esgotamento ${ }^{79}$ : de 1915 — quando mal ultrapassava $7.000 \mathrm{~km}$ - a 1953 não houvera novas construções. A malha até então poderia parecer suficiente. No entanto, a nova fase de exploração industrial em que o país entrava, teria evidenciado os problemas: diferença de bitolas e inadequação de traçados, estrutura da malha que drena quase unicamente as mercadorias para o porto, métodos superados de administração, combustível oneroso —a madeira—, tarifas aviltadas, déficits operacionais. A solução talvez estivesse, segundo o S.A.G.M.A.C.S., na estatização dos serviços. Daí que, quanto ás estradas de rodagem, "a autonomia e a flexibilidade do transporte rodoviário em relação ao ferroviário e fluvial" (este último, "esbarrando então em dificuldades técnicas e financeiras de tal ordem que não parece possível examiná-lo atualmente"), bem como a recente criação de uma nova política rodoviária que se instaurara no país através do Fundo Rodoviário Nacional", as colocavam como elementos fundamentais da estruturação do território ${ }^{80}$ : "a economia brasileira se encontrou melhor servida na sua fase mais recente como o surto verficado nas rodovias do que teria acontecido se, ao contrário, a país se tivesse voltado de preferência para o setor ferroviário" ${ }^{81}$. 
De fato, segundo levantamento do Plano de Ação 1959-1963 do Governo do estado (1959, p.37), a concorrência entre a ferrovia e a rodovia, apresentava para o período compreendido entre 1947 e 1958, data do início das operações da vias Anchieta e Anhanguera, os seguintes números ${ }^{82}$ :

\begin{tabular}{|l|l|l|}
\hline $1949=100$ & rodoviário & ferroviário \\
\hline 1947 & 92,00 & 97,5 \\
\hline 1951 & 116,7 & 123,6 \\
\hline 1953 & 162,3 & 122,1 \\
\hline 1958 & 203,4 & 137,0 \\
\hline
\end{tabular}

Quanto à iniciativa de lançamento de novas estradas ${ }^{83}$,

a política paulista, deste ponto de vista, era indicada pela natureza. Atingida a importância industrial e comercial que a cidade de São Paulo alcançou, era fatal que se procurasse colocar essa capital inicialmente em ligação rápida com seu porto, Santos, bem como com o centro siderúrgico de Volta Redonda e a capital federal, com a importante cidade de Campinas, e de lá com a zona montanhosa contígua, em Minas Gerais, com as velhas zonas de Araraquara, Ribeirão Preto, com o Triângulo Mineiro, com os espigões maiores até atingir o rio Paraná e, mais ao sul com a zona pioneira do Alto Paraná e com a parte montanhosa do Sul, na direção de Curitiba" ${ }_{84}$

Por último, parece importante lembrar para a caracterização do papel concentrador exercido pela metrópole paulistana que, embora tendo começado a funcionar em 1926, a Usina de Cubatão foi antes de mais nada uma solução para os problemas de energia elétrica que aquela enfrentava e foi este o sentido de sua construção. Segundo Goldstein (1972, p.118), pelo fato de sua produção ter sido imediatamente conectada com o planalto, para onde se destinava, bem como pelo preço da energia na Baixada não diferir do preço no Planalto, a Usina acabaria não exercendo, até a década de 50, atração sobre a localização industrial. Sómente com a decisão de instalar a Refinaria de petróleo, Presidente Bernardes, em Cubatão é que o efeito multiplicador se fez sentir pela atração de indústrias do setor petroquímico e depois siderúrgico (ainda que suas razões de localização não estejam unicamente vinculadas à disponibilidade energética). Embora representassem fatores estratégicos de desenvolvimento econômico — petróleo e aço—, a implantação do centro industrial de Cubatão, segundo Godlstein (1994, p.48 e 57), "não se prendeu a nenhuma política de desenvolvimento espacial no sentido mais amplo e nem mesmo a uma política de organização territorial ou de localização industrial, no sentido mais restrito". Sua referência e seus vínculos encontravam-se na metrópole e não na região da Baixada Santista. 
Tendo como referência básica as diretrizes estabelecidas pelo segundo Plano Nacional de Desenvolvimento - II PND 1975/1979_ (recuperar a qualidade de vida na região metropolitana de São Paulo e diminuir as diferenças de oportunidades e desenvolvimento entre as diversas regiões do Estado), e identificando como "patologia" da rede urbana paulista a exagerada urbanização metropolitana e o crescimento acelerado de metrópoles regionais (Ribeirão Preto, São José do Rio Preto, Marília, Bauru, Presidente Prudente e Sorocaba) diante do esvaziamento das pequenas cidades ( $65 \%$ da polulação vivendo em cidades de mais de 100.000 habitantes), a "Política de Desenvolvimento Urbano e Regional do Estado de São Paulo —PDUR" (1976) teria como palavras de ordem do planejamento a "descentralização e desconcentração . Isto na medida em que a organização espacial da rede urbana paulista permitia reconhecer quatro grupos de cidades $^{85}$ que, embora denotassem relativamente grande vitalidade de desenvolvimento, guardavam relação direta de dependência da cidade de São Paulo, centro do sistema onde, no entanto, a urbanização apresentava (e passava a irradiar para a Região Metropolitana e a Baixada Santista) as "manifestações patológicas" da urbanização: uso do solo predatório, transporte congestionado, serviços urbanos básicos insuficientes, habitação precária, poluição crescente, etc.

Segundo aquele documento de política territorial, embora a metrópole (reconhecida institucionalmente em 1973) apresentassse maior ritmo de crescimento, já seriam "detectados sinais visíveis de um processo espontâneo de descentralização da zona metropolitana e de organização das cidades" (em sistemas hierarquizados ou integrados). Neste sentido, as dimensões significativas logradas pelas cidades de Santos, Campinas, Jundiaí, Sorocaba e São José dos Campos, poderia ser interpretada, também, como uma ampliação do espaço metropolitano, indicando "que estas cidades estão desempenhando o papel de absorver o potencial crescimento da metrópole" ${ }^{{ }_{86}}$. Deste entendimento nasceria o conceito de "macro-metrópole ${ }^{87}$ para caracterizar a área que reúne os grupos de cidades constituintes da Região Metropolitana da Grande São Paulo e os aglomerados de municípios contíguos.

De fato, inerente ao ideário de "descentralizar a economia", que a permeou durante toda a década de 70, a análise territorial do período iria encontar nas regiões comandadas por estas quatro cidades - Santos, Campinas, São José dos Campos e Sorocaba-e, mais precisamente nas "vocações" manifestas destes "eixos naturais de penetração", as condições de absorver "parte da moderna industrialização, que se registrou no Estado na última década"в8, centrada quase exclusivamente nas proximidades da Grande São Paulo. Neste sentido, buscando dar operatividade ao PDUR (apenas um "instrumento de reinvidicação de recursos financeiros e de solicitação de delegação de poderes 
a organismos do Governo Federal"), seriam apresentados pelo Governo Estadual, em 1978, os Planos Regionais de Campinas, Litoral e do MacroEixo (do Vale do Paraíba), no sentido de propor condições ao deslocamento da atividade industrial para o interior, analisando e propondo hipótese de crescimento territorial especialmente ao longo dos grandes eixos rodoviários: Rio de Janeiro-São Paulo, Anhanguera e Washington Luiz.

A partir da estratégia de investimentos públicos proporcionarem a infraestrutura básica (sistema viário e de comunicações, distritos industriais, isenções fiscais) para a desconcentração regional, entre 1975 e 1980, no contexto do II PND,

os novos projetos, alguns governamentais, como as duas refinarias da Petrobrás (Paulínia — na região de Campinas-e São José dos Campos) ou a ampliação da siderurgia nacional (Cubatão) se localizaram preferencialmente fora da área metropolitana, o que se viu reforçado pelo deflagrar do Proálcool. Em parte estes projetos iriam estimular a implantação no interior de plantas químicas, junto às refinarias, a indústria bélica e aeronáutica no Vale do Paraíba, a indústria de informática e microeletrônica na região de Campinas, próxima às universidades públicas e institutos de pesquisas. $\mathrm{O}$ desenvolvimento agrícola não apenas reforçaria o processamento agroindustrial e a indústria de insumos químicos, mas teria importância para todo um segmento da mecânica, sobretudo implementos e tratores, além dos estímulos derivados do Proálcool sobre a indústria de equipamentos do interior". ${ }^{89}$

Na metrópole, além das medidas do Governo Federal, foram ainda mais importantes alguns fatores que se convencionou chamar de "custos crescentes de aglomeração". Ao seu lado, o progressivo fortalecimento da atividade sindical no $\mathrm{ABC}$ e o problema ambiental na capital desestimulavam ainda mais a continuidade da concentração anterior: Tudo isto tendia a favorecer $o$ interior do Estado: além da infra-estrutura, aliava-se a crescente independência da grande empresa dos problemas locacionais, voltadas que estavam ao mercado nacional ou mesmo internacional".90

Em relação particularmente à infra-estrutura de transportes, poderia se notar que se alguns traçados rodoviários passariam a não mais seguir, paralelamente, o antigo traçado ferroviário (como o mostram as operações da Rodovia do Açucar, Via D. Pedro I, Rodovia do Alcool), no entanto, os eixos principais passariam a ser duplicados constituindo o que se denominaria sistemas Anhanguera-Bandeirantes e Anchieta-Imigrantes. Ainda que a produção agroindustrial redimensionase (10\%) o papel da ferrovia enquanto modal carga, ligando, através de linhas eletrificadas da antiga Sorocabana, os novos terminais — graneleiro (Boa Vista) e de alcool (Paulínia), ambos na região de Campinas-, ao porto de Santos, essa continuaria a ser preterida onde a frota 
automobilística estivesse suprimindo a demanda (o que levaria, pelo déficit operacional, à contínua deterioração do transporte ferroviário de passageiros $\left.{ }^{91}\right)$.

Quanto aos sistema portuário, em 1972, na esteira do início do funcionamento do terminal petroleiro de São Sebastião, um estudo da Brasconsult-Geipot recomendava a exploração da sua característica principal, "que é a possibilidade de um grande calado natural sem ocorrência de assoreamento"92. Assim, comparando-se os custos para as melhorias dos dois portos e concluindo-se que "a implementação de 4 berços em São Sebastião se justica, ainda que sejam feitas melhorias em Santos" "ə3, projeta-se a ampliação do primeiro "apenas através de terminais de carga geral especializados de alto desempenho, como o terminal para contêiners". O acesso ao porto, desprezando (como inviáveis) os estudos de 1972, que previam uma linha feroviária por Mogi das Cruzes, deveria continuar sendo pela rodovia existente. Nos finais da década de 1980, a duplicação dessa rodovia Tamoios - seria a única solução admitida (agora por razões de ordem ambiental) diante do projeto do Governo do Estado para a construção de uma nova ligação entre a rodovia D. Pedro I (desde Jacareí) a São Sebastião ${ }^{94}$.

\section{Década de 80: crise e redefinição territorial da base produtiva}

Foi lugar comum repetir que "os nos 80 iniciaram-se com a mais grave crise da história do Brasil urbano": seis anos de crise, contra apenas três de crescimento, como resultado das políticas de ajustamento à crise internacional, praticadas a partir do final da década anterior. A recessão, a elevação do desemprego aberto e a crise social adquiriram expressão maior exatamente em São Paulo ${ }^{95}$.

Neste cenário de crise urbano-industrial e de adequação dos apoios terciários da base produtiva (particularmente, no que se refere à intermediação financeira), o dinamismo da metrópole foi decorrência do desempenho do setor de serviços, mesmo porque, em oposição ao crescimento negativo do setor secundário da Grande São Paulo, a interirorização industrial continuava seu movimento. Ou seja, as consequências da crise recairam mais fortemente sobre a região metropolitana, pois "na região de Campinas praticamente todos os setores cresceram acima da média estadual, enquanto no Vale do Paraíba o destaque ficou para a indústria química (refinaria), e em Sorocaba para o segmento metal-mecânico.”96. No conjunto do interior, Ribeirão Preto, Bauru, São José do Rio Preto destacavam-se pela produção agroindustrial). Neste contexto apenas a "região do litoral apresentou crescimento menor que a média estadual”" industrial e o metropolitano, e de outro, repercutindo as restrições de ordem ambiental, que passavam a contituir progressivamente a principal pauta das 
políticas territoriais (mesmo porque os modelos de planejamento territoriais vigentes entrariam em colapso).

Se São Paulo continuava sendo (pelo menos no que se refere a serviços de ordem superior) a referência principal das cidades do Vale do Paraíba, da Baixada Santista e da região de Sorocaba, Campinas despontava como a segunda metrópole paulista, "nem tanto pelo significado da conurbação com alguns dos municípios vizinhos, mas, sobretudo, pela dimensão que adquiriram os serviços de âmbito regional e a interdependência entre as cidades próximas"98. De qualquer maneira, continuam sendo a implantação industrial (no caso de Santos aliada à existência do grande porto e do turismo) e a infra-estrutura rodoviária os fatores indutores não apenas do crescimento da população, mas, do próprio desenho da malha urbana dos quatro principais aglomerados urbanos paulistas. Se a Dutra, a Anchieta e a Imigrantes constituiram desde os anos 50 os grandes eixos estruturadores do terrritório, na década de 80, os investimentos realizados na reforma, duplicação e construção de pistas, potencializaram as ligações rodoviárias, principalmente (mas não só) com a capital, cuja base econômica não mais reflete apenas sua base industrial imediata (bastante heterogênea), mas, ao contrário, passa, na condição de "metrópole nacional" concentradora dos serviços especializados, a receber "o estímulo do crescimento da periferia e do interior do

Estado ${ }^{99}$. Assim, o canal destes estímulos e a fluidez dos intercâmbios plasmar-se-iam, em grande medida, pela operação dos eixos correspondentes à via dos Trabalhadores (Vale do Paraíba); rodovias Pedro Taques, PiaçagueraGuarujá, Mogi das Cruzes-Bertioga, e Rio-Santos (Baixada Santista); vias Bandeirantes, D. Pedro I, Santos Dumont (Campinas), Raposo Tavares. Este conjunto comporia a ossatura da área mais dinâmica do território brasileiro, onde os parques industriais da Grande São Paulo e da região de Campinas (este praticamente uma "extensão" daquele) responderiam por quase $85 \%$ do total da transformação industrial do Estado, enquanto a indústria da sub-região de Santos, embora concentrando cerca de 3\% deste total, apresentava alto valor de transformação.

\section{Década de 90: macrometrópole?}

Na década, a questão da polarização "concentração metropolitana e interiorização" é retomada com força, principalmente a partir de novas abordagens que se apresentam aos estudos da realidade sócio-espacial ${ }^{100}$. A retomada da discussão concentração/centralização/interiorização explica-se pelo fato de que, embora formulada desde a década de 60, ela não chegara, até os 90, a apresentar coerência entre as políticas de desconcentração (particularmente no que tange às realizações nos campos de energia, telecomunicações, sistema rodoviário e pesquisa e tecnologia avançada ${ }^{101}$ ) e os grandes planos e projetos levados a cabo pelos diversos órgãos e empresas estatais, tais como Sistema Cantareira, Hibrace, Sanegran, que, vinculando, 
com financiamento público, "o uso de recursos naturais e ambientais da metrópole e de vastas extensões do território periférico às soluções metropolitanas", (...) “acabaram por configurar um pólo de política oposto ao da interiorização"

Talvez o que importe notar aqui é que na conformação resultante desses processos, um eixo de direção NW/SE (Santos/Grande São Paulo/São José do Rio Preto-Ribeirão Preto) consolidou-se como pólo dinâmico da economia do Estado e do País: "o trecho interior deste eixo, de Campinas em diante, passou a se constituir no "locus" mais competitivo das novas localizações industriais no Estado, apoiado na excelente base de pesquisa e desenvolvimento tecnológico instalada naquela cidade" ${ }^{103}$; base essa que serviria ao processo de modernização, atingindo, também, o setor primário e a agroindústria.

No bojo da discussão sobre a globalização da economia, a reestruturação produtiva e o surgimento do paradigma tecnológico da terceira revolução industrial, a obrigação das empresas, saídas de um forte período de crise que marcara a década anterior, a fazer um forte ajuste na estrutura de custos de produção, evidentemente repercutiria no sistema de cidades paulistas segundo dois movimentos aparentemente contraditórios: desconcentração relativa acompanhada da reconcentração de alguns setores industriais. Para Caiado (1996, p. 56) há indicações

de que deve estar havendo um inflexão na curva da participação de São Paulo no valor de transformação industrial nacional. Parece que foi interrompida a trajetória declinante observada no período entre 1970 e 1985, retornando a produção paulista, em 1994, ao mesmo patamar observado em 1980. Todavia, isto não quer dizer que a trajetória de desconcentração industrial que tem ocorrido dentro do Estado de São Paulo, nas últimas duas décadas, sofrerá uma reversão. Pelo contrário, o processo de interiorização do desenvolvimento, no qual a produção industrial — que até o final dos anos 70 tinha forte concentração na capital — tem se transferido para a periferia metropolitana e para o interior, seguirá ocorrendo, mesmo que em menores dimensões".

Porém este processo, apoiado nas condições estruturais existentes no interior

— infra-estrutura de transportes, comunicações, proximidade ao centro consumidor, existência de mão-de-obra qualificada e de centros de pesquisa e ensino - , não não se dá de modo homogêneo em todo o estado, privilegiando "as regiões mais industrializadas, com alguma sinegia entre as instituições públicas de $\mathrm{P} \& \mathrm{D}$ e a iniciativa privada, e contíguas aos grandes eixos de ligação da metrópole com o resto do país. Assim, as regiões Administrativas de Campinas, Vale do Paríba, Sorocaba, Central (São Sarlos e Araraquara)e Ribeirão Preto já têm sido mais privilegiada"104. No caso da RA de Santos, a dinâmica econômica continua baseada na indústria e no setor terciário. 
Na verdade, além dos centros industriais já consolidados de Campinas, São José dos Campos, Sorocaba e Santos, e seus respectivos entornos, a localização industrial em São Paulo tem se orientado pelos grandes eixos de ligação à capital, privilegiando as cidades com melhor infra-estrutura do seu entorno. Assim, continuam sobressaindo-se os eixos principais representados pela Bandeirantes e Anhanguera (com uma derivação para a Washington Luiz), Presidente Dutra e Carvalho Pinto, e Castelo Branco-Marechal Rondon. No entanto, neste sistema do eixos estruturadores,

A peculariedade está no eixo formado pela rodovia Fernão Dias, que liga São Paulo a Belo Horizonte, pelo fato de estar surgindo um novo implante industrial, em grande medida determinado pela proximidade com São Paulo, mas localizado já em território mineiro, principalmente nos minicípios de Pouso Alegre, Varginha e Poços de Caldas" 105

Na verdade, este eixo e o da Raposo Tavares, entre a capital e Curitiba, duplicados e modernizados com investimentos do governo federal, constituirão parte da chamada Rodovia do Mercosul (que se estenderá a Florianópolis e Osório, no Rio Grande do Sul), e reafirmará, por tangenciá-la, a condição polarizadora da metrópole paulistana. Por outro lado, a construção do "Rodoanel Metropolitano", também obra com participação do governo federal, rearticulará em torno da capital os vários eixos radiais que a demandam, sinalizando a redistribuição territorial das antigas atividades industriais.

Ao lado destas obras, os processos de concessão ao setor privado das rodovias estaduais, da Fepasa (4.900 km de linhas, interligadas em São Paulo à malha ferroviária sudeste da RFFSA, já privatizada), bem como a privatização dos sistemas portuários e aeroportuários e energético, além da conclusão das obras da eclusa de Jupiá (possibilitando a navegação comercial da Hidrovia TietêParaná, interligando Conchas, a 160 km da capital, até os Estados de Goiás e Minas Gerais, ao norte e até a Foz do Iguaçu, no Paraná e ciudad del Este, no Paraguai, ao sul) e do Gasoduto Brasil-Bolívia ( $528 \mathrm{~km}$ em trecho paulista, atravessando 86 municípios, que se bifurcam para o sul e para o vale do Paraíba em Paulínia, na região de Campinas), têm com referência uma rede de 36 municípios com mais de 100 mil habitantes ${ }^{106}$.

Nesta rede evidenciam-se os pólos metropolitanos do Estado (Grande São Paulo, Baixada Santista e Campinas — as duas primeiras reconhecidas institucionalmente como tal) e detecta-se, também, o espaço de irradiação e intercâmbio funcional de caráter metropolitano ususualmente chamado de Complexo metropolitano expandido - CME — ou Macrometrópole de São Paulo", que compreende, "além de São Paulo e sua região metropolitana legal, o centro submetropolitano de Campinas e parte de sua região de influência direta; as capitais regionais de Santos e Sorocaba, com partes de suas 
respectivas regiões; o pólo regional de São José dos Campos e a região do Vale do Paraíba que comanda"ıor. Segundo caracterização da Emplasa (1994, 120):

Esse complexo abriga as atividades metropolitanas típicas de centro financeiro, centro administrativo, centro direcional de empresas e organizações econômicas em geral, polarizadas na Grande São Paulo; centros de pesquisa e investigação científico-tecnológica, distribuídos pelo núcleo metropolitano, Campinas e São José dos Campos; centros universitários e tecnológicos de formação de mãode-obra qualificada (ao lado da Grande São Paulo, Santos, Sorocaba, Campinas, São José dos Campos); refinarias de petróleo (Baixada Santista-Cubatão, Vale do Paríba, regiões de Campinas-Paulínia, Grande São Paulo-Capuava); amplos setores da produção industrial distribuídos ao longo das regiões de influência direta dos pólos caracterizadamente metropolitanos e dos que se conotam como capitais regionais; uma área portuária e retroportuária de grande capacidade, ainda que de implantação e organização administrativaoperacional antiquadas (Porto de Santos/Vicente de CarvalhoGuarujá)". 


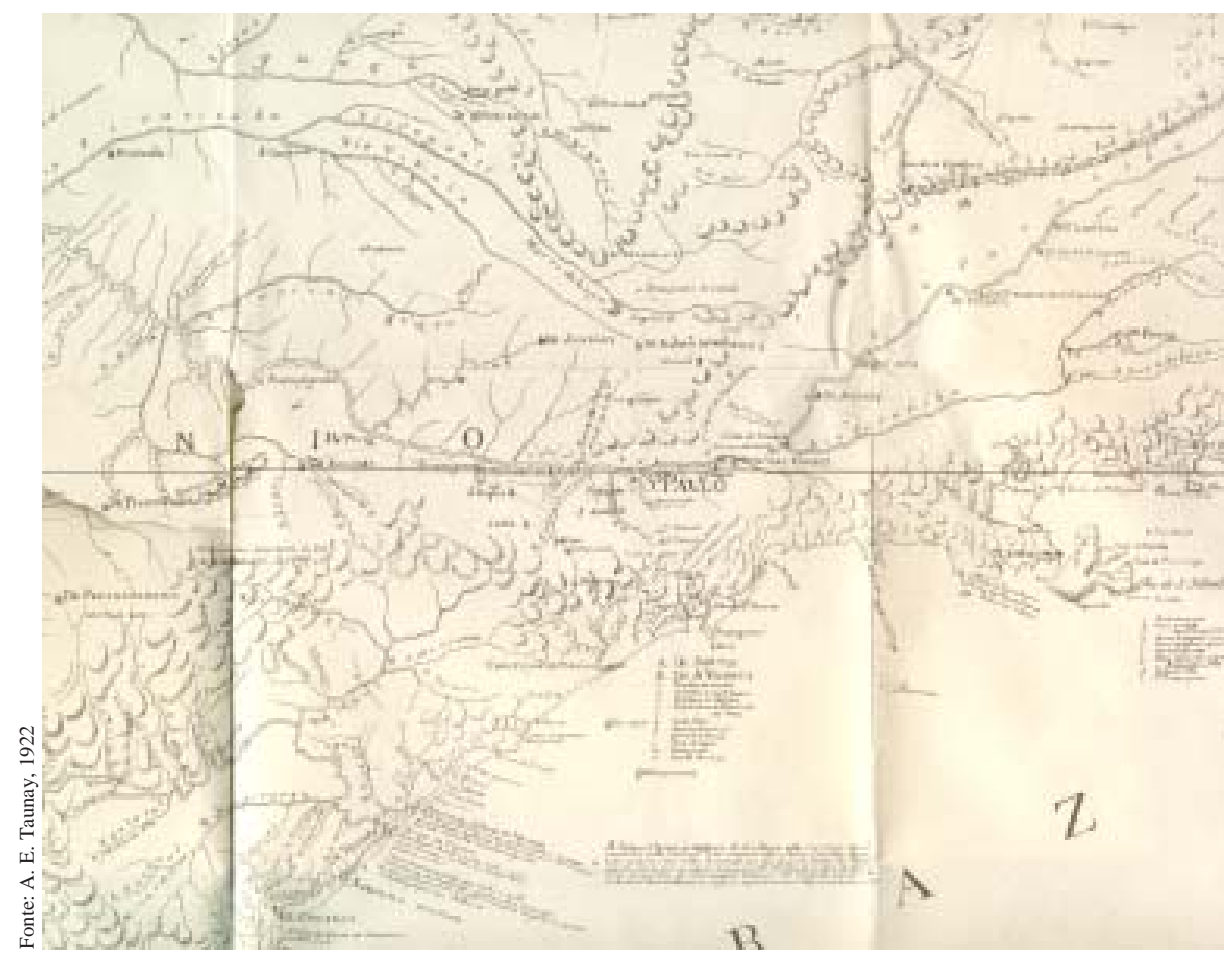

Mappa Chorographico da Capitania de São Paulo”, elaborado em 1972 pelo engenheiro A. R. Montezullo, a mando de Bernardo José de Lorena: a preocupação com os elementos da geografia física é dominante

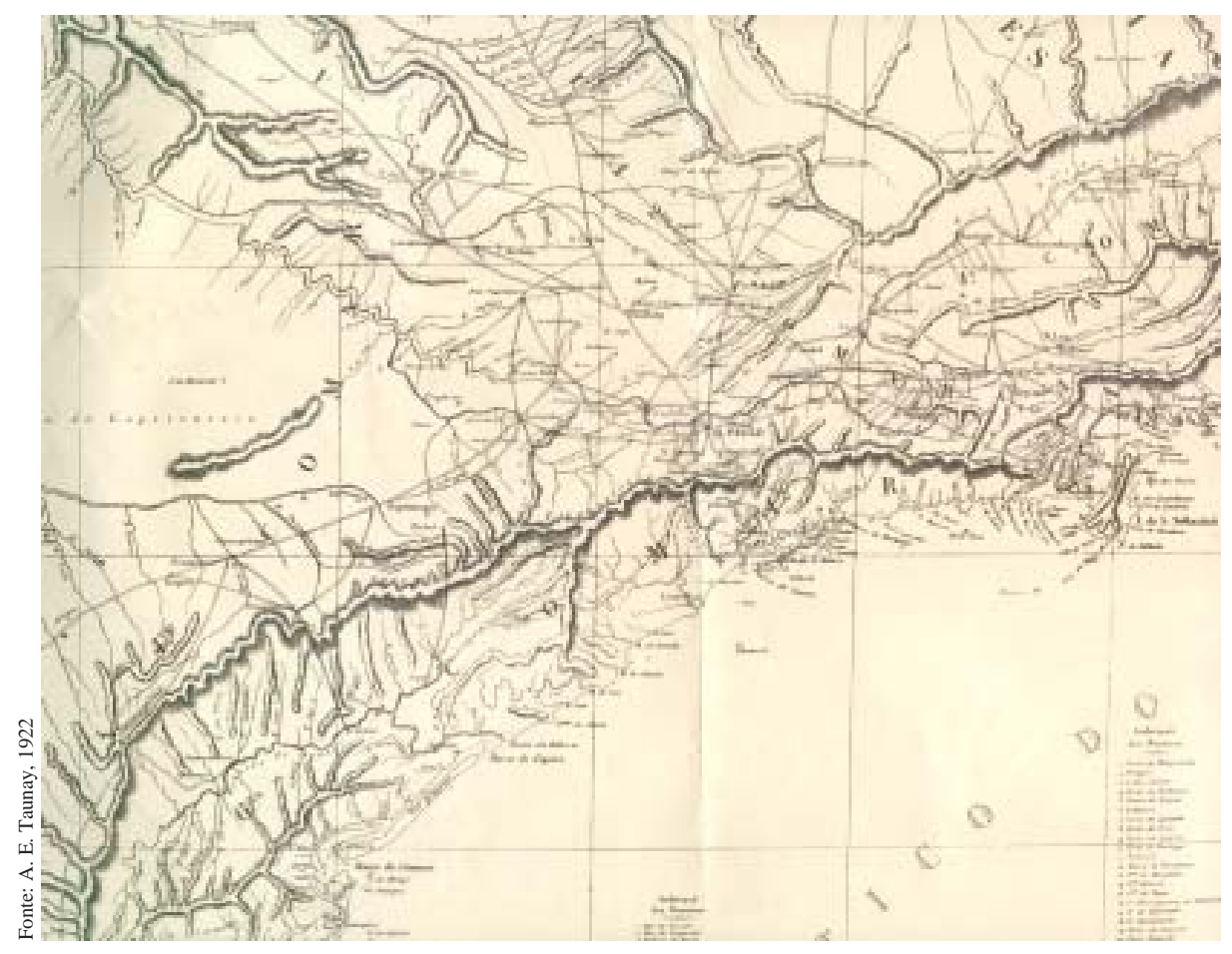

Mappa Chorographico da Província de São Paulo" de Daniel P. Muller, 1837: a rede de caminhos articula um território mais ou menos indifenciado a pontos do litoral. O setor leste da província permanece sertão desconhecido 
Etapas da expansão da malha ferroviária de São Paulo e crescimento populacional, cuja dinâmica desloca-se de nordeste (Vale do Paraíba) a noroeste. A cidade de São Paulo constitui o centro de irradiaçãos das "faixas" territoriais, cada uma servida por uma linha férrea
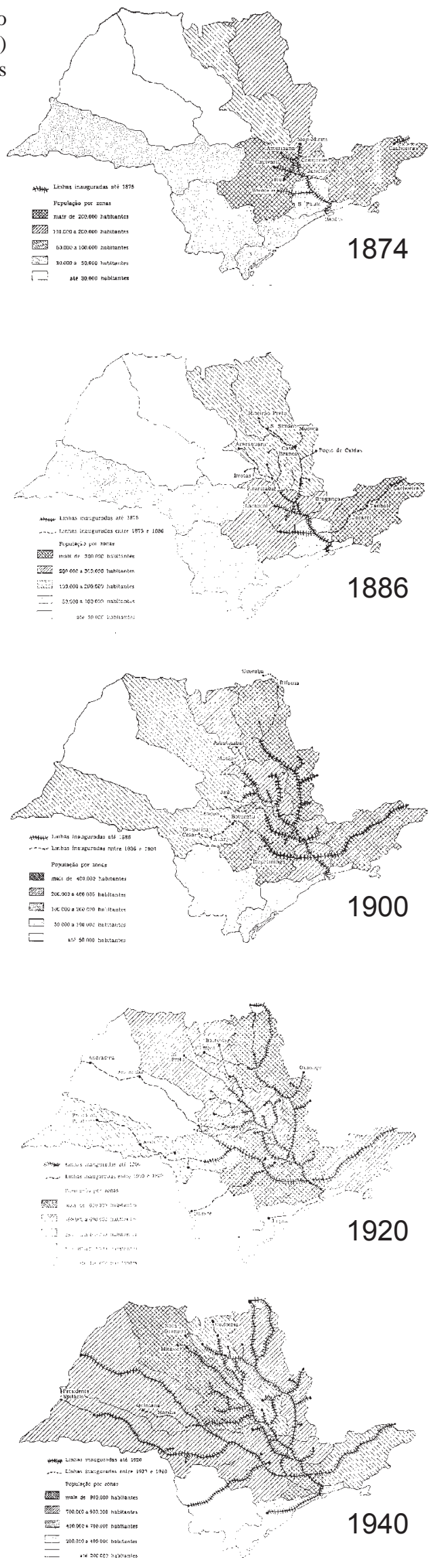

Fonte: A. F. Saez, 1981 
Projeto de 1925 de D. A. MacMillen para a ligação ferroviária São Sebastião-Santos-Mogi das Cruzes-JundiaíCampinas: alternativa ao binômio Santos-São Paulo

Situação da malha feroviária de São Paulo em 1950: consolidação de um modelo em "árvore": o tronco principal é constituído pelas estradas Santos Jundiaí e Paulista

Situação das malhas ferroviárias do Estado de São Paulo: 1970
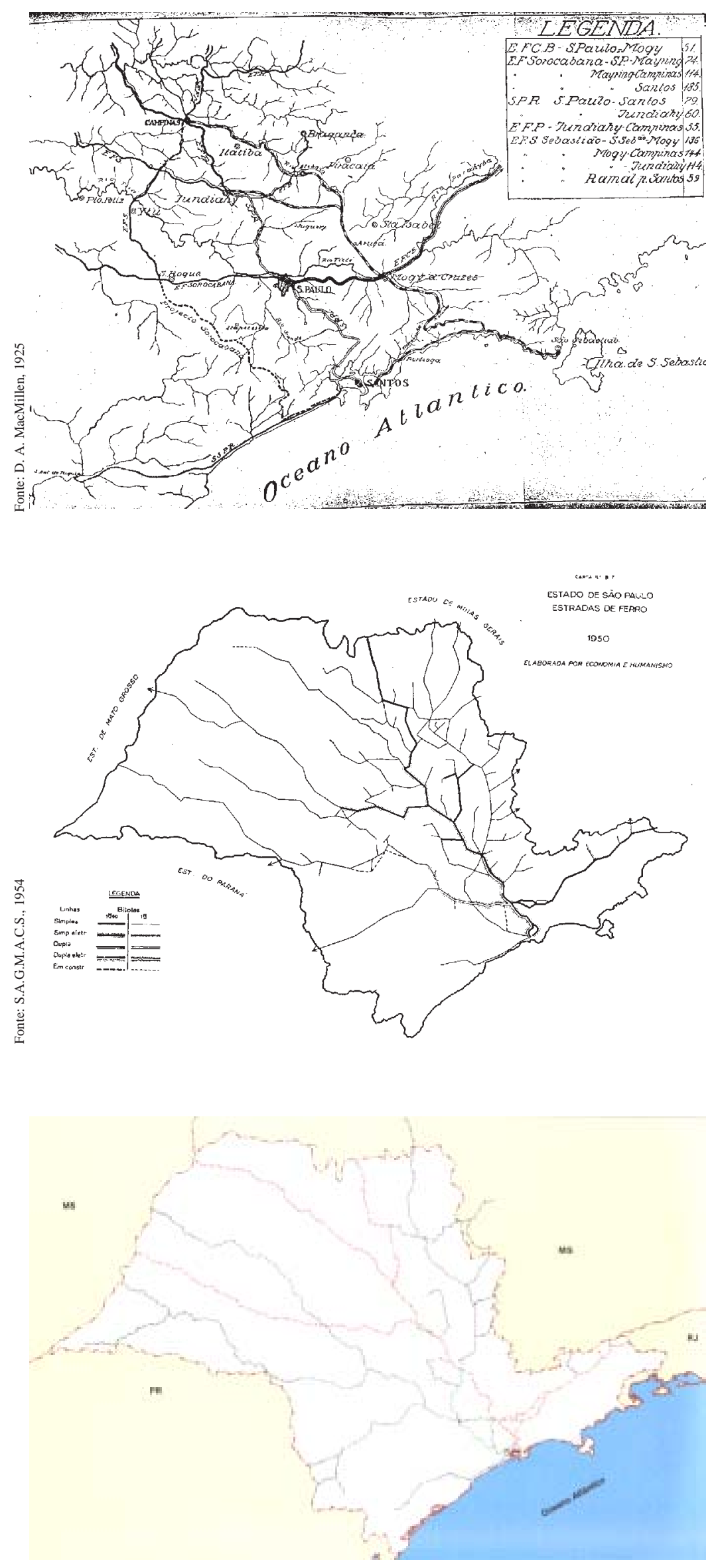
Estradas de rodagem em 1950: os novos traçados iniciam a interligação "transversal" do território. As principais "linhas" de desenvolvimento infra-estrutural traçados ferroviários, ligando a capital ao Vale do Paraíba, região de Campinas, Sorocaba e Santos: estrutura em forma de cruz, "já reconhecida como figurando a extensão de São Paulo" confirmam os antigos
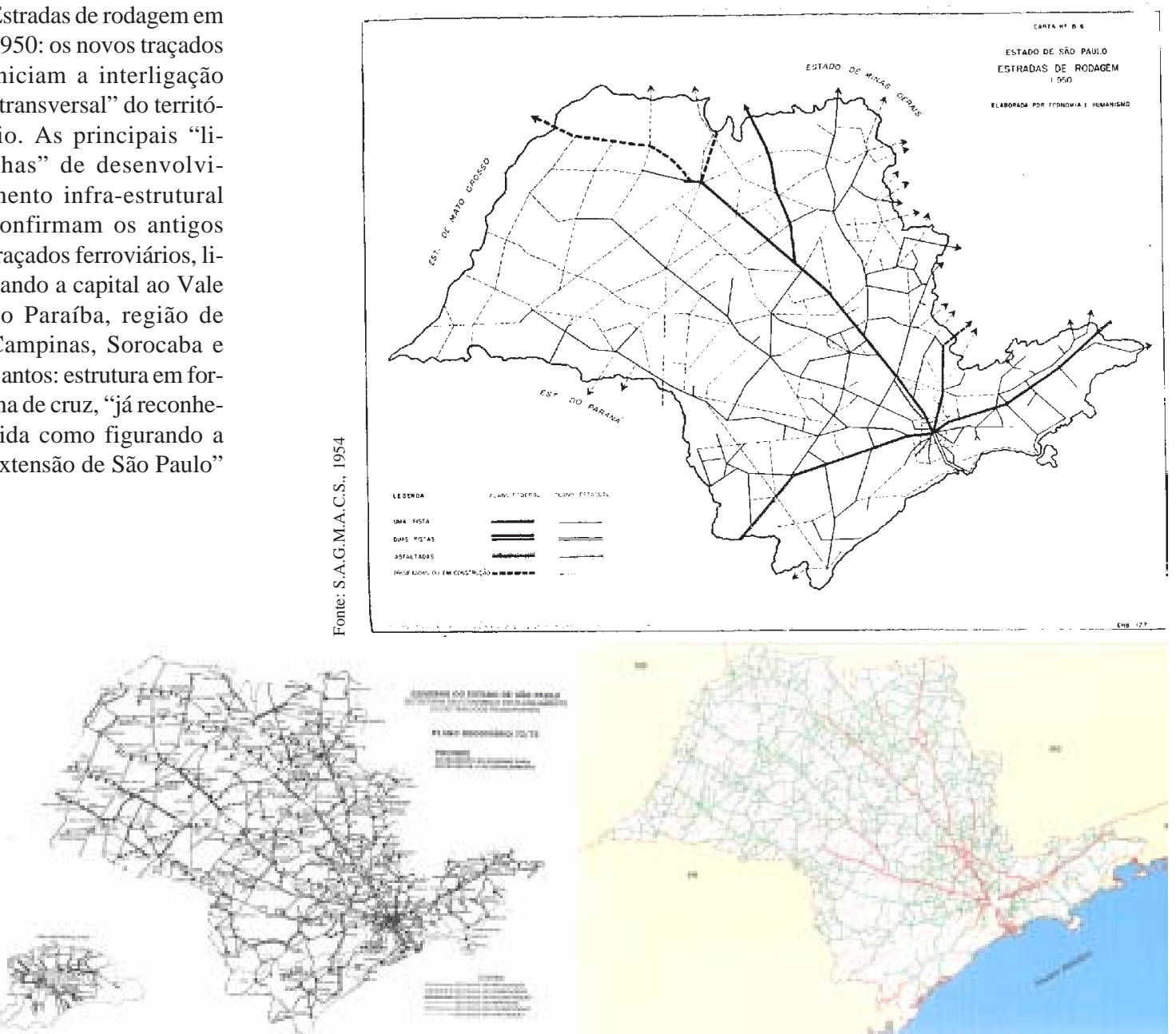

Plano rodoviário 72/75 e situação atual da malha rodoviária do Esatdo de São Paulo: hegemonia do modelo rodoviário na integração do território. Enquanto a ferrovia cessou sua expansão na década de 40, a rede rodoviária evolui pelas seguintes etapas (Zahn, 1988):

1920: São Paulo, Baixada Santista, Campinas 1950: consolidação da rede exsitente

1930: extremo Oeste, Vale do Paraíba, Sul

1960: acessibilidade radial

1940: limites do Estado

1970: ligações transversais de caráter regional não rádio-metropolitano
Rodovias privatizadas no Estado de São Paulo: se o "interesse" pela concessão está relacionado com a rentabilidade da infra-estrutura, pode-se supor a partir do esquema gráfico, as áreas de maior desenvolvimento econômico do território paulista

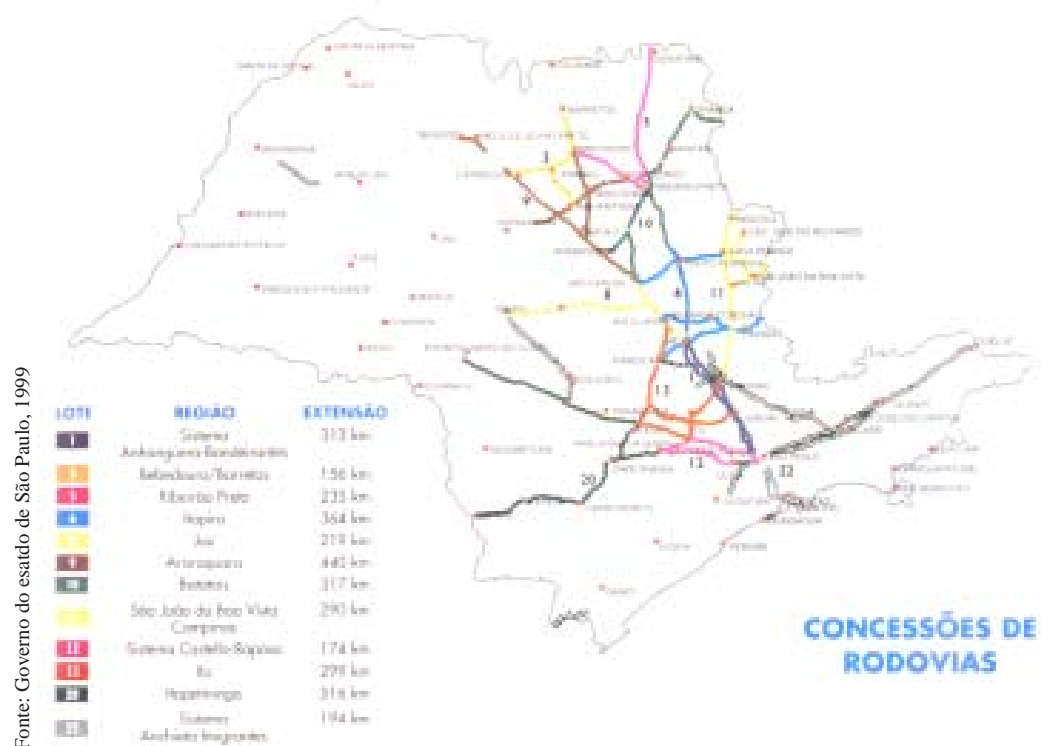


Projeto do porto de São Sebastião comparado com o porto de Santos - situação existente em 1925

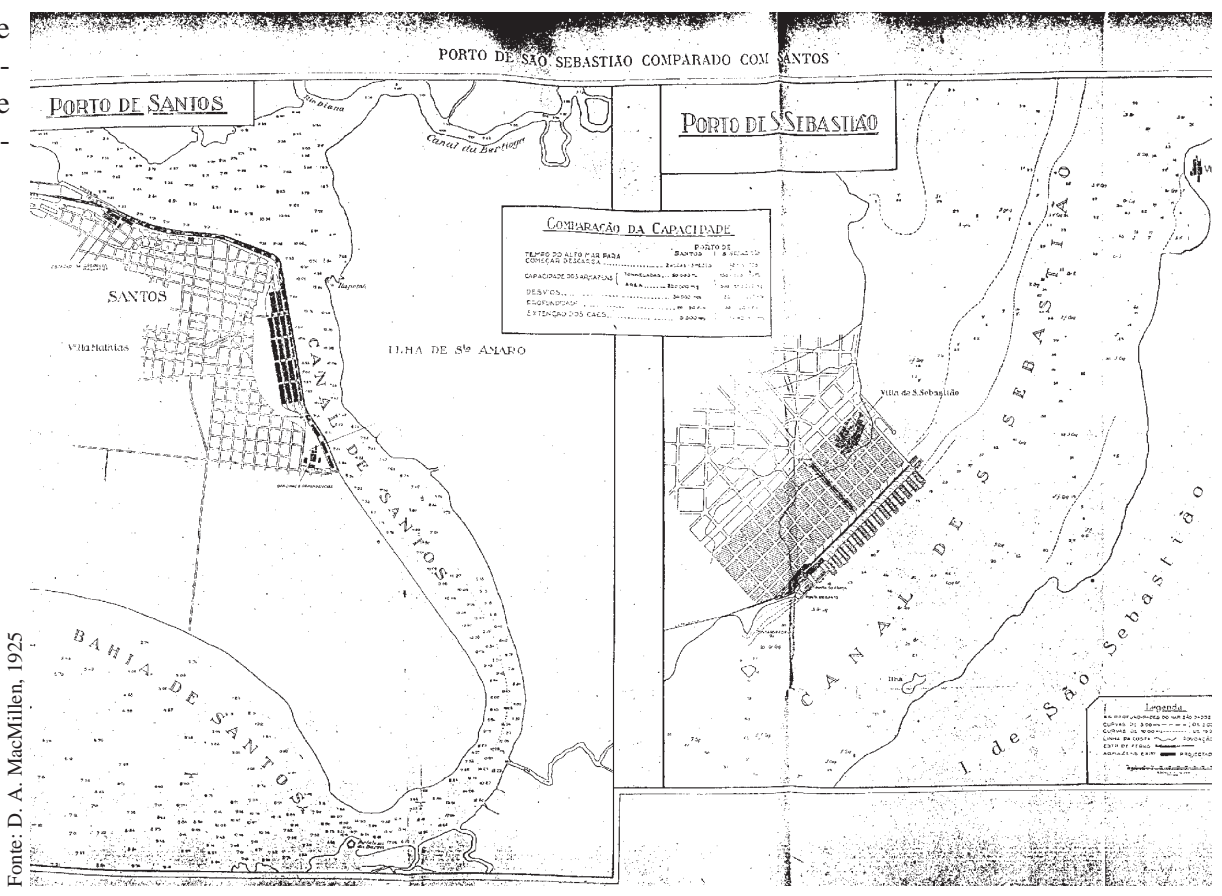

Projeto para porto em São Sebastião (1925) e ampliação da malha urbana sobre o tecido do núcleo existente

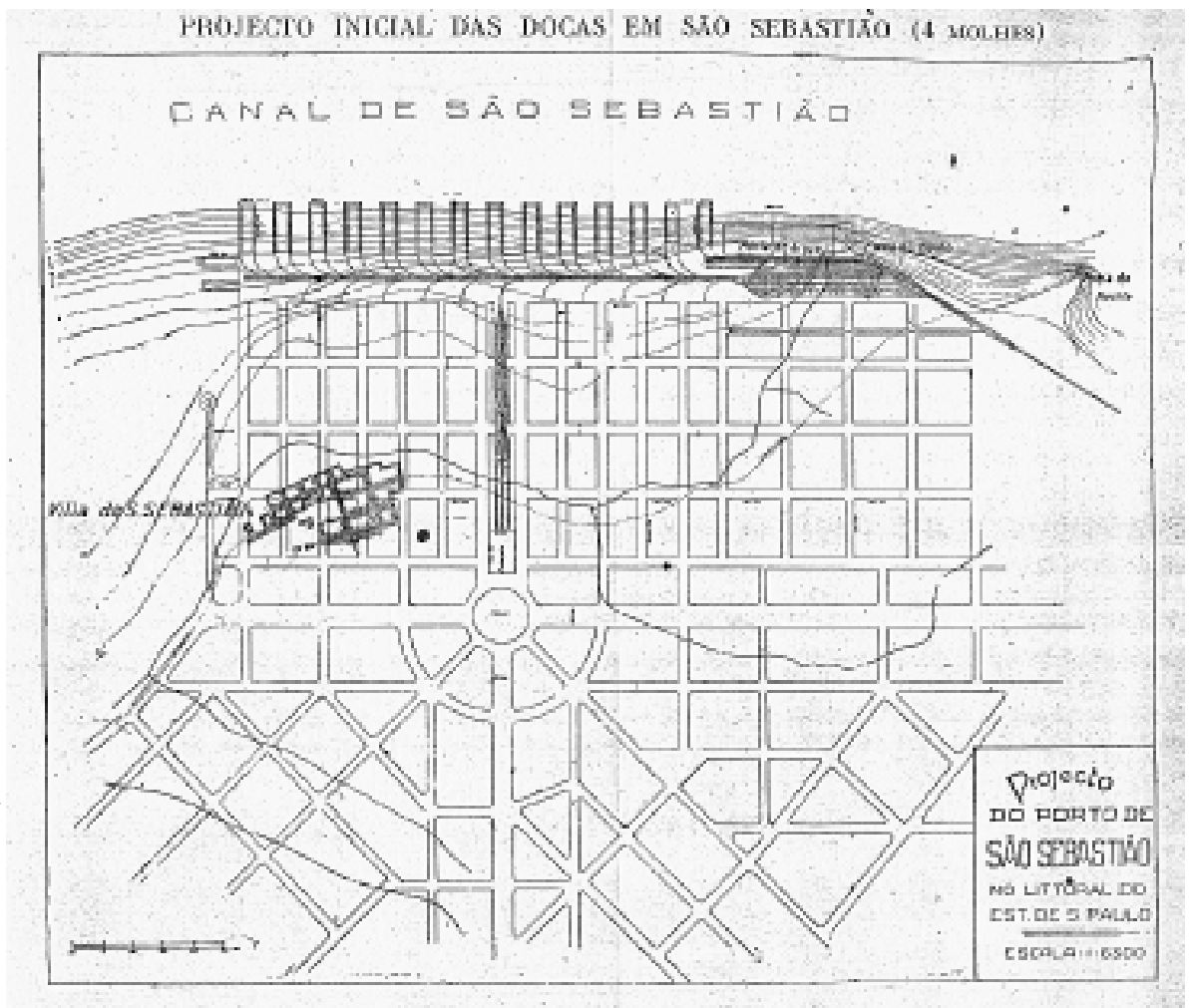


Indicações para a construção de um porto na Enseada do Flamengo em Ubatuba (1954)
Projeto para cosntrução de terminais de contêiners e granéis em São Sebastião, ampliando o cais existente da Petrobrás
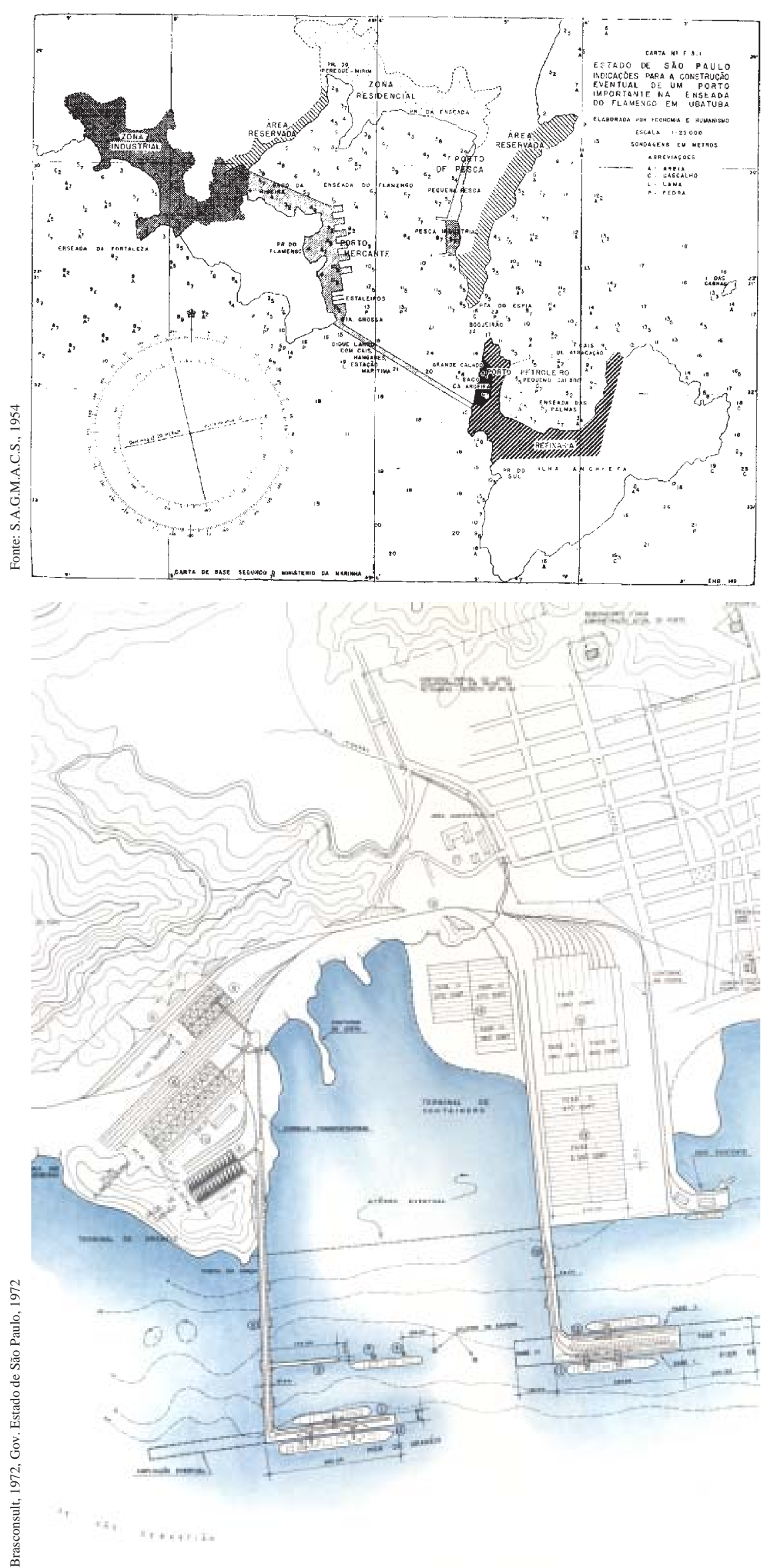


\subsection{A estrutura macrometropolitana: os elementos definidores e as mudanças de seus significados}

Tomando a implantação dos canais de circulação como metáfora (ou metonímia) das intervenções que constituem as políticas públicas (sociais, coletivas) de valorização (ou revalorização) territorial, pode-se buscar interpretar o processo de estruturação do espaço macrometropolitano a partir das relações que os diversos pontos que o compõem mantém entre si e com escalas e âmbitos superiores.

Neste sentido, representando as formas de organização do território como modelos gráficos de conexidade e integração entre os lugares (na verdade, entre as atividades presentes neles), pode-se caracterizar o território colonial paulista a partir de uma trama mais ou menos indistinta e homogênea de caminhos mais ou menos precários, que se estrutura a partir de um sistema de binômios constituídos por núcleos planaltinos e litorâneos que se estende ao longo de toda a linha de serra e que dá sentido territorial ao contexto que articula, debilmente, economia de subsistência e mercado externo. Como escreveu Dennis:

à diferença dos portos onde os caminhos se dispersam em todos os sentidos a partir do porto, no Brasil meridional os portos isolados do interior (pelo obstáculo interposto pela serra do mar) exercem quase exclusivamente a função de porta, a cada um correspondendo uma cidade no interior" ${ }^{\prime 108}$.

Assim é que quando estas regiões paulistas são chamadas para participar da nova etapa da colonização, a ocorrência dos numerosos ancoradouros naturais e os limites que as modalidades de transporte utilizadas no período colonial (tropas de mulas) impunham à localização de áreas agrícolas permirtem explicar a ocupação de toda a faixa planaltina correspondente ao vale do Paraíba, aos compartimentos de planalto da Serra do Mar e às encostas meridionais da serra da Mantiqueira, segundo aquela estrutura de binômios porto-cidade interior que seria polarizada através da navegação de cabotagem pelo porto do Rio de Janeiro.

Dentro do nosso campo de estudos, como se viu, na serra os caminhos interconectavam os portos de Iguape, Santos, São Sebastião, Ubatuba e Parati, respectivamente, com as cidades de Sorocaba, São Paulo, Jacareí, Taubaté, Pindamonhangaba e Guaratinguetá, cujos núcleos definiam-se no ponto de intersecção destes caminhos com a estrada que ligava (precariamente) Rio com São Paulo, de onde se dirigia para o sul, ao longo dos vales encaixados da morraria do Embú. Quanto ao binômio Santos-São Paulo sua área de influência estendia-se a oeste pelo chamado "Quadrilátero do açúcar", formado pela área situada entre as cidades de Sorocaba, Piracicaba, Mogi-Guaçu e Jundiái. 
Se as tentativas de privilegiar o eixo São Paulo—Santos (Calçada do Lorena, restrições à operação dos demais portos da província, etc) tiveram importância apenas relativa na reorganização do território (na medida em que se deram fases de retomada do comércio através dos portos do Litoral Norte com o Rio de Janeiro), o fenômeno ferroviário transformaria completamente o quadro territorial, impondo uma nova ordem espacial e política ${ }^{109}$, que produziria um verdadeiro colapso dos sistema de binômios anteriormente vigente e tornaria Santos o centro monopolizador das relações com o planalto. Mais do que nunca é este o verdadeiro momento da formação do sistema São PauloSantos ${ }^{10}$ segundo um novo contexto de articulação do mercado externo a um incipiente mercado interno. Segundo Reis $F^{o}$ (1999), a nova configuração de caminhos teve três efeitos principais: abriu o interior de São Paulo e grande parte do sul de Minas à cultura do café, a partir de Campinas, reduziu os laços do Vale do Paraiba com o Rio de Janeiro (contribuindo para acelerar a decadência de suas antigas cidades) e, finalmente, transformou Santos em grande centro cafeeiro, competindo com o Rio de Janeiro. Poderia se acrescentar que esta nova configuração explica também o crescimento da cidade de São Paulo que, dos 31.385 habitantes que tinha em 1872, passa a $239.820 \mathrm{em} 1900$ e atinge $579.033 \mathrm{em} \mathrm{1920" \textrm {m } .}$

Neste contexto, o "gráfico" do sistema territorial cafeeiro assume uma forma prevalentemente em "árvore , refletindo uma certa relação de tipo hierárquico entre centros urbanos. Essa relação, em grande medida, funda-se nos e expressa o papel territorial dos pontos de convergência e entroncamento das linhas e ramais ferroviários. Porém, se as ligações diretas (sem demandar São Paulo) dos centros cafeeiros com Santos, então a "verdadeira praça do café", bem como os diversos projetos ferroviários de ligação com o litoral (que não Santos), poderiam supor a possibilidade de um território ainda não rigidamente polarizado pela capital, no entanto, por diversas razões (circunstâncias geográficas, monopólio das companhias ferroviária e portuária, falta de um plano ferroviário geral), esta configuração "em árvore" tenderia (por exclusão de outras alternativas) a estruturar-se em função de um sistema linear principal, correspondente ao traçado da São Paulo Railway e Companhia Paulista de Estradas de Ferro. A partir dele as ramificações, "como vasta mão espalmada sobre o território" "12, desenvolveram-se de forma quase independentes entre si, não articulando-se senão na região central do Estado. Esta configuração acabaria por consolidar a cidade de São Paulo como centro de comunicações e de comando administrativo, político e financeiro do território: "O centro de irradiação deste leque de faixas, servidas cada qual por sua linha de ferro, bem como de rodagem, é a região da capital, que se torna assim o nó onde se articulam todas as vias de comunicação, e para onde se volta, portanto, toda a vida do Estado"»ı3. Aí, o processo de industrialização encontra suas bases para implantação. 
Modelado e desenvolvido pela industrialização, este sistema de polaridade tenderia a reforçar a concentração populacional e produtiva na capital, fazendo emergir, nos anos 50, um esquema basicamente "estelar : seus "raios" rodoviários, principalmente nas diretrizes Dutra, Anhanguera e Anchieta, "dobram" e esvaziam o papel territorial dos eixos ferroviários, ao mesmo tempo que expandem as potencialidades locacionais para a indústria, segundo um gradiente centro-periferia. Por um lado, na lógica deste sistema de aglomeração, centro e periferia, passando a "trocar" residência e trabalho, darão ensejo à constituição do processo de metropolização ${ }^{114}$. Por outro lado, esta lógica, que concentra na região metropolitana, entre a década de 30 e a de 70 , em torno de $65 \%$ do valor da produção industrial do Estado, definirá o papel dos outros pontos do território.

Santos, como porto marítimo, ampliará sua função complementar às do pólo metropolitano. No entanto, se as atividades comerciais portuárias até a década de 50 (data do início da produção do petróleo e aço na Baixada Santista) havia criado uma infra-estrutura suficientemente forte para propiciar as condições iniciais de um desenvolvimento industrial voltado para o mercado da própria Baixada, a partir daí, a transformação do "porto comercial em porto industrial (importador de insumos industriais) provocou o gradativo desvinculamento de suas atividades de Santos, já que o pólo de desenvolvimento industrial se formou em São Paulo e em relação ao qual a indústria e a economia da Baixada são dependentes" "15. Além do mais, os produtos que na sua grande maioria são atraidos do mercado internacional pela sub-região de Santos, "ao que tudo indica são primeiramente interceptados pela região da Grande São Paulo antes de serem distribuidos para outros mercados de âmbito nacional" "16.

As políticas e "fatores" de descentralização da base produtiva, revertendo as tendências, ou pelo menos reforçando alternativas territoriais para a localização das atividades, desenham um novo modelo de conexão que se não equilibra a hegemonia do esquema "estelar", centrado na capital, distribui seu peso segundo "anéis de circulação que não mais demandam diretamente o pólo metropolitano. Este novo padrão de circulação configura, pelos traçados das rodovias D. Pedro I (Campinas/Jacareí) e Santos Dumont (Campinas/ Sorocaba) e da linha ferroviária (Paulínia/Mairinque), alternativa ao predomínio histórico do vetor SE-NO (Anchieta/Imigrantes e Anhanguera/ Bandeirantes). Isto afirma a região Campinas como "vértice" intermodal do sistema agro-industrial exportador, e redefine o sistema logístico de tranporte do porto de Santos, que se torna cada vez mais especializado, em grande medida, precisamente para atender a hinterlândia agrícola. Se a entrada em operação da hidrovia Tietê-Paraná tende a reforçar o papel nodal da região de Campinas, ao mesmo tempo consolida o corrredor de escoamento da região Centro-Oeste para Santos. No entanto, esse corredor passa a sofrer mais diretamente a concorrência de outros canais de distribuição (Hidrovia do 
Madeira, ligando Porto Velho a Itacotiara, Sepetiba e Paranaguá) que tendem a atrair parte das cargas produzidas na região central. Ao mesmo tempo, pelo surgimento de novas hinterlândias, pela privatização e pelas novas lógicas do transporte marítimo ( hub ports, feed-services, transhipment), a concorrência entre os portos (dentro do território nacional e mesmo do "cone sul") não permite afirmar a antiga hegemonia do porto santista.

****

A partir destes modelos de conexão, tomados não apenas em seu aspecto técnico e funcional, mas sim como "metáforas" da integração e valorização territorial, pode-se tentar indagar sobre os elementos "fortes" que definem a cada momento o território, bem como inferir sua mudança de significados.

Assim, pode-se observar que a Serra do Mar, de obstáculo precariamente transponível (portanto, servindo, inicialmente como elemento de defesa e proteção), é "aproveitada" como recurso para a produção energética e, depois, sob os impactos do parque industrial que se instala em suas bordas, impõe o reconhecimento de seu valor (bem como de sua fragilidade) ambiental. Por outro lado, os vales e terrenos plano, passagens fáceis para as primeiras rotas de colonização interior, sucessivamente cortados pelos traçados ferroviários e rodoviários, que se sobrepõem em faixas contíguas, vão conferir o suporte para um sistema de cidades que, desde a primeira ocupação, vai representar, em cada período histórico, pelos efeitos da convergência e acumulação de fatores, a área mais dinâmica do território.

Se a transposição da Serra do Mar selecionou um ponto de irradiação dos caminhos, esse é "fixado" na medida em que o sistema de comunicações encontra aí seu centro de convergência e articulação, o que, em grande parte, acabaria contribuindo para conformar a aglomeração econômica e demográfica que passaria a polarizar todo o território. Assim é que durante três séculos, a cidade de São Paulo constituirá o entreposto comercial que articula a "economia de subsistência do interior" com o "mercado exterior"", realizando o (ainda que precário) intercâmbio econômico entre o planalto e o litoral. Sob os impactos do ciclo açucareiro e, sobretudo, do surto cafeeiro, este papel, sustentado pelo sistema "porto marítimo-porto seco", ampliar-se-á através da sobreposição das funções de centro administrativo e financeiro da província, que passa a articular um mercado externo ampliado com um (sempre mais forte) "mercado interno", conformando, deste modo, pela acumulação de capital, mão-de-obra e infra-estrutura, as bases fundamentais para a capital e sua área mais próxima transformarem-se no principal pólo industrial no plano nacional.

Neste sentido, integrando funções de centro comercial em sua economia industrial, São Paulo tornar-se-ia a "metrópole nacional , polarizando tanto o mercado interno quanto o sistema financeiro e o mercado de capitais. Porém, 
a dinâmica de interiorização da economia, deflagrada nos anos 70, levaria progressivamente ao processo de inversão das relações entre a função comercial e a industrial da metrópole. Se até pelo menos a metade dos anos 70, a ùltima sobrepuja, "subordinando às suas necessidades" ", a primeira, os números mais recentes do valor da produção industrial ${ }^{119} \mathrm{e}$ da PEA indicam a transformação da base produtiva — de eminentemente secundária a predominatemente terciária—, senão da Grande São Paulo como um todo, ao menos, indubitavelmente, do núcleo paulistano. O sistema industrial (tradicional), em declínio, passa a ser substituído pelas atividades mais voltadas ao comércio atacadista e varejista e, sobretudo, aos serviços especializados e às funções territoriais raras, cuja concentração em São Paulo, torna-a "metrópole onipresente para todo o território brasileiro:

prova de que sua função não depende da indústria é que aumenta seu poder organizador ao mesmo tempo em que se nota uma desconcentração fabril... A metrópole informacional assenta sobre a metróple industrial, mas já não é a mesma metrópole"120

Metrópole informacional", "metrópole organizacional", "cidade mundial", constituem metáforas que, se buscam dar conta do novo patamar de relações mundializadas no qual a cidade de São Paulo se insere (ainda que, talvez, de forma incompleta), aqui são úteis no sentido de tentar interpretar os efeitos desta nova "qualidade" metropolitana sobre o quadro territorial contíguo. Assim, como analisa Lencioni: "se a concentração das atividades econômicas, sobretudo a concentração industrial, é que estruturou o aglomerado metropolitano, hoje é a dispersão industrial o elemento funadamental na reestruturação da metrópole de São Paulo"'121. No entanto, "a decisão, o poder de mando, o efeito catalizador, o ambiente inovador, os serviços essenciais de ordem superior, esses continuam concentrados na Grande Metrópole”. Neste sentido,

a metrópole de São Paulo se desconcentra como negação dos mecanismos de concentração e afirma sua centralização". (...) A reestruturação urbano industrial da metrópole de São Paulo tem como fundamento a desconcentração das atividades econômicas que não resulta da perda do poder de atração dos grandes centros urbanos, mas da maior flexibilidade de localização resultante da extensão territorial deste poder, no qual novos papéis na divisão e cooperação do processo produtivo são reservados para cada unidade espacial...Fruto de inovações tecnológicas e gerenciais, essa flexibilidade se amplia na media em que a área de produção pode distanciar-se do centro de decisões, da gestão administrativa e financeira e da prestação de serviços especializados".

Na medida em que o terciário superior continua centralizado na Grande São Paulo, particularmente na capital, reafirmando sua primazia através da concentração não só das sedes dos grandes conglomerados como das 
atividades de gestão financeira, sedes dos principais bancos e serviços especializados (como consultoria legal, adminsitrativa e financeira), os processos de interiorização do desenvolvimento — pauta política desde os anos 70 — não significariam, processos autônomos de metropolização: “ao contrário, são manifestações constituivas da expansão do espaço metropolitano paulista, que se configura numa "macrometrópole", que é reforçada e, não negada, pela dispersão de suas atividades. No entanto, embora a "vontade" de reforçar-se na competição internacional e de desempenhar um papel de mediação entre os sistemas locais regionais e o internacional — própria à nova condição metropolitana de "cidade mundial"—, a ordem implícita a esta nova condição supõe também uma maior especialização e complementariedade territorial e, portanto, senão a diminuição, ao menos a transformação das relações de dependência hierárquica, como as que marcaram a organização "industrial" do território paulista: os "requisitos" locacionais para a implantação de funções antes ditas "metropolitanas" se difundem por outros pontos do território, reproduzindo em outra escala o fenômeno "reticular" que já se manifestava no interior da aglomeração central.

Resolver a ambiguidade contida nesta metáfora e, assim, indagar a nova "condição" do território passa pela interpretação do papel que podem desempenhar os outros nós do contexto macrometropolitano. Neste sentido pode-se observar que os pólos regionais contíguos à Grande São Paulo Santos, Campinas, São José dos Campos, Sorocaba—, tendo, historicamente, superado o declínio da economia cafeeira, (cada um a seu tempo e seu modo, em grande medida, graças á "massa crítica", urbana, populacional, infraestrutural, adquirida no período anterior), puderam apresentar-se como lugares onde o processo de industrialização — enquanto extravasamento das funções metropolitanas-pôde ser "absorvido" desde as décadas de 40 e 50 . As políticas públicas de desconcentração industrial dos anos 70 e os novos fatores locacionais — que se mostram com mais força nos anos 90- resultam em dinâmicas territoriais que sugerem maior difusão e integração das atividades distribuidas sobre o território, que por isto, ainda dentro do conceito de espaço contínuo e homogêneo de região geográfica ("aglomeração") pode ser descrito como "macrometropolitano".

Porém, "quando a velocidade e os tempos de circulação inter-urbana tornamse iguais ou inferiores àqueles de certos tipos de deslocamento intra-urbano, mas sobretudo quando a informação, 'matéria prima' e fator estratégico dos atuais processos de desenvolvimento, circula através de redes, isto é, em um espaço descontínuo, no qual os "nós" (centros urbanos, sedes de empresa, etc), ainda que fisicamente distantes, são mais "vizinhos" entre si (em termos de acessibilidade à informação, facilidade de comunicação, difusão das inovações, etc) do que aqueles espaços interpostos, mesmo que contíguos" "122, quais as relações e quais papéis podem vir a ser desempenhados por cada 
ponto deste território macrometropolitano? Isto significaria que a sorte de cada ponto deste território depende, hoje, menos de suas relações regionais, internas, e sempre mais das relações com o resto do mundo? E, particularmente interessado ao caso santista, cujo desenvolvimento esteve mais diretamente atrelado á metrópole, quais seriam os efeitos espaciais, urbanos desta nova ordem? ${ }^{123}$.

Essas questões são importantes menos no sentido de serem pronta ou definitivamente respondidas - mesmo porque isto representa uma tarefa de difícil solução na medida em que os processos na verdade encontram-se em curso- - Antes interessam, sobretudo, por permitir estabelecer um marco de referência teórico a partir do qual confrontar os modelos recentes de desenvolvimento de Santos e Campinas, no sentido de caracterizar quais fatores externos e quais "condições locais" apresentam-se como "estratégicos" nesta nova ordem territorial. 
Grande São Paulo: origem e destino dos fluxos de produtos "industrializados" (acima) e "agro-pecuários beneficiados" (abaixo). Super concentração das funções industriais do território: produção e consumo

Região do Litoral: origem e destino dos fluxos de produtos "industrializados" (acima) e "agro-pecuários beneficiados" (abaixo). Afora o vetor "exterior", apenas Minas Gerais (siderurgia) compõem a pauta de "atração" da Baixada Santista

Região de Campinas: origem e destino dos fluxos de produtos "industrializados" (acima) e "agro-pecuários beneficiados" (abaixo). Ainda que constituindo área de "extravazamento metropolitano", o esquema sugere a grande diversidade da base econômica da região
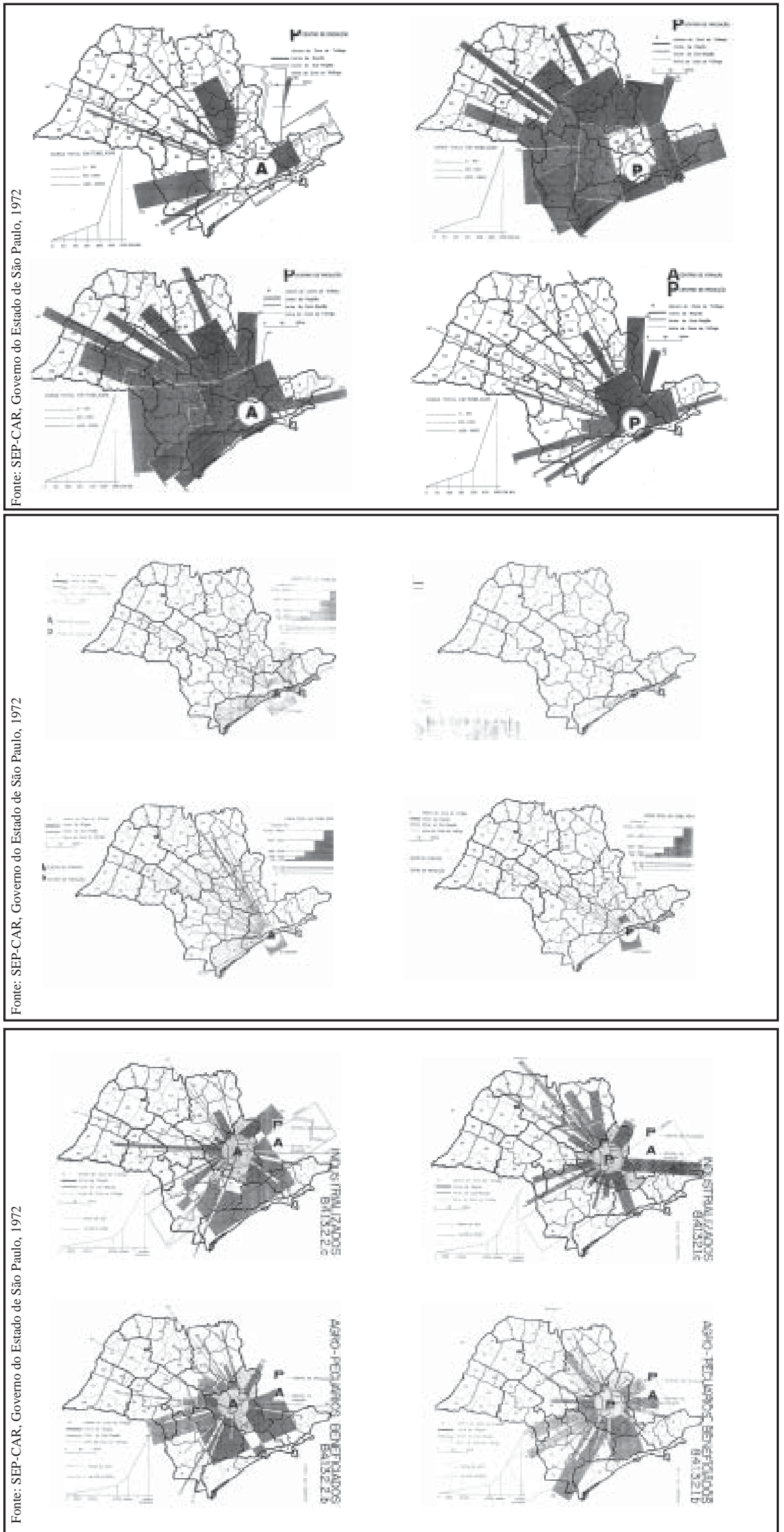


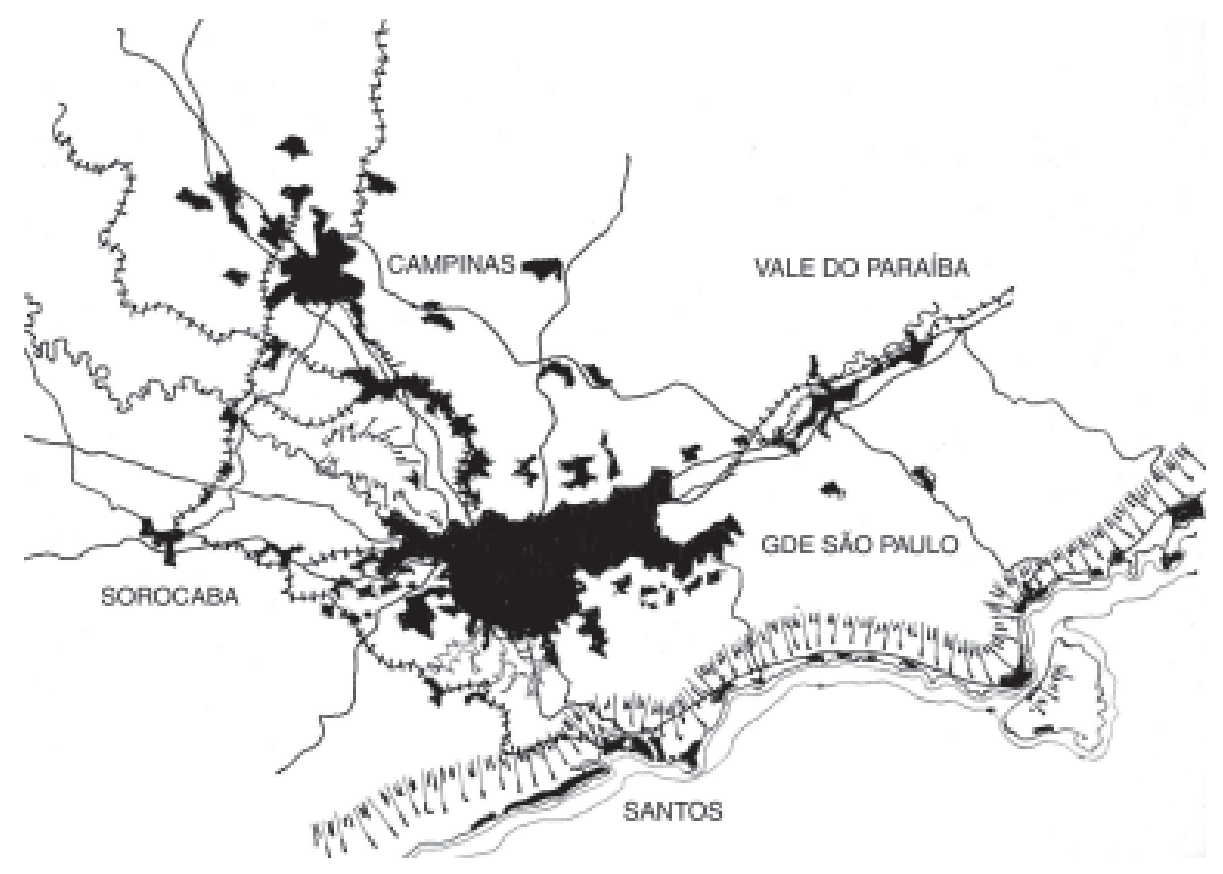

Esquema da configuração territorial da macrometrópole de São Paulo
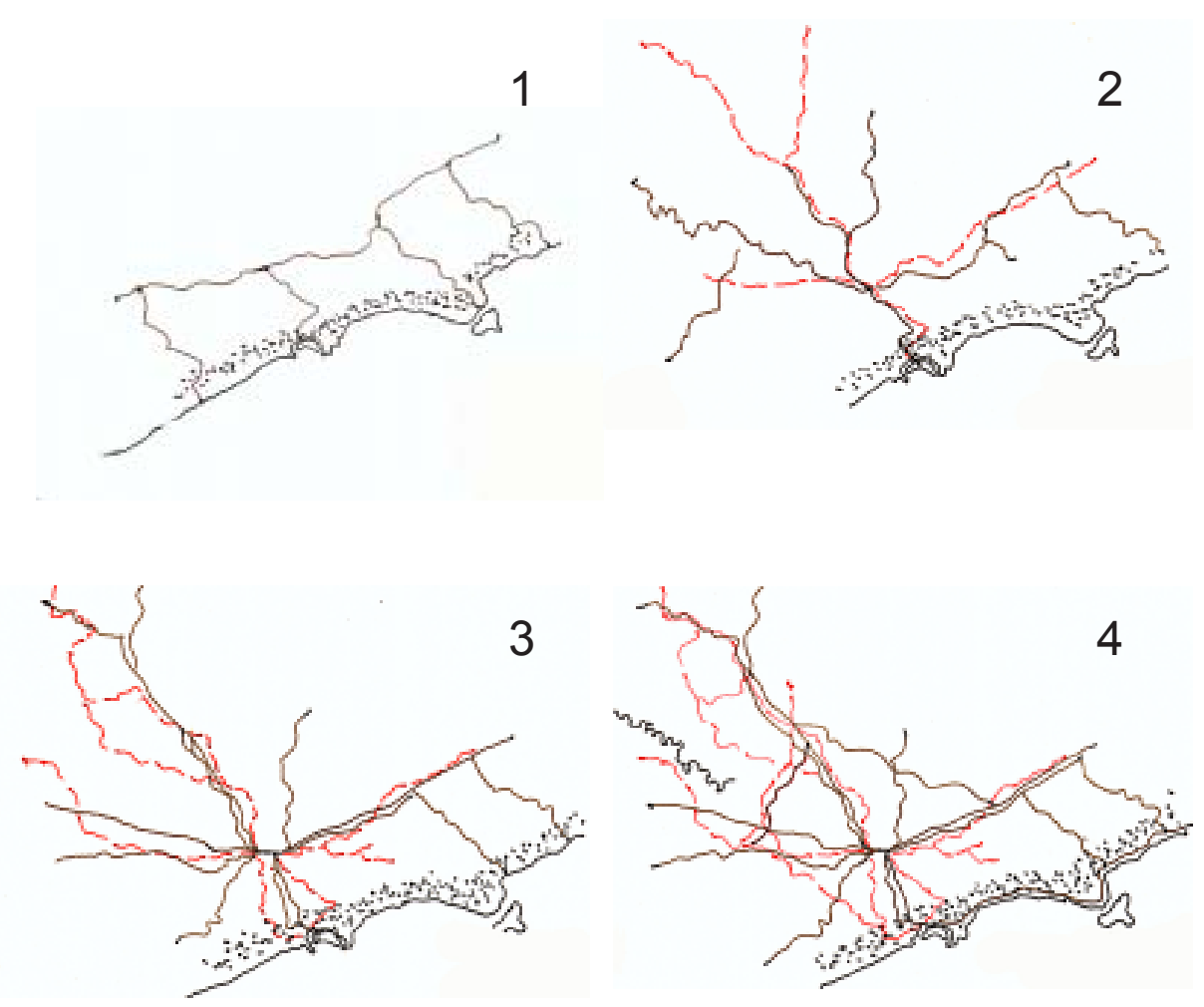

Etapas da articulação infra-estrutural do território macrometropolitano

1. até 1850: caminhos litoral/planalto

2. até 1930: eixos ferroviários

3. 1950/1970: modelo rodoviário rádio-metropolitano

4. 1980/1990: configuração de anéis ferro-rodoviários 


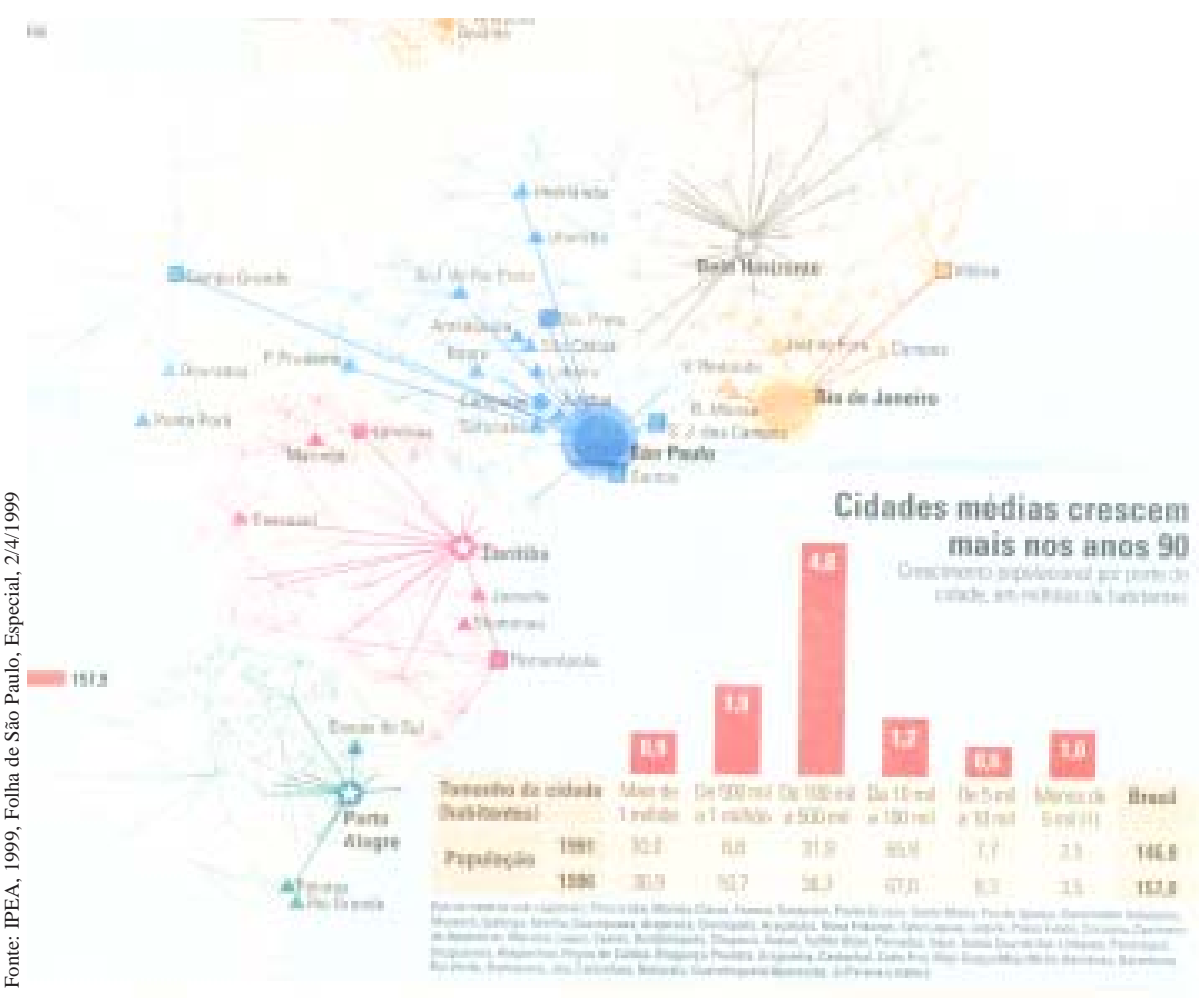

A rede urbana do Centro-Sul: "os fluxos urbanos (representados como linhas ligando as cidades) indicam a demanda por serviços e comércio entre municípios e delimitam a área de influência das principais cidades. No caso de São Paulo, $24 \%$ de todos os tipos de demanda originados nas regiões das metrópoles têm como alvo a capital paulista. Isso significa que ela é procurada para prover desde insumos até serviços de saúde e educação"

1

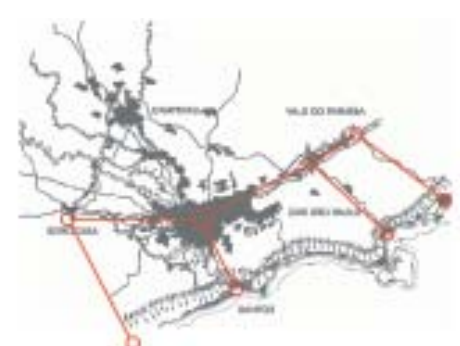

3

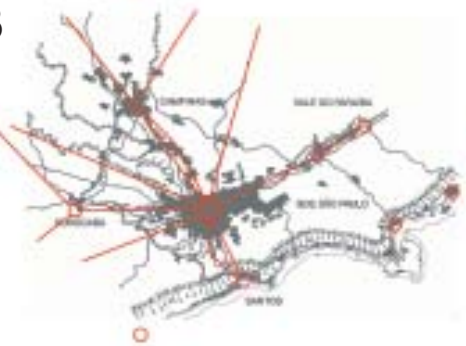

5

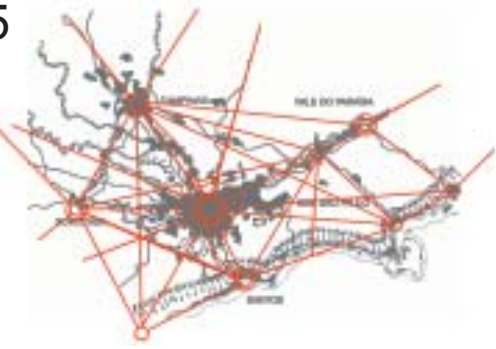

2

(1)

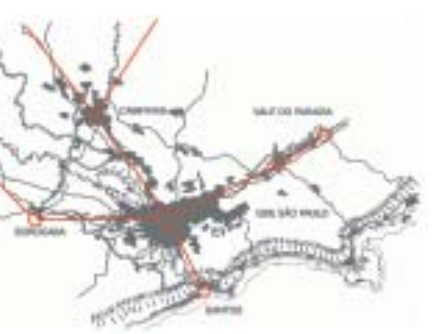

4

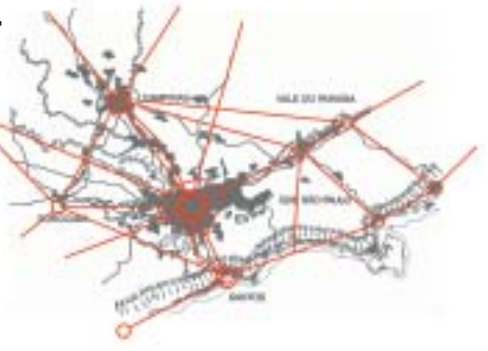

Esquema da transformação das relaçõesde conexidade e integração entre os lugares na macrometrópole:

1. Sistema de binômios

2. Estrutura em árvore "ferroviária"

3. Estrutura estelar "rodoviária"

4. Estrutura anelar, predominante, rodoviária

5. Tendência reticular: fluxos, materiais e imateriais, entre atividades presentes no território 


\subsection{Santos e Campinas}

As "descrições territoriais" realizadas no ítem 2.2 mostram que a condição inicial da cidade de Campinas — "boca de sertão"— se vê contínua e sucucessivamente reinterpretada. A cidade, enquanto elemento de interface capital-interior, desempenha funções de centralidade, com feições próprias a cada etapa do processo de desenvolvimento econômico. Assim é que, respondendo com mudanças na estrutura de produção, Campinas apresentase, nos anos 30, como "maior centro agrícola do Estado" (diversificando a agricultura, antes fortemente sustentada pelo café); depois como primeiro centro manufatureiro do interior (ainda nos anos 30 e 40), que, desenvolvendo a partir dos anos 50 seu parque industrial como sede de empresas internacionais, viria a consolidar-se, nos anos 70, com a implantação dos pólos petroquímico e de alta tecnologia, além de se tornar centro de pesquisa e ensino de importância nacional.

Neste sentido, na década de 1970, estudos do goveno estadual ${ }^{124}$ apontavam que a região de Campinas,

dada sua localização privilegiada a meio caminho das regiões do Oeste Paulista e a capital do Estado, e dada a existência de uma infra-estrutura suficientemente dimensionada (...), vem se projetando como elemento propulsor da industrialização, apresentando características de acentuado dinamismo nos diferentes setores da atividade econômica".

Reforçando aquele papel, apesar de bem servido pelo sistema ferroviário (embora este não tenha "acompanhado o desenvolvimento global do Estado"), o sistema de transportes da região apoiava-se cada vez mais no modal rodoviário, que "possibilita um fluxo de mercadorias e um deslocamento populacional dos mais intensos", não só pelo fato dessa região constituir uma das "mais dinâmicas e industrializadas do país" como "pelo serviço de ligação do centro-Oeste do Brasil, Sul de Minas Gerais e as regiões administrativas de Ribeirão Preto e São José do Rio Preto, com a Grande São Paulo e o porto de Santos" ${ }^{25}$. Esse fluxo teria se intensificado, precisamente, com a ocupação do Brasil Central, fazendo coincidir o principal eixo da região com um dos lados do triângulo SP-Brasília-RJ. Se o sistema radial é o que imperava, tendo como centro a capital, entre as "transversais" destacar-se-ia, então, a inauguração da "Campinas a Jacaréi", permitindo através da ligação como o Vale do Paraíba, Guanabara e Rio de Janeiro, colocar em jogo toda uma área isolada por décadas ${ }^{126}$.

Nos anos 80, as tradicionais funções de Campinas como "porta de entrada" para o interior, reforçadas pela acentuada melhoria dos sistemas de transportes e comunicações e as características de localizar-se como pólo da região, cuja base produtiva (agrícola e industrial) já era a mais avançada e ampla do 
Estado depois da capital, explicavam a acumulação da "massa crítica" econômica e populacional que ensejou sua evolução diferenciada, ou seja, a de passar de centro regional (muito embora, já constituindo o principal pólo manufatureiro do interior) a núcleo de área metropolitana com projeção nacional (em termos de estrutura terciária e urbana ${ }^{127}$ ):

A região de Campinas caracterizou-se na última década (1980) como uma área metropolitana emergente, apresentando para alguns de seus municípios taxas recordes de crescimento, com valor acima de $20 \%$ ao ano. A saturação da região da Grande São Paulo, tanto em termos demográficos, como de industrialização e urbanização, a deterioração das condições de vida consequentes desta saturação, aliada á proximidade territorial das duas regiões, foram sem dúvida os fatores determinantes deste crescimento, que ocorreu de forma diferenciada no tempo e no espaço" ${ }^{228}$.

O processo cumulativo de absorção do "extravazamento" das funções industriais metropolitanas resultaria na "metropolização emergente" da área (23 municípios e 2 milhões de habitantes), comandada pelo núcleo campineiro, que, assim, passa a polarizar "o mais dinâmico e diversificado centro ( com 4,84 milhões de habitantes na região administrativa) de desenvolvimento da indústria, do agrobusines e de serviços do Estado" ${ }^{29}$.

$* * *$

Quanto à cidade de Santos, se a atividade portuária confirmar-se-ia como a mais dinâmica do país, precisamente a partir do movimento exportador do café (fazendo a cidade exercer o papel de "verdadeira praça cafeeira até as primeiras décadas do século), a partir dos anos 50, a ela viriam se somar o parque industrial de Cubatão e as funções turísticas, ampliando e reforçando as relações de dependência com a capital e sua área adjacente. Se até os anos 70, essa relação permite a Santos desenvolver e diversificar sua base econômica (finanças, comércio, atividades de importação e exportação, turismo, lazer), a partir daí, de forma aparentemente paradoxal, as maiores facilidades de conexão com a capital, bem como as ligações com outros pontos do litoral (que passaram a concorrer com as praias santistas, sob processos de degeneração ambiental), de certa maneira, fazem diminuir o ritmo de desenvolvimento urbano, drenando para a capital o comércio e os serviços mais sofisticados.

Nos anos 70, a região de Santos seria entendida como "potencialmente estratégica", não só por estabelecer a ligação da capital do Estado e regiões interioranas com os mercados externos, através da infra-estrutura portuária existente, como também por apresentar um setor industrial com características específicas (dada a proximidade de comunicação com o exterior) e um franco desenvolvimento do setor turístico ${ }^{130}$. Por razões históricas, moldada em função do porto de Santos (fato que seria considerado a causa do atraso 
econômico do Litoral Norte e do Vale do Ribeira ${ }^{131}$ ) a infra-estrutura de transportes do Litoral tinha, então, na via Anchieta o "maior fluxo de tráfego da país" (exportação e importação). Isto colocaria como prioridade a conclusão da Rodovia dos Imigrantes, no sentido de atender tanto o turismo interno como o transporte de mercadorias.

No entanto, Santos, a segunda cidade paulista até os anos 70 (dinamismo que derivou, como se viu, do complexo portuário, das funções turísticas e da proximidade dos pólos petroquímico e siderúrugico de Cubatão), sofreria o impacto negativo da abertura das novas rodovias que

propiciaria o crescente devio dos fluxos turísticos tanto em direção ao sul, no caso dos contigentes de menor renda, quanto para o norte, envolvendo a classe média de maior poder aquisitivo. Esses movimentos, sobrepondo-se aos efeitos do superadensamento populacional causador da poluição e da descaracterização de suas praias, iriam deslocar dali boa parte dos estimulos advindos daqueles fluxos. Ademais a melhoria do sistema viário acabaria por dirigir à própria região da Grande São Paulo demandas que, potencialmente, poderiam encontrar escoadouro na cidade ${ }^{132}$." (...) "Por seu turno, os gravísissimos problemas ambientais decorrentes da operação dos pólos de Cubatão iriam tolher sua expansão, com o que também se imporiam limites severos a maiores desdobramentos terciários e urbanos que dali poderiam fluir" ${ }^{\prime 3}$.

Na década de 1980, a Baixada Santista apresentaria sensível perda de ritmo do crescimento, com ausência de novos investimentos, agravada, evidentemente, pela saturação ambiental, específica da região. Em função desta situação e a despeito da excelente localização do pólo petroquímico, os novos investimentos foram gradativamente "deslocados" para outras regiões do país (Bahia, Rio Grande do Sul) e do Estado de São Paulo (Paulínia e São José dos Campos). Na verdade, "a questão ambiental, assumindo contornos drásticos no início dos anos 80 , levou a Governo estadual a tomar medidas mais rígidas de controle à poluição industrial, causando a diminuição do ritmo de produção, senão o fechamento, de importantes linhas de produção". ${ }^{134}$

No entanto, apesar do arrefecimento do investimento, a atividade industrial, enquanto maior fonte geradora de renda, apresentava-se como um dos pólos dinâmicos da economia da sub-região de Santos. De outro lado, o setor terciário que, "por possuir um raio de ação que ultrapassa os limites da região e do estado, continuava a absorver a maior parcela da população economicamente ativa" ${ }^{35}$. Em relação ao porto, entendia-se que, "muito embora ele continue responsável por ponderável parcela das atividades urbanas, a possibilidade de crescimento do potencial irradiador dessas atividades também parece restrita, pelo menos no curto prazo, dadas por um lado as modificações técnicas nas atividades de embarque, desembarque e 
armazenamento, e por outro o vulto dos investimentos necessários para sua ampliação e modernização."

Neste quadro, embora passe a perder os benefícios de intermediação comercial e não diferencie seu terciário em relação aos centros vizinhos, a cidade de Santos constitui, apoiada no tripé porto-turismo-serviços, a principal cidade da região Metropolitana da Baixada Santista, instituída em 1996, a partir da integração (se bem que por ora mais oficial e retórica que efetiva) de nove municípios, que abrigam uma população de 1,3 milhão de habitantes e população flutuante de 781 mil habitantes ${ }^{137}$.

$* * *$

Nos anos 90, a competitividade de Campinas vem alvancada tanto na capacidade infra-estrutural (rodoviária, ferroviária, aeroviária, energética e de comunicações), quanto na base industrial regional (petroquímica, automotiva e de alta tecnologia) e no sistema científico e tecnológico (universidades e institutos governamentais). Conta também com forte presença do setor comercial. Classificada pela revista Exame ${ }^{138} \mathrm{em}$ nono lugar (atrás de oito capitais e à frente de Recife) como "pólo de atração de negócios", suas vantagens comparativas vêm dadas por condições tais como população (local e regional), potencial de consumo (5,6 bilhões de dólares por ano), PIB regional (9\% do nacional), mão de obra qualificada (ativo para a implantação de indústrias de alta tecnologia), infra-estrutura de transportes e de comunicaçãoes (localização privilegiada da cidade — articulando proximidade com a capital e ligações com os estados do Sul, Rio de Janeiro e Minas Gerais- e expansão aeroportuária ${ }^{139}$ ), serviços pessoais. Tal conjuntura teria sido responsável pela atração de 22 empresas (a maioria multinacionais), correspondendo a investimentos da ordem de 1,1 bilhão de dólares na cidade, desde outubro de 1997.

Quanto a Santos, a importância nacional do complexo ${ }^{140}$ portuário, a presença do parque industrial de Cubatão (o que torna este município o sexto maior arrecadador de tributos federais) e a infra-estrutura rodo-ferroviária instalada constituem fatores de indução para a implantação de 320 plantas industriais (principalmente voltadas aos transportes de cargas) no Distrito Industrial da Alemoa. As quatro universidades particulares, a rede hospitalar relativamente bem dimensionada, e as áreas comerciais existentes na cidade atendem a demanda dos diversos municípios da RM da Baixada Santista. As opções de lazer e turismo completam o quadro (ainda que serviços de hotelaria de Santos apresentem necessidade de ajustes no sentido da adequação aos novos padrões do turismo $\left.{ }^{141}\right)$. Na classificação da Revista Exame Santos comparece em $14^{\circ}$ lugar (atrás de Goiânia, Manaus e Belém, e imediatamente à frente de Ribeirão Preto, Campo Grande e Saõ José dos Campos, pela ordem). Com taxa de crescimento anual negativa (-0,63\% ao ano entre 1991 e 1998), a cidade apresentaria potencial de 2660 milhões de dólares/ano referentes à 
despesas de consumo e 2560 dólares de consumo anual per capita ${ }^{142}$. Por outro lado, segundo o Correio Popular (13/9/1998), a cidade de Santos seria apontada como a terceira melhor cidade do Brasil em termos de qualidade de vida (enquanto Campinas alcançaria a vigésima posição), segundo avaliação da $\mathrm{ONU}^{143}$.

Se estes dados e estas classificações, independente da metodologia empregada, indicam o descompasso que existe entre "desenvolvimento" e "utilidade", por outro lado, talvez se possa observar que, pelo exame do conjunto das análises territoriais realizadas até aqui, as tendências recentes de desenvolvimento urbano e regional no Estado de São Paulo parecem combinar uma base infraestrutural consolidada em termos de transportes e comunicações com sistemas locais de especialização agrícola e diversificação industrial, apoiados na existência de instituições de pesquisa (P\&D). Por outro lado, enquanto o terciário superior (financeiro, de comando, etc) permanece centralizado na área metropolitana de São Paulo (particularemente na capital), outras funções metropolitanas (interessadas à escala nacional ou internacional) distribuem-se entre os centros maiores de acordo com as exigências colocadas pela presença de grandes empresas e pelo aumento do contigente de operários. Isto aconteceria com Campinas, São José dos Campos e Sorocaba. Porém, talvez com excessão de Campinas, estas duas últimas cidades, bem como Santos teriam, pela proximidade da capital e pela melhoria das ligações viárias, limitações ao "desenvolvimento de determinados serviços, notadamente aqueles de maior especialização, conteúdo tecnológico ou que exijam escalas maiores" 144 Neste sentido, por exemplo tomando como referência a "contagem de empresas de serviços de informática" conforme pesquisa recente do SEADE ${ }^{145}$, pode-se observar que diante da 133 instaladas na Região Metropolitana de São Paulo, 13 na Região Administrativa de Campinas e 5 na de São José dos Campos, as regiões de Sorocaba e Santos não contam com nenhuma.

Ao mesmo tempo, deve-se ressalta-se a "tradicional" assimetria da base econômica do município de Santos: o valor adicionado do comércio (em termos de particpação no total do Estado), evidencia a importância da atividade portuária, embora o terciário como um todo sofra pela própria debilidade da demanda regional. Na verdade Santos, dentre as regiões referidas, é a região que apresenta valores mais baixos (inclusive perdendo posições) tanto em relação ao comércio, quanto à indústria, seja em termos de valor bruto de produção, seja em termo de valor adicionado ${ }^{146}$. E isto coloca a questão, tantas vezes discutida, como se verá, da cidade diversificar sua base econômica, na medida em que a própria atividade portuária torna-se tendencialmente cada vez mais autônoma em relação à escala urbana e regional. Infra-estrutura que permitiu a Santos afirmar-se sobre todos os outros pontos do litoral paulista, alavancar o desenvolvimento dos parques industriais de Santos, Cubatão e da Grande SãoPaulo além de escoar os 
produtos agrícolas do interior do país, incrementando as atividades terciárias (comércio atacadista e serviços —o que pode ter sido um dos fatores qure contribuiram para o crescimento da função turística de Santos, São Vicente e, me menor escala, Guarujá), a função portuária, por razões que se tratará adiante, parece ter esgotado sua capacidade de geração de efeitos multiplicadores e inovação sobre a cidade e a região. Em face dos fatores de desenvolvimento territorial e econômico da macrometrópole —não custa repetir: transportes e comunicações, sistemas agrícolas e industriais locais apoiados em P\&D—, o tripé das funções básicas da cidade — porto, serviços, turismo - deve ser redimensionado no sentido de gerar novas condições de valorização de Santos no contexto macrometropolitano.

O processo de valorização territorial de Santos pôde ser descrito pelos vários estágios de implantação de infra-estruturas regionais; estágios esses distintos e bastante caracterizados segundo as escalas dos interesses econômicos presentes na Baixada e que se traduzem metaforicamente nas seguintes realizações ${ }^{147}$ :

- sistema ferroviário: escoamento da produção agrícola para o exterior

- Caminho do Mar (melhoria), Via Anchieta e Padre Manoel da Nóbrega: demanda de transportes de produtos agrícolas, escoados pelo porto

- Ligação Anchieta/Piaçaguera, em função da implantação do pólo petroquímico e siderúrgico de Cubatão

- Pedro Taques e Piaçaguera-Guarujá: demanda de tráfego turístico à escala da própria Baixada

- Imigrantes: reforço da estrutura de ligação espacial entre a metrópole e suas áreas de interesse econômico na Baixada

Se a duplicação da Imigrantes parece ter "90\%" de sua razão no atendimento da demanda que o porto tem de veículos de $\operatorname{carga}^{148}$, a questão que se coloca é sobre o papel do porto na produção e desenvolvimento da cidade.

'M. Santos, Espaço \& método, 1985, p.3

${ }^{2}$ G. Dematteis. Progetto implicito, 1996

${ }^{3}$ O Litoral era concebido como uma das quatro ou cinco "províncias morfológicas", classificadas por Monbeig (1949) e Ab'Saber (1956 e 1958), e incluía as zonas das "Baixadas Litorâneas" e da "Serrania Costeira" (vide J. L. S. Ross e I. C. Moroz, Mapa geomorfológico do Estado de São Paulo, 1997)

${ }^{4}$ P. Monbeig apud São Paulo (Governo do Estado). $2^{\text {a }}$ Região Administrativa Diagnóstico. São Paulo, 1972 e A. R. Penteado, “A ilha de São Vicente" in A Baixada Santista —Santos e as cidades balneárias. Vol III, 1965

5 "As altimetrias variam desde 20 até $1000 \mathrm{~m}$ (altitudes médias entre 800 e 1000m) e as declividades predominates são superiores a $40 \%$, chegando a $60 \%$ em setores localizados em vertentes" (Ross e Moroz, Op. cit., p.37)

${ }^{6}$ A Baixada Santista, na verdade, inclui três baixadas: a Santista, propriamente dita, que intermedia, através de um "golfão", as outras duas - Baixada de Bertioga e Baixada de Itanhaém

'P. Petrone. "Povoamento e caminhos nos séculos XVI e XVII" in A Baixada Santista - Aspectos geográficos. vol II, 1965, p.50.

${ }^{8}$ A. R. Penetado. Op. cit., p. 12 
๑ J. R. Araújo Fo, Santos, O porto do café, 1969, p.38

"Situado entre os morros cristalinos da extremidade sudoeste da Ilha de Santo Amaro e a Ponta da Praia (extremidade oriental da ilha de São Vicente) o estuário santista tem inicialmente um perfil marcadamente assimétrico, prolongando-se como estreito de largura homogênea (400-600m) até o largo onde se interliga com a boca oeste do Canal de Bertioga. Daí, por diante, sucedem-se trechos mais estreitos e mais largos até a embocadura do Rio Piaçaguera, que coleta as principais aguadas provenientes da Serra do Mar e seus esporões (Largos do Caneú e de Santa Rita). A oeste da Ilha do Casqueiro, exatamente à retaguarda da Ilha de São Vicente, inicia-se o canal do Casqueiro, sinuoso e estreito (100-150m), que acaba por se ligar com os largos da Pompeba e de São Vicente, os quais após receber as águas dos rios Boturoca e Piaçabuçu, atingem os estreitos irregulares da Barra de São Vicente. A partir da entrada da Barra até a "boca" do Canal de Bertioga e o tômbolo interior da chamada Ilha Barnabé, o estuário de Santos envolve a porção leste da Ilha de São Vicente, através de 10km de canais, de profundidades médias relevantes (9-23m)"

${ }^{10}$ Citados em J. R. Araújo Fo,. Op. cit., p.33

"Sabe-se por Petrone (1965) que nas relações planalto-litoral, para as sociedades indígenas a comunicação entre estes dois domínios estava estabelecida não só pela prática do nomadismo, mas, sobretudo, em virtude dos movimentos dentro de sua própria área de subsistência. O litoral, neste caso, exercia a função de área periférica com funções econômicas subsidiárias (basicamente, a pesca, além de alternativa aos rigores do inverno planaltino), enquanto o planalto, "verdadeira área de eleição", constituia "um dos nódulos internos de cristalização demográfica. Neste sentido, os caminhos indígenas, como nota Petrone (1965, p.25, citando M. Reinhardt), "interessam sobretudo em virtude da importância que se revestem em termos de colonização européia posterior" dado que "os rumos da expansão sempre estiveram pré-determinados por aqueles caminhos" e, pricipalmente porque "entre os elementos que concorrem para a definição territorial política, muito mais que os tratados, está a posse das cabeceiras dos caminhos pré-colombianos e a respectiva técnica de usá-los"

${ }^{12}$ Ibid., p. 132

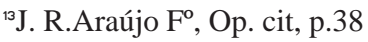

${ }^{14}$ Ab’Saber. Apud. J. R. Araújo Fo. Op. cit., p.34

${ }^{15}$ C. Prado Jr. Evolução política do Brasil e outros estudo, 1961

${ }^{16}$ P. Petrone, Op. cit.

${ }^{17}$ Ross, 1985. Apud J. L. S. Ross e I. C. Moroz, Op. cit., p.31

${ }^{18}$ Ross e Moroz (1997, 31 e seg) identificam as seguintes unidade de relevo regional dentro Planalto Atlântico: Planalto e Serra da Mantiqueira, Planalto e Serra do Bocaína, Planalto de Paraitinga/ Paraibuna, Planalto de Ibiuna/São Roque, Planalto de Jundiaí, Planalto de Serra Negra/Lindóia, Planalto Paulistano/Alto Tietê, Planalto do Alto Rio Grande, Planalto do Ribeira/Turvo, Escarpa/ Serra do Mar e Morros Litorâneos, Planalto do Guapiara e Planalto do Médio Vale do Paraíba

${ }^{19} \mathrm{P}$. Monbeig. Novos estudos de geografia humana brasileira, São Paulo, Difusão Européia do Livro, 1957, 132

${ }^{20}$ Defontaines (1935), Almeida (1964), IPT (1981) citados em J. L. S. Ross e I. C. Moroz Op. cit.

${ }^{21}$ Apud. Araújo Fº. Op. cit., p. 33

${ }^{22}$ Penteado (1976) apud J. L. S. Ross e I. C. Moroz. Op. cit., p. 46

${ }^{23}$ Monbeig (1957, p. 134), seguindo a classificação de Defontaines (1935) indicava a existência de três paisagens/regiões naturais distintas. Enquanto o Moji-Guaçu, abandonando as cristas "apalachianas" da divisa mineira, desenvolve seu amplo vale a menos de $600 \mathrm{~m}$ de altitude entre grande superfícies planas de campos-cerrados, situadas entre 600 e $700 \mathrm{~m}$ e com declividade entre 5 e $10 \%$, e o Tietê, apenas superada a Serra do Japi, rebaixa os talvegues a menos de 500m entre formas tabulares contínuas e uniformes (apesar da existência de formas rígidas, constituindo observatórios naturais), o Paranapanema, deixando as terras altas da Serra do Paranapiacaba, percorre uma topografia com cotas superiores a 700m e declividades das vertentes entre 10 e $20 \%$, mas que, por sua horizontalidade, "lembra a do setor do Moji".

${ }^{24}$ Japi, Cristais, Botujuru, Juqueri, Itaberaba, Pedra Branca, Guina, em relação à Campinas; Serraria de São Roque, Planalto de Ibiuna, Planalto Cristalino Ocidental em relação à Sorocaba

${ }^{25}$ Discurso de posse do Morgado de Mateus no Governo de São Paulo. Apud H. Bellotto. Autoridade e conflito no Brasil colonial, 1979, p.88

${ }^{26}$ Esta debilidade resultaria, segundo diversos autores (Petrone, Ellis, Caio Prado, etc) de uma combinação de fatores. As razões da não participação mais efetiva da Capitania na economia colonial talvez possam ser entendidas se colocadas em termos de competição com outras áreas produtoras ou distribuidoras: assim como aconteceu, nos dois primeiros séculos de colonização, em relação às menores distâncias que o nordeste brasileiro guardava com os mercados consumidores 
europeus, a estrada (Caminho Novo, 1733) que ligou, tempos mais tarde, as áreas mineradoras com o Rio de Janeiro, acabaria relegando, dentro do processo seletivo de colonização, a economia paulista ao empobrecimento e à estagnação. Assim, as características do povoamento da Capitania de São Paulo acabariam apresentando padrões diferentes dos padrões coloniais vigentes, tanto nos séculos XVI e XVII — ao estar voltado para o sertão em vez de vinculado ao cultivo da orla, que se mostrou desde logo, no litoral vicentino, improdutiva — quanto do século XVII —interiorização, não diretamente apoiada na mineração, na expansão pastoril ou mesmo na ação missionária, mas, sim, fundada no abandono de núcleos primitivos em favor de novas terras para roçados de "subsistência" (incluindo-se aí o abastecimento das tropas e dos pequenos núcleos urbanos).

${ }^{27}$ H. L. Bellotto, Op. cit.. p.36

"De fato, foi no aperfeiçoamento dos caminhos do Sul, toscamente abertos pelos Tropeiros, que encontraram as autoridades do Estado do Brasil as possibilidades de socorro ao Rio Grande e à Colônia de Sacramento, ameaçadas pelos espanhóis. Foi no roteiro das Monções que se apoiaram as expedições de exploração e conquista da região do Rio Paraná, assim como para implantação de presídios que constituiram a linha de defesa do Oeste; foi esta agricultura de subsistência que pode responder às solicitações do governo, para alimentação dos soldados que demandavam o Oeste e o Sul"

${ }^{28}$ Segundo os estudos de Canabrava (citada in H. L. Bellotto, Op. cit., p.174) para o Recenseamento de 1766, São Paulo (mais as freguesias de Santo Amaro, Cotia, Nazaré, Atibaia, Jaguari, Juqueri e Guarulhos) tinha 25,30\% da população da Capitania (16.002 habitantes). O vale do Paraíba concentrava 22,37\% (Taubaté - 3.521, Guaratinguetá-3.339 e Jacareí-3.232), enquanto Sorocaba -5.158 habitantes-, Itu —a mais rica—, Parnaíba, Araritaguaba (Porto Feliz), Jundiaí, Arassariguama, Moji-Mirim e Mogi-Guaçu totalizavam 14.326 habitantes (22,65\% do total). A população da Marinha (incluindo Curitiba e São José) atingia 29,63\%. Por estes mesmos dados, tem-se para Santos 12,87\% da população.

${ }^{29}$ Ibid.

${ }^{30}$ Morgado de Mateus. Apud Ibid., p.176

${ }^{31}$ Id., Ibid., p.226

"Em Portaria de 18 de fevereiro de 1768, ordenava o Governador a abertura de um caminho novo "desde esta cidade té ao Cubatão do rio de S. Vicente". Era preciso que se procurasse "a menor distância, a menor altura da Serra, e a menor dificuldade de passar a varja do Rio Grande"

${ }^{32}$ M. T. Schorer Petrone. (1968, p.24) ajusta a delimitação proposta por Caio Prado em "Formação do Brasil Contemporâneo", onde no lugar de Sorocaba havia sido eleita Porto Feliz como um dos vértices do "quadrilátero". Segundo a autora isto de deveu à relativa importância da produção de Sorocaba (que, no entanto, tinha nos negócios de gado a fonte principal de sua riqueza), além de enquadrar, "decididamente", Itú, "importantíssimo centro canavieiro"

${ }^{33}$ Schorer Petrone (1968) expõe as idas e vindas das proibições do comércio do açúcar e aguardente da Capitania com o porto do Rio de Janeiro e mostra como estas restrições (Lorena, 1789 e Franca e Horta, 1803) impuseram grandes dificuldades à produção canavieira de São Sebastião e Ubatuba. A importância destas medidas fica mais evidente quando confrontadas com as disposições de Melo Castro e Mendonça de 1798, permitindo a livre saída dos produtos, que reanimaram a lavoura no litoral Norte, num patamar superior ao encontrado antes da proibição de Lorena

${ }^{34}$ Castro e Mendonça, apud P. Petrone. Op. cit, p.113

${ }^{35}$ Id. Ibid., p. 193

${ }_{36}$ "Os fructos produzidos no interior do paiz merecem mais favor à proporção da distancia d'onde se conduzem; porque d'outra forma não poderão entrar em concorrência com aquelles que se cultivam na beira-mar e em lugares mais vizinhos..." (Veloso de Oliveira, apud Schorer Petrone, 1968, p.38). Ou ainda como descreve Marcelino Pereira Cleto (Apud. Ibid., p.191): "Se o caminho de Santos para S. Paulo, não tivesse todas as dificuldades virião a Santos mais moradores de serra acima com mantimentos para venderem, e levarem o producto em sal como costumão..."

${ }^{37}$ H. L. Bellotto. Op. cit.

${ }^{38}$ A. E. Taunay. Colletanea de Mappas da Cartographia Paulista antiga, 1922 e A. Pinto, História da viação pública de São Paulo, 1903

Os pricipais rumos seriam os seguintes

- $\quad$ À Vila da Constituição (hoje Piraciacaba), com rumo O-NO e desenvolvimento de 180 kilometros, passando por Itu e Porto Feliz. De Porto Feliz seguiam em canoas, pelo rio Tietê, os que demandavam Mato-Grosso

- à Franca do Imperador, passando por Jundiaí, Campinas, Mogi-Mirim, Casa Branca e Batatais, com rumo de $\mathrm{NO}$ e desenvolvimento de 642 kilometros

- às raias de Minas Gerais, passando por Juqueri, Atibaia e Bragança, com rumo de NE e desenvolvimento de 119 kilometros 
- ao Bananal, passando por Mogi das Cruzes, Jacareí, São José dos Campos, Taubaté, Pindamonhangaba, Guaratinguetá, Lorena e Areias, com rumo de NE e desenvolvimento e 390 kilomteros

- a Ubatuba, por Santos, São Sebastião e Caraguatatuba, com desenvolvimento de 280 kilometros

- de Santos a Iguape, passando por Conceição de Itanhaém

- $\quad$ ao Paraná, passando por Cotia, São Roque, Sorocaba, Itapetininga e Faxina”.

${ }^{39}$ M. T. Schorer Petrone, Op. cit, p. 38

"No Vale do Paraíba, apesar de certa importância, a cana de açúcar nunca teve o papel que teve na outra área de "sera acima"...Suas vilas seriam, segundo Manuel Cardoso de Abreu, "todas muito pobres e a maior parte parte miseráveis". As medidas de liberdade para o comércio de exportação de Melo Castro e Mendonça beneficiaria a a agricultura, aproveitando-se "dos portos da costa Norte e de Parati para exportar os produtos".

${ }^{40}$ A. Pinto. Op. cit., p.261

${ }^{41}$ D. P.Kidder Reminiscências de viagem e permanências no Brasil, 1980, p.273

${ }^{42}$ L. D’Alincourt. Memória sobre a viagem do porto de Santos à cidade de Cuiabá, 1975, p. 28 e 30

${ }^{43}$ D. P. Kidder. Op. cit, p.191

"Entretanto, devido à sua enorme declividade não pode ser transitada por veículos. Compreende cerca de 4 milhas de sólida pavimentação e mais de cento e oitenta curvas em todos o seu percurso".

${ }^{44}$ L. D’Allincourt. Op. cit., p.33

${ }^{45}$ D. P. Kidder, Op. cit, p. 209

${ }^{46}$ Ibid., p. 235

${ }^{47}$ J. J. von Tschudi.. Viagens às províncias do Rio de Janeiro e São Paulo, 1980, p.178

${ }^{48}$ S.Millet. Roteiro do café e outros ensaios, 1946, p.36

"Rio de Janeiro, principalmente, onde já se inicou a decadência pela dificuldade da aquisição do escravo"

${ }^{49}$ Citado em O. Matos, Café e ferrovias 1981, p. 44

${ }^{50} \mathrm{~S}$. Milliet., Op. cit.

${ }^{51}$ Segundo A. Pinto (1903) a implantação do sitema ferroviário em São Paulo compreenderia quatro fases de grande desenvolvimento. As quatro fases identificadas por ele, em 1903, seriam: a primeira, a dos "ensaios malogrados" —na esteira da lei Feijó de 1935, que autorizava a concessão de estrada de ferro da Bahia ao Rio Grande do Sul—; a segunda, a dos "notáveis resultados positivos" - inaugurada nas década de 1860 e caracterizada pelas concessões ferroviárias feitas com favores de zona privilegiada e garantia de juros-; a terceira, quando se dipensaria a garantia de juros; e a quarta, "regime de plena liberdade", emancipando-se as companhias da proteção do Estado.

${ }^{52}$ A. Pinto, Op. cit, p. 36-37 e 85

"Não abundando os capitais, nem a Província tendo recursos para empreender um grande sistema de viação aperfeiçoada, certo é que o desenvolvimento ferroviário só podia operar-se à feição e na medida das conveniências e disposições das localidades imediatamente interessadas, e na proporção de seus meios de ação (...) Qual a norma geral que presidiu o desenvolvimento desse trabalho. Qual o plano que os públicos poderes previamente elaboraram, orientando as linhas gerais da rede que se começava a estender? Positivamente nenhum (...)...As malhas da grande rede de viação ligeira, que hoje cobre a porção mais rica e povoada do Estado foram sendo tramadas dia a dia, sem nenhuma preocupação de conjunto, sem sistema ou coordenação de partes visando um certo resultado geral, dos mesmo nos primeiros tempos"

${ }^{53}$ C. Debes apud F. A. Saez. Op. cit, p.176

“A São Paulo Railway contentara-se com tocar Jundiaí, núcleo onde as terras não mais se prestavam para a lavoura. Reconheciam seus mentores ser necessário seguir, pelo menos até Campinas. Para mais distante, sem dúvida, reputavam aconselhável prolongar a linha. Tanto que a concessão que lhe outorgara o Governo Imperial, assegurava-lhe prioridade para atingir a vila de São João do Rio Claro. Não obstante, os ingleses — quer fosse real a alegação que difundiam, de que, em Londres, arrefecera o mercado de capitais; quer porque o trecho que construíram estava estrategicamente localizado, tornando todos os caminhos do interior para o litoral seus tributários inevitáveis, desinteressaram-se por dilatar sua linhas"

${ }^{54}$ A. Pinto. Op. cit, p.85

${ }^{55}$ Ibid., p.86

"Lançando os olhos sobre a carta do sistema geral, o que desde logo se vê é um grande tronco que avança para o interior, até as regiões mais remotas do sertão, segundo a linha média do território do Estado"... Em correspondência com o porto de Santos "—o importante empório de comércio internacional"- e sensivelmente retilíneo em sua extensão total de $500 \mathrm{~km}$, "esse grande tronco é 
formado pela linha de Santos a Jundiaí da São Paulo Railway Company e pela artéria principal do sistema ferroviário da Companhia Paulista de Vias Férreas e Pluviais que começa em Jundiaí e termina atualmente em Jaboticabal, passando pelas cidades de Campinas, Rio Claro, São Carlos e Araraquara."... "Enquanto o eixo principal corre sobre o extenso maciço, divisor de águas das bacias do Mogi-Guaçu e do Tietê, servindo a vasta região intermédia, os sistemas secundários desenvolvem-se pelos quatro grandes vales: do Paraíba (ramal de São Paulo da Estrada de Ferro Central do Brasil), Paranapanema (Sorocabana), Tietê (margem esquerda - Ituana) e Mogi-Guaçu (margem direita-Mogiana). "Como se vê, o traçado das grandes linhas está feito como naturalmente se deve fazer - acompanhando todos grandes vales, os cinco importantes fragmentos que a natureza repartiu o território do Estado"...

${ }^{56}$ A.Pinto, Op.cit., p.115

${ }^{57}$ J. R.Araújo F ${ }^{o}$. Op. cit, p. 54/55

Além do Rio de Janeiro, que era o porto nacional, e de Santos, que se valeria da posição geográfica pela construção da linha férrea ligando-o à São Paulo, "uma série de pequenos portos se enfileiravam ao longo desta costa recortada do Brasil de Sudeste, de São Sebastião a Itabapuana; todos serviam à Baixada Litorânea, especialmente a fluminense, e particularmente aos compartimentos de planalto do reverso da Serra do Mar, ao vale paraibano e às encostas meridionais da Serra da Manriqueira. São Sebastião, Ubatuba, Inhumuirm, Mambucaba e Parati servindo ao território paulista então chamado Norte de São Paulo; Angra dos Reis, Mangaratiba servindo ao Oeste fluminense; Cabo Frio, Barra de São João, Macaé, São João da Barra, serviam não só à Baixada Fluminenese como também ao Vale doParaíba mineiro-fluminense. As mercadorias que a eles chegavam, particularmente o café, eram colocadas em pequenas embarcações à vela, seguindo depois para o grande porto centralizador, o Rio de Janeiro, onde iam ter também os barcos que vinham dos pequenos portos do fundo da Baía da Guanabara. Assim, um tráfego de cabotagem bastante intenso se fez por mais de meio século neste trecho da costa brasileira. È quando a estrada de ferro substitui a tropa de muares, numa rede cada vez mais intensa, interligando as áreas de produção cafeeira aos seus dois grandes portos, Rio de Janeiro e Santos, todo esse sistema de circulação que vinha da época colonial entrou em colapso até um desaparecimento total em fins do século XIX. Aliás esse fenômeno é idêntico e contemporâneo ao que aconteceu na Zona da Mata Nordestina..." ${ }^{58}$ Araújo $\mathrm{F}^{\circ}$ (1969) enumera pelo menos uma dezena de projetos de ligação litoral-planalto deflagrados desde as décadas finais do século XIX, entrando até ao menos a década de 1920. Grande parte destes projetos constituíram iniciativas das próprias companhias ferroviárias e muitos deles apontavam inclusive na direção da construção de um novo porto, seja em Cananéia, seja em São Sebastião (servido então por pequenos vapores de cabotagem), prevendo ao mesmo tempo, traçados que alcançassem regiões ainda não servidas pelas linhas paulistas.

O extraordinário aumento do movimento de cargas verificado nos últimos anos da década de 1890 evidenciara não só os problemas do porto de Santos — desaparelhamento, obstrução do estuário por assoreamento e encalhe de embarcações, más condições sanitárias da cidade—como suscitara o debate sobre a insuficiência dos transportes ferroviários, principalmente por ser única a via de comunicação entre a hinterland e o porto. Assim é que, durante um período de grande euforia econômica (pós-“encilhamento”), em 1891 concedeu-se autorização para a Sorocabana levar suas linhas de São João a Santos e em 1892, autorizava-se à Mogiana a construção da linha de Ressaca (Santo Antonio da Posse) a Santos, ao mesmo tempo que à Paulista autorizava-se o prolongamento de sua estrada de Jundiaí (ou de outro ponto mais conveniente) ao porto de São Sebastião, com um ramal para Santos. Embora as evidências apontem que apenas o projeto da Mogiana tenha chegado a um estudo definitivo de traçado, em meio às discussões sobre invasão de zonas privilegiadas e sobretudo, como já observado, devido a dificuldade na obtenção de financiamento externo, a crise dos transportes daquela década encontrou sua solução (1900) na duplicação da linha da São Paulo Railway no trecho da serra, facilitando assim o escoamento mais rápido das mercadorias do porto. Solução provisória, já que em 1924, refeito o tráfego mundial, logo após o término da primeira guerra mundial, nova crise dos transportes causaria um prejuízo de 300.000 contos de réis, na moeda corrente da época. Ou seja, segundo a publicação de 1927, especialmente dedicada pela Associação Comercial de São Paulo a encontrar novas soluções para a ligação litoral-interior, tal soma representaria "mais do que o capital necessário para a construção de um novo porto e de uma nova estrada de ferro". Criticando abertamente o monopólio dos serviços ferroviários e portuários, o estudo da Associação Comercial (1927, p.16) entendia que sómente o aparelhamento de um novo porto e, portanto, a construção de uma nova linha ferroviária que o atendesse, poderia constituir solução mais conveniente. Mesmo porque, como já fazia notar MacMillen (1925, p.6), "ao passo que a nossa lavoura e as nossas indústrias têm a sua área de máxima intensidade num ângulo de mais de 90 graus, tomada com vértice a capital paulista, todo o escoamento de seus produtos deriva para um único ponto, através de um exíguo condutor". Ou ainda: "ao passo que (o esforço do paulista) fez convergir para a Capital as estradas de ferro do vasto hinterland, conservou 
da capital ao Oceano uma única via férrea e esta sem a capacidade e as condições favoráveis que devera offerecer". Asim, nas palavras desse engenheiro: "essa via férrea e a sua irmã gemea a Companhia Docas de Santos- representam hoje o maior entrave ao progresso paulista" (MacMillen, 1925, p.9). Segue-se que sendo o porto de Santos "um porto condenado", "não seria melhor abrir um porto novo e construir uma nova Estrada de Ferro de efficiencia moderna e de capacidade ilimitada, uma vez que esses $\$ 4,000,000$ (calculados sobre as taxas cobradas pelo porto de Santos) de dollars são mais que suficientes para pagar a construção e mesmo o custeio anual"? Neste mesmo sentido, recolhendo os estudos e sugestões realizados por instituições e renomados técnicos da época, a Associação Comercial, na publicação "Soluções para a crise do porto de Santos" $(1927,128)$, pregando medidas para "remover os grandes obstáculos que prejudicam a expansão econômica de São Paulo" elenca os seguintes pontos:

- $\quad$ ligação ferroviária do porto de São Sebastião à cidade de São Paulo e a Santos, merecendo estudo o projecto da construção de um ramal de Mogy das Cruzes a Jundiahy ou Campinas, ou a ambas estas cidades, destinado a servir à exportação;

- $\quad$ aparelhamento do porto de São Sebastião;

- $\quad$ adopção, para este porto, do regime de autonomia portuaria;

- estabelecimento, nesse local, de um porto franco ou zona franca".

Alfredo Lisboa, importante nome em assuntos portuários, em seu notável "Portos do Brasil" (1926), engrossaria a corrente favorável à construção de um novo porto no litoral paulista, atendido por uma nova linha férrea de penetração até Jundiaí, argumentando que, ainda que essa solução devesse ser combinada com a expansão e melhoramento do aparelho portuário de Santos e com a construção de uma terceira via da São Paulo Railway na serra, suas vantagens se mostrariam tanto pela inferioridade das taxação portuária e dos fretes ferroviários (apesar do aumento da distância), quanto "pela concorrência benéfica para a economia do Estado" (fazendo frente às companhias que monopolizam os serviços de transporte entre o litoral e o interior), ou memo pela ausência de prejuízos que tal solução poderia acarretar à praça de Santos (na medida em que se propunha ligá-la por ramal férreo à São Sebastião), o que, no caso da interrupção forçada dos serviços das Docas ou da São Paulo Railway, "poderia vir a remediar o mal temporariamente" (p.455).

"Poderá o porto de São Sebastião servir de escoadouro de cargas que o comércio exportador de São Paulo preferir expedir pela estrada de ferro ligada a este porto e de trânsito das mercadorias importadas que aos negociantes convier receberem em consignação por tal via" (A. Lisboa, 1926, p.455)

Sem a necessidade de aprofundar o mérito (econômico-financeiro, tecnológico, ou mesmo político) da não realização dos diversos projetos discutidos desde os fins do século XIX até a década de 1920, a não ser talvez sugerindo que o monopólio da inglesa assumiu, no lugar da topografia, o papel de obstáculo intransponível para escalada da serra, o que se poderia notar, de acordo com Araújo $\mathrm{F}^{o}$ (1969, p.93), é que o debate sobre as alternativas portuárias e ferroviárias deu-se em torno da existência de duas categorias de traçados: "uma de via de penetração, com "objetivos de incrementar a produção de uma rica região ainda pouco explorada por falta de transportes, o Sul de Minas, através de Taubaté ou São José dos Campos, ou mesmo Mogi das Cruzes. Outras seriam meras linhas de ligação ao porto a ser construído ao sistema ferroviário paulista existente, de maneira a trazer para São Sebastião parte das cargas que hoje só podem ter escoamento pelo porto de Santos. Seriam os traçados São Sebastião a Campinas, São Sebastião a Jundiaí (pontos de intersecção com a Paulista) e São Sebastião a São Paulo (articulação com a Sorocabana), com ou sem ramal para Santos".

${ }^{59}$ L. Derrom in MacMillen. A solução do problema dos transportes de S. Paulo ao littoral 1925, p.149

${ }^{60}$ C. Stevenson. Apud Associação Comercial de São Paulo. A solução das crises do porto de Santos. 1927, p.141

"Basta olhar o mapa da rede ferroviária do Estado, para ver que (o grande) centro ferroviário é, inelludivelmente, Campinas. Em Campinas se reunem as estradas de ferro Paulista, Mogyana e Ramal Ferreo Campineiro; Campinas é cortada pela estrada de ferro Sorocabana, no seu ramal de Itaicy a Padua Salles. E isto quer dizer que o tráfego de quasi toda a rede ferroviária do Estado passa por Campinas... De Campinas poderá, indiscutivelmnete, ser traçada uma linha mais curta para S. Sebastião, que a discutida obrigando os productos a fazer a volta por Jundiahy". No entanto, Stevenson, no debate sobre a construção de um novo porto e de uma nova linha que o servisse, levanta a questão da zona de privilégio da Cia Paulista.

${ }^{61}$ A ligação Mairinque/Santos da Sorocabana, concretizada apenas na década de 40, responderia a apenas $4 \%$ do transporte das cargas destinadas/originárias do porto

${ }^{62}$ Segundo O. Matos (1981, p.94), a exponencial expansão da malha ferroviária, na década de 1880 , dobra a quilometragem até então existente $(1212 \mathrm{~km})$ para atingir em $1930,7100 \mathrm{~km}$. Se as 
duas décadas seguintes vão apresentar forte diminuição no ritmo da expansão das linhas (5\% de crescimento a cada década), na década de 1950 este crescimento cai a $0,35 \%$.

${ }^{63}$ F. A. M. Saez. As ferrovis de São Paulo 1870-1840, p.187

Ao nosso ver, o próprio processo de industrialização, ao concentrar na capital grande contingente populacional, substitui em parte o mercado externo como pólo de atração da atividade econômica do interior. Desta forma criam-se os novos fluxos de transporte (alimentos e matérias-primas) a que nos referimos. Embora estes novos fluxos não sejam tão remuneradores quanto o do café, pelo menos as estradas têm algum serviço a realizar. Entretanto, a fase de prosperidade das Companhias de Estadas de Ferro já passara. Agora a necessidade de manter estes serviços (ainda essenciais para a economia) leva, mais cedo ou mais tarde, à estatização das ferrovias: a Mogiana no começo da década de 1950 e a a Paulista no fim desta mesma década. Em suma, o Estado passa administar o sistema de transportes já em franco declínio: obviamente não se poderia esperar de tal sistema a obtenção de grandes saldos operacionais."

${ }^{64}$ N. G. Reis, Memória do transporte rodoviário, 1996

${ }^{65}$ Ibid.

${ }^{66}$ T. Penteado. As grandes obras rodoviárias de S. Paulo in Engenharia, 1942, p.49

"Tratava-se de iniciar novo serviço; tarefa mais difícil do que melhorar ou ampliar um já existente. Além das dificuldades surgidas pela falta de pessoal especializado, operários práticos nesse novo gênero de trabalho, recusa dos tarefeiros ou empreiteiros que temiam uma aventura, havia uma incompreensão quase geral, quer por parte do público, quer por parte de alguns jornais e mesmo alguns membros do Congresso, que não viam ou não queriam enxergar o verdadeiro alcance das rodovias no progresso material do Estado"

${ }^{67}$ Id.Ibid., p.51

${ }^{68}$ Id. Ibid.

${ }^{69}$ Instituto de Engenharia. A crise dos transportes, 1925, p. 3

${ }^{70}$ W. Cano et al. A interiorização do desenvolvimento econômico no Estado de São Paulo (19201980), 1988

${ }^{71}$ S.A.G.M.A.C.S. Problemas de desenvolvimento: necessidades e possibilidades do Estado de São Paulo, 1954, p.370

${ }^{72}$ Ibid., p.262

"Apenas oito município paulistas apresentaram em 1950 população superior a 80.000 habitantes: São Paulo (2.198.096), Santos (203.562), Campinas (152.547), Santo André (127.032), Sorocaba (93.928), Ribeirão Preto (92.160) e Marília (86.844)"

${ }^{73}$ Ibid., p. 372

${ }^{74}$ Ibid.

${ }^{75}$ Ibid., p.372

${ }^{76}$ Ibid., p.373

${ }^{77}$ H. Damante. Apud O. Matos. Op. cit., p.118

${ }^{78}$ S.A.G.M.A.C.S. Op. cit, p. 314

"A densidade das vias férreas em relação à superficie é de 7 vezes a média do Brasil" e $20 \%$ mais densa em relação à população, assegurando $52 \%$ do tráfego ferroviário do país.

${ }^{79}$ Ibid, p.292

Variação das cargas transportadas m ferrovias paulistas entre 1952 e 1953

$\begin{array}{ll}\text { Mogiana } & -30,6 \\ \text { Santos-Jundiaí } & +11,8 \\ \text { Paulista } & -12,4 \\ \text { Sorocabana } & -4,4 \\ \text { Noroeste } & +1,5\end{array}$

${ }^{80}$ Tráfego rodoviário —número de veículos em trânsito (S.A.G.M.A.C.S, 1954, 292)

\begin{tabular}{|l|l|l|l|l|l|l|}
\hline & carro passag. & & ônibus & & caminhão & \\
\hline & 1952 & 1953 & 1952 & 1953 & 1952 & 1953 \\
\hline Anchieta & 533 & 560,1 & 107,1 & 113,3 & 175,6 & 140,7 \\
\hline Anhanguera & & 185,1 & & 34,2 & & 188,9 \\
\hline
\end{tabular}

${ }^{81}$ Ibid, p.317 
${ }^{82}$ Segundo esse estudo —Plano de Ação 1959-1963 (1959, p. 100)—, os principais fatores da evolução do modal rodoviário sobre o ferroviário seriam a limitação da capacidade de transporte das ferrovias (principalmente no trecho paulista da Central do Brasil e na Noroeste) e o nível relativo das tarifas ferroviárias rodoviárias (acréscimo de $85 \%$ das primeiras e $52 \%$ das segundas: a reforma cambial de 1953, se de um lado aumenta o preço dos veículos de carga, por outro lado, deixa livre os leilões de importação de combustíveis e lubrificantes). Desta maneira, em 1958 tinhase $10.555 \mathrm{~km}$ de rodovias, sendo $3.084 \mathrm{~km}$ pavimentadoss

${ }^{83}$ S.A.G.M.A.C.S. Op. cit, p. 313

"Os novos equipamentos de construção de estradas permitiram a criação rápida de uma imensa rede rodoviária que avança como os dedos de uma grande mão sobre o país inteiro, com ligações transversais que põem termo ao isolamento de cada espigão em relação aos seus vizinhos"

${ }^{84}$ Ibid., p.322

Em relação à indústria pesada, condicionante do desenvolvimento de um país, o Estado de São Paulo, com excessão do cimento - Sorocaba, principalmente — e do alumínio — São Roque — não apresentava grandes realizações, como era o caso da siderurgia, que fazia o Estado depender do exterior ou de Minas e Rio. Neste sentido, o estudo estabelecia a construção de uma usina em Piaçaguera, no minucípio de Santos; usina essa que, à falta de energia hidro-elétrica de Paraibuna e na tentativa de evitar a importação de carvão, transformável em coke ("que torna muito vulnerável a exploração da usina nacional de Volta Redonda"), deveria ter como combustível o carvão de madeira, obtido através da "exploração racional da floresta tropical nativa do sul do Estado e das novas plantações de eucaliptos"

${ }^{85}$ Os quatro grupos de cidades, cada um objeto de estratégias territoriais específicas (respectivamente, recuperação da qualidade de vida, controle, dinamização e promoção do desenvolvimento) seriam os seguintes:

- $\quad$ Região Metroplitana;

- áreas contíguas à cidade de São Paulo e as que constituem o entorno da região Metropolitana (aglomerados de Santos, Jundiaí, Sorocaba, São José dos Campos);

- Àreas mais afastadas da metrópole onde se encontram três sistemas integrados de cidades, cujos centros urbanos encontram-se "localizados nas imediações ou não muito distantes dos três grandes eixos rodoviários do Estado": Via Anhanguera (Rio Claro, Americana, Araras, Santa Bárbara do Oeste e Piracicaba), Rodovia Presidente Dutra (Taubaté, Guaratinguetá e Cruzeiro) e, de expresssão mais recente, Rodovia Castelo Branco (Tatuí e Itapetininga);

- Cidades isoladas, "normalmente centros regionais, sediados no hinterland paulista e distantes da zona metropolitana": Ribeirão Preto, Franca, Bauru, São José do Rio Preto, Araçatuba, Presidente Prudente e Marília.

${ }^{86}$ Assim, as áreas abrangendo o espaço contíguo à Grande São Paulo, o eixo São Paulo-Rio de Janeiro, o eixo São Paulo-Campinas e a Orla Marítima (incluindo o Litoral Norte), deveriam ser objeto de controle, a fim de evitar o "perigo de reprodução/ampliação das características" diagnosticadas para a cidade de São Paulo. Aliás, quanto aos dois eixos, a mesma preocupação vinha claramente expressa no II PND que, entre outras recomendações, priorizava "o disciplinamento de ocupação urbana e rural das áreas contíguas às duas metrópoles nacionais, particularmente no eixo Rio de Janeiro-São Paulo e São Paulo-Campinas” (Governo do Estado PDUR, 1976, p.14)

Ao mesmo tempo recomendava-se a coordenação em infra-estrutura e a regulamentação do uso do solo nas regiões metropolitanas de São Paulo e Rio de Janeiro, "de modo a conter a taxa de crescimento dessas metrópoles e induzir a descentralização das atividades produtivas, particularmente das indústrias para centros perféricos de médio-porte, que apresentam potencialidades locacionais" (II PND. Apud PDUR, 1976, p.7).

${ }^{87}$ SEP-CAR, Plano Regional de Campinas, 1978, p. 2

${ }^{88}$ São Paulo. (Gov Estado), 5 a Região Administrativa — Diagnóstico, 1972, Introdução

${ }^{89}$ W. Cano. O processo de urbanização paulista no período 1970-89 in SEADE. São Paulo no limiar do século XXI, 1992, p.28

${ }^{\circ}$ W. Cano. Op cit, 28

${ }^{91}$ São Paulo, Governo. Plano Regional de Campinas, 1978, p.57

${ }^{92}$ São Paulo, Governo Plano Regional do Litoral, 1978, p.44

${ }^{93}$ Ibid., p.45

${ }^{94}$ Folha de São Paulo, 20/5/1991

${ }^{95}$ W.Cano. Op. cit, p.30

${ }^{96}$ Ibid, p.34

${ }^{97}$ Ibid., p.35

${ }^{98}$ Ibid., p.63 
${ }^{99}$ Ibid., p.66

${ }^{100}$ A. S. C. Caiado. "Desenvolvimento regional: novos requisitos para a localização industrial em São Paulo" in Tendências demográficas/reestruturação produtiva, 1996, p.54

Os novos fatores: "Desindustrialização e crise global do capital num suposto sistema mundial; surgimento de uma nova divisão do trabalho a partir das estratégias das multinacionais de busca de mão-de-obra; novas relações de produção; alta tecnologia e reorganização das forças produtivas; e o surgimento de um novo regime de acumulação do capital, denominado flexível, que tem substituído o regime fordista de produção"

${ }^{101}$ Descontado o apelo retórico a que muitas vezes acabariam efetivamente relegadas a políticas de interiorização e a falta de integração com as demandas da infra-estrutura urbana, tem-se que as primeiras, de fato, tiveram papel orientador das ações do financiamento público

${ }^{102}$ São Paulo (Estado). Plano metropolitano da Grande São Paulo. 1993-2010, 1994,, p.125

${ }^{103}$ A. S. C. Caiado. Op. cit., p.57

${ }^{104}$ Id., Ibid.

${ }^{105}$ Id., ibid..

${ }^{106}$ SEADE. www.seade.gov

${ }^{107}$ São Paulo (Estado). Op. cit., p.122

${ }^{108}$ Apud J. R.Araújo Fo ${ }^{\circ}$ 1965, p.32

${ }^{109}$ Nestor Fo. Op. cit; P.Petrone. Op. cit.; J. R. Araújo Fo. Op. cit.

${ }^{n}$ C. Prado. Op. cit.; J. R. Araújo Fo. Op. cit.

"' C. Prado. Op. cit., p.128

${ }^{112}$ T. Sampaio in C. Prado. Op. cit.

${ }^{113}$ C. Prado. Op. cit., p.122

${ }^{14}$ Ou seja, segundo Ribas I Piera (1979, p.7)

"Nos sub-centros contíguos passam a existir empregos para os não residentes e existem residentes que trabalham no centro, fenômenos estes que resultam no seu crescimento demográfico e edificatório (desses sub-centros)"

${ }^{115}$ Prefeitura Municipal de Santos 1976, p.30

${ }^{116}$ São Paulo (Governo). $2^{\mathrm{a}}$ região Administrativa —Diagnóstico, 1972, 8.4/1.7

${ }^{117}$ P. Singer. Desenvolvimento econômico e evolução urbana, 1968

${ }^{118}$ Id. Ibid.

${ }^{119}$ Folha de São Paulo, 2/5/1999

Se em 1980 a Grande São Paulo concentrava 64\% do valor adicionado pela indústria paulista na produção, em 1995 este percentual caíra para 52\%. "A fatia da cidade de São Paulo caiu junto, de $36 \%$ para $22 \%$ ".

${ }^{120}$ M. Santos. A urbanização brasileira, 1993, p.92

${ }^{121}$ S. Lencioni. in M. Santos, M. A. Souza, M. L. Silveira (org) Território, globalização e fragmentação, 1994. p.198

${ }^{122}$ G. Dematteis, Op. cit, p. 87

Como exemplo, atualmente, os operadores da bolsa de Nova York, Tokyo, Londres e Paris são muito mais "vizinhos" entre si do que o seriam em relação "a outros agentes de outros setores presentes nas respectivas cidades".

${ }^{123}$ Ibid. p.86

Se cidades industriais sediavam o ciclo produtivo completo (por exemplo da fabricação do automóvel, reunindo aço, componentes, montagem, etc), mesmo que mantendo as bases desta produção, hoje elas partcipam de uma rede de input-output (semimanufaturados, partes mecânicas, componentes, acessóriso e informações especializadas) alargada à escala continental, e para certas etapas produtivas, também planetária

${ }^{124}$ São Paulo. (Gov Estado). 2 ${ }^{\text {a }}$ Região Administrativa — Diagnóstico, 1972, Introdução

${ }^{125}$ Ibid., 8.4/2

${ }^{126}$ São Paulo (Governo do Estado). Plano regional de Campinas, 1978 p. 57.

A importância da D. Pedro I pode ser medida pelo fato que a previsão de tráfego para a década inicial de seu funcionamento foi superada nos dois primeiros anos.

${ }^{127}$ U. C. Semeghini. "A região administrativa de Campinas" in SEADE. São Paulo no limiar do século XXI. vol. 8, 1992, p. 62/63

"Nesse sentido (o do aprofundamento das funções urbanas "metropolitanas"), um conjunto de equipamentos implantados, na maioria, durante os anos 70, constitui uma das faces mais visíveis da metropolização em curso. Entre esses destacam-se o aeroporto internacional de Viracopos, que foi durante bom tempo o principal do estado e que, mesmo com a entrada em operação do aeroporto 
de Guarulhos, permanece como o primeiro em movimento de cargas; a Unicamp, hoje em muitas áreas a mais importante universidade do país; dois grandes hospitais de Clínicas, o da própria Unicamp e o da PUCC; um complexo de entrepostos e hipermercados, situados nos principais eixos rodoviários, e que atraem clientela inclusive de outros estados; um grande shopping center o maior do país em área; duas estações de TV em operação, cobrindo grande região do interior; e o aparato de pesquisas científicas, envolvendo Universidades, Instituto Agronômico, Telebrás, SEI, Sinclotron/CNPq, Observatório Astronômico, Embrapa. Ainda quanto a complexos de dimensão nacional caberia lembrar, no setor industrial, o petroquímico nucleado pela Replan e o de microeletrônica e informática, organizado em torno dos centros de pesquisa”. Além do aparato terciário da cidade (comércio, serviços produtivos, equipamentos culturais, artísticos e de lazer, etc), "uma outra importante função local relaciona-se ao setor de transportes, citando-se aí não apenas as rodovias, com a presença do complexo Anhanguera/Bandeirantes, ou as duplicações da D. Pedro I, Santos Dumont, Campinas-Monte Mor e Campinas-Mogi Mirim, mas a importância das ligações ferroviárias, por onde circulam mais de metade do total de carga de exportação da Fepasa e que passaram por acentuada melhoria recente (conclusão do ramal Helvetia-Guianã, modernização da ligação Campinas/Santos) e os terminais de Viracopos"

${ }^{128}$ SEADE. Análise Demográfica Regional Campinas - "O surgimento de uma nova área metropolitana, 1983, p.

${ }^{129}$ SEADE. www.seade.gov

${ }^{130}$ São Paulo (Governo do Estado). Plano Regional de Santos, 1978

${ }^{131}$ Ibid. 8.4/1

${ }^{132}$ M. A. dos Santos. "A região administrativa de Santos" in SEADE São Paulo no limiar do século XXI, 1992,p. 83

Com a abertura da BR-116 e da Rodovia dos Tamoios, no início dos anos 60, Santos deixou de polarizar tanto a porção norte quanto a sul do litoral paulista. Registro passou à área de influência da capital e São sebstião à de São José dos Campos

${ }^{133}$ W.Cano. Op. cit., p.56

${ }^{134}$ M. A. dos Santos.,Op. cit, p. 75

${ }^{135}$ SEADE, Análise demográfica regional - Litoral — Região do Litoral: um trecho de disparidades intra-regionais", 1982, p. 6

${ }^{136}$ Id. Ibid, p.56

${ }^{137}$ SEADE. www.seade.gov

${ }^{138}$ N. Caixeta, "Advinhe quem ganhou" in Revista Exame, 26 /12/1998,

${ }^{139} \mathrm{O}$ aeroporto de Viracopos, contando com investimentos da ordem de 30 milhões de dólares entre 1995 e 1997, passa a movimentar 200.000 toneladas/ano de carga contra apenas 25.000 toneladas/ano do início da década

${ }^{140}$ Ibid., p.66/67

"Escoadouro para a produção agrícola e industrial dos estados de Minas Gerais, Goiás, Mato Grossso, Mato Grossso do Sul e Paraná"; escoadouro cuja racionalização, com a transformação em curso da logística do sistema de transporte estadual, projeta repercussões relevantes na competitividade do comércio exterior no plano nacional e, particularmente na Baixada Santista"

${ }^{141}$ A Tribuna 28/2/1999

A crise hoteleira tem como causas principais a falta de ocupação durante o ano, a inexistência de centro de convenções, a inadequada articulção dos transportes metropolitanos e a baixa atração das ofertas turísticas

${ }^{142}$ N. Caixeta, Op. cit., p. 26

Esses mesmos indicadores para Campinas apresentam os seguintes números: U\$5.569 milhões

(despesas de consumo) e U\$5.943 (consumo annual per capita)

${ }^{143}$ O Programa das Nações Unidas para o Desenvolvimento (Pnud) avalia fatores como longevidade, sistema educacional, renda familiar per capita, índice de custo de vida, programas voltados para a infância e situação habitacional

${ }^{144}$ Id. Ibid, p. 55

${ }^{145}$ SEADE. PAEP, 1999

${ }^{146}$ Ibid.

${ }^{147}$ Prodesan, PPDI 76, 1976, p.101

${ }^{148}$ Diário Oficial de Santos. D.O. urgente, 7/8/1993 


\section{Capítulo 3}

\section{A CONSTRUÇÃO E EXPANSÃO DO PORTO DE SANTOS}

Imaginar um porto é algo quase imediato, talvez para a maioria das pessoas. Isso fisicamente. No entanto, nesta caracterização se forem incluídos aspectos funcionais e institucionais provavelmente essa imagem não seja tão imediata". Sob este ponto de vista, de acordo com Bussinger ${ }^{2}$, o porto assume três dimensões:

- elo da cadeia logística" (equipamentos, processos e organizações necessários para a movimentação de cargas);

- $\quad$ agente econômico" (alteração do valor dos produtos —-mercadoriapelo seu fluxo e presença no mercado, gerando riqueza, parte na região onde opera, parte em sua hinterlândia);

- ente físico" (infra-estrutura aquaviária e terrestre, espaços e equipamentos que compõem as instalações portuárias).

Se no capítulo precedente, o porto pôde ser entrevisto enquanto "elo da cadeia logística" e "agente econômico", esta parte do trabalho procura entendê-lo sobretudo como produto técnico e social - e não apenas como meio de produção- Mas isto implica reconhecer de antemão as outras duas dimensões, isto é, a natureza funcional específica dessa infra-estrutura, sua lógica relativamente autônoma na organização do espaço, são orientadas pela racionalização que possam requerer, a seu tempo, as tecnologias e as políticas interessadas à cadeia geral dos transportes. Neste sentido, se "a transformação de um porto pré-capitalista em um porto capitalista implica a transformação do seu processo produtivo e a rearrumação do espaço numa nova lógica ${ }^{3}$, essa nova lógica tem por objetivo principal a racionalização daquele processo, afirmando as exigências de fluidez, especialização e estandartização. No entanto, não cabe aqui o aprofundamento do estudo do "aparelho portuário" em si, mas, sim, ressaltar as "demandas" do porto em termos de espaço, isto é, de solo urbano (ou não), de infra-estrutura e de edificação. Portanto, por este lado, ou seja na face do porto enquanto "forma construída", pretende-se individualizar a relação entre suas "tipologias" de expansão e a estrutura urbana, no sentido de fornecer elementos para discutir adiante a incidência dessas mesmas tipologias nos modelos de crescimento de Santos.

Isto se fará em duas partes. A primeira procura descrever os planos de expansão do porto moderno de Santos e suas tendências de transformação. Algumas referências toponímicas serão melhor caracterizadas no capítulo seguinte: neste estudo "monográfico", aqui servem como "marcos" geográficos que se retêm, para a passagem da escala territorial à urbana. A segunda parte procura caracterizar as mutações gerais da relação porto-cidade, 
buscando-se evidenciar a regularidade, senão a universalização, de certas "soluções" que resultam das transformações tecnológicas da infra-estrutura portuária.

\subsection{O porto moderno}

A lei $n^{\circ} 1746$ de 1869 autorizava o governo imperial a contratar empresas privadas para a construção de docas e armazéns, para "carga, descarga, guarda e manutenção de mercadorias". Baseado nessa lei e vencidas duas concessões (1870-1878 — Conde de Estrela e F. P. A. Pertence—, 1881-1886 -Governo Provincial de São Paulo), sem que nenhuma obra tenha sido realizada por falta de recursos, o contrato para a construção de um cais em Santos foi assinado em 1888 entre o governo imperial e a firma encabeçada por J. Pinto de Oliveira, C. Gaffreé e E. P. Guinle ${ }^{4}$. A concorrência pública, pautando-se pelo projeto ${ }^{5}$ de 1879 , elaborado por Silva Sabóia como revisão do projeto do engenheiro inglês W. Milnor Roberts, autorizava obras que constavam de um cais corrido entre um extremo da ponte velha da São Paulo Railway e a rua Brás Cubas, reservando-se ao longo dele um faixa de $20 \mathrm{~m}$ de largura para o depósito de mercadorias durante as operações de carga e descarga ${ }^{6}$.

Estando previstos três anos para a conclusão das obras, seu uso e gozo por parte da empresa, com todos os ônus (organizar, administrar e executar os serviços do porto) e vantagens (cobrança de taxas de carga e descarga, de atracação, de utilização do cais, além de isenção de direitos de importação para material empregado na construção), far-se-ia por um prazo de 39 anos, "findo o qual, reverterão para o Estado sem indenização alguma as obras, terrenos e benfeitorias, bem como o material rodante da empresa" . No entanto, as sucessivas autorizações, concedidas em 1892, para prolongamento do cais, primeiro até o Paquetá ${ }^{8}$ e depois do Paquetá até o Outeirinhos ${ }^{9}$, implicaram também na alteração seja do prazo global da concessão, que passaria a ser de 90 anos (ampliando-se também os direitos de comercialização, que passavam a incluir a permissão da cobrança de novas taxas por parte da companhia), seja do tempo previsto para a conclusão das obras (cinco anos, contados de sete de novembro de 1895, "data em que deveria estar terminada a construção de todo o cais concedido antes desta data" $\left.{ }^{\circ}\right)$. Na realidade, a partir de novas bases estabelecidas para os termos da concessão", este último prazo seria ainda prorrogado em 1900, por dois anos, e em 1906, por mais cinco anos, obrigando-se a Companhia Docas a construir além de dique para reparo de navios na "Mortona", na parte sul dos Outeirinhos, prédios para o serviço da Alfândega e dos Correios e Telégrafos. 
Neste andamento, em 1892 seria autorizado o tráfego provisório nos $260 \mathrm{~m}$ então concluídos, junto às instalações ferroviárias da São Paulo Railway, e apenas em $1909^{12}$, findo o aterro da enseada dos Outeirinhos, atingir-se-ia $4720 \mathrm{~m}$. Tal dimensão, atingida em pouco mais de duas décadas, permaneceria inalterada, (se excluída a construção, no final da década de 20, de $301 \mathrm{~m}$ de cais na Ilha Barnabé, para a movimentação e armazenagem de petróleo), até meados da década de 40, justamente quando "o café começa a perder sua hegemonia como principal e quase único produto exportado por Santos" Portanto, apesar das várias crises de congestionamento que, como se viu no capítulo 2, atingiram o porto e apesar dos vários planos de expansão estudados é o trecho que vai da rampa do Valongo ao extremo do chamado cais da "Mortona", no Outeirinhos, aquela que corresponde à construção da "cidade moderna" de Santos, definindo e fixando as formas, ou melhor, o modelo da relação entre ela, o porto e o estuário.

$\mathrm{Na}$ verdade, este primeiro trecho de cais apresentaria, inclusive pela diferença temporal que mediou a construção de cada uma delas, duas seções com características técnicas e físicas bastante diversas. O acanhamento das dimensões da primeira seção, ou seja, a linha de $2271 \mathrm{~m}$ de cais do Valongo ao Paquetá, seria explicado pela falta de previsão do desenvolvimento do porto de Santos, "causa da construção do primeiro trecho de cais, com águas pouco profundas e sem a necessária largura, entre a cidade e a muralha, para assegurar as precisas facilidades de transporte de e para a estação da via férrea"14 . Segundo Alfredo Lisboa (1926), a precariedade das técnicas disponíveis no país e a impossibilidade, então, de uma visão mais abrangente sobre o futuro econômico do Estado de São Paulo teriam sido os fatores responsáveis pelos defeitos apresentados por aquela seção (defeitos que persistem até os dias de hoje, estrangulando as vias de circulação internas e, portanto, resultando no avanço sobre as ruas vizinhas de grande movimento de cargas). Já a seção que vai da curva do Paquetá ao Outeirinhos — nome do promontório que seria arrasado para o aterro da enseada - seria construída segundo novas tecnologias ${ }^{15}$, ganhando novo solo ao mar. Sua linha de murada desenvolve-se por 2449 metros, contendo a aterro em forma de semicírculo imperfeito, com flecha máxima de 500m, o que resultou em uma área de 75 hectares para a disposição de sucessivas faixas de armazéns internos (em número de 15, sendo um deles destinado a frigorífico) e externos (3 filas, sendo as duas primeiras de 5 armazéns e a terceira de 4 ), separadas por ruas transversais (30 metros) e longitudinais (35 e 20 metros) e pátios (30 metros) ${ }^{16}$.

Quanto à extensão do cais do Outeririnho à Barra, da mesma forma que a concessão obtida pela Estrada de Ferro Sorocabana para "ir à Santos" levara a Companhia Docas a exigir, pela preferência de seu contrato, a concessão do prolongamento até o Outeirinhos, a intenção do Governo do Estado ${ }^{17}$, movido pelas polêmicas em torno a custos abusivos cobrados pelas operações 
portuárias, de solicitar a construção de um cais naquela direção, desencadeou a reação da Companhia, "dizendo-se preparada para as obras de direito suas para o que procederia à necessárias reduções em algumas taxas, sobretudo de exportação". A defesa do monopólio da Companhia, auto-instituída representante do Governo da União (portanto, segundo relatório da sua diretoria de 1908, "não sujeita às leis do Estado, nem às leis e autoridades do município"18), baseava-se na idéia de que "toda a porção do litoral que for sendo necessária ao serviço do porto, constitui um privilégio exclusivo": assim é que independente de novas concorrências, o primeiro núcleo de concessão foi sendo sucessivamente ampliado. Neste sentido, em 1926, diante da grave crise de congestionamento que atingira o porto e a ferrovia, levando como se viu, à proposta de implantação de um porto em São Sebastião, Gustavo Guinle afirmaria que a "Companhia se prontifica a ampliar o porto de Santos sem ônus para o Governo Federal (garantia de juros, além da promessa de redução de taxas cobradas) e não parece razoável que o Estado de São Paulo, que pode gozar de tal regime, vá conceder garantias de juros onerando o tesouro sem necessidade" ${ }^{\prime \prime}$.

Nem as taxas cobradas pelo porto seriam reduzidas e tampouco seriam realizados os projetos do governo do Estado, que embora ainda manifestasse em 1927 a intenção de construir não um, mas dois portos (além de São Sebastião, São Vicente), optara pelo prolongamento da Sorocabana a Santos, fazendo cair no esquecimento aquela intenção, até então firmememnte cobrada pela Associação Comercial de São Paulo. O Governo Federal adotaria a decisão de ampliação do porto, aprovando em 1926 os estudos do "plano geral" apresentado pela Companhia Docas, ainda que restringido sómente às obras previstas para o decênio 1826/1935. Mesmo porque, menos resposta ao problema da crise, mas, sobretudo, defesa de seu monopólio, esse plano, em sua grandiosidade (prevendo a ampliação de 5.000 para 33.000 metros de cais), abarcava a utilização de todos os terrenos naturalmente disponíveis para a ampliação do porto. Neste sentido vale deter-se na descrição desse plano tendo em vista a "pré-figuração" do domínio portuário sobre ambas margens do estuário e porção da faixa continental, revelando a ideologia que nortearia a relação deste domínio com a cidade.

\section{Oplano de 1926}

A memória descritiva das obras, documento elaborado por Guilherme Guinle, justificando a necessidade de um plano geral iniciava-se com considerações a respeito da "estreita lógica que existe entre o porto e a cidade ${ }^{20}$ :

é esta que tem que se adaptar às exigências daquele e muitas vezes essa adaptação se faz às custas de grandes sacrifícios, quer para os cofres municipais, quer para quem custeia as obras do porto, sem falar na série enorme de prejuízos, pequenos, mas em 
grande número, que sofrem os particulares estabelecidos e que, por sua vez, são incomodados e têm que mudar, procurando, eles também, a adaptação necessária à situação, que o desenvolvimento do porto lhes cria"...(Dispondo de um plano geral), "tudo o que for feito obedecerá a um plano harmônico; nada será feito sob ameaça de demolição ou perda futura"

A análise técnica que fundamenta o plano, ponderando as vantagens e desvantagens das direções de expansão (qualidade do terreno, exigências de fundação e aterro, distância em relação à ferrovia e à entrada do estuário), levaria à indicação da localização junto ao rio Sabóo, pelas conveniências que oferecia à manipulação e transporte de carvão, gasolina e sal (mercadorias que estariam a chegar cada vez em maior quantidade). Seguia considerando que, face aos defeitos do primeiro trecho do cais construído e às exigências da execução (mais cedo ou mais tarde) do prolongamento para a barra, o fato de ser "muito estreita a cidade, entre o atual cais e o Monte Serrat" e a impossibilidade de rebaixamento do fundo do estuário (o sistema de construção empregado não o permitiria), imporia a necessidade de reconstrução da muralha, através do prolongamento do "alinhamento reto que existe entre o armazém 9 e a curva do Paquetá", o que resultaria na reconstrução de "1420 metros lineares de cais, em frente, justamente, à parte mais central da cidade" . Ainda que, para evitar "prejuízo real ao porto , a proposta adotasse a solução do alargamento para o lado da terra, na faixa correspondente, com a finalidade de se obter "a largura indispensável para as vias, que férreas, quer de rodagem, necessárias para assegurar franco transporte"22. Quanto ao trecho Paquetá-Outeirinhos, "a que corresponde grande área de armazéns, amplas avenidas e rede de linhas férreas", os oito metros de calado permitiria "a atracação de vapores de maior calado" ${ }_{23}$.interpondo-se entre a linha de cais e as embarcações flutuantes de não mais de 4 metros-.

Desta maneira, ao lado da cidade de Santos, o plano geral de desenvolvimento abrangeria para execução imediata obras de prolongamento (1.000 metros lineares no Saboó e dois alinhamento retos em direção à barra) e reconstrução de cais (o que supunha "a desapropriação da parte necessária dos prédios da rua Xavier da Silveira, entre a Alfândega e o Paquetá" ${ }^{24}$ ), de construção de cais de saneamento e de avenida pública, margeando o canal ("até onde se caracterizar a praia de areia ) e a instalação de tanques de óleo na ilha Barnabé.

Quanto ao futuro, o documento discutia duas alternativas:

- prolongar o cais para o interior da baia, além da foz do rio Saboó, permanecendo na margem da cidade;

- abandonar essa margem, passando para a fronteiriça, que deveria ser ocupada desde a ilha Barnabé até a curva da entrada do canal”25. 
Ponderando as vantagens e os incovenientes ${ }^{26}$ apresentados por cada uma das alternativas, o documento fazia prevalecer a supremacia da segunda sobre a primeira, entendendo sobretudo que a construção de pontes seriam de interesse geral pela possibilidade de estabelecer comunicações com todo o Litoral Norte do Estado. Assim, além da construção das pontes e das ligações ferroviárias e rodoviárias, o projeto supunha a construção de cais que, contornando a sul e sudoeste a ilha Barnabé e desenvolvendo-se na ilha de Santo Amaro junto à Base Naval de Aviação (2800 metros em alinhamentos retos), seriam arrematados por três grandes docas oblíquas em relação ao canal.

\section{Novas realizações e o porto industrial}

Aos 4240 metros de cais em operação desde a década de 1910, descontados as obras da usina de Itatinga (1910), da ilha Barnabé (300 metros de cais construídos no biênio 1929/1930), além da construção do primeiro trecho do Saboó, quase nada seria acrescentado às dimensões físicas do porto até o fim da década de 1950. Como observou Nelson Werneck Sodré (1947), as circunstâncias externas, incidindo sobre o desenvolvimento comercial de São Paulo, contribuiram para diluir os sucessivos problemas de congestionamento do porto. Ou seja, como concorda Maia $(1947,51)$, "sempre que a saturação portuária se aproxima, coincide sobrevir um fato externo a reduzir-lhe o movimento e mascarar-lhe a deficiência do serviço". Teria sido assim em 1914, quando a discussão sobre o monopólio dos serviços acabou relegada pelas repercussões da primeira guerra. Da mesma maneira, a crise de congestionamento e a alternativa São Sebastião, discutidas entre os anos 1924/ 1929, foram superadas pelos impactos da crise econômica de 1929 sobre a curva do movimento do porto. Queda de movimento que, influenciada também pelas consequências da revolução de 1932 e da segunda guerra mundial, acabaria postergando por quase 40 anos a execução de obras de expansão do aparelho portuário ${ }^{27}$.

De qualquer modo, como lembra ainda Maia $^{28}$, o próprio plano de 1926 não "teria sido seriamente considerado, mas antes mantido como mera garantia do alegado privilégio ou monopólio da concessão”. Isto na medida em que o engenheiro considerava que aquele plano, encadeando-se a uma perversa tradição da gestão das infra-estruturas e dos serviços publicos,

surgiu como consequência da crise de 1925 , como o contrato da Light em 1909 surgira com as ameaças das Docas, como a proposta da mesma Light em 1925 resultava da aparição dos ônibus, como o estudo da São Paulo Railway de 1895 (linha por aderência em Cubatão) seguiu-se ao congestionamento de 92 , como o projeto da mesma em 1927 (linha por aderência no Quilombo) sucedeu aos congestionamentos de 1912 e 1925, como esta última crise também 
impeliu a Sorocabana à linha de Mairinque, e como o congestionamento de 1947 talvez conduza à ampliação do porto de Santos".

A crise de congestionamento, que se verificou no cais de Santos em 1947, relacionava uma vez mais, segundo tese de Araújo Fo (1969), o grande aumento de movimentação (tonelagem superior a 5 milhões), insuficiência do aparelho portuário e inadequadas condições de transporte terrestre. No entanto, parece ter sido a clássica "ameaça" de São Sebastião o que motivou a elaboração do Plano Regional de Santos, apresentado pelo próprio Maia "como defesa de Santos como porto, a pedido da cidade e de grupos ligados às atividades portuárias" ${ }^{29}$. Considerando suas propostas uma adaptação, segundo um ponto de vista mais amplo (e integrado), do plano de 1926, Maia indicava a necessidade de alterar a ordem cronológica da obras estabelecida por esse ultimo, "no sentido de atacar em ação conjunta com o governo estadual, a ligação Saboó-Barnabé-Santo Amaro, em um primeiro trecho do cais junto a Itapema" (na margem esquerda do estuário). Assim o porto garantiria seu futuro e o Estado atacaria problemas regionais relevantes: o acesso à ilha de Santo Amaro, a ligação à Bertioga, ao Litoral Norte, a implantação da industria naval, em moldes grandes e perfeitos..." ${ }^{30}$

Em relação ao acesso à Bertioga a ligação ferroviária e/ou rodoviária em ponte ou túnel Saboó-Barnabé-Monte Cabrão-Santo Amaro deveria estar associada à construção de ponte (com $25 \mathrm{~m}$ de vão central elevadiço) ou túnel na altura da linha de Itatinga. Na margem esquerda, junto com a sugestão de transferência da Base Aérea para a Praia Grande, Maia proporia a construção de pátios ferroviários e, mais ao sul, bacias e molhes, como a terceira etapa de implantação de seu projeto

Se as propostas "regionais" de Maia foram concretizadas parcialmente (integração ferroviária e ramificação rodoviária em Cubatão ${ }^{31}$ ), o fato é que com respeito ao porto seria a crescente importação de granéis líquidos que, roubando, a partir da década de 1940, a hegemonia da participação do café na movimentação geral ${ }^{32}$, o fato que passa a pautar as obras de equipamento e ampliação. Seguindo ainda o plano de 1926, que sómente seria modificado em 1960 —alterações que se impunham para atender as tendências observadas $^{33}$-, e financiada pela Taxa de Melhoramentos Portuários aprovada em 1945, diante da necessidade de aparelhamento dos portos brasileiros para fazer frente ao aumento do comércio mundial, ocorrido quando terminada a segunda guerra — a expansão portuária avançaria lentamente em duas frentes: oeste — Sabóo/Alemoa— e sul em direção à Ponta da Praia. Tal lentidão pode ser observada na programação orçamentária referente à Taxa de Melhoramentos Portuários — nova lei, criada em em 1958, para prover de recursos o Fundo Portuário Nacional, destinando 40\% ao porto arrecadador—, que contemplava ainda, para o período 1958/1962, a 
continuação da construção de 1500 metros lineares de cais no Macuco e 500 metros na extensão Saboó. E, apesar de constar nos "Relatórios" do período, a sucessiva construção de cais naquelas duas direções, é interessante notar que os estudos para Plano Diretor Físico de Santos de 1967 apontem que a Companhia Docas submetera em 1962 ao governo federal um "Plano de emergência para a expansão do porto de Santos" ${ }^{34}$. Neste andamento, são os terrenos na Alemoa ${ }^{35}$, equipados e interligados através do oleoduto da Companhia de Estradas de Ferro Santos a Jundiaí36, ao Saboó e Ilha Barnabé, que contribuem, com os 919 metros de cais construídos até 1953, para uma das mais importantes fases do porto, precisamente alavancada pela movimentação do petróleo ${ }^{37}$ :

Para caracterizar a auspiciosa fase vivida pelo porto nesse período (1955-1968), é importante observar que o petróleo e seus derivados foram os responsáveis pela duplicação da tonelagem movimentada pelo Porto de Santos, atingindo o total aproximado de $16.500 .00 \mathrm{t}$ em 1968".

As refinarias Presidente Bernardes, em Cubatão, e União, no planalto em Capuava, começaram a funcionar em 1955 e seriam responsáveis por aquelas marcas, cuja grandeza levara a Companhia Docas a construir, na ilha de Santo Amaro, na margem esquerda do estuário, o cais de Conceiçãozinha: 500 metros de comprimento e 13,5 metros de profundidade, exclusivamente para o recebimento de petroleiros de grande calado. No entanto, em virtude da falta de ligação por oleoduto aos tanques do Saboó ou da refinaria de Cubatão e sobretudo pelo impasse criado com a Petrobrás ${ }^{38}$, que inauguraria em 1969 um terminal de petróleo em São Sebastião (450 metros de cais, ligado por 120 km de de oleoduto á refinaria), os planos de expansão das Docas são uma vez mais interrompidos. Neste sentido, em 1967, o Plano Diretor Físico de Santos apontava a competitividade de São Sebastião (desviando parte da movimentação do petróleo bruto, que representava em 1965, 65\% do movimento global do porto de Santos), a proximidade do término do prazo de concessão da exploração do porto pela Companhia das Docas, além de um supostamente elevado custo das obras, como as principais causas da paralização, desde 1958, de qualquer iniciativa da expansão portuária santista..

Se as mudanças da pauta de movimentação do porto santista — da exportação de café e importação de bens de consumo à importação de petróleo-, refletiram-se na adaptação do equipamento portuário, no entanto, parecem mesmo ser a brusca interrupção — abril de 1969— do próprio movimento petroleiro em favor de São Sebastião, e, sobretudo, a construção, no "fundo do Largo de Caneú", de terminais especializados por parte da COSIPA ${ }^{39}$ (minério de ferro) e Ultrafértil ${ }^{40}$ (fertilizantes), rompendo, ao amparo do governo federal, a prolongada resistência da Cia. Docas, os principais acontecimentos que marcam a passagem do "porto do café" para o porto 
industrial ${ }^{41}$. Isto implicaria na readequação das instalações portuárias, incluindo a necessidade de grandes volumes de dragagem para o aumento das profundidades do canal de acesso e na ampliação do cais sobre a margem esquerda do estuário, que se inicia efetivamente com a conversão do terminal da Conceiçãozinha para o recebimento de sal e fertilizante. A ocupação da margem direita do estuário estaria quase esgotada com a entrega, em 1968, para operação do trecho (1.261 metros) do Macuco até a Ponta da Praia, o que totalizaria 7.034 metros de cais constrtuído.

O fim da fase do predomínio agro-exportador, fundada no café e responsável pelo desenvolvimento de indústrias tradicionais e, sobretudo, pelas funções terciárias da cidade, ensejaria o debate sobre a industrialização do município na medida em que supunha-se, como se verá, que a economia santista, com o porto voltado definitivamente para o mercado extra-regional, entraria em colapso. De qualquer maneira

\section{Os terminais especializados}

Os últimos anos da administração da Companhia Docas foram marcados pela ausência de investimentos próprios na expansão e melhoria portuária. Isto se deveu à promulgação, em 1969, de ato Complementar que estipulava que os investimentos feitos pela empresa privada, cujos bens seriam pertencentes à União, perderiam valor. Como afirmava Guinle Machado, presidente da companhia — que reorientara sua participação para outros setores da economia ${ }^{42}$-, "desse período em diante, os investimentos foram feitos pela Portobrás, através da Taxa de Melhoramentos do Porto", pois a companhia não teria interesse em prorrogar o contrato de exploração dado o pequeno retorno do capital aplicado (10\% ao ano).

Sob nova orientação financeira e política, centralizada na coordenação da Cosesp ${ }^{43}$, foram iniciadas obras de grande importância para o modelo econômico adotado durante o regime autoritário ${ }^{44}$. Assim é que os novos terminais construídos - cais do Novo Macuco, terminal de cereais e de granéis líquidos na Alemoa, terminal de fertilizantes e de contêiners, na margem esquerda do estuário, em Conceiçãozinha-, bem como as infraestruturas de transportes necessárias para seu funcionamento (Ramal Ferroviário da Conceiçãozinha, Avenida Portuária), podem ser tomados como os melhores exemplos dos canais a serviço exclusivo dos sistemas exportadores. Neste contexto, se em 1971 seria inaugurado o Tefer (terminal de fertilizantes), em 1972, resultado da assinatura de acordo do governo federal com a "Zencoren" (Federação Nacional das Associações de Cooperativas do Japão), que se comprometia a importar 4 milhões de toneladas/ano de cereais brasileiros desde que racionalizado o escoamento da produção - "Corredores de Exportação"-, o cais do Macuco Novo, antes utilizado provisoriamente para armazenagem de contêiners, seria aparelhado 
com tecnologia japonesa para funcionar como terminal de cereais. Do mesmo modo os cais da Alemoa e Saboó seriam equipados como terminais de granéis sólidos e líquidos, enquanto o Tecon — terminal espacializado para contêiners-inicia suas operações em 1980.

È nesssa data que, extinta a concessão de noventa anos da Companhia Docas, e construídos 10.831 metros de cais, a Codesp — sociedade de economia mista controlada pela Portobrás-, assume a administração do porto, que apresentava déficit acumulado quase igual a seu capital social ${ }^{45}$. Ainda assim, mesmo em um período de forte crise econômica, dois planos elaborados pela Codesp-Portobrás —em 1983 e em 1988 - visavam lançar uma nova opção para a futura expansão do porto através da integração da função industrial: planos grandiosos de retificação e dragagem de canais e aterro de mangues para a construção de um sistema portuário-industrial, para a ocupação, entre o rio Casqueiro e o rio Cubatão, de área aproximadamente quatro vezes maior que a da trama urbana do município de Cubatão. Na mesma época, foi iniciada, pelo aterramento de uma faixa 190 metros de largura, a recuperação da antiga linha de cais Valongo-Paquetá para o recebimento de navios ro-ro. As dificuldades financeiras bem como as restrições de natureza ambiental tiveram o efeito de bloquear a primeira iniciativa e paralisar as obras da segunda, que se encontra, atualmente, em fase licitação para a iniciativa privada. Portanto, desde 1981, inauguração do terminal de contêiners, nenhuma outra obra seria realizada até fins da década de 1990, quando se inicia a construção, ainda em anadamento, do segundo terminal de contèiners -Tecon II.

Na verdade, a extinção da Portobrás e mais tarde a lei no 8.630 de 25/2/1993 de privatização dos portos, representando o redirecionamento das diretrizes da política portuária, fizeram com que as principais ações empreendidas, com excessão do início das obras de construção do segundo terminal de contêiners na margem esquerda, ficassem resumidas aos processos de privatização da instalações portuárias, de maneira tal que, somando-se aos terminais privativos da Cosipa, Ultrafértil (esses dois "excluídos" da área do Porto Organizado, portanto não sujeitos à regulação, fiscalização e cobrança de taxas administrativas por parte da Autoridade Portuária), Dow Química, Cutrale e Cargill, 75\% das instalações portuárias da Codesp encontram-se arrrendadas ${ }^{46}$. Se, restando a privatização dos terminais de grãos (Tegran), de fertilizantes (Tefer) e de contêiners (Tecon 2, em construção), há indícios, como se verá adiante, de melhoria do desempenho dos terminais arrendados para a movimentação de contêiners, e, ainda que se tenha mecanizado as operações de movimentação de sólidos a granel (principalmente açúcar), poder-se-ia levantar a hipótese que a concessão dos armazéns do setor do Outeirinhos, não obedecendo o preceito da "escala" mínima como garantia de desempenho econômico, fragmenta o controle das instalações em diversas empresas não conexas entre si e talvez com a operação portuária propriamente 
dita, segundo um procedimento que de forma paradoxal sugere a

(re)"trapichização" do cais.

Neste novo quadro institucional e administrativo, o Plano de Desenvolvimento e Zoneamento Provisório da Codesp (1996) destaca entre os projetos de infraestrutura básica a serem executados em curto prazo a extensão da Avenida Portuária, o aprofundamento do canal e a construção de terminais rodoviários integrados. A eles deve-se acrescentar o projeto do túnel de ligação SantosGuarujá, cuja construção antes concebida para ser realizada com recursos do governo federal, hoje aguarda eventuais interessados da iniciativa privada.

Nesse mesmo documento, quanto aos cenários desenhados em relação ao "porto e seu meio", ao lado da previsão de envolver "todo o estuário e área contígua, para uso portuário e atividades associadas" (particularmente interessadas à "agregação de valor"), vem proposto o reestabelecimento do equilíbrio ambiental da Baixada Santista e a integração com o "meio urbano com redução de interferências, dos conflitos, cabendo ao porto o papel "de agente de suas revitalizações". Neste sentido vem apenas sugerida a reserva de áreas para projetos "de integração do Porto com áreas históricas do centro da cidade, em parceria com a Prefeitura Municipal de Santos, bem como a implantação de um "Centro de Negócios Internacionais"47 e uma estação de passageiros, em ação conjunta com a iniciativa privada.

***

Se alguns estudos sobre o porto de Santos distinguem ao menos oito fase fases de seu desenvolvimento ${ }^{48}$ (às quais haveria que se somar a atual, marcada pela privatização das instalações e operações portuárias), talvez para o que interessa aqui, ou seja, entender o rebatimento das inovações portuárias sobre a forma e o "funcionamento" urbanos, pudessem ser caracterizadas as seguintes "tipologias" de instalações portuárias:

- cais corrido convencional de carga geral equipado com armazéns (Valongo, Paquetá, Outeirinhos, parte do Macuco, ou seja, os antigos setores da margem direita, implantados em contato direto com o tecido urbano da porção leste da cidade);

- terminais de inflamáveis, píers e tanques de armazenagém (Saboó, Alemoa, Barnabé), isolados da trama urbana;

- terminais especializados - píers com equipamento mecanizado para granel líquido e sólido ( Cutrale, Cargill e Tefer, na margem esquerda, e Ponta da Praia - terminal do "Corredor de Exportação". localizado justamente no ponto mais distante de articulação com as vias regionais);

- terminais de contêiners com extensos patios livres (margem esquerda do estuário e parte do setor correspondente ao armazém 37, no Macuco). 
Respondendo cada vez mais à demandas específicas, "individualizadas", as novas tipologias que configuram os terminais especializados, "desenham" novas formas de relação com a água, a estrutura urbana e o sistema de transportes terrestres, diferenciando-se, seja sob o aspecto físico, seja sob o aspecto funcional e operacional, dos antigos cais "urbanos". A verificação das mutações gerais por que vem passando, nos últimos dois séculos, a infraestrutura portuária e sua relação com o território, pode ajudar, pelas semelhanças e regularidades que existam entre elas e a "dinâmica tipológica" do porto santista, a caracterizar as contradições e conflitos que se manifestam entre esse e a cidade e assim sugerir tendências de transformação de sua relação. 
Porto de Santos, Praia do Consulado, 1882 : pontes de madeira para o embarque de mercadorias. A precariedade $\$$ do sistema não impediu sua duração por mais de 30 anos: de 1857, construção da primeira ponte, até 1892, quando se inaugura o primeiro trecho de cais corrido

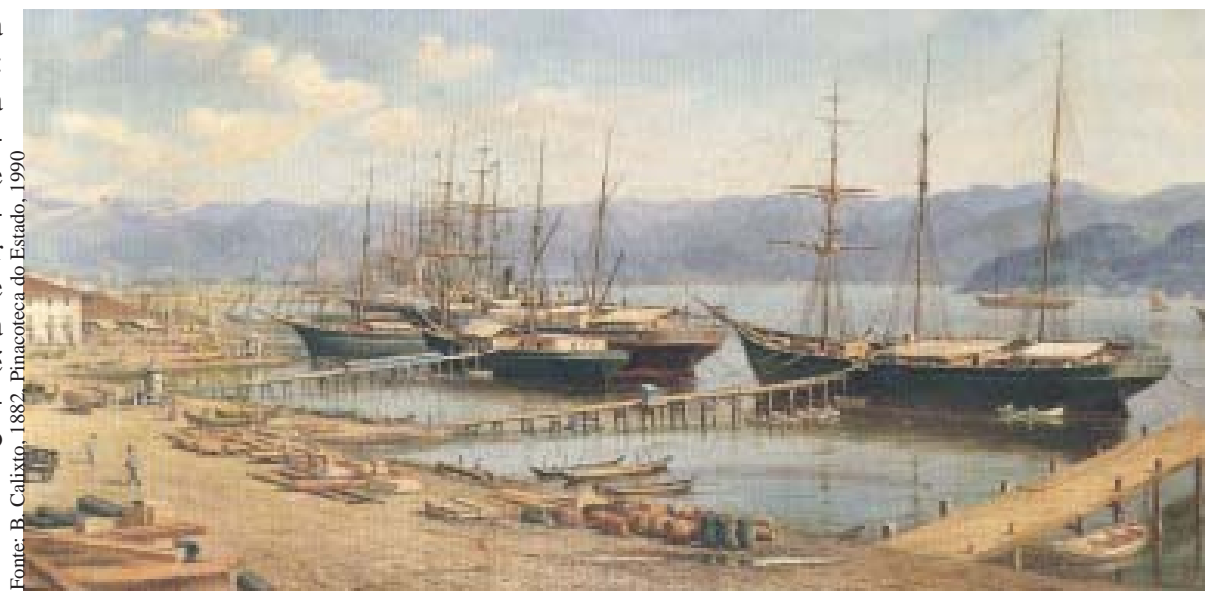

O porto de Santos, c. 1885, "quando a febre amarela ceifava as tripulações inteiras dos veleiros que se aglomeravam no ancoradouro, enquanto refaziam suas esquipagens"

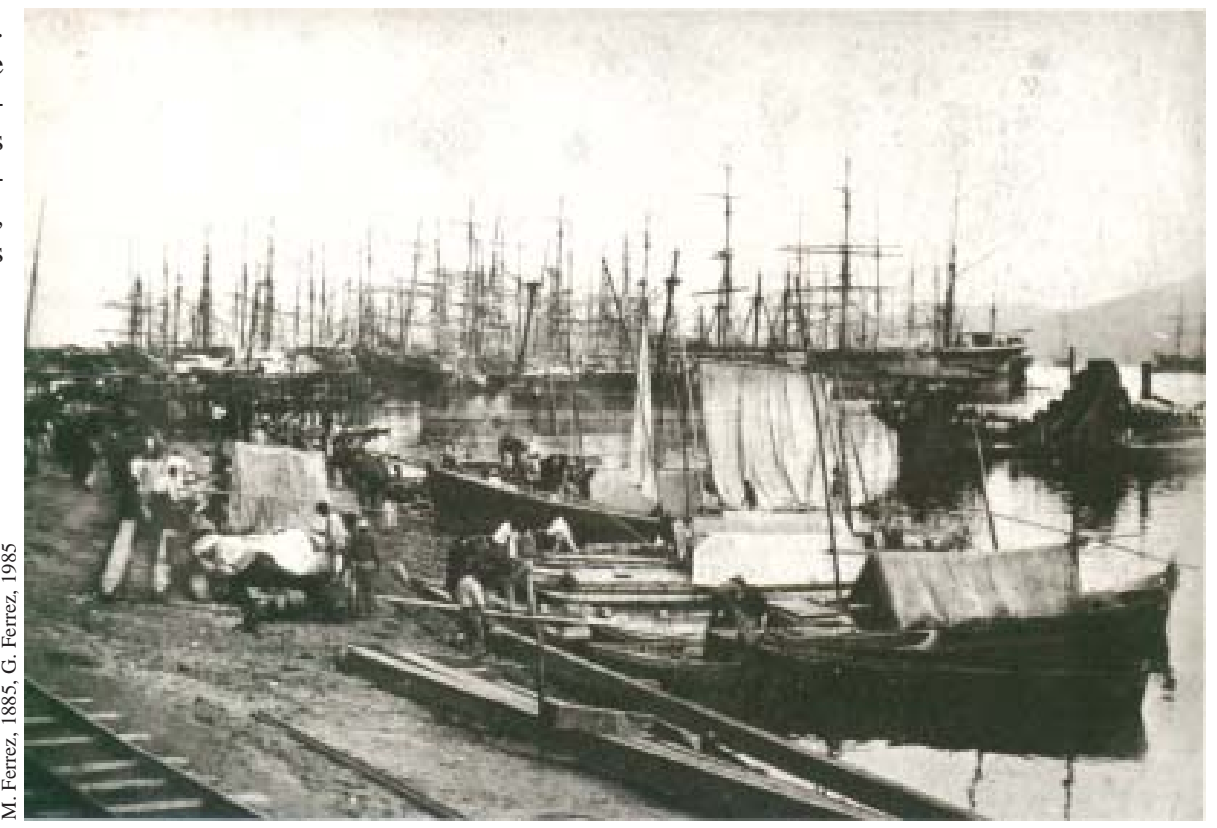




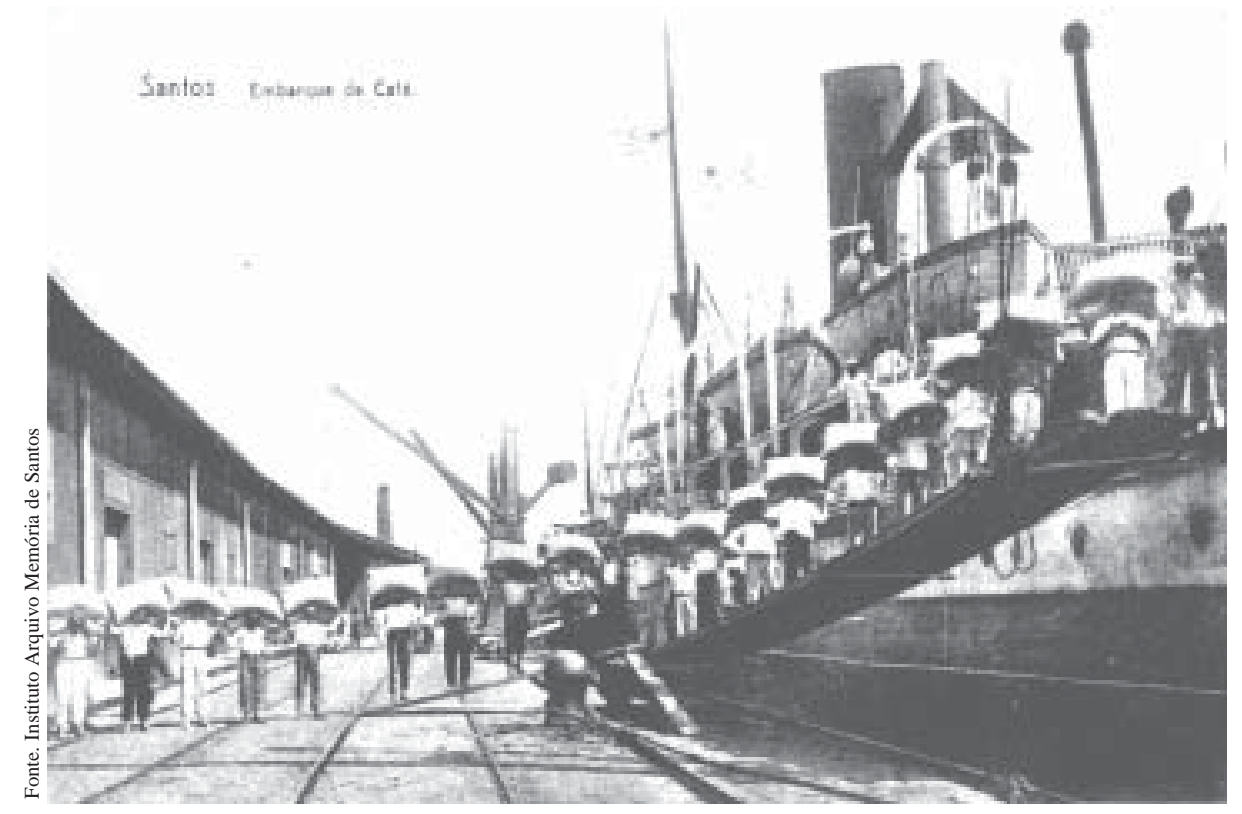

A nova organização do espaço e do trabalho no porto moderno, para o embarque do café

Construção do cais Outeirinhos.

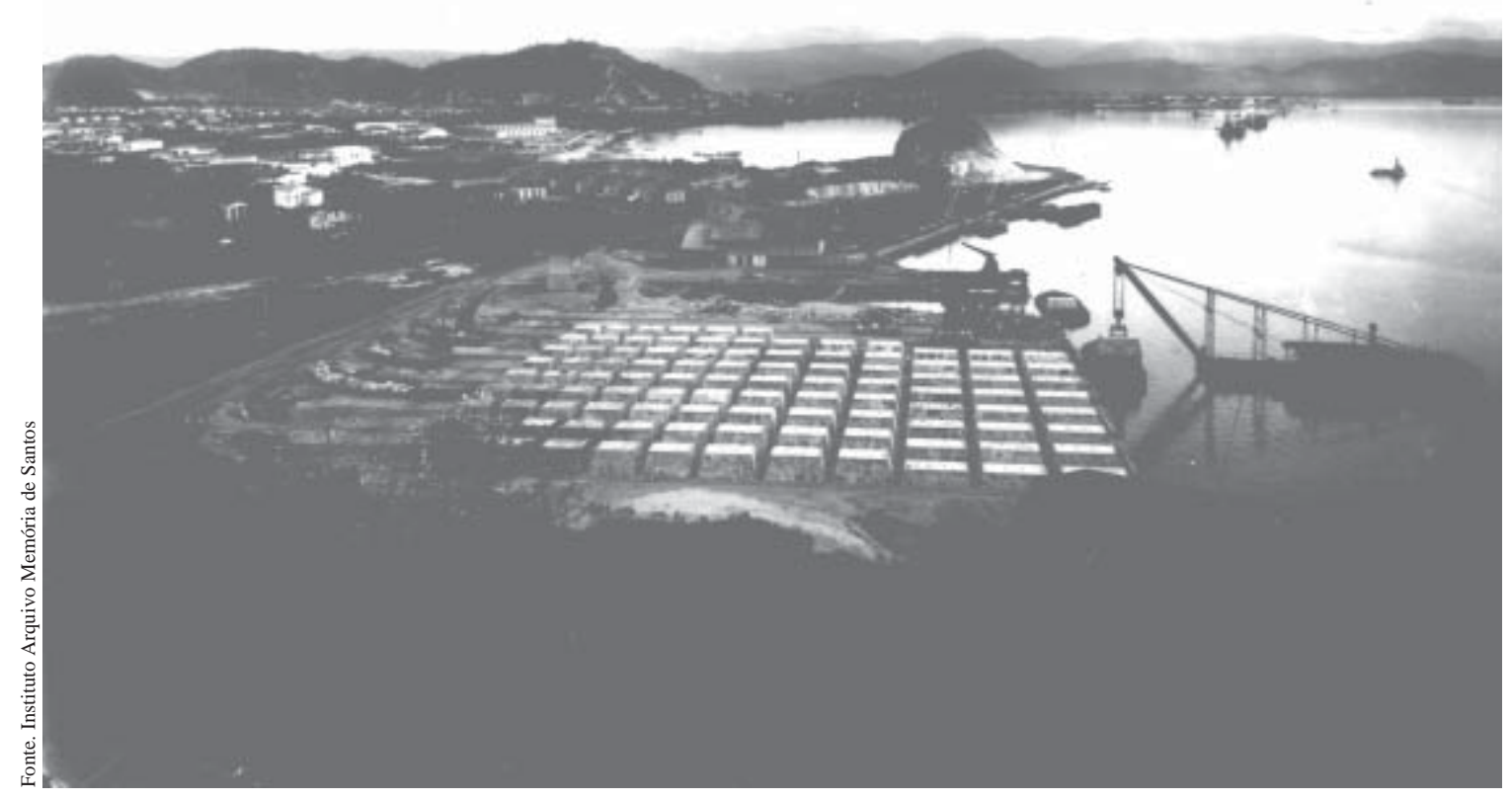


1897- Planta geral do cais da Companhia Docas. Além do cais e armazéns do Valongo e Paquetá, está indicado o prolongamento da muralha, previsto para o setor dos Outeirinhos
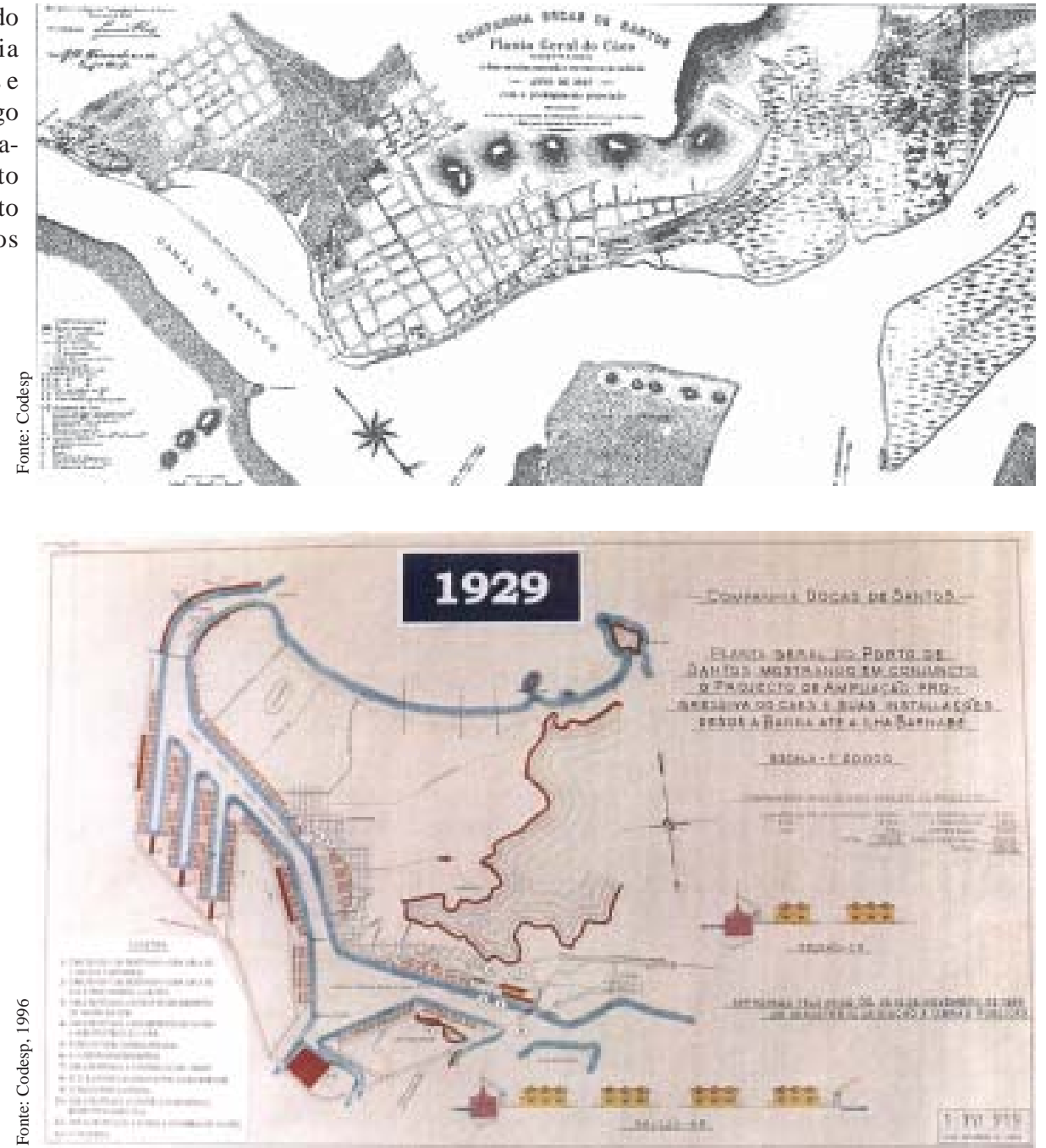

Planta geral do plano de 1926 de ampliação progressiva do cais. Desde a barra até a ilha Barnabé, toda a frente estuarina seria reservada ao domínio portuário, garantindo o monopólio da Companhia Docas de Santos sobre os previstos 33.000 metros lineares de cais As pontes previstas de ligação com a ilha Barnabé, bem como as bacias na margem esquerda não seria executadas. Excetuando 300 metros de cais construídos na ilha Barnabé (1930), ao trecho Valongo/Outeirnhos (4720 metros) nenhum outro setor seria acrescentado até meados da década de 1940

Em face do aumento da movimentação ocorrida no período pós-guerra, além da extensão em direção ao Saboó (1945) e da construção do oleoduto Saboó/Alamoa/ Baranabé, o plano geral de 1951 do porto previa o aproveitamento das três barras de acesso

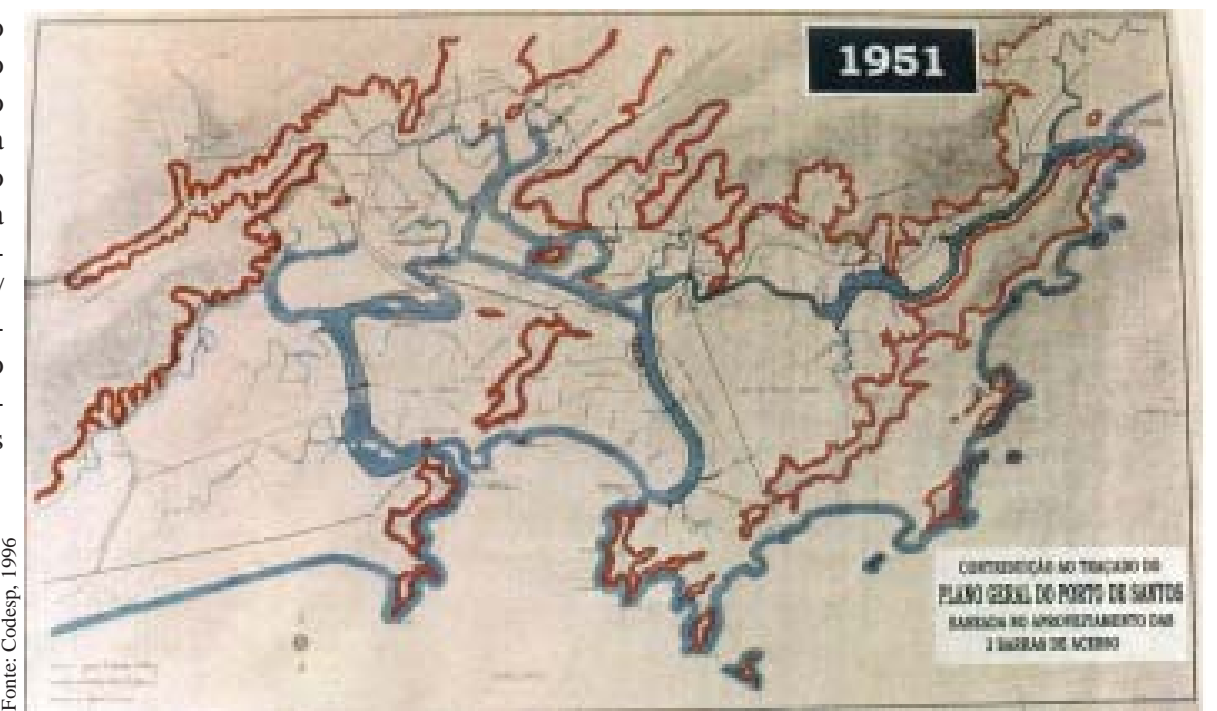


Extensão do cais: evolução da construção e utilização na década de 1960
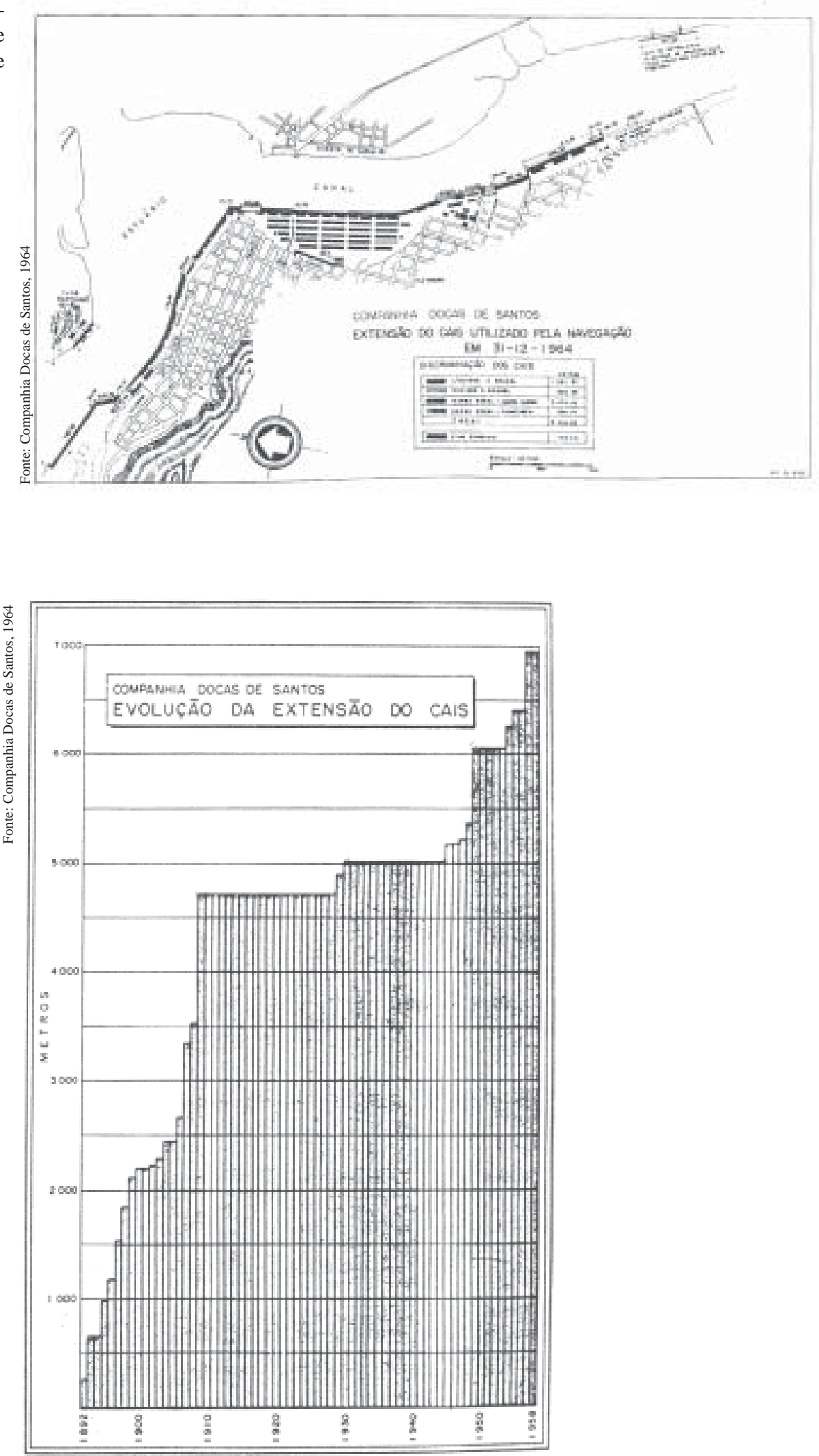

$5.953 .30 \mathrm{~m}$ \& a extenşabo do çdis para navios de grande porte. Há mais $140,70 m$, destinados a embarcaçōes do trafego interno 6 $567,00 \mathrm{~m}$ da Terminal de Petroleiros.

Total eonstruido: 7.667 metros. 
Pressupondo sua afirmação como "industrial" (fase que se inicia em 1955 e entra em crise em 1969, com a inauguração do terminal petroleiro em São Sebastião) e tendo quase esgotadas as reservas naturais da margem direita (7.034 metros de cais), o porto de Santos planeja sua expansão, já sob financiamento por parte da Portobrás, sobre as áreas continentais (seguindo o canal de acesso para a Cosipa) e a margem direita. O plano diretor de 1969 é de autoria da NEDECO —Netherlands Engineering Consultants— de Haia

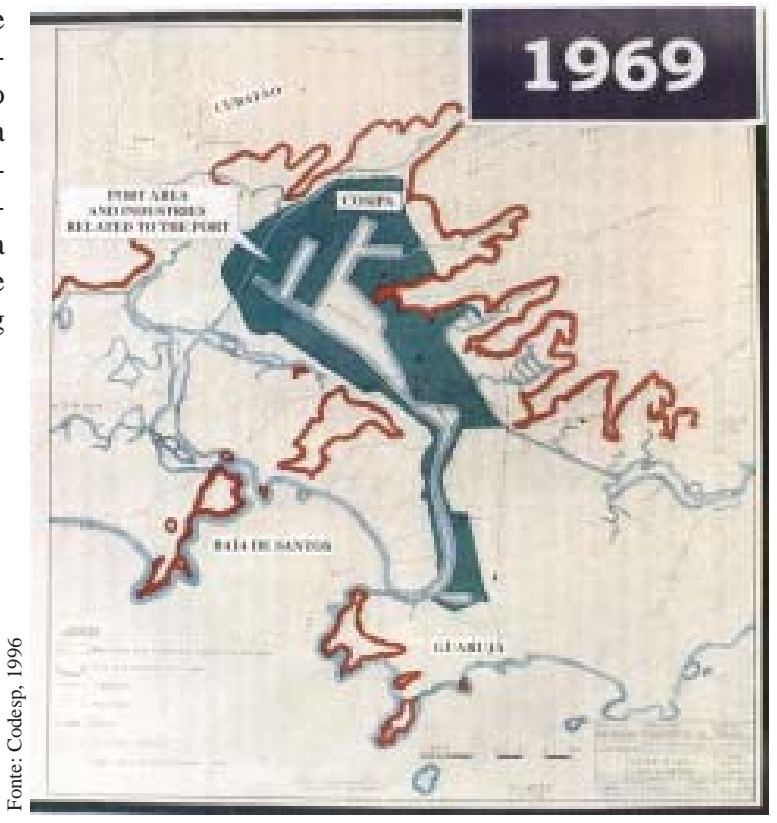

1976 O último plano diretor do porto sob a administração da Companhia Docas de Santos, embora essa tenha deixado de investir diretamente nas obras de melhoria portuária desde 1969. Respondendo à politica econômica agro-exportadora, o plano de 1976, além da consolidação dos novos terminais especializados para fertilizantes e granel sólido ("corredor de exportação" no Novo Macuco), prevê a construção de terminal de contêiners na margem esquerda
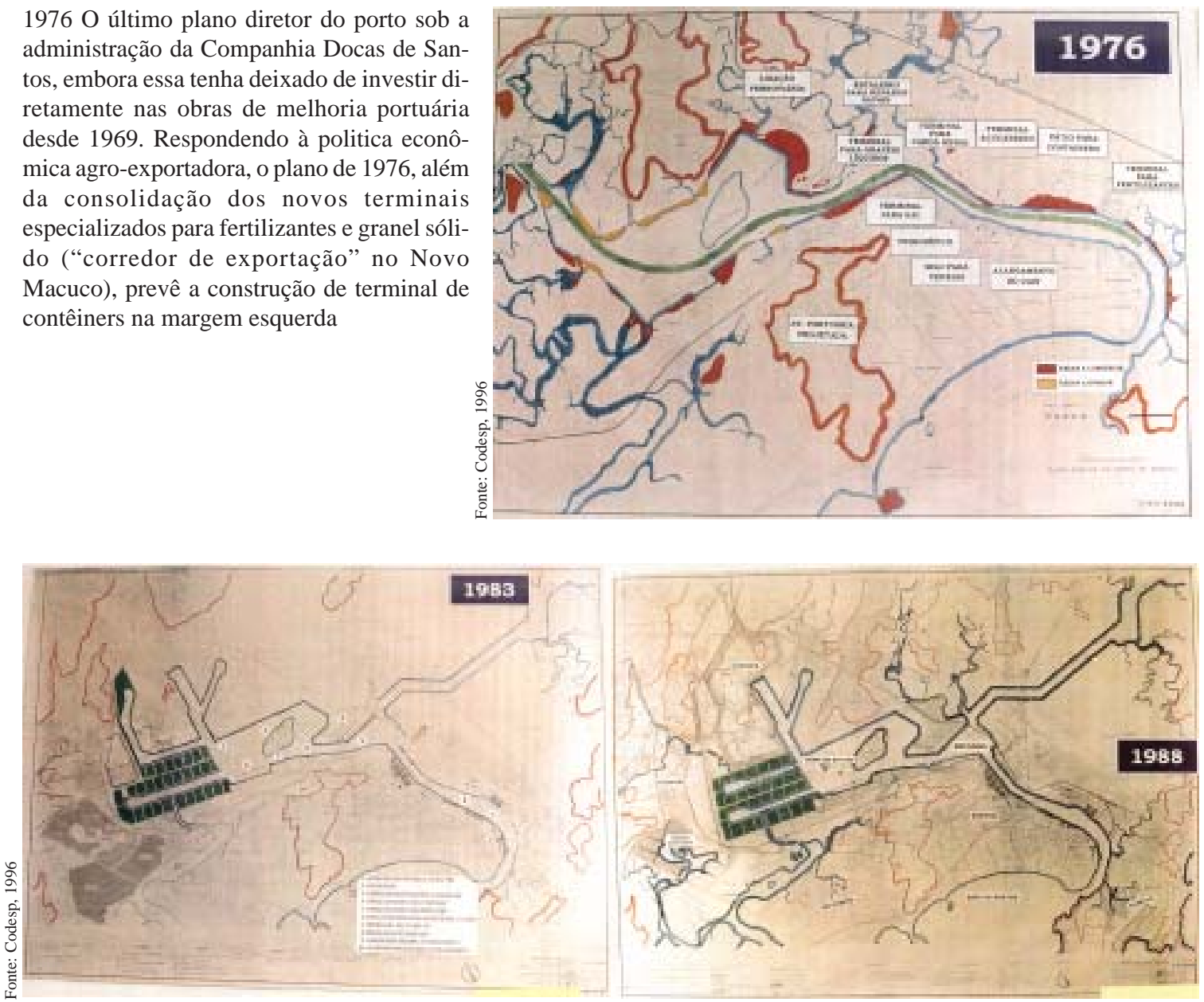

1983 e 1988: os projetos da Codesp de estabelecimento de sistema portuário-industrial em Cubatão. Ao lado da ampliação dos terminais especializados (contêiner, ro-ro, fertilizantes, granéis), repercutindo as exigências das novas tecnologias de transporte marítimo, os planos de integração portuária-industrial prevêem a extensão sobre áreas de manguezais e abertura dos canais de acesso, não demonstrando qualquer sensibilidade com as questões ambientais, já em discussão desde o início da década de 1980 . O peso que assumem essas questões bem como a "interiorização" dos investimentos fazem esses planos cairem no esquecimento 


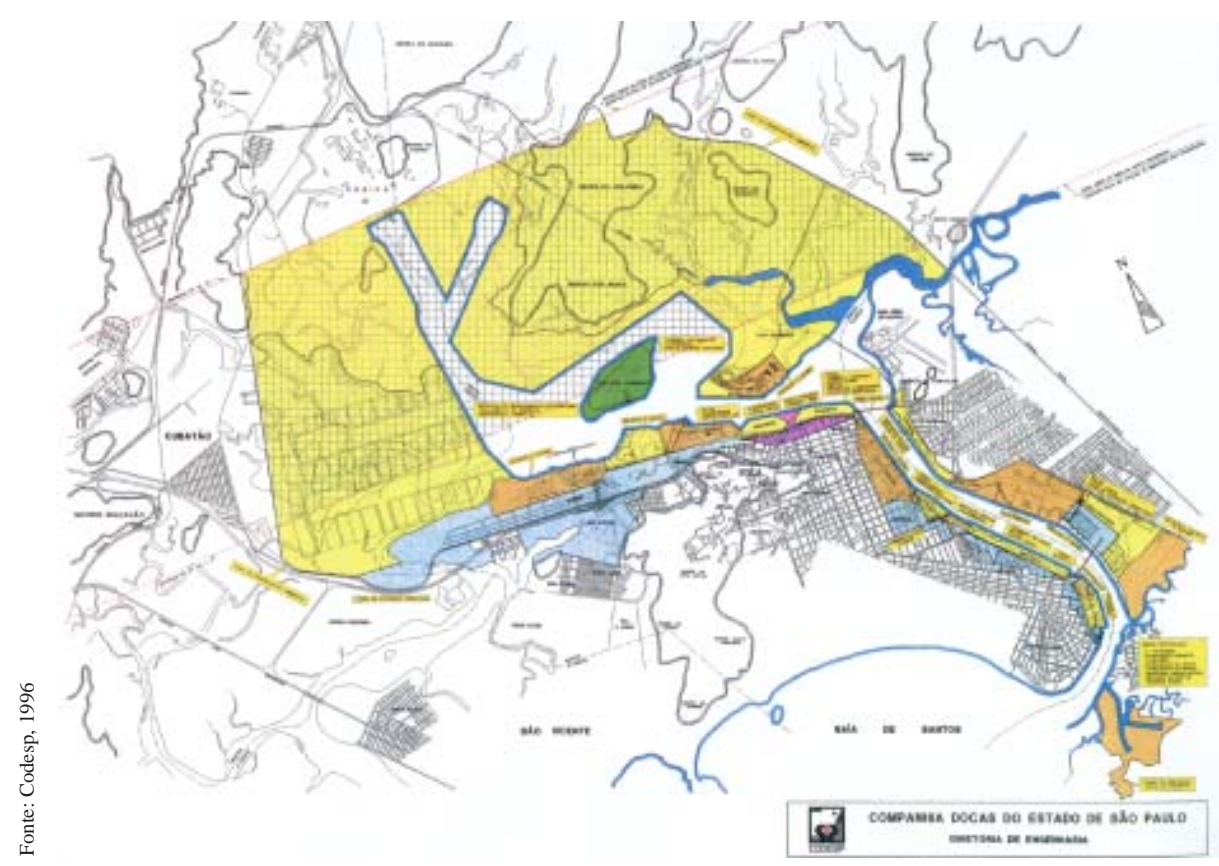

1996: à luz da nova "lei do portos" (8.630/93), o Plano de Desenvolvimento e Zoneamento "Santos-2000", elaborado pela Codesp, pretende-se "condicionador ou limitador" da iniciativa dos empreendedores privados, a quem caberia "o papel motor de desevolvimento do porto". Todas as áreas do "Porto Organizado" (cujos novos limites exclui as áreas dos terminais privativos da Cosipa) seriam objeto de concessão (uso público geral ou especial) para construção e exploração. Nota-se pela desenho a ocupação de toda a frente estuarina, reservando-se para um convênio Codesp-Prefeitura Municipal de Santos uma pequena abertura entre a ampliação dos cais do Valongo e Paquetá. Para a ligação Santos-Guarujá duas opções são indicadas: Paquetá e Macuco: ambas eminentemente "portuárias"

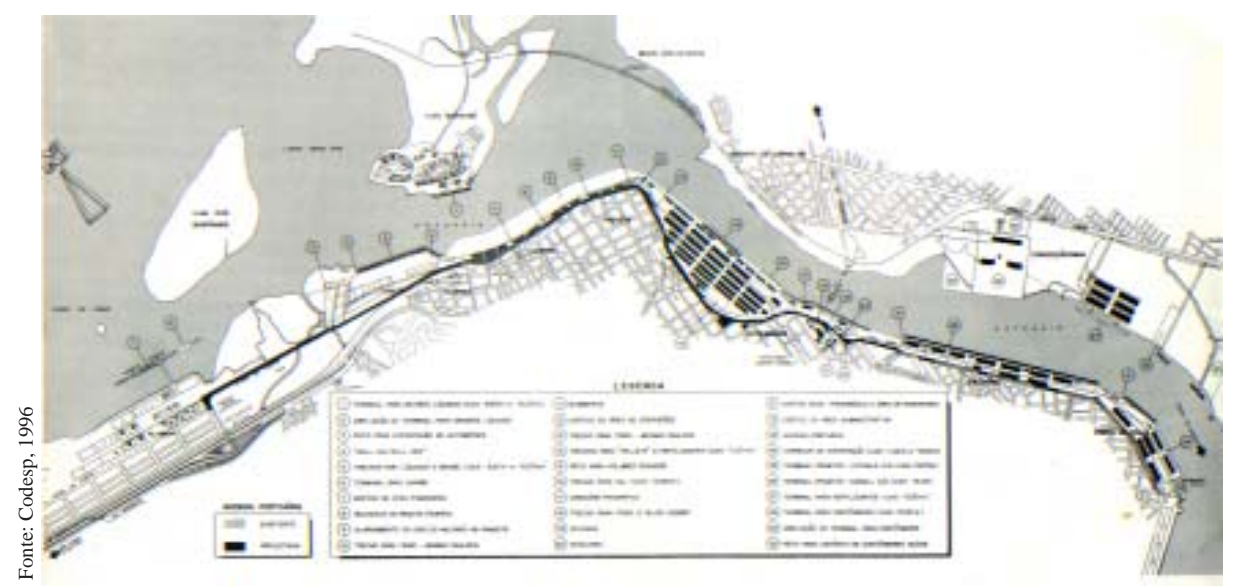

Setorização funcional do porto 

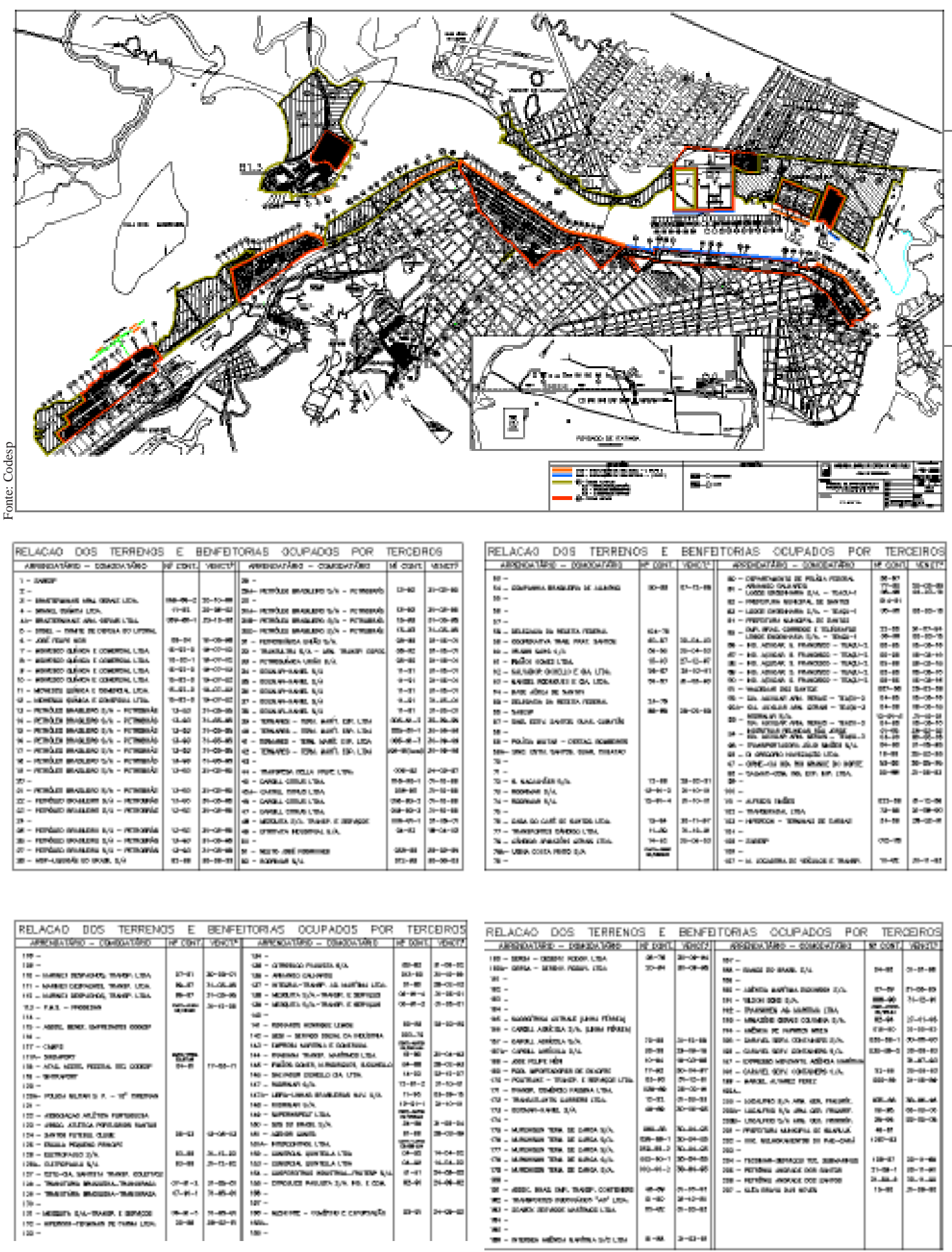

Esquema de distribuição das áreas arrrendadas — PROAPS. A excessiva fragmentação e o uso extensivo das instalações fazem supor uma contradição com a escala mínima exigida para o desempenho econômico das atividades portuárias, ao mesmo tempo que implica no domínio dos operadores sobre os arrendatários, colocando em questão o princípio da concorrência. 
Curva do Paquetá: primeira expansão, mantendo a mesma faixa estreita de cais. No primeiro plano o moinho Paulista, caracterizando a ocupação do bairro por indústrias e armazéns

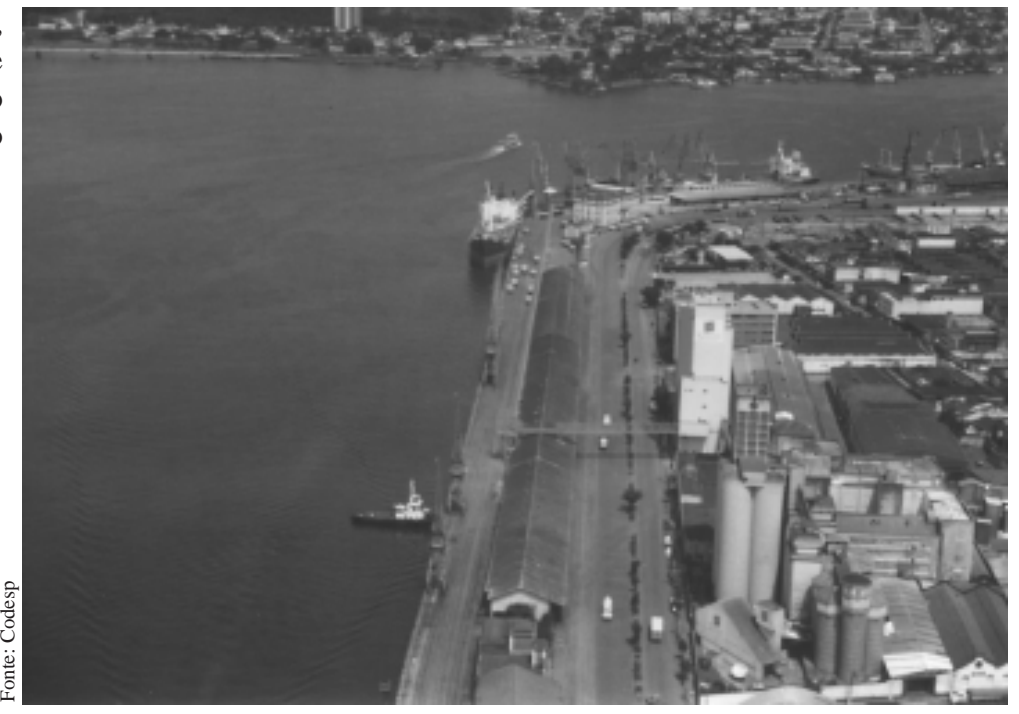

A enseada do Outeirinhos: aterro em forma de semi-círculo irregular (2000 metros de frente e 500 metros de flecha máxima). Organização do espaço através de linhas internas e externas de armazéns, ruas e pátios. A privatização dos armazéns, fragmentando física e operacionalmente a área, e a indefinição do traçado da Avenida Portuária são fatores da caótica ordenação espacial. A bacia e o canal do Mercado (servindo às catraias para Vicente de Carvalho) representam um dos poucos pontos de contato da cidade com o estuário

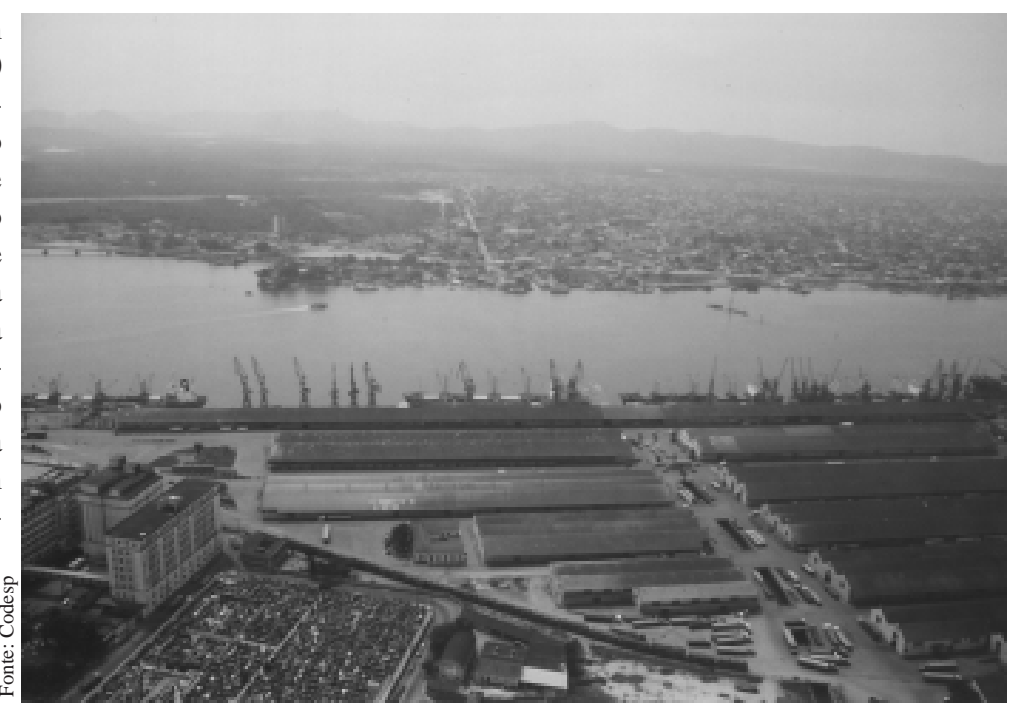

Ilha Barnabé: cais construído em 1930 para recebimento de granéis líquidos (inflamáveis). Interligação por oeloduto com Sabóo e Alamoa, inaugurando a expansão externa à ilha de São Vicente. Na parte posterior, cogita-se da implantação de terminal automotivo e de contêiners

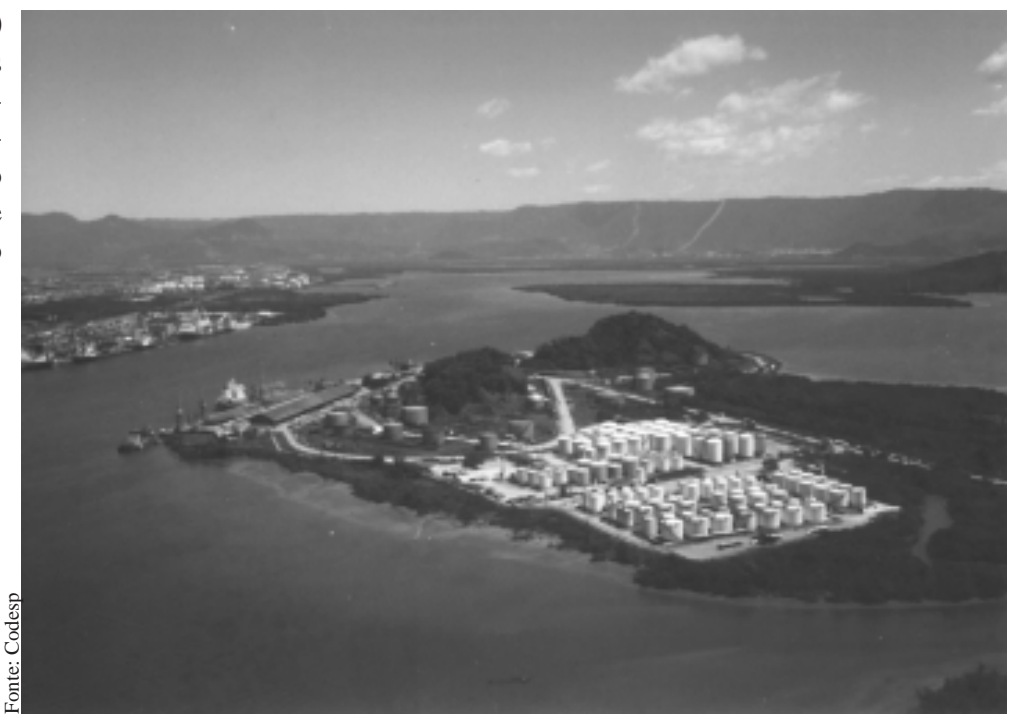


Saboó: a proximidade com o terminal ferroviário e a interligação por oleoduto com a ilha Barnabé favoreceram a implantação deste setor de expansão para atender o crescente movimento verificado após a segunda guerra. Hoje além de líquidos a granel, o terminal movimenta carvão e tráfego ro-ro. À direita da imagem, extensas áreas do pátio ferroviário que estrangulam a entrada da cidade. As margens do tramo viário de articulação com a Via Anchieta seriam reservadas para a implantação industrial

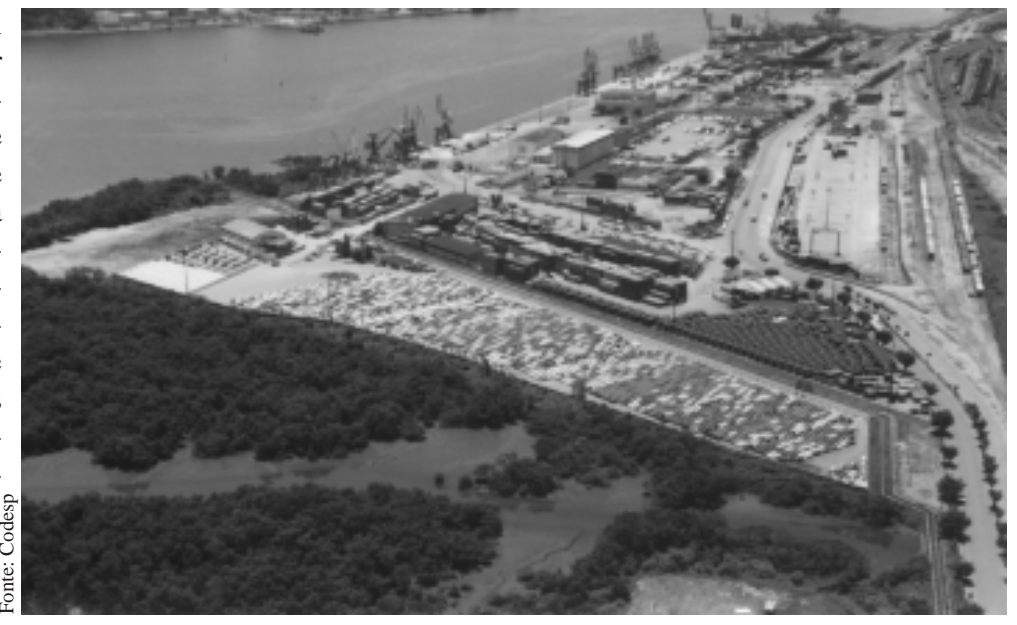

Alamoa: área da porção oeste do domínio portuário equipada com terminal em píer para recebimento de líquidos a granel. Na retarguarda, o distrito industrial de Santos

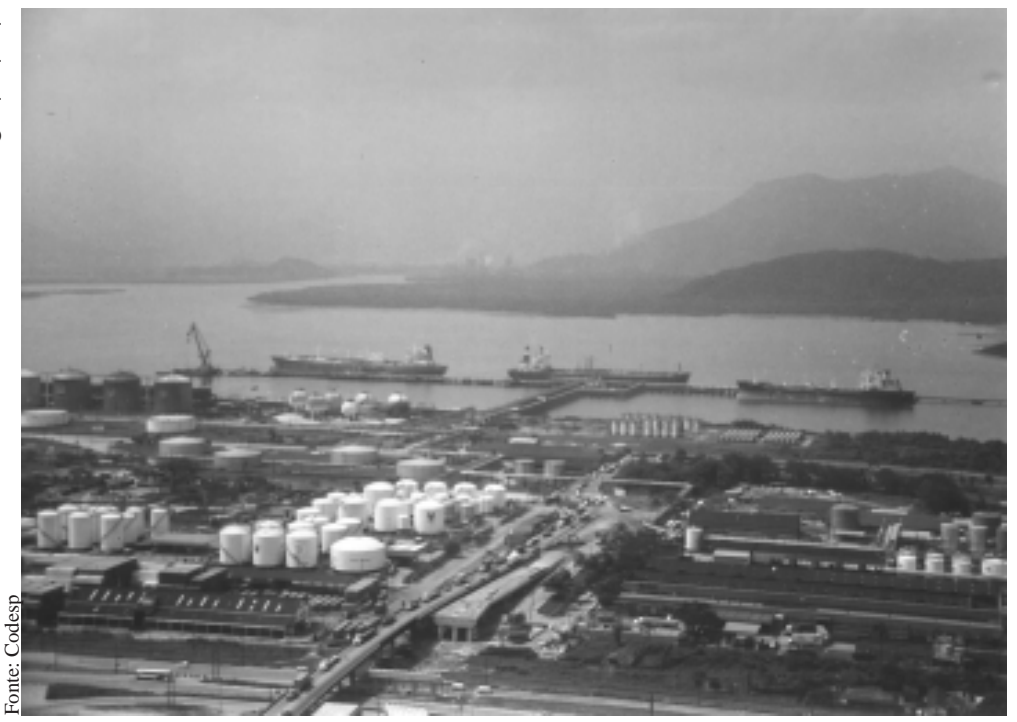

Macuco: o prolongamento do cais ao sul dos Outeirinhos desenvolve-se desde 1945 até o final da década de 1960. A ocupação portuária deste setor seria criticada pela distância em relação á ferrovia e pela incompatibilidade com a ocupação residencial pré-existente, a qual ver-se-ia desvalorizada pelo impacto do traçado da Avenida Portuária (um dos poucos trechos implantados) e da localização de atividades retroportuárias

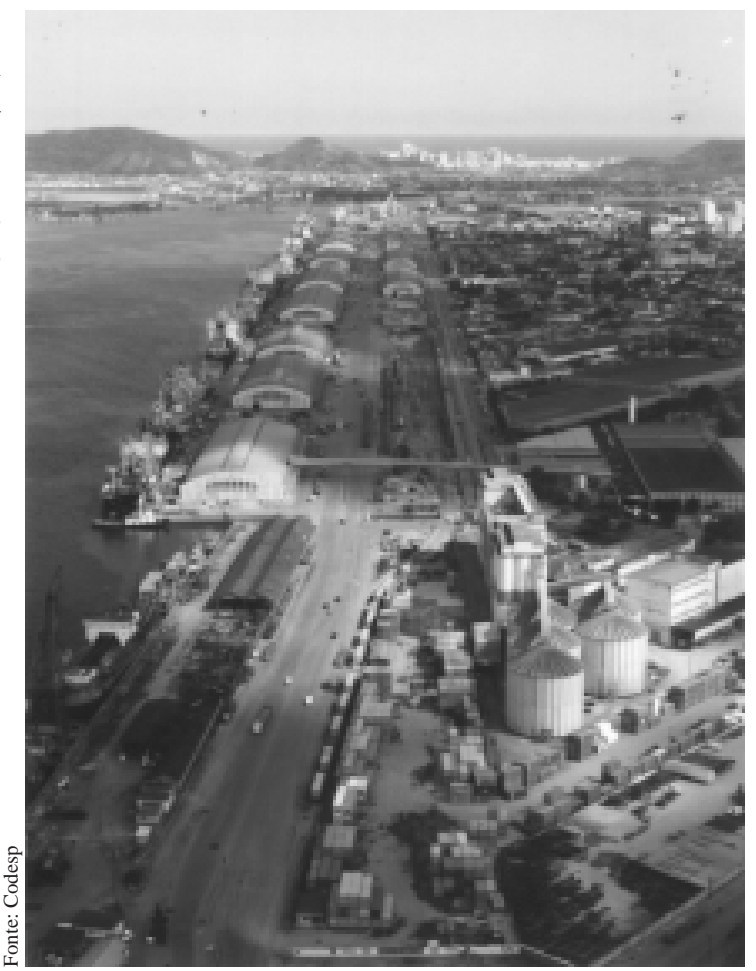


Ponta da Praia: a contraditória implantação do "corredor de exportação", precisamente no ponto mais distante de articulação com as vias regionais, sinalizando a incongruência dos imperativos da política agro-exportadora

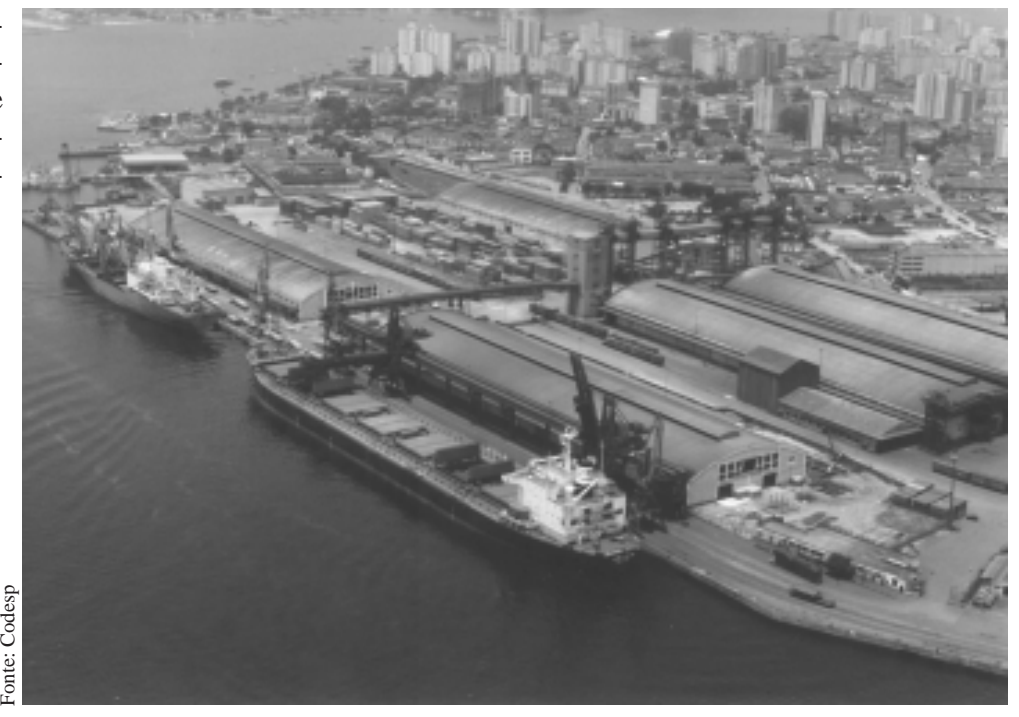

Terminal de fertilizantes - Teferque se implanta utilizando-se as primeiras instalações (para recebimento de petroleiros) da margem esquerda. Guindastes, esteiras e armazéns escoam material "agressivo" para caminhões e trens-ramal ferroviário da Conceiçãozinha, construído no final da década de 1970. A malha urbana de São Vicente ocupa progressivamente as áreas de retaguarda

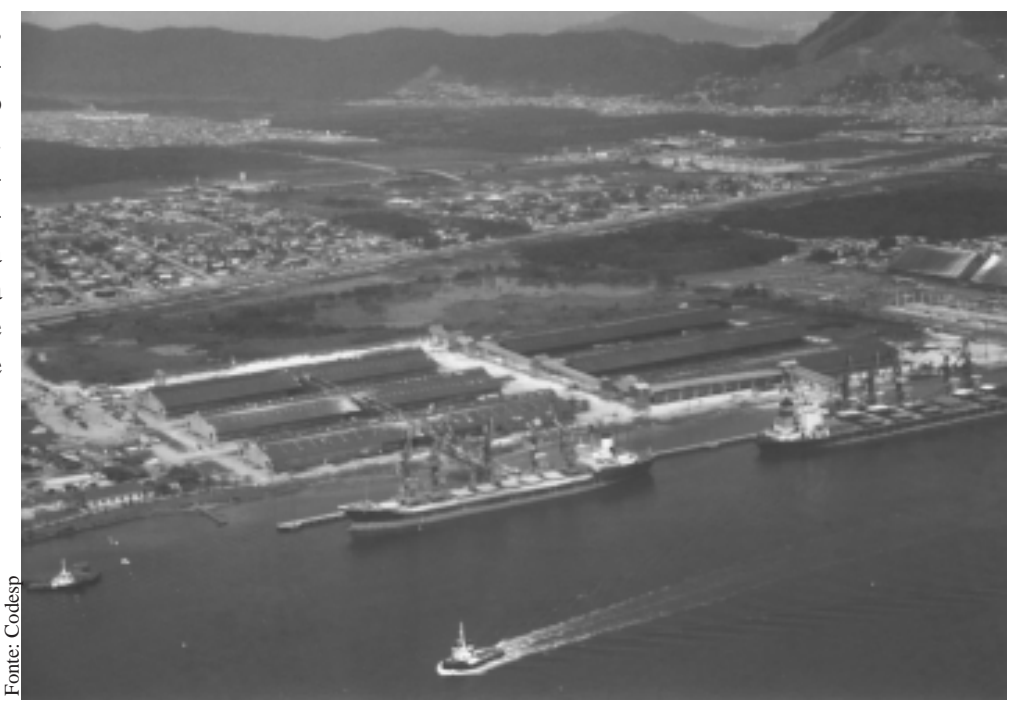

Terminal de contêiners - Teconinaugurado em 1981: respondendo, tardia e timidamente às mudanças tecnológicas do transporte marítimo, a construção do terminal não inibiu a proliferação de áreas improvisadas para armazenagem da carga. A obra da ampliação das instalações - Tecon2já dura dez anos

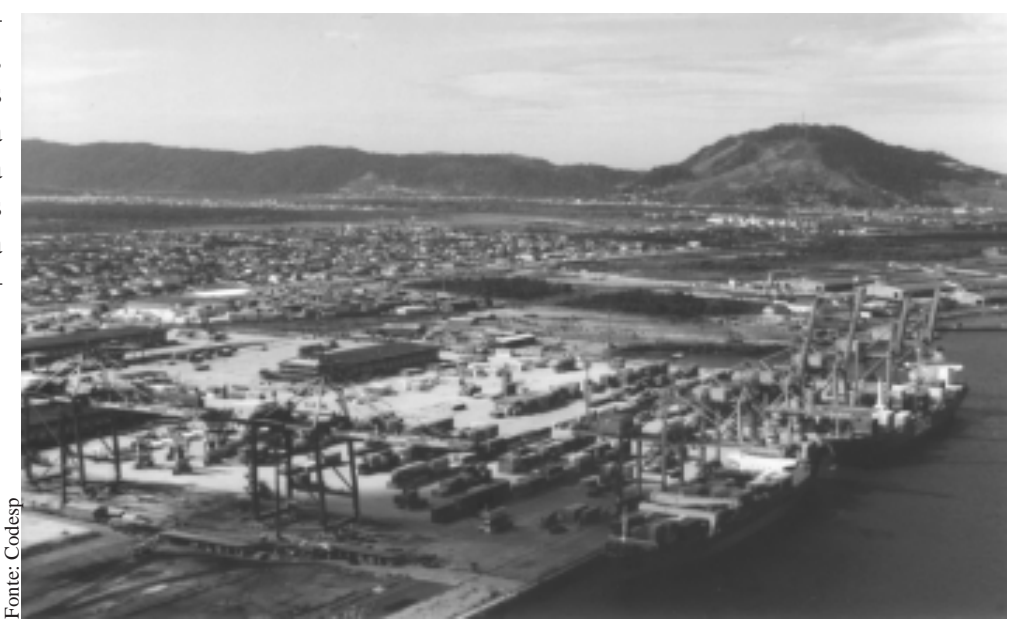




\subsection{As mutações da relação porto-cidade}

A importância dada ao deslocamento das mercadorias e pessoas, bem como a posição central das infra-estruturas portuárias em relação à cidade tanto em termos físicos como no próprio imaginário da população, representando "progresso e modernidade", além da possibildade de articular a cidade com regiões cada vez mais vastas, são os fatores que vão determinar a partir do século XIX a forma e o caráter do porto. Se na cidade pré-industrial porto e cidade constituiam uma única entidade econômica e espacial, com o waterfront representando o foco da vida urbana, a configuração espacial da cidade portuária industrial do século XIX, fundada na expansão do desenvolvimento comercial e industrial e nas novas modalidades de comunicação-ferrrovia e "vapor"—, caracterizar-se-ia pela ampliação dos limites do porto sobre novas áreas e pela consequente influência que essa ampliação exerceu sobre os padrões de uso do solo urbano. A despeito da imbricação física e funcional que ainda persistia na relação cidade/porto, a lógica que passaria a dominar progressivamente esta relação seria a dominante especialização do waterfront. E a situação de verdadeiros enclaves formados por extensos pátios e docas, ladeados por indústrias e armazéns e linhas ferroviárias, no interior do tecido urbano, marcaria decisivamente os sítios urbanos, na maioria das vezes centrais, onde, evidenciando seu papel fundador, localizavam-se as instalações portuárias. Constituir-se-ia assim uma das principais razões da separação espacial das atividades "produtivas" (concentradas em setores próximos às áreas de expansão portuária) das funções residenciais, cuja localização, pelo menos aquela referente à certas classes sociais, passa a orientar-se no sentido oposto ao da primeira. No entanto, a par da crescente segregação física das funções portuárias no interior da cidade, derivada da afirmação (sempre crecente) dos imperativos de racionalidade e produtividade e, portanto, da autonomia funcional do aparelho portuário, uma forte articulação econômica entre cidade e porto ainda se fazia presente, como sucedeu por exemplo em Roterdã, Barcelona ou Marselha.

Como produto da segunda revolução industrial, o aumento da capacidade e das dimensões dos navios e a crescente especialização industrial, mais a necessidade por parte do porto de implantar áreas para a recepção e refino de petróleo, seguida pela introdução de mudanças tecnológicas (particularmente a conteneirização iniciada nos anos 50) — tudo isto requerendo vastas áreaslevariam à aceleração da separação dos usos e funções portuárias e urbanas. Por outro lado, pesadas infra-estruturas viárias incrementariam o processo de degradação das áreas de interface repelindo outras funções e isolando as instalações portuárias definitivamente do contato direto com a cidade. Do exemplo de Marselha, Barcelona e Roterdã, passando pelos casos de Gênova, Nova York, Boston ou mesmo as Docklands de Londres (ainda que não situadas no tecido urbano central), a recorrência deste processo é, como constata Meyer $^{49}$, suficientemente expressiva para demonstrar a 
universalização destas soluções. No entanto, cidade e porto, até pelo menos os anos 50 (nos Estados Unidos) e 70 (na Europa), mantiveram relações que, ainda que pudessem ser consideradas urbanisticamente conflituosas, constituíam um sistema baseado na imbricação e complementariedade de suas diferentes funções. No entanto, um novo paradigma dessa relação levaria a uma nova e radical etapa do processo de separação cidade-porto.

Esse novo paradigma pode ser ilustrado ainda pelo caso de Marselha, ou melhor pelo complexo industrial-portuário de Etang de Berre (1919) e Fos (1965). Nessas novas áreas, distantes até $70 \mathrm{~km}$ dos ecritórios da administração portuária (que se manteriam localizados junto ao "Vieux Port", no centro urbano da cidade), a implantação das atividades petroquímicas e siderúrgicas, junto com a operação portuária propriamente dita, promovendo a geração de novos postos de trabalho, induziriam o assentamento da população na ordem de meio milhão de pessoas, levando, de forma aparentemente paradoxal à política francesa de "equilibrar" o território, a cidade central a uma situação de crise econômica e social:

"O planejamento da zona industrial-portuária de Fos e da área metropolitana responderam às mutações consideráveis que estavam a se produzir nas condições e modalidades de transporte, nas lógicas de implantação industrial e, mais amplamente, (responderam também às mutações) na organização do território"50.

Neste quadro de transformação, estes novos fatores, confrontados às novas preocupações de ordem ambiental, reforçariam o processo de separação entre as vastas áreas requeridas pelo aparelho portuário e (qualquer) núcleo urbano. Se o porto de Roterdã, bem assim como as ilhas artificiais portuárias japonesas, podem ser tomados como exemplos mais acabados desta nova condição, a mesma, em uma escala mais modesta, pode ser observada também em cidades de países sub-desenvolvidos (como Quênia e Tanzânia) ${ }^{51}$. O resultado mais sensível deste processo é a presença dos grandes vazios espaciais e funcionais legados dentro da estrutura urbana pelo deslocamento das instalações portuárias urbanas centrais. De todo modo, como constata Hoyle (1988, 8), diante da inadequação atual da maioria dos sítios portuários, tanto no sentido de satisfazer as dinâmicas exigências do porto quanto no de acomodar as sucessivas fases de crescimento urbano, é somente nas cidades onde o crescimento urbano não foi particularmente rápido e onde o aparelho portuário não adotou as novas inovações tecnológicas (apesar da cidade portuária como um todo todavia permanecer razoavelmente ativa), portanto, é sómente em "relativamente pequenas cidades portuárias (...) onde a tradicional "intimidade" entre porto e cidade tem em geral se mantido".

O fato é que a conteneirização e a intermodalidade afetariam não só a operação e a estrutura portuária mas também as tradicionais funções dos 
$\operatorname{portos}^{52}$, na medida em que torna a operação terrestre tão importante quanto a marítima. Se a movimentação de cargas gerais foi, tendo em vista o anterior deslocamento do tecido urbano dos tanques de óleo e dos terminais especializados, aquela que ainda se encontrava ligada funcional e espacialmente à cidade, a unitização de cargas exigiria novos equipamentos, tornaria obsoletos os armazéns e implicaria na integração intermodal dos transportes: os convencionais lay-outs dos terminais de carga geral resultariam completamente inadequados. Segundo Hayuth $(1988,56)$, os novos terminais necessitando de 10 a 15 hectares de áreas desobstruídas, não encontrando espaço nos antigos waterfronts urbanos e sendo impossível imaginar "centenas de milhares de contêiners manobrando através das congestionadas áreas centrais", levariam os portos ao deslocamento de suas instalações para novas localizações, distantes 50,100 km de sua posição original, não só pela disponibilidade de superfície de retro-terra e profundidade das águas, mas tão importante quanto, pela necessidade de conexão direta às rodovias, ferrovias e hidrovias de porte nacional e mesmo continental.

Lógicamente, estas mutações trariam importantes consequências econômicas ${ }^{53}$ para a cidade. As mudanças tecnológicas (no sentido da ampliação do uso do capital fixo em detrimento do variável ${ }^{54}$, incremento esse reforçado pelos processos de privatização dos serviços ${ }^{55}$ ), a relocação do aparelho portuário, as lógicas da intermodalidade (que torna o porto apenas um ponto de transferência e passagem de carga), implicariam na perda dos postos de trabalho gerados pelas atividades de movimentação e armazenagem (acarretando grande redução do emprego de mão-de-obra, secundariamente absorvida pela indústria de contêiner). Por outro lado, ao mesmo tempo que o desaparecimento do tráfego de passageiros se dá em favor da aviação e que as mudanças na indústria pesqueira fecham os portos destinados à essa atividade, a possibilidade de implantação de estações aduaneiras interiores drena, pela falta de espaço retro-portuário, pelo congestionamento dos cais "urbanos" e pelo alto custo da terra e do trabalho, atividades econômicas anteriormente realizadas junto aos waterfronts. Poder-se-ia também elencar tendo em vista a redução do tempo em que o navio permanece atracado e a mudança da "sociologia" da tripulação $0^{56}$, os efeitos sobre os serviços de clubes, bares e restaurantes dedicados ao atendimento aos marinheiros, fazendo decair as tradicionais áreas de entretenimento.

Finalmente, a nova consciência ambiental, ao menos a partir da década de 80 , tendo em vista particularmente as questões de poluição do ar e sonora, além dos problemas decorrentes da armazenagem de cargas perigosas, funciona como obstáculo à expansão portuária ao mesmo tempo que reinvidica, pela mudança da atitude das comunidades em relação a seu porto, o uso do waterfront urbano, criando pressões contra a manutenção de atividades que não justificam sua proximidade na vizinhança da linha de água. 
É portanto movido pela combinação de dois fatores — mudanças tecnológicas e logísticas no transporte marítimo e motivações e pressões ambientalistasque os terminais portuários implantam-se em território extra-urbano segundo um movimento que se realiza gradualmente, ainda que, em muitos casos, fazendo manter nas áreas mais centrais da cidade o terciário interessado à sua operação, quando esse, dada as novas facilidades das comunicações, não se instala e opera a partir das metrópoles centrais, como Paris ou mesmo de São Paulo.

O novo quadro das exigências tecnológicas e espaciais da infra-estrutura portuária, supondo o abandono das antigas implantações centrais, resultou em novas possibilidades de operações de waterfront renewal. Se as experiências de Barcelona e Roterdã são analisadas na parte final deste trabalho (seu interesse reside não só na escala de sua influência sobre a cidade e o território, como colocam sugestões sobre as hipóteses técnicas e de gestão de sua realização), aqui parece importante descrever os principais aspectos das operações de reconversão urbanística de áreas portuárias. Neste sentido podese observar que iniciado nos anos 50 nas principais cidades portuárias norteamericanas, nas décadas seguintes, o processo de decadência das áreas portuárias centrais traria consequências espaciais profundas. Só em Londres 2000 ha de antigas áreas portuárias foram abandonados pelo deslocamento das instalações portuárias em direção às águas profundas de Tilbury.

Coincidentemente, estas mudanças seriam seguidas pela grande desindustrialização das cidades, determinada, entre outras razões, pela necessidade de localização das plantas industriais próximo às rodovias de âmbito nacional, ampliando o processo de perda de dinamismo de alguns portos e tornando, consequentemente, redundantes grandes extensões de áreas urbanas centrais. Neste novo quadro territorial, é precisamente sobre o estoque de solo central, tornado obsoleto funcionalmente pelo deslocamento das antigas instalações portuárias (bem como ferroviárias e industriais), onde as exigências de "atualização competitiva" das cidades (desencadeada pelos processos de integração econômica dos anos 80) iriam encontrar sua oportunidade de realização, conferindo o suporte ao movimento de "recentralização" das cidades baseado no potente crescimento do setor de serviços e da demanda de novas formas de moradia. Assim, Barcelona e Roterdã, entre tantas outras cidades portuárias não só européias ${ }^{57}$, iriam lançar programas de reabilitação urbana fundados em projetos especiais de requalificação das extensas áreas tornadas sub-utilizadas, quando não totalmente desocupadas, pela perda de vigência das originais funções portuárias.

De qualquer modo, a relação de divergência cidade-porto moderno —onde o último termo funciona mais como "porta" que como um centro de atividades, e onde as evoluções tecnológicas no setor marítimo debilitam (ou explicitam de maneira contundente as contradições d') os tradicionais vínculos funcionais 
entre os dois termos, tornando-os entidades cada vez mais distintas (quando não distantes) — coloca com clareza a necessidade de se colocar em tela a questão da zona da interface dessa mesmas entidades. Zona essa que, modelada e organizada em torno da atividade portuária, aparta-se por isto mesmo do tecido físico e funcional urbano (não podendo integrar-se a ele facilmente). E que na atualidade, portanto, duplamente defasada com está, tanto em relação ao porto como à cidade, revela-se como uma fratura espacial cujas potencialidades, apesar dos entraves inerciais de toda ordem que pesam sobre ela, se põem como importante oportunidade de operações de "atualização" urbana. 
Evolução do aparelhamento de guindastes $1885 / 1949$
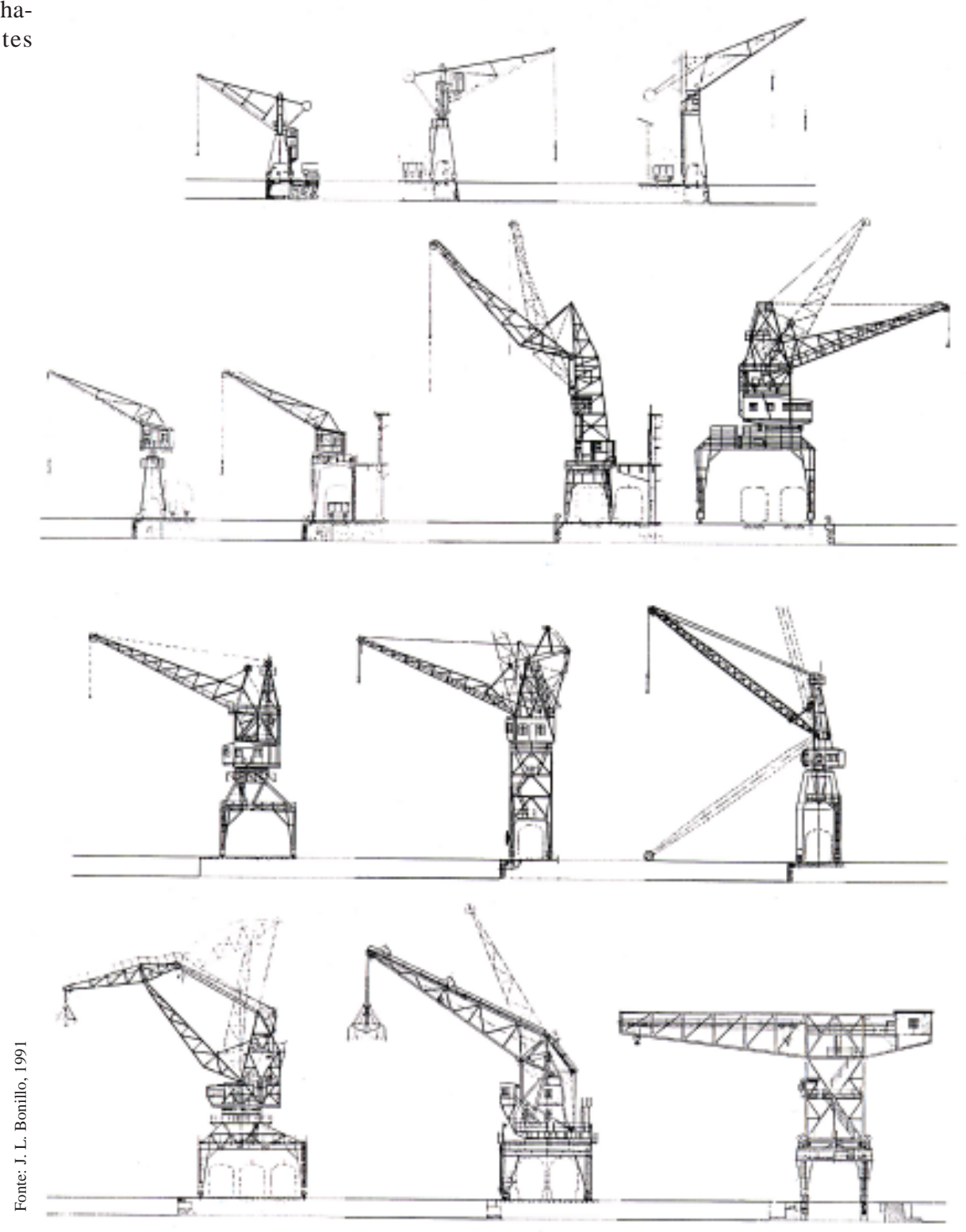

Paralelo entre a evolução das dimensões dos navios, área, calado e equipamentos para a operação portuária. Um ter-

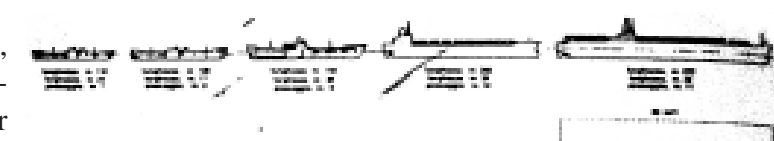
berço de atracação de 300mx300m

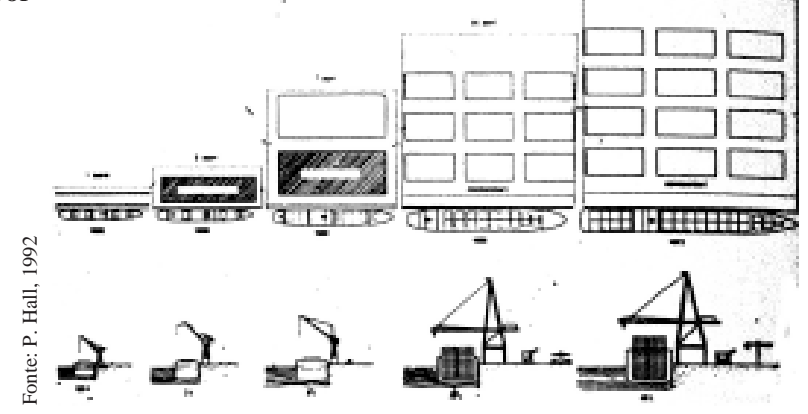


O porto e o território Marselha: o desenvolvimento industrial-portuário do golfo de Foz, iniciado nos anos de 1960 , reorganiza o território marselhes em um âmbito de 70 km de extensão litoral. O Vieux Porto e Joillet, na cidade central, são desativados para as operações portuárias
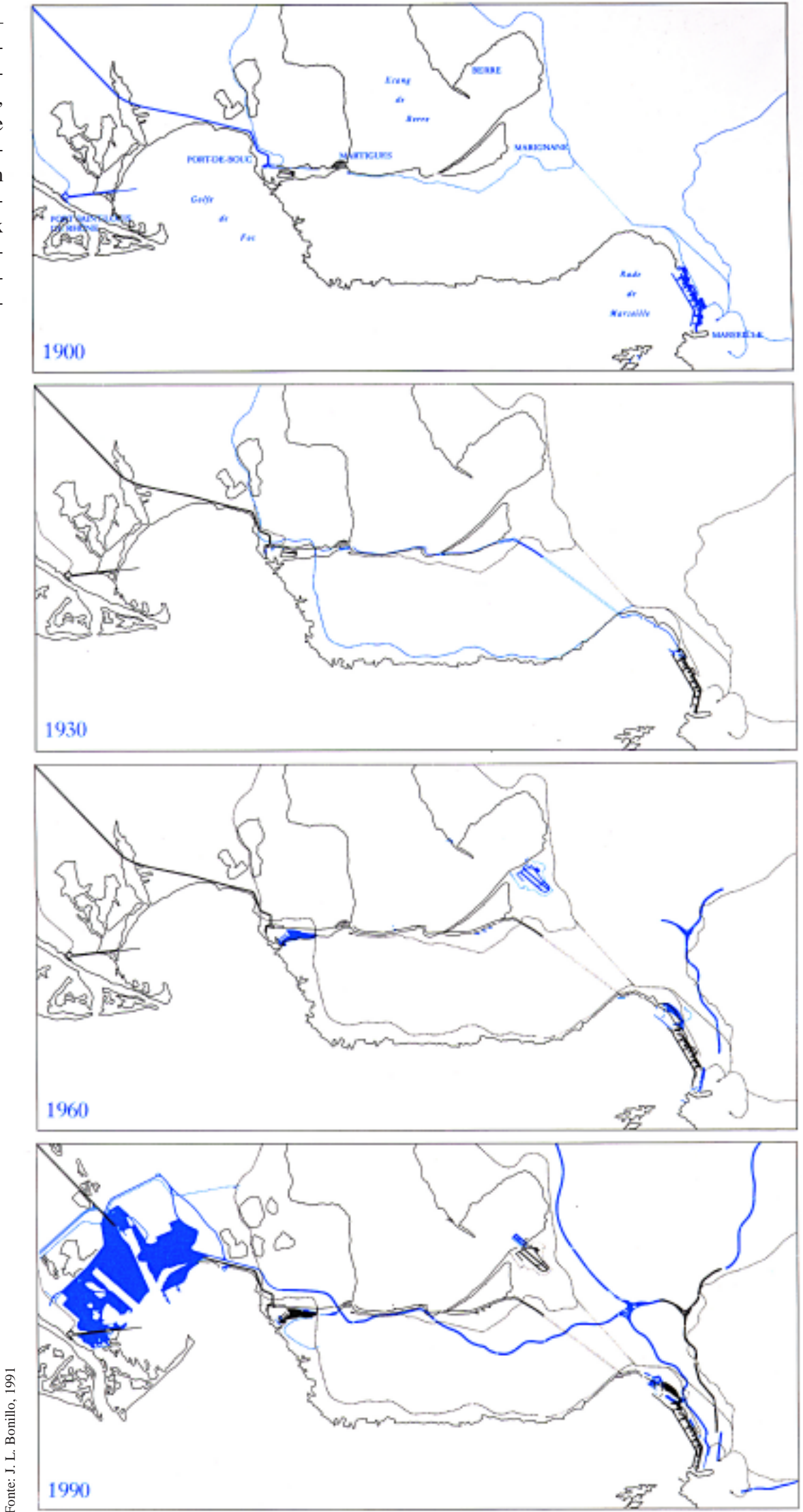

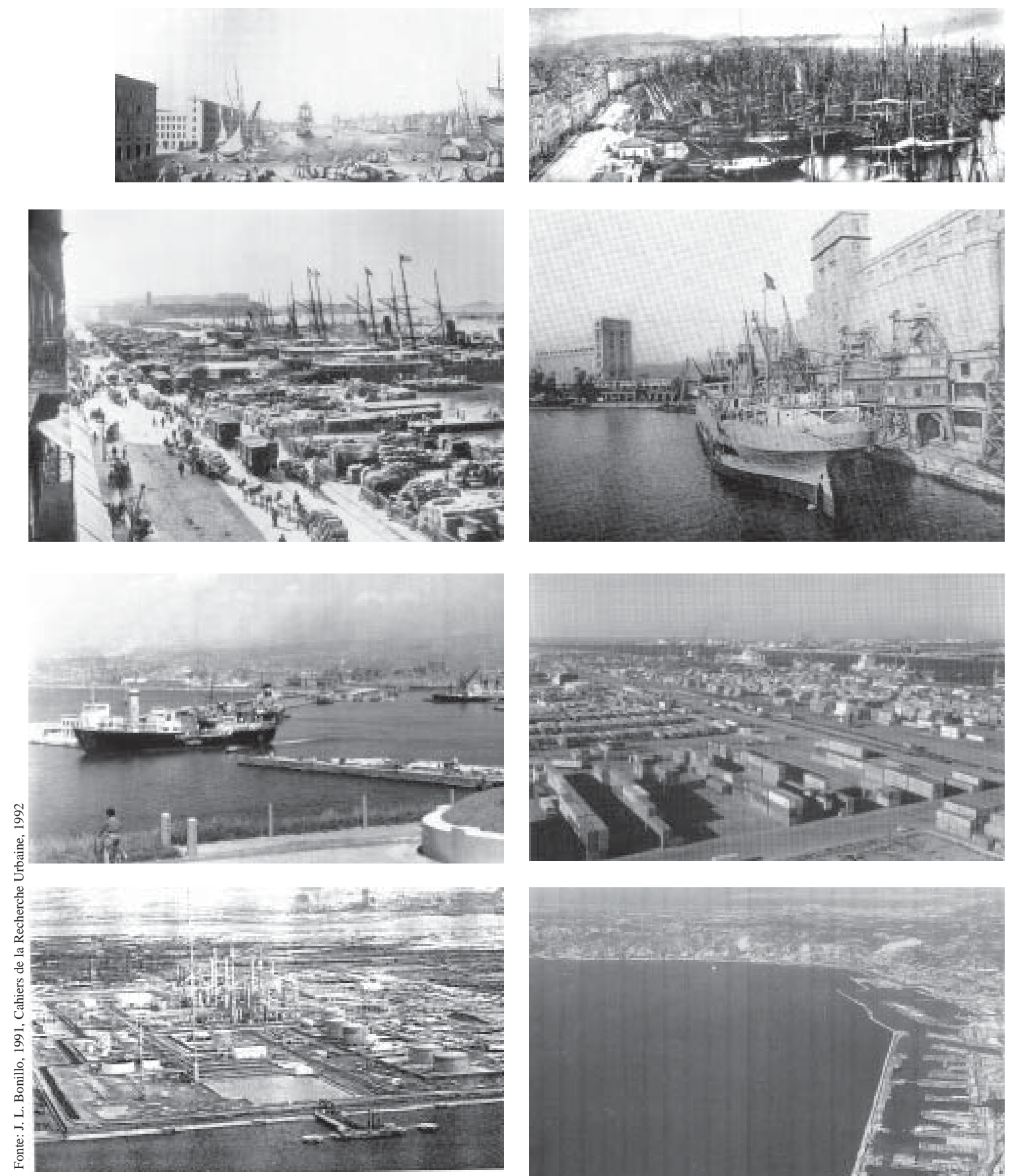

Transformações do porto de Marselha do porto urbano à expansão territorial

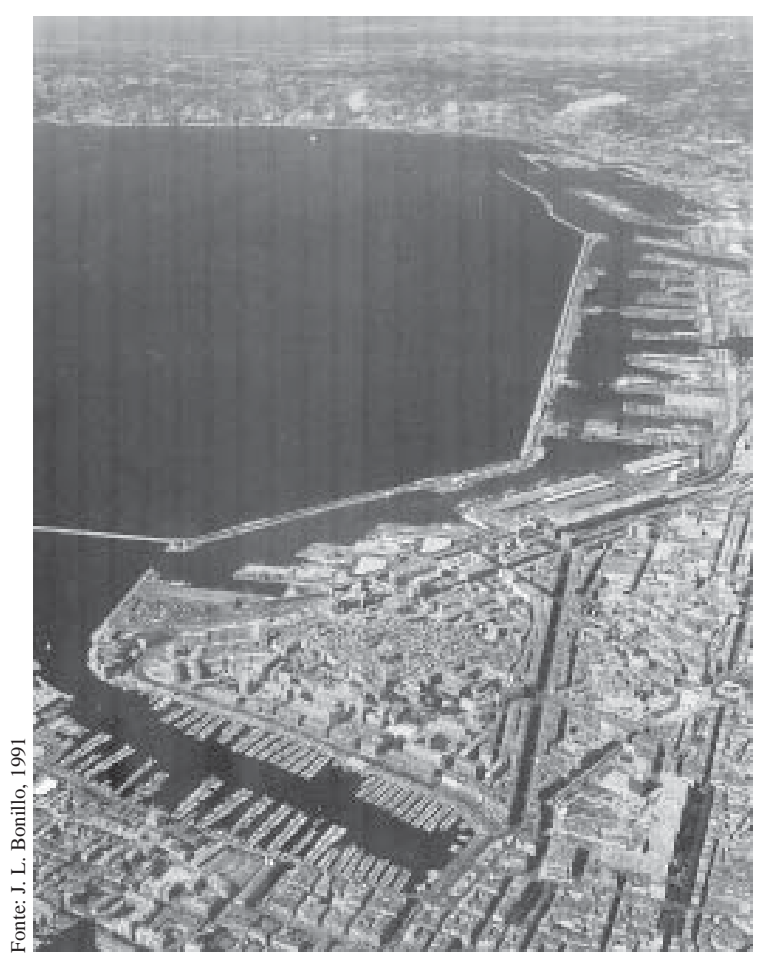

Vista do Vieux Port no coração urbano de Marselha. Apó a destruição provocada pelos bombardeios da segunda guerra, as bordas do porto são reconstruídas e a bacia é utilizada como marina. A extensão de Joillet, iniciada no começo do século, implicou na extensão da malha urbana, separada das áreas portuárias por pessadas infra-estruturas de transporte 
'F. Bussinger, Reformas e regulação portuária, s.d., mimeo, p.8-9

${ }^{2}$ Ibid.

${ }^{3}$ C. Honorato. O polvo e o porto, 1996, p. 155

${ }^{4}$ Segundo Honorato (1996), a origem do capital da companhia provinha do comércio de mercadorias importadas (tecidos), possibilitado pelo excedente das exportações de café, não canalizado para o setor produtivo

${ }^{5}$ H. Lobo, Op. cit., p. 24/25

O projeto de 1879 , revisto em 1886 , previa:

- obter profundidade suficiente de água para os vapores estrangeiros

- alterar o espaço compreendido entre a praia e o cais projetado de modo a melhorar as condições sanitárias do porto;

- $\quad$ organização de um plano geral de fácil execução por empresas particulares que deviam também construir os armazéns e demais dependências e acessórios que necessitem, mediante a concessão de privilégio e favores, por um período determinado em remuneração do capital empregado em tão vultuoso empreendimento".

A partir destas premissas, dos 3 planos estudados (cais corrido com enrocamento fundado a $5 \mathrm{~m}$ de profundidade em baixa mar, cais corrido e molhes, cais corrido com ponte de 139 m na Alfândega), o primeiro, por mais econômico, menores despesas de conservação e maior linha de atracação, é o escolhido (A. Lisboa, 1926, p.419)

${ }^{6}$ H. Lobo, Op. cit., p.13; A. Lisboa, Portos do Brasil, 1926, p.420 Ver também "Cláusulas do contrato entre o Governo Imperial a Companhia Docas de Santos". Apud J. R. Araujo Op. cit, p.127.

Este cais estaria aparelhado de vias férreas de bitola de $1,60 \mathrm{~m}$, para o serviço de guindastes hidráulicos do sistema Armstrong e de vagões de descarga, bem como telheiros ou galpões para o abrigo provisório de mercadorias .

${ }^{7}$ Decreto 9979 de 12/7/1888 apud J. R. Araujo F', Op. cit, 218

${ }^{8}$ Legislação relativa ao porto, vol I, 1828 a 1937 e H. Lobo, Op. cit., p. 214

Decreto ${ }^{\circ} 790$ de 8/4/1892, que autoriza "faixa livre de 35 metros" e a permuta com a Municipalidade de "terrenos necessários, e fazer as desapropriações precisas, afim de alargar a rua marginal do cais, de modo a dar-lhe a largura regular de 20 metros, em toda a extensão do cais" ()

${ }^{9}$ Legislação relativa ao porto, vol I, 1828 a 1937, Lobo, Op. cit., p.224

Decreto $^{\circ} 942$ de 15/5/1892 que aumenta o capital da companhia, fixa o prazo (6 meses) para a entrega do primeiro trecho Capitania-ponte da São Paulo Railway e autoriza a construção do cais Paquetá-Outeirinhos As plantas e o orçamento das obras seriam aprovado em 1897

${ }^{10} \mathrm{H}$. Lobo, Op, cit., p.424.

"Ibid.

As razões alegadas pela Companhia Docas para o atraso do andamento das obras incluíam desde os problemas jurídicos de origem fundiária e de utilização das antigas pontes, até as decorrentes das epidemias que assolaram Santos e a consequente falta de mão-de-obra, o que obrigou a companhia a manter serviço de imigração de trabalhadores nordestinos Em todo caso, a Câmara Municipal, ao mesmo tempo que concedida autorização para a construção de novas pontes, solicitava ao governo a ampliação do cais até Outeirinhos, alegando que os benefícios seriam maiores que os incovenientes provocados pelo monopólio das operações portuárias.

${ }^{12}$ Os sucessivos prolongamentos foram os seguintes:

- $\quad 988 \mathrm{~m}$ (122m a mais do que estipulava o primeiro contrato) desde a "ponte nova" da estrada de ferro até a Rua Braz Cubas

- $884 \mathrm{~m}$, desde este último ponto até a curva do Paquetá, totalizando $1872 \mathrm{~m}$ lineares de cais, sendo que a dimensão da faixa útil do cais passasse de $20 \mathrm{~m}$ para $35 \mathrm{~m}$.

- $2848 \mathrm{~m}$, correspondentes ao aterro da enseda do Outeirinhos, perfazendo $4720 \mathrm{~m}$.

Se a data de 1909 consta como a data da conclusão da muralha, tem-se a indicação de que em 1912 já se fazia a carga e descarga até Outeirinhos, "estando ainda em construção os armazéns e acessórios entre este ponto e o Paquetá” (Lobo, 1936, p.385). Porém o início da guerra de 14, levando à diminuição do movimento portuário, faria com qua as novas instalações (como armazém frigorífico) fossem adequadas para as necessidades dos aliados.

${ }^{13}$ J. R. Araujo Fo, Op. cit, p. 75

${ }^{14}$ Companhia Docas, Relatorio apresentado à assembléa geral ordinária de 30 de Abril de 1927, 1927, p.54

${ }^{15}$ Segundo Gitahy (1992, p. 27)

“O primeiro trecho, de 988 metros do Valongo à Alfândega, como o segundo até o Paquetá (884 metros) era construído sobre estacas de fundação, constando de um maciço de concreto sobre o 
qual erguia-se a muralha de pedra. O último trecho, do Paquetá até os Outeirnhos (2.848 metros), foi construído com grande blocos artificiais de alvenaria de pedra, assentados sobre um enrocamento aplainado. Sobre eles ergue-se a muralha de alvenaria de pedra semelhante a dos primeiros trechos". De acordo com Lisboa $(1926,425)$, o terrapleno da área ganha ao mar foi realizado com terrra saibrosa, trazida por linha férrea do Jabaquara, onde a a Companhia explorava uma pedreira e "havia estabelecido magníficas instalações para fabrico de blocos artificiais"

${ }^{16}$ A. Lisboa, Op. cit

${ }^{17}$ H. Lobo, Op. cit, p.422.

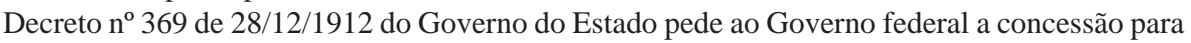
melhoramentos, desde o Outeirinhos até a Barra

${ }^{18}$ Ibid.

${ }^{19}$ Apud Ibid., p.521

${ }^{20}$ Alomo Transportes Ltda. O porto de Santos e sua história, 1992, p.51

${ }^{21}$ Ibid., p.52

${ }^{22}$ Ibid.

${ }^{23}$ Ibid.

${ }^{24}$ Ibid., p.53

${ }^{25}$ Ibid.

${ }^{26}$ Alternativa Saboó: evitar a travessia dos canais e menor transporte entre via férrea e o cais (vantagens) e péssima qualidade do terreno, profundidade das águas, dragagem e aumento do percurso médio dos vapores, entre o oceano e o ponto de atracações (incovenientes)

Alternativa margem esquerda: terrenos de melhor qualidade, profundidade e áreas necessárias às manobras comuns entre as duas margens, redução do percurso médio dos vapores, possibilidade de construção de docas de grande dimensão (vantagens) e necessidade de construção de pontes e alongamento dos transportes

${ }^{27}$ Segundo Araújo $\mathrm{F}^{\circ}(1969,75)$, a incidência dos fatores externos pode ser medida pelas marcas de movimentação do porto. Assim é que se em 1929 essa marca atingiu em torno de 3,2 milhões de toneladas, em 1932, em função do bloqueio militar a que foi submetido o porto durante a Revolução Constitucionalista, ela desce a 1,8 milhões, para em 1938 atingir os 4 milhões e daí decrescer novamente no biênio $42 / 43$ para 2,8 milhões

${ }^{28}$ F. P.Maia Op. cit, p. 84

${ }^{29}$ F. Serrano, "O Plano Regional de Santos de Francisco Prestes Maia" in Leopoldianum n ${ }^{\circ}$ 64, 1997, p. 94

${ }^{\text {sо }}$ F. P.Maia, Op. cit, p.49

${ }^{31}$ F. E. Serrano. "O Plano Regional de Santos, de Francisco Prestes Maia" in Leopoldianum n’64, 1997

${ }^{32}$ L. Goldstein, A industrialização da Baixada Santista - estudo de um centro satélite 1972, p.37. A quantidade do café exportado decresceu de 3/4 para 1/3 do volume total de exportações de Santos, sendo desde 1940 e, principalmente depois de 1954, progressivamente desbancado pelo petróleo

${ }^{33}$ Companhia Docas. Relatório de Diretoria, 1961, p.28

${ }^{34}$ Do qual constam os seguintes itens, que, com excessão do segundo aquele documento, teriam sido aprovados:

- 840 metros de cais, no Macuco, em prolongamento aos 360 metros já construídos com profundidade de 11 metros

- 585 metros de cais aberto (profundidade de 12 metros) na ilha Barnabé, destinado à atracação de petroleiros, para exportação de derivados de petróleo e importação de "óleo baiano", restituindo assim, o cais de Saboó à sua destinação primitiva (granéis sólidos)

- construção de 529 metros de nova muralha de cais, à frente da existente, entre o pátio dos armazéns 19 e 20 e o canal do Mercado, para alargamento da faixa portuária de 19 para 30 metros e aumento de profundidade de 7 para 11 metros.

Se a extensão do cais do Macuco em direção à Ponta da Praia houvera, já em 1914, sido objeto de solicitação (negada), a portaria 239 do Ministério da Viação e Obras Públicas de 31/3/1958, em susbstituição à Portaria pertinente de 1951, aprova o projeto e o orçamento de 694,14 metros de cais com profundidade de 11 metros, a ser construído entre os canais 4 e 5

${ }^{35}$ Nesta época constam também, nas atas e relatórios da Companhia, diversas solicitações de permuta e compra de terrenos no Jabaquara e nas ruas Rodrigues Alves e Manoel Tourinho, além de imóveis em Santos detinados à construção de porto e entreposto de pesca

${ }^{36}$ Concessão feita pelo Conselho Nacional de Petróleo em 1949

${ }^{37}$ Codesp. Plano de desenvolvimento e zoneamento portuário, 1996, p.8 
${ }^{38}$ J. R. Araújo Fo, Op. cit, p.134

A necessidade de dragagem periódica do "estreito" canal de Santos, a deficiência das instalações para carga líquida, além da proximidade das instalações de carga seca e passageiros, a possibilidade teórica da entrada de grandes petroleiros, a necessidade de divisãode carga feita no canal de São Sebastião seriam as razões apontadas pela Petrobrás, justificando a construção do terminal de São Sebastião

${ }^{39} \mathrm{O}$ cais de atracação, para o recebimento de minério de carvão, é "constituído por uma estrutura de concreto armado de 200 metros de comprimento por 22 metros de largura, sendo destes, 50 metros de ponte de acesso entre o terreno e o píer e 150 metros que constitui a atracação propriamente dita. (Lopes Leão. Apud L. Goldstein, 1972, 48). No entanto, como a mesma Goldstein e Carvalhaes $(1984,49)$ fariam notar posteriormente, que, proposta como siderurgia marítima, a COSIPA "teve que que encarar soluções feroviárias pela precariedade das instalações portuárias, pelas limitações impostas pela pouca profundidade do estuário e pelas disputas entre a empresa empenhada na construção de um terminal e a companhia detentora da concessão do porto"

${ }^{40}$ L. Goldstein, Op. cit.

O cais de 240 metros de comprimento e 15 metros de largura bem como os equipamentos empregados possibilitarm um rendimento de descarga três vezes maiores que o conseguido pelo porto de Santos, onde antes a Ultrafértil fazia o recebimento de sua matéria-prima (nafta, amônia)

${ }^{41}$ Ibid.

${ }^{42}$ Segundo o jornal A cidade de Santos, de 15/8/1980, tais setores seriam os de agro-pecuária, telecomunicações, informática, imobiliário, financeiro

${ }^{43}$ Comissão Especial para a Coordenação dos Serviços Portuários de Santos, criada em 1969 e constituída por representantes dos diversos órgãos do governo, para dinamizar os serviços portuários, melhorar e ampliar o porto, tendo em vista sua integração ao Plano Estratégico de Desenvolvimento no setor de transportes e o fortalecimento econòmico da nação (decreto $n^{\circ} 64.359$ de17/04/1969)

${ }^{44}$ Principalmente no período correspondente às presidências Geisel e Figueiredo

${ }^{45}$ Segundo o jornal Cidade de Santos de 8/10/1982: "Aliás, déficit é uma palavra que já fazia parte do vocabulário finaceiro do porto, mesmo naa épovca da Docas de Santos, e também era coberto pelo Governo, mostrando que não se trata de uma atividade superavitária, mas sim prestadora de serviços sem fins lucrativos"

${ }^{46}$ Codesp.Op. cit, 1996

Os 12.254 metros de cais (10.871 metros da Codesp — sendo $8.742 \mathrm{~m}$ de cais "convencional" e $2.129 \mathrm{~m}$ de cais "especializado- e 1.383 metros de uso privativo) encontram-se assim distribuidos em função de sua destinação.

Margem direita

Alamoa — sólidos e líquidos a granel

Saboó - contêiners, ro-ro, sucos cítricos

Valongo — contêiners e carga geral

Paquetá — carga geral, granel sólido e áreas de revitalização em parceria com a prefeitura

Outeirinhos — sólidos a granel, terminal de passageiros e administração

Macuco - terminais de suco, contèiners e carga geral

Ponta da Praia — contêiners e carga geral

Margem esquerda

Ilha Barnabé — terminal automotivo, contêiners e inflamáveis

Itapema — reparos navais

Pae-Cará — contêiners

Conceiçãozinha — terminais privativos e contêiners, sólidos e líquidos a granel, carga geral

${ }^{47}$ Ibid., p.15

${ }^{48}$ R. Muriel, O porto de Santos, mimeo, s.d.

As sucessivas implantações e ampliações do cais seriam:

1891/1909: 4720m para a movimentação do café

1910/1928: sem extensão do cais e volume de importação 2,33 vezes maior que o de exportação 1929/1930: construção de setor para inflamáveis na Ilha Barnabé

1931/1944: mesma extensão de cais e queda do movimento de café

1945/1954: Taxa de Melhoramentos dos Portos , ampliação (6.259m), reaparelhamento do cais e recorde da exportação de café

1954/1968: movimentação de petróleo, importação correspondendo a 80\% da movimentação geral e ampliação de cais do Macuco $(7.034 \mathrm{~m})$

1959/1980: fim da administração da Cia. Docas e construção de terminais de cereais, granéis líquidos, fertilizantes e contêiners na margem esquerda ( $10.831 \mathrm{~m}$ de cais) 
1980/1993: administração Codesp (12.000m de cais contínuo), movimentação de 30.000 .000 ton/ ano

Desde 1993, a nova política portuária é orientada pelo processo de privatização das operações. O movimento atinge 40.000 .000 ton/ano

${ }^{49}$ H. Meyer. "The discreet charm of port and city" in Van Rusel J. (ed.). Antwerp. Reshaping a city, 1990

${ }^{50}$ J. L. Bonillo. Marseille Ville \& Port, 1991, p.10

Neste caso específico, como resultado da política francesa das "metrópoles de equilíbrio".

${ }^{51}$ B. S. Hoyle. "Development dynamics at the port-city interface" in B. S. Hoyle, D. A. Pinter, M. S. Husain. Revitilizing the waterfront, 1988

${ }^{52}$ Y. Hayuth "Changes on the waterfront: a model based aproach" in B. S. Hoyle, D. A. Pinter, M. S. Husain. Op. cit

${ }^{53}$ Quanto aos impactos econômicos que o complexo portuário produz sobre a cidade ou a região, Hayuth (1988, p.58) elenca os seguintes:

- diretos (gastos, rendas e empregos gerados pelos serviços, onde se incluem desde os relativos aos trabalhos de estiva e manutenção até os administrativos, até os referentes à remuneração de agências e ao próprio capital invertido pelo porto, além daqueles correspondenets a serviços bancários e de seguros),

- indiretos (atividades econômicas das indústrias).

- $\quad$ efeitos que advém da compra dos serviços e bens gerados pelos dois primeiros.

O porto de Nova York-Nova Jersey calculou em 1985 aproximadamente 191.600 pessoas direta ou indiretamente empregadas em atividades correlatas, representando uma folha de pagamento annual de U\$4,2 bilhões e gerando U\$0,4 bilhões em taxas municipais e estaduais, enquanto em São Francisco 44.450 pessoas vinculada à indústria portuária que injetou U $\$ 2,1$ bilhões na economia regional

${ }^{54} \mathrm{Um}$ terminal de contêiner requer apenas 1/10 de homens/hora/tonelada do que os necessários por um terminal convencional operando a mesma quantidade de tráfego

55 “J. Alemany, “Amérique Latine: Le système portuaire latino-américain aujourd'hui” in Villes \& Ports, 20/12/1997.

Sobre os efeitos da privatização: "O porto de Buenos Aires passou de 7138 empregados em 1991 a 1830 em 1994; o porto de Valparaiso (Chile) —o primeiro a ser privatizado_- passou de mais de 2500 empregos portuários em 1979 à sómente 100 em 1984 e em Montevidéu, passou-se, nos últimos cinco anos (1990-1950) de 4300 a 1900 postos de trabalho"

${ }^{56}$ Vide B. S. Hoyle. Op. cit.

${ }^{57}$ Brutomesso (1993) estuda os seguintes exemplos de operações de reconversão de frentes portuárias:

Europa: Amsterdã, Antuérpia, Barcelona, Bordeaux, Bristol, Dordrecht, Dublin, Gênova, Glasgow, Hamburgo, Istambul, Londres, Lubeck, Marselha, Roterdã, Southampton, Portsmouth, São Petersburgo, Veneza.

Ásia: Bankoc, Hong Kong, Shangai, Kobe, Osaka, Tóquio, Yokohoma

Austrália: Melbourne, Sidney

África: Cidade do Cabo

América do Norte: Baltimore, Boston, Nova York, São Francisco, San Juan, Toronto

América do Sul: Buenos Aires 


\section{Capítulo 4 \\ O PORTO E OS MODELOS DE CRESCIMENTO DA CIDADE DE SANTOS}

Em grande medida, devida à sua própria natureza técnica e gerencial, a infraestrutura portuária incide nos modelos de crescimento urbano através dos efeitos persistentes, duradouros, verdadeiras marcas inerciais que imprime no tecido da cidade, condicionando sua definição física, o uso que se faz dos seus espaços, bem como os modos de sua apropriação e controle.

Ao analisar a relação porto/cidade através dese prisma, uma dificuldade apresenta-se: a de isolar, de especificar as relações bilaterais "puras", "isentas" da incidência de outros elementos, entre o porto e a cidade. Isto na medida em que a variedade de influências a que está submetida a cidade, a complexidade dos modos de sua transformação, resiste à determinação do "peso" de uma determinada tensão no resultado de um processo urbano. Daí que a "prova" é frequentemente parcial e quase nunca definitiva e está sujeita a um certo grau de incerteza, senão de subjetividade, ainda maior se considerado o fato de que sómente através da agregação do estudo de outros "processos" (econômicos, sociais, políticos, simbólicos) poder-se-ia obter uma imagem mais global das relações entre a infra-estrutura portuária, suas atividades de suporte e a cidade. Porém, esta aproximação não descarta estas considerações, mas trata de integrá-las a partir das consequências que ditos processos têm no nível espacial, entendido como síntese que condiciona e traduz processos mais amplos.

Tendo como objetivo flagrar as marcas que o porto legou à estruturação e configuração dos espaços e usos da cidade, a análise enfatizará como "materiais urbanos" aqueles que referem-se aos "sistemas de lugares"; sistemas esses que definem as pautas e das regras do processo de crescimento e transformação urbana, referindo-se aos aspectos ambientais, da mobilidade, da centralidade, da residência e da produção. A ordenação morfológica que assumem ao longo do tempo e as relações que mantém entre si orientam processos específicos e favorecem determinados interesses. Esta perspectiva torna imprescindível uma aproximação histórica. Não só porque as transformações são em geral lentas, desenvolvendo-se através de longos períodos de tempo, mas, também, pela necessidade de identificar as "permanências e "emergências, as "inovações e "resistências, que através do processo de "seleção cumulativa" caracterizam cada estágio de desenvolvimento urbano. 


\subsection{Santos, antes do porto moderno}

Como já analisado no capítulo 2, enquanto unidade territorial, geomorfológicamente diferenciada do litoral paulista, a Baixada Santista tem nas ilhas de São Vicente e Santo Amaro a condensação dos seus principais atributos geográficos —os canais, os morros e a planície sedimentar-.É senso comum atribuir a eles a explicação para o aparecimento do porto e para o início do povoamento de Santos. Porém, uma interpretação mais atenta sobre a lógica que presidiu a escolha do fundo do estuário, isto é a porção norte da ilha de São Vicente, como local privilegiado de ocupação', deve combinar os argumentos do aproveitamento das melhores condições naturais com razões de defesa e de intercâmbio ${ }^{2}$. Neste sentido, pode-se perceber que a disponibilidade de águas "calmas" e abrigadas, bem como de de aguadas provindas dos morros (que forneceriam também a pedra necessária para as construções) e de terrenos relativamente secos da planície, encontraria suporte na possibilidade de proteção do sítio escolhido (através da disposição de fortalezas às margens dos canais -o central e o de Bertioga-), e, sobretudo, na maior proximidade desse sítio em relação ao ponto de subida da serra Cubatão-, o que facilitava o "comércio com a vila de São Paulo e povoações de serra acima"3. Embora não possa ser tomada isoladamente, esta última condição mostrar-se-ia decisiva: a definição de Santos como o principal ponto de articulação das comunicações do planalto com o mar ressalta a importância da relação de complementariedade que, baseada na cisão entre a função de porto e a de centro distribuidor, caracterizaria a relações litoral-planalto e explicaria o significado do "binômio Santos-São Paulo"4 nas dinâmicas e processos territoriais santistas.

Em um primeiro momento, que se estenderia até meados do século XVIII, os reflexos de tal vínculo sobre o núcleo urbano de Santos, por um lado, ajudam a explicar a longa duração de sua falta de dinamismo e a exígua dimensão de sua área urbana: o estado de grande pobreza econômica vigente na Província como um todo e no litoral santista, em particular, não permitiu que Santos se desenvolvesse como outros portos coloniais brasileiros ${ }^{5}$, que ademais tinham a vantagem da menor distância em relação à metrópole. Indicador desta situação tem-se o fato de que o porto de Santos, em 1796, respondia por apenas $0,45 \%$ das exportações e $0,7 \%$ das importações de toda a colonia ${ }^{6}$. Por outro lado, a importância do vínculo com o planalto evidencia-se na orientação de crescimento da cidade a oeste, fazendo articular, através de uma única via ao longo da costa, o núcleo inicial dos Outeirinhos (com funções predominantemente militares e administrativas) ao do Valongo, que respondia, face à sua posição mais próxima à Cubatão, pela concentração das funções comerciais. Sintetizando este estado de coisas, Florence ${ }^{7}$, em 1825, constatava que: 
há uma única rua ao longo do rio e travessas que da praia vão ter ao alto das colina... Bem que se note muito pouca atividade na resumida população, é este o porto o mais importante de toda a província e o entreposto exclusivo do comércio de importação e exportação que busca a parte setentrional de São Paulo".

Se o início do comércio de exportação do açúcar e as maiores facilidades, conferidas a ele, pela abertura da calçada de Lorena (1791) e pelo aterro da ligação Santos-Cubatão (1827), fizeram crescer o movimento portuário, no entanto, o aumento da população ${ }^{8}$, provocado por este crescimento, não chegaria a ter efeitos sobre os limites da cidade; sendo o incremento populacional ainda quase inteiramente absorvido dentro deles. Superando a presença dos três ribeirões - Itororó, São Jerônimo e São Bento- que seccionavam no sentido morro/estuário a incipiente trama de ruas, a construção do novo casario preencheria o exíguo espaço existente entre os mencionados núcleos. A planta de 1822 mostra apenas um avanço na direção norte-sul, com o acréscimo da antiga rua do Rosário (hoje João Pessoa), "estando as águas do estuário nas proximidades das ruas Tuiuti e praças Azevedo Junior, Barão de Rio Branco e Praça da República” .

Mudanças mais importantes neste quadro dar-se-ão sómente a partir de 1850, portanto quando o movimento do café ultrapassa o do açúcar na pauta do comércio de exportação ${ }^{10}$. Se, para atender a maior movimentação comercial, a construção de "pontes" representa o primeiro (1857) equipamento do aparelho portuário (articulado em terra a um armazém alfandegado "trapiche"-, onde as mercadorias importadas ou para exportar ficavam guardadas), no entanto seria a inauguração da linha ferroviária da São Paulo Railway (1867), cuja estação no Valongo seria construída sobre os terrenos onde outrora existira o Convento de São Francisco, o investimento em infraestrutura que marca o ponto de inflexão do desenvolvimento da cidade. Articulada pela ferrovia a um sempre mais vasto e rico território cafeeiro, a cidade transforma sua estrutura, muda sua imagem, sinalizando a importância das funções comerciais que ela passa a desempenhar.

A ação reformadora teve início com a derrubada do Outeiro de Santa Catarina (1869, época em que o convento do Valongo já havia sido demolido para dar lugar às instalações ferroviárias) e seria impulsionada pelas novas exigências "técnicas" (desconhecidas antes da eclosão do café) em termos de armazéns, oficinas e depósitos: transformar-se-ia o espaço urbano, retificando o traçado (Largo da Matriz, Largo e rua do Rosário, rua 15 de Novembro) e substituindo a arquitetura, inclusive religiosa (Matriz, Rosário, capela da Graça), por espaços e edifícios interessados à nova ordem social e econômica que se instaurava". O arruamento estendeu-se, desenvolvendo uma malha ortogonal mais regular, a leste, até o Paquetá, e a norte, até a altura do largo Sete de Setembro, no sopé da montanha, enquanto as ruas existentes 
começaram a ser alargadas, valorizando os terrenos marinhos até então aparentemente desprezados, como o sugere o contraste entre a anterior orientação das quadras, "de costas" para a praia, e a localização de edifícios de consulados e hotéis nas áreas mais próximas da estação, particularmente naquela, compreeendida entre a Rua Santo Antonio e a Rua da Praia, que ficaria conhecida como Quatro Cantos.

O sistema ponte-trapiche, que havia se estabelecido primeiro na faixa compreendida entre a Alfândega e o Valongo, depois, expandir-se-ia no sentido contrário, até o Paquetá. A reconhecida precariedade do sistema de pontes número insuficiente para a quantidade dos navios, necessidade de usar "pontões" (embarcações que traziam para terra as mercadorias diretamente dos navios), má qualidade das construções, agravamento das condições higiênicas pela piora da circulação das águas — não impediu que, à medida que a exportação crescia em volume e valor, o número de trapiches-pontes aumentasse, atingindo a marca de $23 \mathrm{em} 1889^{12}$. Indicador da rentabilidade dos negócios é o fato da a própria companhia ferroviária inglesa ter construído pontes para seu próprio uso.

A "planta de Santos de 1878" de Jules Martin, deixa entrever o sistema de relações que a cidade mantinha física, social e economicamente com o estuário. As sucessivas pontes, constituindo o elemento de conexão terra/água, não só caracterizavam uma ocupação "discreta", por pontos, da frente marítima, como supunham a multiplicidade de proprietários dessas mesmas pontes, além de um determinado tipo de organização dos negócios e do trabalho, da circulação e dos espaços ${ }^{13}$. No entanto uma nova lógica, a do porto moderno, impulsionada pela exigências da expansão da economia cafeeira e associada à maior fluidez "ferroviária" do território e às iniciativas de modernização da cidade, acabaria impondo-se desde fora. Assim é que mesmo sendo, desde a década de 1870 , objeto de reinvidicação por parte da Associação Comercial de Santos — "questão vital tanto para a salubridade de uma cidade, como para os interesses do nosso comércio"14-, a construção do cais não poderia evitar as reações das forças locais à ação da Companhia Docas, nome sob o qual a empresa de Guinle e Gaffre passaria a exercer o monopólio absoluto sobre as obras e a operação do porto. A amplitude dos termos da concessão obtida em 1888 pela Companhia ultrapassara as reinvidicações das elites locais e levaria, inevitavelmente, à supressão total do rentável negócio do sistema de pontes e trapiches, iniciado há 30 anos.

Neste sentido, o termo "Dokopolis", cunhado no começo do século pela linguagem jornalística de oposição à Companhia, talvez sintetize sem exagero a força e a amplitude das intervenções levadas a cabo pela empresa. $\mathrm{O}$ domínio portuário, estendendo-se por toda a extensão dos terrenos marinhos, que limitavam a norte e a leste a área urbana então constiuída, cortaria de 
maneira quase absoluta o acesso da cidade ao litoral. Segundo o Diário de $\operatorname{Santos}^{15}(9 / 7 / 1904)$ :

a empresa começou apoderando-se de todo o litoral do porto e pouco a pouco, foi-se estendendo até os Outeirinhos. A cidade ficou sem acesso livre até o porto e quem lá quiser ir tem de ser hóspede da Companhia, que lhe mandará abrir seus pesados portões de ferro. Nas noites de diversão, em que as sociedade de sport náutico, realizavam festas venezianas, ou nos dias de corridas e apostas, o nosso povo lá tem de ir ao Paquetá, para contemplar os encantadores barcos... E procura-se o Paquetá por enquanto, porque o Paquetá também pertence à Companhia que por ali prolongou as suas obras, as quais concluidas terá seu litoral isolado da cidade pelos armazéns e pelas grades. A cidade não tem servidão propriamente sua para o porto: este tornou-se propriedade da Companhia, e esta munida de excepcionais privilégios, avança resolutamente, plantando-se definitivamente no solo que quer".

Ou como faz publicar o mesmo jornal' ${ }^{16}$ em 22/2/1905:

A Companhia Docas, Estado no Estado, fechou de vez Santos, sem deixar uma só frincha por onde passsar uma mosca. A Câmara, no interesse das populações ribeirinhas, tem tentado em vão mover a Companhia do propósito em que está de não deixar no litoral um só trecho que sirva de docas à canoas que, de diversos lugares, nos trazem lenha, frutas, pescado, todos os produtos de sua lavoura".

Se em $1902^{17}$ um novo um mercado foi construido junto à foz do rio dos Soldados, no Outeirinhos, para substituir o antigo mercado de peixes existente no cais do Bispo do Valongo, foi apenas em 1906, "quando a poderosa companhia construiu um canal em meio ao aterro que executava na Vila Nova (Outeirinhos), que as canoas tiveram acesso ao mercado concluindo o complexo abastecedor de Santos com docas para canoas e grande mercado de alvenaria, segundo os padrões encontrados em outras cidade como Salvador e Rio de Janeiro"18.

Na feliz análise de Lanna (1996, 63), "se o porto se fechava fisicamente para a cidade, excluindo, parte dos comerciantes locais de sua exploração, ele se abria, ou melhor integrava-se e estimulava as transformações radicais que estavam ocorrendo no quadro urbano mais global" e que caracterizaria, segundo ela, o momento de "ruptura" da cidade com seu passado colonial:

tratava-se de criar novos modos de morar, trabalhar, fruir a cidade adequados à modernidade que se buscava implementar. O esforço do governo na execução dessas transformaçãoes, que pode ser visto tanto em Santos como no Rio de Janeiro, fazia parte desta estratégia de assegurar para o país o papel de parceiro confiável das nações civilizadas". 
Parceria essa na qual a condição santista -enquanto articuladora das relações do planalto com o mercado exterior - deveria assegurar os meios eficientes seja para escoar a produção cafeeira, seja para importar trabalhadores para a lavoura. Neste contexto, além do avanço "físico" e do domínio da companhia sobre os terrenos de marinha (e também sobre os morros da pedreira do Jabaquara), a gestão e o controle não só das atividades de embarque e desembarque ${ }^{19}$, bem como dos serviços de energia (travando disputa com a Light), indicavam com contudência a força monopolizadora, tentacular, da Companhia Docas e supunham conflitos com os interesses locais, estaduais, bem como com as outras forças em jogo. Portanto, além dos problemas de reestruturação do espaço que as obras do porto impunham à cidade, suprimindo as pontes e trapiches, reposicionando os edifícios e equipamentos, sucessivas embates jurídicos em torno dos termos da concessão oporiam a Câmara Municipal, o Governo do Estado, as Associações Comerciais de Santos e São Paulo, a São Paulo Railway, a União e a Companhia Docas (as duas últimas geralmente do mesmo lado). Se a "composição" dos atores de cada uma das confrontações jurídicas ${ }^{20}$ seria definida em linha com a possibilidade de obtenção de privilégios e benefícios próprios, parece certo, como mostra Gitahy ${ }^{21}$, que por ocasião da eclosão das greves ("paredes") que se sucederam, esses grandes interesses acabariam unindo sua forças para, como nos dizeres do Relatório do ano de 1905 da Companhia Docas, "a terminação das desordens que aqui se desenrolaram"22.

No entanto, o que interessa notar é que, de maneira geral, a causa principal das disputas entre instituições e companhias em torno das obras e operação do porto de Santos, prende-se ao estatuto legal de "território federal", atribuido seja aos terrenos de marinha seja aos direitos tributários ${ }^{23}$. Se a questão envolvendo os terrenos de marinha encontrava definição já em $1895^{24}$, a discussão a respeito dos contratos de concessão, da cobrança de impostos municipais e dos custos e taxas portuárias suceder-se-ia ao longo do tempo, adquirindo contornos próprios a cada etapa de expansão do porto e do desenvolvimento da cidade. 
Plantas da Vila de Santos nos anos de 1765 e 1822 , segundo ensaios de B. Calixto: o crescimento do núcleo se faz pela abertura de ruas paralelas à linha de costa, interligando os núcleos do Valongo (oeste) e do Paquetá (leste)

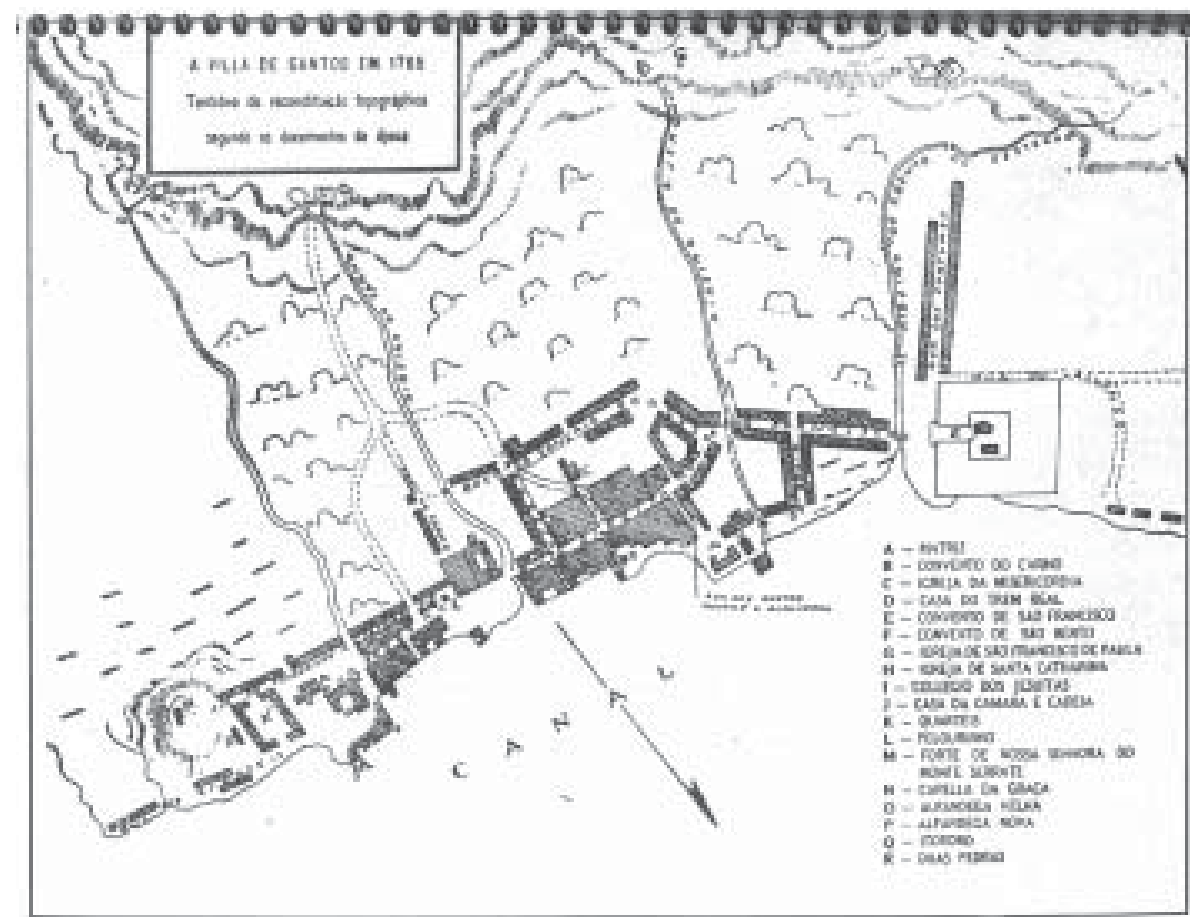

Ensaio de Benedicto Calixto

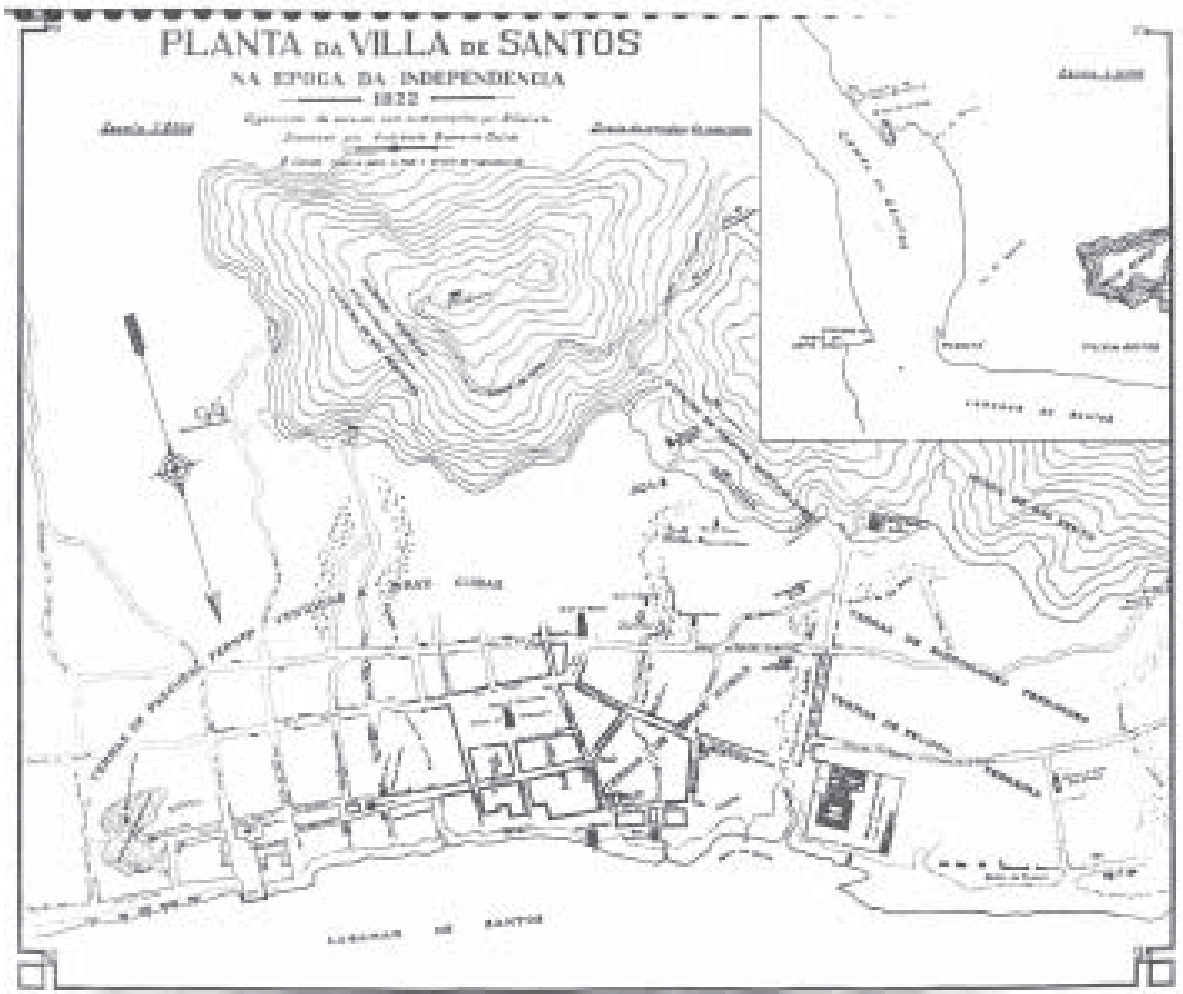


Imagem panorâmica do núcleo santista, 1822: a trama urbana concentra-se na faixa compreendida entre o estuário e os morros

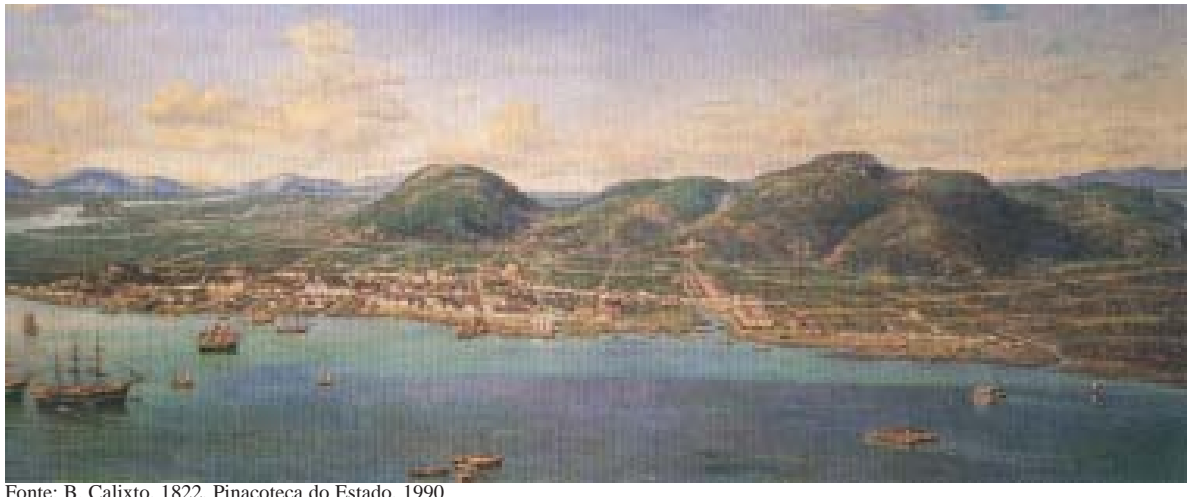

Fonte: B. Calixto, 1822, Pinacoteca do Estado, 1990

A marinha e o porto de Santos: 1826 e circa 1880. Valorização do estuário e relação franca com a cidade: o que não deixa de supor a precariedade do sistema de pontes: número insuficiente, precariedade da estrutura, estagnação das águas
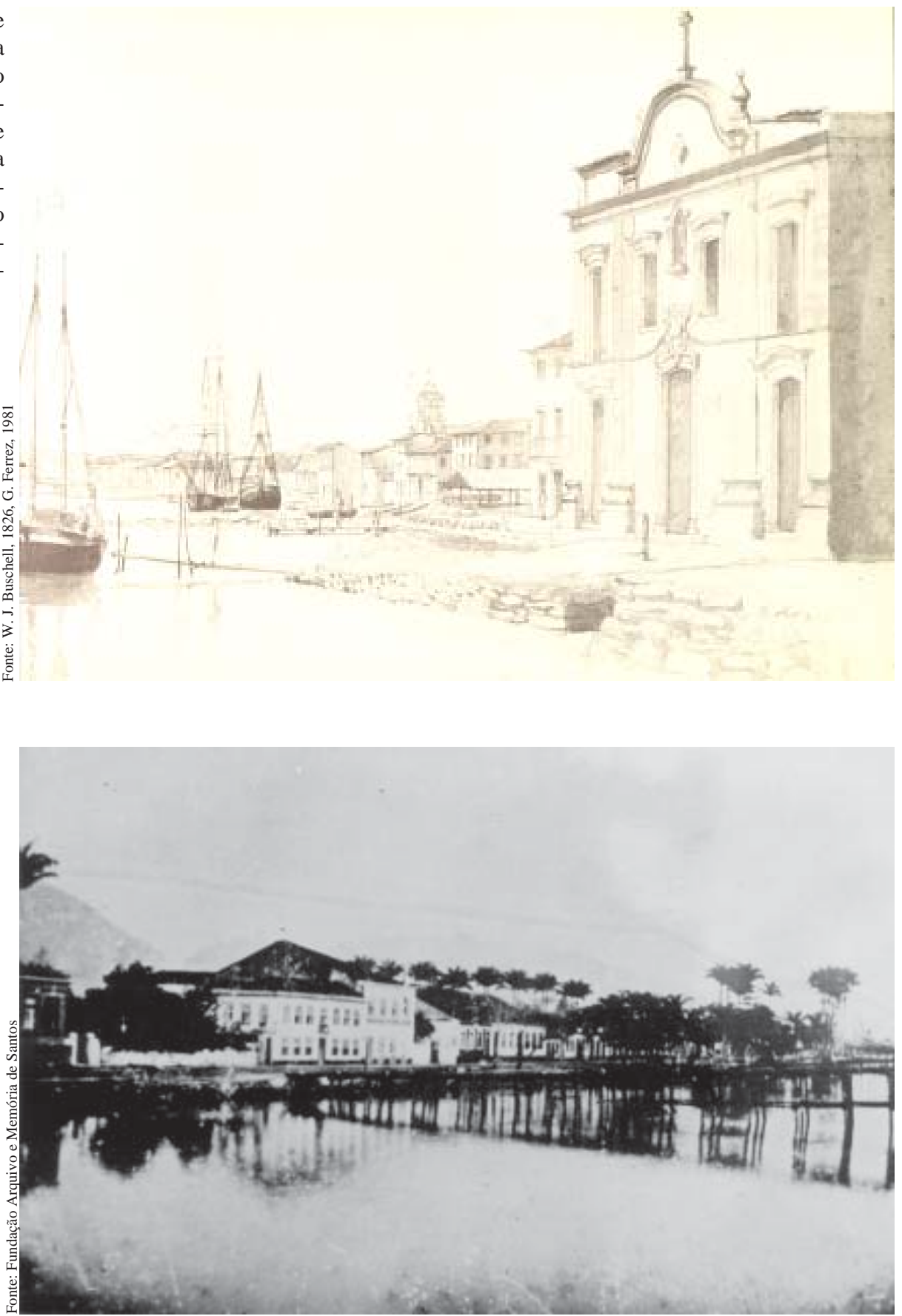
A abertura da cidade para o estuário: antes da construção do cais, o mercado de peixes no Valongo (acima, s.d.); sua transferência para o Outeirinhos, vendo-se no segundo plano o hospital (imagem do meio, 1902.); e o novo mercado (inaugurado em 1906), servido pela bacia e canal implantados em meio às obras de expansão do cais, que se fez através do aterro $\dot{z}$ do golfão dos Outeirnhos (abaixo, 1910)
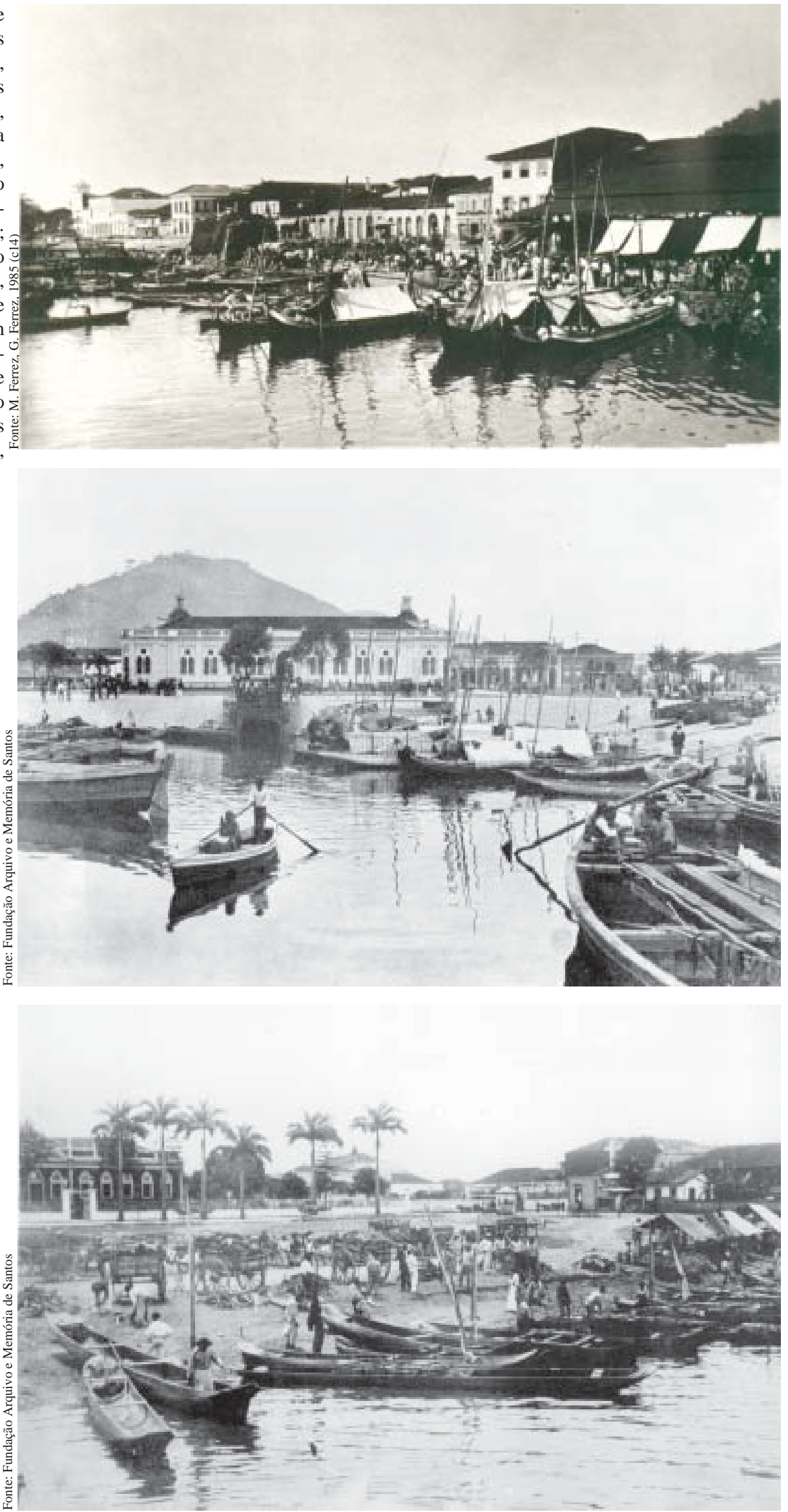


\subsection{As formas de crescimento urbano de Santos}

Como se analisou, os fatores que condicionaram a formação e as primeiras expansões do núcleo urbano santista conjugam aspectos de melhor aproveitamento das condições naturais com razões de defesa e, principalmente, de proximidade com o ponto de subida da serra. No processo de constituição da cidade moderna, se as razões defesa perdem sua importância, a ferrovia impõe uma mudança de valor ao fator proximidade. A estação do Valongo, implantada precisamente nos limites orientais da área urbana, assumindo o papel de "porta" para o planalto, de um lado reforça o "tradicional" caráter de centro comercial e de negócios das quadras fronteiriças. Por outro lado, além de esvaziar o significado do antigo caminho —ao provocar o colapso dos espaços intermediários entre Santos e a serra-, "estrangula", com suas instalações, a passagem do já confinado (entre os morros e água) vetor de crescimento oeste. Portanto, se o significado e a força das comunicações com o planalto determinaram a constituição (no ponto mais próximo da subida da serra) e a manutenção (induzida pela "porta" ferroviária) do centro principal da cidade na "entrada" da cidade, essa mesma posição urbana mostrar-se-ia, de forma aparentemente contraditória, "deslocada" quando o processo de crescimento urbano define outros vetores de expansão. É que, tendo sido ocupada toda a faixa norte, compreendida entre os morros e o estuário, o crescimento populacional e os desdobramentos urbanos dos negócios do café definiriam o vetor sul como a nova direção de expansão da cidade, fazendo ocupar, primeiramente, apenas os terrenos mais secos da ilha. Como resultante deste processo, até pelo menos 1903, a área urbana de Santos apresentava três padrões diferenciados de traçados — a estrutura mais irregular de origem colonial, os arruamentos ortogonais da nova expansão urbana e a faixa residencial litorânea-. Dois grandes eixos, representados pelos traçados das avenidas Conselheiro Nébias e Ana Costa e servidos por linhas de bonde a tração animal, punham em comunicação a "cidade" e a "praia", transpondo o espaço intermediário, alagadiço, que mostrava-se inadequado para a ocupação.

Neste sentido, a implantação dos canais, concebidos no plano de Saturnino de Brito de 1905, supôs a ocupação de toda a superfície da porção leste da ilha, não só drenando os terrenos (o que combina as razões de erradicação dos perigos das epidemias -"leit motiv" do trabalho da Comissão de Saneamento ${ }^{25}$ - com a possibilidade de "criação" de solo urbano) mas, também, orientando e estruturando, através da disposição desses mesmos canais, os processos de crescimento futuro da cidade. No entanto, se as condições topográficas e as pre-existências construídas são respeitadas e incorporadas por Saturnino ao plano, a homogeneidade da malha proposta descuida da previsão do assentamento de outras atividades, como por exemplo a portuária e a industrial, cuja implantação, apesar de mencionada em relatórios, não encontra tradução física diferenciada no projeto. Mesmo para 
Silva Telles ${ }^{26}$, diretor de obras do município, na polêmica travada com a autor do plano, a questão residencial era o que importava, ao escrever que:

sempre quarteirões da mesma natureza, limitados por vias de largura quase uniforme a parcelar toda a área disponível para o crescimento da cidade. Não se vê um local apropriado para vilas, com vias sinuosas e sombras, não se vê um que se preste a construções operárias com grandes jardins internos..."

Porém, uma outra leitura possível que enfatizasse o papel eminentemente portuário da cidade poderia ressaltar que à semelhança do plano de Cerdá para Barcelona, a expansão urbana parece no plano de Santos ser paradoxalmente entendida simplesmente como âmbito da residência. Ainda que em Barcelona, á diferença de Santos, tenham sido previstas as ligações e instalações ferroviárias necessárias para o funcionamento da cidade e do porto.

Na realidade, a concepção de Brito da cidade como totalidade, cujo futuro poderia e deveria ser "planejado" a partir de princípios técnicos, aliados (embora em posição dominante) às preocupações sociais e à dimensão estética $^{27}$, encontra sua lógica operativa na implantação de uma rede de infraestrutura, que reúne em seu traçado circulação e serviços (água, esgoto, verde) e assim enseja novas e potentes lógicas de expansão urbana ${ }^{28}$. Portanto se o princípio ordenador do plano apóia-se na construção dos canais de drenagem, "preparando" terrenos para a ocupação e, logo, na definição dos eixos estruturadores da rede viária, (que dividem a cidade e sua expansão futura em distritos), o crescimento da malha se faria primeiramente sobre a área contida entre a Conselheiro Nébias e o canal 1 (o primeiro a ser consttruído -1907), preenchendo ${ }^{29}$, embora não sem solução de continuidade, os vazios entre a Vila Matias e a praia (do José Menino ao Boqueirão). A realização parcial do plano ${ }^{30}$, embora respeitadas em linhas gerais as diretrizes estruturantes representadas pelos canais-avenidas, iria dar ensejo à deformações da malha proposta ${ }^{31}$, tanto maiores quanto mais tardia seria a implantação de novos loteamentos, condicionadas por questões fundiárias, por tipologias diversas e pelo sabor dos interesses. Assim é que se a ocupação do setor correspondente á faixa do Boqueirão, Gonzaga e José Menino mantém uma certa correspondência com o traçado propoposto por Brito, a porção sudeste da ilha, de ocupação posterior vai apresentar uma maior heterogeneidade de orientação do traçado e granulação das quadrículas. Constituindo áreas menos valorizadas no processo de expansão da cidade, até para Brito, a ocupação desta zona só se daria, num "futuro remoto, desde que se saia da orla da praia".... pois "toda esta zona (excessão feita aos terrenos fronteiros à praia da Barra) está baldia, sendo muito raras as edificações e de baixo valor" ${ }^{32}$. De fato, se a porção sudeste da ilha só seria efetivamente ocupada a partir dos anos 30 , o certo é que até a década de 50, o crescimento da cidade, resultado do desempenho comercial do porto, deu-se pela 
agregação de novas áreas, seguindo a implantação dos 9 canais previstos e anexando novos bairros ${ }^{33}$ às partes já urbanizadas da cidade. Bairros esses que abrigariam "a quase totalidade dos trabalhadores portuários, ensacadores de café, da Cia City, da antiga São Paulo Railway, das construções civis, etc" ${ }^{34}$.

Seja como for, apesar de realizado muito parcialmente, mas, antecipando as formas de crescimento da cidade e, assim, as expectativas das rendas do solo (mesmo porque a cidade assume outro significado para o sistema, isto é, ela passa a ser objeto de acumulação de capital), o plano de Brito vai servir para orientar a distribuição das atividades e da população em função de três principais "fatores locacionais": o centro comercial, a área portuária e a orla marítima, cada um deles exercendo efeitos diferenciados sobre as formas e os processos de crescimento urbano.

Quanto ao porto, apesar da relação de segregação espacial que mantinha desde suas origens com a cidade, a dinâmica sócio-econômica, que esse e suas atividades de suporte imprimem àquela até pelo menos os anos 50, traduziu-se na consolidação de uma área comercial cafeeira, no assentamento dos trabalhadores do cais, na implantação de plantas indústriais e no atendimento de infra-estrutura (saneamento, energia elétrica) cujo nível de entrosamento com as questões urbanas resultou em benefício para a população em geral ${ }^{35}$. Neste contexto de integração funcional entre porto e cidade, o Plano Regional de Santos, elaborado por Prestes Maia em 1947, revelava a preocupação com uma maior coerência entre a expansão portuária e o crescimento urbano. No entanto, com excessão das tradicionais operações de "sventramento" de ruas centrais, que tornadas obrigatórias pelo Plano Regulador da Cidade de 1951, seriam realizadas parcialmente, (segundo Serrano ${ }^{36}$, para sorte da arquitetura do café, à qual, "Prestes Maia não dava valor"), questões ${ }^{37}$ mais importantes no sentido da integração cidade-porto não tiveram a mesma sorte. Entre elas deve-se destacar o tema da entrada da cidade (deslocamento do traçado da via férrea $^{38}$ e construção de túnel sob o morro de São Bento), articulada (através da Xavier Pinheiro — segundo solução "em viaduto", semelhante à de Corbusier para o Rio de Janeiro) à ponte para Santo Amaro, onde o plano previa a implantação de uma cidade portuária.

Projeto mais ambicioso, a implantação da nova cidade na ilha Santo Amaro (na área hoje correspondente ao distrito de Vicente de Carvalho) deveria articular-se com o novo cais projetado pelo próprio Plano segundo um traçado e uma distribuição espacial de funções que se orientava pelos seguintes princípios:

a zona nova de Santo Amaro mais próxima ao cais prefere uma malha geométrica e regular, de ruas suficientemente amplas, pois será o futuro centro comercial e portuário. A faixa adjacente ao 
porto conterá os armazéns externos. A seguinte o comércio, com ruas em duas direções: a paralela ao cais, que é também a direção Ponte Cabrão-Guarujá, e a transversal, que é também a direção Ponte do estuário-Perequê. O interior da ilha será industrial no norte e nordeste; o residencial popular ao sul, junto dos morros" ${ }^{\prime 3}$.

Correspondendo antes a uma "imagem" da cidade que propriamente a um projeto (embora sejam pre'-figurados no desenho elementos referentes a pontes, sistema viário, parcelamento do solo, edifícios públicos, acidentes geográficos, traçado urbano ${ }^{40}$ ), e talvez dada, como alertava o engenheiro, a evidência da "ausência do poder público, sómente preocupado, pela pobreza dos recursos, com questões secundárias ou de vigência imediata" ${ }^{41}$, o certo é que da "cidade portuária" muito pouco, além de algumas diretrizes de traçado de avenidas, restaria na efetiva ocupação de Vicente de Carvalho. O processo de ocupação da área obedeceria a outra lógica, impulsionada, antes de mais nada, pela pressão demográfica, pela baixa disponibilidade de solo urbano e, logo, pelas determinações do mercado imobiliário.

Essa lógica, resultante do início da industrialização de Cubatão e do surto turístico, alavancado pela melhoria das ligações rodoviárias com o planalto, daria, a partir dos anos 50, novo impulso ao crescimento populacional, contribuiria para o crescimento da classe média santista e alteraria as características de ocupação do espaço urbano em nível regional. Assim é que, à expulsão da residência operária, cujo espaço seria "requisitado" para assentar a classe média, seguir-se-ia não sómente a alteração da paisagem dos bairros, antes caracterizada pela tipologia do "chalé", como a ocupação de espaços disponíveis na ilha, intensificando-se deste modo, a ocupação dos morros, da porção noroeste ${ }^{42}$ e de espaços remanescentes na porção leste. Ao mesmo tempo ocorre o início da expansão residencial em São Vicente e Vicente de Carvalho, ampliando o processo de ocupação clandestina do território (ao longo de eixos rodoviários, áreas inundáveis ou com fortes declividades). Este processo, tendo em vista o saturamento de áreas disponíveis, é seguido pela "verticalização" das edificações, particularmente nas valorizadas áreas próximas à orla, bem como pelo adensamento geral da área urbana.

Se a lei $n^{\circ} 1831$ de 9/4/1956 dividia a cidade em oito zonas principais (duas comerciais, três residenciais, industrial, portuária e rural —essa na porção noroeste da ilha), permitindo a verticalização (segundo alturas decrescentes da orla -52 metros — aos bairros do miolo da ilha $-12 / 18$ metros), seriam as normativas estabelecidas no Plano Diretor Físico de 1968, representando a consolidação das tendências espontâneas expressas, ou mesmo, "um pacto de solidariedade com o mercado imobiliário" ${ }_{43}$, que reforçariam, até os dias atuais, este processo de adensamento vertical. Tendo como principal preocupação disponibilizar espaço físico de forma a suportar os acréscimos de 
população previstos ${ }^{44} \mathrm{e}$, assim, reverter a tendência do processo de esvaziamento da população fixa de baixa renda, que se verificava supostamente em favor da população turística (mesmo porque o principal objetivo defendido pelo PDF era a industrialização do município, como resposta ao "desequilíbrio" da base econômica predominantemente terciária), aquele documento de desenvolvimento urbano, propunha medidas que, facilitando o crescimento vertical da cidade, permitiriam dobrar a densidade residencial pela substituição das casas térreas por blocos de apartamentos de três andares, ao mesmo tempo que incentivava a construção de "edifícios de até 10 andares nas zonas comercial e residencial e de 14 na zona turística, promovendo a difusão de altas densidades em extensa área do território" ${ }^{45}$. No entanto, o adensamento proposto, em nome de uma paisagem menos compacta, bem como da garantia de condições de ventilação e iluminação, deveria seguir um novo padrão consubstanciado em um "novo" (certamente refletindo o projeto de Brasília) arranjo da distribuição de edifícios nas quadras, intercalando-os com espaços livres e contínuos de uso coletivos. A ausência de dispositivos legais de estímulo à essa forma de "renovação urbana", não permitiu outro avanço que o da consolidação dos processos de estruturação urbana que já se manifestavam, impulsionados pelas leis do mercado imobiliário. O zoneamento adotado, vigorando por 30 anos, resultaria em distorções e conflitos nas formas de uso e ocupação do solo, inclusive, como se verá, no que diz respeito à invasão das atividades retroportuárias sobre o tecido urbano.

Os estudos realizados no biênio 1976/78, que dariam ensejo à elaboração do documento do Plano Preliminar de Desenvolvimento Integrado, reavaliam as hipóteses anteriores trabalhadas pelo PDF quanto ao turismo ${ }^{46}$ e à industrialização ${ }^{47}$, argumentando que o espaço econômico de Cubatão se desdobrava sobre o de Santos. Esse, portanto não deveria ser visto como um "espaço fechado", mas antes como pólo terciário "aberto" à toda da Baixada. Assim, no sentido de reforçar a "posição do centro de Santos como centro da Baixada Santista, atendendo principalmente às funções de apoio ao porto e às indústrias da região e polarizando os serviços mais especializados à população"48, o PPDI 78 proporia, de modo coerente com suas premissas "terciárias", a necessidade de "um plano de hierarquização de centros e vias" ${ }^{49}$. O modelo de ordenação física adotado definia uma estrutura urbana configurada através de uma malha ortogonal

cujos nós definem maciços de alta densidade, ligados entre si por corredores de média densidade que por sua vez envolvem ilhas de baixa densidade ou remansos ambientais, onde predomina a escala local, relativamente livre de interferências das estrutras de hierarquias superiores"so.

O plano de 1978 não só deixaria de entrar em vigor como “os resultados 
projetados obtiveram êxito sómente pelo ângulo da queda da qualidade de vida da população" ${ }^{51}$. Talvez a intervenção administrativa a que ficou sujeita a cidade no período explique em parte este processo, que repercutiria principalmente no déficit habitacional e na interferência espacial das atividades portuárias (as mudanças na paisagem causadas pela "invasão" do contêiner não teriam "sido" previstas). Daí que os problemas realtivos à escassez de áreas, aos custos praticados pelo mercado imobiliário e à inacessibilidade à moradia por boa parte da população (por isto mesmo, obrigada a se deslocar para outros municípios), seriam agravados pela violenta expansão das atividades retroportuárias, que encontravam nas normativas em vigor brechas para avançar sobre o tecido urbano. Diante deste quadro, a administração municipal de esquerda (89/96) adotaria um modelo de planejamento que se poderia dizer "defensivo". No que toca à parte insular, a política urbana orientou-se pela criação das Zonas Especiais de Interesse Social, ${ }^{52}$ —que visavam melhorar as condições de fixação da população, ampliando a oferta de serviços e equipamentos e revitalizando áreas degradadas-. Quanto à àrea continental, o sentido foi o de reverter através do instrumento da Àrea de Proteção Ambiental Santos-Continente ${ }^{53}$, as expectativas (contempladas e incentivadas pela legislação anterior) de ocupação residencial e produtiva das áreas de restingas e manguezais. Se as ZEIS permitem uma maior atenção à urbanização marginal (com mais eficiência em áreas de favela e morros e quase nehuma nas áreas mais centrais), a APA inibiria (não sem resistências) tentativas de criação de solo industrial na parte continental. No entanto, os planos de expansão do porto, ainda que abandonando a grandiosidade dos projetos dos anos 80 (mesmo que localizados no município de Cubatão), não parecem constranger-se com as restrições estabelecidas nela. Por outro lado, seria inaugurada uma (ainda que efêmera) discussão sobre a integração cidadeporto. Em todo caso, o projeto de centro de serviços proposto pela prefeitura em 1996 para a área Paquetá daria as dimensões deste incipiente processo de integração, na justa medida em que, mesmo advogando uma ocupação urbana de pequena escala, constrangida entre as áreas de expansão do cais do Paquetá, acabaria não saindo do papel.

Já no final da década de 1990, estabelecendo como áreas prioritárias de ação o turismo, o porto e o comércio e prestação de serviços e visando o "desenvolvimento sustentável" (objetivo assentado na hipótese que combina iniciativas de adensamento de áreas com infra-estrutura ociosa, de recuperação e conservação do patrimônio cultural, natural e construído e de estabelecimento de parcerias com a iniciativa privada), o Plano Diretor de Desenvolvimento e Expansão Urbana do Município de Santos reproporia as zonas de uso e ocupação do solo (zonas central, intermediária, orla, noroeste, portuária, morros). Ao mesmo tempo, definiria certas "zonas de preservação paisagística" e corredores de "proteção cultural" e de "desenvolvimento e renovação urbana", mantendo-se algumas das "zonas especiais de interesse social". Os coeficientes de aproveitamento estabelecidos em patamares 
equivalentes a 4/6 vezes a área dos lotes supõem, com excessão dos morros, verticalização generalizada de toda área urbana, e particularmente, dos "corredores de renovação" e "núcleos de intervenção e diretrizes estratégicas ${ }^{54}$, onde através de concessão onerosa (os primeiros) ou não (os segundos), estes mesmo coeficientes podem ser ampliados.

A cidade consagrada (pois reafirma tendências expressas) nesta proposta é uma cidade dividida em "estratos" relativamente homogêneos e classificados segundo sua posição "geográfica"; "estratos" que a sintetizam (ou melhor esquematizam-na) a partir dos fatores praia, porto, centro, e morros, os quais, na verdade, têm sido os fatores que condicionaram o modelo de distribuição das atividades e do domínio e controle do espaço na cidade de Santos.

$* * *$

Ao se examinar o papel de planos de ordenação física de Santos (sempre concebidos a partir da cultura disciplinar do "zoneamento"), deve-se destacar que, ao menos desde os anos 50, suas normativas deram suporte à superocupação das áreas mais valorizadas (orla) ao mesmo tempo que permitiram a instalação de usos (principalmente retroportuários) não compatíveis com a estrutura urbana. Neste sentido, referências a um maior controle urbanístico do porto (submetido sómente à legislação federal), ou mesmo da incidência de seus "efeitos" na estrutura urbana, são quase invariavelmente tímidas quando não exsitentes. O "território federal" sempre se impôs como território extraurbano. Assim é que se o plano de Saturnino de Brito faz menções às atividades portuárias e industriais, não as traduz em um desenho diferenciado que anuncie e preveja com clareza sua inserção na trama urbana (a construção das avenidas "portuárias" propostas, por estar em domínio da Companhia Docas, estaria condicionada, no entender de Siva Telles, à sua aquiescência).

Se o Plano Regional de Santos propõe uma maior integração cidade-porto (ligações rodo-ferroviárias, cidade comercial, reserva de frente estuarina para função residencial e de lazer), a forma que assume como instrumento de politica urbana reduz-se à previsão do alargamento de ruas centrais.

O Plano Diretor Físico de 1968, embora enfatizando a necessidade de diversificação da economia como alternativa à base portuária-turística ao mesmo tempo que propõe maior adensamento da ilha, abre "brechas" legais, pela indefinição ou mesmo permissividade do "zoneamento", por onde as atividades retroportuárias acabariam invadindo o tecido urbano ao longo da faixa estuarina. O PPDI de 1978, mais atento à cidade "terciária", apenas faz genérica referência, no sentido de valorizar a "unidade ambiental" correspondente ao centro histórico, à "abertura para o porto (hoje escondido por uma série de armazéns)...", como "reconquista do conjunto de fatores que deram significado a Santos: o mar e a montanha"s5. Por outro lado não 
consegue captar a expansão das atividades retroportuárias, que deveriam (embora na Ponta da Praia já estivesse em operação o terminal graneleiro) ficar "contidas" nos bairros do Valongo e Paquetá.

Nos anos 90, a preocupação com a preservação ambiental da parte continental expressa na legislação municpal da APA, não parece representar qualquer restrição aos planos de expansão portuária sobre os tecidos urbanos. E o "pragmatismo" do Plano Diretor de 1998 apenas regula, confirmando, as áreas já tomadas pelas atividades retroportuárias. Por outro lado o descompasso entre a adminsitração municipal e a portuária fica evidente na diversidade dos traçados concebidos para a complementação da Avenida Portuária. 
Esquema comparativo do crescimento urbano entre o terceiro quartel do século XVIII e do século XIX. O impulso gerado pelo negócio do café e pela operação da ferrovia faz expandir a trama urbana agregando novas quadras ao núcleo original, ao mesmo tempo que implica a expansão do sistema pontetrapiche que domina pontos da frente estuarina compreendida entre Valongo e Paquetá
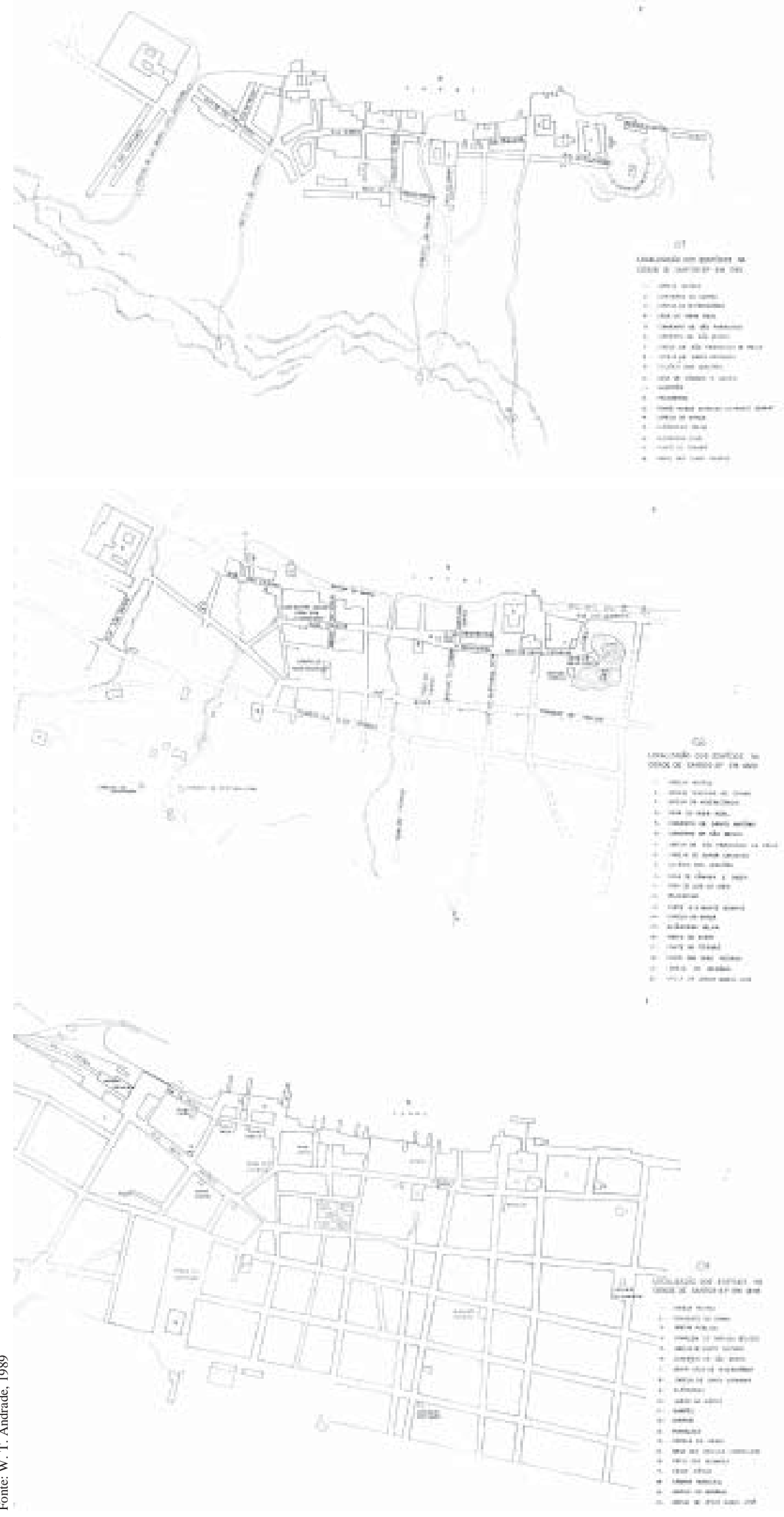


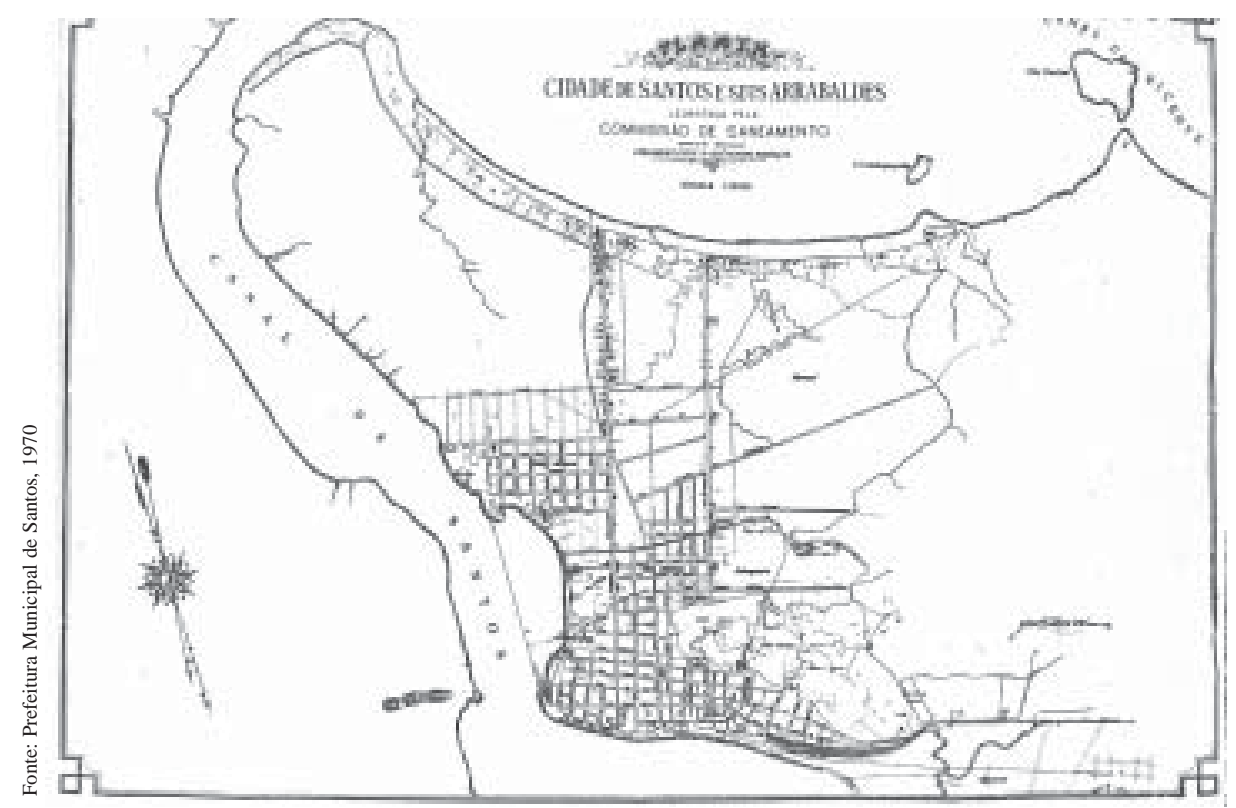

Planta da cidade - 1903 - levantada pela Comissão de Saneamento: a infra-estrutura portuária promove pela construção do cais o alinhamento da costa bem como sua segregação da cidade. Os eixos norte-sul de ligação "cidade"-praia redefinem o padrão dos traçados e organizam os vetores de crescimento urbano. Razões de ordem sanitarista passam a pautar as intervenções na cidade

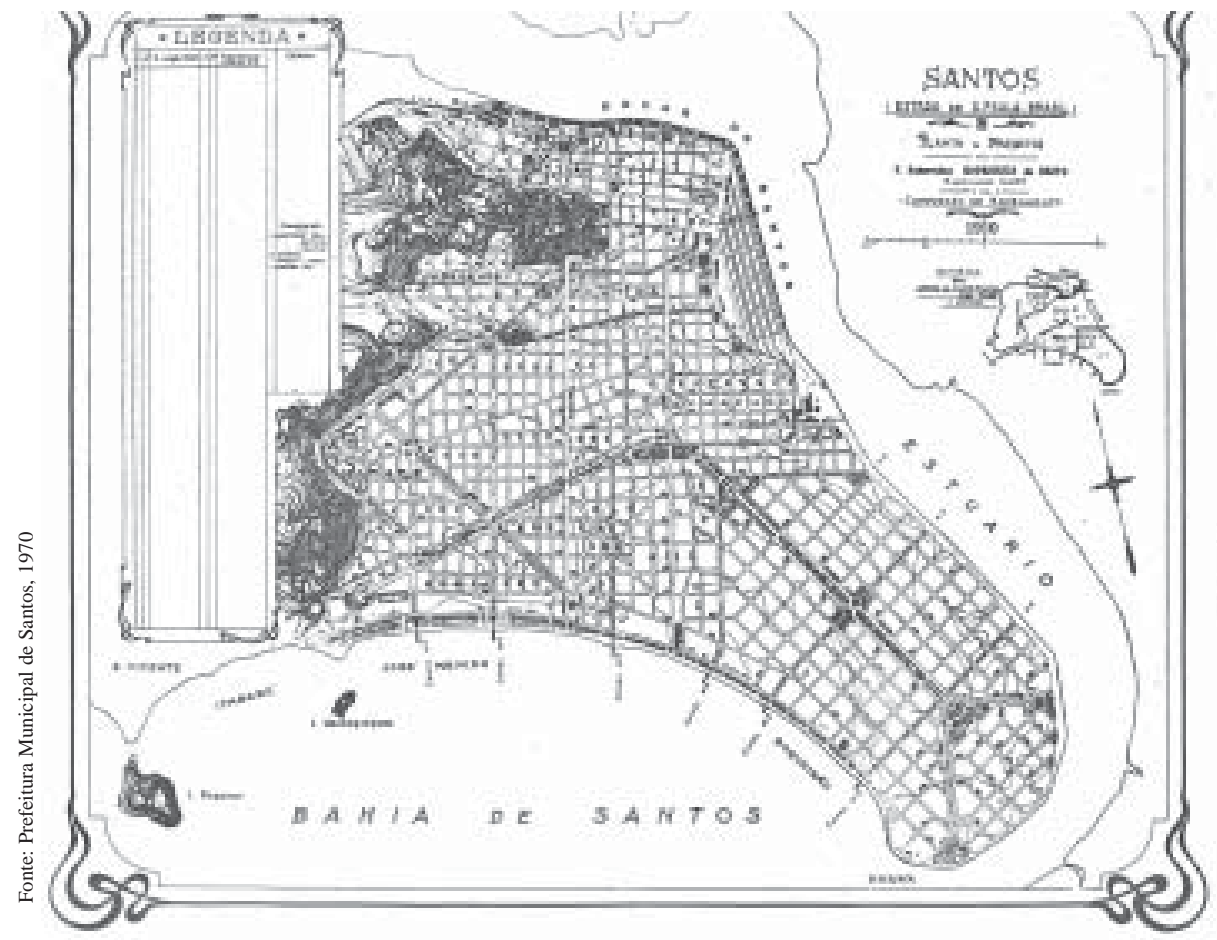

Planta e projetos — 1910 - elaborados por Saturnino de Brito para a Comissão de Saneamento. A construção dos canais de drenagem suporia a possibilidade de ocupação de toda porção leste da ilha segundo um plano global. No setor sudeste, apesar da maior autonomia e padronização do traçado proposto - talvez desconsiderando as exigências espaciais para a expansão das atividades portuárias e industriais—, a ocupação efetiva acabaria definindo uma malha menos homogênea ao sabor dos interesses fundiários. Apesar da realização parcial do plano, o traçado dos canais estabeleceu a ossatura de crescimento da cidade e suportaria as posteriores transformações edilícias 


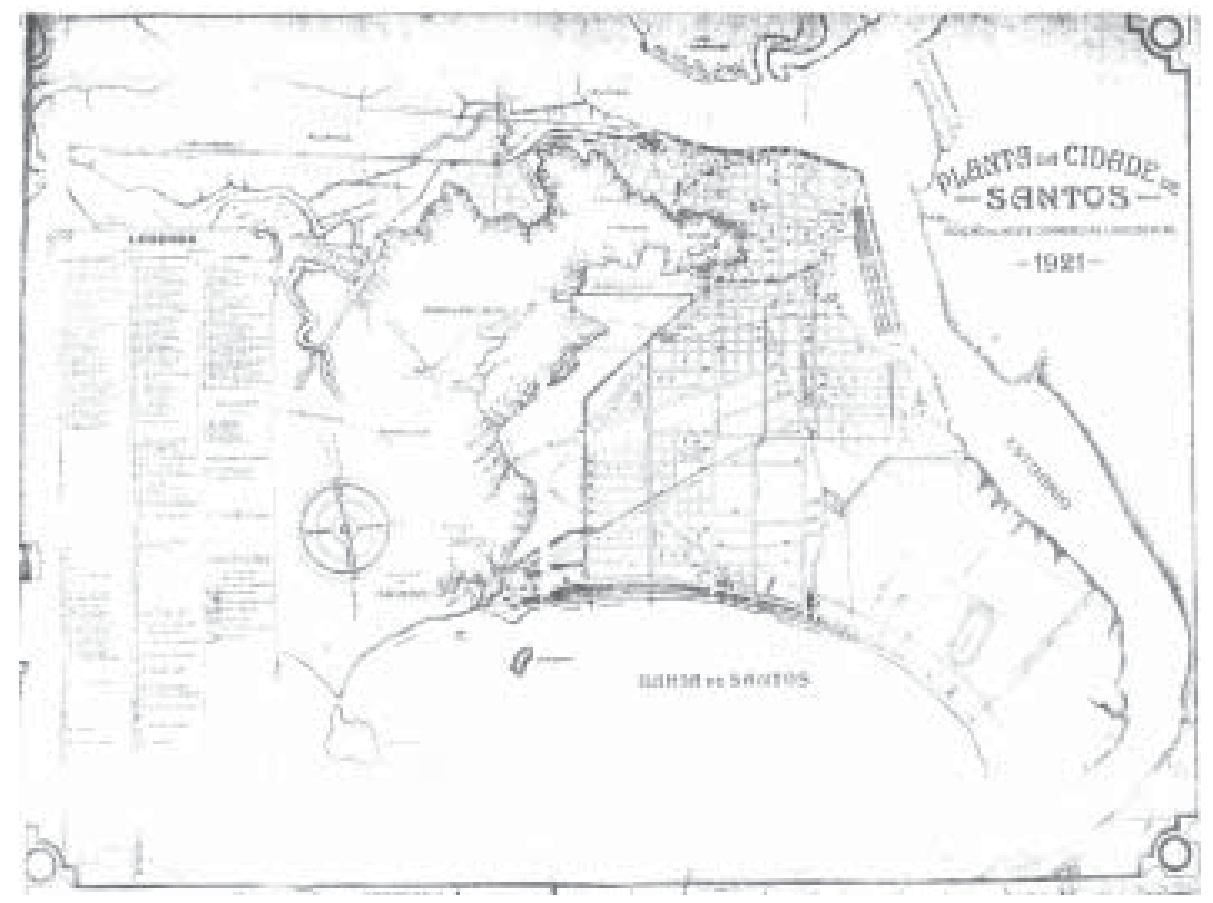

Planta de Santos (c.1930). O crescimento urbano, impulsionado pela exportação do café e infra-estruturado pelos canais e pelos serviços públicos (operados pelas companhias concessionárias de energia — produzida pela Cia Docas-, luz, bonde, ônibus, gaz, água — City of Santos Imp. Co.— e telefone_Brazilian Telephone Co.—), preenche progressivamente os vazios existentes. As instalações portuárias apesar de manter os limites estabelecidos na década de 1910, de certa forma têm "reservadas" suas áreas de expansão ao longo da linha de água.

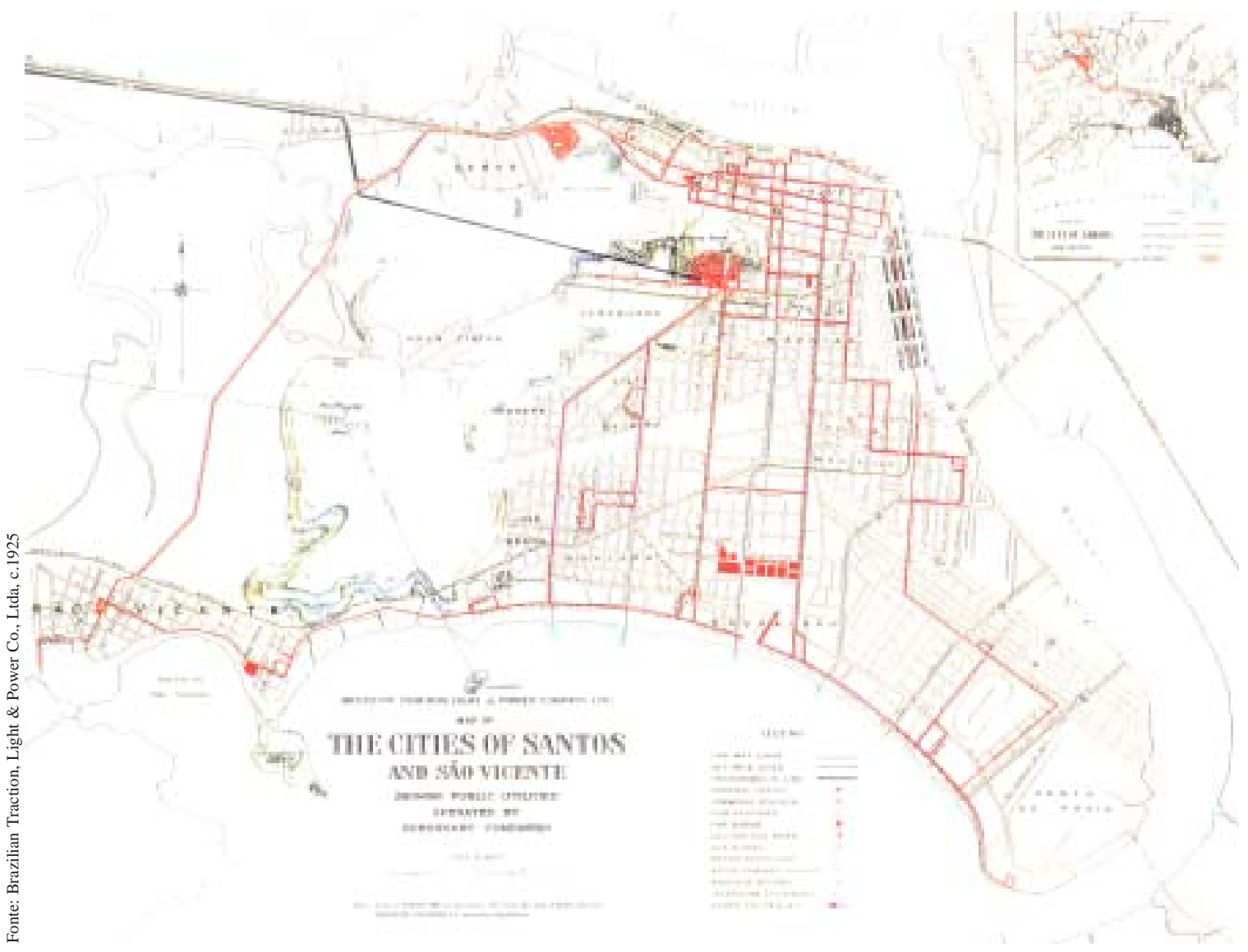


Plano Regional de Santos, elaborado em 1947 por F. P. Maia. A tentativa de integrar porto e cidade levou à propostas de reestrutração das infraestruturas de circulação e transportes regionais e urbanas, enfati-zandose a necessidade de superação dos obstáculos naturais, a resolução da "entrada" da cidade e a ocupação da ilha de Santo Amaro

Projeto de implantação da cidade comercial-portuária na Ilha de Santo Amaro. A \&ั interligação com Santos far-se-ia pelo estuário através de ponte elevadiça, cujo eixo, associado a outro, paralelo à linha do cais, organiza a malha geométrica e regular do centro comercial A faixa estuarina seria ocupada por instalações portuárias, enquanto o interior da ilha seria industrial ao norte e nordeste e residencial popular ao sul. Traçado evolumetria "beaux arts e zoneamento funcionalista compõem a imagem e estrutura da nova cidade
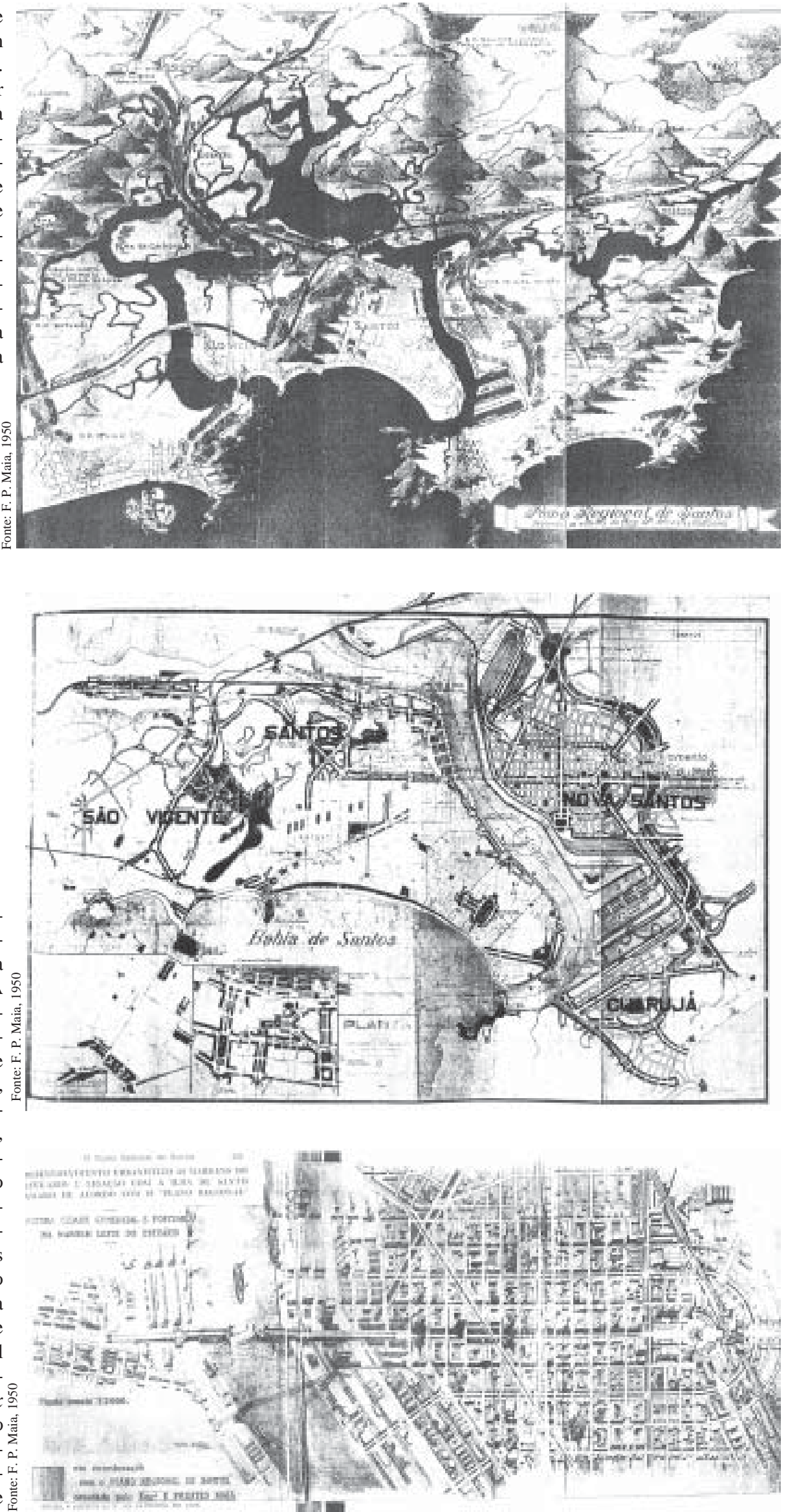


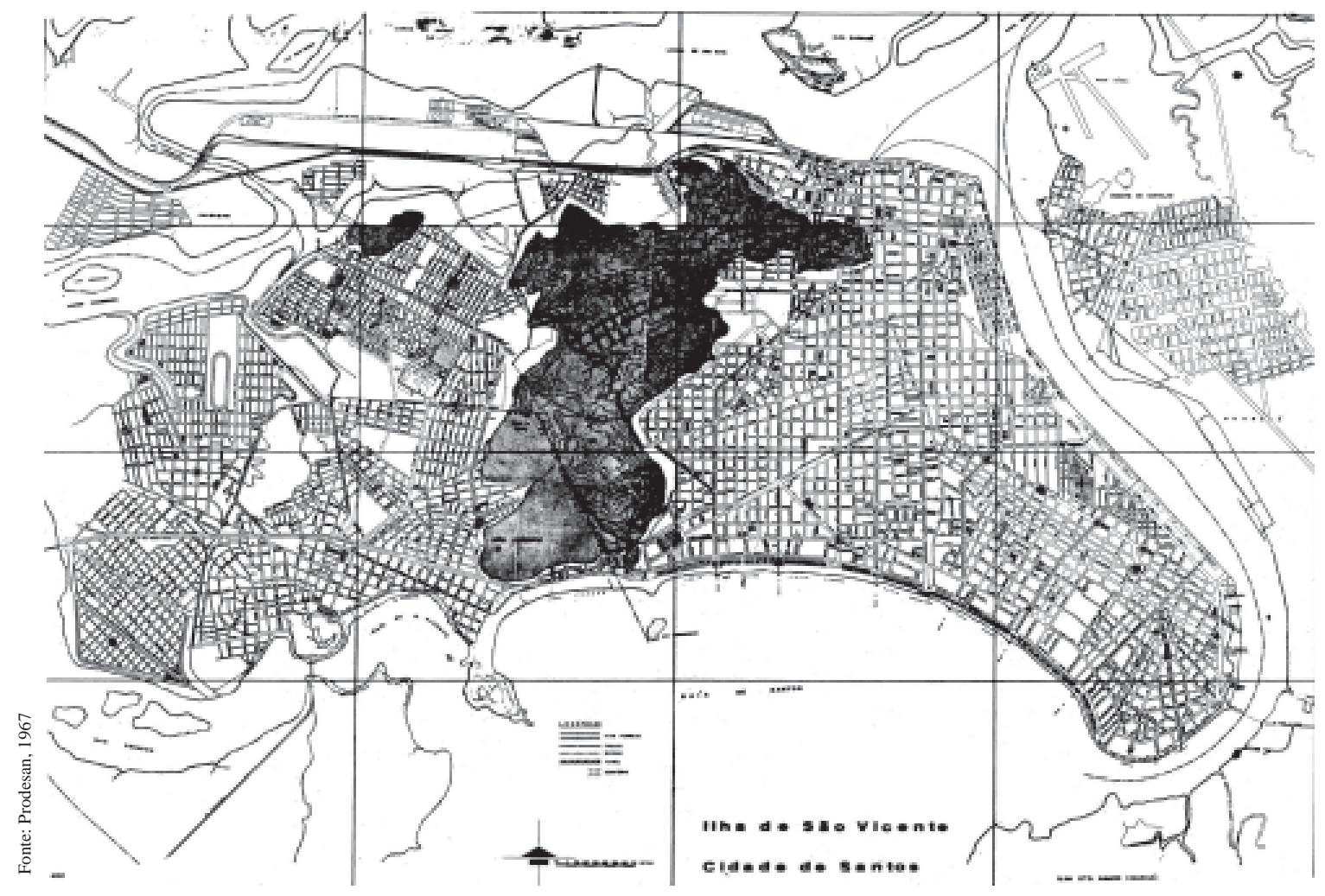

Planta de Santos, 1965. A consolidação do desenvolvimento industrial de Cubatão e a pressão da demanda habitacional (composta por parcela da pressão da "segunda residência") fazem extravasar o crescimento urbano em escala regional: o adensamento da zona leste tem contrapartida na criação de novas periferias na zona noroeste, São Vicente e Vicente de Carvalho. As instalações portuárias estendem-se por toda margem esquerda do estuário, da Alamoa (noroeste) ao Novo Macuco (sudeste)
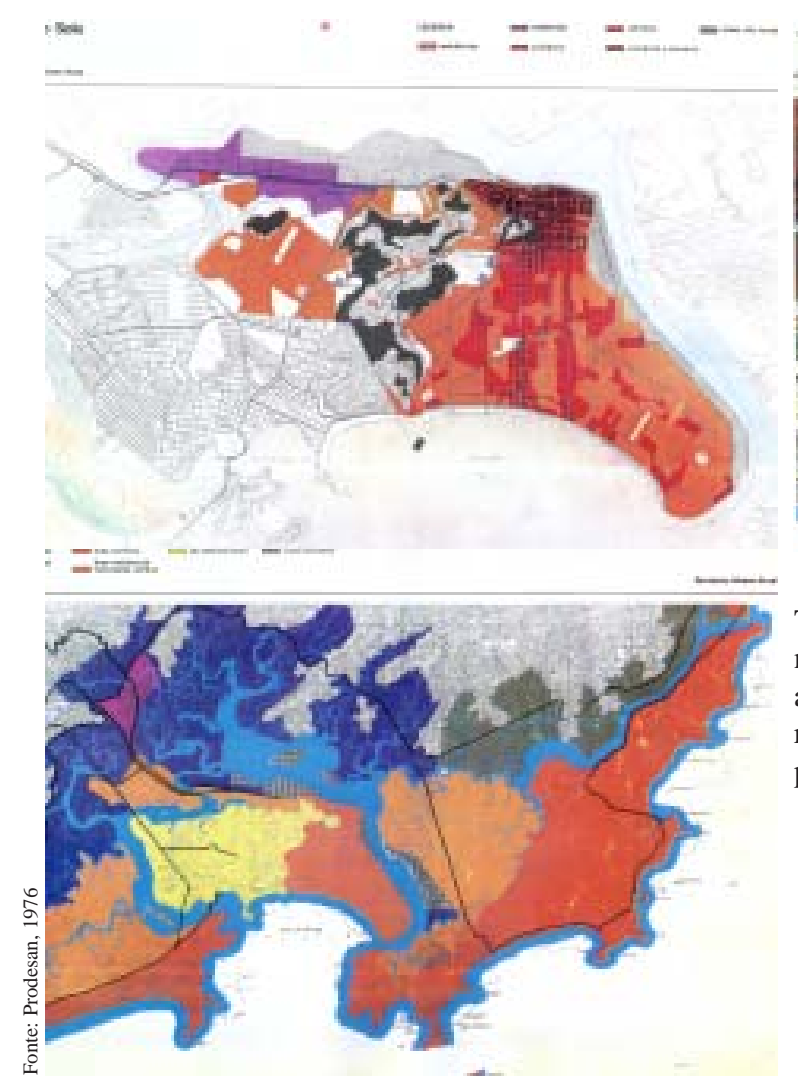

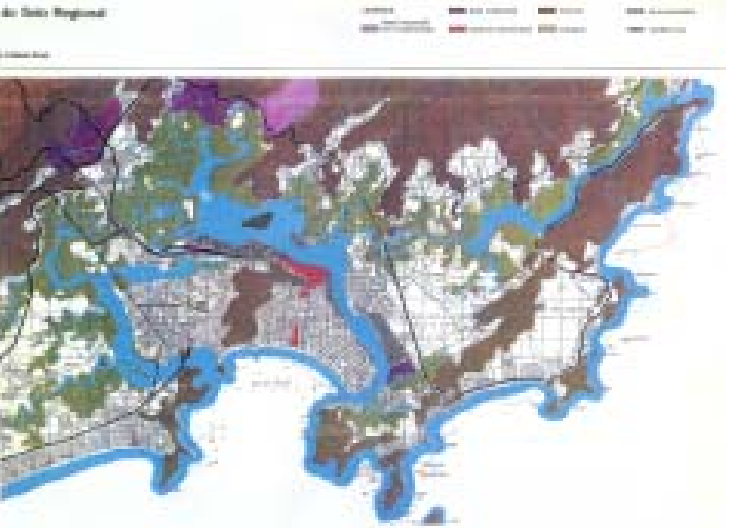

Tendências do crescimento e uso do solo urbano regional na década de 1970. Se a previsão de criação de extensas áreas de solo industrial não se realizou, a periferia residencial estendeu-se por àreas naturalmente inapropriadas para a ocupação 


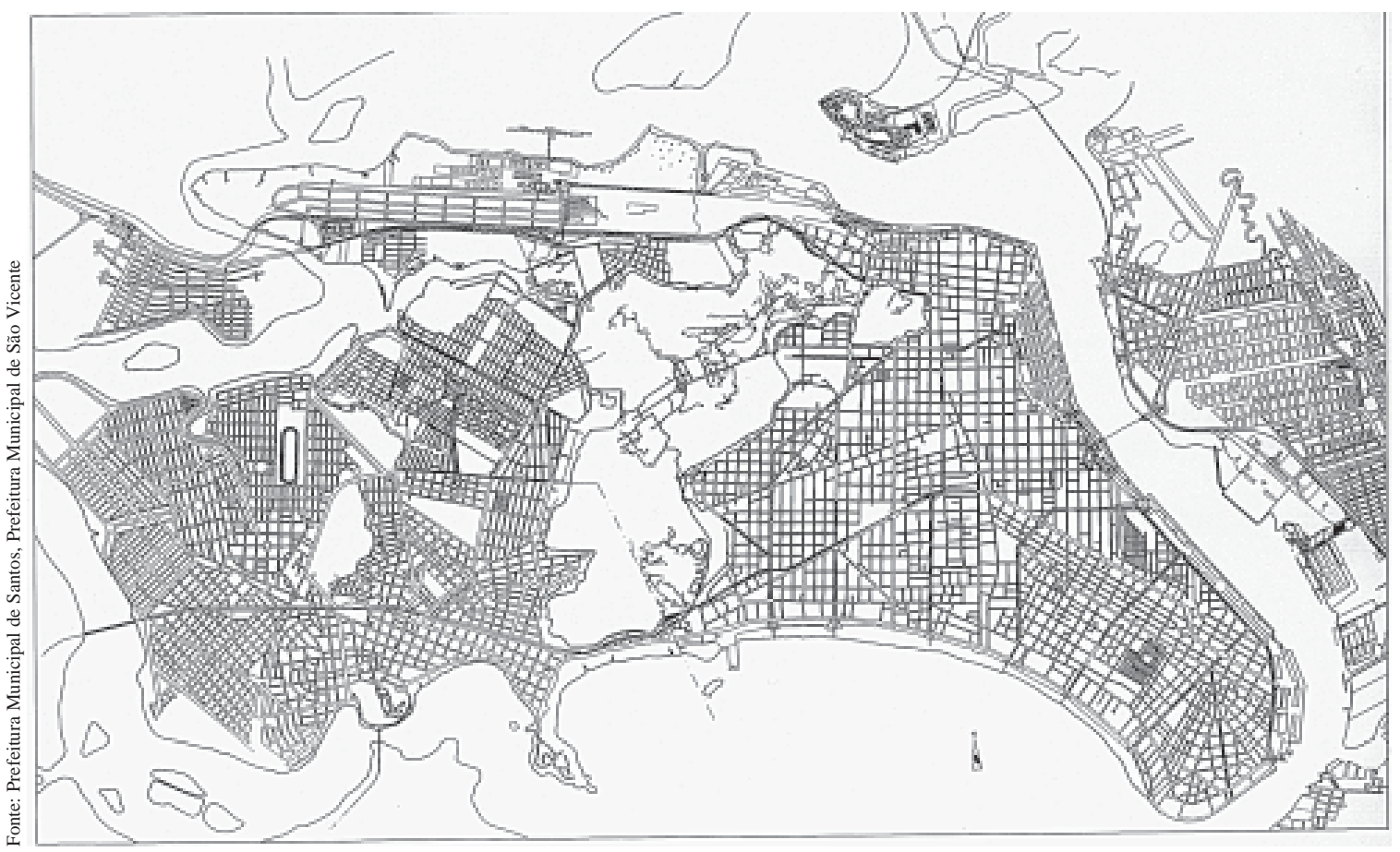

Ilha de São Vicente: "colmatagem" e adensamento da planície e crescimento da ocupação dos morros: A margem esquerda constitui a única reserva natural disponível para a expansão portuária

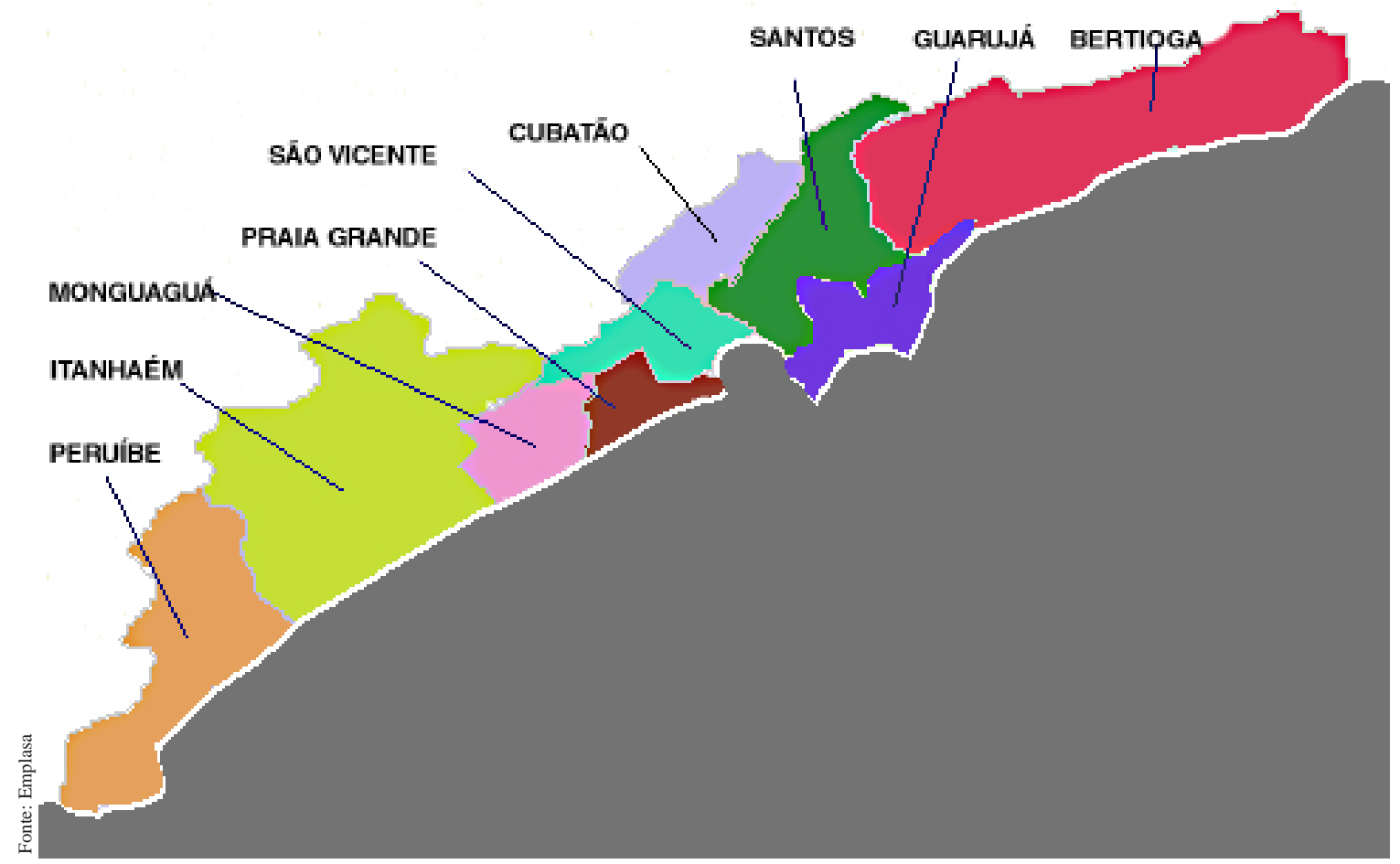

Municípios componentes da Região Metropolitana da Baixada Santista. As cidades vizinhas à Santos passsam a absorver o crescimento populacional 

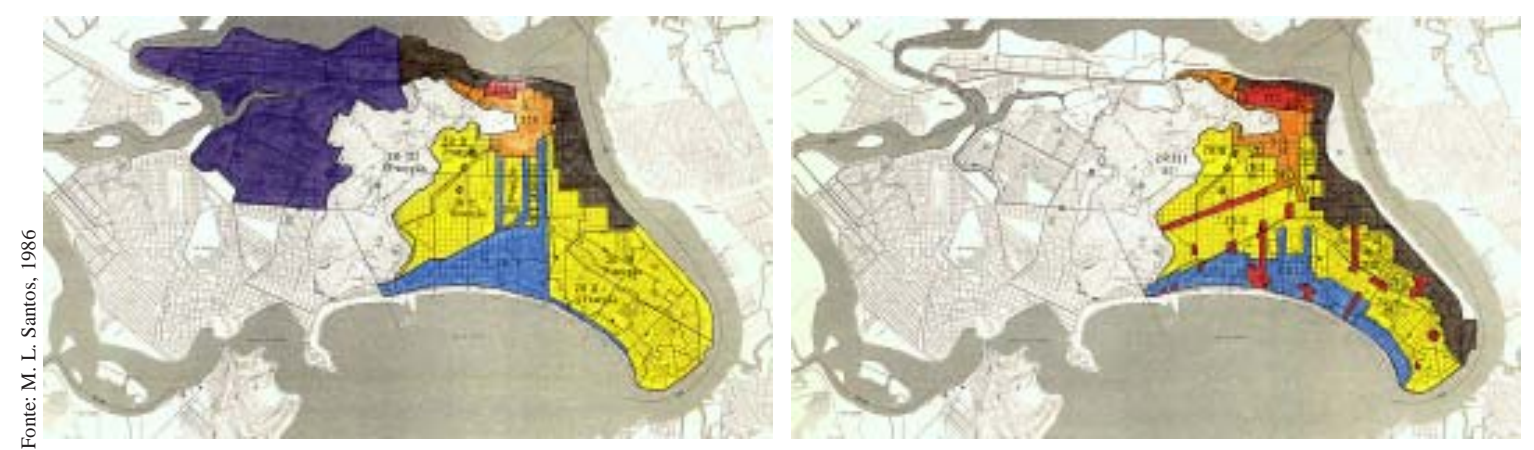

Zoneamento de uso e ocupação de solo, segundo legislação municipal de 1945 e 1956, onde já se definiam áreas, externas ao domínio federal, destinadas às atividades retroportuárias, fundamentalmente concebidas em termos de armazenagem e de moinhos

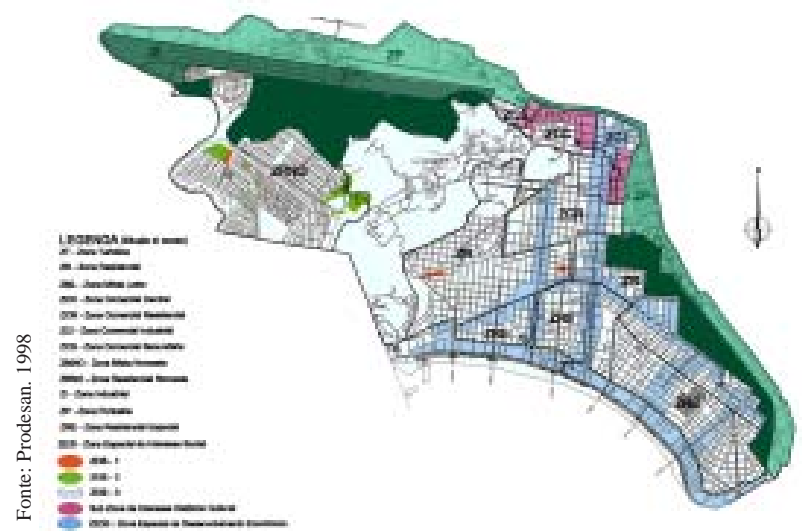

O zoneamento que, estabelecido pela leı n $3529 / 08$, vigorou desde 1908 por trinta anos, separa o domínio portuário (ZP) das áreas retroportuárias urbanas (que passam a a ser classificadas como Zonas Mistas e Industrial). A indefinição dos padrões de ocupação e dos usos permitidos na ZM Leste (Macuco, Aparecida, Ponta da Praia) geraria a intensificação dos conflitos entre a função residencial e a portuária, principalmente pela implantação do terminal do Corredor de Exportação. A definição da Zona Especial de Interesse Econômico (eixos achurados em azul) é de 1996, enquanto as Sub-zonas de Interesse Histórico e Cultural foram decretadas em 1989 e 1995

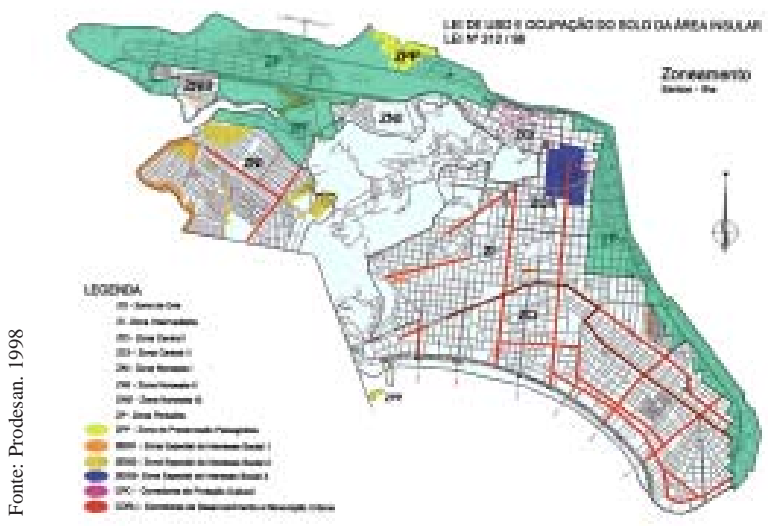

Na legislação de uso e ocupação do solo em vigor desde 1998, as zonas de desenvolvimento econômico são transformadas (com acréscimo de setores dos eixos Mendonça de Carvalho, N. S. Fátima, etc) em Corrredores de Desenvolvimento e Renovação Urbana, ao mesmo tempo que se consagram os Corredores de Proteção Cultural e e as Zonas Especiais de Interresse Social (definidas em 1996). As áreas portuárias, retroportuárias e industriais são novamente englobadas em uma mesma classificação de Zona Portuária, que tem seus limites físicos restringidos e sua utilização redefinida (estando vetada a função residencial) em relação às antigas Zonas Mistas. O destino da "indústria de conteneirização", anteriormente estabelecida nos bairros do Macuco e Aparecida, estaria associado à incentivos fiscais, visando a ocupação de áreas internas ao porto 
4.3 O porto e os sistemas intra-urbanos: mobilidade, residência, produção, ambiente e centralidade

Buscando examinar as contradições e conflitos decorrentes da implantação e operação do porto que se manifestam na forma e no uso do espaço urbano, bem como flagrar seus efeitos na estrutura e na imagem da cidade, trata-se a seguir da caracterização dos "sistemas de lugares" de Santos: a análise de suas lógicas de implantação e transformação, bem como da relação que mantém entre si, deve permitir identificar a incidência da infra-estrutura portuária sobre o crrescimento urbano e clarear as pautas de possíveis projetos de transformação.

O sistema de mobilidade: traçados, acessibilidade e conectividade

Já se observou que as comunicações com o planalto definiram a estrutura de crescimento da cidade colonial. Constrangida pela faixa de terra compreendida entre os morros e a água e paralela à frente marítima, a diretriz dominante dessa estrutura, que antes fez articular por uma única rua os núcleos do Outeirinhos e o do Valongo, define a primeira expansão urbana através de uma malha ortogonal, suportada pelo prolongamento dos eixos orientados na direção leste-oeste. Esgotada as áreas ocupáveis daquela faixa e redimensionado pela ferrovia, como se viu, o papel do vetor oeste, a diretriz norte-norte sul de ligação da "cidade" com a praia reorientaria o vetor de crescimento da cidade.

A abertura dos $6 \mathrm{~km}$ em linha reta da Avenida Conselheiro Nébias — projeto do início da década de 1870 de Inácio Wallace da Gama Cochrane-viria a substituir o Caminho Velho da Barra, traçado sinuoso de ligação da Rua Braz Cubas à porção sul da ilha ${ }^{56} \mathrm{e}$, assim, apesar de combatida pelos proprietários de terrenos ${ }^{57}$, inauguraria um novo padrão e uma nova dinâmica de expansão urbana. Reforçada pela operação de uma linha de bondes que a percorria, a avenida ensejou a constituição de novos bairros — Vila Mathias e Vila Macuco- que se formaram a partir do arruamento de terrenos que constituíam antigas chácaras. Juntamente com a avenida Ana Costa (aberta em 1887 por Mathias Costa e também servida por linha de bondes que ligava a Vila Mathias até o Gonzaga), a Conselheiro Nébias "constuiria a espinha dorsal do sistema urbanístico de Santos, pré-estabelecendo as condições de paralelismo e verticalismo das futuras ruas" ${ }^{\text {"58 }}$. Concebidas segundo padrões diferenciados — dimensão da secção, arborização, pavimentação— atrairiam para si seja a atenção do poder público, seja as residências das famílias mais abastadas, além de propiciarem a abertura de outras vias, "permitindo o acesso público a áreas que eram antes domínio de vegetação"

Porém, como se sabe, a ocupação plena da planície sómente efetivar-se-ia com a implantação dos canais do Plano de Saturnino de Brito, cuja 
construção, sucedendo-se de 1907 (canal 1) até 1927 (canal 5) 50, pautaria as fases de agregação de novas áreas urbanas e estabeleceria o sistema geral de circulação da cidade. Reunindo infra-estrutura de saneamento (canal de drenagem a céu aberto e tubulação subterrânea de esgotamemto segundo "sistema de separação absoluto" ${ }^{\prime 1}$ ) e avenidas e calçadas arborizadas em ambos os lados, os canais, com secção média em torno de 30m e implantação perpendicular à faixa marítima ${ }^{62}$, dividiriam a cidade em diversos "distritos" e criariam a ossatura principal de suporte aos "traçados reticulares não sistemáticos, com avenidas diagonais que facilitem as comunicações dos arrabaldes" ${ }^{63}$. No plano os traçados pré-existentes (como a avenida Gaffré Guinle a rua Carvalho de Mendonça) são respeitados, e a divisão por "distritos" permite um arruamento com certa independência. Portanto é apenas na porção sudeste da ilha, até então desocupada, onde o plano prevê um traçado com maior autonomia, orientado pelas direções paralelas e perpendiculares à margem do estuário (linhas de menor distância entre esse e a praia) e tendo como eixo geométrico a avenida-parque da Barrra, esse traçado desloca-se em relação à diretriz dominante norte-sul, desenvolvendo-se segundo um malha ortogonal regular, apenas cortada pelo "patte-d' oie" das avenidas Sul e Leste. È interessante notar que no desenho desse setor a expansão portuária ${ }^{64}$ — “seja nas mesmas condições de cais do porto, seja servindo apenas para embarcações de menor calado" - tenha sido considerada mais detidamente. Saturnino argumentava que "uma faixa do litoral será certamente ocupada pelos armazéns e pelos estabelecimentos industriais, e estes gêneros de construções não admitem os devaneios artísticos do "pistolet"; o que se quer é a linha reta, formando blocos regulares"65 e que seria portanto "de todo infeliz a idéia que se teve de instalar nesta praia uma vila operária; esta ficará melhor situada entre a Avenida da Barra e os quarteirões destinados aos armazéns e aos estabelecimentos industrais". Já se pôde observar que, apesar da variedade das funções previstas, a argumentação limita-se à posição relativa dos edifícios dentro de uma malha conformada por ruas de largura uniforme e quadras de geometria absolutamente homogênea. A ocupação tardia da Barra (refletindo questões de partição fundiária e mesmo a relativa desvalorização desta porção da ilha) daria ensejo a outras hipóteses de desenvolvimento. No Plano Regional de Santos, embora defendendo a expansão portuária em ambas margens do estuário, particularmente para este trecho, Maia advertia sobre o "incoveniente urbanístico" de aproximar demais o porto da zona residencial em formação. Por outro lado entendia que além de impedir "uma pitoresca vista da (futura) zona portuária fronteira", este prolongamento poderia agravar ainda mais a travessia do tráfego ferroviário ao longo de toda a faixa portuária, já congestionada”" ${ }^{\circ}$.

Da mesma forma que as avenidas (Leste e Sul), bem como as diagonais propostas por Brito, não foram implantadas, ou quando o foram, seriam de forma distorcida (alterando-se, com excessão ao que diz respeito à avenida litorânea, seja sua posição, seja seus atributos paisagísticos), na Barra o porto 
não só ocupou a faixa estuarina, como quando o fez, concentrou aí grande parte do movimentação agro-exportadora, fazendo com que ocorresem grandes conflitos entre as atividades e circulação intererssadas a esse movimentação e os tecidos residenciais.

Mas de forma geral, a estrutura viária da porção leste da ilha demonstra certa coerência interna e organização em função do traçado dos canais que, precedendo o surto imobiliário dos anos 50 e 60, suportou e conferiu clareza à organização espacial. Assim, o resultado da implantação, mesmo que parcial, do plano de Brito é que a estrutura urbana passou a ter uma configuração de grade, com os canais assumindo, por sua dimensão e por sua disposição espacial, o papel de vias "arteriais" (canais 1 e 2) e "coletoras" (3, 4, 5 e 6) na hierarquia viária. Dentro dessas estrutura prevalecem sobretudo os corredores da direção Norte-Sul (ligação centro-praias), principalmente os definidos pelas Avenidas Ana Costa e Conselheiro Nébias e canais. No sentido Leste-Oeste, o bloqueio interposto pela linha férrea da antiga Sorocabana, que atravessa a ilha longitudinalmente, prejudicando a continuidade das vias secundárias na direção Norte-Sul e dificultando a utilização de sua via marginal, reforça o desempenho dos corredores Norte-Sul, não só pela obrigatoriedade de circulação através de segmentos quebrados como pela falta de outra alternativa.

Se, a porção leste apresenta certa coerência e legibilidade dos traçados viários, o lado oeste, seja em Santos, seja em São Vicente, ou ainda, do outro lado do estuário, na ilha de Santo Amaro, Vicente de Carvalho, dada a ocupação através de operações fragmentadas de loteamentos e na ausência de um plano prévio, o sistema de traçados apresenta-se segundo tramas descaracterizadas e descontínuas, vinculadas em grande medida como são, sem mediação hierárquica, às vias regionais.

Por outro lado, a articulação leste-oeste, quer seja no nível intra-urbano quer seja com o sistema territorial, dada à presença do maciço, que se localiza tranversalmente na ilha, é limitada às suas bordas norte e sul, sendo que na parte central ela se faz precariamente pelo morro de Nova Cintra. Incluindo a questão da interligação das margens do estuário, a magnitude do problema da interrupção da trama urbana e estrangulamento das saídas da cidade talvez possa ser avaliada não só pelo volume de estudos realizados quanto pelas dificuldades que cercam a realização das alternativas de sua solução. E na medida em que esse problema envolve a sobreposição e as formas de articulação dos sistemas territoriais e urbanos, particularmente tendo em vista as questões portuárias e metropolitanas, parece importante deter-se sobre os estudos e alternativas concebidos desde pelo menos os anos 20 .

Desde o plano elabrado pela Cia. Docas em 1926, a questão do tráfego portuário, tanto no que se refere à interferência com o sistema urbano quanto 
à articulação com o sitema territorial, tem sido objeto de projetos que buscam enfrentar as dificuldades de superação das condições interpostas pela geomorfologia da Baixada à integração de suas diversas partes. Se o sistema viário regional, como se viu, apresenta distintas e bastante caracterizadas fases de implantação (segundo as escalas dos interesses econômicos presentes na Baixada), sua articulação com o sistema urbano e portuário de Santos tem sido inevitavelmente constrangida pelos morros e pelo estuário. A superação destes pontos de estrangulamento deu-se pela construção das pontes sobre o Mar Pequeno (Ponte Pênsil) e sobre os canais do Casqueiro (Anchieta e Av. Bandeirantes), do Pompeba e Mar Grande (Imigrantes) e de Bertioga (ferrovia). No entanto, pode-se ainda elencar os seguintes estudos:

1926-Cia Docas: Saboó-Barnabé-Itapema

1947-P. Maia: ponte rodo -ferroviária Saboó - Barnabé - Monte Cabrão Santo Amaro e ponte Vila Matias/Macuco-Santo Amaro ${ }^{67}$ (tramway e veículo particulares)

1993- DERSA: ligação em túnel Santos-Guarujá pela Av. Xavier Pinheiro, complementada pela implantação das ligações Xavier da Silveira e Ferryboat ${ }^{68}$,possibilitando o tráfego diferenciado (portuário, comercial e de massa)

$1987^{69}$ - Codesp: "Retão" da Alamôa/Ilha dos Bagres

Curva do Paquetá/Base Aérea

Outeirinhos/Vicente de Carvalho (Santos Dumont)

Ponta da Praia/Conceiçãozinha

Prefeitura Municipal: Valongo/Ilha Barnabé

1997-Codesp: ligação em túnel pela rua Almirante Tamandaré, articulada à avenida portuária em torno da bacia do Macuco, e seguindo, em Vicente de Carvalho pela linha de transmissão de Itatinga

1997- Figueirdo Ferraz: desenvolvimento da proposta da Codesp de $1997^{70}$ 1998-Codesp- em túnel, na altura do cruzamento entre Xavier Pinheiro e av. Portuária, da qual deriva tangencialmente em direção também à linha de transmissão em Vicente de Carvalho.

Por outro lado, a limitação natural imposta pela barreira representada pelos morros, constrangindo a norte e a sul os pontos de contato entre as duas porções da ilha, levou à solução em túnel Valongo-Jabaquara, no sentido de desviar da área central parte do tráfego de entrada da cidade. No entanto, face à existência de novas alternativas de ligação do Sistema Anchieta/Imigrantes a São Vicente e Santos, e sobretudo diante do processo de metropolização em curso, tem sido ao menos aventada a hipótese da construção de túnel que, atravessando o maciço segundo sua linha de menor secção, permitria novo eixo de conexão às vias regionais e às estruturas urbanas situadas a leste e a sul. Neste mesmo sentido, tendo em vista o grande volume de viagens (117.000/dia), que se realizam entre Praia Grande, São Vicente, Cubatão e Santos, estudos sobre o aperfeiçoamento do sistema ferroviário datam do fim da década de 80. Através de projeto de integração das antigas RFFSA e 
FEPASA $-3^{\circ}$ trilho e acesso ao terminal intermodal de Alemoa, o que, também, evitaria o tráfego de composição de cargas ao longo da zona leste-, a liberação da linha da antiga Sorocabana permitiria a implantação de sistema de Veículo Leve sobre Trilhos - VLT — de ligação entre Samaritá e o Macuco, podendo integrar-se à malha ferroviária da Codesp e assim alcançar o cais Valongo-Paquetá. "Entre Samaritá e Peruíbe, de um lado, e Valongo e Cubatão de outro, a extensão do sistema poderia ser realizada pelo próprio Trem Inter-metroplitano — TIM—, aos moldes dos trens de suburbio"

Para concluir a análise do sistema de mobilidade da Região Metropolitana, a questão da interface cidade/porto tem na configuração da Avenida Portuária, sua referência imediata. Projeto concebido pela Portobrás ${ }^{72}$ em 1973, para dar apoio aos terminais de granéis que integram os corredores de exportação, a série de indefinições que têm marcado as fase de sua implantação, iniciada dois anos depois, pode ser caracterizada pelos vários traçados planejados. Problemas com recursos financeiros, desapropriações, interligações, competências, etc não permitiram que, até 1977, dos 11,6 quilometros da pista (sendo 1,7 mil metros em forma de viadutos), previstos para margear o cais, mais de 4.000 metros fossem realizados da Ponta da Praia até o Macuco (na altura do canal 4). Posteriormente seriam concluidos os trechos Alemoa-Saboó (1.400 metros), Valongo-Paquetá (1,800 metros). Em 1982, seria inaugurado o Corredor Norte, e em 1987 o "Retão" de Alamôa, compondo um complexo de pistas, pontes e viadutos (destinados a favorecer o trânsito dos caminhões que procedem do porto, em direção da Via Anchieta, e vice-versa), destinados a liberar a malha viária de Santos do tráfego pesado e aliviá-la, pelo acesso direto dos caminhões ao porto, "da incômoda poluição sonora e ambiental provocada pelos caminhões" ‘s . Paradoxalmente, pelo novo traçado, apresentado em 1997 pela Codesp-Paeps, "para desviar o trânsito urbano, que circula no porto (através da av. Eduardo Guinle), e para possibilitar o adensamento e aumentar áreas arrendatárias à iniciativa privada" ${ }^{4}$, o trecho a implantar "ficará mais perto da área urbana, afastando-se do cais"

Imagem da autonomia e do caráter impositivo com que a administração portuária sempre tratou as questões urbanas, talvez possa ser sintetizada por um projeto da Avenida Portuária, que contrariando a lei 3.529 de 16 de abril de 1968 (Plano Diretor Físico da Cidade), anvançava sobre ruas pertencentes à Zona Mista Leste (não estando portanto incluídas na Zona Portuária), configurando-se, segundo A Tribuna de 8/11/1975, “uma nova invasão da área urbana do município, representando cerca de 8 por cento de ocupação ilegítima da Ilha de São Vicente, que só poderá ser tornada legal se for alterado o plano Diretor Físico." Nesta ocasião a Prodesan, segundo o mesmo jornal, desconhecendo oficialamente o novo traçado, assim se manifestava pelas palavras de seu engenheiro-diretor: ... "em função do projeto anterior da Avenida Portuária, elaborado no tempo do Coseps, é que a Prodesan projetou o sistema viário à entrada da cidade, onde se incluem o elevado e o viaduto do 
Monte Serrat. Se o traçado da Portuária mudar, logicamente o sistema viário da Cidade deverá ser alterado".

Se o traçado da Portuária, como se viu, até hoje permanece problema sem definição física e sem alternativa financeira, o certo é que mesmo nos trechos onde este traçado encontra-se implantado, à falta de terminal intermodal de carga, que regule a entrada de veículos pesados na trama urbana, sérios problemas de congestionamento, degradação de vias e poluição não encontram solução ${ }^{76}$.

Territorialidades: os sistemas da residência e da produção A expansão residencial

Em 1873, Wallace da Gama Cochrane ${ }^{77}$, em relatório apresentado à Câmara Municipal em 1873, dando conta dos desdobramentos que a articulação ferroviária induzia, escreveu: "é incontestável o rápido desenvolvimento que vai tendo esse importante município; sua população cresce, e cada dia mais se ressente da falta de casas; a cidade tende a estender-se necessáriamentte para o bairro do Quartel (a leste do núcleo original) e em direção à Barra (a sul)”.

Se a cidade crescia a leste e para o sul, a planta elaborada por Araújo $\mathrm{F}^{\mathrm{o}}$, mapeando os cortiços existentes na cidade de Santos entre 1880 e 1889, mostra que este tipo de habitação proliferava-se sobre toda a área da primeira expansão da cidade, segundo uma mancha que envolveria o núcleo original, desde a rua de São Bento até a Alfândega, da Rua General Câmara até as franjas do Monte Serrat. As obras de construção do porto, e a consequente demanda por trabalhadores, não só colaboraria para o adensamento e precariedade das habitações nos tecidos mais antigos da cidade como também implicaria na expansão da área urbana. Se a maioria da população dos cortiços era composta de "trabalhadores do cais, estradas de ferro, estivadores, porque a habitação é mais barata e mais perto do trabalho"rs e ainda que, mais tarde, haja menção sobre a existência de vilas residenciais construídas pela Companhia Docas para seus trabalhadores no Jabaquara e no Outeirinhos ${ }^{79}$, os novos bairros que seriam abertos, Macuco e Vila Matias, seriam ocupados, essencialmente, por habitações populares e "médias", também destinadas aos trabalhadores do cais.

O segmentos de renda mais alta ocuparam em um primeiro momento o Paquetá $^{80}$. O prolongamento do cais e a construção do cemitério contribuiram para desvalorizar o bairro, que seria suplantado pela Vila Nova, onde, principalmente junto à avenida Conselheiro Nébias, aqueles segmentos construíram seus palacetes art-noveau. O seu deslocamento definitivo para a orla viria na esteira do saneamento da cidade, da melhoria da circulação urbana, proporcionada pelas linhas de bonde, e da expansão da área comercial (que requisitaria os antigos edifícios residenciais para novas funções); tudo isto 
contribuiu para que os mais ricos elegessem a faixa da praia como lugar de moradia, ocupando, pelo loteamento de grandes glebas no Gonzaga, José Menino e Boqueirão, as antigas chácaras de veraneio.

Assim é que sobre estrutura física definida pelos canais e polarizada pela praia, vão distribuir-se, segundo faixas paralelas a partir da orla, os lugares de residência dos segmentos sociais segundo suas rendas. A primeira faixa litorânea, antes lugar preferencial de residência dos segmentos sociais locais de alta renda, vai, a partir dos anos 50, transformar-se tipológicamente, através da verticalização das edificações, para atender a demanda turística de segunda residência, deslocando, assim, para as quadras posteriores a residência das elites sociais locais. Se este processo, foi conduzido em um primeiro momento por empresas construtoras da capital, determinando o "tipo" das edificações e as formas de aprveitamento do solo, nos anos 70, retomadas as atividades do setor da construção civil depois do esgotamento do mercado turístico, os edifícios passsariam a ter características diferentes (maior tamanho de apartamentos, taxas de ocupação menores) no sentido de atender (agora por parte de empresas santistas) a demanda local ${ }^{81}$.

A residência da classe média ocupará, como já se observou toda a coroa intermediária da estrutura urbana. Em um primeiro momento, por iniciativa de empresas construtoras locais, substituindo os antigos chalés ou casas de alvenaria (construídas no alinhamento e com porão alto) por casas térreas e sobrados mais amplos. Depois, como resposta ao crescimento da população, uma nova substituição iria suceder. Ditada pelas leis de mercado e impulsionada e estimulada pelas normativas urbanas de 1968 que entendiam como positivo o adensamento da zona leste, este processo adotaria, ao lado da verticalização da faixa praiana, um padrão tipológico bastante homogêneo, agora difundido no "prédinho de 3 andares"

Este processo de ocupação obrigaria o deslocamento de segmentos populares que, á excessão de certas zonas encravadas neste tecido intermediário, vão ser obrigados a assentar-se sobre novas áreas criadas fora dos limites urbanos consolidados. Segundo as palavras de Araújo F F $^{\mathbf{1}}(1965,38)$,

foi assim que "áreas dos morros, até uns vinte anos atrás, fracamente ocupadas, transformaram-se em densos bairros operários (Penha, Fontana, Nova Sintra), e áreas de várzeas, porém, de além-Maciço Santista, passsaram a se transformar em bairros operários, como Chico de Paula, Areia Branca, Matadouro, ainda no município de Santos, e Vila São Jorge, Vila Jóquei Clube, Vila Paríso, etc., no município de São Vicente; sem falar no extravasamento, para a ilha de Santo Amaro, defronte ao cais do Paquetá, no atual bairro de Vicente de Carvalho". 
Assim, aparentemente menos condicionado pelo avanço das áreas turísticas (como defendido pelo PPDI 78), mas inerente à lógica própria do mercado imobiliário, tem-se o fato do crescimento da população regional, principalmente aquele que se refere às camadas de menor renda, ser absorvido fora do bloco urbano Santos-São Vicente, como ocorrrera até a década de 50. Neste sentido, como já mencionado, ao lado da ocupação da porção oeste da ilha — que se intensifica—, verifica-se também a ocupação, neste caso, sob a forma de invasão, dos terrenos situados em ampla faixa da margem esquerda do estuário. Impulsionados pelo desmoronamento dos morros em $1956 \mathrm{e}$ seguidos por uma limitada ação urbanizadora, promovida pela atuação governamental do IPESP ${ }^{\text {s3 }}$, a quem competiu desapropriar uma gleba de 220 ha e normalizar a presença dos ocupantes, essa ocupação faria do distrito de Vicente de Carvalho ${ }^{84}$ cidade dormitório de Santos, conectada à sua trama urbana por precário serviço de barcas.

Este processo, atuando em cadeia, ocupação / equipamento / verticalização / expulsão, incidindo nos bairro de mais nova formação (inclusive através de programas de nível federal, como o CURA), iria responder não só pelo crescimento dos município vizinhos, mas também pela ocupação de áreas impróprias e manter-se-ia ativo não só pela especulação com solo residencial, mas também pela requisição de terrenos centrais para a expansão das áreas comerciais e portuárias. $\mathrm{O}$ crescimento populacional dos muncípios da Baixada pode ser examinado pelo gráfico abaixo.

\begin{tabular}{|l|l|l|l|l|l|}
\hline População & Santos $^{85}$ & S. Vicente & Guarujá & Cubatão & P. Grande \\
\hline 1970 & 345.630 & 116.485 & 93.963 & 50.906 & 19.694 \\
\hline 1991 & 417.100 & 268.730 & 210.268 & 91.048 & 122.104 \\
\hline
\end{tabular}

Quanto à Santos, já nos finais da década de 70, tanto a área central (que nunca constituiu lugar preferencial para a moradia, abrigando no período apenas $3 \%$ da população ${ }^{86}$ ), quanto a Vila Nova e a Vila Matias (25\% do total), davam sinais de decrescimo do contingente populacional acompanhado de deterioração das condições residenciais. "Ali, antigas casas e casarões são divididos ao máximo para abrigar, em regime de sub-habitação, população de baixa renda, sendo esta uma das poucas opções de permanência destes estratos dentro da ilha" ${ }^{87}$. Neste sentido, o zoneamento que vigorou desde 1968 por 30 anos, ao definir essas áreas como Zonas Comerciais, impedindo nelas a construção residencial, acabou por contribuir enormememente com o seu processo de marginalização ou de "periferização interna". No início da década de 1990, como se viu, as iniciativas adotadas pela administração municipal de esquerda, para enfrentar as distorções alimentadas por este processo, resultaram na lei que contemplava normas específicas para a 
implantação de projetos habitacionais de interesse social, possibilitando "implantar melhorias ou realizar regularização fundiária em favelas, loteamentos irregulares ou clandestinos, cortiços e terrenos vazios ou mal utilizados”. No caso da ZEIS de Vila Nova e Vila Matias, que prevê contrapartidas em termos de potencial construtivo para empreendimentos residenciais realizados nas áreas e destinados à população moradora de baixa renda, no entanto, tavez à falta da definição de hipóteses operativas, pouco resultado foi obtido, sendo mantida no Plano Diretor de 1998, que, ademais, para o restante das zonas centrais passa a incentivar a instalação do uso residencial.

Se, como observado, as leis de zoneamento "reservaram" áreas de uso portuário ou "misto" na porção leste da ilha, sua ocupação efetiva por instalações de atividades retroportuáriase parece ter emergido com mais força em meados dos anos 80 pois, o PPDI de 1978 constatava que os setores de apoio do porto (transporte, comunicação e armazenagem), não devendo crescer senão a taxas baixas, teriam sua expansão contidas nos limites das áreas onde até então se encontravam — ZH1/Valongo e ZH3/Paquetá. Esta previsão talvez se ligue ao entendimento, expresso naquele documento, de que estaria esgotada a primeira fase da industrialização induzida pelo porto (com a implantação de estabelecimentos voltados para o mercado da própria Baixada). A transformação do porto comercial em porto industrial (importador de insumos industriais) teria provocado o gradativo desvinculamento de suas atividades de Santos, no sentido de estar polarizado pelas atividades industriais metropolitanas. No entanto, a indústria da conteneirização e a implantação do terminal graneleiro do "corredor de exportação" na Ponta da Praia acabariam atraindo a instalação de atividades que, aproveitando-se da permissividade da legislação, ocupariam amplos setores da faixa sudeste da ilha. O Plano Diretor de 1998 não só ratifica a ocupação anterior como, apesar de ter diminuido os limites da antiga "zona mista", inclui outras no traçado da atual "Zona Portuária", causando o protesto de moradores vizinhos, na medida em que os "transtornos provocados pelas transportadoras e pátios de contèiners (...) poderá se agravar com as mudanças propostas"в8.

Seja como for, mesmo considerando a importância sócio-econômica que o porto representa para a cidade, deve-se notar a crescente incompatibilidade entre as instalações e atividades portuárias e a forma e a vida urbana. Este conflito evidencia-se quando se observa o grande decréscimo da densidade populacional de áreas contíguas ao porto. Comparando dados demográficos relativos às décadas de 60 e 90 tem-se, face a uma dinâmica de aumento da densidade geral da cidade de 86,2 hab/ha em 1968 para 105,48 hab/ha em 1991, o seguinte quadro para os bairros: 


\begin{tabular}{|c|l|l|l|l|l|l|}
\hline $\begin{array}{c}\text { Ano } \\
/\end{array}$ & Centro & Valongo & Paquetá & V. Nova & Macuco & Estuário \\
\hline 1968 & 86 & 108 & 129 & 178 & 143 & 131 \\
\hline 1991 & 17,3 & 19,77 & 60,15 & 103,96 & 120,75 & 138,81 \\
\hline
\end{tabular}

Se estes números referem-se a bairros inteiros, portanto incluindo áreas não diretamente afetadas pelas atividades retroportuárias, um estudo realizado pela Prefeitra Municipal de Santos ${ }^{89}$ relativo à concentração da indústria do contêiner na cidade, indica que a evolução das densidades demográficas, nas áreas diretamente afetadas (uma faixa de profundidade média de $500 \mathrm{~m}$ desde o Paquetá até a Ponta da Praia), obedeceria a uma curva decrescente muito mais acentudada. A razão da "expulsão" da residência em áreas contíguas ao porto é a necessidade de espaço livre ( $3 \mathrm{~m}^{2}$ por TEU) para a movimentação da carga conteneirizada: assim essas áreas têm sido gradualmente "evacuadas para dar lugar àquelas empresas (compreendendo armazenagem, oficinas de reparos e terminais em terra, alfandegados ou não). Segundo Gazal (1989, 47), à medida que o TECOM, decorridos apenas sete anos de sua entrada em operação (1981), atingira sua máxima capacidade operacional (sendo que esta representava apenas $35 \%$ do tráfego conteneirizado do porto), "um crescente número de navios transportando contêiners, além de outras cargas não unitizadas, continuou a atracar na margem direita (cais convencional)". A progressiva (e até "recentemente imprevista") necessidade de espaço físico causou um forte impacto ambiental nas áreas adjacentes ao porto. "Grande parte destas áreas - mais de 10\%— foi ocupada por firmas diretamente ligadas à operação com conteiner". Assim fora a ocupação propriamente dita do espaço físico de antigos lotes residenciais, os impactos ambientais, "ruidos gerados, por uso inadequado — equipamento subdimensionado—, tráfego excessivo, estacionamento irregular em áreas residenciais, ameaças devidas ao transporte de cargas perigosas, sem mencionar congestionamento de tráfego em horas de pico" resultam em "situação constrangedora entre a atividade portuária e a vida da cidade que com o porto convive" ". As contradições entre o porto moderno e a cidade resultam na própria ineficiência operacional do primeiro, pois é próprio à lógica do contêiner a fluidez da movimentação, o que implica conexão direta das areas portuárias aos sistemas territoriais intermodais de transporte. Ao mesmo tempo, os conflitos conjunturais demonstram a incompatibilidade absoluta entre o porto moderno a forma $\mathrm{e}$ vida urbanas: cada vez mais "conteneirizado", o funcionamento portuário, implicando no aparecimento de atividades em terra, com nível industrial, passa a exigir amplas e vastas áreas de retaguarda, que no caso de Santos, em grande medida têm sido representadas pela própria área urbana

\section{O sistema da produção}

O desdobramento das atividades portuárias sobre a industrialização da Baixada 
Santista em geral e sobre Santos em particular, talvez possa ser flagrada segundo três períodos distintos. A primeira fase, que iria até 1955, caracterizou-se pela instalação de indústrias tradicionais (alimentação, principalmente), que, aproveitando-se das externalidades geradas pelo porto (facilidade de abastecimento de matéria-prima, armazenagem em silos construídos nas áreas portuárias e logística de transporte), teriam âmbito de atendimento à escala regional e implantação preferencialmente urbana, funcionando como atividade de apoio à função residencial e à evolução urbana. Afora o setor de armazenagem exigidas pelo comércio do café cujas instalações predominantemente localizaram-se junto à estação ferroviária, as grandes unidades fabrís (Moinho Paulista, Moinho Santista, Cia União dos Refinadores, Cia Usinas Nacionais, Moinho Faria, etc), implantar-se-iam nos bairros do Paquetá e do Macuco, enquanto a indústria voltada à produção pesqueira seria localizada na Ponta da Praia, junto ao terminal e entreposto Cibrazem.

O período seguinte caracteriza-se pela industrialização pesada (petróleo e aço) que se implantaria em Cubatão, "com uso do solo extensivo e implantadas em áreas de topografia pouco acidentada, o mais perto possível da infra-estrutura de transportes disponível e, em alguns casos, junto a canais com potencial para a construção de terminais marítimos próprios, como é o caso da Cosipa e Ultrafértil". ${ }^{11}$ Com excessão do último fator locacional —a possibilidade de terminais, que acabariam, em uma primeira etapa, não correspondendo às previsões do abastecimento de matéria-prima via marítima-, todos os outros estariam melhor disponibilizados no Planalto, onde na verdade localizava-se o centro consumidor da produção industrial da Baixada.

A pouca expressão do valor da produção industrial do município de Santos, correspondendo a apenas 1,09\% da produção estadual nos anos 60, levaria o documento do Plano Diretor de 1968 a defender uma maior diversificação econômica, que pudesse equilibrar o peso das atividades portuárias (11.000 postos de trabalho, representando 35.000 dependentes ou $10 \%$ da população) e de turismo, já que a industrialização de Cubatão não favorecia Santos. Motivados pelo objetivos de contrapor-se aos sintomas de estagnação de uma economia fortemente terciária como a santista ${ }^{92}$, estudos ${ }^{93}$ realizados no final da década de 1960 analisavam a viabilidade de implantação de um distrito industrial de 871 ha (primeira fase, 169 ha) na região do rio Quilombo, tendo em vista, a disponibilidade de solo, a proximidade de Cubatão — que estaria com a área disponível comprometida—, bem como das vias regionais de transporte rodo e ferroviário. Porém, como se viu, a política de desconcentração industrial, um dos argumentos utilizados para demonstrar a viabilidade da alternativa santista, reorientaria os investimentos para outras regiões do Estado.

Neste sentido, em 1976, constatando a tendência de crescimento negativo das 
indústrias de pequeno e médio porte (relativas ao primeiro desenvolvimento industrial), bem como um certo esgotamento de crescimento industrial da Baixada, o que, no entanto, não teria representado "estancamento do progresso do município", os estudos prévios para a elaboração do PPDI definiam como problemática a idéia de "um forte desenvolvimento industrial de Santos" ". De forma inovadora face aos cânones do planejamento da época (ao eleger o setor terciário como principal pilar de sustentação econômica), os estudos do PPDI de 1976 argumentavam que o fato do espaço econômico de Cubatão (que ampliara-se na década de 70) "desdobrar-se" (apenas com prejuízo dos tributos municipais) sobre o de Santos, faria essa "drenar" sob a forma de bens e serviços parte da renda gerada pela Refinaria, pela Cosipa e pelas outras indústrias. O desenvolvimento de Santos deveria apoiar-se portanto na reafirmação de sua condição de pólo regional, atendendo às atividades de apoio ao porto e às indústrias regionais e concentrando os serviços especializados.

Mesmo porque, transformado em "industrial", isto é, importador de insumos industriais, o porto de Santos, a não ser pela geração de empregos diretos e indiretos ${ }^{95}$, tornar-se-ia cada vez mais desvinculado economicamente da cidade. No entanto, a tentativa de maior integração das funções portuárias e industriais, desenhada nos planos da Codesp da década de 1980 para o "fundo do estuário", esbarraia, até pela "escala" de suas pretensões, seja em entraves decorrentes da crise e da política econômica recessiva, seja na "saturação ambiental", específica da região, desde então objeto de medidas restritivas quanto a implantação e funcionamento de indústrias poluidoras.

A terceira fase de industrialização está vinculada fundamentalmente ao processo de conteneirização que, embora mais diretamente interessado ao setor transporte, passa a exigir em nível industrial atividades relacionadas ao acondicionamento e manuseio da carga. Tais atividades retroportuárias, à excessão da já comentada invasão de áreas urbanas vizinhas ao porto no Macuco, Estuário, Vila Nova e Paquetá, reunem 320 empresas no distrito industrial de Alemoa. Mais recentemente, Cubatão preparou um plano para ocupação dos terrenos da Vila Socó e a Codesp vem defendendo a construção de uma indústria de óleo de soja no distrito industrial de Alemoa, cuja transformação em área primária, ou alfandegada, vem sendo discutida. De todo modo, a localização industrial mais ampla na Baixada Santista parece ter encontrado suas "limitações" econômicas e ambientais.

\section{Sistema ambiental}

Embora descritos mais detalhadamente no capítulo 3, referente à geomorfologia da planície litorânea, deve-se observar que os elementos definidores do sistema ambiental da Baixada Santista apresentam-se como condicionantes da descontinuidade da área urbana regional. Os morros 
separam as porções leste e oeste da cidade de Santos bem como essa de São Vicente. O estuário divide os municípios de Santos e Guarujá, assim como entre a primeira e Cubatão a existência de extensas áreas de mangues colocase como divisor das áreas urbanas. Por último tem-se que a parte continental de Santos é ocupada pela Serra do Mar.

Essa, "por ser uma unidade com formas de dissecação muito intensas, com vales de grande entalhamento, com alta densidade de drenagem e vertentes muito inclinadas, (...) apresenta um nível de fragilidade potencial muito alto, estando sujeita a processos erosivos pluvio-fluviais agressivos e movimentos

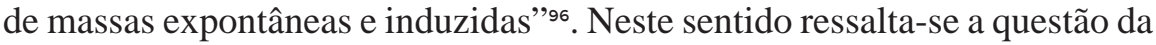
fragilidade do ambiente natural, sujeito à ação antrópica, que responde em cadeia às pertubações que afetam a estabilidade das vertentes serranas dependente da proteção da massa florestal da serrra e dos maciços isoladosbem como a integridade do sistema de mangues. Daí, como já ressaltava Araújo $^{97}$, a necessidade de se manter a estabilidade e a integridade desses elementos em função tanto dos riscos de deslizamento como da própria sobrevivência da função portuária, continuamente ameaçada de comprometimento pelo processo de assoreamento do estuário e dos canais secundários. Neste sentido, basta ter em vista os esforços de dragagem realizados pelo porto desde o começo do século, além dos conflitos e desastres ambientais provocados pela indevida oucupação de solo não adequado. A implantação da indústria pesada em Cubatão representaria um importante fator de agravamento das condições ambientais ${ }^{98}$, expondo o contraste que marca $o$ prório desenvolvimento portuário, cindido entre as necessidades de garantir a navegabilidade do estuário, a expansão das instalações e a integração da função industrial.

A partir de meados da década de 1980, normas de preservação ambiental passaram a vigorar tanto no nível federal e estadual quanto no municipal no sentido de regular e ordenar a ocupação do espaço regional, bem como o funcionamento das plantas industriais pré-existentes à essa legislação. Se seus efeitos se fizeram sentir no arrefecimento do ritmo de investimentos industriais na Baixada, os planos recentes de expansão portuária, mesmo redimensionando a escala das intervenções projetadas, como aquelas dos anos 80 referentes à implantação do Sistema Industrial Portuário de Cubatão SPIC_- parecem não se constranger por essas mesmas normas, ao preverem a ocupação futura do fundo do estuário, abrindo e dragando novos canais e retificando suas margens. Tal desenho de expansão, não só afetaria o sistema de mangues, como isolaria de forma absoluta o acesso das cidades aos canais do delta estuarino.

Mas de forma geral, no que se refere à ilha de São Vicente, a característica formal da relação entre o porto e a cidade é marcada pela inexistência de qualquer vínculo, contato ou relação física, e mesmo visual, daquela com o 
estuário. Excetuando-se as docas do Mercado da Vila Nova e da estação de barcos perto da Alfândega, pontos de embarque para a travessia SantosVicente de Carvalho, o estuário permanece completamente impermeável à cidade, obstruído pelos extensos muros da companhia portuária.

Portanto dos elementos naturais, definidores do significado da cidade, sómente os morros e a praia mantêm sua dimensão coletiva: o estuário "privatizado" e "operacionalizado" pelas docas tem, à semelhança do que ocorreu com outros canais de navegação, como por exemplo o rio Maas de Roterdã, apenas o sentido de meio de produção.

\section{O sistema de centralidades}

A função comercial do antigo núcleo do Valongo ver-se-ia reforçada pela intensificação do comércio exportador e pelo início da construção da ferrovia em 1860. Não só este trecho da frente marítima seria objeto de autorização para a construção de pontes e aterrados, como a antiga área de mangues "Ilhota" - seria ocupada pelas casas comissárias e exportadoras, bancos e consulados. As antigas Ruas Direita e Antonina (hoje 15 de Novembro) e Santo Antonio (hoje do Comércio), passagem obrigatório entre o Valongo e o Outeirinhos reafirmam seu papel de eixo comercial, ligando a estação ferroviária à Alfândega e à Praça da República (a primeira construída no local outrora ocupado pelo "convento dos Jesuítas" — já desapropriado em 1765 para abrigar funções de administração- — a segunda, ampliada pela demolição do edifício da Matriz). Segundo Lanna ${ }^{99}$ :

Todos esses novos espaços foram circundados por ruas que arruadas, calçadas e com construções alinhadas (as platibandas e sacadas em ferro substituindo os antigos beirais) deveriam servir para as atividades eos encontros desta cidade moderna. A antiga Rua Direita transformou-se num elegante bulevard, de não mais que 300 metros, agora com o nome de XV de Novembro. Lojas com vitrinas, bancos, a imponente Associação Comercial, calçadas que separavam o tráfego da rua e o das pessoas compunham o cenário desta via que era um dos orgulhos locais e um dos mais evidentes sinais das forças de transformação por que passava a cidade".

A área compreendida entre a estação da inglesa, onde predominam os armazéns, até a Praça Barão do Rio Branco, tendo como eixo a XV de Novembro e suas casa comissárias e bancos, definir-se-ia como verdadeiro território das operações de "manipulação e venda" do café, território esse que Araújo $\mathrm{F}^{9100}$ denominou área do "Alto Comércio do Café". A partir da 15 de Novembro e Praça Rui Barbosa, e compreendida em um primeiro momento dentro do polígono Frei Gaspar, Praças Mauá, Visconde do Rio Branco, República, Rua Brás Cubas e sopé do Monte Serrat, a atividade comercial 
varejista e os serviços em geral (repartições públicas, profissionais liberais, etc) instalar-se-iam em uma paisagem remodelada pela ampliação de praças e ruas, pela substituição dos velhos casarões por prédios e construção de novos edifícios públicos que com sua arquitetura neo-clássica buscavam exprimir a imagem da cidade enquanto maior centro cafeeiro do país. Papel esse que hoje, com a deslocamento das últimas firmas dedicadas a esse negócio, só sobrevive como legado de um passado poderoso: o edifício da "Bolsa Oficial do Café", antiga sede dos negócios do café no país, converteu-se, restaurado, no "Museu Brasileiro do Café".

Após a segunda guerra, as atividades comerciais expandiramm-se em direção ao Paquetá (mesclando-se com armazéns, moinhos de trigo, oficinas mecânicas, residências e bordéis, que viriam a substituir a antiga ocupação residencial) e à Vila Matias (comércio especializado), enquanto as profissões liberais depois de um certo esgotamento no processo de verticalização da área central, iriam, preferencialmente, ocupar os eixos de maior acessibilidade, representados pelas avenidas Conselheiro Nébias e Ana Costa. No entanto, este movimento não se faria através da irradição desde a área central, como o primeiro, que anexa novas áreas vizinhas, mas antes, dar-se-ia no sentido contrário, isto é, desde a praia em direção ao centro, repercutindo o processo de verticalização que da orla refluía para o centro.

Os pontos de contato desses eixos com a avenida litorânea definiram uma ocupação diferencida, até como suporte à segunda residência que se desenvolveu, em altura, pela orla. Tanto a redefinição dessa demanda turística, que perde fôlego, quanto o crescimento da cidade a noroeste, implicando no redirecionamento do comércio da área central, que se torna mais voltado ao consumo popular, precisamente por ela tornar-se o principal ponto de articulação entre as zonas leste e oeste da cidade, fizeram com que, em torno daqueles mesmos pontos, porém com mais força no Gonzaga, um comécio mais sofisticado, dirigido aos segmentos de rendas médias e altas locais, viesse a se estabelecer no espaço antes, hegemonicamente, voltado à população flutuante. Neste processo destacam-se a implantação do primeiro shopping center e de galerias comercias.

Por outro lado, em torno da praça do Mercado, na Vila Nova, favorecidos pela movimentação da Bacia do Mercado — ponto de atracação de pequenas embarcações, que serviam os sítios de banana da Baixada—e pela própria existência do mercado, construído em 1906 e remodelado em 1940, instalaram-se pontos de comércio varejista diversificado, casas atacadistas de produtos alimentícios e de materiais de construção, além de escritórios de firmas exportadoras de banana. A invasão pelas casas de comércio ou pequenas indústrias, as primeiras fortalecidas pela ocupação de Vicente de Carvalho, cuja população gera um fluxo obrigado pela necessidade de utilização do transporte oferecido pelas catraias (que operam na bacia, 
enquanto alternativa às balsas que atracam na Alfândega), acabou por degradar o tecido residencial, que "encortiçou-se" ou passou, a partir da década de 1970, a abrigar depósitos para a distribuição do comércio atacadista, provindo cada vez em maior parte da área metropolitana planaltina. Comércio esse que, facilitado pelas maiores diponibilidades de comunicação e transportes entre a região metropolitana e a a Baixada, encontraria outros canais regionais de distribuição, apontando para o enfraquecimento do poder polarizador de Santos, em favor de uma menor diferenciação do terciário das cidades vizinhas que passam a atender, de forma relativamente independente, as demandas básicas originadas da desconcentração populacional. Além do mais, segundo Alves dos Santos ${ }^{101}$, como se viu no capítulo 2, além de declinante, o poder polarizador de Santos, em meados da década de 1980, exercia-se sobre uma população pobre, mesmo para os parâmetros paulistas: "consequentemente o terciário santista não se destaca pela modernização ou inovação". Apesar de equipamentos modernos, os indicadores deste terciário seriam modestos, comparados com outros centros regionais. ${ }^{102}$ Apesar da falta de indicadores mais recentes, a observação recomenda reconhecer a continuidade desse processo, na medida em que ocorrrem poucos empreendimentos novos no município santista (dada a saturação da área urbana, as novas instalações ocorrem nos municípios vizinhos, seja para atender a população local, seja para atender a população metropolitana). Em relação ao terciário mais especializado (atacados, saúde, intermediação comecial), estudos ${ }^{103}$ mostram ter sido desviado para o planalto.

Seja como for, e ainda que se note um mais recente desenvolvimento de atividades terciárias de caráter não só local sobre a Avenida Afonso Pena, não parece ser difícil de reconhecer que a rede de centralidades das cidades da Baixada e de Santos em particular, tem seu elemento definidor no constrangimento físico imposto pela geomorfologia; isto na justa medida que condicionam e caracterizam as linhas e pontos de maior acessibilidade da ilhas. Assim é que, na parte mais antiga da cidade, as funções comerciais e terciárias predominam, reforçando-se, na medida que o centro passa a funcionar como ponto de contato e intermediação entre a porção leste e a oeste da ilha. Quando a ferrovia perde seu papel de principal elemento de articulação territorial, a permanência daquela “centralidade", em parte, derivará da força adquirida pela concentração, em épocas anteriores, de funções terciárias (comércio, finanças, administração) e, em parte, se dará em função do processo de crescimento noroeste da cidade, que ligado à porção leste pela "passagem" do Valongo, encontra no velho centro seu ponto de articulação com a estrutura urbana. Isto, como se viu, explica a mudança do caráter das funções deste centro, as quais, ao mesmo tempo que avançam sobre as áreas mais próximas, progressivamente voltam-se ao consumo popular. E em grande medida explica também a origem do sub-centro do Gonzaga: o entrecruzamento dos fluxos norte-sul, pela avenida Ana Costa, e leste-oeste, Av. Presidente Wilson, não só determinou a localização das funções 
anteriormente destinadas à demanda turística, quanto, depois, diante do esvaziamento daquelas, induziu ou favoreceu, pelo seu alto grau de acessibilidade e pela vizinhança da residência das classes de maior renda, $o$ aparecimento de funções de atendimento ao consumo local de nível superior, que deslocam-se do centro principal da cidade, diferenciando as formas e padrões padrão de consumo.

Da mesma forma que Santos tem sua principais centralidades localizadas sobre os pontos de entrada da cidade, São Vicente tem sua área central organizada sobre o eixo de articulação com a estrutura urbana santista e o setor comercial de Vicente de Carvalho desenvolve-se ao longo do eixo (Av. Thiago Ferreira), que liga o ponto de atracação das barcas ao interior do tecido urbano e à rodovia Piaçaguera-Guarujá.

Sendo assim, pode-se observar que o porto, em sua distintas fases históricas de expansão, só relaciona-se, mais diretamente, sobre a configuração das centralidades da cidade de Santos até os primórdios do período cafeeiro. Ainda que tenha sido antes a estação ferroviária o elemento catalizador da concentração de funções comerciais cafeeiras. A própria Alfândega, parece ter tido papel secundário na organização do espaço do núcleo urbano. $\mathrm{Na}$ verdade, como se verá, o porto moderno, como espaço crescentemente organizado em termos de especialização, acabaria constituindo um elemento separado do corpo urbano. Neste sentido pode-se observar que sómente na bacia do Mercado, um dos únicos dos pontos de contato que as instalaçãoes portuárias mantém abertos para a cidade, desenvolveu-se certa concentração de atividades diversificadas. E mesmo assim por razões estranhas ao porto. Portanto, além de cortar de maneira absoluta qualquer vínculo que a cidade pudesse manter com o estuário, as instalações portuárias induziram um desenho da interface, que moldado de forma a atender as exigências de suas operações, acabou repelindo outras funções que não as interessadas a elas mesmo.

$* * *$

Em Santos, a história econômica e social repercutiu materialmente na paisagem física de modo claro e reconhecível, fazendo perdurar no tempo suas marcas. Se a geografia física da cidade estabelece como entidade formal de grande qualidade — morros, estuário, praia — um sistema de referência morfológica definitivo e expressivo, os territórios construídos permitem individualizar seus vínculos com os diversos processos sociais e econômicos, materializando-os de maneira específica em cada situação. A arquitetura da área central - "preservada" em uma escala maior que em outra grande cidade - marca a riqueza do período cafeeiro, enquanto os canais-avenidas constituem poderosas imagens da expansão da cidade, oferecendo-se como potentes estruturas que suportaram e conferiram legibilidade às transformaçãoes urbanas sucessivas. A paisagem verticalizada da orla da praia 
evidencia os ciclos turísticos, enquanto os efeitos da industrialização de Cubatão podem ser entendidos pelos padrões diferenciados da residência "central" e periférica. As mutações da atividade portuária manifestam-se nas várias tipologias e "cenários" portuários, embora suprimindo cada vez mais pelo domínio exclusivo do estuário, o contato com a trama urbana.

É precisamente a partir do reconhecimento da identidade desta estrutura e imagem urbana, suas potencialidades e debilidades, onde se pode fundar alternativas de transformação da cidade, dectando através da geração de novas relações as oportunidades para ações inovadoras de intervenção. 
Vista (final do século XIX) do traçado da avenida Conselheiro Nébias e dos loteamantos de Vila Matias (á direita da imagem) e Macuco que se organizam em torno dela
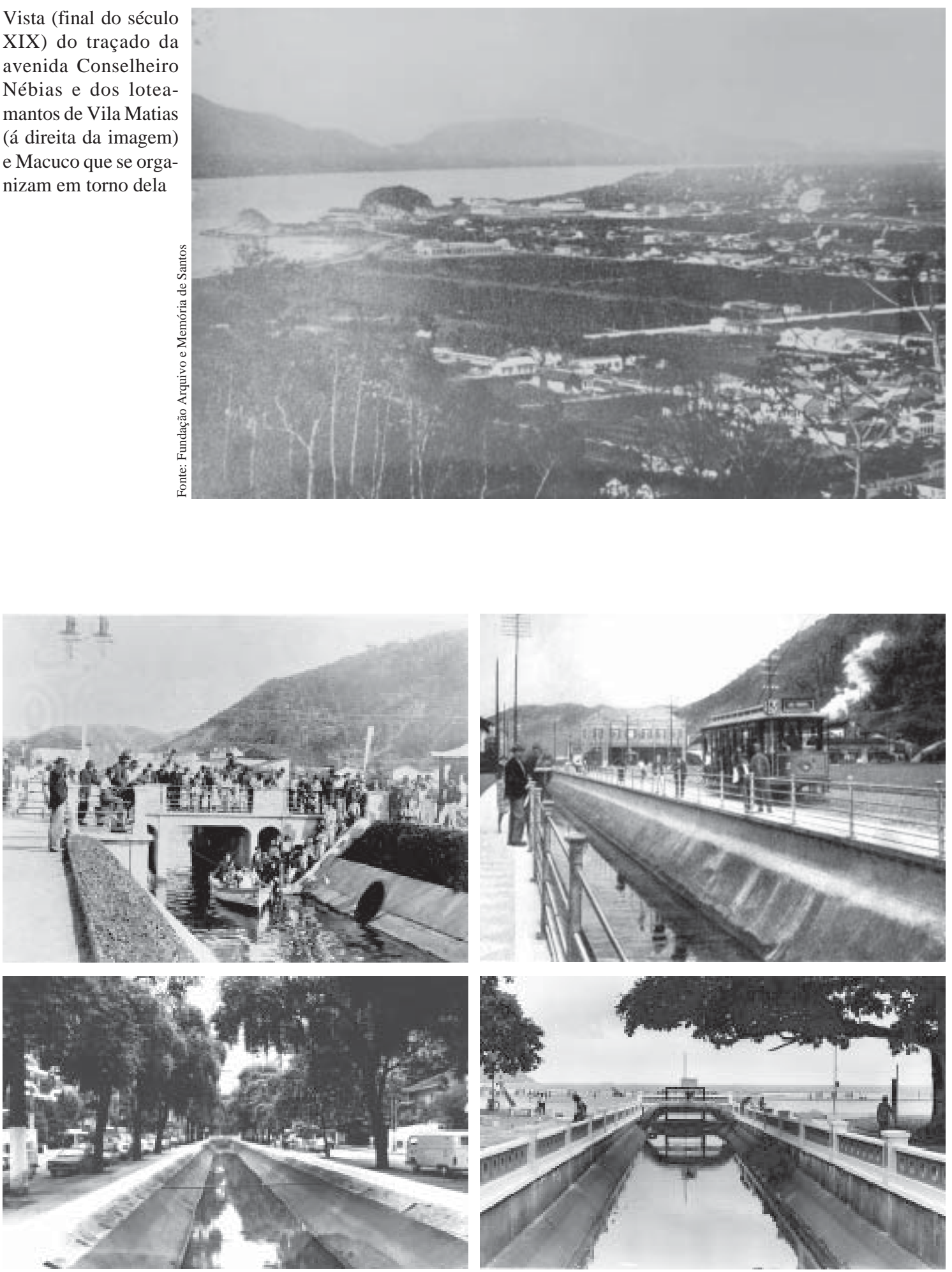

Vista dos canais do plano de Saturnino de Brito: infra-estrutura que, associando saneamento, circulação e verde, constitui a armadura do crescimento urbano a partir de 1905 


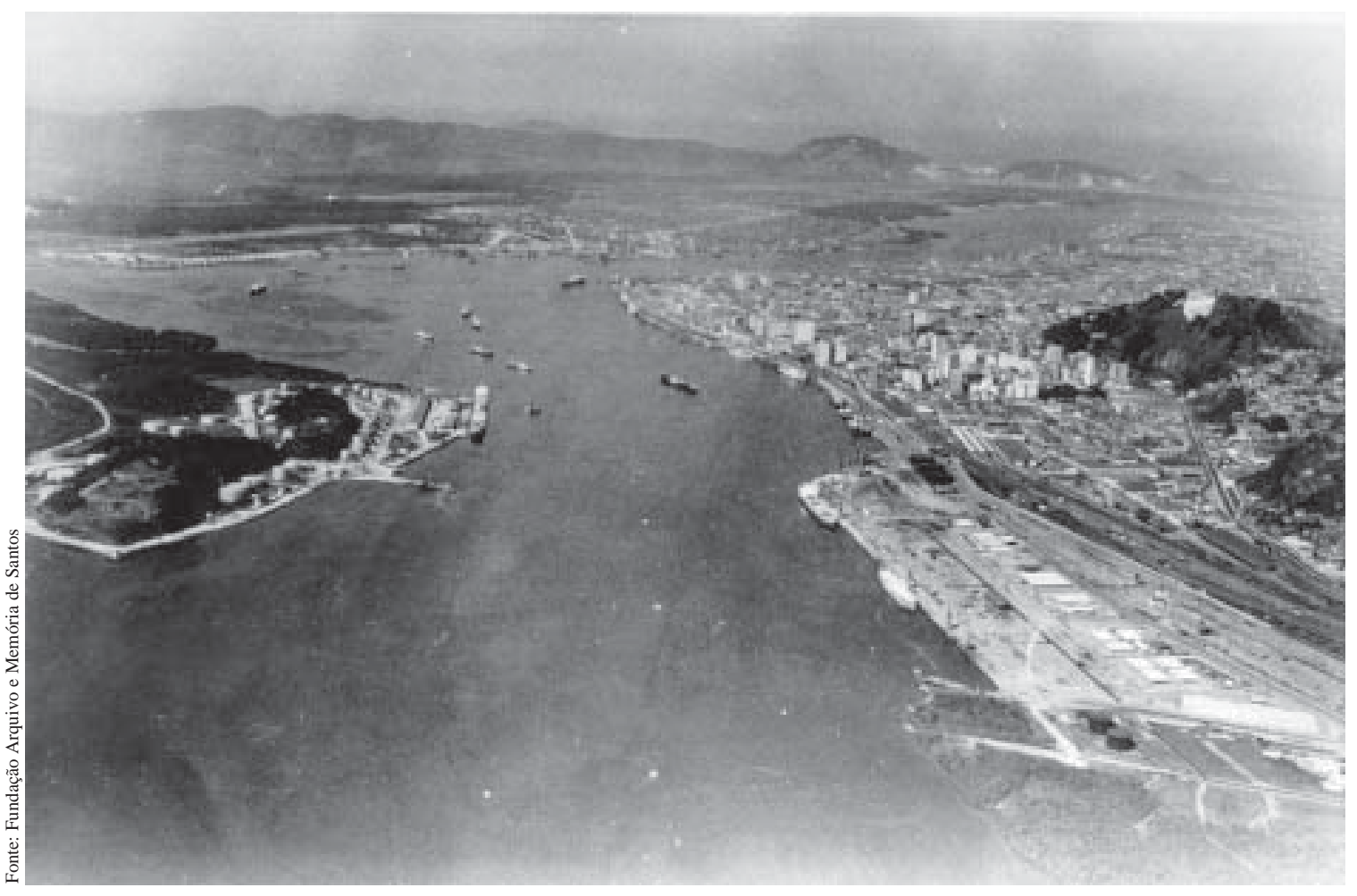

Vista da entrada da cidade: a estreita faixa entre o maciço e o estuário é ocupada pelos sistemas portuário, ferroviário e rodoviário

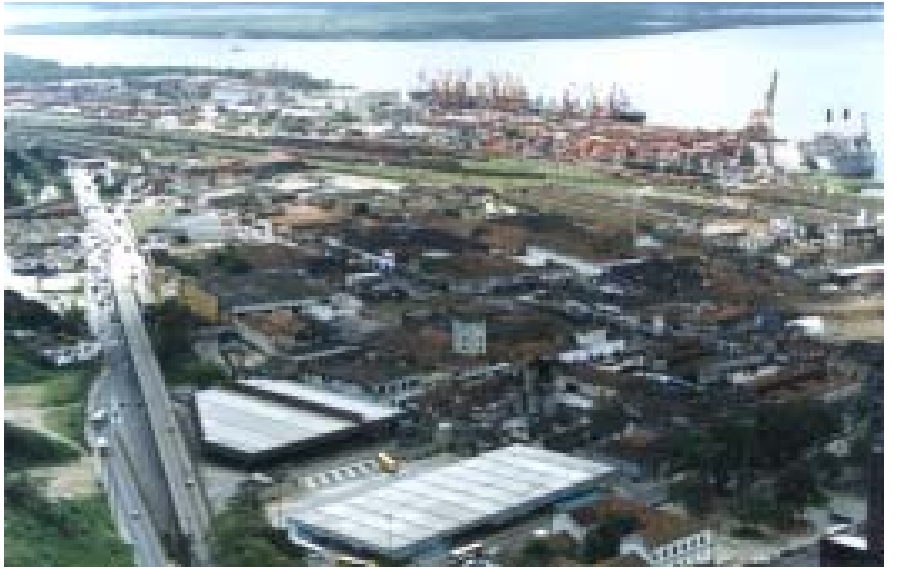


Sistema viário principal e fluxo de veículos -1976: a clareza do traçado dos canais não resolve o problema da circulação longitudinal por "segmentos quebrados". A ligação leste-oeste, no ámbito da ilha, é restrita às passagens norte e sul
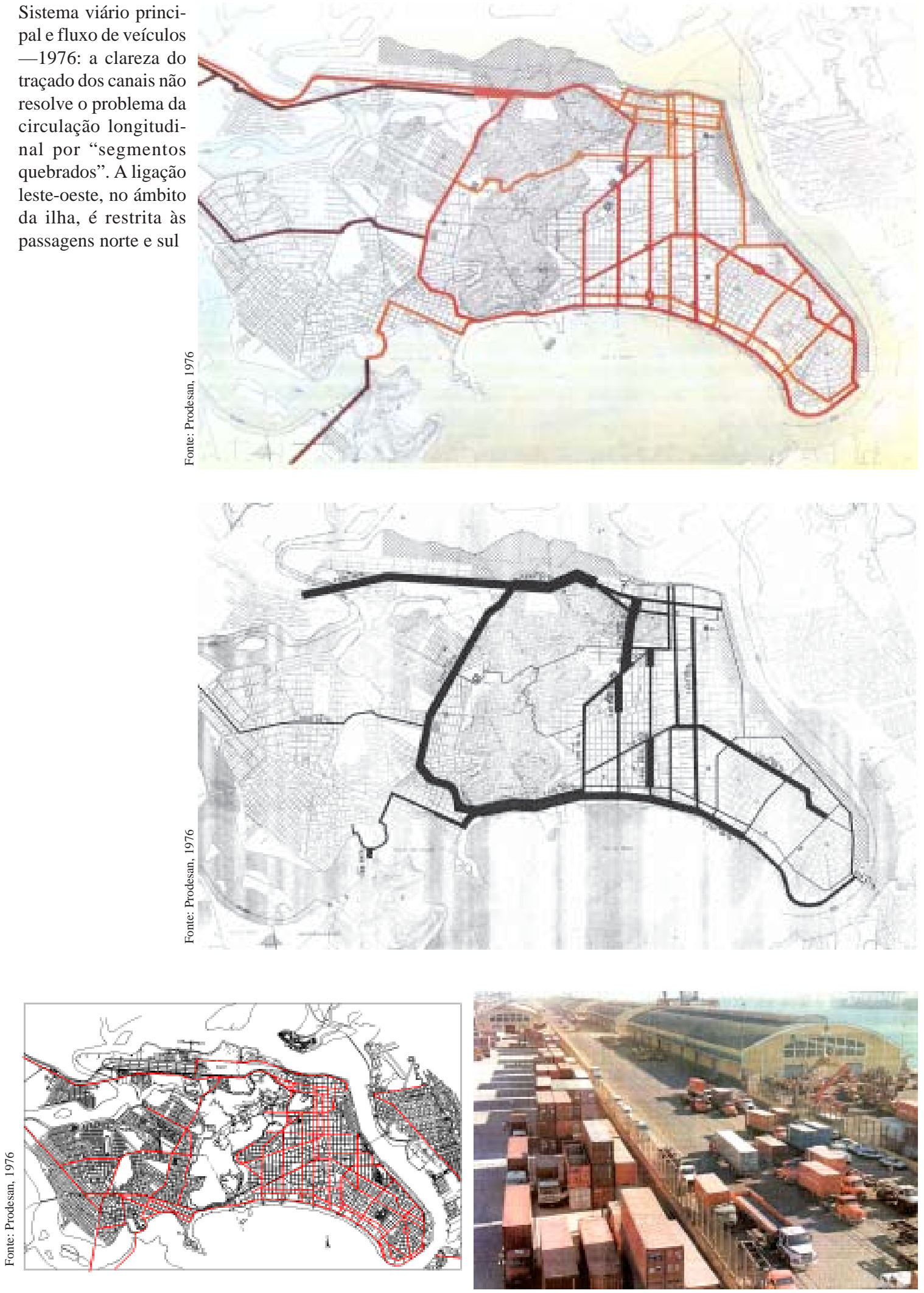

Sistema viário principal proposto pelo Plano Diretor de 1998: redimensionamento do número de vias arteriais sem resolução do problema da circulação leste-oeste. Se o "retão da Alemoa" (1987) separa o tráfego portuário do urbano na entrada da cidade, a indefinição do traçado da avenida Portuária e a falta de áreas de estacionamento e de terminais para transporte de carga causam a invasão da malha urbana pelo tráfego pesado 
Alternativas de transposição do estuário estudos da década de 1980: as ligações com o continente remetiam-se às hipóteses de implantação industrial na porção continental do município de Santos
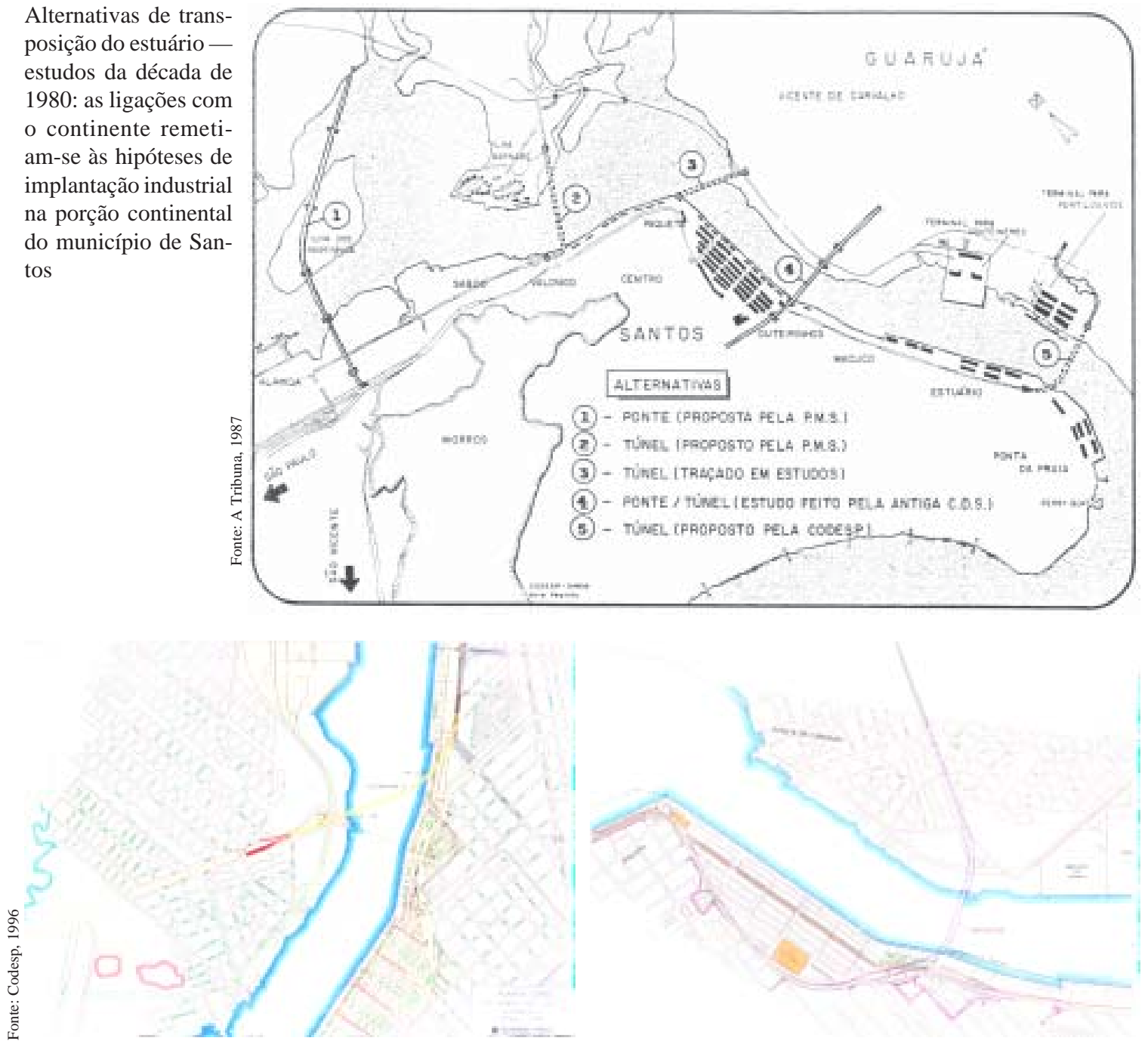

Estudos de 1996 para o túnel Santos-Vicente de Carvalho: a "lógica" da circulação portuária determina o traçado

Elenco de alternativas históricas da travessia do estuário: as alternativas centrais (Macuco/Outeirinhos), apresentando maior coerência urbana, ganham força com a hipótese do túnel "morros". A linha em vermelho representa a possível utilização da antiga linha da E. F. Sorocabana para a implantação do Trem Intermetropolitano entre Samaritá e Valongo

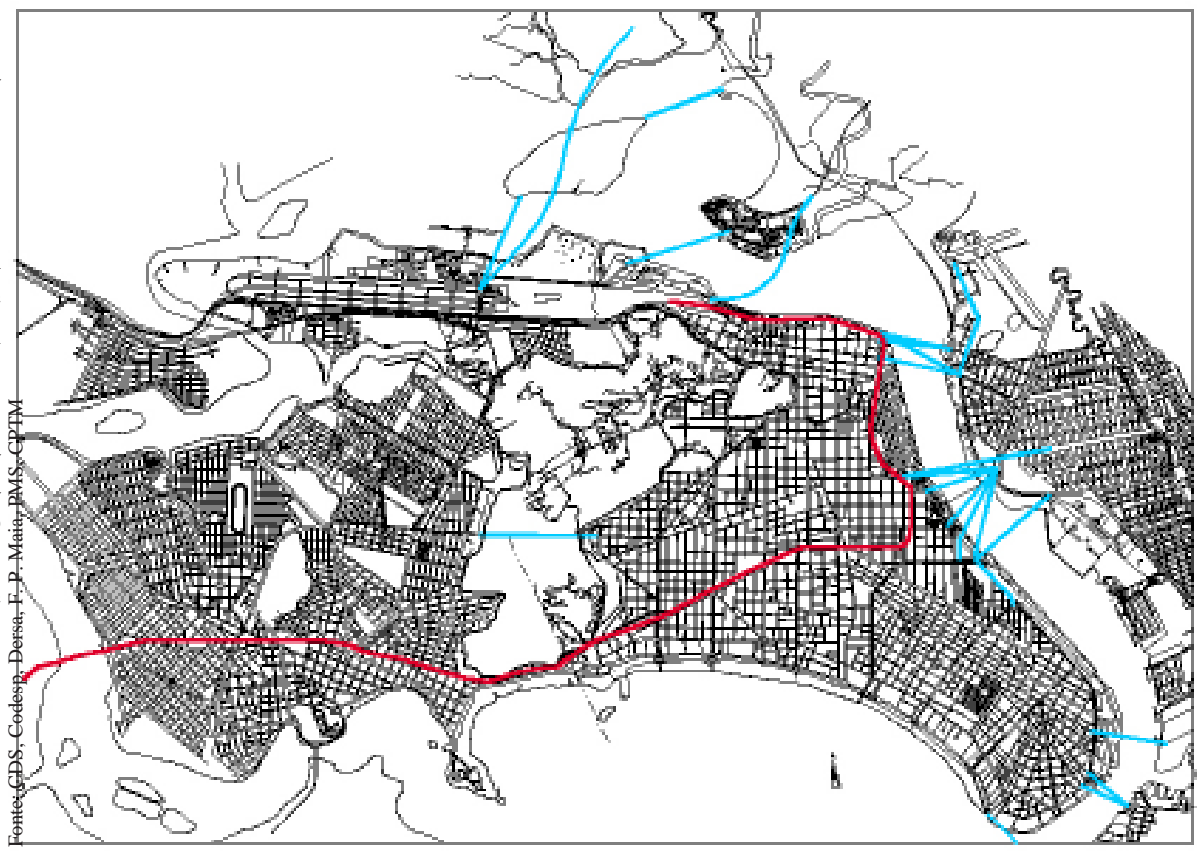



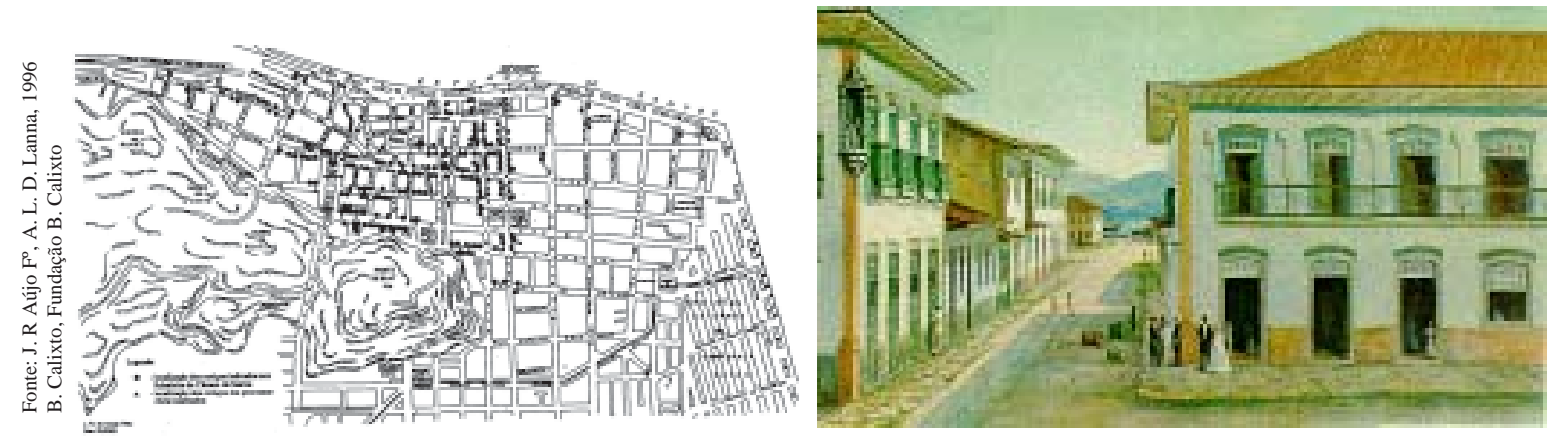

Cortiços existentes na cidade de Santos entre 1880 e 1889 e aspecto da imagem urbana no período —Quatro Cantos
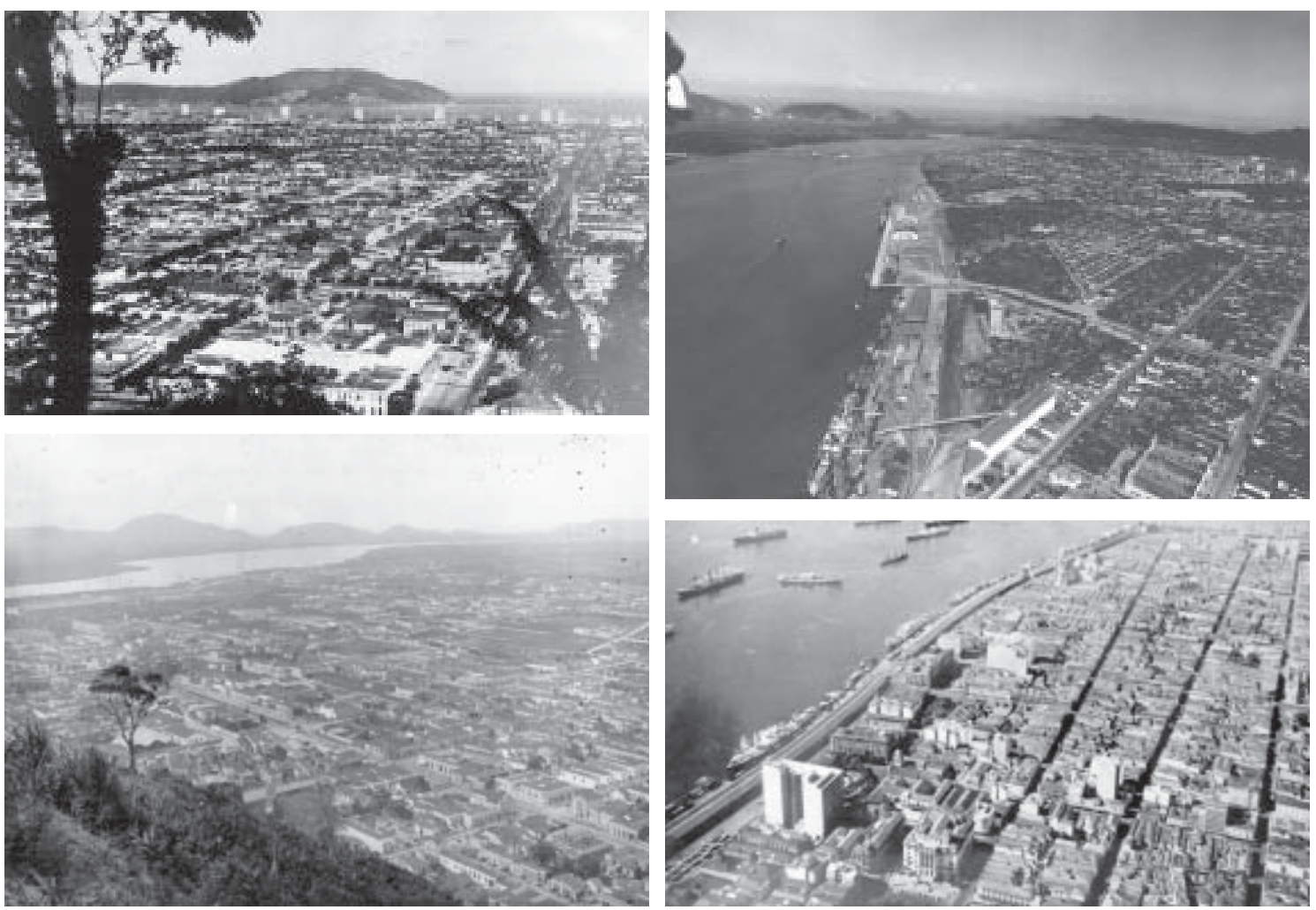

Vistas do tecido urbano residencial (c. década de 1950): acima à esquerda, o início da verticalização da orla e à direita, o vazio entre a malha urbana e a faixa portuária do Macuco: estoque de terras "reservado" ao porto. Abaixo, vistas da Vila Matias e Vila Nova e do Paquetá 
Preço do solo, sua ocupação segundo a renda familiar e gabarito de altura das edificações, segundo PPDI de 1976
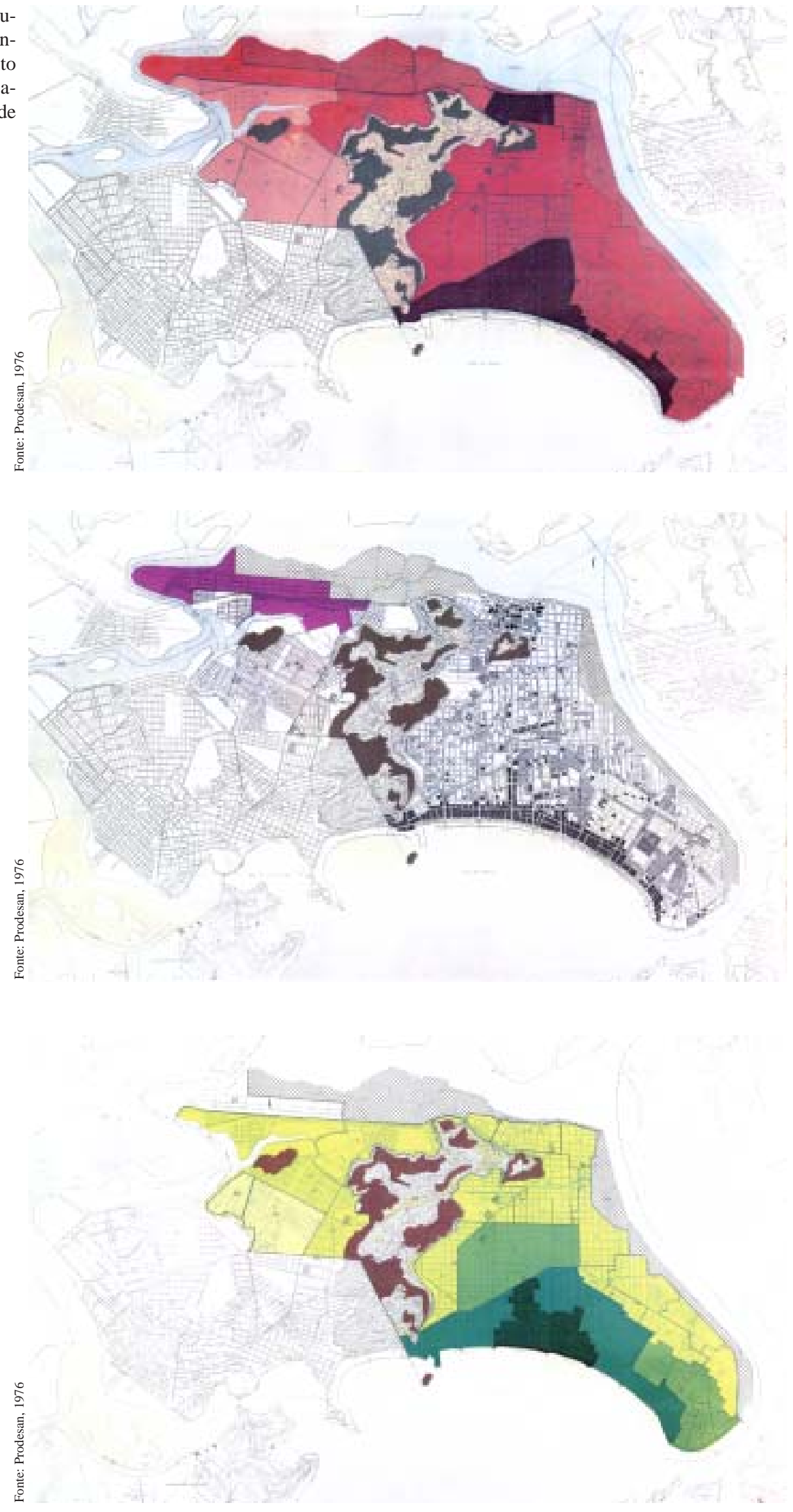
Hipótese esquemática da distribuição da ocupação residencial do solo segunda a renda familiar 1996: a verticalização expande-se a partir da orla e setores ser ocupados por condomínios residenciais para alta renda. $\mathrm{O}$ miolo da ilha abriga a residência da classe média (zona leste) e média baixa (zona oeste) dos morros passam a
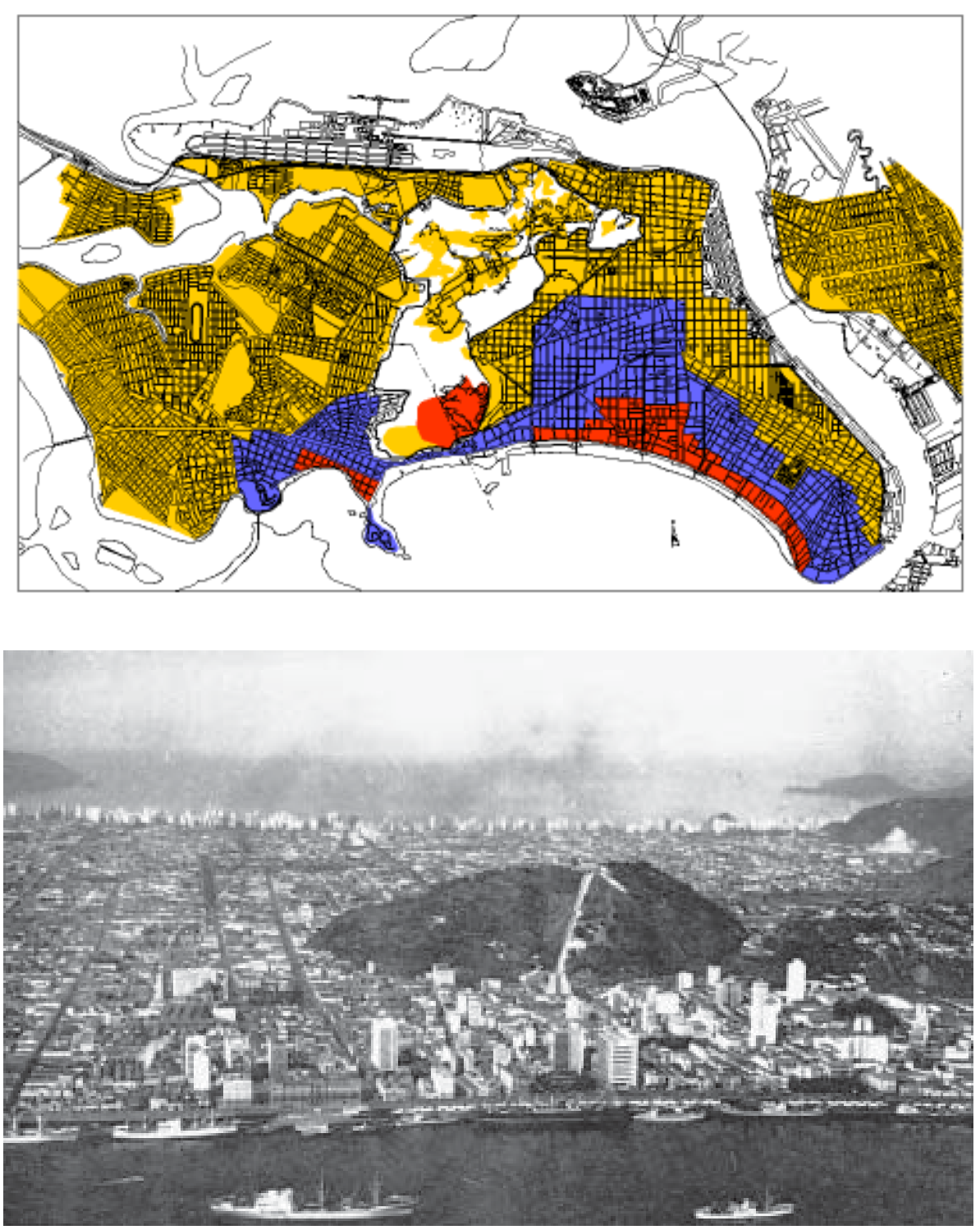

EVOLCĊOONAS DENGIDADES DFMOGRÁPICAS

Evolução das densidades populacionais: total da cidade (A) e áreas afetadas (B) pela implantação central das atividades retroportuárias, segundo estudo da Prefeitura Municipal de 1989. As tendências da curva descendente, embora carentes de verificação empírica atualizada, parecem confirmadas pelo zoneamento em $\approx$ vigor (ZP), principalmente nos bairros do 궝 Valongo, Paquetá, Vila Nova e Macuco 言

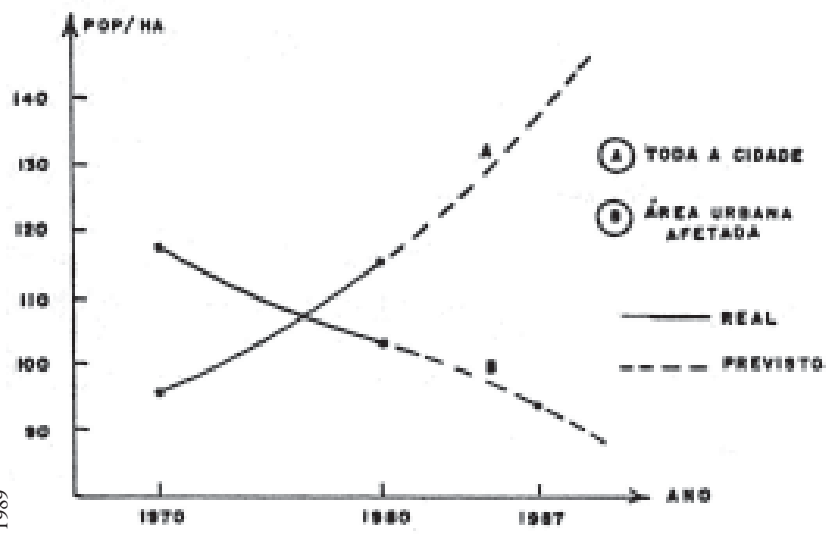

Fomes: Censas de 1970 e 1950 + arrisiers ele Servan pereleiruve de Sonios 


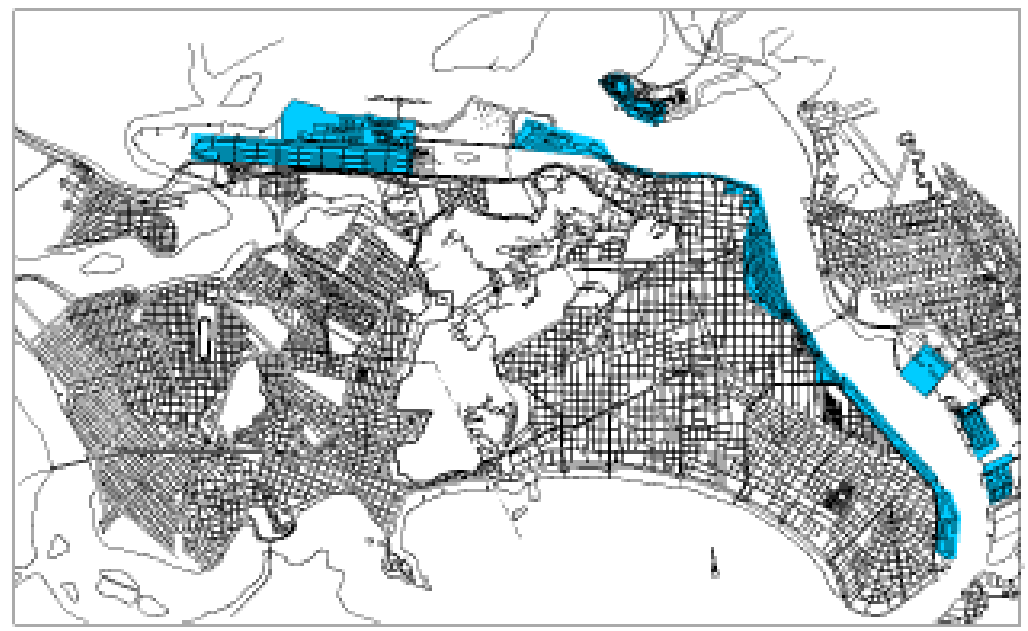

Setores ocupados por atividades portuárias, industriais e de serviços de transporte e distribuição
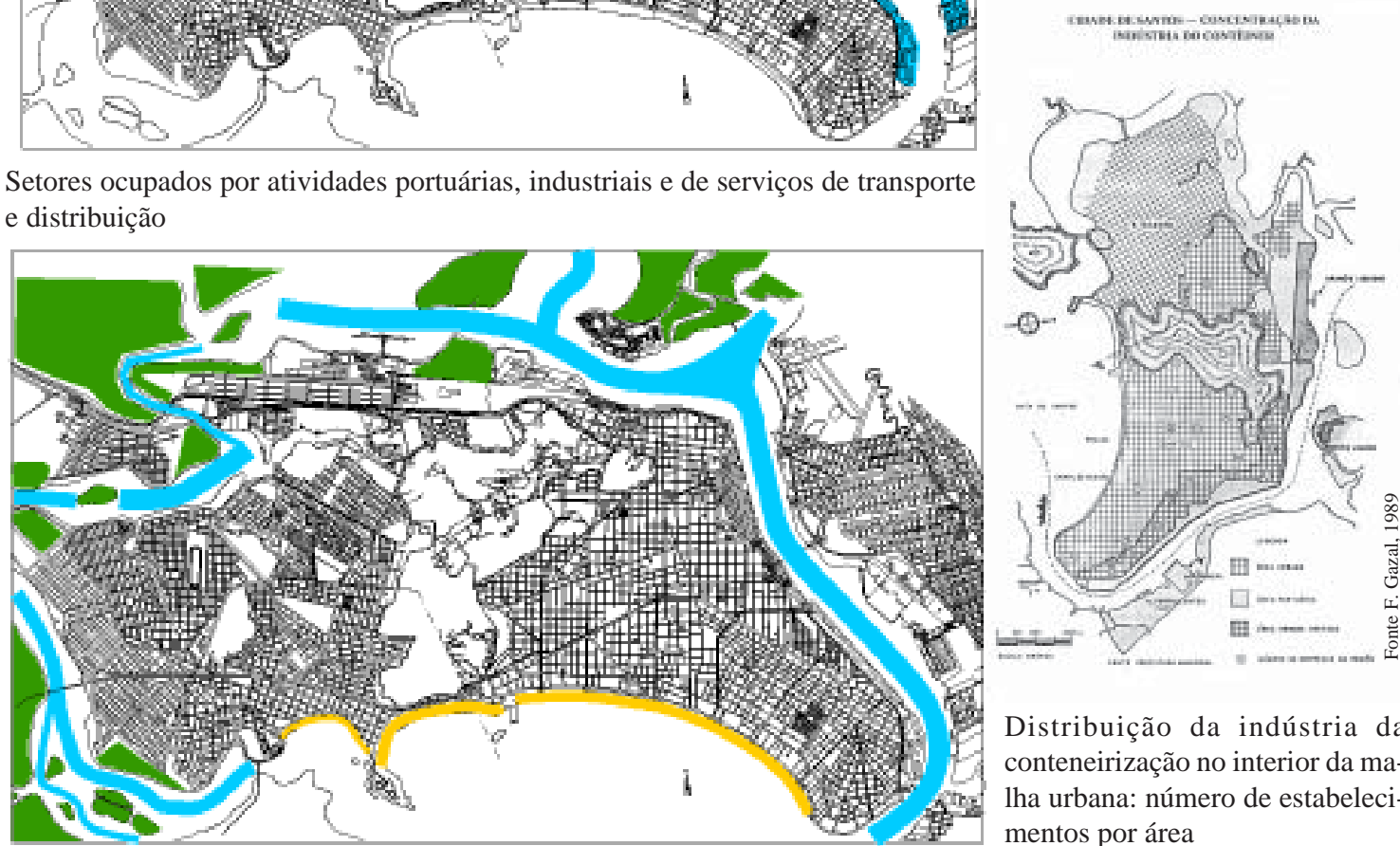

Distribuição da indústria da conteneirização no interior da malha urbana: número de estabelecimentos por área

Esquema do sistema ambiental: estuário, morros, praia

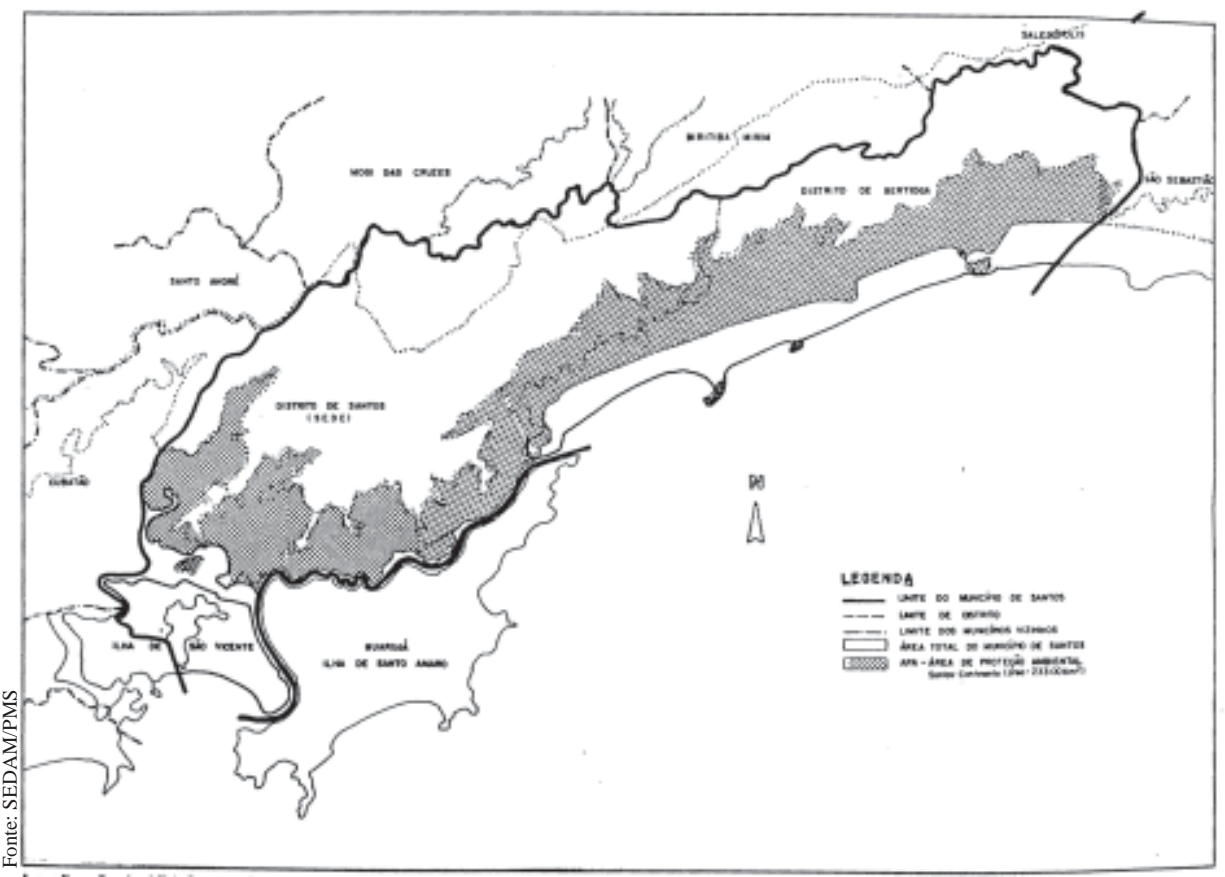

Localização da Área de Proteção Ambiental — Santos Continente— segundo lei 

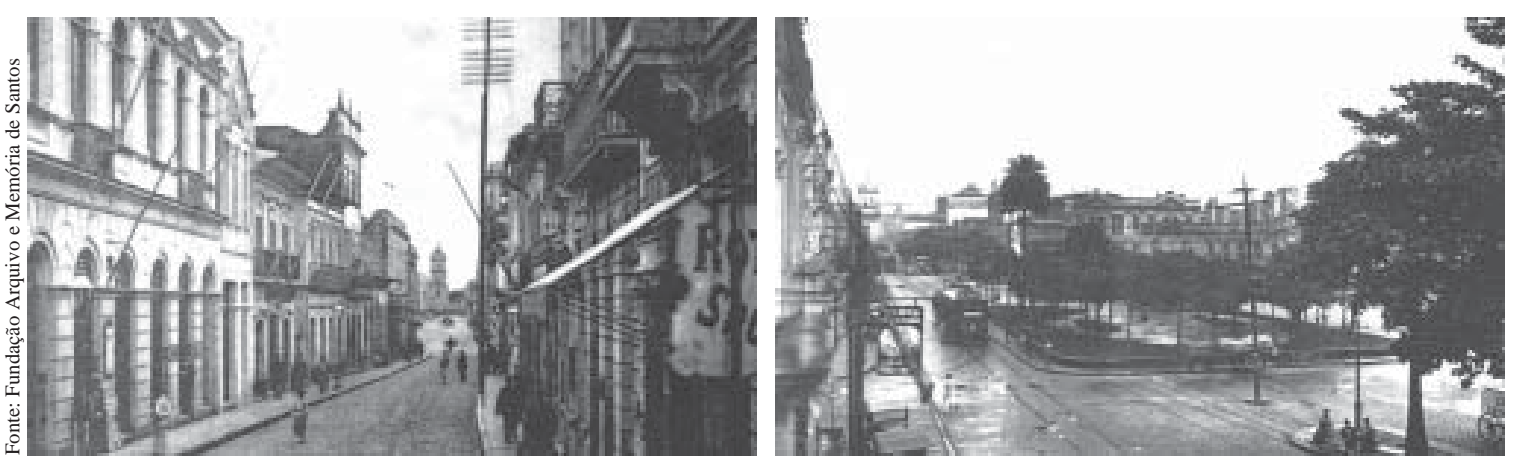

Vista da rua 15 de Novembro e da Praça da República nos primeiros anos da virada do século: platibandas, balcões e espaço público. A antiga Matriz seria demolida em 1906

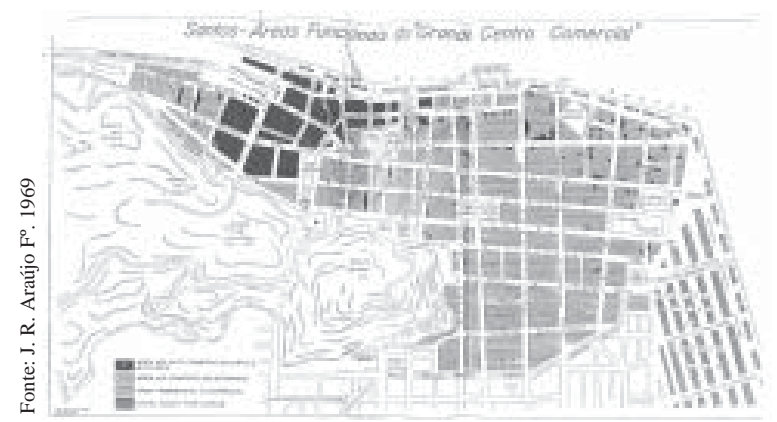

O centro da cidade e suas áreas comerciais — década de 1960-: em negro, contíguas ao terminal ferroviário, as áreas ocupadas pelo comércio do café e instituições bancárias
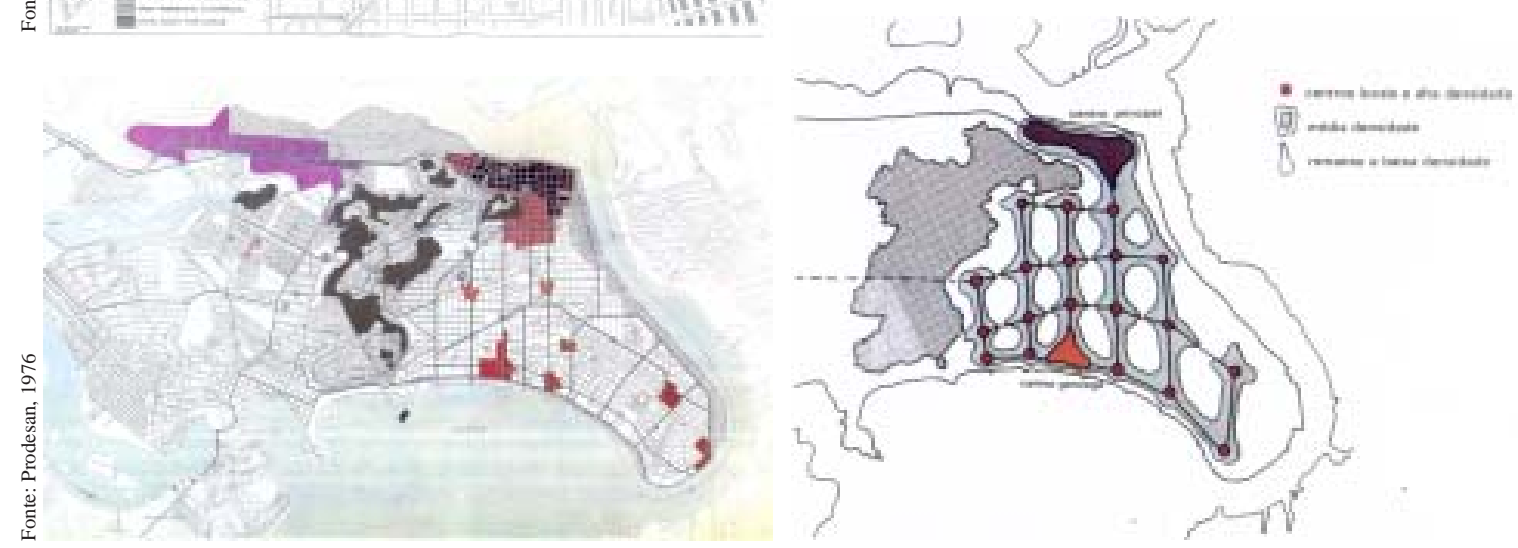

As centralidades existentes e a proposta do PPDI de 1976: estrutura primária em malha ortogonal e a rede de centros

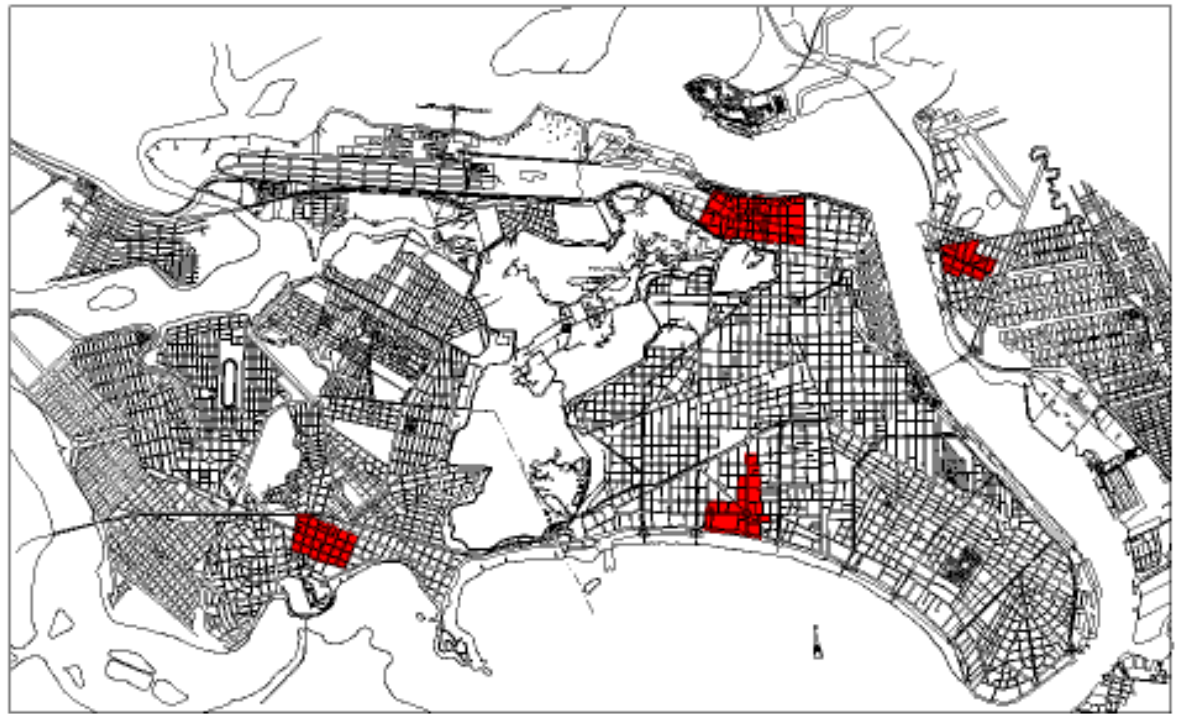

As principais centralidades regionais: localização condicionada pela acessibilidade 
'F. P. Maia. O plano regional de Santos, 1950, p.19.

Na verdade, o início da colonização das terras vicentinas dispôs de dois ancoradouros: a entrada do estuário (Barra da Ponta Praia) e o Tumuaru, ou porto de São Vicente própriamente dito. No entanto, este último ancoradouro "raso e perigoso", ficaria para pequenas embarcações, enquanto o primeiro, embora "franco e seguro" "distava da população (até então concentrada no núcleo de São Vicente), não dispunha de nascente, além de estar rodeado de "terrenos baixos e alagadiços" ${ }^{2}$ F. P.Maia, Op. cit.

${ }^{3}$ Frei Gaspar Madre de Deus. Apud A. D. Lanna. Santos, uma cidade na transição, 1996, p. 38

${ }^{4}$ P. Petrone. "Povoamento e caminhos no século XVIII e primeira metade do século XIX" in A Baixada Santista, aspectos geográficos, 1965

${ }^{5}$ Como resume M. C. Carvalho (Apud J. R. Araújo Fo. Santos, o porto do café, 1969, p.50)

"Sem terras próprias para o cultivo da cana, longe dos distritos de mineração, abandonado pela própria população local, Santos cai em marasmo que durou até o século XIX. Desapareceu a moeda corrente, passando as trocas a serem feitas sómente em espécie; fugiram das águas tranquilas do estuário os cinco ou seis navios que então o procuravam, interrompendo-se mesmo a ligação direta com Portugal e Angola; o porto de Santos passou a ser tributário do Rio de Janeiro, por intermédio do qual podia fazer comércio exterior, conservando sómente o comércio direto com os outros portos brasileiros ".

${ }^{6}$ J. R. Araújo Fo. Op. cit., p.56.

${ }^{7}$ H. Florence. Viagem fluvial do Tietê ao Amazonas: 1825 a 1829, 1977, p.33

${ }^{8}$ J. R. Araújo F ${ }^{\circ}$. Op. cit

Em 1801 Santos contava 3446 habitantes; em 1822, 4781 habitantes; em 1854, 7855.

${ }^{9}$ Souza Alberto. Apud J. R. Araújo Fo, Op. cit., p.27

${ }^{10} \mathrm{~J}$. R. Araújo Fo . Op. cit., p.52.

Em relação ao porto tem-se a seguinte movimentação:

\begin{tabular}{|l|l|l|}
\hline & Açúcar (arrobas) & Café (arrobas) \\
\hline 1826 & 154.166 & 8.331 \\
\hline 1828 & 489.650 & 22.640 \\
\hline 1829 & 470.889 & 22.773 \\
\hline 1830 & 443.619 & 30.610 \\
\hline 1831 & 511.581 & 25.775 \\
\hline $1836 / 1837$ & 433268 & 87.559 \\
\hline $1842 / 1843$ & 194.509 & 51.663 \\
\hline $1846 / 1847$ & 597.551 & 236.737 \\
\hline $1854 / 1855$ & 184.049 & 773.892 \\
\hline
\end{tabular}

"W. T. Andrade. O discurso do progresso: a evolução urbana de Santos 1870-1930, 1989

${ }^{12}$ C. Honorato. O polvo e o porto, 1996

${ }^{13}$ Vide J. R.Araújo Fo , Op. cit., p. 68; A. L. D. Lanna, Op. cit. e C. Honorato, Op. cit.

${ }^{14}$ Apud. H. Lobo. Docas de Santos, 1936, p.8

"Este porto precisa sómente e com a máxima urgência de um cais corrido ou paredão, que vindo em continuação da estrada de ferro, se estenda até diante da alfândega".

${ }^{15}$ Apud H. Lobo. Op. cit., p.131

${ }^{16}$ Ibid., p.131

${ }^{17}$ Legislação relativa ao porto, vol I, 1828 a 1937; H. Lobo. Op. cit., p.286

Em 1897, definia-se o local para a construção da doca destinada a mercado de peixe e respectiva praça, bem como a cessão do terreno marginal necessário para essa construção

${ }^{18}$ A. Lanna, Op. cit., p.68

${ }^{19}$ Cidade de Santos 20/12/1898, apud H. Lobo, Op. cit., 123

"Não contente como o monopólio do porto, com taxas de armazenagem exageradas, constitui a Companhia armazém para o recebimento do café, fazendo desaparecer em futuro próximo os transportes em carroças e caminhões, matando, portanto, uma indústria que tanta vida dá a Santos"

${ }^{20}$ Lobo (1936) relata sete momentos de crise que a companhia teria enfrentado desde sua fundação até 1936, envolvendo questões de concessão, prorrogação de prazo, taxas cobradas, localização da alfândega e greves.

${ }^{21}$ M. L. C. Gitahy. Ventos do mar, 1992

${ }^{22}$ Ralatorio do anno de 1905 da Cia. Docas de Santos, apud C. Honorato. Op. cit, p.145 
${ }^{23}$ Vide C. Honorato, Op. cit., 182-185.

"As disputas das Câmaras Municipais com o Governo Federal pela concessão de títulos de aforamento de terrenos da marinha advêm da contradição entre o Decreto número 4.105 de 22/2/ 1868 - que regulamentou o instituto de Terras de Marinha, cabendo à Capitania dos Portos o controle e concessão dos respectivos títulos-e a Lei número 3.348, de 20 de outubro de 1887, que concedeu às Câmaras Municipais o aforamento de tais terrenos. Mais ainda, pelo Decreto número 1.746 , de 13/10/1869, no seu parágrafo $10^{\circ}$, o Poder Público concedia o direito de desapropriação das propriedades e benfeitorias existentes nas terras de marinha que se achassem em terrenos necessários às obras portuárias”. Quanto à questão tributária, o decreto número 4.228 de 6/11/ 1901, relativo ao contrato de concessão para as obras do porto do Rio de Janeiro, que seria estendido às demais companhias concessionárias, estabelecia que "sendo federaes os serviços que por esta concessão ficam incubidos a Companhia, goza ela de isenção de quaesquer impostos que não os federaes, dos quaes igulamente fica isenta".

${ }^{24}$ Segundo parecer do Ministério da Viação e Obras Públicas de 24/1/1985 (Apud H. Lobo, Op. cit. 23), "os terrenos da marinha fazem parte do domínio nacional e foram aos poucos reservados à União na partilha constitucional atendendo-se à necessidade de defesa militar, alinhamento e regularidade do cais, servidão pública, navegação, bom estado e alfandegamento dos portos e criação de entrepostos, serviços estes exclusivamente a cargo da União"

${ }^{25}$ Ante os sucessivos surto de epidemia, instalou-se em Santos, no ano de 1893, a Comissão de desinfecção e, no ano seguinte, a Comissão sanitária. Sucederam-nas a várias comissões nomeadas pelo Estado: Ferraz (1892/4), Fuertes (1894), Cochrane (1894?), Lisboa (1895 e 1901) e Saturnino de Brito (1905). O plano de Saturnino previa, segundo Andrade (1989, p. 175) a "divisão da cidade em distritos, o sistema separador absoluto, isto é, separação do esgoto das águas da chuva; o esgotamento dos despejos pelo sistema de elevação, sendo o dos morros apanhados por um canal de contorno; o destino dos despejos seria fora da ilha, no continente...Para tanto, o projeto Saturnino previu a construção de uma ponte pênsil (encomenda na Alemanha e montada em São Vicente em 1914) para levar as tubulações de esgotos para Itaipu..."

${ }^{26}$ Parecer de F.T. Silva Telles 1914, apud S. Brito, A planta de Santos, 1915, p. 223

${ }^{27}$ C. R. M Andrade. A peste e o plano, 1992

${ }^{28}$ S. Brito. Op. cit., 1915, p.7

“A necessidade de planos gerais para a previsão da expansão das redes sanitárias, e portanto do arruamento, impõem-se... Não é permitida qualquer modificação no traçado das futuras ruas sem a consulta prévia de sua influência na rede de esgotos" A beleza da cidade dependeria "mais dos detalhes arquitetônicos e artísticos de que do traçado dos planos e vias, mas o traçado em dadas condições concorrerá para o efeito estético e a conveniente utilização (trânsito e saneamento)".

${ }^{29}$ Loteamento de grandes glebas que formavam antigas chácaras de veraneio

${ }^{30} \mathrm{~S}$. Brito Apud Lanna, Op. cit, p.75

"Sobre a planta que encontrei projetei a expansão da cidade com pequenos jardins, sem a preocupação das extensas ruas retas, que formam um xadrez nas plantas geométricas; são os patês de maisons na expressão de Camilo Sitte"

${ }^{31}$ S. Brito. Op. cit., p. 22

"O traçado em xadrez regular só existe nos planos da Vila Macuco e Vila Matias, executados antes de 1905, e no projeto para o lado da barra, mas justamente esta é a zona para futuro remoto, desde que se saia da orla da praia"

${ }^{32}$ Ibid.

${ }^{3}$ Araújo Fo (1965, p.36) indica a seguinte cronologia do preenchimento do "entremeio" das Vilas Matias e Macuco e as zonas praianas: "Vila Belmiro (1910-15), Campo Grande (1915-25), Vila Santista (1915-25), Marapé (1930-40), Ponta da Praia (1930-50) e Jabaquara (1920-50)

${ }^{34}$ Ibid.

${ }^{35}$ Prodesan, PPDI 76, 1976, p.29

${ }^{36}$ De acordo com Serrano (1997) este Plano foi aprovado pela lei no 1316 de 27/12/1951. As proposições concretizadas em Santos referem-se à seguintes ruas e equipamentos: Rua Visconde do Embaré, Rua João Pessoa, Rua Visconde de São Leopoldo, túnel Andradas-Jabaquara, Avenida Rei Alberto (ferryboat) e construção da estação rodoviária, junto à Praça dos Andradas

${ }^{37}$ Entre estes projetos há menção ao de Saturnino (como questão superada), de Ismael Silva (ligação dos principais "pontos de interesse" da cidade —Estação, Paço, Catedral e Mercado— - ) e Paulo Martins (deslocamento do centro para Oeste, concentrando o comércio no Paquetá). Quanto ao plano viário, criticando projetos precedentes, Maia (1950) preocupar-se-ia com os seguintes temas: 
- entrada da cidade associada ao deslocamento da linha férrea, alargamento da Rua Visconde de São Leopoldo e túnel sob o morro de São Bento, que se interligaria ao sistema perimetral central de distribuição do tráfego e estacionamento

- alargamento de ruas centrais e abertura de diagonais e praças

Além desses pontos há menções genéricas a respeito da localização de equipamentos, áreas de lazer e parques e reservas florestais e sobre as formas de expansão e preenchimento dos vazios urbanos, cujos projetos deveriam estar condicionados às pré-existências, "ao tempo e à evolução da técnica".

${ }^{38}$ Para a linha da Estrada de Ferro Sorocabana, que desde a década de 30 penetrava no tecido urbano utilizando-se do antigo traçado da São Paulo Southern Co. (uma linha que ligando Santos a Juquiá destinava-se ao transporte de produção agrícola — banana— para exportação), o estudo propunha duas alternativas: ligação São Vicente/Saboó de onde bifurcar-se-ia em direção a Santo Amaro (em ponte) e à estação da Inglesa, que seria ampliada em forma de L, ficando com frente para uma praça a ser criada na quadra contígua. A segunda alternativa, acompanhando a SantosJundiaí desde Cubatão, alcançaria a faixa portuária pela Alemoa. No sentido de enfrentar o problema do "estrangulamento" da entrada da cidade no Valongo, previu-se o deslocamento de 150 metros em relação ao traçado existente, desde a ponte do rio Casqueiro até o porto: a faixa assim liberada entre a ferrovia e a rodovia seria ocupada por implantações industriais e de armazenagem.

${ }^{39}$ P. Maia Op. cit, 222

${ }^{40} \mathrm{Na}$ análise de Serrano (1997, p. 112), o desenho apresentado revela em seus detalhes "uma visão do urbanismo do autor, com sabor do século XIX, pelo seu traçado hipodâmico, suas radiais, a partir da praça com o obelisco, jardins geometrizados, quadras com edifícios ocupando os perímetros e dotados de pontos centrais, edifícios públicos fechando as perspectivas de grandes avenidas"

${ }^{41}$ P. Maia, Op. cit., p. 222

Canais, avenidas e "parkways" demarcariam as unidades residenciais: "seria interessante ensaiar unidades do tipo Radburns, com faixas verdes internas, e casas de planta invertida, voltando a fachada principal para o centro ajardinado e os fundos para as ruas de acesso"

${ }^{42}$ Prodesan, PPDI 76, 1976, p. 18.

Esta ocupação está ligada à recuperação de áreas através das obras do DNOS (diques e canais) ${ }^{43}$ M. A. Santos. "A região administrativa da Baixada Santista" in Seade, São Paulo no limiar do século XXI, vol. 7, 1992, p.86

${ }^{44} \mathrm{Na}$ verdade, sempre marcados pelo exgero dos números: tanto é que o número de $460 \mathrm{mil}$ habitantes atuais deveria, segundo o PDF de 1968, ser atingido já em 1980 (número 50\% superior à população de 1968). Para o ano 2000 a previsão era de 600.000 habitantes contra os 412,2 mil atuais (417 mil habitantes em 1991)

${ }^{45}$ Prodesan, Plano Preliminar de Desenvolvimento Integrado de Santos, 1978, p. 82

${ }^{46}$ A estabilização em $22,3 \%$ do total de habitantes do "setor" turismo poderia ser então comprovada pela ausência de lançamento de edifícios de temporada. Isto, por outro lado, colocaria problemas de outra natureza para a administração, no sentido de adequar a "oferta" para o turismo de um dia ${ }^{47}$ Confrontadas com as propostas de industrialização de Santos, defendidas fortemente pelo PDF de 1968 e que seria objetos de seguidos estudos, o PPDI de 1976, constatava a tendência negativa das indústrias de pequeno e médio porte

${ }^{48}$ Prodesan. PPDI 1978, 1978, p.110

${ }^{49}$ Id. PPDI 76, 1976

${ }^{50}$ Id. Ibid.

${ }^{51}$ A Tribuna, 26/1/1989

${ }^{52}$ Prefeitura Municipal de Santos Lei complementar no 53 de 15/5/1992

${ }^{53}$ Id. Lei complentar $n^{\circ} 54$ de 9/6/1992

${ }^{54}$ Engenho dos Erasmos, Monte Serrat, Valongo, Hospedaria dos Imigrantes, Estação Sorocabana, Terminal Pesqueiro

${ }^{55}$ Prodesan. PPDI 78, 1978, p.113

${ }^{56}$ Este traçado ainda hoje persiste, constituindo as ruas Brás Cubas, Luis de Camões e Oswaldo Cruz

${ }^{57}$ Andrade, (1989, p.164) afirma que entre outros proprietários contrários à abertura da nova avenida estava D. Luiza Macuco

${ }^{58}$ Ibid., p.167

${ }^{59}$ Ibid., p. 171

${ }^{60} \mathrm{O}$ canal 8 seria entregue em 1953 e o canal da Av. San Martin na Ponta da Praia, que não fazia parte do projeto de Saturnino de Brito, foi entregue pela prefeitura em 1968 
${ }^{61}$ Ou seja separação das águas de drenagem das águas do esgotamento

${ }^{62}$ A ligação dos canais tanto com a baía como com o estuário permite a limpeza permanente através do aproveitamento do movimento das marés, cujas águas vazantes eram controladas por comportas. No entanto, foi o fechamento das comportas da praia o que permitiu na década de 1990 a diminuição dos níveis de poluição que afetavam a sua própria balneabilidade

${ }^{63}$ S. Brito Op. cit, p. 21

${ }^{64}$ Em relação às avenidas, duas delas, a "Gaffré e Guinlle" e a "Docas de Santos", seriam, no plano, traçadas quase exclusivamente em propriedades das Docas, o que tornaria sua execução dependente, segundo parecer de Silva Telles, do consentimento da companhia

${ }^{65}$ S. Brito, Op. cit. p. 22

${ }^{66}$ P. Maia, Op. cit, p. 71 e 86

${ }^{67}$ Maia (1950, p.179) faz a menção a um estudo de ponte na Ponta da Praia

${ }^{68} \mathrm{O}$ estudo da Dersa (Análise das alternativas para ligação Santos-Guarujá, 1993) compra as seguintes hipóteses

Themag/Promon — Rua Xavier da Silveira

Promon -Pedra do Itapema

Hidroservice - Travessia do Paquetá

Themag-Promon —Av. Xavier Pinheiro

Hidroservice - Macuco

Promon - Av. Siqueira Campos

Themag - Al Almirante Cochrane

Zuccolo - Av. Francisco Glicério

Promon/Figueiredo Ferraz — Av. Afonso Pena

Themag-Hidroservice — Ferryboat

Themag —Av. da Praia (ponte)

${ }^{69}$ A Tribuna, 12/12/1987

${ }^{70}$ Figueiredo Ferraz. Ligação Rodoviária margem direita e esquerda do porto de Santos — Relatório técnico e econômico, 2 vol., 1997.

Neste estudo são pré-avaliadas quatro alternativas. Além da alternativa 1, a escolhida para desenvolvimento, constam:

- Rua Brás Cubas (sob a praça da República) — Ilha Barnabé

- Nossa Senhora de Fátima -canal entre Bagrinhos e Barnabé

- General Câmara (aramazém 12) - Itapema

"Prefeitura Municipal de Santos Cidade/porto —Propostas para um desenvolvimento integrado, mimeo., s.d.

${ }^{72}$ Cidade de Santos, 13/5/1978

Taxa de Melhoramentos dos Portos, depositadas a crédito no Fundo da Fase II do Programa de Corredores de Exportação do Ministério dos Transportes (

${ }^{73}$ General ÊÊÊEEnio da Silva Pinheiro, diretor da Dersa in A Tribuna, 26/6/1982

${ }^{74}$ A Tribuna, 16/2/1997

${ }^{75}$ Ibid.

${ }^{76}$ A Tribuna, 1999

"Escoamento - Caminhões congestionam a Avenida Portuária", não deixa dúvidas sobre os impactos da atividade dos "corredores de exportação"

"Diante da rotineira confusão no trânsito e congestionamento de carretas, que ontem somam cerca de 300, entidades que representam os caminhoneiros autônomos distribuião hoje senhas aos proprietários das carretas que chegam à Cidade para descarregar soja no Corredor de Exportação, na Ponta da Praia. O objetivo é reduzir o tráfego de veículos na Avenida Portuária, retendo parte desses caminhões ainda na entrada da Cidade, no retão da Alemoa.

A medida é para acabar com um problema comum na Cidade. Com o início do escoamento da safra do produto pelo porto, centenas de carretas transformam — por absoluta falta de espaço em área do porto - a Avenida Portuária em estacionamento.

Assim, filas quilométricas se estendem naquela região. Ontem, por exemplo, além do trecho do Corredor de Exportação, as carretas alcançaram a regão do Canal 5. Chegaram a formar fila tripla e também a bloquear parte das vias.

Com o reduzido número de plataformas e moegas - apenas três para cargas que chegam por rodovia e outras três para as que vêm via ferrovia -, no local ocorrem congestionamentos quase diários, que se iniciam na área do cais, chegam na Avenida Portuária e seguem até os bairros próximos".

${ }^{77}$ I. W. G. Cochrane. Relatório apresentado à Câmara Municipal de Santos, em sessão de 30 de 8 
de 1873. Apud. J. R. Araújo Fo "“A expansão urbana de Santos”, 1965, p.30

${ }^{78}$ Relatório ao Diretor Geral do Serviço Sanitário do Estado de São Paulo, 1895. Apud Lanna. Op. cit, p.62

${ }^{79}$ Segundo Lisboa (1926, 545 ), "atrás da última fila de armazéns (do cais do Outeirinhos) fica a vila operária projetada, sendo que atualmente já existem algumas casas construídas para esse fins ocupadas por pessoal da companhia". Quanto á residência para trabalhadores, Lobo (1936,), citando o jornal A Imprensa de 9/11/1909, faz referência à existência de acomodações "que mercem especial atenção... pois são, na realidade habitações com todas as comodidades, podendo servir de residência para numerosas famílias de operários"

${ }^{80}$ J. R.Araújo Fo. Op. cit., p. 61

"Os trechos finais das atuais ruas General Câmara, João Pessoa (antiga do Rosário), Amador Bueno e São Francisco, bem como as respectivas transversais, constituíam os quarteirões onde havia os casarões de beiral dando frente diretamente para a rua, com grupos de quatro, às vezes mais janelas, e quase sempre recobertos de azulejos. Assim, era um bairro residencial muito próximo da zona altamente comercial"

${ }^{81}$ Vide O. C. L. Seabra, A muralha que cerca o mar, 1979

${ }^{82}$ Pilotis, implantação tradicional no lote, bloco arquitetônico homogêneo

${ }^{83}$ L. M. Rodrigues. "Vicente de Carvalho" in Vários. A Baixada Santista,1965, p.105

Ao Instituto de Previdência de São Paulo - IPESP - competiu "buscar evitar a invasão por terceiros e, ainda, manter a ordem, a discilina e as condiões mínimas exigidas pela habitação em comum", acrescentando mais adiante a obrigação de "traçar planos de urbanização, saneamento e melhoramentos públicos e, bem assim, do loteamento e venda a prestações, mediante financiamento, aos atuais ocupantes das respectivas áreas"

${ }^{84}$ Ibid.

Vicente de Carvalho hoje pertence ao município de Bertioga, que foi desmembrado de Santos depois da Constituição de 1988. A origem deste núcleo está ligada à presença da estação da linha férrea para o Guarujá. A invasão sucede a desapropriação dos terrenos de Itapema, que ocorre para a implantação da base aérea de Santos, e o loteamento promovido pelas famílias e companhias proprietárias dos antigos sítios. Sómente na década de 70 a Companhia Docas passa a efetivamente ocupar a margem esquerda do estuário. Assim ainda que houvesse uma "nesga de paisagem industrial" na faixa da marinha ao longo do estuário, onde até há pouco existiam os estaleiros de recuperação e construção de barcos de madeira, Vicente de Carvalho, ao lado das funções residenciais, apresenta sómente funções de comércio de âmbito local.

${ }^{85}$ Em Santos, em 1991, sem contar a área continental, a população distribuia-se do seguinte modo: 319.007 hab. nos bairros consolidados da zona leste (densidade 160,94 hab/ha), 66.984 hab. na zona noroeste (62,52 hab/ha) e 29.333 nos morros (50,92 hab/ha)

${ }^{86}$ O. C. Gonçalves et al. Plano Diretor Físico, 1965, p.21

${ }^{87}$ Prodesan. PPDI 1978, p.29

${ }^{88}$ A Tribuna, 25/7/1997

${ }^{89}$ F. Gazal, Portos \& Navios, agosto de 1989

${ }^{90}$ Ibid.

${ }^{91}$ Prodesan, PPDI 1976, p.30

${ }^{92}$ O. C. Gonçalves. Op. cit.

"A industrialização de Santos surge cada vez mais, como único caminho a ser seguido para se evitar o estancamento de seu progresso"

${ }^{93}$ Grupo de Planejamento Integrado, estudo de viabilidade do distrito industrial de Santos, São Paulo, 1969

${ }^{94}$ Prodesan. Op. cit., p.72

${ }^{95}$ Transportes, armazenagem e comunicações (o que inclui o porto) responderiam por $27 \%$ dos empregos oferecidos em Santos

${ }^{96}$ J. L. S. Ross e I. C. Moroz. Mapa geomorfológico do Estado de São Paulo, 1997, p. 37/38

${ }^{97}$ J. R.Araújo Fo. Op. cit, p. 41

${ }^{98}$ L. Goldstein e S. G. Carvalhaes, Op. cit.

${ }^{99}$ Lanna, Op. cit, p.94

${ }^{100}$ J. R. Araújo Fo "As áreas funcionais de Santos”, 1965, p. 58

${ }^{101}$ M. A. dos Santos. "A região administrativa da Baixada Santista" in Seade. São Paulo no limiar do século XXI, p.82 
${ }^{102}$ Id. Ibid.

"À guisa de exemplo, as lojas de departamento de Santos realizaram, em 1985, vendas equivalentes a 1/3 das efetuadas pelas congêneres de Ribeirão Preto. Sua rede física de supermercados contava, no mesmo ano, com 145 estabelecimentos, bem menos do que a rede de Campinas formada por 641 estabeleciementos"

${ }^{103}$ M. A. Santos. Op. cit. 


\section{Capítulo 5 \\ UMA SÍNTESE COMO POSSIBILIDADE}

\subsection{O porto e os processo de produção da cidade}

No caso de Santos ainda que de maneira geral se possa distinguir as grandes fases que caracterizam a gestão dos investimentos em infra-estrutura no país (como descrito por Santos) e, neste sentido, tendo em vista as sucessivas políticas de integração do país na economia mundial, sua correspondência com as próprias mutações "universais" por que passa o aparelho portuário, aqui interessa tentar responder à questão do papel da infra-estrutura portuária enquanto meio de produção da cidade. Ao identificar a interdependência e inter-relação que possa haver existido entre de um lado os investimentos realizados nesta infra-estrutura e a concentração de capitais que esses induziram, e de outro, a estrutura e a forma urbana resultantes do processo de crescimento, procura-se fazer emergir a partir das contradições e conflitos, bem como das potencialidades latentes impressas naquela relação, o "possível" como contraponto à retórica do "tecnicamente necessário".

Viu-se que, vinculando-se à maior articulação do território possibilitada pela ferrovia, e logo à expansão do comécio agro-exportador, a construção do porto moderno supôs uma concentração de interesses e capital (nacional e estrangeiro) na cidade que transformaria, não sem conflitos, a forma de sua própria produção. Quanto à inversão dos capitais, pôde-se verificar que, implantavam-se novos loteamentos para "atender uma crescente camada urbana de servidores públicos e empregados qualificados muitos deles pertencentes aos quadros das docas". Assim, ao mesmo tempo em que a política sanitarista excluia grande parte da população trabalhadora dos lugares que ocupava, destinando-lhe os espaços menos adequados para a ocupação ${ }^{2}$, uma rede de serviços públicos (abastecimento de água, luz a gás e depois elétrica, linhas de bonde) possibilitaria a ocupação de outras partes da ilha. Ocupação que, sob a hégide dos ideais de higiene, racionalidade e beleza, encontraria no Plano de Saturnino o meio de se realizar de forma mais ampla, antecipando e distribuindo pelo próprio plano "valor" ao solo urbano segundo fatores locacionais de certa maneira pré-figurados em função da negação da paisagem colonial, da presença das atividades ou equipamentos produtivos e dos atributos naturais próprios da ilha de São Vicente. Por outro lado, há que se ter presente que ante os problemas que as epidemias geravam em sua construção e operação (declínio de movimentação diante da negativa das empresas de navegação em atracarem em Santos), seria o próprio porto, a razão e, logo, um dos principais beneficiados das intervenções sanitaristas promovidas pelo governo do Estado. O entusiasmo com que a Companhia 
Docas saudava o empreendimento pode ser verificada pelo entendimento de que

saneada a cidade, retirados dos boeiros do caes os perigosos encanamento de matérias fecaes, que tanto o prejudicam, apavorando com seus perniciosos effeitos a navegação e a todos os que trabalham no litoral e ali recebem o germen de epidemias que (...) veremos immediatamente os benefícios que resultarão dessa imprescindível obra, pela execução da qual toda a cidade de Santos renderá graças ao Governo do Estado".

Ou ainda pelo relato da diretoria da Companhia de $1906^{4}$ que afirmava que "progrediram muito, no ano findo, as obras de esgoto de Santos, que, quando funcionarem terão satisfeita a maior necessidade de higiene de Santos, ou antes, do Estado de São Paulo", para logo em seguida, embora alegando razões diversas (que incluíam a mudança dos operadores do comércio importador para o Rio de Janeiro), acusar a continuação, "durante todo o ano findo, da depressão já existente no movimento do porto, tanto na importação quanto na exportação".

De todo modo, ao modernizar a cidade e melhorar sua imagem — pré-requisito ideológico da participação do país no comércio mundial—, a construção dos canais-avenidas impulsionou e suportou a urbanização, garantindo a entrada de novo solo urbano no mercado. Assim, a cidade de Santos, de lugar de aglomeração da força de trabalho passsa, por seu próprio crescimento, entendido como produção de valor, a constituir objeto e marco de consumo, ainda que seletivo e diferenciado, na medida em que pelo menos em termos de acesso à moradia -escassa e precária—, acabaria excluindo, regido pelas leis de mercado, os extratos mais pobres da população.

Depois dos movimentos imigratórios iniciais, que triplicam a população entre os anos de 1890 (13.102 hab.) e 1900 (50.389 hab.) e duplicam-na nos primeiros vintes anos do século $\left(102.589 \mathrm{em} 1920^{5}\right)$ —embora a pressão demográfica apresentasse sinais de diminuição de ritmo entre os anos 20 e 50, precisamente à época de grandes oscilações do movimento e de paralização da expansão portuária—, o certo é que toda a porção leste da ilha já se encontraria quase completamente ocupada até essa última data. Deste modo, face às taxas de crescimento populacional em torno de $30 \%$ a cada década $\mathrm{e}$ às consequentes novas demandas de solo, então impulsionadas, por um lado, pelo crescimento da classe média, decorrrente do processo de industrialização de Cubatão, e por outro, pela expansão da demanda turística, o esgotamento de solo na porção leste da ilha não só faria com que a ocupação horizontal fosse substituida pelo processo de verticalização como, enquanto outra face do mesmo processo imobiliário, geraria uma dinâmica de expulsão dos segmentos sociais de menor renda, cuja alternativa de moradia passaria a ser a porção noroeste, os morros e a franja oeste da ilha de Santo Amaro. Funcionando como válvula de escape para a falta de áreas para moradia, a ocupação destas 
áreas acabaria gerando rendas absolutas sobre solo marginal, o que, consequentemente, faria aumentar o valor diferencial das posições centrais, particularmente aquelas referentes à orla da praia e ao antigo centro. As primeiras impuseram-se como as mais valorizadas em termos comerciais e pólo de concentração da população de alta renda, fato que estaria por trás do adensamento construtivo que se realizaria, notadamente a partir de meados da décade de 1950, pela verticalição. Tal processo de adensamento teria contrapartida no esvaziamento demográfico da área central da cidade, que no entanto passa a cada vez ser mais solicitado como passagem dos fluxos que demandam a Zona Noroeste, os empregos industriais e de Cubatão e a capital $^{6}$. No esquema da distribuição espacial da cidade, pode-se observar que, intercalando-se aos dois setores, e apresentando mais dinamismo apenas em torno dos eixos norte-sul que os conectam, uma grande faixa intermediária residencial medianamente adensadada desenvolve-se segundo um arco oeste/ sudeste, abarcando em seu interior o comércio e os serviços de âmbito local.

Quanto ao porto, a análise feita no capítulo 4, pôs em evidência a completa separação física que suas instalações modernas (em contraponto à forma com que o sistema ponte-trapiche, por sua própria precariedade, fazia relacionar cidade-estuário) impuseram ao tecido urbano, impedindo, por sua expansão em toda extensão norte e leste da ilha, qualquer vínculo entre água e a cidade. O plano de 1926 já estabelecia os marcos territoriais da expansão portuária, revelando (e garantindo) o poder monopolístico da Companhia sobre o domínio de toda faixa estuarina, comprendida entre o extremo noroeste da ilha, Alemoa, até sua extremidade sudeste (Ponta da Praia) e, na margem esquerda, de Itapema a Conceiçãozinha. Esta verdadeira "privatização" de "território federal" acabou privando a cidade de qualquer contato direto com o estuário e definiu, facilitada por uma legislação municipal permissiva, os tipos de atividades que se implantariam contiguamente ao longo da faixa portuária. Assim, a zona de interface cidade-estuário, modelada e organizada em torno da atividade portuária, distingue-se por isto mesmo do tecido e do funcionamento urbano; tal zona não só deixa de integrar-se a eles como, "alargada", exclui a cidade do convívio com o porto e o estuário.

Neste sentido, mesmo a localização do forte setor terciário, engendrado pelo comércio exportador do café, foi mais influenciada pela proximidade da estação ferroviária (e talvez da Alfândega) que de qualquer instalação própriamente portuária. Essa, antes de mais, constituiu, em alguns pontos específicos de sua extensão, fator de atração para a implantação industrial, interessada ao beneficiamento de certos produtos primários, bem como de instalações interessadas às atividades retroportuárias. De maneira geral, a implantação de tais atividades transforma a paisagem dos bairros, que, como o Paquetá, acabaria devalorizado como lugar para a residência. Sucessivamente, este processo de "contaminação" de áreas urbanas, contido até meados dos anos 70 neste bairro e no Valongo (este, "destinado" aos grandes armazéns 
cafeeiros), estender-se-ia à toda área vizinha à faixa portuária, que seria "reservada" (pela referida indefinição da legislação municipal) para as atividades de suporte do próprio porto, qundo não desapropriadas para sua extensão. Assim é que, primeiro as antigas (Macuco) e, depois, as novas (que ocupariam os grandes vazios nos bairros Aparecida e Ponta da Praia) áreas residenciais limítrofes, seriam invadidas pelo tráfego e pelas instalações portuárias e de suporte. A incompatibilidade física e funcional existente entre as duas entidades, cidade e porto, e suas lógicas de organização do espaço, geraria constrangimento e ineficiência mútuas. Do lado do porto, indicador deste conflito, basta lembrar os contínuos reclamos da administração portuária sobre o fato de que era a cidade que devia adaptar-se ao porto ou mesmo que "o crescimento urbano de Santos veio a conturbar o crescimento do porto", pois ao concentrar "ele uma das principais atividades da cidade, é evidente que estas tendem a crescer em direção ao porto"; e o fato de não se proceder à reserva de "áreas necessárias ao seu futuro desenvolvimento resultou no estrangulamento que se observaram principalmente no trecho ValongoPaquetá, o que ensejou a elaboração de estudos visando ao alrgamento desse trecho do cais" . Alargamento esse, não é demais lembrar, que aguarda solução desde a década de 20: isto talvez mostre com clareza que a política da Companhia Docas sempre orientou-se pela anexação de novas áreas e pelo uso extensivo do território.

Confirmação desta "orientação", em grande medida conflitante com a ocupação residencial original, pode ser encontrada na contraditória implantação dos terminais dos "corredores de exportação" na Ponta da Praia, precisamente o ponto mais distante da articulação com os sistemas de transporte regionais, o que obriga, como já havia sido antecipado no Plano Regional de Santos de 1950, a extensos deslocamentos de carga ao longo de toda zona de interface urbano-portuária. Movimentos eses agravados pela descontinuidade, senão inexistência, do traçado da avenida perimetral. Tudo isto demonstrando, como se viu, a ausência de uma mínima articulação e coerência entre a gestão urbana e a portuária, traduzida muitas vezes em zoneamento permissivo, senão em submissão da primeira às determinações administrativas da última, cuja autonomia de ação, garantida por estatuto legal, fez estender ou induziu sobre todo o "terreno" que lhe interessou — seja em termos físicos, seja em termos fiscais - seus "negócios", ainda que muitas vezes de modo contraditório às expectativas de maior eficiência do aparelho portuário e de maneira alheia ao controle dos impactos que provoca.

Neste sentido, pelo estudo de Honorato ${ }^{8}$, pode-se observar que a autonomia e o poder monopolístico da gestão portuária, foram montados sobre uma "tradição" jurídica "inventada", que, buscando atender os reclamos de uma burguesia urbana em construção, definia o papel do Estado nessa nova ordem: ordem na qual este último deteria a propriedade das terras de marinha e deliberaria sobre as concessões de serviços, enquanto à primeira caberiam os 
investimentos. Tal estrutura jurídica, permitindo à Companhia Docas autointitular-se representante do poder central, portanto não subordinada aos escalões estaduais e municipais, explicaria os conflitos fiscais e espaciais, que, antepondo a Companhia Docas (e o poder central) aos interesses da administração e elites locais, no entanto, só fariam demonstrar a soberania da primeira.

Se esta questão perdura, com contornos próprios a cada período, até os dias atuais, em uma perspectiva histórica, à ela, ou seja, à perda de poder de comando das elites locais face às decisões do poder central e estadual, pode-se acrescentar que, associado ou, melhor, pactuado (embora não sem conflitos conjunturais) com o monopólio ferroviário da São Paulo Railway, o poder da Companhia Docas acabaria impedindo por muito tempo o desenvolvimento de outras alternativas interessadas ao desenvolvimento territorial, como o poderiam ser as tentativas abortadas de se construir um porto em São Sebastião, ou mesmo em Santos, como prentendido pelo governo estadual (sem mencionar os entraves interpostos pela Companhia Docas para a implantação do terminal de Cubatão). Neste sentido deve-se observar que a hegemonia mantida por Santos e seu porto produziu-se, antes de mais nada, sobre uma história de ingerência de ordem superior e de submissão às decisões exógenas à cidade, em particular, e à Baixada Santista, em geral. Isto não só se mostra na construção, operação e administração do porto pela Companhia Docas, como também explicita-se na reforma saneadora da cidade (decidida e realizada pelo Estado), ou mesmo, mais tarde, na industrialização de Cubatão (objeto de definição da política central, que beneficiaria diretamante o próprio porto, como se faz notar pelas altas taxas de movimentação alcançadas até 1969, época da inauguração de terminal da Petrobrás em São Sebastião).

Se, por um lado, como quer Lanna ${ }^{9}$, essa história remonta às razões da importância da construção de uma nova imagem do país, como parceiro confiável do mercado internacional no começo do século, por outro lado, a relação de dependência de Santos com a metrópole paulista e seus interesses econômicos hegemônicos talvez ajude a iluminar a persistência e recorrência destas "soluções" definidas em âmbitos superiores. Da mesma forma que o plano de saneamento do início do século representou uma intervenção externa na construção da cidade, no processo marcado pela centralização da economia e pelo autoritarismo político, que caracterizou os anos 70, não só a administração da cidade ficaria sujeita (de 1968 a 1984) à intervenção federal, como o aparelho portuário adaptar-se-ia de forma imediatista às necessidades de movimentação agro-exportadora, como o mostra a implantação do referido "corredor de exportação" e seus impactos sobre a estrutura urbana. Por outro lado, a crise econômica dos anos 80 (derivada dos ajustes "necessários" das finanças do país em relação à sua dívida), bem como a não previsão das implicações que a conteneirização do transporte marítimo supunham, principalmente em termos de áreas para operação, resultaram em fortes 
impactos sobre o tecido urbano; fato que, admitido até mesmo pela administração portuária, encontraria nas brechas da legislação de uso e ocupação do solo, espaço para, como se viu, invadir antigas áreas residenciais, expulsando população e desvalorizando imóveis.

O porto, como se verificou, em um sua primeira fase agro-exportadora, gera efeitos multiplicadores no âmbito local, na medida em que que "desencadeia", sob a forma de "capital fixo", sucessivos processos de desenvolvimento. Tal entendimento funda-se no reconhecimento de que sua implantação supôs o investimento do capital em um engenho tecnológico novo, assegurando a conexão entre áreas produtoras e o mercado internacional, ao mesmo tempo que se comportava como meio de produção da cidade, envolvendo os outros dois fatores produtivos: solo e trabalho. Dessa maneira talvez se possa entender que a criação de condições para a fixação da população (dotação de solo urbano e infra-estrutura, relações capitalistas de trabalho "livre", emprego em uma economia de serviços) e o incremento das atividades terciárias de suporte, ou mesmo ainda, a instalação de indústrias que se aproveitam da proximidade da matéria-prima para uma produção que atende basicamente a escala regional, constituem fatores que dotam a cidade e a sua economia de uma mais alta composição orgânica, ainda que o grau da socialização de seu desenvolvimento, tenha sido invariavelmente parcial e seletivo.

A partir de sua "industrialização", iniciada com os investimentos no equipamento, desde a década de 1930, dos terminais de Barnabé e Saboó para o recebimento de óleo de companhias nacionais e estrangeiras, o porto desvincula-se economicamente de forma progressiva da cidade e da Baixada na medida que, inserido nos esforços de crescimento industrial do país, tem no planalto metropolitano sua principal hinterlândia.

No entanto, a passagem do "predomínio cafeeiro" para o "predomínio industrial", sem implicar no desaparecimento das atividades de suporte ao comércio cafeeiro (o que só viria a ocorrer na década de 1990), representaria antes, como quer Alves dos Santos ${ }^{10}$ o surgimento de novas demandas ao município de Santos e grande parte do litoral sul. O rebatimento deste processo sobre a cidade se faria sentir pela necessidade de espaço para o assentamento populacional e pela expansão da oferta de serviços (ambos decorrentes da maturação industrial de Cubatão); no crescimento da oferta turística (primeiro impulsionada pela capital e depois pelo interior) e no reaparelhamento e expansão portuária (primeiro em função da industrialização da área metropolitana, e depois, pela "expansão dos produtos agrícolas e industrias exportaveis, da produção energética (alcool e petróleo) e a implantação de novos setores industriais de alta tecnologia"" , desde a década de 80 , realizadas no interior paulista. 
Viu-se que, a partir da década de 1980, agravada pelo esgotamento ambiental da Baixada, a ausência de novos investimentos (reorientados para outras partes do país e principalmente para outras regiões do Estado de São Paulo), supôs o arrefecimento do processo de crescimento da cidade de Santos. E, anulado, ou pelo menos relativizado, o efeito "distância", pelas facilidades crescentes de comunicação e transportes, a demanda turística "desloca-se" para outras áreas e o terciário superior é drenado para a capital. Por outro lado, desde pelo menos a década de 1950 , o porto, interessado a outras escalas que não apenas a regional, em sua crescente autonomia espacial, funcional e administrativa, deixa de se constituir para a cidade um centro gerador de atividades inovadoras. Desta maneira o porto reduziu-se à sua capacidade de atração e captação de mão de obra (empregando diretamente na década de 1970 em torno de 15.000 trabalhadores, número que cairia para 1977 postos de trabalho em 1999, se desconsideradas as anunciadas previsões de "corte" ${ }^{2}$ ). Assim, apesar da participação crescente das atividades de suporte ao porto em termos de receita fiscal ${ }^{13}$, e de certo modo na absorção de mão de obra nos terminais privatizados, o certo é que, por razões de ordem econômica, tecnológica e administrativa, ele deixa de gerar efeitos multiplicadores inovadores sobre a cidade e a região:

“o porto era (sic) um enclave, um território federal, que não se misturava com a cidade. Era (sic) um centro de captação de mãode-obra, sem relações de planejamento, sem relações culturais, sem desenvolvimento de seu potencial que pudesse ser integralmente aproveitado pelos cidadãos que residem em torno do porto"14.

Neste sentido, embora não caiba aqui estender-se sobre a questão, as tentativas de regionalização ${ }^{15}$ do porto de Santos têm partido tanto de administrações progressistas quanto de conservadoras: suas razões envolvem, de um lado, o problema da democratização da gestão (tripartite governoempresários-trabalhadores) e de outro a concorrência que se estabelece a partir da lei no 8630 de 1993 que extingue a Portobrás, companhia estatal de administração portuária, e privatiza os serviços portuários. Razões essas que coincidem na busca de maior competitividade do porto, que mesmo tendo aumentado a eficiência dos terminais arrendados para empresas privadas ${ }^{16} \mathrm{e}$ reduzido o tempo de espera das embarcações, não trouxe consequências práticas para os setores exportadores e importadores, além de impactar negativamente a receita dos trabalhadores avulsos em $30 \%$, nos dois últimos $\operatorname{anos}^{17}$; fato que, mesmo tendo em vista os incrementos anuais de movimentação portuária, tende a agravar-se (já que estruturalmente inerente à lógica da produtividade portuária), pelo entendimento empresarial a respeito dos entraves interpostos pelas exigências sindicais ${ }^{18}$. Por outro lado, o que importa notar, é que apesar dos investimentos realizados pelo setor privado junto com o governo federal, em obras de infra-estrutura, equipamentos e sistemas de informática, esses mesmos investimentos não só parecem 
insuficientes para superar a obsolescência de amplos setores portuários (notadamente, os mais antigos do Valongo e Paquetá — sub-utiliziados há tempos-e Outeirinhos, esse último como se observou uma versão mecanizada dos antigos trapiches), como orientam-se muito mais pelo conceito de infra-estrutura específica, "personalizada", (como o podem ser os sistemas dutoviários, terminais especializados operados pelos próprios donos das cargas, etc), do que, como antes, de "porto".

As implicações deste novo paradigma técnico e administrativo, por um lado (ainda que o menos interessante para este trabalho), sugerem que a Codesp, propondo-se assumir o papel semelhante ao de (por ora, má) "administradora de shopping center", tem apresentado déficits de receitas e de certa forma tem se ausentado do tratamento — conservação e ampliação— das infraestruturas gerais do porto. Por outro lado, embora a Companhia Docas tenha "utilizado" a cidade de Santos como mero suporte físico e infra-estrutural das atividades portuárias e embora o porto industrial que se implanta a partir dos anos 50, seja mais voltada aos interesse econômicos da metrópole, tal paradigma faz supor que os interesses dos novos operadores, voltados aos sistemas exportadores e, assim, referidos a uma ordem superior que se manifesta e opera a nível nacional, senão mundial, tendem a não coincidir com, senão antepor-se aos interesses econômicos e culturais locais. Neste sentido, deve-se lembrar que "a prática recente mostra que os novos operadores são demasiadamente frágeis na cadeia logística portuária, a menos que sejam eles mesmos os arrrendatários das instalações do porto. Estão nas mãos dos armadores" 1 . Por outro lado, diante das novas fusões, alianças e aquisições que ocorrem (principalmente nos países do hemisfério sul), concentrando o mercado de transporte marítimo internacional, o resultado, de acordo com estudo do BNDES ${ }^{20}$, "é de que os portos fiquem cada vez mais sujeitos às exigências de operação dos armadores internacionais", tornando infrutíferas as tentativas locais de competição no mercado internacional: o que determina "o sucesso dos portos são os grandes armadores, e não mais o potencial de cada porto". Às fase de "autonomia" ou "centralização" que caracterizaram a gestão portuária no país, e particularmente em Santos, sucede-se a lógica "produtivista" dos armadores: não é mais o navio que vai de encontro à carga, mas a carga é que deve procurar os portos eleitos em função do benefício dos armadores, sobrelevando a escala regional, macroregional e mesmo nacional. Neste sentido, a uma economia urbana, dependente das atividades portuárias como é a de Santos, face, entre outras razões arroladas, à imprevisilidade dos fluxos mundiais, a discussão de modelos alternativos de desenvolvimento parece imperiosa. 


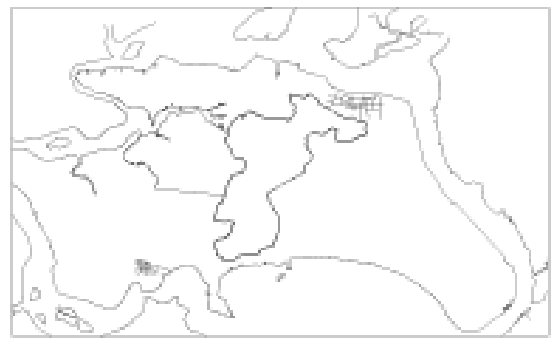

1822

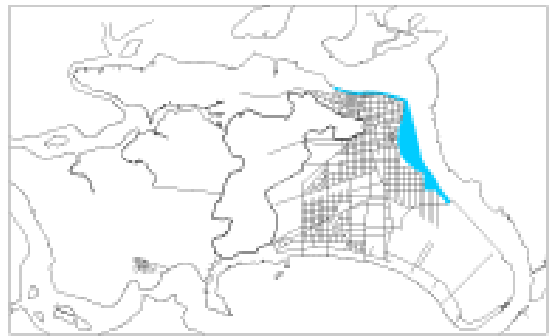

1921

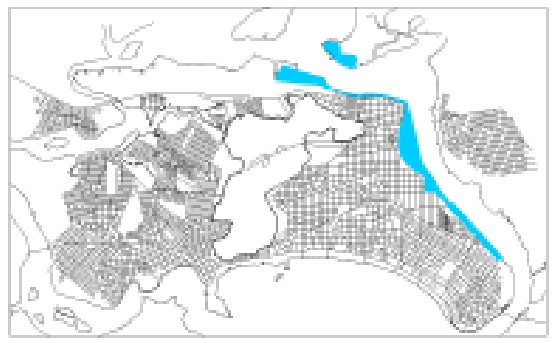

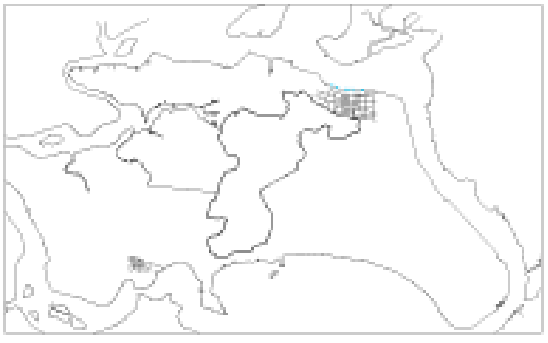

1878

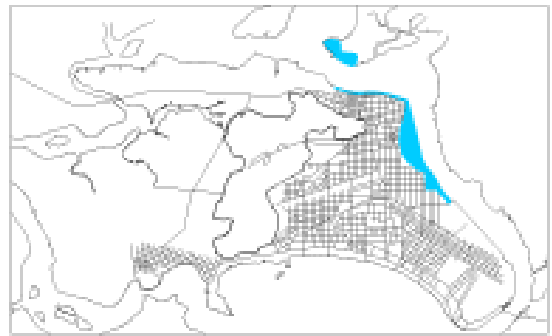

1935

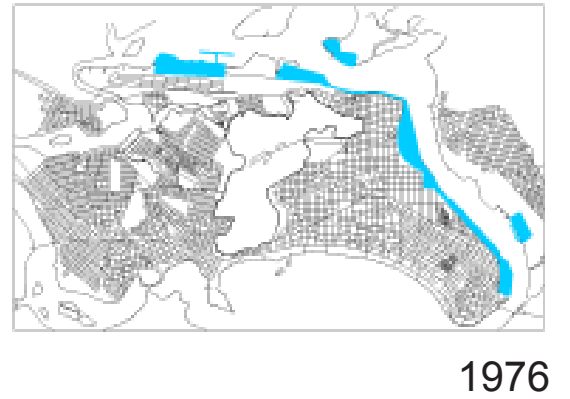

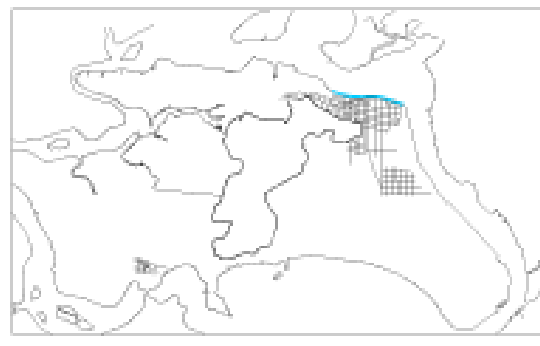

1897

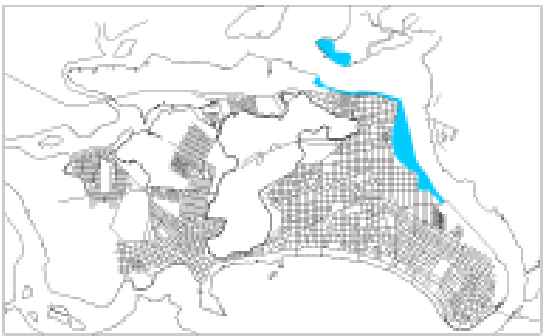

1945

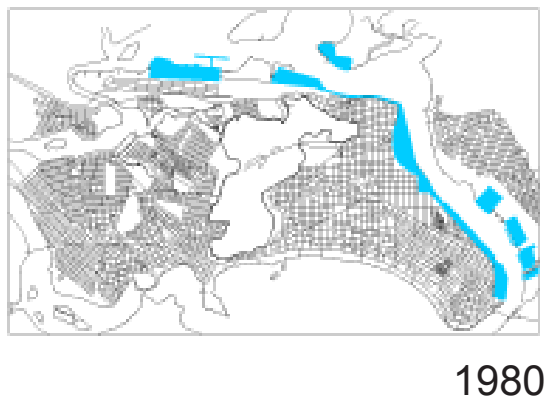

980

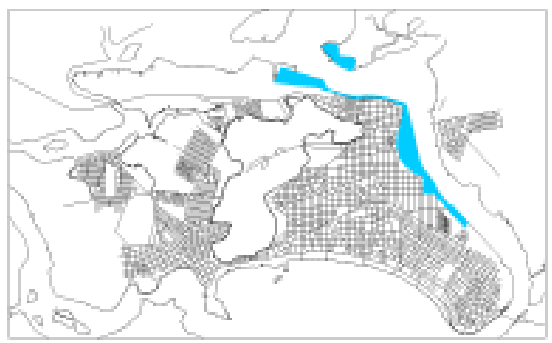

1950

Paralelo entre crescimento urbano e expansão portuária.

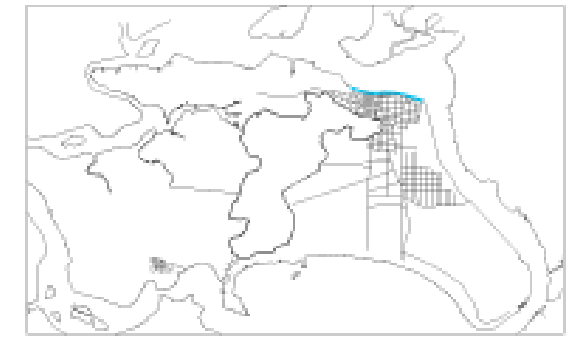

1903

Desenhos: B. A. Godinho 


\subsection{Hipóteses de uma nova relação porto-cidade: elementos para um projeto}

Buscando responder à pergunta "como anda nossa economia?", o jornal A Tribuna, de 26 de janeiro de 1989, partia da premissa que "a geografia é uma rua de mão dupla para Santos". Pois ao mesmo tempo em ela constitui principal "vantagem" da cidade, "graças às facilidades (que propicia) para o maior porto da América Latina" e graças à proximidade com a capital, não deixa também de ser "o maior entrave ao desenvolvimento pleno do seu potencial econômico". Daí a matéria sentenciava: "O município se ressente, mais do que qualquer outra coisa, de espaço". Sob este ponto de vista, os pontos de estrangulamento da economia, portanto, resultavam do esgotamento de alternativas de crescimento físico da cidade. A ocupação da parte continental (pela indústria e pelos serviços) e a metropolização ("no sentido de evitar o isolamento da cidade e fornecer a a infra-estrutura necessária para o aproveitamento racional dos investimentos privados"), forneceriam, segundo a mesma matéria, as bases para superar aquelas limitações.

Em 1998, o mesmo jornal, no dia 3 de agosto, noticiava que "a situação de estagnação e ameaça de desemprego convive como um movimento que aponta para novos e médios grandes investimentos privados, estimados em $\mathrm{R} \$$ 1 bilhão 467 milhões e com previsão de geração de pelo menos 27 mil empregos". Mesmo aparentemente não contabilizando os recursos destinados pelo Ministério dos Transportes para a construção do segundo terminal de contêiners na margem esquerda (este "esquecimento" seria sintoma da perda, por parte do porto, de capacidade de geração de riquezas?), a cifra destinada prioritariamente a investimentos em infra-estrutura de transportes e equipamentos de turismo e lazer ${ }^{21}$, era considerada, pelo jornal, pequena se comparada aos $\mathrm{R} \$ 35$ bilhões que teriam sido, segundo a mesma matéria, investidos no interior durante os quatro últimos anos.

Confrontando as "expectativas" da cidade no período dos últimos dez anos, bem como as razões para o estrangulamento do desenvolvimento econômico e a situação de estagnação da cidade e da Baixada, a argumentação desenvolvida permite apontar, por um lado, a não vigência da "solução" indústrial (entre outras razões, pela questão ambiental e pelas atuais políticas públicas de investimento), e por outro, a necessidade de matizar seja o "fator" porto seja o "fator" proximidade com a capital, como "vantagens" sobre as quais, pelo menos na forma que assumem contemporaneamente, apoiar a superação daquela situação de crise de reestruturação da base econômica do município em particular e da Baixada em geral.

Neste sentido, por um lado, pode-se observar, inclusive, que quanto à indústria, tanto o Plano Diretor de 1998, quanto a destinação dos investimentos previstos supõem o abandono, pelo menos no que diz respeito à 
cidade de Santos (embora Cubatão tenha planos de reocupação de áreas para a indústria "leve"), da idéia de apoiar seu desenvolvimento no setor secundário. Por outro lado, viu-se que o fator "proximidade", se em um primeiro momento permitiu, pela cisão geográfica entre o centro distribuidor e o porto marítimo, o estabelecimento de relações econômicas de complementariedade entre Santos e a capital, hoje parecem ser outras as condições de desenvolvimento, menos baseadas como são nas diferenças "quantitativas" (distância e dimensão) e mais nas de natureza qualitativa (infra-estrutura, inovação e qualidade de vida).

É que se antes o desenvolvimento dava-se como "mancha de óleo", "expandindo-se" sobre um teritório contínuo e homogêneo, hoje ele tem como marco um espaço descontínuo e não homogêneo, cujas carcterísticas variam segundo a disposição das diversas redes de relação econômica, culturais e políticas que passam por cada lugar. Portanto, o fator "proximidade" perde tendencialmente força enquanto fator estratégico de desenvolvimento: viu-se que é a especialização de um lugar, a natureza das trocas que tem com os outros pontos da rede e as condições ambientais locais o que define sua "posição" no território. Daí que, anuladas ou ao menos redimensionados os papéis que o fator "proximidade" da capital (o qual, na verdade, facilitadas as comunicações, passa, invertendo seu sinal, a agir como "sucção" do terciário especializado santista), porto e indústria poderiam representar enquanto vantagens comparativas de Santos, e diante das tendências de valorização territorial, que no Estado de São Paulo referem-se à agricultura/indústria/ $\mathrm{P} \& \mathrm{D}$, ao lado do terciário superior e sistemas turísticos, das alternativas colocadas pelos analistas do modelo de desenvolvimento santista, parece ter restado a "metropolização" como suporte do desenvolvimento futuro.

Mas qual o significado da "metropolização" como fator de desenvolvimento? A criação da Região Metroplitana da Baixada Santista — Lei complementar $n^{\circ}$ 815 de 30/7/1996 — define entre as funções públicas de interesse comum os campos funcionais do "planejamento e uso do solo, transporte e sistema viário regional, habitação, saneamento básico, meio ambiente, desenvolvimento econômico e atendimento social".

Admitindo-se que sejam esses os problemas a serem enfrentados pelas políticas públicas (embora, a argumentação até aqui desenvolvida aponte para contradições existentes na própria base de sutentatação econômico-portuária), ante o reconhecimento que a questão que se coloca para Santos é da atualização da cidade sobre si mesma, (dada a própria carência de espaço para expansão), poder-se-ia perguntar como integrar esses "campos funcionais" em um projeto de intervenção que, embora parcial, possa ter efeitos "metropolitanos"? E neste sentido, seriam os investimentos previstos, bem como as propostas do novo Plano Diretor, medidas ou condições suficientes para uma nova dimensão "metropolitana", enquanto possibilidade de gerar novas sinergias entre as funções fundamentais que a cidade exerce? A resposta 
a esta pergunta parece ser negativa na medida que tais proposições não permitem vislumbrar uma "idéia" de cidade que possa reativá-la como lugar de atração de novas atividades. Para isto talvez, mirando-se no exemplo de outras cidades portuárias, se requeira melhoria da infra-estrutura, ampliação da oferta de serviços especializados, desenvolvimento habitacional e equipamentos de alto nível, precisamente no sentido de afirmar em outras dimensões suas próprias condições locais: complexo portuário-urbano (onde a questão da pesquisa logística apresenta-se como importante alternativa diferencial), centro turístico e pólo terciário. E desse modo haveria que se "descobrir" na própria forma e estrutura urbana da cidade as alternativas para sua reativação. E assim, hipóteses projetuais, como exercício de explicitação das alternativas, constituem condição necessária para poder, pelo debate dessas mesmas alternativas, construir um consenso de idéias e garantir o compromisso de sua execução através da participação dos diversos agentes sociais, onde o poder público, principalmente ao nível local, deve exercer, incorporando o instrumento projetual ás decisões políticas de governo urbano, seu papel irrenunciável como motor de arranque dos processos e como garantia dos valores coletivos da cidade.

$* * *$

Um simples esquema gráfico que sintetize a ocupação da ilha de São Vicente talvez evidencie com clareza a correspondência entre a loacalização das funções mais dinâmicas da cidade, quais sejam as portuárias, turísticas e terciarias, e "valorização" das bordas de água. Com excessão da "fachada" oeste da ilha —onde terrenos menos apropriados seriam ocupados por formas de residência específicas-é nesta faixa "perímetral" onde as funções portuárias, os sistemas residenciais turísticos e as "centralidades" localizam-se. Essas últimas, desde os requisitos de acessibilidade, são definidas nas passagens de ligação entre as duas porções da ilha e vêm reforçadas pela configuração dos eixos de articulação norte-sul (avenidas Conselheiro Nébias e Ana Costa), que é por onde se expandem suas funções correlatas ou complementares. Circunscrita por esta borda dinâmica de atividades, distribuem-se segundo um arco oeste/sudete dois setores de tecido residencial, diferenciados entre si, mas internamente bastante homogêneos quanto à forma e ao uso, que são caracterizados pelo Plano Diretor de 1998 como Zona Intermediária e Zona Noroeste ${ }^{22}$.

Portanto, se é verossímel a hipótese da localização dos centros nas "entradas" da porção leste da ilha (Cubatão/São Paulo e São Vicente), bem como ao longo dos eixos norte-sul —estrutura viária primária mais carregada até pela ausência de outras alternativas no sentido leste-oeste que não a Afonso Pena e a avenida da praia - , segue-se que um novo eixo que pusesse em contato duas novas "entradas" da cidade, como o supõem os projetos dos túneis morros (São Vicente) e estuário (Vicente de Carvalho/Guarujá), não só 
ajudaria a articulação longitudinal da estrutura urbana, melhorando a acessibilidade das áreas periféricas à zona leste, como, por isto mesmo, induziria o estabelecimento de funções centrais metropolitanas.

Projetos de articulação entre os diversos "territórios" que compõem a Baixada Santista, como se viu, já eram aventados nos estudos e planos elaborados desde a década de 20, seja pela Companhia Docas, seja, mais tarde, por Maia, pela Codesp, pela prefeitura ou pela Dersa. Dentre eles, tendo em vista a hipótese referida acima, ou seja a corrrespondência que possa haver entre "entradas" da cidade e localização das centralidades, há um estudo da Dersa, do fim dos anos 80, que aponta como a mais equilibrada ligação SantosGuarujá aquela cuja diretriz define-se pelo eixo da Rua Xavier da Silveira. Isso porque, segundo aqueles estudos, esta alternativa representa, comparada com outras alternativas (ao norte, como continuidade da Anchieta, e ao sul, desde São Vicente pelo morro do Voturuá), a possibilidade de constituição de uma nova ligação, que não as já existentes, atravessando o baricentro de São Vicente e Santos. Assim articulado o sistema Anchieta/Imigrantes (desde o ponto intermediário de suas interligações aos sistemas viários urbanos) com a Piaçaguera Guarujá, desfaz-se a resistência de comunicação entre as duas porções da ilha e desta com a ilha de Santo Amaro, facilitando a acessibilidade dos bairros períféricos à cidade central, melhorando a conexão com o Litoral Sul e atendendo ao significativo movimento local que se verifica entre Santos e Vicente de Carvalho. Neste sentido a flexibilidade da "alternativa central" revela-se não só quanto ao uso (cargas e passageiros) como em relação ao posicionamento, "a meia distância de todos os pontos de controle: porto, Vicente de Carvalho, centros de Santos e São Vicente, Guarujá, acesso ao litoral sul, a futura área de expansão de Samaritá, a continuidade da Rodovia dos Imigrantes, terminal inter-modal de carga e finalmente do melhor balanceamneto do tráfego da Baixada"².

Quanto a este último ponto, ao mesmo tempo que permite tanto o fluxo das cargas portuárias entre as duas margens, quanto o alívio na demanda de viagens pelo eixo da praia (equilibrando melhor os fluxos nos fins de semana), a "alternativa central", ao cortar tranversalmente as cidades de Santos e São Vicente (em Vicente de Carvalho segue pela faixa da linha de transmissão de Itatinga), ajuda na distribuição do tráfego da malha existente: interssecciona-se com as principais artérias norte-sul e contribue para superar o problema derivado da escassez de alternativas leste-oeste.

Considerando que o estudos da prefeitura têm apontado como melhor solução para o túnel dos morros aquela que o atravesssa como continuidade da rua D. Duarte Leopoldo Silva, no Embaré, e emboca-se a oeste com a avenida divisória Francisco da Costa, lançar os olhos sobre a planta de Santos evidencia como ligação "natural" (inclusive apontada nos estudos da Dersa) entre os dois túneis — estuário e morros—o eixo definido pela Rua Xavier de 
Mendonça. Esta "evidência" torna-se particularmente "forte" não só pela "vocação" de eixo arterial, como pela possibilidade da constituição de um binário através da continuidade do traçado das ruas João Carvalhal e Augusto Paulino - traçado esse interrompido muito provavelmente de forma indevida, como o sugerem não só o processo de sua ocupação e a existência de faixas de domínio residuais, como o próprio "parcelamento" do solo e as provisórias soluções adotadas em muitas das construções. A importância teórica da definição deste binômio, articulado, desde o cruzamento com a Avenida Conselheiro Nébias, através das Ruas Xavier Pinheiro e João Guerra, ao "túnel-estuário", funda-se no reconhecimento do papel das "diagonais" em malhas ortogonais e revela-se, tomados os devidos cuidados projetuais e de controle de impactos ambientais (constituindo os canais de Santos um exemplo notável a se seguido), na possibilidade de representar potente eixo de desenvolvimento de atividades centrais ao constituir linha de maior acessibilidade à escala metropolitana, conectando diretamente os sistemas de vias regionais e os sistemas infra-estruturais — portuário e aeroviário.

Neste sentido este traçado redefine, pela nova "localização" adquirida, o valor de espaços e lugares, até então marginais ou destinados a usos menos importantes ou incompatíveis com o funcionamento urbano. Assim é que, na porção oeste da ilha, a ampla gleba desocupada, situada no bairro de Areia Branca sobre o eixo da Avenida Divisória, ganha novo sentido urbano, consideradas as possibilidades de seus 20 hectares para implantação de complexo residencial/comercial e de áreas verdes. Do mesmo modo, as áreas no sopé dos morros, antes destinadas à exploração de pedreiras, podem supor, dentro do conceito de pré-parques, uma maior utilização social. Em Vicente de Carvalho, a área de Itapema, que vem sendo abandonada pelos estaleiros, permite, pela reconversão paisagística da faixa estuarina e melhorada sua acessibilidade, a possibilidade de se estabelecer uma nova relação da cidade com o porto e o próprio estuário, rompendo o isolamento desses do contato urbano e assim redefinido, mesmo que parcialmente, sua imagem e seus significados simbólicos.

No entanto, é na área que se desenvolve em torno dos limites que os bairros Macuco e Vila Matias fazem entre si e com os domínio da Codesp - tendo como referência precisamente o eixo do binômio Xavier Pinheiro/João Guerra — onde desponta a mais rica possibilidade de transformação positiva da relação cidade/porto. Essa área constituirá o baricentro de uma rede de três grandes linhas de circulação metropolitana: ali, além da "diagonal central" que interligaria o Sistema Anchieta/Imigrantes à Piaçaguera Guarujá, devem confluir a Avenida Portuária e o sistema de transportes leves sobre trilho, projetado para circular entre o Samaritá e o centro da cidade (chegando talvez até Cubatão), em grande parte, utilizando-se a linhas da antiga Sorocabana. Neste sentido, de um lado desenha-se a consolidação físico-funcional da estruturação metropolitana. E de outro, o "nó intermodal”, tomado como 
ponto de intersecção entre infra-estrutura e cidade, não apenas coloca o problema em termos da "resolução" de uma parte da cidade, mas passa interessar sobretudo à questão de como interconectar permanentemente esta parte a toda rede territorial, induzindo sobre este ponto, singular, uma maior concentração e diversificação de atividades, que se querem, por isto mesmo, "raras".

E, assim, parece ficar patente que, de maneira exponcialmente superior à suposta valorização das demais áreas referidas, os setores externos da seção portuaria dos Outeirinhos adquirem novo sentido urbano, precisamente pela mudança de seu grau de acessibilidade: considerada a constituição daquele "nó" intermodal de fluxos metropolitanos, a manutenção de usos portuários convencionais representaria um grande "desperdício" face à singularidade de sua posição, à disponibilidade de área e, consequentemente, à possibilidade de se desenhar uma nova centralidade para a cidade de Santos e a área metroplitana como um todo.

Frente à ideologia que defende cada metro linear de cais e cada metro quadrado de armazém como indispensáveis ao funcionamento portuário, poder-se-ia arrolar, para além da constatação da sub-utilização dos armazéns externos deste setor — argumento talvez muito débil face às "exigências" da engenharia portuária—, uma outra razão, "interna" à essa mesma engenharia, e que diz respeito às técnicas de melhor aproveitamento de terminais já existentes. E essa razão baseia-se no fato de que a transição para a completa "conteneirização" do comércio marítimo devendo ainda perdurar por longo tempo, tem levado os armadores a optar, para a operação nas próximas décadas, por uma relativamente grande variedade de tipos de embarcações. E particularmente nos países em desenvolvimento, onde apenas um número limitado de portos têm condições de "prover imediatamente e em escala real" ${ }^{24}$ instalações especializadas para o manuseio de contêiners, ro-ro, lash e outras cargas unitizadas, a Unctad, órgão das Nações Unidas para o comércio mundial, propõe a provisão de "terminais multi-uso", no sentido de garantir eficiência e flexibilidade na operação portuária.

Sem a necessidade de estender-se sobre as questões técnicas conexas, bastaria aqui lembrar que os estudos realizados a partir do conceito "multi-uso" única opção viável para os portos polivalentes enfrentar a variedade de demandas específicas, desde que "incorporando métodos modernos de manuseio de cargas e técnicas gerenciais avançadas" ${ }^{25}$ - apontam para um lay-out de terminal portuário, cujo modelo, desenvolvido por Gazal ${ }^{26}$, supõe para seu correto funcionamento, entre outros, os seguintes parâmetros dimensionais: comprimento de cais de mil metros; retagurada de 270 metros (área total de 270 mil metros quadrados). 
Tomando-se como premissa válida esses parâmetros dimensionais, um novo traçado da Avenida Portuária, construindo de forma coerente a interface cidade/porto, poderia "liberar" para uso urbano, segundo uma forma triangular com vértice no cemitério do Paquetá e base definida sobre o alinhamento da Rua Xavier Pinheiro —uma das embocaduras do túnel estuário — uma superfície de quase 35 hectares de terreno, que se tornaria (se já não é) redundante para a operação portuária. Sabendo-se que à essa área, circunscrita apenas ao domínio portuário, podem somar-se aquelas correspondentes ao terminal ferroviário e à outras quadras vizinhas —além das englobadas pela ZEIS, aquelas hoje "invadidas", ainda que sob amparo da nova legislação, pelos armazéns de contêiners-, a nova posição estratégica que assume o conjunto potencializa-se não sómente em termos dimensionais (massa crítica de solo disponível), funcionais (terciário portuário, turismo, etc) ou de acessibilidade (condição sine qua non da consolidação da estrutura metropolitana e fator de coesão social), mas também como possibilidade de revitalização social e econômica e de representação formal à escala de toda a cidade, enquanto constituição de novas referências urbanas, arquitetônicamente definidas. Novos agenciamentos arquitetura/infra-estrutura e a integração de tecidos historicamente separados e segregados, valorizando o patrimônio construído, podem conformar as principais pautas projetuais, no sentido da possibilidade da constituição de "peças" urbanas identificáveis, não autônomas (embora podendo admitir tipologias "mutantes", articuladas de modo complementar à cidade), que sejam resolvidas de forma a garantir baixos índices de potencial construtivo ${ }^{27}$ (até como possibilidade de se permitir maior destinação de solo aos sistemas gerais — viário, equipamento e verde publico).

$* * *$

Poder-se-ia perguntar porque dentre outras áreas que se mostram "problemáticas", ou melhor potencialmente disponíveis para uma nova ocupação ou um nova ordenação, seja pela sua posição urbana (como os pátios ferroviários do Valongo e Ana Costa), seja pelo seu valor histórico (centro da cidade), a opção para a "atualização" da cidade aqui defendida recai sobre as possibilidades de configuração de um novo "eixo central". Ainda que nos limites deste trabalho não caiba verificar a viabilidade técnica e econômica desta hipótese projetual, poder-se-ia argumentar que seu potencial reordenador da cidade (o que não descarta outras alternativas arroladas, mas a faz dominante, precisamente por seu poder de articular à escala metropolitana essas alternativas) vem dado pela própria "polivalência" da solução na medida em que reúne a possibilidade de enfrentar pela soma de escalas e temas "estratégicos" da cidade contemporânea ${ }^{28}$ algumas das "pendências" da estrutura urbana de Santos, quais sejam: 
- configuração estrutural, de caráter estável, que condiciona a forma territorial e modifica seu funcionamento, melhorando o sistema de mobilidade e de intercâmbio entre os diversos setores da metrópole;

- articulação enquanto superação dos elementos barreira (morros, estuário) que incidindo sobre a acessibilidade metropolitana, tem efeitos sobre a difusão dos equipamentos, dando coesão aos diversos setores urbanos e produzindo efeitos de requalificação e renovação;

- transformação e atualização de tecidos urbanos cujos usos e funções perderam vigência ou são incompatíveis com a forma e vida urbana;

- definição de pontos de intercâmbio modal de transportes, revalorizando as possibilidades de uso e qualificando a imagem urbana através da requalificação dos tecidos urbanos;

- definição de novas centralidades que, baseada no "acesso a espaços urbanos mais qualificados e aos sistemas de informação bem alimentados", oferece-se, enquanto possibilidade de atração de atividades múltiplas, como alternativa complementar aos "centros" existentes.

No entanto, se aqui não cabe o desenvolvimento de um "projeto" específico para a área (como hipótese metodológica para o projeto urbano, a definição físico-formal dos elementos constituintes talvez deva ater-se àqueles considerados "fortes" no sentido de estabelecerem-se certas regras, inegociáveis quanto a certos pontos — espaços abertos, circulação, verde-, mas que permitam a flexibilidade na realização arquitetônica de outros componentes), o que se quis demonstrar com esta possibilidade de reconversão das áreas do porto de Santos é que uma nova relação desse com a cidade pode e deve funcionar como uma "infra-estrutura" potente para permitir redimensionar e ativar, pela valorização "macrometropolitana" das condições específicas locais (pense-se nas atividades requeridas em termos do reforço ao setor comercial e de serviços, direta ou indiretamente ligados ao porto, da logística dos transportes, da pesquisa marítima), a base econômica e social da cidade, reinserindo-a de forma coerente com sua prórpia vocação na rede das trocas múltiplas. Trata-se enfim de produzir um novo sentido para a cidade e a região metropolitana, precisamente a partir da afirmação das "regras" físicas e culturais de sua coerência interna. 


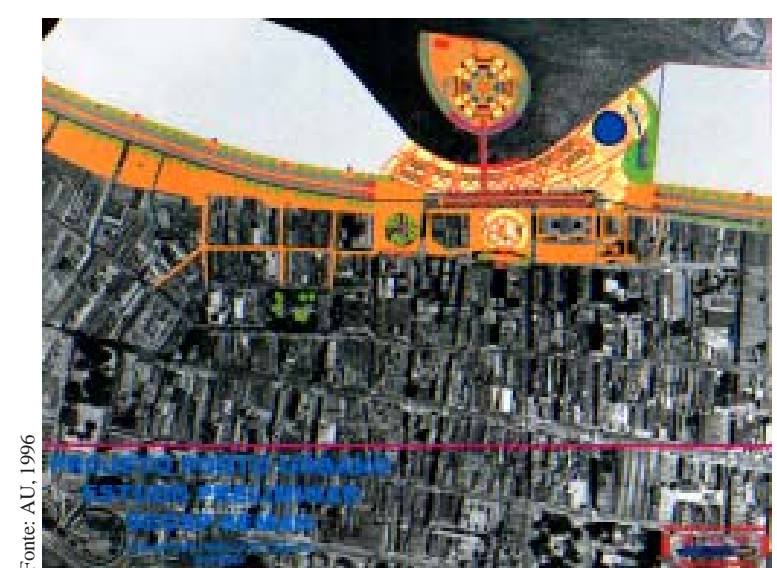

1. Arq. N. G. Lima, PMS, 1976: centro de serviços entre as áreas de aterro para ampliação do cais Valongo-Paquetá

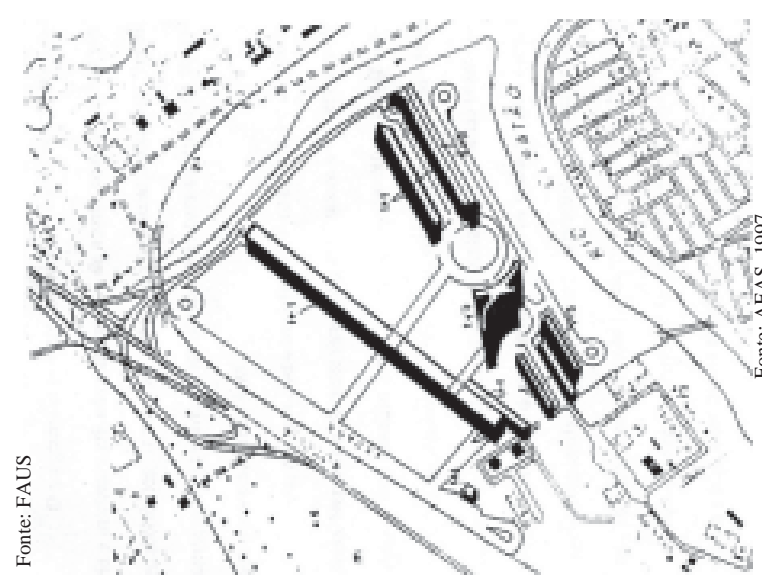

3. A. F. Franco, TGI/FAUS, 1994: implantação de terminal intermodal e centro logístico em Cubatão

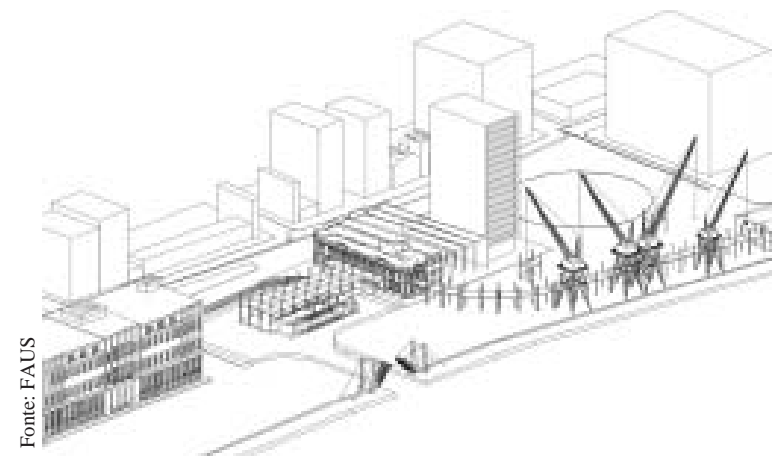

5. D. Q. Rodrigues, TGI/FAUS, 1998: terminal de passsageiros no Paquetá

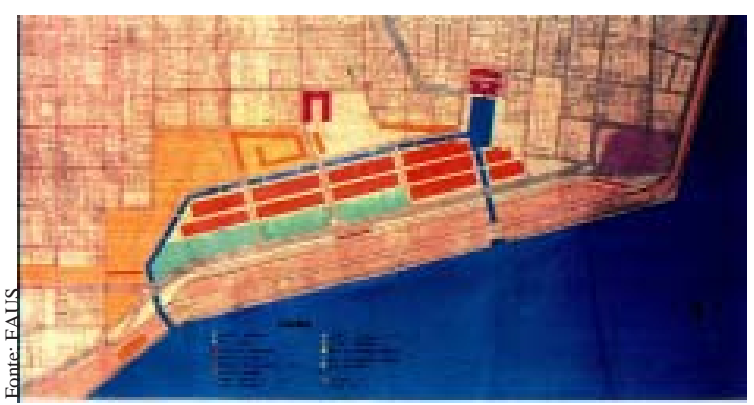

2. A. G. N. Mantovani, TGI/FAUS, 1994: requalificação do setor de armazéns do Outeirinhos

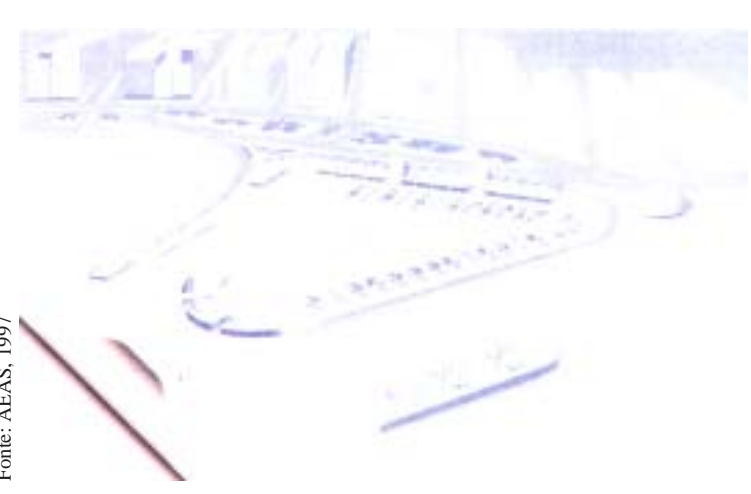

4. Arqs. A. Seco e N. G. Lima, AEAS/A Tribuna: marina na Ponta da Praia — hotel, escola, restaurantes

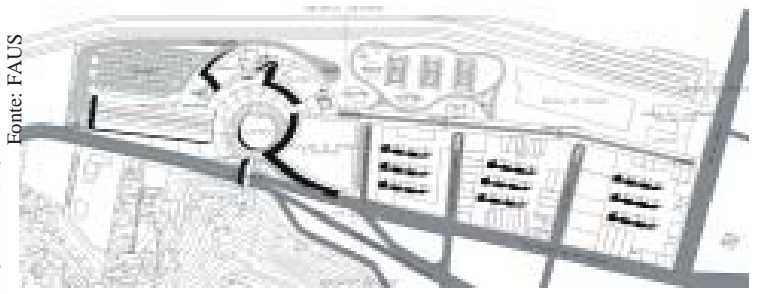

6. E. G. Pason, TGI/FAUS, 1998: centro de convenções, parque e unidades residenciais nos terrenos do termial ferroviário do Valongo

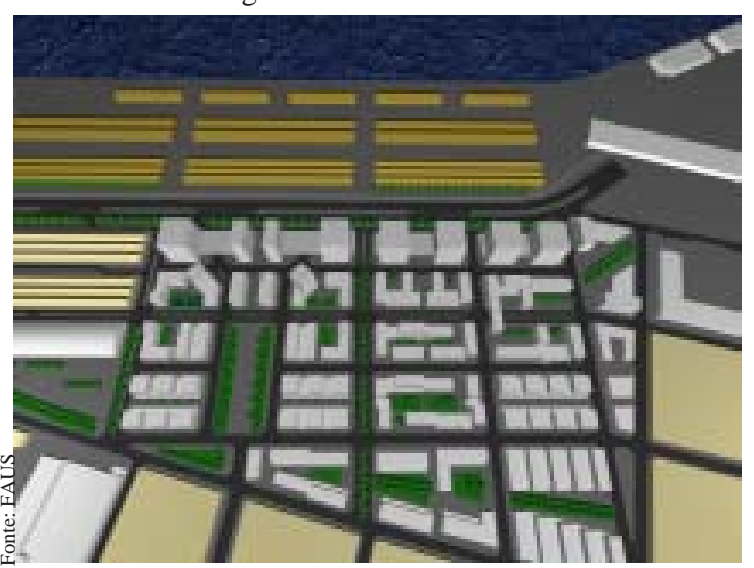

7. B. G Andrade, TGI/FAUS, 1998: reconversão urbanística do setor Outeirnhos: centro de negócios e residência 


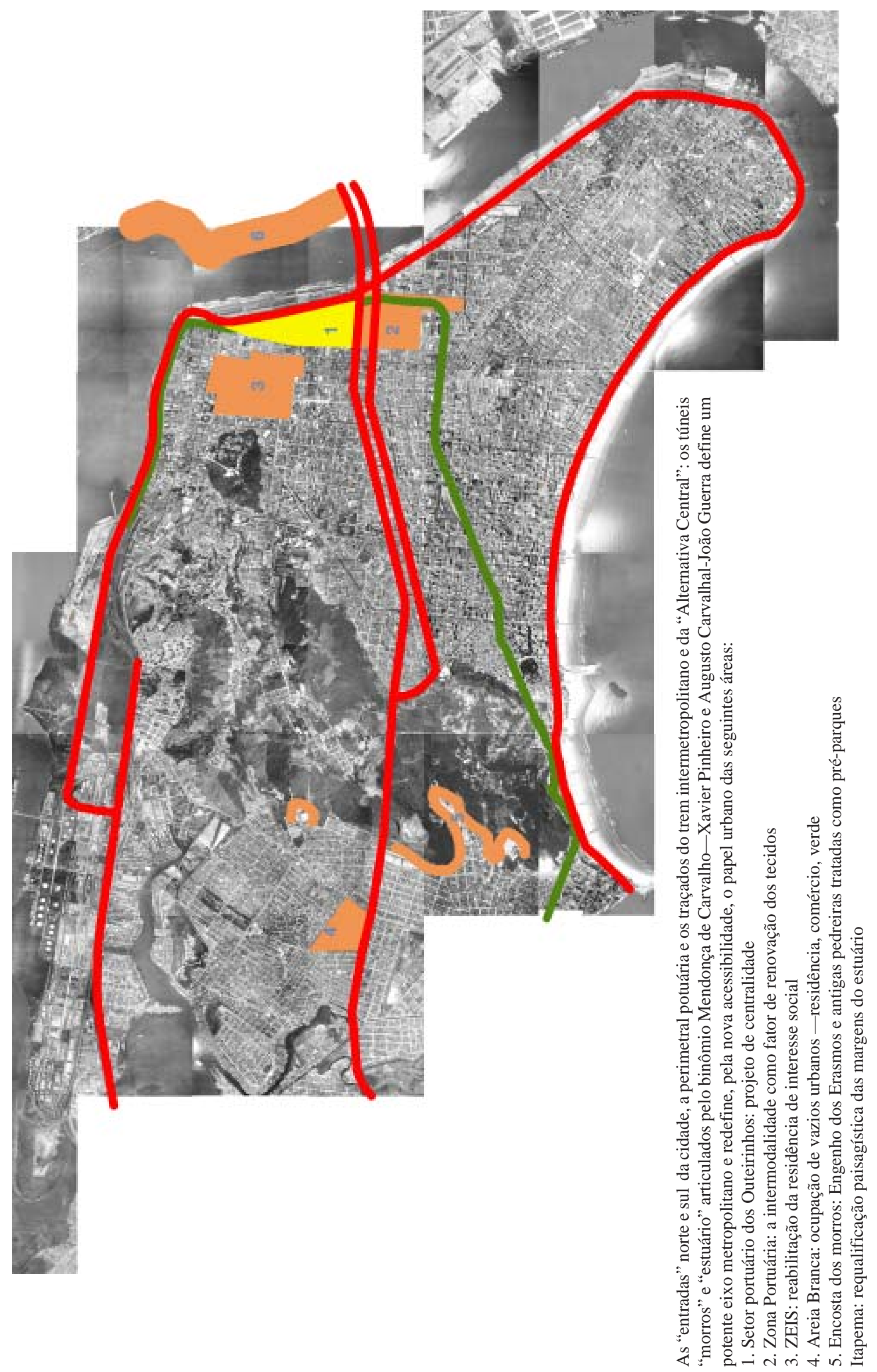




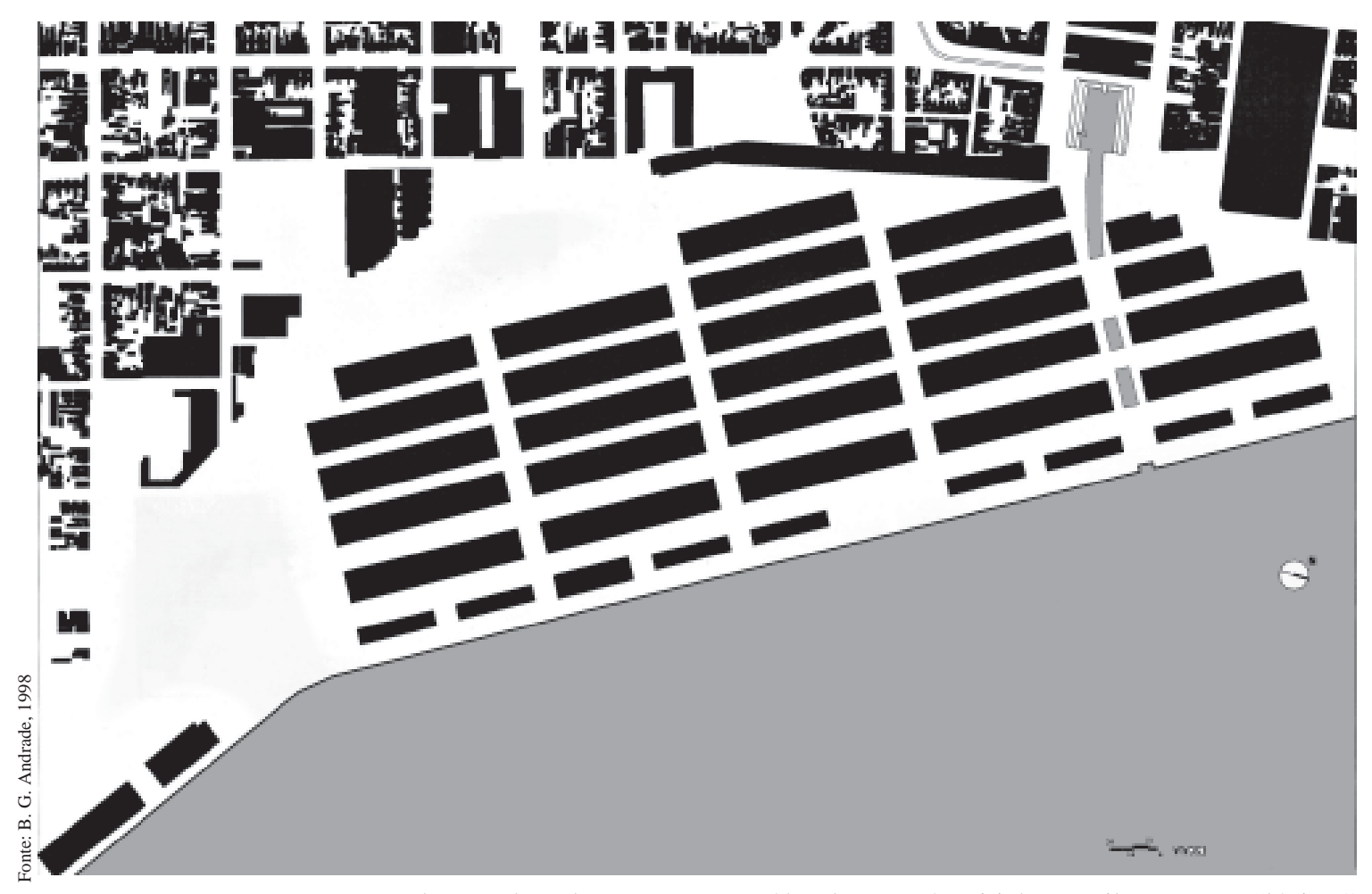

Estrutura do traçado e do espaço construído do setor Outeirinhos-Vila Nova: as "lógicas" portuárias e urbanas sem a configuração de interface

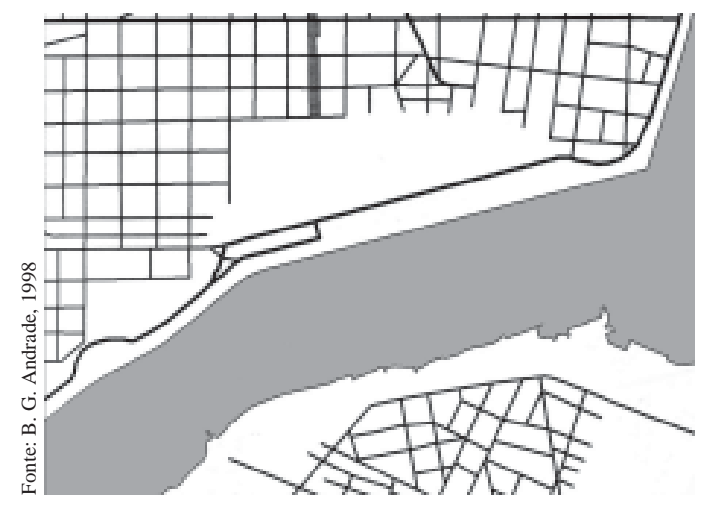


Vista desde o Monte Serrat do estuário: os armazéns do porto e o tecido resicencial de Santos e Vicente de Carvalho
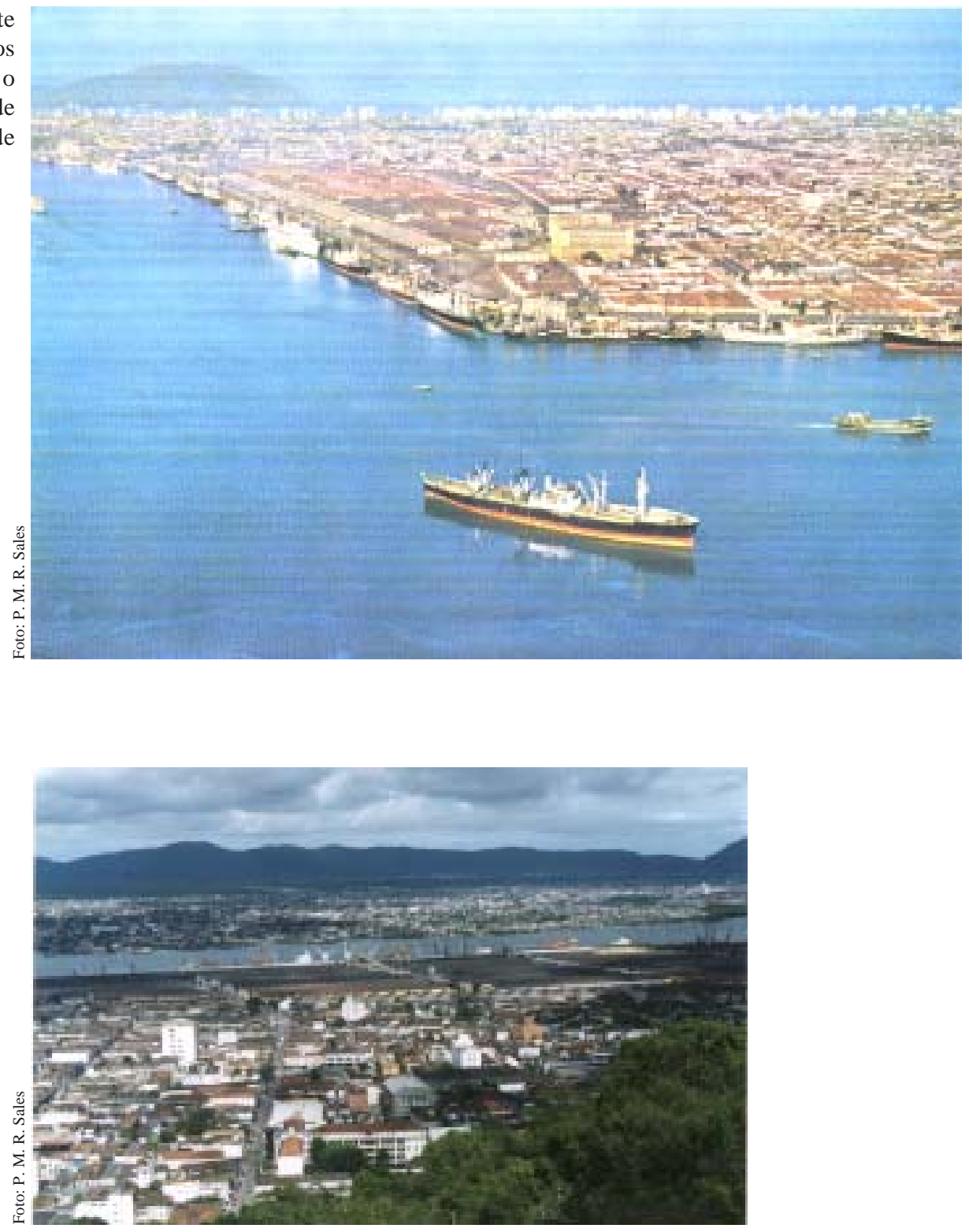

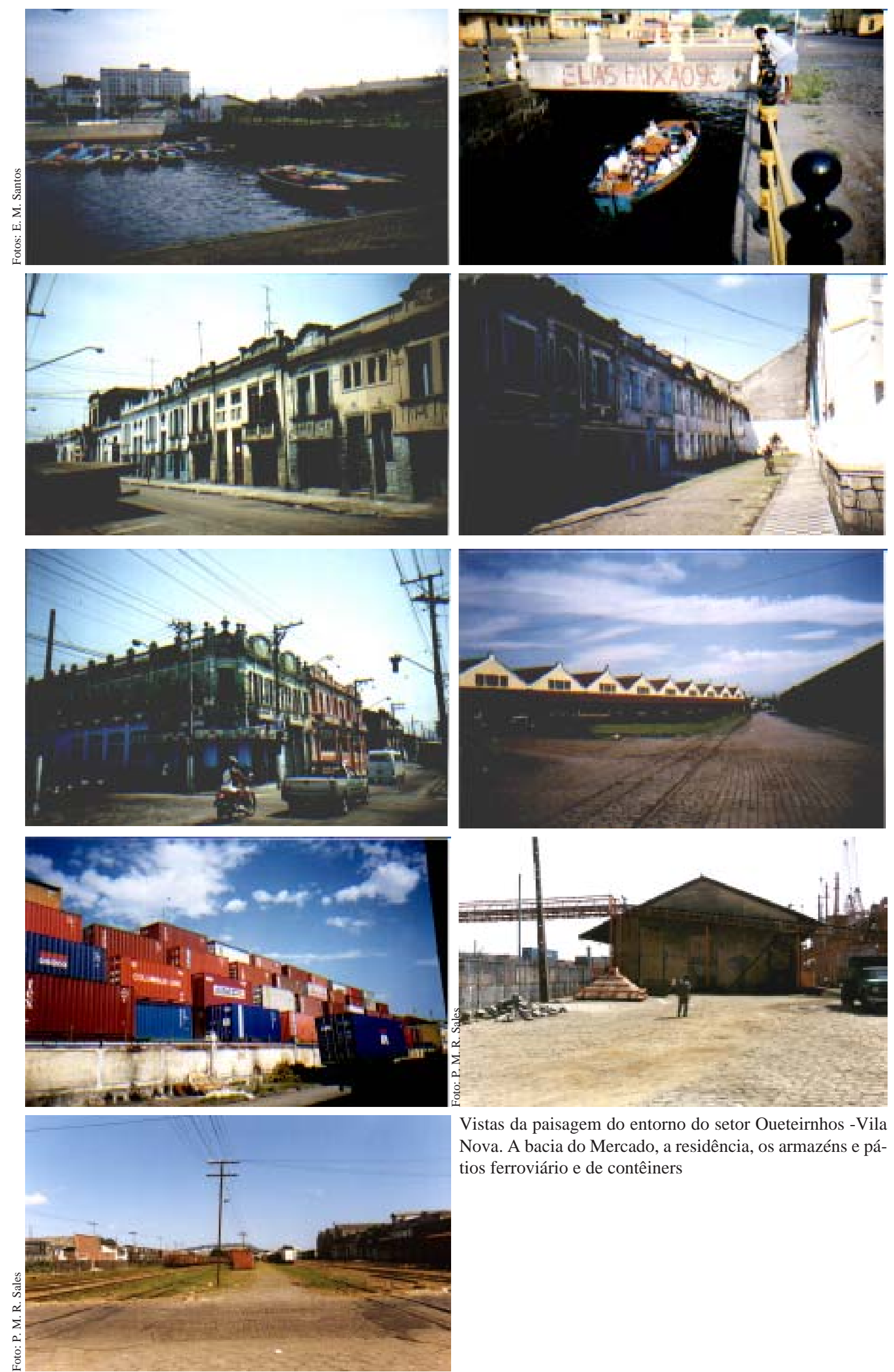

Vistas da paisagem do entorno do setor Oueteirnhos -Vila Nova. A bacia do Mercado, a residência, os armazéns e pátios ferroviário e de contêiners 
Foto aérea do setor Outeirinhos e entorno: delimitação das áreas de intervenção propostas
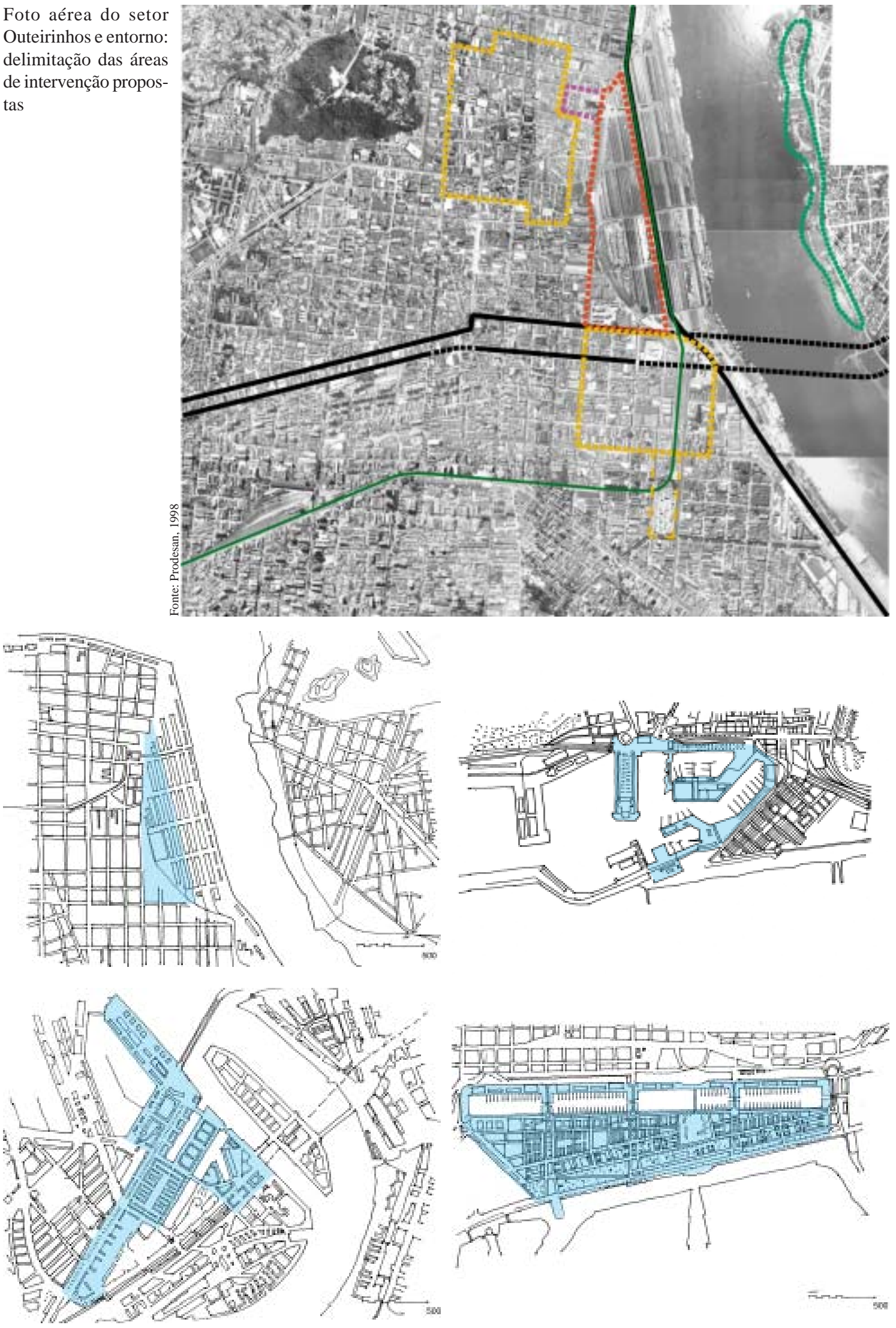

Comparação entre as áreas da faixa portuária proposta para reconversão em Santos e os projetos de renovação de "waterfront" em três cidades. Acima, Santos (35 ha) e Barcelona-Port Vell (54ha). Abaixo Roterdã-Kop van Zuid (125 ha) e Buenos Aires-Porto Madero (projeto Consultores Europeus Associados, 171,3 ha) 
${ }^{1}$ A. L. D. Lanna, Santos: uma cidade na transição 1996, p.36

${ }^{2} \mathrm{O}$ processo de encortiçamento localizava-se principalmente nas quadras mais próximas do sopé dos morros, que diante dos programas de erradicação "sanitarista" dos cortiços, e da inexistência de alternativas acessíveis, tornar-se-iam também opção de lugar de moradia para os trabalhadores das companhias feroviária e portuária

${ }^{3}$ Cia Docas de Santos. Relatorios da Directoria (1900-1902) apud C. Honorato, O polvo e o porto., 1996, p.138

${ }^{4}$ Cia. Docas de Santos. Relatorios da Directoria — 1903 a 1906. 1906, p.3

${ }^{5}$ O. C. Gonçalves. Plano Diretor Físico. Caracterização sócio-econômica, 1965

${ }^{6}$ Prodesan, PPDI 76, 1976, p.20

${ }^{7}$ Codesp. Plano de desenvovlimento e zoneamento provisório, 1996, p.9

${ }^{8} \mathrm{C}$. Honorato. O polvo e o porto, 1996.

${ }^{9}$ A. L. D. Lanna, Op. cit, 1996

${ }^{10}$ M. Alves dos Santos. "A Região Administrativa da Baixada Santista" in Seade. São Paulo no limiar do século XXI, 1992, p.71

"Ibid.

${ }^{12}$ Marinha Mercante, suplemento de O Estado de São Paulo, 12/5/1999

Segundo W. G. Rossi, presidente da Codesp, “o redimensionamento das áreas (de direção) irá abranger todos os níveis, fazendo um enxugamento sobretudo onde a Codesp deixa de atuar, como é o caso das operações. Isso implicará na redução do quadro de funcionários de 1.977 para cerca de 1.100. Na medida do possível, pretendemos que os trabalhadores sejam passados à iniciativa privada".

${ }^{13}$ Diário Oficial de Santos nº1062, 7/8/1993

J. Rodrigues, assessor para Assuntos Portuários da Prefeitura estimava que o porto empregasse em 1993, direta ou indiretamente, 41 mil pessoas que, com suas atividades (incluindo retroporto, agências de navegação, de transportes), contribuiriam com $30 \%$ do orçamento do município, então estimado em 100 milhões: "Hoje a Codesp é a principal repassadora do ISS do Município. De todo o ISS que a prefeitura arrecada, 20\% são repassados pela Codesp, que cobra dos usuários dos portos. Além disso, temos em torno do porto cerca de 50 ou mais terminais contêiners de expressão que pagam taxa de licença, IPTU e tem partcipação de valor adicionado para o Município com relação ao ICMS. Nós calculamos que essas atividades portuárias, incluindo Codesp e retroporto, contribuem com pelo menos 30\% do Orçamento de Santos. Embora possamos aperfeiçoar essa contribuição, estamos em negociação sobre o IPTU das áreas da Codesp. O que nos interessa é que nas áreas do porto, ou contíguas a ele, possamos instalar indústrias voltadas para a exportação, centros comerciais, atividades ligadas ao turismo, como novo terminal de passageiros cujas obras vão se iniciar no antigo armazém frigorífico como um ponto de atração turística, não apenas para passageiros". Por outro lado, reportagem de A Tribuna, 9/3/1999 noticiava que "a Codesp acumula dívidas de $\mathrm{R}$ \$ 30 milhões com fornecedores de produtos ou prestadores de serviços que não são pagos em dia, mas garante que nenhum serviço executado pela empresa está ou poderá ficar comprometido em razão de inadimplência. O valor abrange os débitos que a Prefeitura de Santos quer cobrar, relativos ao Imposto Sobre Serviços (ISS), de R \$ 2 milhões e 400 mil, mas não inclui a dívida referente ao Imposto Predial e Territorial Urbano (IPTU), de R 105 milhões". Ainda mais: "Entraram R \$ 251 milhões nos cofres da estatal ao longo de 98, contra um volume de despesas que somou, também nos 12 meses do ano passado, R \$ 248 milhões (...) A Codesp não explicou por que a receita é maior que as despesas e ainda assim não paga os fornecedores de serviços em dia. Nos últimos anos, houve uma queda relativa na receita operacional da Codesp porque a companhia deixou de atuar na operação portuária, que passou para as mãos da iniciativa privada. Em contrapartida, receita com os arrendamentos de áreas e instalações a empresas particulares aumentou". Segundo Marinha Mercante (12/5/99)., "apesar de ser a maior gestora do porto de Santos, o maior do Brasil (...) a Codesp foi a única companhia Docas que fechou suas contas no vermelho em 1998: um déficit de R $\$ 86,9$ milhões"

${ }^{14} \mathrm{~J}$. Rodrigues. Ibid.

${ }^{15}$ B. Mansur, prefeito de Santos in A Tribuna 18/3/1999: "Quando se tem de tomar uma decisão no porto, seja na área de investimento, mudança no sistema viário ou a construção de um túnel, estaremos sempre mexendo no dia-a-dia dos municípios. O porto, pelo que sinto, está apartado da Cidade. O porto não paga ISS ou IPTU à Prefeitura de Santos. Quando precisamos de uma informação, temos muita dificuldade de conseguir qualquer resposta. E o porto está dentro dos limites dos municípios".

${ }^{16}$ O Estado de São Paulo, 9/8/1998 
“O Terminal de Contêiners (Tecon), privatizado em setembro do ano passado, registrou a atracação de 320 navios no primeiro semestre deste ano, $76 \%$ a mais do que a Codesp conseguiu atender no primeiro semestrre do ano passado antes da privatização"

${ }^{17}$ Marinha Mercante, Op. cit.

${ }^{18}$ O Estado de São Paulo, 9/8/1998.

Enquanto os sindicatos continuam impondo numerosas equipes para trabalhar no cais ou a bordo dos navios, as empresas entendem que dos 14 mil estivadores em ação no Porto de Santos, bastariam apenas 2 mil, como forma de reduzir o custo da operações. "Na Argentina, cada contêiner movimentado tem um custo de U\$ 110. Em Santos, só o custo dos trabalhadores da estiva e capatazia é de U\$150"

${ }^{19}$ A Tribuna, 1/9/1998

${ }^{20}$ Marinha Mercante, 7/7/1999.

O estudo realizado pelo BNDES denomina-se "As novas empresas mundiais de navegação determinam a evolução dos portos"

${ }^{21}$ Investimentos a serem realizados no sistema Anchieta-Imigrantes, túnel do porto, aeroporto do Guarujá e de Itanhaém, entreposto atacadista, hotel, shopping center e parques temáticos.

${ }^{22}$ Lei complementar n³11 de 23 de novembro de 1998, Diário Oficial de Santos, p.4

Zona Intermediária, que constitui na porção leste, "área residencial de baixa densidade em processo de renovação urbana onde se pretende incentivar novos modelos de ocupação";

Zona Noroeste, "área residencial de baixa densidade e vias comerciais definidas, onde se pretende incentivar a verticalização e a ocupação dos vazios urbanos com empreendimentos habitacionais de interesse social, bem como incrementar os Corredores de Desenvolvimento e Renovação Urbana".

${ }^{23}$ DERSA, Análise das alternativas para ligação Santos-Guarujá, s.d., p.9

${ }^{24}$ F. Gazal. "Os terminais multi-uso" in Navios e Portos, janeiro 1989

${ }^{25}$ A Tribuna, 31/1/1988

${ }^{26}$ Ibid.

${ }^{27}$ Estudos comparativos realizados por J. Busquets em relação ás operações de requalificação urbana indicam o índice 2 (para a equação àrea construída/área total de terreno) como parâmetro que garante viabilidade econômica e qualidade ambiental. Estudos realizados por mim em relação à coversão urbanística de áreas portuárias apontam um índice entre 1,5 e 1.

${ }^{28}$ Vide C. Llop. "Lògiques I espais projectuals d'una metrópoli. Barcelona 1976-1992" in Papers $n^{\circ} 28$, janeiro 1997 


\section{CONCLUSÃO}

A motivação incial desta pesquisa nasceu de indagações que o trabalho de dissertação de mestrado sobre possíveis projetos para a cidade de Campinas apenas apontava e que diziam respeito sobretudo à obsolescência das infraestruturas ferroviárias, que haviam suportado o primeiro desenvolvimento daquela cidade. Pareceu-me então que só a compreensão das formas e processos de inserção dessas infra-estruturas na construção e transformação do território paulista poderia fornecer pistas mais consistentes para uma interpretação, que se queria projeto, não de um "vazio urbano" mas de uma "peça" da cidade que pudesse ser re-articulada produtivamente com escalas mais amplas.

Desse modo, o eixo Santos-São Paulo-Campinas, isto é precisamente a espinha dorsal do território, construído e transformado a partir da ferrovia novecentista, evidencou-se como o âmbito a partir do qual a problemática "obsolescência/possibilidade futura" poderia ser recortada e enfrentada. Daí, ao lado das áreas do complexo ferroviário campineiro, o setor mais antigo da implantação industrial de São Paulo e o complexo portuário santista, recontextualizados, despontavam teoricamente como o campo privilegiado fundamental do projeto da (macro)metropóle contemporânea.

No percurso de investigação, primeiro as áreas industriais de São Paulo (por obedecer a outras lógicas como propriedade privada do solo, fatores de localização específicos, etc), e depois, talvez por falta de fôlego, talvez pela existência de outros estudos (e mesmo por sugestão da prória "banca de qualificação"), as áreas ferroviárias de Campinas, teriam seu estudo relegado a outras oportunidades. Ao mesmo tempo, apesar de existirem estudos importantes, senão definitivos, sobre o tema da construção da cidade e do porto moderno (e aqui tais referências foram largamente utilizadas), a complexidade específica da realidade santista, bem como as dificuldades encontradas para reunir material adequado sobre o desenvolvimento urbano e, principalmente, o portuário (os arquivos da Codesp são algo inacessíveis), fizeram-me concentrar as atenções no caso santista, por entender que representava "material" adequado, mesmo porque menos examinado, para a reflexão sobre o projeto da cidade contemporânea paulista.

No entanto, a certeza da necessidade de um contexto mais amplo de referência, do qual recortar a relação porto/cidade em Santos, não permitiria abrir mão da verificação das inter-relações que permeiam historicamente o desenvolvimento daquelas três cidades, e que assim, de certa maneira, definem seu papel no terriório e condicionam sua evolução (o que faz intuir à exemplo da Randstad holandesa a necessidade de formulação de uma política 
territorial que explore a sinergia que se possa criar entre projetos para essas cidades macrometropolitanas no sentido de valorização de seu potencial físico e econômico como fator de vantagem competitiva no âmbito da integração do cone sul).

Neste sentido, focado na realidade santista, o percurso analítico orientou-se pelo conceito de "valorização territorial”, ou seja a definição do valor das condições locais por sua relação com contextos mais amplos ou complexos conceito de interesse atual e renovado em um mundo cuja realidade é "interdependência universal dos lugares" (Santos, 1994) e onde, de forma aparentemente contraditória, o "local" revela sua autonomia e importância-. A periodização proposta para essa análise, tendo em vista particularmente a importância do papel das inter-relações entre Santos e São Paulo, moldou-se segundo as variações que se pode observar nos "modelos de integração territorial" (sistema de binômios, gráfico em árvore, em estrela e em rede) com o sentido de repesentar pelas categorias descritivas (polaridades, gradientes, centralidades, redes) as condições e tendências recentes dos fenômenos de valorização do território macrometropolitano paulista. Aqui, confrontando os processos de reestruturação do sistema produtivo, de inovação nas comunicações e transportes e de desenvolvimento urbano de Campinas e Santos, sem perder de vista o papel de comando, onipresente em nível nacional, exercido pela capital, a análise permitiu observar que o modelo econômico santista, fundado no tripé porto/turismo/serviços e comércio, deixara, desde pelo menos os anos 70, de gerar efeitos multiplicadores sobre a cidade e a região. Até aquela data pode-se considerar que as externalidades geradas na capital foram as responsáveis pelo desenvolvimento santista. Porém, mudado o papel da metrópole e de certa forma "repelidos" pela saturação ambiental da Baixada Santista, os investimentos públicos e privados seriam reorientados para outras regiões, onde a articulação agricultura/ indústria/P\&D mostrou-se decisiva, passando essas regiões a constituir a "hinterlandia" agro-exportadora do porto; "hinterlândia" essa que dadas as facilidades proporcionadas pela inovações da tecnologia dos transportes e comunicação passa a competir como sede de serviços aduaneiros acoplados a trabalho de armazenagem, de carga e descarga de mercadoria, com redução equivalente nas zonas próximas do porto. Procurou-se assim mostrar que todo esse conjunto de novos fatores locacionais acabaram por minar a base produtiva da cidade de Santos, particularmente em termos de geração de inovações.

No capítulo 3 e 4 foram analisadas a relação entre a expansão portuária e os modelos de crescimento urbano de Santos através de sua incidência nos sistemas de mobilidade, centralidade, de produção, de residência e ambiental da cidade. Ficou patente a falta de integração entre a gestão portuária e a municipal. As principais consequências da incongruência das ações revelamse com mais contundência nos aspectos relativos à circulação e ao uso e 
ocupação do solo na ante-faixa estuarina, invadida por atividades retroportuárias, cuja localização urbana, induzida pela expansão do aparelho portuário e estimulada por legislação permissiva, revela-se incoerente com a própria eficiência da operação portuária e alheia aos efeitos que provoca. Ao mesmo tempo, contraposta à modernização (especialização, ou mesmo "personalização") das instalações do setor Saboó/Alemoa e da margem esquerda (contêiners, fertilizantes, granéis), observou-se o processo de esvaziamento funcional e depredação física dos setores mais antigos, ainda que aparentemente camuflada pela "privatização" das instalações: a imagem da "trapichização mecanizada" mostra-se adequada para representar o fenômeno. Com respeito à estrutura urbana, se por um lado a "lógica" da implantação das centralidades e o papel dos eixos estruturadores, bem como sua influência, ao lado das orlas marítima (turimo) e estuarina (porto), na localização das atividades e da residência, indica a "força" da morfologia "geográfica" e urbana, por outro lado, a ausência de outros processos ligados às formas mais dinâmicas de consumo ou de produção sinaliza e talvez possa ser tomada como "causa" da inércia territorial e da estagnação econômica da cidade de Santos.

Se nesses capítulos precedentes buscou-se o "porque" de uma hipótese de reconversão urbanística do porto, o capítulo 5 procurou indagar "como", "para que" e "onde" essa hipótese se mostra válida. Neste sentido, constatouse a repercussão da primeira implantação portuária na produção da cidade. Modernizada pelos investimentos sanitaristas, como condição de sua participação no comércio mundial, a cidade "pré-figura" seu crescimento, garantindo a entrada de solo urbano no mercado. Deste modo, antes lugar de concentração de força de trabalho, Santos torna-se também, pelo crescimento urbano, elemento de produção de valor e consumo, seletivo e diferenciado. Neste processo, o "modelo ecológico" da cidade vai distribuir as atividades e a residência segundo gradientes de valor -mais elevados na orla e na antiga área central, e descrescente no sentido do estuário aos morros. Viu-se que a pressão populacional, de natureza flutuante (turismo, segunda residência) e fixa (com significativo aumento das classes médias, decorrente do processo de industrialização de Cubatão), resultaria, impulsionada pelo mercado e servida por uma legislação permissiva, em dois efeitos complentares sobre a demanda de solo da porção leste da ilha: substituição mais ou menos generalizada da edificação pela verticalização e ocupação da zona noroeste e áreas de município vizinho por parte da população de menor renda, expulsa das áreas mais centrais. As atividades retroportuárias, antes circunscritas à porção norte da cidade, criariam nova pressão sobre a demanda de solo em toda faixa de interface cidade-porto, impactando a residência e ampliando o desvinculamento físico da cidade com o estuário. Por outro lado, pode-se observar que se os "interesses" portuários e urbanos nem sempre coincidiram, a privatização, supondo operadores “desterritorializados" em relação à cidade, supõem também a não coincidência de seus interesses com interesses 
econômicos e sociais identificados com a cidade. Poder-se-ia dizer, no limite, que, se a cidade "precisa" do porto (captação de mão-de-obra, cargas tributárias, etc), para o porto, por suas próprias características de "autonomia" física, funcional e administrativa (aliás, característica universal dos aparelhos portuários contemporâneos), a cidade representa cada vez mais, senão um entrave, ao menos um simples âmbito físico para sua operação.

Assim tendo em vista, de um lado, a estagnação do desenvolvimento econômico da cidade e o esvaziamento das possibilidades elencadas para a superação deste estado de coisas (até recentemente, centradas na industrialização de base do município), e de outro, a inexistência, no recente Plano Diretor, de uma "idéia" que possa "ativá-la" espacial e econômicamente, a argumentação realizada levou à discussão de uma hipótese de reestruturação do território e de requalificação de setores urbanos como "suporte" da transformação funcional e econômica da metrópole. Isto na medida em que a ação de articular projetos (setoriais) de infra-estruturação metropolitana, pendentes, com uma revisão dos modos de uso dos recursos físico-formais e ambientais presentes pode comportar uma força de atração a novos interesses econômicos e produtivos no sentido de valorizar os recursos locais, como o são o potente patrimônio portuário, terciário e turístico de Santos.

A configuração de novos sistemas de mobilidade, integrando por uma linha de grande potência as várias unidades ambientais que compõem a Baixa Santista, do Samaritá à Bertioga, redefine os valores das áreas mais diretamente servidas por ela (na medida em que cria uma alternativa estrutural para o território) e define as condições para a criaçao de novas centralidades do território. Neste quadro, especialmente o setor portuário do Outeirinhos e seu entorno urbano, revalorizados pela nova "acessibilidade metropolitana" $\mathrm{e}$ reconvertidos urbanisticamente, passam a constituir a referência para o reconhecimento do território como conjunto unitário, reforçando o tecido de relações que ligam as diversas partes urbanas.

Neste tecido, por sua relevância histórica e geográfica, ocupacional e simbólica, o porto constitui elemento fundamental: desse modo às tendências de segregaçâo física, funcional e administrativa que marcam sua dinâmica de transformação, aqui buscou-se discutir uma alternativa através da qual, reintegrá-lo, ainda que como "solução" parcial, ao conjunto de fatores de valorização e desenvolvimento urbano. 


\section{APÊNDICE \\ ESTUDOS DE CASO DE RECONVERSÃO URBANÍSTICA DE ÁREAS PORTUÁRIAS}

\section{Infra-estrutura portuária e a cidade: as características dos projetos em curso}

Peter Hall' afirma que os projetos de reconversão das áreas portuárias representaram em seu conjunto o tema paradigmático do urbanismo dos anos 80. Porém, se as grandes operações de reconversão urbanística de áreas portuárias tiveram, na verdade, início nos anos 50 com a experiência de Boston seguida pela de Baltimore, o "êxito" comercial alcançado por ambas acabaria por torná-las modelos a serem exaustivamente copiados em diversas cidades do mundo. Lastreadas na oferta de "diversão" como preconizava seu promotor, James Rouse - “cities are fun -, a revalorização das áreas portuárias destas cidades imprimiram, principalmente no caso de Baltimore, dinâmica retomada do centro antigo da cidade, "estendendo-o" através da implantação de um inevitável "parque de atrações" — centro de ciências, aquário, museu marítmo e um festival market - associado com outros empreendimentos — hotéis, centro de negócios-; empreendimentos esses catalizados justamente pela transformação do waterfront.

Em todo caso, o significado deste modelo "non-place urban realm, ainda que seguido por outras operações (de maior ou menor escala) de reconversão, deveria ser segundo Meyer $^{2}$, relativizado. Particularmente se for considerada a relação que o mesmo estabelece com a cidade ou mesmo com o waterfront como um todo. Seja em termo físicos, formais, funcionais como simbólicos. Neste sentido, Busquets ${ }^{3}$ e M. Law ${ }^{4}$., sugerem, em trabalhos diversos uma classificação geral das operações de reconversão a partir da consideração de alguns condicionantes principais:

- posição relativa da área portuária em relação à cidade

- a forma do porto 6

- as dimensões das áreas envolvidas (tendo-se como parâmetro a escala dos 100ha: esta dimensão representaria um dos condicionantes, a par das restrições institucionais, da inclusão ou não da função residencial no programa das operações)

- os mecanismos de gestão.?

Por um lado, a combinação destas variáveis resulta, ainda de acordo com Busquets ${ }^{8}$, em modelos de operação "continentalizados": 
- o norte-americano: transformação de pequenos setores sem um sistema de referência mais geral

- europeu: projetos globais de reconversão desenvolvidos por partes

- asiático: grandes operações urbanas de carater multifuncional

Por outro lado, os modelos de reconversão das áreas portuárias incluem desde a criação de fragmentos isolados, que podem ou não funcionar como catalizadores da renovação de seu entorno, até a criação de verdadeiras "cidades dentro de cidades" como ocorrido na experiência de Battery Park City, onde apesar de algumas condições impostas pela administração municipal (manutenção de corredores visuais, destinação de 30\% da área para espaço público), a solução urbanística adotada mantém o complexo fechado sobre si mesmo $^{9}$. Aqui cabe ressaltar o papel das grandes firmas de empreendimentos imobiliários (como por exemplo, a canadense "Olimpia\&York", responsável pela transformação dos portos de Nova York, Toronto e do setor de Canary Wharf em Londres) que acabam impondo um mesmo "estilo" de operação, fazendo convergir a um modelo "padrão" (muitas das vezes cópias de situações análogas) as soluções formais e funcionais ${ }^{10}$. Por outro lado, a face econômica destes empreendimentos voltados à "economia global", centrados como são na criação de espaços para escritórios, mostrou sua vulnerabilidade diante das mudanças dos mercados mundiais e das condições dos mercados imobiliários locais. Como constata Malone" :, "embora Londres tenha realizado uma grande exibição do "músculo" financeiro de Docklands, a bancarrota de Canary Wharf em 1992 expôs a sensibilidade do desenvolvimento dos (projetos de) waterfront aos fatores econômicos internacionais. (O caso de) Docklands também mostrou que o nível do suporte oficial aos projetos exacerbou o significado do malogro que envolveu muitos projetos no fim (da década) de 1980", denunciando as operações de "demandled planning , que resultaram em uma paisagem completamente alheia e desvinculada às pré-existências físicas e sociais.

No entanto, um outro "tipo" de resultado possível de ser alcançado contempla a integração porto-cidade através do desenho coerente dos espaços para uso público, mantendo a identidade da paisagem marítima enquanto forte signo de continuidade física e histórica da cidade, de tal maneira como por exemplo, sucede nas operações do Moll de la Fusta em Barcelona ou ainda em setores do antigo porto de San Francisco e de Marseille.

A partir destas considerações, Hans Mayer ${ }^{12}$ sugere uma tipologia de projetos de reconversão de áreas portuárias que os dividem grosso modo em duas categorias: 
- a dos projetos desenvolvidos de forma mais ou menos independente da cidade: na perspectiva comercial e econômica que os caracteriza, a ênfase é colocada no design arquitetônico, sem qualquer referência ao contexto morfológico ou dos significados históricos e culturais da cidade. Primeiramente implantados nas cidades norte-americanas no entanto, a influência desta "tipologia" dissseminou-se por várias partes das Docklands, de Kop van Zuid, do porto de Antuérpia ou do Port Vell de Barcelona.

- a dos projetos integrados a estratégias de transformação urbana, onde "as novas funções e significados são associados às estruturas e significados historicamente desenvolvidos na cidade". Exemplos desta visão podem ser encontradas nos portos do Mediterrâneo em geral e, particularmente, no exemplo do Moll de la Fusta em Barcelona.

Ainda que se deva considerar alguns outros aspectos que de certa maneira condicionam as operações de reconversão de áreas portuárias obsoletas (como por exemplo, o dinamismo da própria cidade, os aspectos de gestão e financiamento da operação, etc) talvez em última instância, esta discussão pudesse ser resumida no entendimento que se tenha da área portuária em sua relação com a cidade: um possível vazio a ser preenchido de maneira mais ou menos autônoma, em termos arquitetônicos e urbanísticos, funcional e simbólicamente fragmentados e compartimentados, ou pelo contrário, flagrá-la como ponto estratégico (as condições de sua implantação original, bem como de seu papel produtivo e de sua imagem urbana, favorecem este entendimento). E a partir daí, desde uma leitura de mais amplo fôlego dos problemas e potencialidades da cidade e do território, ancorar projetos de transformação que busquem resolver mesmo que parcialmente, os temas urbanos e territoriais pendentes, sem perder a possibilidade de redinamizar a referência econômico-social e cultural representada pelo porto, como critério e parâmetro daqueles projetos. 


\section{Barcelona}

Cidade com 2000 anos de existência, alternando períodos de grande desenvolvimento com largos ciclos de estagnação e dificuldades políticas (e talvez por isto mesmo) Barcelona tenha afirmado sua identidade, seus valores e aspirações através de uma "consciência" urbana endogenamente construída e continuamente renovada ao longo de todo o processo histórico de transformações do qual a cidade participou ativamente.

Após o esplendor político e econômico conhecido durante a Baixa Idade Média (séculos XII a XIV), a crise e o declínio experimentados por três séculos (XV ao XVIII), as retomadas criativas dos séculos XIX e XX, Barcelona é uma cidade relativamente pequena (1.700.000 habitantes / $\left.7.6 \mathrm{~km}^{2}{ }^{13}\right)$ que, apesar de sua posição "central" no contexto territorial espanhol e mediterrâneo, constitui um centro econômico e financeiro de apenas relativa importância se comparado às grandes metrópoles internacionais ${ }^{14}$. Esta ambição - desempenhar um papel decisivo no contexto europeu - foi até pelo menos 1992, frustrada em grande medida, pela falta de apoio, senão oposição mesmo, por parte do governo central ${ }^{15}$. Daí o fato da cidade, em sua transformação e modernização ser ( mais do que qualquer outra e antes de mais nada) criação de seus cidadãos e da aliança de facto entre o governo local e as forças econômicas e políticas também locais ${ }^{16}$.

Esta relativa "debilidade" econômica e política e este "consenso" social de base iminentemente civil podem ser considerados portanto, a razão principal da criação e do fortalecimento desta identidade cultural específicamente barcelonesa. A expressão material desta cultura urbana pode ser encontrada na reinterpretação do patrimônio físico (notadamente o "casco" medieval que à diferença de outras tantas cidades antigas, participa, integrando-se às exigências da modernização e inovação, da vida ativa da cidade dos últimos 200 anos), na (ainda) potente estrutura urbana do Eixample (plano oitocentista de expansão da cidade cuja implantação, apesar de imposta por decreto real, foi levada a cabo pela associação dos proprietários e conselheiros municipais) nas renovações imprimidas na cidade por ocasião das exposições universais de 1888 e 1929 como afirmação da burguesia industrial catalã e, mais recentemente, na política de renovação (infra-estrutura, espaços públicos e projetos urbanos) que arrancou com os eventos olímpicos de 1992.

Tudo isto acabou tornando Barcelona referência obrigatória dentro do panorama urbanístico internacional. A reconhecida coerência (e potência) de sua estrutura urbana, no entanto, foi construída com grandes contradições. A maior delas talvez tenha sido a de uma cidade mediterrânea que cresceu voltada de costas para o mar. 


\section{O porto e a ferrovia}

Barcelona apesar de sua boa localização como ponto de contato das rotas marítimas e terrestres e do domínio marítimo, militar e comercial sobre o Mediterrâneo Ocidental, teria que esperar até o século XV para ter um porto, pelo menos na acepção moderna da palavra'r. Pois, as limitações que as condições naturais impuseram ao desenvolvimento do potencial portuário só seriam superadas após séculos de esforços técnicos de estabilização da costa com a construção de um porto artificial e da "muralha do mar", elementos que iriam definir por muito tempo a forma da cidade e do porto.

Paradoxalmente, a contradição de uma "grande capital mediterrânea sem porto"18 seria resolvida (embora ainda de modo incipiente, porque haveria de se esperar até o século XVII para a construção de um molhe e contramolhe definitivos) no momento de grande inflexão demográfica e econômica que acabaria isolando a cidade dos circuitos internacionais ${ }^{19}$. Este período de estagnação contribuiu em boa parte para a fixação da forma urbana e portuária segundo uma figura "única, linear, precisa e característica" dada pela Muralha do Mar que de Drassanes ao Baluarte do Nascente, tangenciava os limites do centro gótico. A faixa que se deixara livre entre a cidade e o mar, além da função defensiva, iria receber a expansão renascentista e se converter assim em um importante espaço representativo - o Passeo de la Riba. ${ }^{20}$

Desta maneira a nova fachada do mar (construída a cinco metros de altura em relação à cota natural do porto) alinhava os velhos campanários ${ }^{21}$, os conventos e os palácios nobiliários enquadrados entre a montanha de Montjuic e o espigão de Barceloneta (construído em 1753). Neste último, sobre a área formada pelo progressivo aterramento na parte posterior do dique, iria estabelecer-se, segundo um sistema urbanístico diferenciado (já em moldes militarmente "clássicos") a população marinheira desalojada do bairro da Ribera para a construção da fortaleza da Ciudadela.

Já no século XIX, a incidência do incremento da atividade portuária na organização e configuração urbanas revelou-se na urbanização em 1825, do Plá de Palau que iria definir sob um aspecto monumental, no espaço compreendido entre a frente do porto, a Ciudadela e o portal do Mar, o primeiro centro de negócios da cidade, reafirmando o caráter de passeio público da Muralha do Mar. Porém, transformações significativas nesta paisagem só se dariam no bojo da nova dinâmica urbana e industrial que Barcelona iria protagonizar já no primeiro terço do século XIX. O aumento da população, a consolidação do setor industrial e comercial e a articulação do território por ferrovias suporiam mudanças estruturais. No entanto, face aos problemas acarretados pela atividade industrial que se instalava intra-muros (congestionamento de setores da cidade, pressão social, etc), Barcelona orientaria seu crescimento no sentido interior, ocupando progressivamente 
através da malha homogênea e unitária proposta por Cerdá (1859), os terrenos do "llano" (planície), desde a área envoltória de restrição miltar que envolvia o casco antigo, até os núcleos urbanos pré-existentes de Grácia, Sants e Sant Andreu. Neste sentido, destinando uma grande reserva ferroviária à frente marítima de Barcelona (já ocupada em 1848 pela primeira linha férrea até Mataró ${ }^{22}$ ), a previsão do plano Cerdá reforçou a dinâmica do crescimento urbano definitivamente voltado de costas para o mar. Assim, o isolamento entre a cidade e o mar produzir-se-ia progressivamente (segundo coroas sucessivas desde Barceloneta até Poble Nou e depois a foz do rio Besós) pela instalação de uma faixa de plantas industriais e de centrais energéticas que permaneceu impermeável pela presença do obstáculo representado pela própria linha férrea. Ao mesmo tempo, a modernização portuária (já como um sistema independente) iria tornando os molhes, zonas cada vez mais especializadas e, portanto, segregadas da cidade.

A tendência de ocupação interior ganhou impulso com a ordenação urbanística resultante das obras para a Exposição Internacional de 1888, consolidando o Ensanche em seu ajuste com a cidade velha através da demolição dos baluartes da Ciudadela, da construção das "rondas" e da urbanização da Plaza Catalunya (novo centro de Barcelona e ponto de encontro das linhas de bonde). Em 1929, por ocasião de outra exposição internacional, esta estrutura foi reforçada, definindo pela extensão da Avenida Diagonal a oeste, um novo vetor de crescimento da cidade que se apoiaria na criação de um novo centro a Plaça Espanya- para expandir-se até o Delta do Lobregat e a zona baixa de Hospitalet.

Porém, no período "desarrollista" franquista, pós guerra civil, frente ao incremento populacional resultado das migrações internas, bem como às crescentes necessidades de infra-estrutura e equipamentos e face ao próprio desenvolvimento industrial, além do fortalecimento do setor financeiro e turístico (em detrimento do agrário), as limitações do modelo urbano vigente, anteriormente apoiado pela burguesia industrial catalã, levaram à exigência de uma reflexão e ação (ambas comprometidas com o regime autoritário que se instalara) a escalas maiores que a cidade. O modelo territorial que se consolidava -macrocefalia barcelonesa e a consolidação do subúrbio comarcal como o lugar do assentamento residencial e industrial -, condicionado à lógica da reprodução das forças econômicas dominantes, apoiou-se, então, na política de construção intensiva de habitação econômica e de desenvolvimento de um sistema de infraestruturas (predominnantemente rodoviárias) política essa que buscava, antes de mais nada, a apropriação da mais valia gerada, principalmente, pela criação de novo solo urbano e pela permissividade das normas urbanísticas. Neste contexto e com um importante impacto no solo industrial "amplia-se o porto em direção oeste e se reconverte o solo do "porto franco" (proposto na década de 30 pelo plano Maciá) no polígono industrial 
denominado "zona franca", para transformar-se na maior área produtiva do país" ${ }^{23}$.

A estrutura resultante destes processos de crescimento acabou opondo, portanto, setores com desenvolvimento de natureza muito diversa: de um lado, o centro consolidado (que tem no Eixample uma imagem muito definida ainda que submetido a pressões de adensamento e de sobrecarga de trânsito) e, de outro, a periferia residencial composta pelos bairros suburbanos (tramas originais do século XIX - Sant Andreu é um exemplo), bairros de urbanização marginal (processos ilegais e desordenados de ocupação do solo) e os "polígonos de vivienda masiva" (conjuntos residenciais públicos ou privados). Note-se ainda o desenvolvimento desigual dos dois extremos da Avenida Diagonal: a oeste, a cidade universitária e emprendimentos residenciais de alto nível, a leste terrenos industriais ao lado de conjuntos residenciais. De qualquer maneira, quanto a esta última direção, há que se frisar que a expansão portuária e industrial, por um lado, complementaria o domínio da costa na faixa que se estende desde o Besós até o Lobregat, relegando portanto zonas depreciadas, insalubres e isoladas pelas linhas férreas. Aí intercaladas às "coroas" de áreas industriais (que iriam se tornando progressivamente obsoletas), implantaram-se os "polígonos" habitacionais dos anos 50. Por outro lado, a extensão do porto a oeste, acentuaria o rompimento entre os novos sítios portuários e o centro de Barcelona ${ }^{24}$.

Neste quadro, frente às fortes pressões sociais para recuperação urbanística da cidade desencadeadas pelos estertores do regime franquista, a revisão em 1976, do Plano Geral Metropolitano de 1953 iria permitir, avançando algumas questões importantes (reserva de solo para equipamento e áreas verdes, zoneamento não mais em função de índices e categorias de usos mas segundo processos identificáveis de recuperação, adensamento, renovação, etc), conformar uma base relativamente consistente para as atuações que o governo democrático instaurado em 1978 iria promover. Buscando assim, resgatar o déficit infra-estrutural e as carências que se acumulavam há mais de 25 anos sob a lei da incontrolada especulação que regia as transformações da cidade no período do totalitarismo político e de seu corolário urbanístico da expansão "desarrollista".

Entre as estratégias postas em prática para a recuperação urbana pela administração social-democrata (que assumiria o poder municipal em 1979), conta-se desde ações pontuais para a melhoria de praças e parques (reabilitação urbana) até atuações mais globais de reequilíbrio da cidade (planos setoriais e reestruturação urbana) que iriam atacar, ao lado da reorganização do viário, o problema de espaços obsoletos ou abandonados.

Portanto é na escala dos projetos de reestruturação urbana, particularmente aqueles referentes ao programa de "Áreas de nova centralidade" intervenções para a transformação do Port Vell iriam se inscrever. Ou seja, 
dentro do programa que buscava requalificar espaços urbanos que, apesar de sua boa localização (inclusive no nível metropolitano), afetados por grandes infra-estruturas ou equipamentos industriais em processo de obsolescência funcional, estavam a entrar em decadência, ocasionando problemas urbanísticos importantes. Tal requalificação deveria portanto, se pautar pela inserção morfológicamente coerente de novos equipamentos e atividades que, permitindo a melhoria dos setores periféricos onde se localizam, ao mesmo tempo, complementariam o setor central tradicional da cidade, diminuindo a pressão do terciário sobre o mesmo.

\section{Do plano ao projeto: a transformação da cidade}

No panorama urbanístico espanhol que sucedeu o período da ditadura franquista, a recuperação urbanística de Barcelona seguiu um percurso metodológico que teve como ponto de partida o Plano Geral Metropolitano de 1976. Segundo Oriol Bohigas ${ }^{26}$, mesmo elaborado em um período claramente antidemocrático, o PGM “acabou sendo em muitos aspectos uma inteligente antecipação, devida, sem dúvida a uns técnicos "infiltrados" que iriam atuar (...) "impondo" abnegadamente o ponto de vista e as exigências de seus âmbitos disciplinares e profissionais". ${ }^{27}$ Apesar de suas deficiências (e da excessiva inflexibilidade e "mão pesada", seguindo a linha da tradição repressiva e uniformizante dos antigos planos), os avanços revelaram-se na reserva de solos para espaços públicos e equipamentos, na proposta de reequilíbrio de usos e densidades (que iria incidir nos vetores "naturais" do desenvolvimento especulativo), na substituição da primazia do zoneamento e dos padrões quantitativos por "um processo de localização e formalização que inicia timidamente a superação do planejamento pelo projeto" ${ }^{28}$.

O ajuste conceitual e operacional das linhas do $\mathrm{PGM}^{29}$, realizado desde $\mathrm{o}$ início das gestões municipais democráticas, iria ser levado a termo pela elaboração simultânea de diversos Planos Especiais de Reforma Interior e diversos projetos de ação pontual dentro da área de influência desses PERIS. Neste quadro, assumindo que o problema da cidade européia, em geral, não era mais de crescimento e sim de melhoria de qualidade de vida (conforto e representação), os planos e projetos, por sua intermediação com os diversos agentes sociais, deveriam ser capazes de engendrar umas "idéias-força" no sentido da valorização da cidade, transformando-a e atualizando-a sobre si mesma.

A partir de um "forte compromisso com o componente físico da cidade e com sua capacidade executiva real" ${ }^{30}$, estas idéias globais materializaram-se em um processo de trabalho no qual passariam a coexistir diversas escalas de aproximação: 
- reabilitação urbana - iniciativas públicas de pequena escala sobre espaços urbanos e espaços verdes (eixo pedestre de Sant Andreu, plano setorial do Raval, diversas praças e parques são exemplos)

- reestruturação urbana - estratégias de maior alcance que buscam o reequilíbrio entre fragmentos e áreas da cidade (reorganização viária, áreas de nova centralidade)

- organização morfológica da cidade - intervenção sobre as "chaves" estruturais da cidade segundo estratégias mais globais (Diagonal, frente litoral, grandes "contenedores").

O vasto programa de atuações cuja sistematização deveria ir se racionalizando no próprio processo de atuação (pois a necessidade de dar resposta a problemas concretos foi prioritária), incidiu estrategicamente (sobrepondo-se, encadeando-se) sobre toda a cidade segundo as seguintes pautas:

- recuperação dos distintos componentes da cidade velha, do Eixample, dos núcleos dos antigos municípios rurais anexados pela expansão urbana (Sant Andreu e Sagrera entre eles)

- requalificação da periferia degradada, das áreas industriais internas atualmente vazias e das áreas de construção residencial abusiva

- complementação da rede viária primária

- determinação de áreas de nova centralidade para organizar o crescimento urbano diminuindo a pressão sobre o Eixample

- construção de uma relação estável com as fachadas da montanha e do $\operatorname{mar}^{31}$.

A coincidência histórica de um ciclo favorável de retomada da economia pelo aporte de capitais externos com a escolha de Barcelona como sede dos Jogos Olímpicos de 1992, conferindo recursos e garantindo o apoio do governo central, acabou definindo uma direção e uma meta para a concretização de alguns desses grandes projetos e permitiu, assim, pôr em prática uma longa história de reflexão projetual, iniciada ao menos dez anos antes, no sentido de uma estratégia geral de reurbanização e renovação da cidade, suprindo em termos de infra-estrutura, de transportes e de qualidade de vida em geral, carências que se acumulavam há muito tempo.

Como parte desta estratégia quatro áreas distintas da cidade receberam as instalações olímpicas: duas no limite da cidade com a montanha de Colserolla (Vall D’Hebron e zona universitária) e duas situadas no litoral (Montjuic e Poble Nou). Se a escolha de Montjuic buscava reafirmá-lo como lugar representativo da cidade, reinterpretando-se as referências simbólicas, arquitetônicas e urbanísticas da Exposição de 1929, a Vila Olímpica de Poble Nou respondeu a outro tipo de preocupações: abrir a cidade para o mar, dando novo uso àquela faixa até então isolada pela ferrovia e reverter assim as 
orientações e tendências estabelecidas pelo vetores de crescimento interior da cidade.

O projeto do Port Vell em sí, tal como seria realizado, não se incluia no projeto olímpico. Ainda que previsto no escopo do programa das "Areas de nova centralidade" sua realização deveu-se a uma conjunção de fatores, dentre os quais é necessário destacar tanto a "euforia olímpica", quanto, sobretudo, o papel "metodològico" do projeto "Moll de la Fusta" (1987/1992) Este, em sua resolução urbanística abarcou alguns problemas fundamentais da relação cidade-porto (infra-estrutura de circulação urbana e rearticulação espacial e visual da cidade com o mar) e, assim, acabou embasando idéias mais ambiciosas, como seriam a própria concepção da Vila Olímpica, a requalificação de Barceloneta e inclusive a transformação do velho porto.

\section{A paisagem do porto urbano}

Com a progressiva especialização do porto, o único ponto (20 m de largura) de contato entre a cidade e o mar seria constituído pela "Porta da Paz," situada em frente ao monumento de Colombo. Pois o passeio que se construiu entre o parque da Ciudadela e as Ramblas, ao longo da frente portuária, foi cada vez mais perdendo este caráter para tornar-se um segmento (litoral) da grande circulação urbana perimetral. Neste processo, a linha de palmeiras, assim como o canteiro central, que marcavam o eixo do passeio desapareceriam para dar lugar a uma via segregada rápida, rompendo definitivamente o contato da cidade com porto.

As dársenas e diques que adquiriram sua configuração atual de pequena baía segundo os projetos oitocentistas de José Rafo, face às exigências práticas da modernização ditadas pelas novas tecnologias de transporte marítimo, iram ser progressivamente densificadas e, em seguida, abandonadas em favor de outros setores portuários mais capazes construídos a oeste. Este deslocamento propiciaria a redefinição dos usos sociais do velho porto: "O slogan de abrir a cidade para o mar que começa a se popularizar sob administração municipal franquista torna-se fato com os novos prefeitos democráticos" ${ }^{{ }_{32}}$.

Os planos de ocupação

A reconversão urbanística do Port Vell de Barcelona deve ser compreendida, como já mencionado, de um lado dentro de um contexto maior das contradições da cidade com sua frente litoral e de outro, decorrente desta primeira questão, como um elemento do processo de recuperação urbanística da cidade, encadeando-se temporal e espacialmente com outras intervenções em diferentes escalas de abrangência e fases de realização. 
Como também já foi observado, a expansão extra-muros da cidade, desde os fins do século XXI, privilegiou a direção interior: a Estação de França e o "centro de negócios" do Plá de Palau não se mostraram suficientemente potentes para equilibrar aquele desenvolvimento. A ligação da fachada marítima com a estrutura da cidade foi definitavemte abandonada em favor da destinação definitiva da primeira para a instalação de serviços e infra-estrutura urbana (cemitério, gazômetro, linhas ferroviárias, plantas industriais, serviços portuários). O isolamento de Barceloneta, bem como o forte desequilíbrio físico e social que este bairro sempre apresentou, exprimem significativamente a atitude que orientou o crescimento da cidade. Apesar de seu "valor magistral" como exemplo do estabelecimento da nova planta "clássico-militar" do século XVIII (valor esse identificado "no traçado de seu modelo viário, na ordem tipológica de suas quadras, na modulação de suas casas e na geografia urbanística de sua posição, perímetros e espaços coletivos" ${ }^{33}$ ), a subdivisão das casas e a adição de novos pisos, seguindo as pautas da especulação, resultariam na alta densidade, na falta de espaço público e equipamentos, na insuficiência de dimensões das unidades residenciais e no consequente envelhecimento da população.

As tentativas de se reverter esta tendência foram inicialmente aventadas no bojo do Plan Maciá de 1932. Esse plano, elaborado pelo GATEPAC ${ }^{34}$, sob a liderança de Joseph Sert e Torres Clavé e contando com a expressiva participação de Le Corbusier, em sua proposta de cidade funcional, iria definir entre outra zonas, a "zona de produção": o porto, as zonas industriais e a city. Enquanto ao porto era destinada a expansão oeste, a "city" configurada por uma série de edifícios-torre em Y, localizar-se-ia enquanto novo centro direcional de Barcelona, na convergência das avenidas Parallel e Meridiana sobre os terrenos do velho porto, o qual, pela proposta de deslocamento de suas funções tradicionais, deveria converter-se em porto esportivo e de pesca. A nova imagem da frente marítima (que Le Corbusier reproduziria para outras cidades portuárias como Argel e Buenos Aires) seria valorizada com um novo traçado, reinterpretando a malha de Cerdá através da ampliação de escala e segundo os princípios da Ville Radieuse. Por razões políticas - eclosão da guerrra civil- este plano não teve tempo para amadurecer e desenvolver-se (como aconteceria com os planos para as outras cidades ainda que por motivos diversos).

Deste modo, o tema da relação cidade-frente litoral só popularizar-se-ia a partir dos anos 60 através dos slogans da administração franquista e de acordo com as propostas contidas no plano Geral do Porto de 1966. E seria nos anos 70, objeto de grande debate popular, desta vez desencadeado pela apresentação do Plano da Ribera ${ }^{35}$. Um plano que a cavaleiro das realizações públicas da administração central (estações de depuração de águas residuais para recuperação das praias, reestruturação das infra-estruturas viárias, ferroviárias e metroviárias, deixando livre de ocupação uma faixa de 50 ha de 
terreno) propunha-se a promover a reurbanização de toda a faixa litorânea (em uma extensão de 5000m x 500m) através de um tratamento homogêneo que, apoiando-se em uma nova (e própria) proposta de traçado do cinturão litoral, desde Barceloneta (remodelada), passando por Poble Nou (arrasando-o), estender-se-ia até a foz do Besós. No entanto, esse plano, lançado como "Plano do Setor Marítimo Oriental" pela holding Ribera S.A, acabaria recebendo a oposição frontal das associações de vizinhos e colégios de profissionais que realizaram, por sua parte, um concurso de idéias alternativas ao projeto oficial:

A discussão alternativa do projeto busca romper o determinismo ecológico que tendia a utilizar um plano remodelador como o oficial, estabelecendo uma coerência que permitisse uma melhoria do setor com a manutenção dos setores residenciais alí existentes" ${ }^{36}$

As orientações estabelecidas neste contra-plano permitiram, então, entrever as lógicas que deveriam presidir, vinte anos depois, os projetos da Vila Olímpica. Ainda que seu desenvolvimento concreto tenha suscitado sérias dúvidas quanto aos objetivos alcançados, particularmente sob o aspecto da gestão e comercialização do empreendimento, bem como em relação às soluções arquitetônicas (apressadas) que, como se diz, não representam a melhor produção de cada um dos arquitetos envolvidos. Neste sentido, poder-se-ia levantar a hipótese de que o projeto da Vila Olímpica, renovando todo o setor costeiro de Poble Nou, reproduz de certa maneira o projeto do Plano da Ribera. Embora sua concepção urbanística revele interesse ao interpretar a malha de Cerdá (através sistema de quadras fechadas mas em escala "corbusieranamente" ampliada), associando-a às idéias do desenvolvimento interno segundo conjuntos residencias em blocos de meia altura (resolvendo os tradicionais problemas de conforto ambiental da quadra fechada).

Em todo caso, como já mencionado, dando nova força às preocupações de imprimir um novo sentido à relação da cidade com o mar, o marco fundador desta linha evolutiva de indagações foi definitivamente representado pelo projeto do Moll de la Fusta que, de fato, ensejaria uma nova dimensão ao enfoque das relações entre a cidade e o porto, dando início a uma operação de grande alcance ou seja, a da reconversão de toda a parte leste da cidade: novas praias limpas e novo desenvolvimento residencial, transformação do velho porto e requalificação do bairro de Barceloneta.

\section{O projeto Moll de la Fusta}

O caráter ativo do projeto Moll de la Fusta advém de uma atitude de enfrentamento de um problema supostamente de natureza exclusivamente viária, que desdobra-se segundo uma ordem global sobre o espaço entre a cidade velha e o porto e assim incide diretamente sobre a renovação do centro histórico e o futuro desenvolvimento do porto urbano. Três elementos são 
fundamentais neste projeto: o passeio de Colón, o cinturão litoral e a esplanada do Moll com sua vista sobre o mar.

Causada pelo emparedamento de sua fachada marítima (armazéns, divisas portuárias, fechamentos murados, etc) e, sobretudo, pela carga de circulação que sobrepôs, progressivamente, movimentos viários rápidos (comunicação porto / bairros industriais e operários, articulação perimetral até então sem continuidade, desdobrando-se sobre as vias circundantes), a degradação ambiental do passeio de Colón (antes uma avenida "amável e ordenada") estava a exigir uma organização global. O problema a ser enfrentado era o de articular um sistema viário moderno que permitisse a conexão costeira ao longo do litoral, que desse acesso ao centro histórico e possibilitasse a circulação perimetral da cidade. Ao mesmo tempo deveria ser resgatada a função histórica do passeio e a utilização "cidadã" da frente portuária dentro de uma idéia de reconversão global do velho porto para uso recreativo, desportivo, institucional e marítimo ${ }^{37}$.

O projeto de Manoel de Solá-Morales, realizado entre 1987 e 1992, propõe, através da recomposição dos movimentos (pedestres e motorizados) em faixas e níveis resolvidos em secção, conciliar “o tráfego 'através' com o tráfego urbano superficial, dedicando a maioria do espaço ao pedestre que, por fim, pode voltar a aceder à borda da água"38. Aproveitando alguns dos edifícios portuários significativos para usos institucionais ou culturais e renovando, recuperando e integrando o Plá de Palau e a Estação em um sistema de jardins, vias e rótulas que conectam Barceloneta à cidade, bem como propondo o rompimento do espigão do Moll de España para transformá-lo em uma ilha (o que até não viria a acontecer, pelas razões que se verá adiante), o projeto buscava converter em um recinto único toda a superfície aquática sobre a qual o Moll de la Fusta e o de Barceloneta emergeriam como referências fundamentais da paisagem. Com suas respectivas fachadas a refletir-se mutuamente, estes mollhes deveriam marcar os pontos focais de um percurso que desse "a volta" ao porto de forma tal que o espaço urbano tivesse seu clímax na parte mais distante, na porção posterior do porto, propiciando, assim, um uso mais intenso da mesma.

Deve-se observar que este plano iria diluir-se em grande medida quando a autoridade portuária lança seu próprio.plano, comprometendo a contundência das idéias originais em favor de um um esquema que previa uma ocupação a ser desenvolvida fragmentariamente, segundo um modelo bastante próximo ao norte-americano de Boston e Baltimore.

\section{Oplano de Barceloneta}

O plano especial de Barceloneta (PERI iniciado ainda no período prédemocrático) continha três programas de atuação: 
- estudos das possibilidades e dos custos de reabilitação de pisos (apartamentos) para passar dos quarts de casa (unidades de $35 \mathrm{~m}^{2}$ resultado da divisão em 4 dos apartamentos originais, correspondendo a $70 \%$ do bairro) a casas de mig, de superfície duas vezes maior que as primeiras. Propunha-se soluções técnicas para acondicionar instalações e serviços da habitação com um custo não superior a $50 \%$ de um apartamento novo.

- restauração das ruas do bairro, renovação das fachadas, pintura e acabamentos, pavimentação e adaptação viária de ruas intermediárias e conservação de oito edifícios catalogados e protegidos por seu interesse histórico-arquitetônico.

- substituição dos edifícios obsoletos ou em estado ruinoso por outros de nova planta que regulados por uma ordenação arquitetônica de cumprimento obrigatório, teriam que respeitar a composição urbanística original.

O plano de Barceloneta incluindo-se no rol dos projetos da Cidade Velha combinava pela própria natureza homogênea - portanto mais generalizavel das questões tipológicas e morfológicas de formação desta parte da cidade, atuações pontuais de recuperação com projetos de reestruturação mais globais (praças, jardins, ligações viárias, construção de conjuntos residenciais). Como lugar de habitação dos trabalhadores do porto, e apesar das mudanças funcionais por que passou, Barceloneta conservou sua personalidade: os projetos tiveram portanto que levar em conta, a partir das fortes oposições que suscitaram, a participação ativa dos moradores que, no entanto, não conseguiram conservar os edifícios mais ou menos precários que abrigavam os restaurantes populares da praia, finalmente demolidos sob o pretexto de se abrir a cidade para o mar.

Em todo o caso, a supressão da barreira ferroviária (eliminação da linha litoral e soterramento do leito da linha interior) bem como a reconstituição das áreas de praia permitiram, ainda que com prejuizo do projeto original, a resolução dos problemas das bordas do bairro bem como sua conexão com a cidade. Quanto ao Moll de Barceloneta o projeto de Solá-Morales previa a abertura do cais ao público reutilizando os "tinglados" (armazéns) como equipamentos recreativos e culturais. No entanto, o projeto do Porto Autônomo de Barcelona optou pela demolição destes armazéns e a construção de uma grande esplanada que se não tem um uso "positivamente" definido, ao menos permite a integração visual do bairro com a cidade segundo perspectivas bastante interessantes e de forte significado simbólico.

\section{Projeto Port Vell do Porto Autônomo de Barcelona}

Impulsionado pelo clima da "euforia olímpica" que a cidade vivia e pelas novas condições urbanísticas da frente portuária propiciadas pelo projeto Moll 
de la Fusta, o Porto Autônomo de Barcelona criou uma agência específica Port 2000- para elaborar e gerir um projeto próprio de reconversão do espaço portuário. Este projeto realizar-se-ia sob uma forte polêmica em grande parte gerada pela natureza eminentemente rentabilística de sua concepção, traduzida em um aproveitamento exarcebado do solo vacante (como forma de financiar parte da expansão do porto comercial).

Face a essa autonomia (aliás comum ao sistema portuário espanhol que, entre outras normas, proibe a destinação residencial em seus domínios), a administração municipal contrapôs um "Plano Especial" que buscava estabelecer parâmetros para a relação entre o uso público e a ocupação do solo. Ocupação essa que estaria vinculada a mecanismos de concessão por parte do porto para o desenvolvimento de empreendimentos privados (naturalmente representados por grandes firmas internacionais). No entanto, a estratégia operativa adotada pela autoridade portuária condicionada apenas por alguns índices urbanísticos (altura máxima dos edifícios, taxas de ocupação do solo), manteria a geometria dos diferentes molhes, designando um uso diferenciado para cada um deles.

Desta maneira, hoje, o Moll de España acolhe edifícios para comércio (Maremagnum - centro comercial de $20.000 \mathrm{~m}^{2}$ projetado pelos arquitetos Viaplana e Piñon) e para atividades lúdicas (Multicine e Aquário). O Moll de Barcelona, segundo um projeto de I. M. Pei, abriga a construção de um trade center de $80.000 \mathrm{~m}^{2}$, além de instalações para passageiros. Demolidos seus velhos edifícios de depósitos com excessão do Edificio del Deposito, projeto de Elias Rogent, que recebe instalações comerciais e de serviços, além de um museu histórico, o Moll de Barceloneta é utilizado como espaço aberto. Com tramos retráteis para permitir a passagem de embarcações fundeadas ao largo de todo o recinto aquático do porto, uma passarela (Viaplana e Piñon) em aço e madeira constrói a continuidade da tradicional Rambla, interligando a antiga Porta da Paz, frente ao monumento de Colombo, com a face sul do Moll de España. Além dos estacionamentos subterrâneos do Moll de la Fusta e de Barceloneta (500 vagas cada um), constroem-se no Moll de España (justificando a não supressão do braço que o ligava à cidade), 1.000 vagas, também subterrâneas, para atender o centro comercial. O único acesso, precisamente conformado por aquele braço de ligação, para esperados 12 milhões de visitantes/ano faz supor problemas de congestionamento de veículos na área.

De maneira geral, sem outra referência que a máxima utilização horizontal do solo (a maior altura é, por exigências técnicas de projeção cinematográfica, a de 37 m do "cinema multivisão") e não obedecendo a qualquer esquema mais geral ou idéia de conjunto, as concepções arquitetônicas competem entre si em sua inadequação à paisagem marítima. 
Os dois níveis de inserção urbana do projeto Moll de la Fusta -um à escala local do centro velho e outro à escala de todo setor litorâneo da cidadeimplicaram esforços de gestão diferenciados os quais, coordenados pela prefeitura, envolveram sobretudo vários escalões da administração pública.

À escala da cidade, a continuidade e extensão da Ronda Litoral, que em seu papel "colonizador" suporia a necessidade de modificação do desenho das linhas férreas, contou com a participação decisiva da Renfe (Rede Nacional de Ferrocarriles). À escala local, apesar de todos os terrenos pertencerem às entidades pùblicas - 57,66\% do Ayuntament, 39,1\% do porto e 3,3\% da Renfe- coube à própria estrutura formal do projeto, a partir da análise dos campos de atuação e dos possíveis pontos de conflito, abrir as possibilidades de colaboração; colaboração que no entanto teria que ser mais tarde, duramente negociada quando o Porto Autônomo de Barcelona anunciou sua própria proposta.

No entanto, as ações impetradas pelas associações de profissionais e moradores (que acabaram não sendo acatadas pelos tribunais) iam no sentido do rechaço do que consideravam como uma privatização do espaço, "criticando a edificação de instalações de exploração privada nos molhes que eram (e como o projeto original propunha) livres". ${ }^{39}$

Os significados e a crítica

Com o Moll de la Fusta convertendo-se em passeio urbano e com a urbanização posterior (ainda que segundo um desenho distinto do original) do Moll de Barceloneta, porto e cidade deixaram de se dar mutuamente as costas. A autoridade portuária havia cedido seus velhos molhes à cidade, mas não quis renunciar a uma rentabilização econômica que ajudaria a financiar a expansão do porto comercial. Assim, planejou a construção de um centro de negócios no Moll de Barcelona e do centro comercial e lúdico no Moll de España, concebido como um grande foco de atração de moradores e turistas. A sucessão destes fatos e seu significado correspondem a um movimento que vai da euforia e do consenso à realidade e à polêmica.

O projeto Moll de la Fusta é conhecido pela coerência entre "seu método pragmático de desenho" e seu caráter simbólico de abrir a cidade ao mar, reinterpretando sua condição de lugar de passagem e de passeio. O desenho resolve em secção os diversos movimentos (como parte do cinturão litoral) e articulações com os episódios urbanos (monumento de Colombo de um lado e Plá de Palau, Edificio del Deposito e Barceloneta de outro) criando recintos, visual e funcionalmente distintos e inter-relacionados (salão do Passeo de Colón, a terraça balaustrada, a esplanada do Moll) para a transição - 
problema típico de cidade portuária - entre o centro antigo e a água, designa funções (estacionamento, pequeno comércio, gastronomia) e permite usos (passeio, festas populares) e perspectivas que redefinem a frente portuária em uma nova dimensão. Além do mais, como afirma Semerani ${ }^{40}$ :

A neutralidade arquitetônica, a construção expressiva e a escala do projeto propiciam a possibilidade de intervenções sucessivas de desenho menor (quiosques, farolas, esculturas)".

Quanto à Barceloneta, o Passeo Nacional é reurbanizado: ainda que demolidos os restaurantes - forma tradicional e popular de contato das pessoas com o mar - e apesar da crítica de não se ter encontrado um uso criativo para a recuperação dos armazéns portuários, a integração visual acabou gerando na população do bairro um sentimento de participação única na estrutura viva da cidade.

Se ambos os projetos, Moll de la Fusta e Barceloneta, desencadeiam juntamente com os projetos de recuperação da cidade velha, um processo de "gentrificação" (aburguesamento) da população ${ }^{41}$, no entanto, o projeto que suscita mais polêmica é aquele posto em execução pelo Porto Autônomo, sobretudo pela ocupação excessivamente densa (e arquitetônica e urbanísticamente fragmentada e compartimentada) e pelo caráter privado de sua utilização e domínio.

As mais diversas opiniões manifestas por ocasião da inauguração do Port Vell talvez sintetizem melhor que qualquer análise a incoerência urbanística do novo projeto:

No esta mal hacer cosas, pero esta especie de Disneylandia se podria construir en otros puntos de la ciudad" (Josep Martorell, arquiteto).

"Los muelles no son solares para construir, y ninguna arquitetura puede disimular que estamos vendiendo la geografia por un plato de lentejas, por un negocio de fiera" (M. SoláMorales, arquiteto).

"Desde los muelles de la Fusta y de la Barceloneta se deberá ver el mar, si se derribaron los tinglados que había, era para ello".

"Me parece un error garrafal. Lo que hace falta en el Port Vell es ver mas cielo y agua, pero se cierra el horizonte con edificios".

"Toda la vida hemos vivido aislados de Barcelona, aunque solo distamos 15 minutos de la Plaza Catalunya. No sabes lo que significa para nosostros salir al paseo y ver el Moll de la Fusta, 
Correos, Colón...es si como Barcelona nos hubiera acogido en su seno".

"Durante este tiempo salíamos de casa y veiamos Barcelona y ahora resulta que entre el Maremagnum, el Imax y la (...), solo vemos el barco del De La Rosa y el campanàrio de Santa Maria del Mar" (Martinez Domech, morador ${ }^{42}$ ).

A falta de uma estratégia global de reconversão, os limites que a propriedade da terra impõem ao controle da administração pública, a adoção de um modelo baseado nas experiências norte-americanas, e apesar do relativo sucesso de público, tudo isto acabou diluindo a força de um projeto unitário e coerente com a história e geografia de Barcelona. 
O atual desenho da frente marítima de Barcelona: ao norte a Vila Olímpica, Port Vell e a expansão portuária ao sul

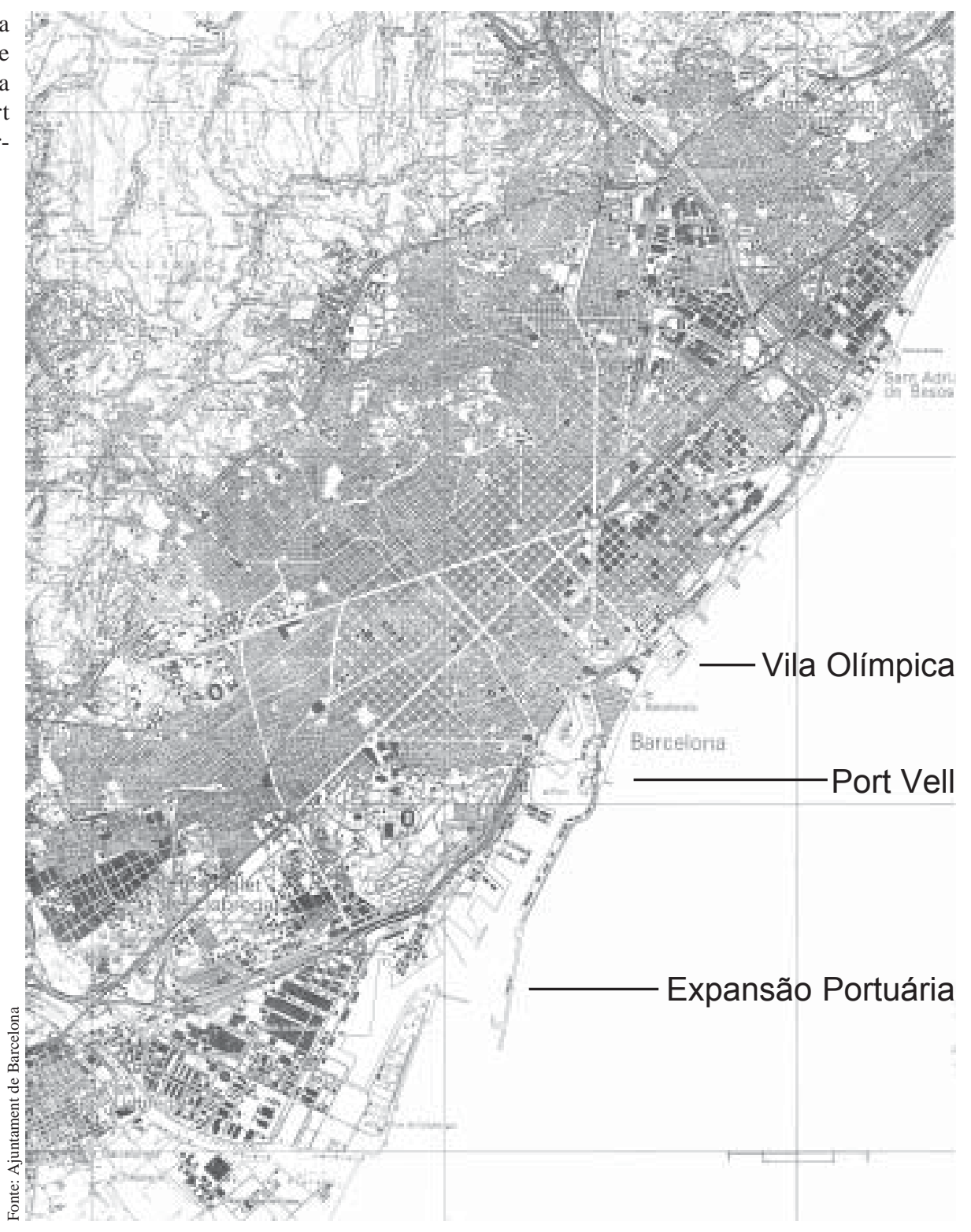

Vista aérea de Barcelona: a montanha de Colserolla, os tecidos dos antigos núcleos suburbanos, o ensanche de Cerdá, a "cidade velha" e a frente marítima reconvertida -Port Vell, Barceloneta, Vila Olímpica

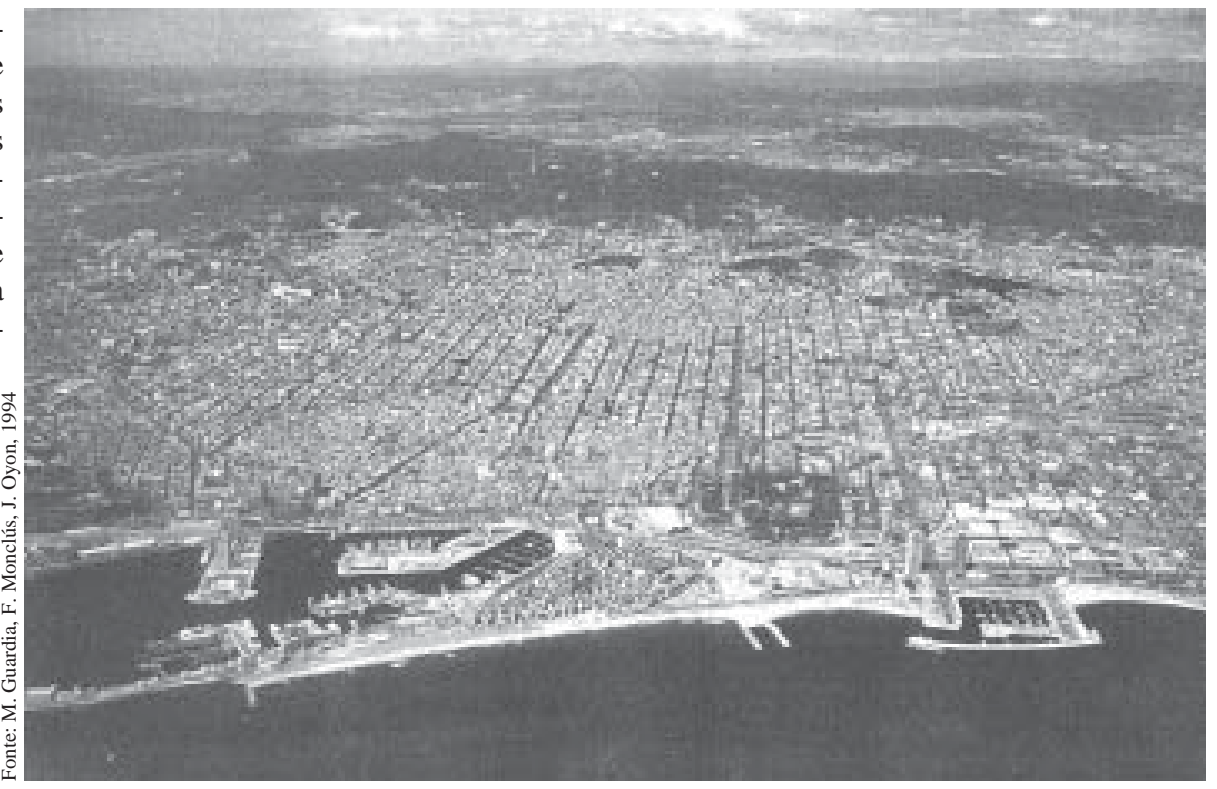


Imagem do porto de Barcelona quando da construção do primeiro dique (século XVII)

A relação da "cidade velha" com o porto e Barceloneta. À direita, a Ciudadela e o Plá de Palau, primeiro centro de "negócios" da cidade

Configuração resultante do projeto de José Raffo (meados do século XIX)
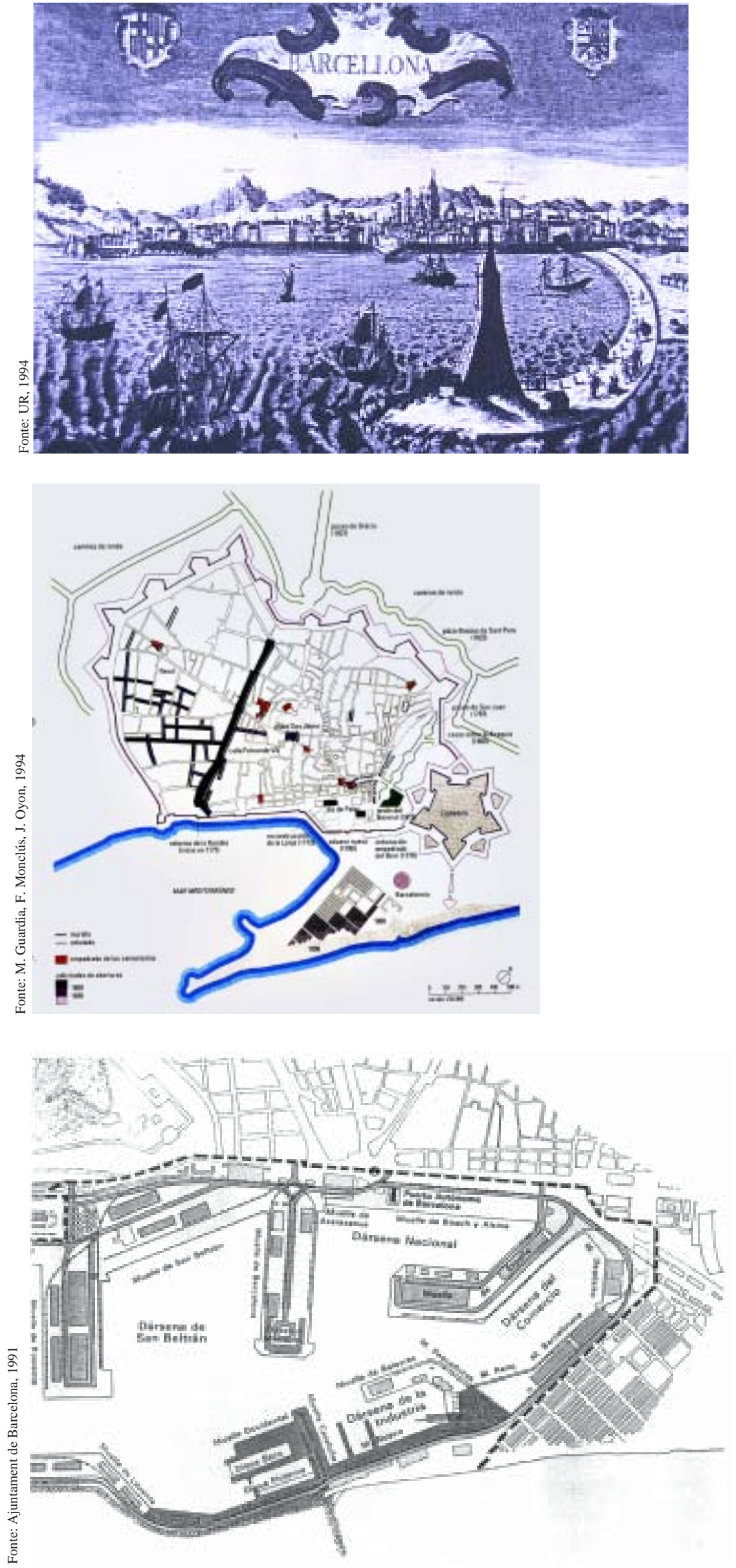
Vista da frente portuária: Port Vell e expansão sul
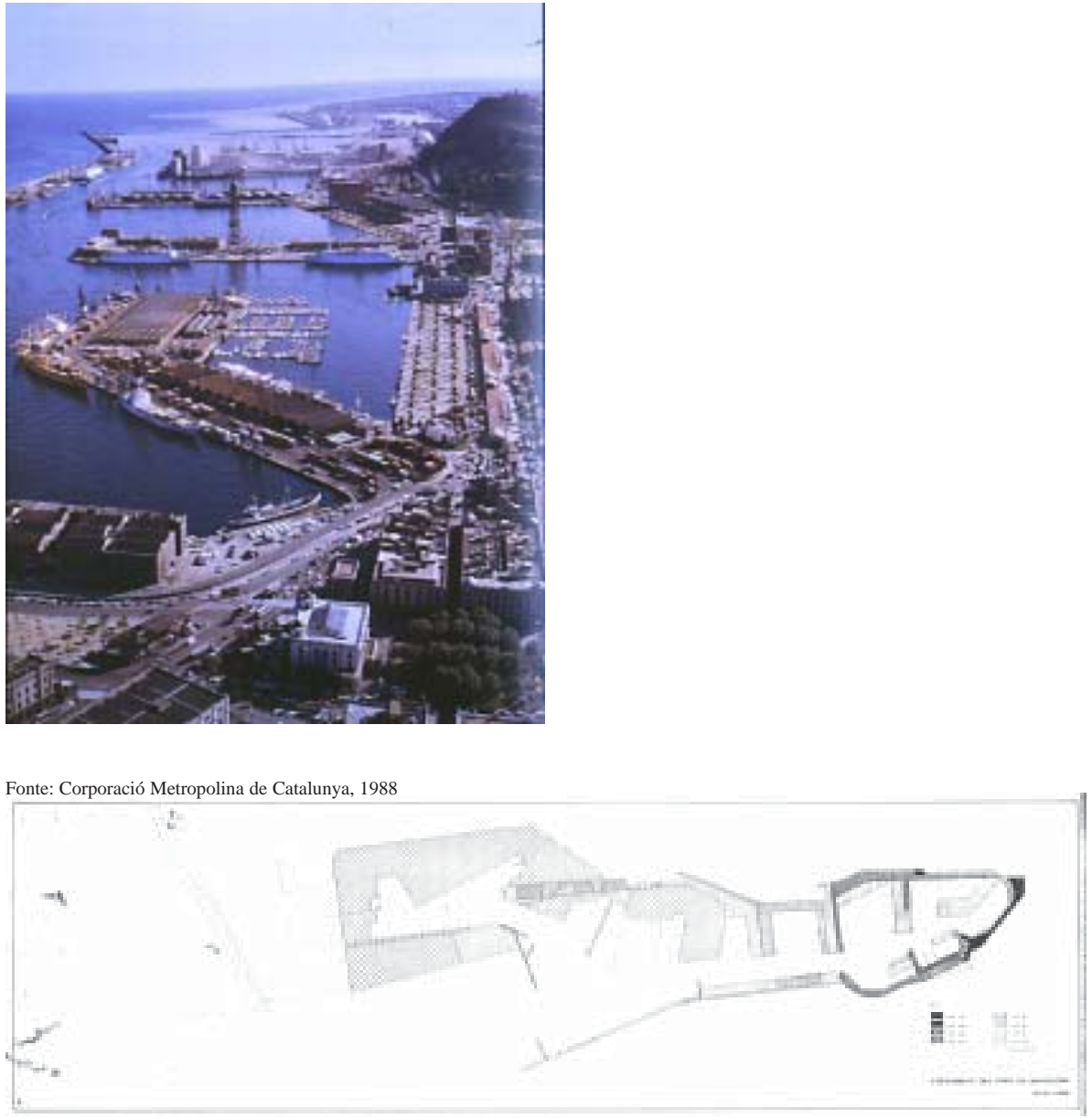

Etapas de expansão do porto de Barcelona: a expansão sul pré-figurada no plano Maciá da década de 1930, realiza-se na década de 60, juntamente com a implantação da Zona Franca do Lobregat

Projeto de ampliação portuária: atuação na rede de rodo-ferroviária e implantação da Plataforma Logística do Delta do Lobregat

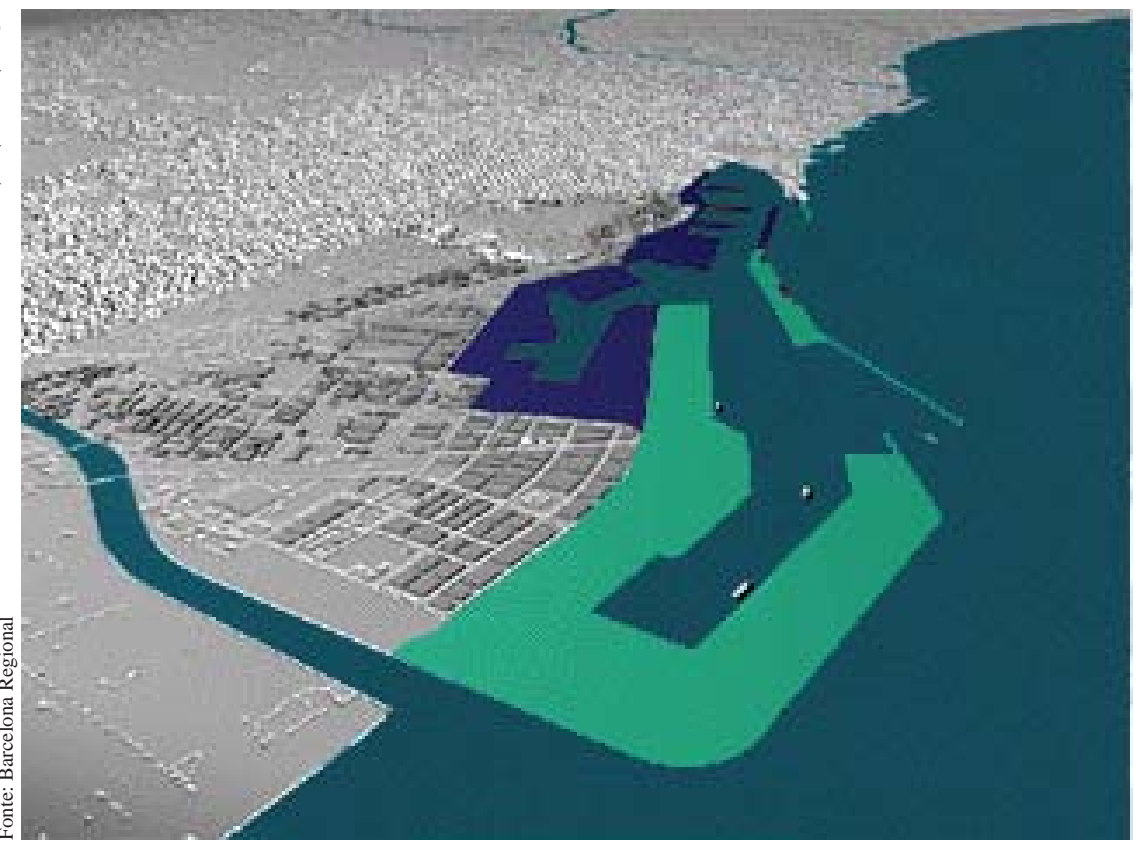



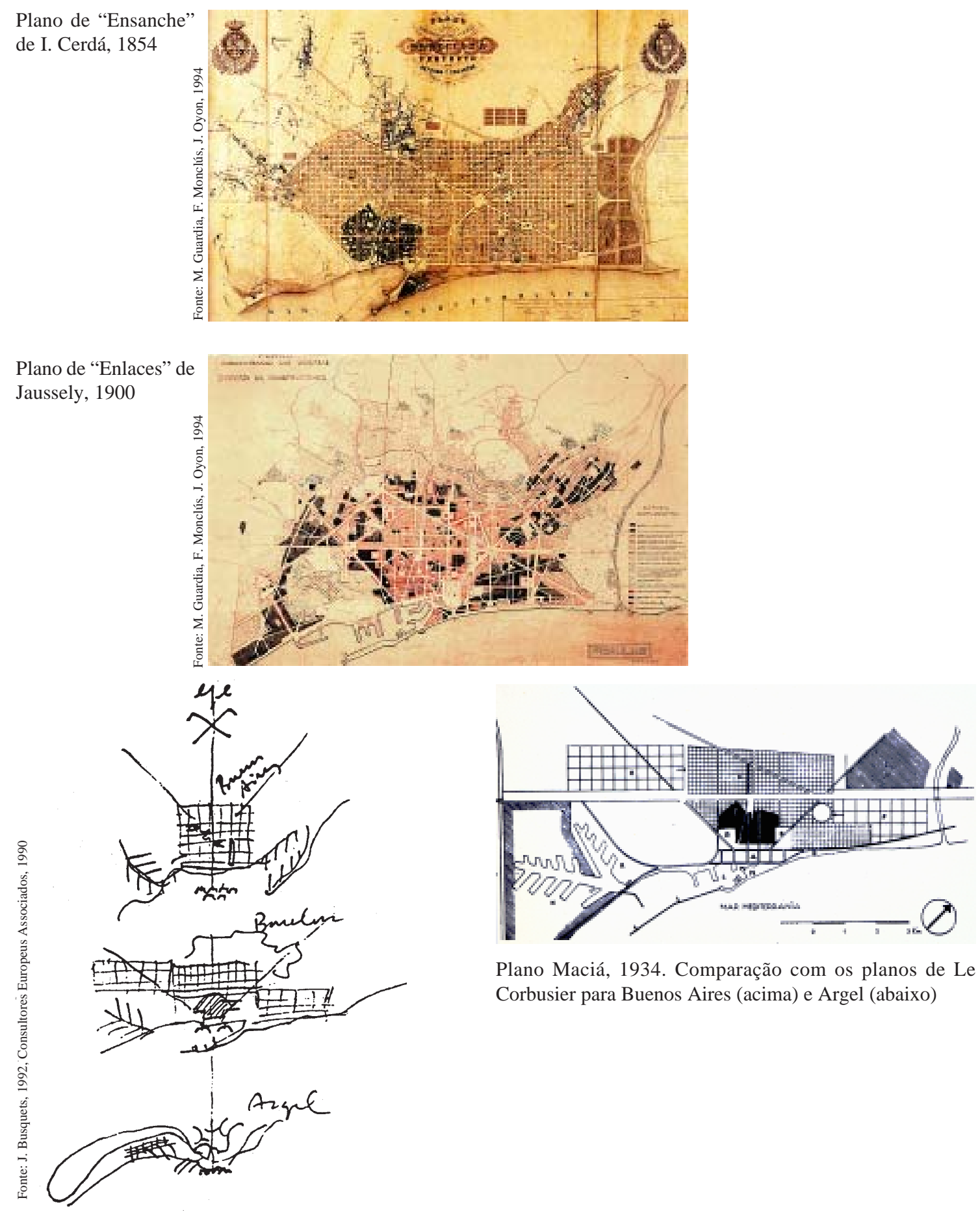

Plano Maciá, 1934. Comparação com os planos de Le Corbusier para Buenos Aires (acima) e Argel (abaixo)

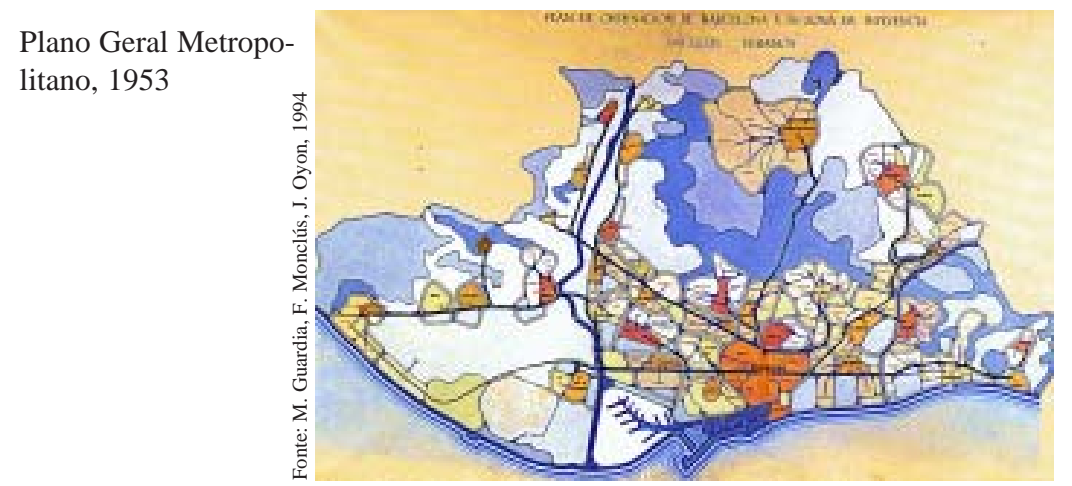


Plano Geral Metropolitano, 1976
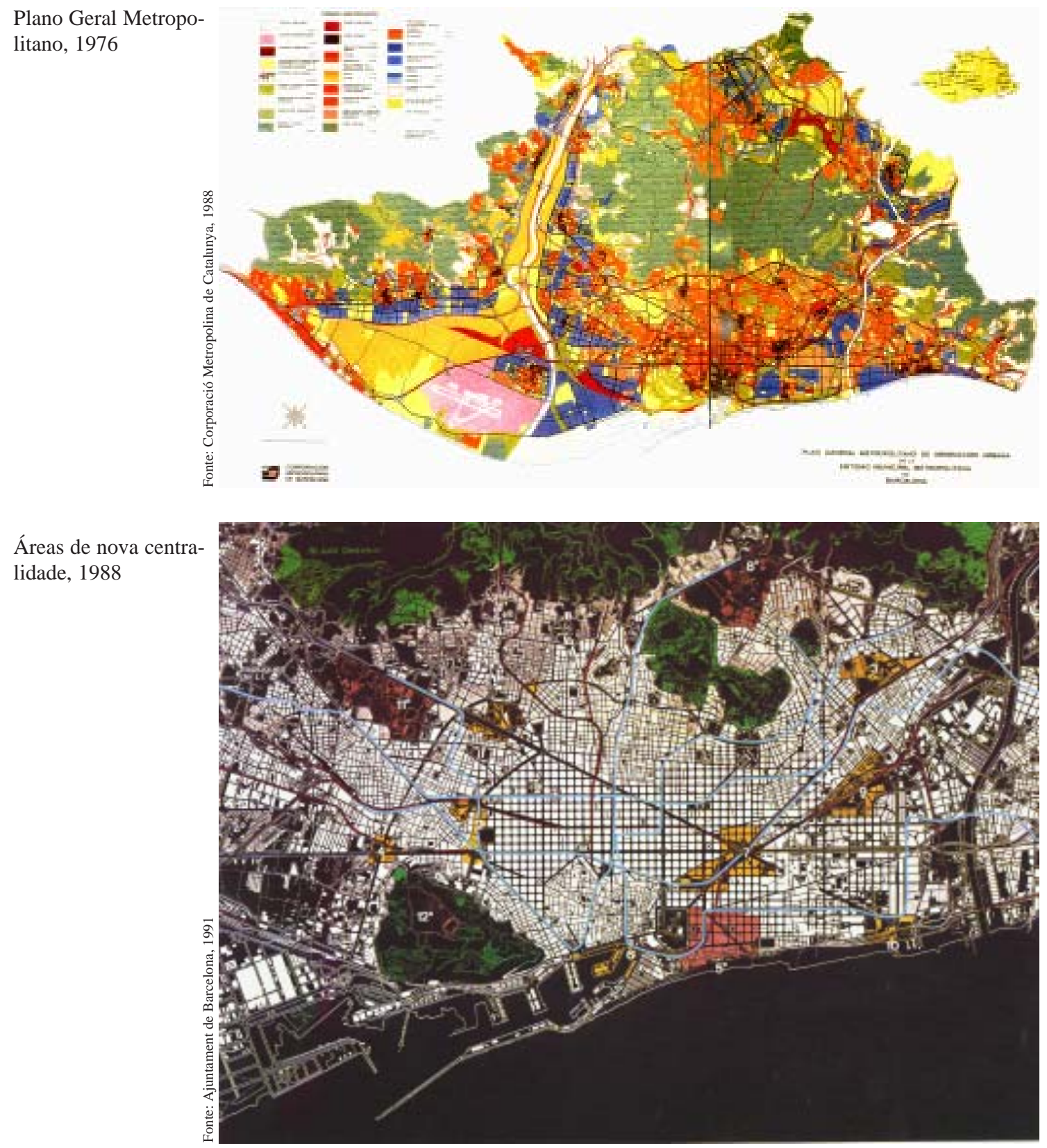

Projetos estratégicos Barcelona 2000

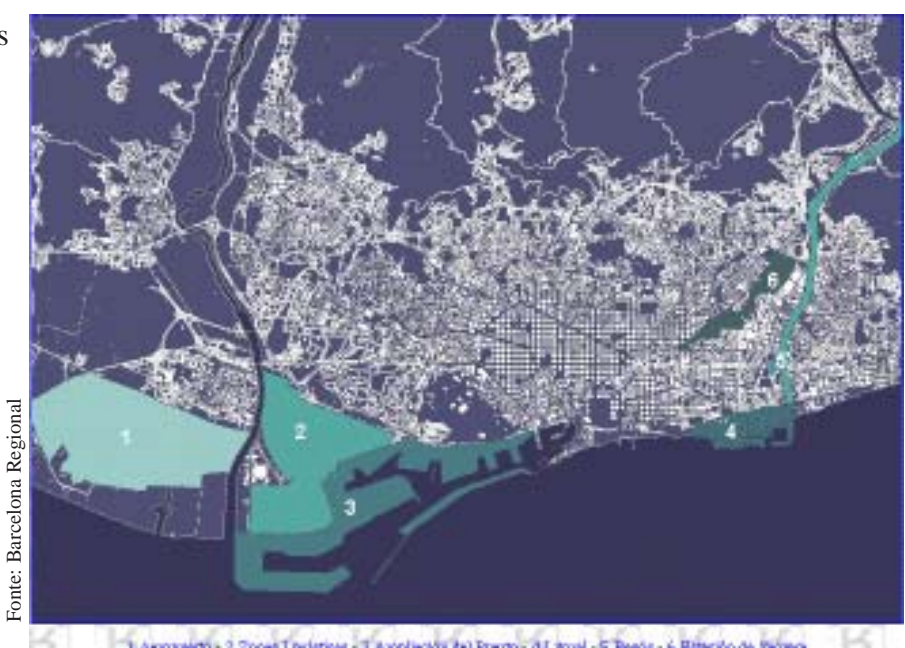



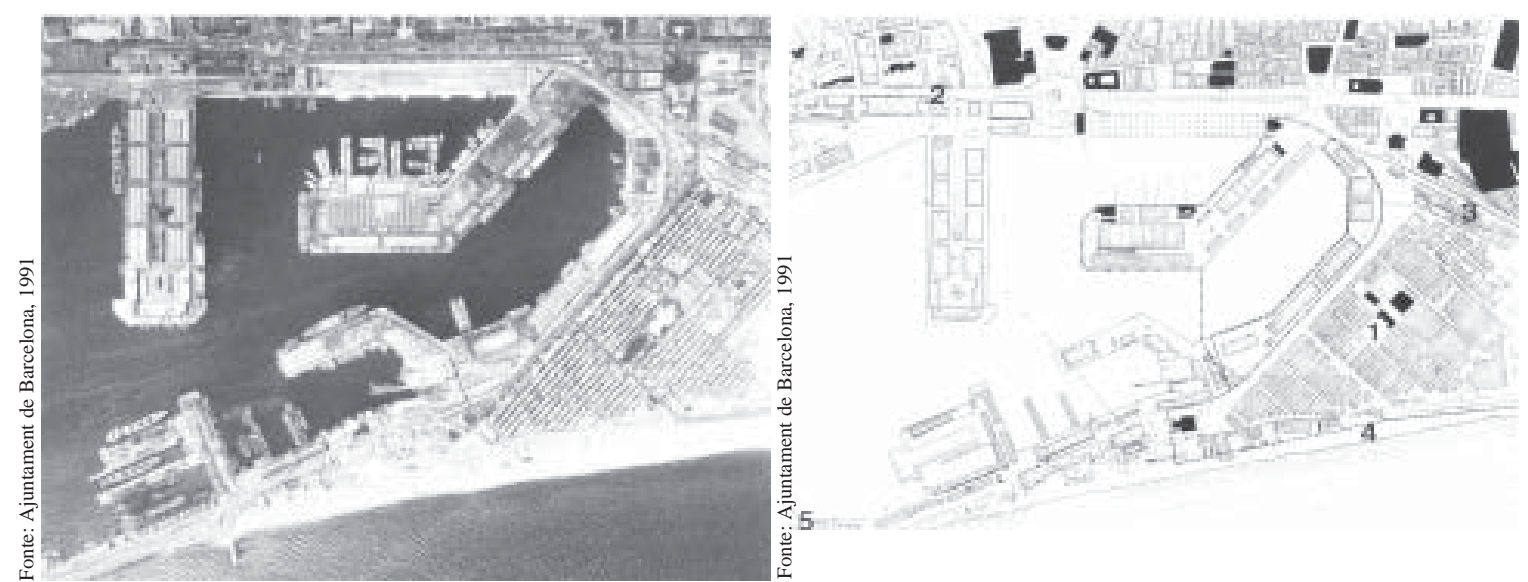

Aerofoto do Porto de Barcelona, 1978

Intervenções em curso no início da década de 1990

1. Barceloneta: plano especial de reforna interior, 1985

2. Avenida Litoral (setor Morrot-Colom)

3. Avenida Litoral (setor Moll de la Fusta-Poblenou)

4. Passeio Marítimo Barceloneta e defesa da costa

5. Porto urbano

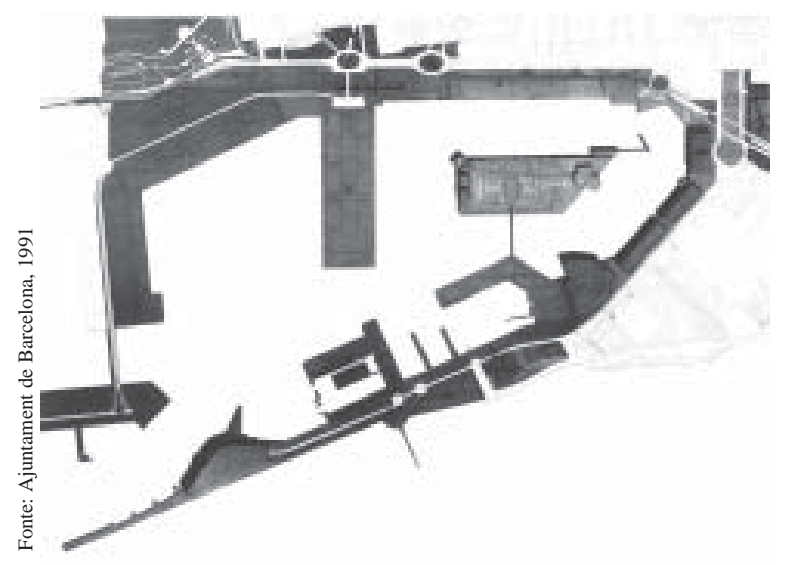

Plano geral de Solá-Morales: demolição do braço de interligação do Moll de España, visando convertê-lo em uma ilha, destinada às atividades náuticas, e abertura de uma "boca" no contra-dique dos pescadores, facilitando o acesso das embarcações

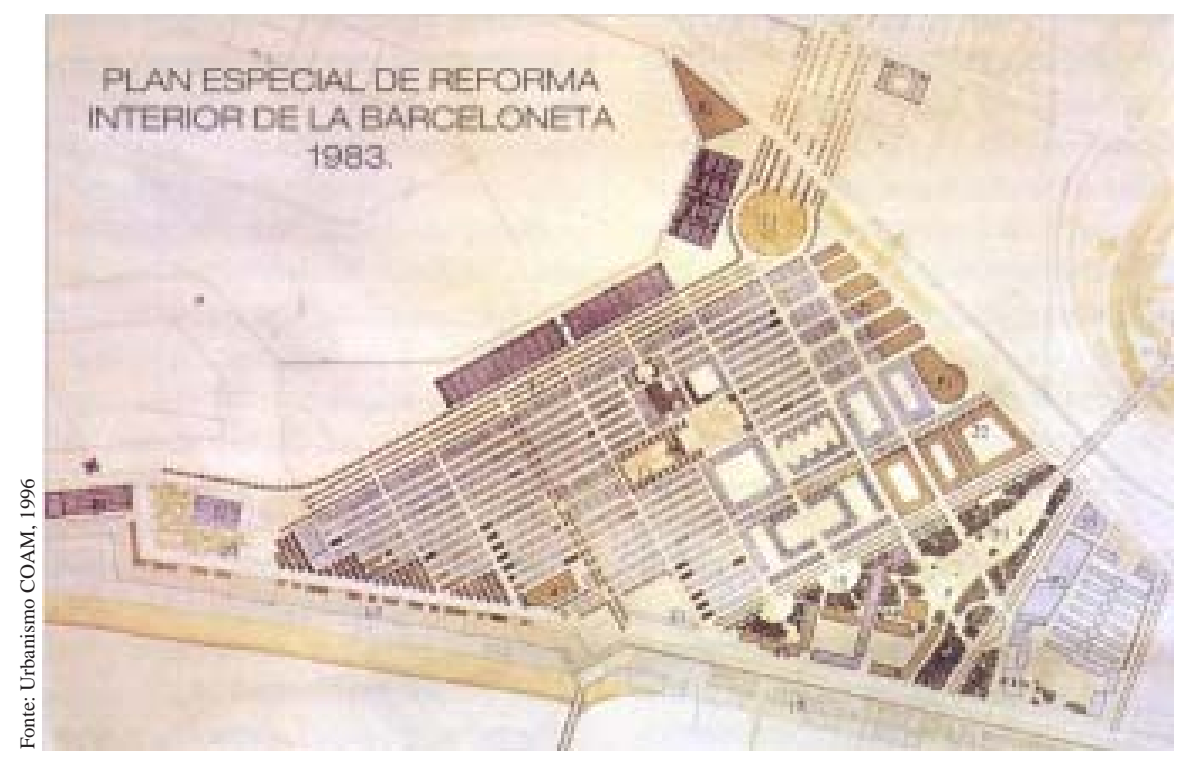

Plano de Barceloneta: interligação com o Plá de Palau e o parque da Ciudadela e alinhamento da costa 
Vistas do Passeo de Colom e do Moll de la Fusta a transformação do (ainda) passeio em via expressa e a demolição dos armazéns do cais para o depósito de contêiners
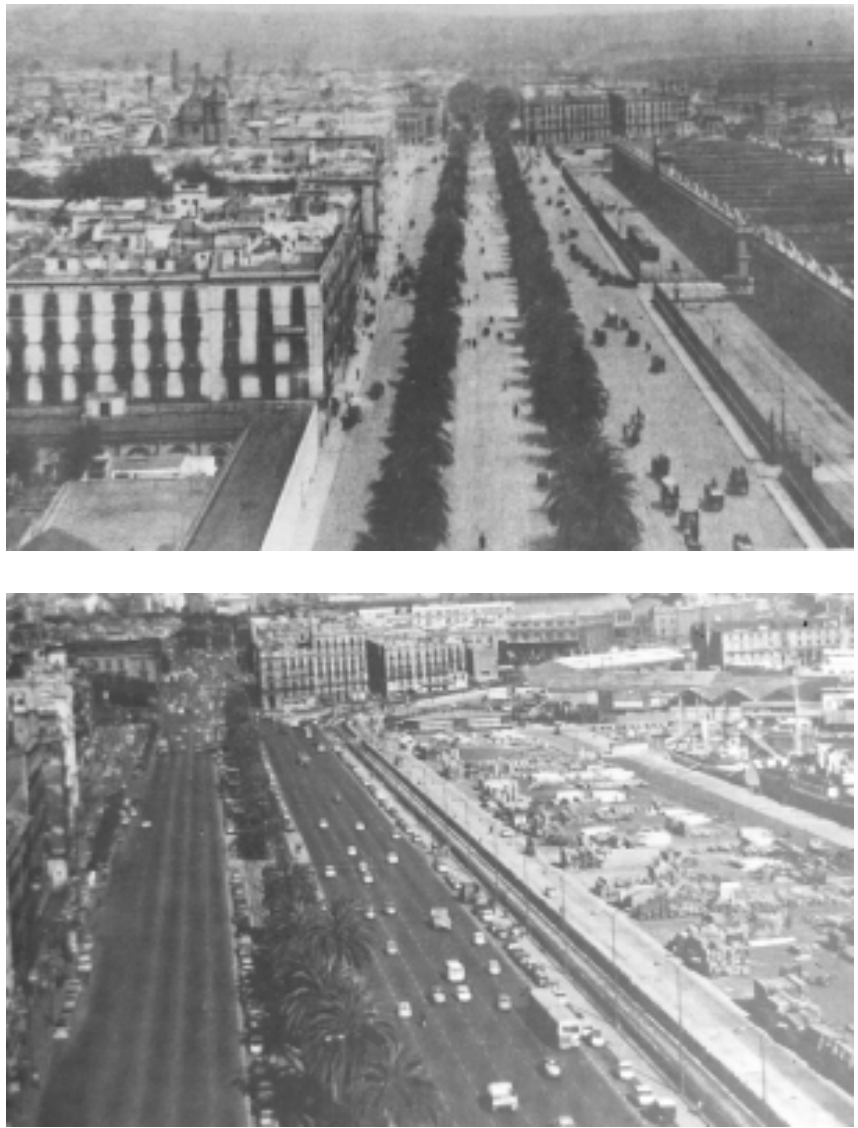

Secção mostrando os diversos níveis ("terraço", estacionamento, circulação rápida) e "recintos" criados (Passeo de Colom, "terraço", Ronda Litoral e esplanada)

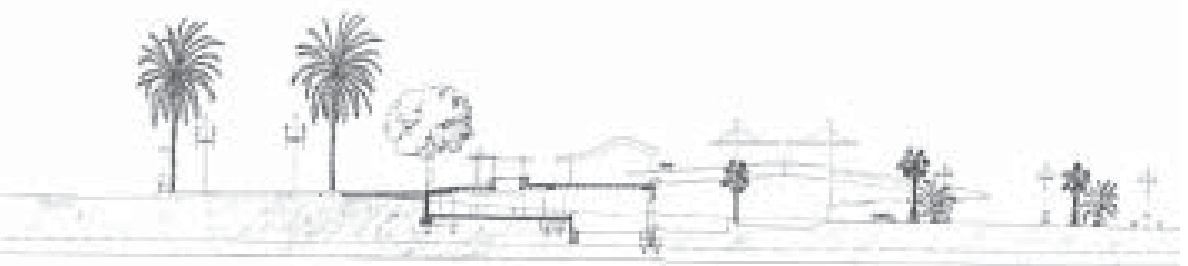

Fonte: O. Bohigas, 1991

Moll de la Fusta: vista do "terraço" que resolve em níveis a articulação do Passeo de Colom e Ronda Litoral com a esplanada ganha ao porto, conciliando os movimentos ao longo dos primeiros com o fluxo de pedestres que os cruza

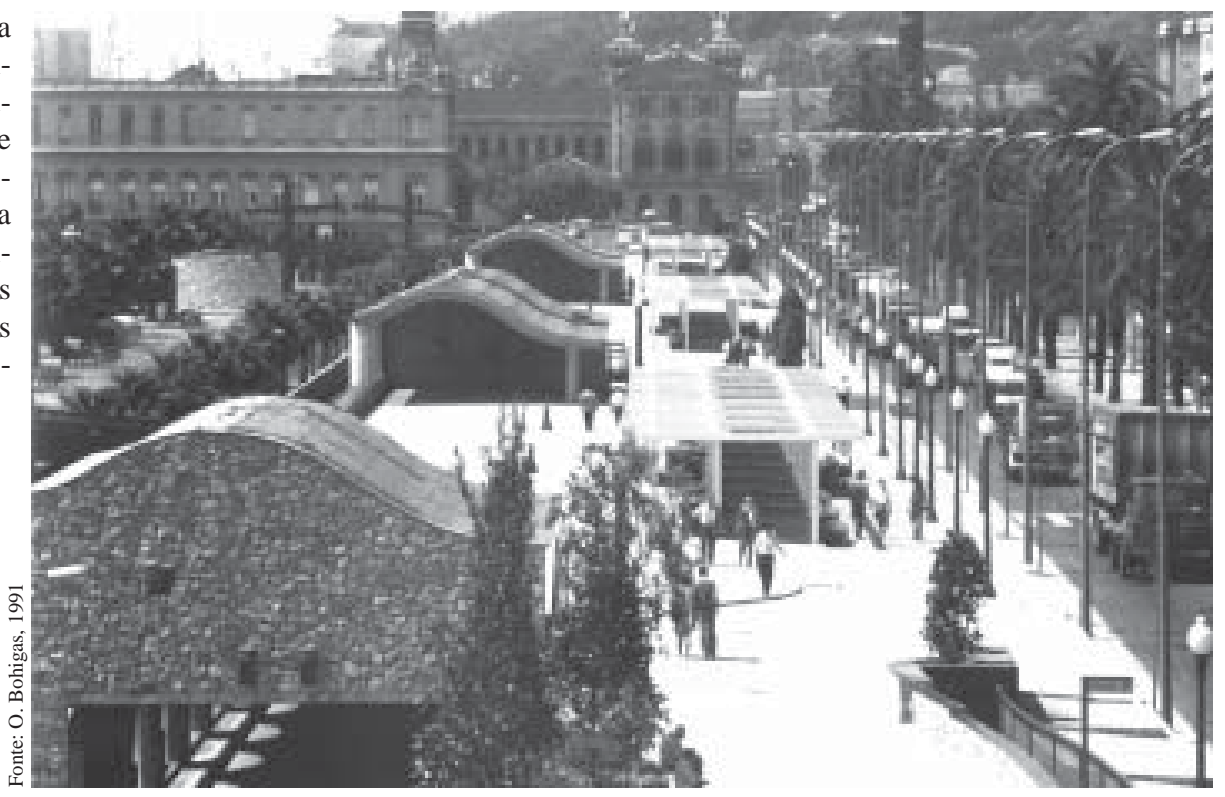




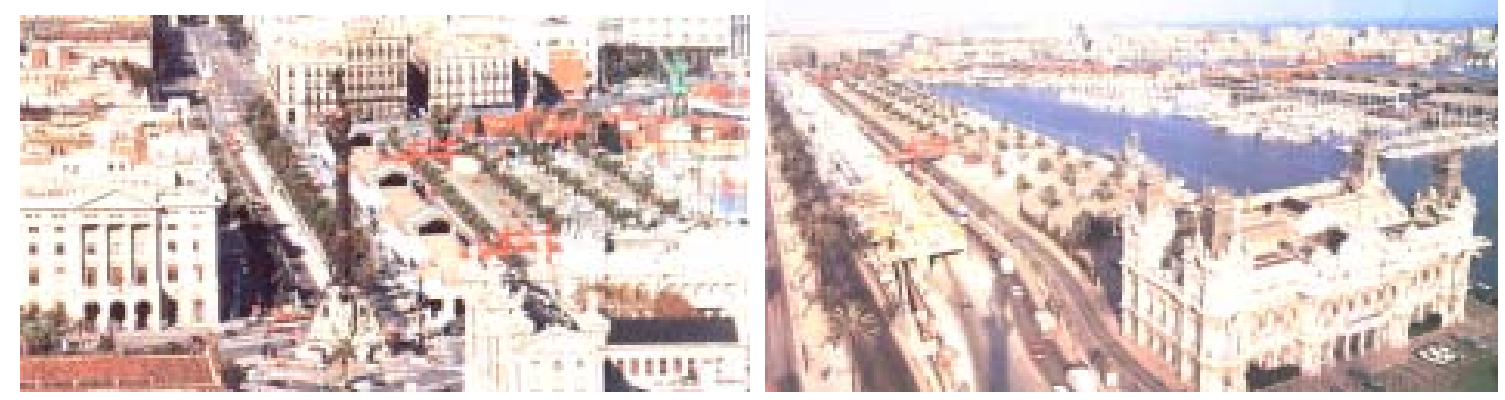

Vistas gerais do Moll de la Fusta: no primeiro plano o edifício da Marinha e ao fundo o Edifício del Deposito enquadram a nova área criada entre o Passeo de Colom e a frente marítima recuperada para uso urbano

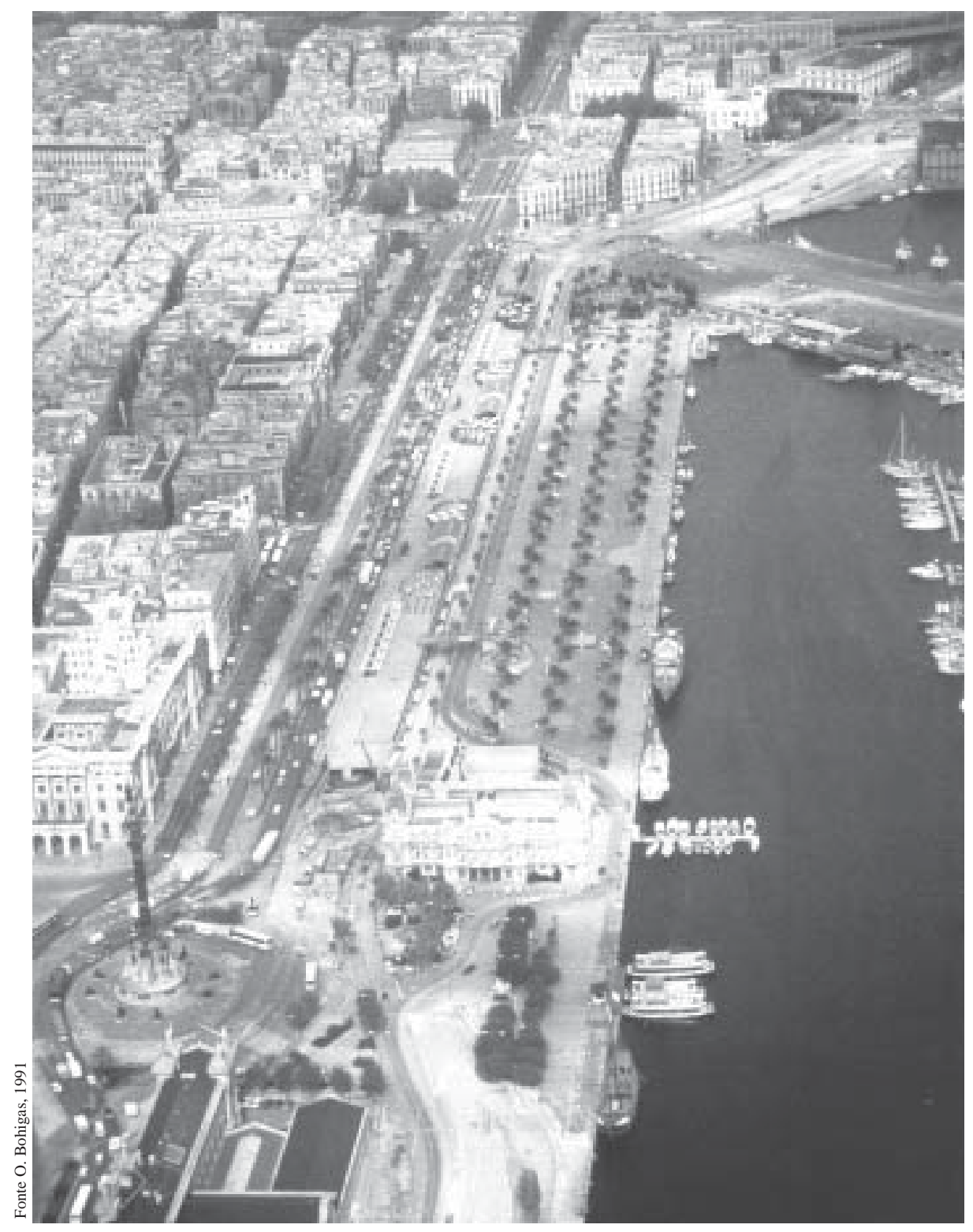



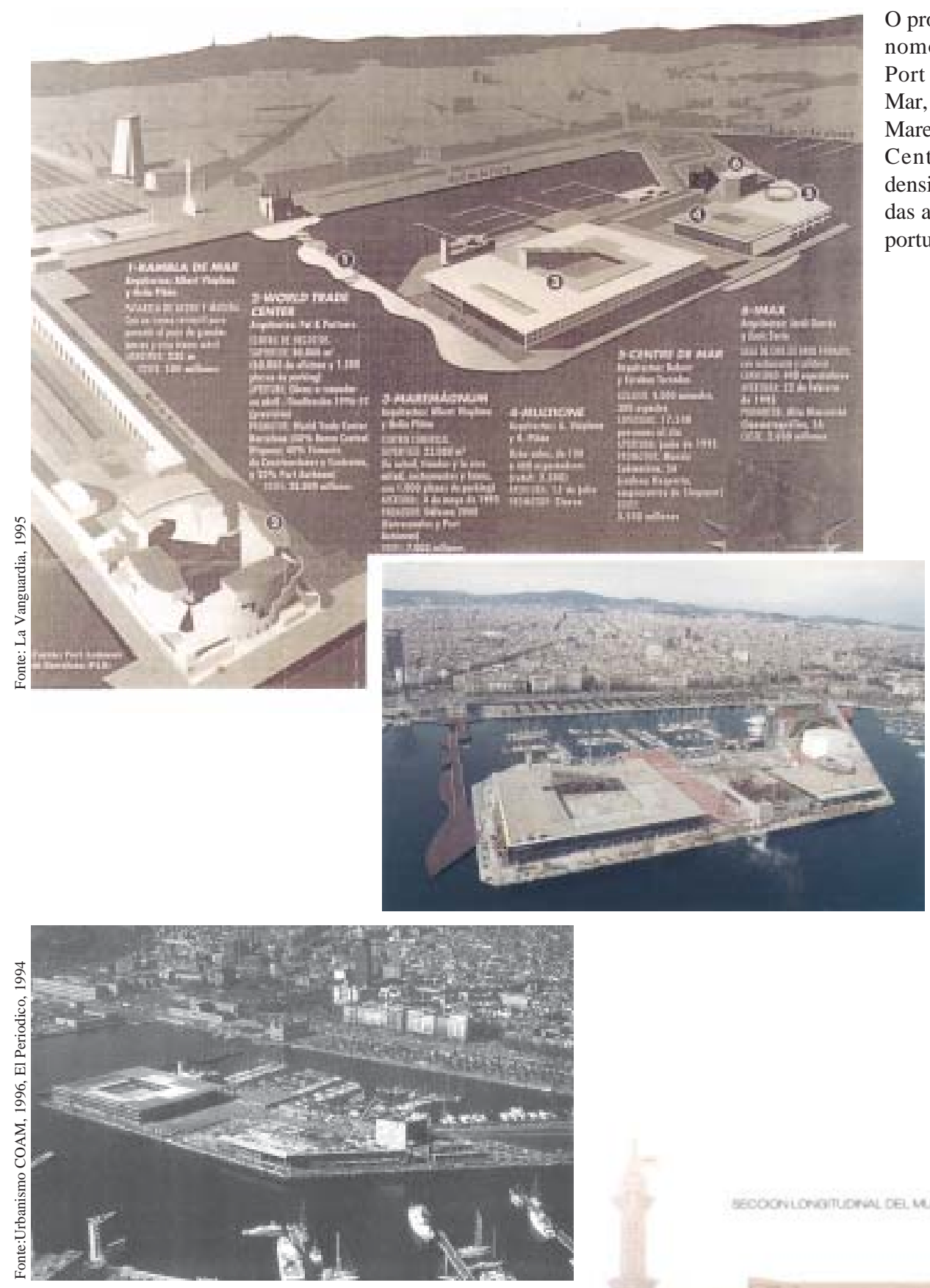

Vista geral do Moll de España: o conjunto comercial (shopping, center, aquário, cinema). As ligações com a cidade se fazem pelo antigo "braço" e por nova passarela retrátil (Rambla del Mar). Ao fundo a esplanada do Moll de la Fusta
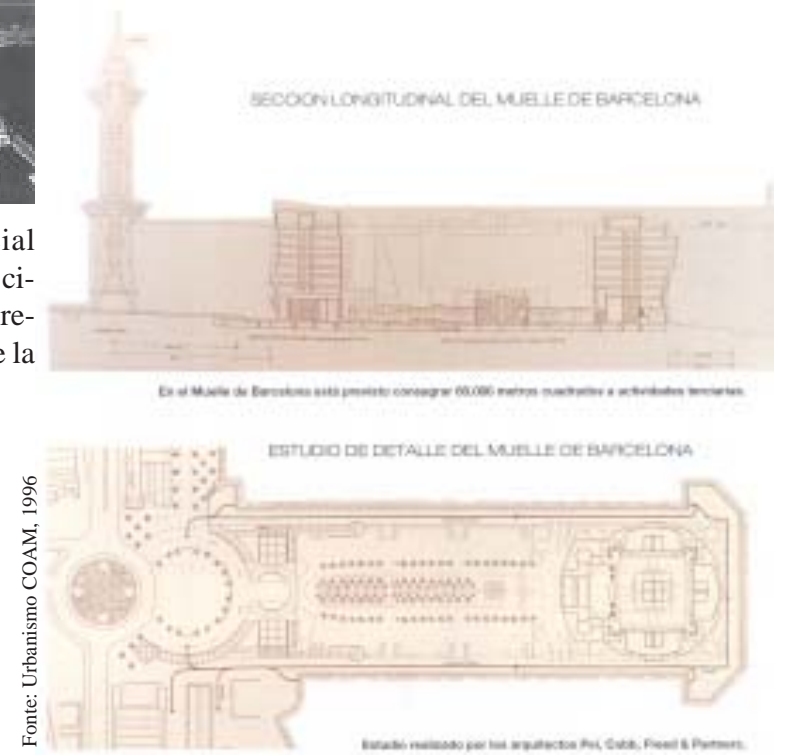

Projeto do World Trade Center 

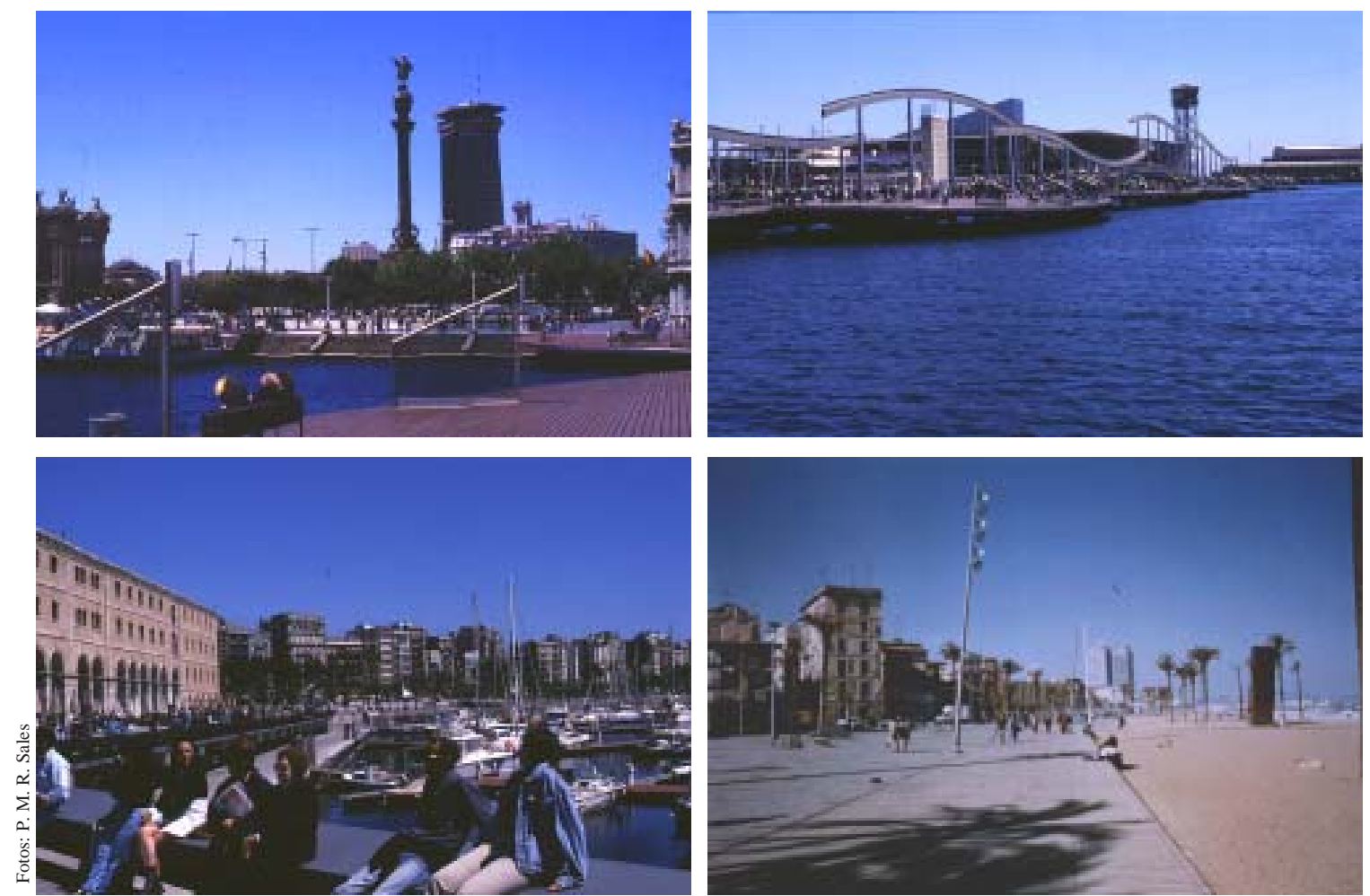

A nova relação com a cidade: Colom, a Rambla del Mar, Barceloneta e sua nova orla
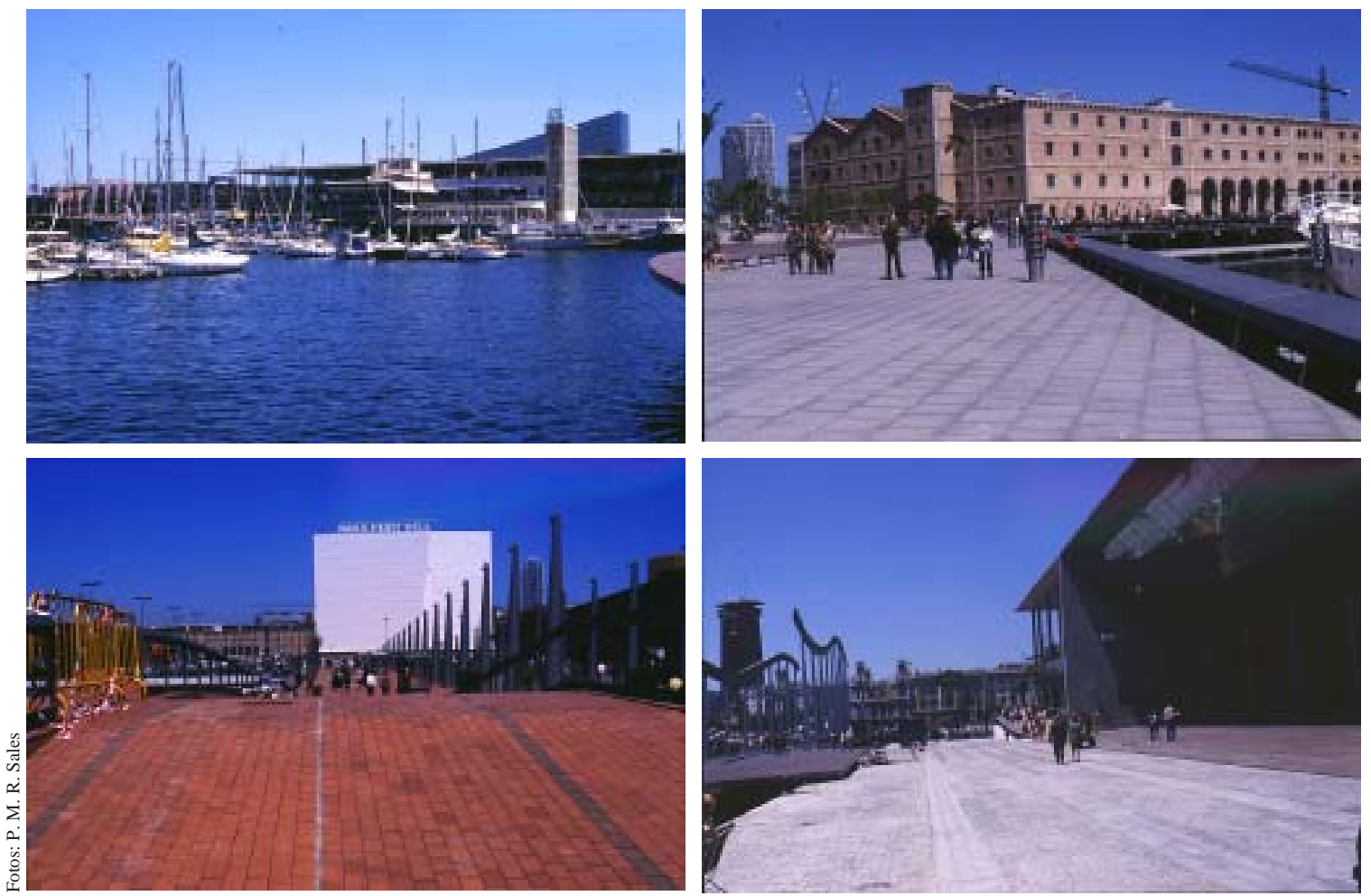

Vista do conjunto do moll de España e os edifícios do Depósito, Cinemax e conjunto comercial 


\section{Roterdã}

A posição de Roterdã no campo econômico europeu sempre esteve diretamente relacionada à importância de seu porto. Ainda que este tenha se tornado cada vez mais autônomo em relação à cidade: seja pela expansão física-territorial de suas instalações à escala regional, seja pelo âmbito mundial de suas relações funcionais.

No nível nacional, Roterdã constitui uma das quatro grandes cidades que compõem a Randstad, região metropolitana a oeste da Holanda que conforma o pólo dinamizador da economia holandesa, embora na década de 80 , esta região tenha apresentado crescimento inferior ao do resto do país.

Neste quadro, a espiral de declínio à qual Roterdã, após a década de 70, parecia crescentemente condenada, revelava-se tanto pelo progressivo abandono das antigas funções portuárias encravadas no tecido urbano quanto pela assimetria de sua composição social, causada pela perda para os subúrbios vizinhos da população representante dos setores de mais alta renda. Este estado de coisas colocava em cheque o próprio papel metropolitano da cidade.

A política de recuperação da cidade visando reintegrar a wet and dry economy encontraria um de seus pilares de sustentação precisamente na atuação sobre as obsoletas áreas portuárias distribuídas ao longo da duas margens urbanas do rio Maas. As soluções urbanísticas adotadas bem como os objetivos sócioeconômicos do sucessivo "resgate" urbano das áreas portuárias variaram segundo a motivação dos distintos momentos políticos da cidade. E, portanto, imprimiram características próprias às diversas fases do processo de reconversão dessas mesmas áreas, incidindo de maneira distinta nas diversas partes da cidade. Se este processo no início dos anos 80 foi marcado fundamentalmente pelos objetivos sociais da provisão de moradia, principalmente aquela de caráter público, o fim da década e os anos 90 marcariam uma nova orientação ao mesmo, implusionada como foi pelos desafios da competição entre as metrópoles européias.

\section{A cidade e o porto}

A localização - decisiva - sobre o estuário do Rhine e o aproveitamento ótimo - das oportunidades propiciadas por tal localização constituem os fatores que permitiram a Roterdã "originalmente uma cidade insignificante dotada de um porto", conhecer, após a metade do século XIV, um desenvolvimento que iria torná-la o centro de transportes mais importante da Europa ${ }^{43}$.

Entre 1850 e 1890, a transferência do porto, da margem norte para a margem sul do Rio Maas, consubstanciada na sucessiva construção de bacias, diques e 
das pontes Willembrug, Queensbrug e Hefbrug, veio configurar, alterando definitivamente a paisagem desta última margem - de rural à industrialportuária - a ossatura da Roterdã atual. A cidade passou a contrastar a sua porção norte (que monopolizaria o comércio, administração, lazer e habitação de alto padrão) e a sua porção sul (atividades portuárias e habitação proletária).

Só interrompido em função da Segunda Guerra Mundial e, particularmente, pela destruição por bombardeio do centro da cidade, o crescente fluxo de mercadorias em direção à região do Rhur estimulou continuamente a adequação, o aumento da capacidade infraestrutural e o crescimento das áreas portuárias, cujas instalações foram estendendo-se sucessivamente, por partes, em direção oeste, ao longo do novo canal, até a costa do Mar do Norte. O crescimento exponencial do porto até os anos $60^{44}$ levou, tanto em termos de superfície como de importância econômica, a um desequilíbrio em relação à cidade. Desequilíbrio esse, em grande parte, resultado da unilateralidade da política levada a termo no processo de reconstrução da cidade. Processo no qual a indústria ocupou um lugar central e onde um grupo fechado de administradores, empresários e engenheiros impôs, tecnocraticamente, seu domínio e suas decisões dentro da administração municipal ${ }^{45}$.

Ainda nesta mesma linha da hegemonia da autoridade portuária na condução das políticas territoriais, o "Plano 2000+" de 1969 tinha por objetivo tomar as medidas necessárias à realização de sítios portuários suplementares e de estruturas previsíveis para o futuro, englobando Roterdã e região ${ }^{46}$. Aí concebia-se Roterdã como "núcleo de uma aglomeração urbana fortemente expandida da qual fazem parte a integralmente nova Gravelingstad, uma enorme área industrial e portuária e dois novos aeroportos ${ }^{47}$. Porém, boa parte de tudo isto não se realizou. No período de transição onde a indústria, particularmente a petroquímica, enfraquecia-se com a crise dos anos 70, o Conselho Municipal assumiria (como nas principais cidades em que a maioria era social democrata do Partij van Arbijd) a questão social dos moradores, subordinando de todas as formas a política do porto às novas orientações administrativas e políticas que se instaurava. Neste contexto é exemplar o caso da ponte Hefbrug, obra de engenharia relativamente simples, ter levado 15 anos para sua construção, de 1971-1986.

A partir daí, a época da reconstrução foi considerada acabada. Iniciada com o Basis-plan de 1947 e passando pelo plano de $1955^{48}$, a política que até então referia-se ao nível globalizante da cidade inteira "foi substituída por métodos sobretudo concernentes a aspectos parciais, sejam setoriais, sejam territoriais, baseados na organização descentralizada do planejamento e na participação ativa dos moradores" $"$. 
No entanto, nos anos 80, a situação socio-econômica da cidade apresentavase seriamente problemática: decréscimo acentuado de população, diminuição do nível de empregos - particularmente pelo encerramento das atividades da indústria naval, que não conseguia mais competir na construção de navios cada vez maiores, tensão nas relações sociais e perda de importância em relação à região ${ }^{50}$. Desindustrializando-se, Roterdã tornou-se, cada vez mais, centro de negócios e serviços comerciais. Os novos postos de trabalho seriam atribuídos às pessoas de melhor nível de formação: justamente aquelas pertencentes aos setores sociais de mais altos rendimentos que abandonavam a cidade e instalavam-se nos arredores. Tudo isto, no que concerne à composição da população da cidade, resultou em uma base social assimétrica (imigrantes, segurados, desempregados) e, quanto ao perfil econômico, em uma estrutura comercial desequilibrada já que os serviços e o comércio mais sofisticados tendiam a acompanhar o deslocamento espacial da população.

A impotência da política de cunho quase exclusivamente "social" em representar um elemento significativo de recuperação da cidade levou a administração a lançar o programa-slogan The New Rotterdam: um programa integralmente orientado a combater o processo de declínio econômico e social ${ }^{51}$. O sentido buscado foi o de descobrir e explorar os aspectos positivos, embora latentes, da cidade para transformá-la em uma cidade "completa" e, assim, competitiva em relação à sua região e a outros centros. A ênfase seria posta no "aumento da atividade na cidade, no rerforço de sua economia e na continuação da renovação urbana", entendida como possibilidade de ampliação da estrutura turística e recreativa, de reforço das funções culturais, de recrutamento de novas atividades e de melhoria da qualidade do espaço público.

O porto, por seu lado, como protagonista do desenvolvimento, tornava-se mais e mais autônomo e sua referência seria cada vez menos Rotterdam, e sim, a região. Neste contexto, o último plano portuário, o "Plano 2010" de 1989, se de um lado, embora abandonando o velho estilo tecnocrático dos anos 50 e incorporando novas preocupações, ainda sugeria que a política econômica fosse a base sobre a qual os demais interesses sociais e ambientais deviam apoiar-se, de outro, no entanto, em função das novas exigências da dinâmica portuária e como estratégia de sucesso dos portos de importância mundial, demandava o desenvolvimento da cidade e da região em uma nova dimensão $0^{52}$. Essa nova dimensão, embora as expansões mais recentes do porto mostrem intensificação das atividades e dos fluxos de transporte à escala da região de Reijmond, implicaria no fato de que Roterdã ainda deveria ter um papel importante a desempenhar. Daí a necessidade de adaptar-se como centro urbano. Pois, a perspectiva portuária, a partir do conceito de "valor agregado" tomado como elemento estratégico de desenvolvimento, impõe, além da função de embarque, as de comércio e processamento em geral. Isto 
pressupõe o desenvolvimento de um forte setor terciário e de pesquisa, direta e indiretamente, ligado ao porto.

Neste sentido, a nova política da cidade foi dirigida pela necessidade de criar condições para a atração de novas atividades, através da melhoria da infraestrutura, da ampliação da oferta de serviços especializados, do desenvolvimento habitacional e de equipamentos de alto nível. Procurou-se consolidar a cidade como futuro centro logístico internacional com participação expressiva no PIB e, dentro da Randstad, como um complexo econômico portuário-urbano com posição nacional e internacional destacada nos setores de saúde, educação, pesquisa, eventos, artes aplicadas e arquitetura $^{53}$.

\section{O processo de revitalização}

Desde meados dos anos 70, as intervenções públicas seguindo a linha socialdemocrata da administração municipal foram pautadas por programas de revitalização dentro e em torno das áreas portuárias legadas do século XIX.

Ao lado da estratégia geral da reabilitação das propriedades existentes -ditada pela valorização do ambiente urbano e pela tentativa de minimizar o processo de perda populacional - a atuação sobre as áreas portuárias da cidade passou de modo dominante pela construção de novas habitações, orientada, no entanto, pelos mesmos objetivos e respondendo inclusive, pela demanda gerada pelo próprio processo de reabilitação que levava à diminuição do número de habitações disponíveis pela ampliação do tamanho das unidades reformadas.

Embora tenha que se distinguir as estratégias adotadas em cada parte da cidade, de modo geral, as primeiras iniciativas de reconversão das áreas portuárias foram dirigidas às necessidades das camadas de renda mais baixa. Na margem sul $80 \%$ das construções foram financiadas por recursos públicos e destinadas ao aluguel social; na margem norte, fora da Waterstad, este número atinge $93 \%{ }^{54}$.

Além deste aspecto, devem ser notadas outras características marcantes deste programa $^{55}$ :

- a busca de objetivos sociais estendeu-se à construção de equipamentos públicos (notadamente escolas);

- os recintos de água, apesar de seu potencial paisagístico e recreativo, foram em boa parte aterrados incrementando, como em Feijnoord e Katendrecht, o espaço utilizável e permitindo melhor aproveitamento de terrenos de formas alongadas; 
- a preocupação com diversidade morfológica, a imagem e a identidade dos lugares pautou de certo modo, como no Paperclip em Feijnoord, as soluções projetuais da arquitetura;

- ainda que a construção tenha sido dominantemente realizada pelo setor público, as faixas de terreno mais privilegidas do waterfront foram apropriadas pelo capital privado.

A presença do capital privado, no entanto, se fez muito mais marcante no desenvolvimento da Waterstad - complexo de bacias dispostas na margem norte do rio Maas. Aí os temas do lazer, do escritório e da habitação de padrão diferenciado impuseram-se, embora seu desenvolvimento tenha se dado segundo uma estrutura definida e aplicada pelas autoridades municipais. Assim é que os museus construídos - Maritme Museum e Inland Shippingtenham boa parte de sua área de exibição avançando externamente sobre os espaços abertos circundantes e se localizem, juntamente com outros grandes equipamentos públicos e privados, nos extremos da Waterstad, buscando dinamizar e integrar suas duas porções, divididas e caracterizadas como eram pela existência do antigo leito ferroviário sobrelevado ${ }^{56}$.

Em todo caso, a divisão leste-oeste da Waterstad refletiu-se na apropriação de seu espaço por novas moradias. A hierarquia social desta ocupação acompanhou tanto o movimento que leva da metade leste (áreas remanescentes do bombardeio reocupadas através de participação do setor público - construção e aluguel subsidiado) à metade oeste (apartamentos "um dormitório" de alto padrão, sobre o cais em forma de dedos de Leuvehaven), quanto aquele que aproxima-se do rio (Tropicana e proximidades do Econocenter), tirando partido das vantagens dos aspectos ambientais e paisagísticos do waterfront.

Quanto aos edifícios de escritórios, o impacto espacial das torres ficou, devido às limitações impostas pelo zoneamento vigente, circunscrito a um anel ao longo do waterfront entre o Inland Shipping Musem e Leuvehaven. Ao lado da Weena, o eixo terciário de prestígio de Rotterdam. Este espaço concentra os novos empreendimentos imobiliários, espelhando pela construção em altura uma imagem aparentemente nova-yorquina.

No quadro de relativo equilíbrio que existia entre as duas abordagens que conviviam em Roterdã nos anos 80 - uma fortemente orientada aos objetivos sociais e outra atendendo às pressões comerciais e à demanda residencial por parte de segmentos de alta renda - o projeto de Kop van Zuid constituiu um fator de transformação na medida em que representou, face à crise que a cidade atravessava, a necessidade de buscar respostas ao contexto da integração continental, gerando condições de atratibilidade para novos ativos financeiros e segmentos sociais de mais alta renda. Neste sentido, a mudança da política urbana de Roterdã dar-se-ia conjuntamente com as de Amsterdã e 
Haya: a perspectiva de aproximação à unidade política e econômica européia, sem dúvida, apresenta-se como fator dominante comum a elas ${ }^{57}$. O processo de competição entre as metrópoles européias e de eliminação de barreiras alfandegárias e sua consequência no nível regional, levou o governo central, através de sucessivos memorandos a assumir essas mudanças com o fim de revalorizar o patrimônio físico e econômico destas três cidades, redefinindo seu papel estratégico no território. Buscava-se, estimulando a renovação urbana como opção política e técnica, superar o caráter difuso de seu denvolvimento e a própria competição interna entre as mesmas, tornando-as capazes

"de competir com as cidades da Europa setentrional, tais como Londres, Paris, Bruxelas, Antuérpia, Hamburgo e Frankfurt. Poder que resultaria do concurso dos três centros urbanos, cada qual dotado de características próprias. Amsterdã, com sua concentração de serviços financeiros e de outros gêneros e com o aeroporto de Schipol; Haya, sede do governo e de suas instituições; Roterdã, porto internacional com um grande complexo petroquímico e todas as atividades ligadas às docas (transporte, armazenagem, serviços comerciais)...No quarto memorando, sublinha-se em particular, a importância de um planejamento conjunto por parte das autoridades do comércio e da indústria, com o fim de requalificar a infraestrutura da Randstad (enquanto) o governo empenha-se em elaborar os projetos de reestruturação - complexa, mas fundamental para o desenvolvimento urbano - no centro de Amsterdã (estação central de Ij e bacia oriental), de Haya (área do Fórum e da autoestrada Utrechte-baan) e de Roterdã (zona portuária da cidade e Kop van Zuid). ${ }^{58}$

Em Roterdã esta iniciativa viria coincidir com o programa municipal Het Newe Rotterdam (A Nova Rotterdam), posto em marcha no início dos 80 e que tratava da necessidade de se dar corpo à reavaliação de sua própria urbanidade através da renovação social, econômica e física da cidade. Os projetos de Inner-city, Noordrand e Kop van Zuid, reavaliando criticamente todo o processo de reconstrução da cidade, constituem a opção estratégica deste programa.

\section{A cidade como um conjunto unitário}

O principal problema de Roterdã nos anos 80 podia ser expresso segundo Riek Baker ${ }^{59}$, pelo fato da cidade, apesar de possuir um porto de importância mundial, não ter por sí, nem conteúdo nem importância comparáveis às de outras metrópoles: 
"Depois da experiência terrível do bombardeio de 1940, a principal coisa em que se pensou foi colocar toda a energia e dinheiro na reconstrução do porto. Era a coisa fundamental a se fazer. Além do mais, para as pessoas era suficiente saber que existiam condições de habitabilidade digna para alojar os trabalhadores do porto. Quarenta anos depois, por uma série de circunstâncias, entre as quais se deve destacar em primeiro plano, a do abandono do porto histórico, reconheceu-se que era talvez chegado o momento de fazer de Roterdã uma cidade de verdade."

E isto implicou ter que demonstrar, em uma cidade cuja tradição foi sempre concebê-la apenas em termos de políticas de habitação social, a importância da mudança de significado de certas áreas a partir da inserção de novas funções vitais para a cidade, evidenciando a própria condição de centralidade das mesmas. Tratava-se enfim, ainda segundo Baker, de "um primeiro passo, de um movimento para um outro modo de pensar a cidade e de considerá-la focalizando atenção sobre suas áreas mais importantes."øo

O slogan The New Rotterdam foi interpretado pelo Conselho Municipal e vários departamentos municipais como um problema de transformar Roterdã em "uma cidade completa" 6 . Isto requeria um novo tipo e uma nova cultura de plano de desenvolvimento. As iniciativas de renovação programática, de desenvolvimento da cidade e de reforço de sua estrutura física teriam um papel tão (ou mais importante) que as outras. Redefinição conceitual dos problemas urbanos e mudanças na organização administrativa dos órgãos de planejamento foram os fatos que, interligados, impulsionaram a este novo patamar a discussão do processo de declínio econômico e social de Roterdã ${ }^{62}$. Assim, a cidade é lida e interpretada de modo a evidenciar todos os caracteres estruturais (funcionais e espaciais) e se destaca sobretudo "a potencialidade que a disciplina projetual é plenamente capaz de explicar e de explorar" "в . O processo de trabalho instaurado culmina -confrontadas, sobrepostas, condensadas e mediatizadas pela viabilidade política, as diversas pesquisas setoriais- na "Carta dos 30 pontos".

Este documento, estabelecendo critérios de prioridade - definidos em termos de potencialidades, carências, problemas -, é assumido na sua condição de programa projetual e de ação como um verdadeiro e próprio plano da cidade. E como resposta orgânica aos "pontos" do documento destacam-se três projetos:

- Binnenstad (o centro urbano e em particular, Weena -área entre a praça da Estação e Hofpein) onde se concentrará o desenvolvimento intensivo de áreas terciárias e de serviços. O primeiro passo nesta direção foi a introdução do princípio de sobreposição de funções bem como a 
atribuição de tratamentos temáticos a áreas específicas: Museum Quarter, Waterstad (cidade da água), etc., revendo assim, a destinação das velhas áreas portuárias da margem direita do Maas. Estes projetos completam-se com a intensiva verticalização do eixo este da cidade (Weena);

- Noordrand (periferia norte) onde o aeroporto e a zona de sua vizinhança serão objeto de extensão e renovação: estudos econômicos e ambientais dão suporte para o projeto de construção de novo aeroporto e de edifícios residenciais e de serviços;

- Kop van Zuid (margem sul do Maas em frente ao velho triângulo central) onde as áreas portuárias do século XIX, desocupadas de suas funções originais, permitirão a expansão do centro da cidade em um novo registro de qualidade, colocando em relação partes da cidade (tradicionalmente isoladas e desigualmente desenvolvidas) através de um potente sistema de infra-estruturas.

O objetivo de dar coerência a estes projetos principais e, ao mesmo tempo, em uma cidade que passou a conhecer desde 1988 um verdadeiro boom imobiliário com localizações, dinâmicas e efeitos tão diversos, garantir a capacidade competitiva de Roterdã e sua região integradas à rede européia, levaram em 1992, à elaboração do "City Plan". Plano este que esboça uma perspectiva de desenvolvimento da cidade até 2010, apostando na coerência entre projetos urbanos e políticas setoriais não apenas nas faixas ao longo do rio, mas no contexto da previsão de novas áreas de expansão e de resevas naturais ${ }^{64}$.

\section{O projeto Kop van Zuid}

A paisagem

O nome Kop van Zuid -testa do sul- advém da relação entre a imagem da acentuada forma convexa criada pela inflexão do Rio Maas em sua margem esquerda (porção mais ao norte da ilha de Feijnoord) e sua posição urbana, diretamente oposta ao velho triângulo da cidade. Seus 125 ha de superfície entre as bacias de Binnenhaven, Spoorghaven e Rinjhaven compõem o conjunto de áreas portuárias do século XIX que, assentadas além do aterro que protege a cidade da água, formam uma barreira entre o rio e esta, a qual, desde 1870, passaria a crescer em ambas as margens daquele.

Sua paisagem seria expressão das rápidas transformações tecnológicas da atividade portuária do século XIX e início do XX. As tipologias que a compõem dividiriam Kop van Zuid -um fascinante enclave de bacias, piers, gruas, linhas férreas na margem sul de Rotterdã" ${ }^{\prime 65}$.- segundo dois ambientes extremamente diferenciados. Por um lado, estreitas bacias orientadas ortogonalmente ao rio e paralelamente aos pátios ferroviários (desenho apropriado para o transbordo navio-ferrovia) e, por outro, as bacias mais 
amplas de Rinjhaven e Maashaven do início do século, com suas bocas voltadas rio abaixo para facilitar as transferências longo percurso-cabotagem-

E, na divisão norte-sul da cidade, o rio tem seu potencial simbólico próprio:

"Durante o processo de ocupação portuária da margem esquerda do Maas no início do século, o rio é visto antes de mais nada como fator econômico, fonte de oportunidades de emprego. Já em 1927, a substituição da velha linha ferroviária pela ponte Hefbrug, mais do que uma infra-estrutura, simbolizou o avanço de Roterdã sobre o Maas e, consequentemente, o desenvolvimento de Roterdã como uma cidade de trabalhadores" $" .$.

O posterior deslocamento da expansão portuária em direção a oeste relegou a área a uma posição marginal de abandono, encravada entre a estrutura espacial de sua vizinhança, fundamentalmente de caráter residencial.

Os planos de ocupação

Até 1968, a municipalidade buscou preservar a função portuária das velhas bacias de Kop van Zuid. No entanto, refletindo as mudanças políticas dos anos 70 e a participação direta das organizações de moradores neste quadro político ${ }^{67}$, seu incontestável estado de abandono acabou estimulando uma sucessão de planos de ocupação, em sua grande maioria, de caráter habitacional.

Assim, é que no "Plano Estrutural" de 1978, a municipalidade de Roterdã estabeleceu a qual das velhas áreas portuárias seria dada uma nova função: o local entre Binnenhaven e Spoorghaven acabaria configurando uma área residencial para 400 apartamentos. Em 1979, a associação dos moradores Feynoord-Noordereiland elaborou seu próprio plano. Este foi o primeiro projeto para Kop van Zuid desde a realização dos planos para a área do fim do século XIX. Em 1984, Roterdã fez uma proposta para sediar os Jogos Olímpicos de 1992 na qual Wilhelmina Pier é designada como sede do “Centro de Imprensa Olímpico". Em 1982, um evento promovido pelo Rotterdam Arts Council procurou colocar a política pública habitacional da cidade em um registro cultural mais amplo, convidando quatro arquitetos de renome internacional (Rossi, Ungers, Kleihues e Walker) para desenvolver projetos para a totalidade da área de Kop van Zuid; projetos esses que embora em nível substancialmente demonstrativo, poriam sob nova luz a escala e o significado urbano de uma operação de reconversão da área ${ }^{68}$.

De qualquer maneira, seja por problemas financeiros seja por conflito com os interesses do porto, os planos criados pela municipalidade para Kop van Zuid acabaram sucumbindo. Sómente como resultado da nova visão sobre os 
problemas da cidade que vinha ao longo dos anos 80 tomando corpo pelo aprofundamento dos trabalhos então desenvolvidos pelo "Departamento de Urbanismo" (Stadsontwikkelung), a área de Kop van Zuid, interpretada na perspectiva mais globalizante e integradora da "Carta dos 30 Pontos", revelarse-ia de fato como oportunidade única de Roterdã "realizar suas ambições" Neste contexto, a partir de um termo geral de referência ${ }^{70}$, Teun Koolhaas é contratado para desenvolver um projeto para a área.

\section{O projeto Koolhaas}

O plano apresentado (sob a forma de maquetes, indicação de destinações funcionais e algumas secções demonstrativas das diversas densidades edificatórias, quantificadas em uma tabela anexa) formula uma perspectiva visual daquelas "ambições", ou seja, religar as duas margens da cidade sobre o Maas, rompendo seu isolamento através de uma série de medidas de caráter infra-estrutural:

"A expectativa é que com a atuação das novas infraestruturas se realize um novo contexto urbano complementar ao existente que, uma vez implantado ao longo do eixo que desde o aeroporto a norte da cidade, através da nova ponte Coolsingerbrug alcança Kop van Zuid, seja capaz de atrair empresas de caráter internacional."

As principais características estruturais do projeto ${ }^{72}$ são:

- criação de uma nova centralidade com acessibilidade e proximidade ao centro garantidas pela construção de uma ponte e através da proposta de um programa formal e funcional diferenciado;

- definição do traçado da nova infra-estrutura e de seus pontos de ancoragem (metrô, túnel ferroviário-TGV, ponte Coolsingerbrug);

- conexão entre as novas áreas e as pré-existentes superando com uma proposta clássica de distrito residencial (avenidas, ruas, quadras fechadas) sua divisão historicamente determinada (tanto em termos funcionais como morfológicos);

- inclusão e valorização dos antigos edifícios portuários como suportes de identidade histórica.

Articulando estes elementos estruturais, o plano define setores funcionais onde Wilhelmina Pier destaca-se como ponto de atração e continuação das atividades terciárias e dos serviços localizados no centro da cidade: ao longo de seu waterfront propõe-se uma imagem forte de frontalidade-continuidade entre norte e sul através da disposição intensiva de edifícios para escritórios, áreas de turismo e comércio, inseridos em complexos residenciais de alto nível. 
Porém, o elemento estratégico de todo o plano é representado pela ponte sobre o Maas pois, se por um lado, simboliza as novas relações entre o norte e o sul da cidade, por outro, ao conectar Kop van Zuid à rede nacional e internacional, confere prestígio à proposta como uma perspectiva econômica $\mathrm{real}^{73}$.

\section{O master-plan como revisão do plano Koolhas}

A importância do elemento infra-estrutural - particularmente, a ponte - é revelada pela própria atenção que merece no processo de revisão do plano original. O traçado anteriormente proposto - formado por um sistema ponte/ bulevar/viaduto - que parecia ignorar a estrutura espacial de Roterdã sul, é alterado no sentido de conectar fortemente os episódios urbanos mais significativos: o aeroporto a norte, Noordrand, o centro da cidade (Hofplein, Weena, Coolsingel), as bacias de Waterstad e da margem esquerda, a estrutura residencial a sul, o centro de serviços Zudplein, indo até o cinturão sul. O concurso para a realização do projeto da nova ponte é ganho pelo arquiteto Ben van Berkell e a obra iniciada em 1992, sob grandes festividades, foi concluída e inaugurada em setembro de $1996 .^{74}$

Por outro lado procurou-se reforçar a importância da travessia do rio através do complexo da ponte Willemsbrug/Queensbrug/Rosestraat (que parecia ter sido substituído naquele primeiro projeto), além da interligação por um sistema de ferry-boat do distrito do "Museu da Cidade" à Wilhelmina Pier (uma ponte de Wilhelmina Pier a Katendrecht atenderá o tráfego de baixa velocidade). $\mathrm{O}$ master-plan avança ainda nas questões relativas às conexões entre a nova área e as existentes no sentido de proporcionar condições para a renovação econômica e social dos distritos vizinhos, ao mesmo tempo em que reavalia a proposta de transformação das bacias portuárias em áreas verdes, buscando assim manter, até quando for tecnicamente possível, a identidade marítima da área. Esta decisão enseja a possibilidade de serem criadas novas esplanadas públicas e novas relações na paisagem. Medidas estas, reforçadas pela proposta de manutenção das linhas visuais que, ao longo da extensão dos velhos armazéns, interconectam o rio, o skyline do centro e as áreas residenciais vizinhas, identificando cada um destes elementos por configurações paisagísticas próprias (parques, praças, bacias) ${ }^{75}$.

Quanto à Wilhelmina Pier, a municipalidade de Roterdã viria a firmar um convênio com três companhias privadas (uma inglesa, outra francesa e a terceira holandesa) com a finalidade de desenvolver um plano que conjugasse qualidade arquitetônica com perspectivas comerciais. $\mathrm{O}$ arquiteto inglês Norman Foster contratado em 1992, apresenta uma proposta na qual uma estrutura de elementos públicos (cais, ruas e praças) deve servir de base para o desenvolvimento posterior: em altura nos limites exteriores do cais e mais baixo no centro, "dando coerência e integrando a arquitetura dos velhos depósitos e garantindo através desta zonificação simples, iluminação e 
ventilação das áreas públicas"ᄁ". Assim, contrariamente à definição tipológica e compositiva dos planos de Koolhaas e do próprio Master-plan - rígida definição arquitetônica que tornaria vulnerável a estratégia da parceria públicoprivado do empreendimento-, Foster propõe uma simples estrutura para definição arquitetônica posterior, estabelecendo algumas pré-condições tais como o estabelecimento de linhas visuais, das funções do pavimento térreo e de áreas subterrâneas de estacionamento e a manutenção do caráter público do cais.

\section{O plano de desenvolvimento}

A aprovação em 1991 pelo "Conselho Municipal" do "Plano de Desenvolvimento de Kop van Zuid oficializou os vários instrumentos técnicos e legais (atualizando-os por uma reinterpretação da base jurídica corrente) no sentido sobretudo de guiar e controlar, em vez de especificar, os resultados do processo de renovação. Um mapa geral indica as infra-estruturas principais e define de forma "simples e flexível" a função dos vários setores e suas principais diretrizes (estruturas de acesso, rotas de tráfego de baixa velocidade, linhas visuais) no sentido de ancorá-los à estrutura urbana do entorno (segundo critérios de altura e forma envoltória dos edifícios, características dos bulevares, funções do pavimento térreo, áreas de estacionamento, incorporando as diretrizes propostas por Foster) e garantir a qualidade desejada no que concerne à participação governamental na criação dos espaços públicos.

Instrumentos suplementares (1993) foram especificados (e sugeridos por referências gráficas) em três "livros de padrão de qualidade" "r7 referindo-se às várias instâncias de intervenção propostas:

- a da cidade: transposição do rio, bacias portuárias, waterfront;

- a do desenho do plano: setores urbanos e seus elementos espaciais e programáticos;

- a da arquitetura: referência às composições e materiais empregados.

Como previsão geral até 1999 deverão estar disponíveis sobre os 125 ha de Kop van Zuid :

- 5.300 novas unidades residenciais

- $400.000 \mathrm{~m}^{2}$ de área para escritórios

- $35.000 \mathrm{~m}^{2}$ de área produtiva

- $30.000 \mathrm{~m}^{2}$ de área para equipamento educacional

- $30.000 \mathrm{~m}^{2}$ de área para equipamentos de lazer e ócio

O esquema de ordenação espacial articula segundo setores mais ou menos definidos em suas imagens características, um pólo de negócios mais 
verticalizado (Wilhelmina Pier) com o desenvolvimento residencial a leste, de media altura e quadras semi-fechadas, através de um centro comercial e de escritórios a ser implantado sobre o eixo "Laan op Zuid , o qual da Erasmusburg (ponte) caminha a sul entre as bacias de Rijnhaven e Spoorweghaven e onde se sobressai, mais pela massa volumétrica, o edifício da Wilheminahof. Esse edifício em seu interior abrigará uma estação de metrô. Uma outra estação, essa ferroviária, no extremo leste de Kop van Zuid completa, junto com aquela e a ponte, o sistema geral de acessibilidade á área.

\section{Os projetos em curso}

Realizada a interconexão com o centro da cidade através das principais infraestruturas de transporte - ponte sobre o rio, metrô e estação ferroviária - a primeira etapa de implantação do projeto deu-se no setor leste de Kop van Zuid, em torno das bacias de Binnenhaven e Entrepôthaven, principalmente através da construção de edifícios residenciais e da reciclagem de um armazém de 1879 para uso comercial, preenchendo, assim, os espaços mais próximos do renovado (1995) conjunto habitacional Peperklip. Nessa primeira fase, outra operação de reciclagem, desde já exitosa, é a realizada no extremo oeste de Wilhelmina Pier no prédio da AmericanLijn (antigo ponto de embarque de imigrantes para os Estados Unidos), transformado em complexo hoteleiro. Arquitetos holandeses de pretígio internacional, como Rem Koolhaas, Joe Coenen e a equipe Mecanoo, desenvolvem projetos para a área: o primeiro um edifício para teatro e os dois últimos, edifícios residenciais.

\section{Gestão}

A designação pelo governo central de Kop van Zuid como "key project" implicou tanto na consideração da importância estratégica do mesmo no programa de reordenação do território, como na montagem da associação público-privado como condição fundamental para sua realização, definido-se de antemão direitos e obrigações recíprocas de cada uma das partes envolvidas. Por exemplo, no âmbito público, o governo central comprometeuse com o suporte financeiro para a área de infra-estrutura e habitação (envolvendo vários ministérios). Em contrapartida, a administração local assumiria a responsabilidade dos seguintes pontos:

- "criar um "centro-cidade" único ao longo de ambas as margens do Maas;

- estruturar a economia dos distritos nos arredores de Rotterdã sul;

- realizar um empreendimento de nível internacional para habitação, escritórios, comércio e atividades de lazer"'s.

Neste contexto, a transferência da propriedade das áreas portuárias obsoletas ou redundantes das mãos da "Port Authority" para a administração municipal 
propriamente dita, representou fator de importância fundamental na medida que as estruturas de poder e os estatutos legais das duas organizações diferem radicalmente (ainda que a administração portuária seja atributo municipal):

Por exemplo muitos controles urbanísticos não se aplicam à autoridade portuária, mas a municipalidade está sujeita ao conjunto de todas regulamentações. Entre outras coisas isto significa que deve haver participação pública local no planejamento, e isto pode ter influenciado as estratégias municipais que privilegiaram a questão habitacional" ${ }^{\prime}$.

A partir de um enfoque integral (e não apenas programático e de procedimentos administrativos, mas também, e sobretudo, espacial) e tendo o plano como guia e instrumento de controle, procurou-se montar diversas parcerias entre os setores públicos e privados ${ }^{80}$. Nos vários sub-projetos que este enfoque e esta política propiciam, a participação do governo, ao lado de seu papel de supervisão democrática do processo, realizando de comum acordo, projetos, despesas e lucros, permite que estes, com base nestes mesmos acordos, assumam formas de divisão dos encargos que não as meramente financeiras. Isto é, o "enfoque integral" pode combinar as fases de realização dos vários empreendimentos garantindo, além do padrão de qualidade dos mesmos, a convergência dos interesses, como por exemplo os que existem entre disponibilidade de infra-estrutura (ponte, metrô, etc) e a qualidade locacional de uma área.

\section{Os significados}

A repercussão internacional de Kop van Zuid (publicações especializadas ou de simples marketing, exposições, conferências, etc) tanto advém de sua base polítco-institucional (ao definir um papel claro e ativo dos vários níveis de governo em um contexto onde o liberalismo econômico mostrava seu apogeu), como deriva dos aspectos técnico-disciplinares da elaboração e condução do plano, redefinindo dentro da praxis urbanística (holandesa e mesmo internacional), metodologias e conceitos. Neste sentido avança em relação à cultura da renovação urbana, (substancialmente "localista" como era própria dos anos 70 na Europa) e vincula-se segundo uma perspectiva complexa mas coerente, a uma estratégia de definir a cidade como um "conjunto unitário". A isto soma-se "uma atenção toda nova ao valor de mercado e político da qualidade da arquitetura" e à sua "própria capacidade de traduzir em imagens os desejos e expectativas da nova política urbana, além de seu próprio valor de uso"s1.

Quanto à discussão dos critérios de inserção do projeto na cidade, a questão da identidade urbana de Roterdã evidencia duas posições. A primeira diz respeito ao significado estratégico representado pela nova travessia do rio 
Maas. Se a cada momento histórico desta iniciativa correspondeu uma revalorização simbólica tanto da cidade como do rio ${ }^{82}$, a construção da ponte Erasmusbrug, recompondo a unidade entre as duas margens, permite pensar na criação de uma "única Roterdã" ${ }^{3}$ cujo centro "mental e geográfico" agora desloca-se para o próprio rio ${ }^{84}$. A segunda posição refere-se à perda de importantes referências históricas da cidade do século XIX. Em todo o caso, se o soterramento da linha ferroviária permitiu dispor de uma importante área no lado norte da cidade ${ }^{85}$, ou a valorização dos edifícios portuários mais antigos ${ }^{86}$, de certa forma, "legitimou" a operação. No entanto, a criação de uma imagem a la Manhattan permanece polêmica pela altíssima densidade dos edifícios-torre que desenham em grande escala a linha do waterfront de Wilhelmina Pier que, por ironia, assumida ou não, representou o lugar de saída de milhares de imigrantes rumo à Nova York.

Segundo A. Tzonis, esta imagem, pretensamente sedutora, seria mais dirigida a convencer os meios financeiros que a deixar visualizar um novo tipo de $v_{\text {vida }}{ }^{87}$. Além do mais, a não adequação da morfologia arquitetônica e urbana em relação à água e ao terreno ${ }^{88}$, parece não reconhecer os valores recreativos de uma grande bacia e tampouco oferecer seja condições ambientais, ecológicas e micro.climáticas, seja uma imagem que facilite a compreensão e o uso. No entanto, discutindo a relação entre monumentalidade e informalidade que tanto caracteriza, a construção da cidade de Roterdã, o projeto Kop van Zuid, segundo H. Meyer ${ }^{89}$, contemplaria o primeiro aspecto pela preservação de alguns edifícios portuários e pelo desenho dos espaços públicos e o segundo, através da estrutura dos espaços abertos e pelo alto nível de liberdade dado ao design dos edifícios e suas funções (sem falar do próprio estigma da área que de sua condição originalmente rural passou a acolher a caótica natureza das atividades do porto).

Em um contexto (novo para Roterdã) em que a renovação econômica pretendida vem expressa por international business enviroment and firstclass opportunities, a polêmica que se estabeleceu em termos do retorno social do empreendimento nas discussões promovidas pelo "The Social Return Study Group" com as diversas partes envolvidas (municipalidade, setores comerciais e os distritos vizinhos), procurou ser equacionada pela oferta à organização dos moradores, de postos de trabalho, de oportunidades de estudos do idioma e da criação de centro de serviços e empregos, além das tentativas de reforçar a estrutura econômica dos bairros através de novas ligações e articulações espaciais ${ }^{\circ 0}$. Neste sentido, é interessante notar a posição daqueles que vendo na política de revitalização econômica adotada mais uma orientação de desenvolvimento imobiliário que econômico estritu sensu, enfatizam a necessidade de se combinar, em uma perspectiva estratégica coerente e explícita, a oferta de novas possibilidades de formação e educação com as exigências da economia portuária do futuro"»?.

Mas de qualquer maneira, tomado o conjunto das sucessivas operações de 
recuperação das área portuárias urbanas de Roterdã, poder-se-ia concordar com Pinder e Rosing ${ }^{92}$ quando dizem que a cidade conseguiu juntar o melhor dos dois mundos. Aquele mais voltado para as questões da moradia social e aquele derivado das exigências de atualização da cidade motivadas pelo processo de competividade territorial. 
Planta de Roterdã: 1839 e 1950
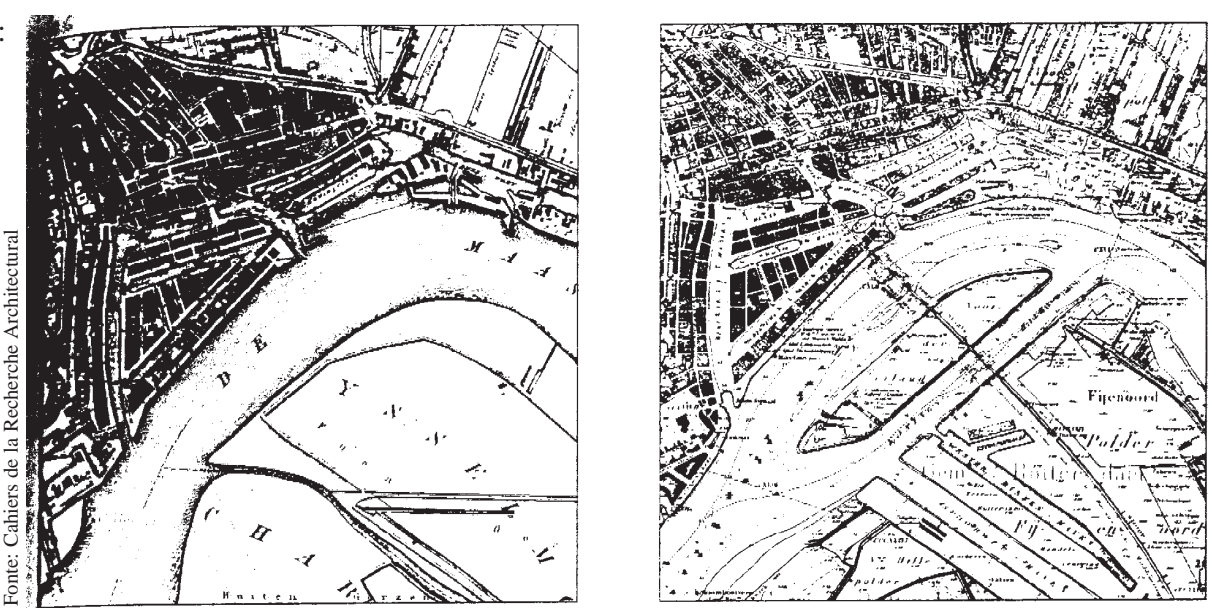

Plano de Roterdã 2000

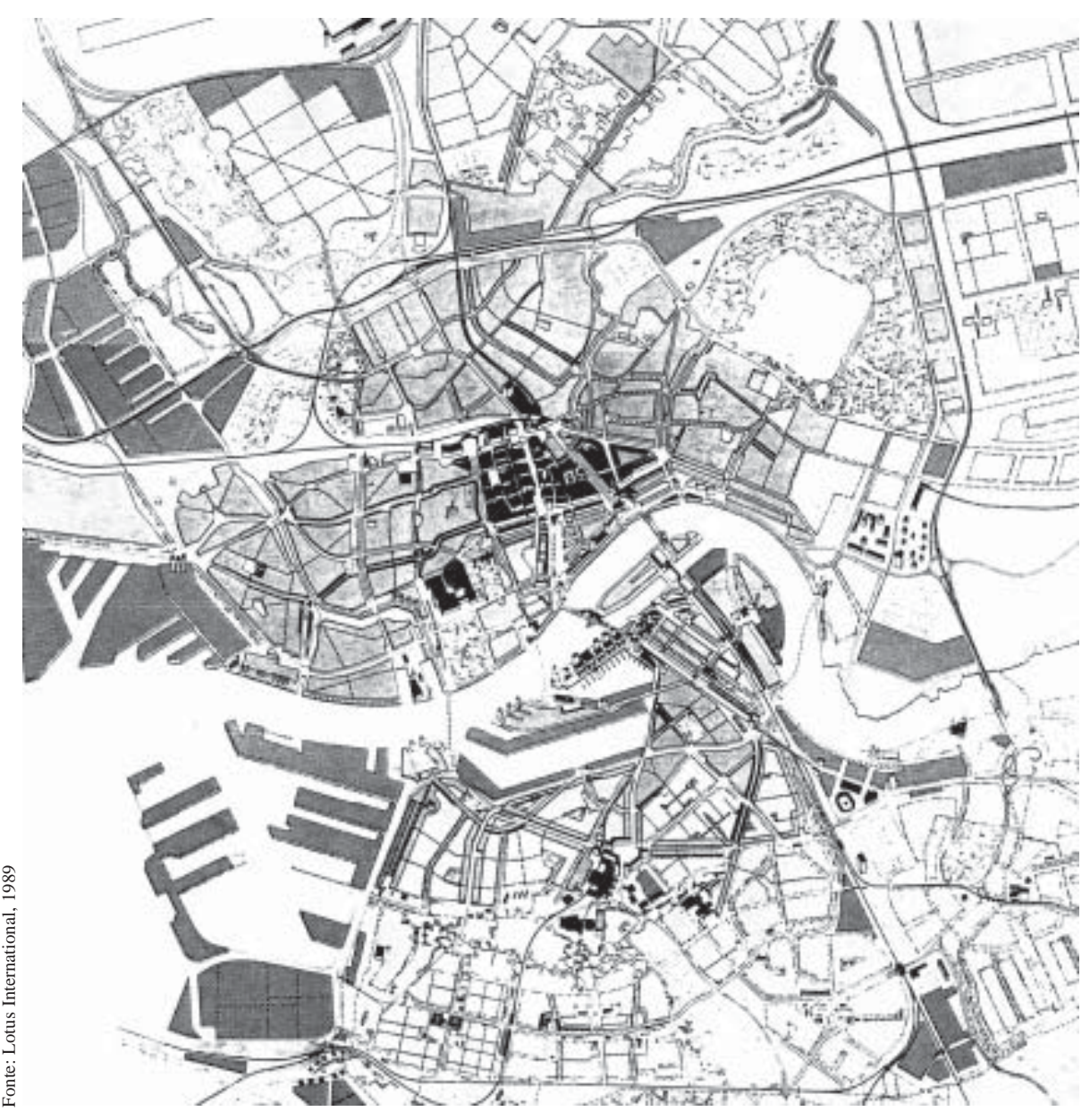



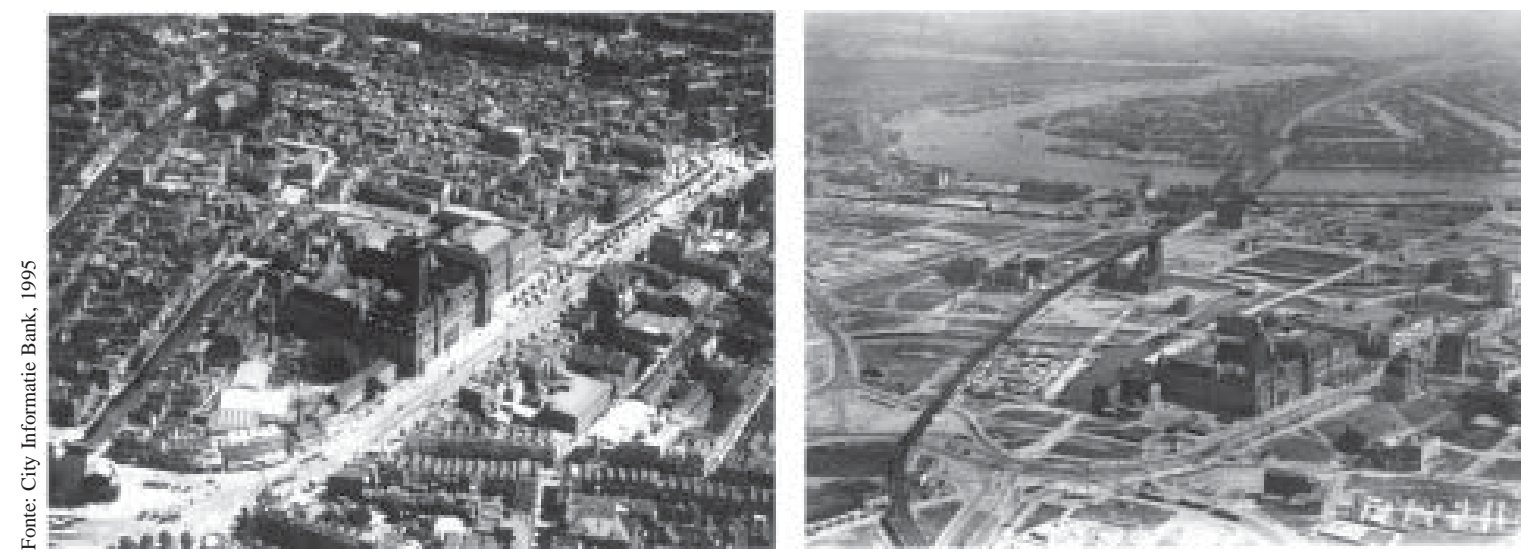

Vista geral do centro de Roterdã: antes e depois da demolição provocada por bombardeios da segunda guerra

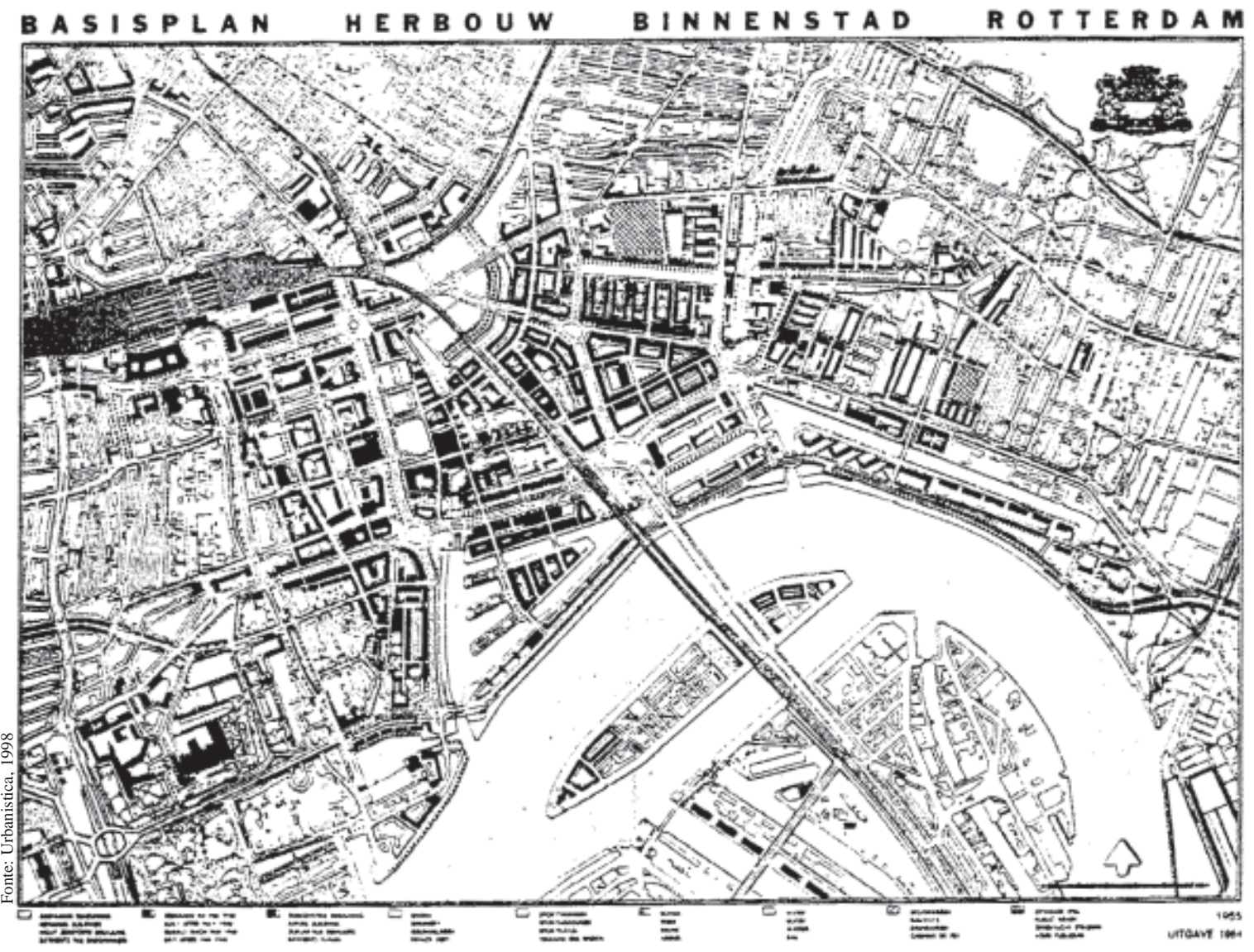

Basisplan” 1954: plano de reconstrução de Roterdã, enfatizando a recuperação da área central e das instalações portuárias 

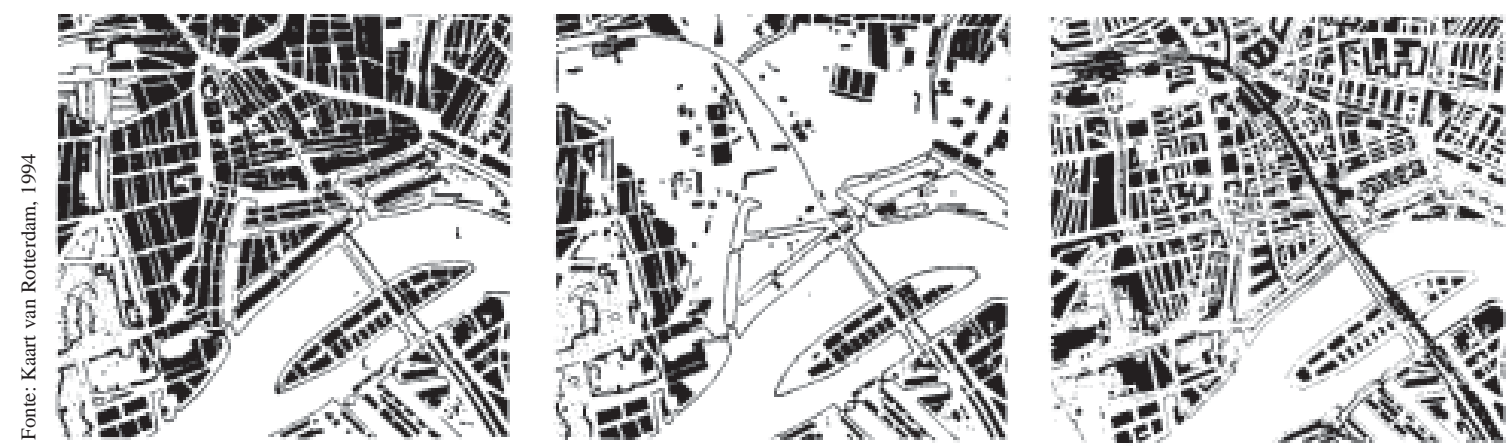

Etapas da transformação do centro da cidade: antes de 1940, depois do bombardeio e em 1989

Estrutura viária principal: os grandes eixos seguem a expansão portuária

O eixo central de novo desenvolvimento, conectando o aeroporto (norte), o centro urbano (Hofplein, Coolsingel, Waterstad), Kop van Zuid (margem esquerda) e Zuidplein (sul)
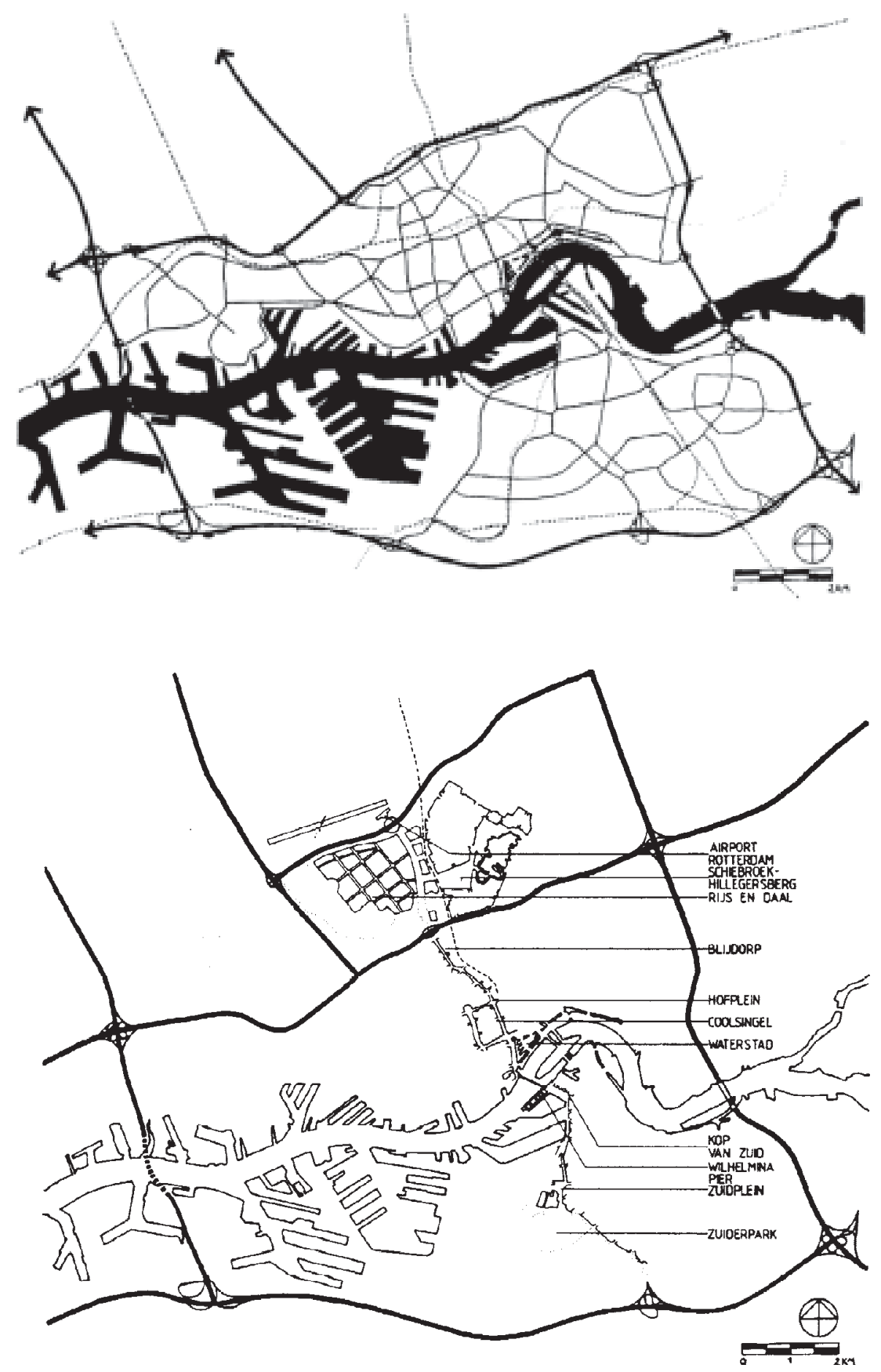
Projeto G. J. Jong de 1895: primeira expansão portuária na margem esquerda do Rio Maas -Kop van Zuid

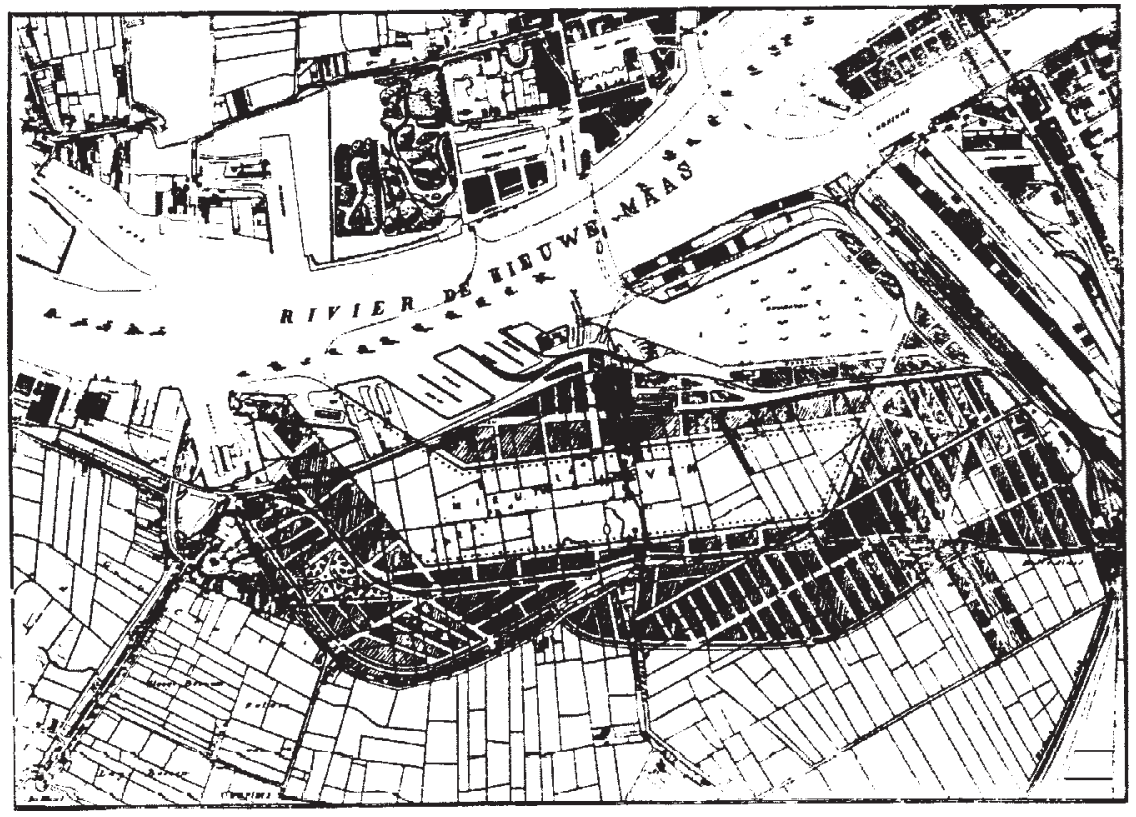

Aerofoto do território do porto de Roterdã
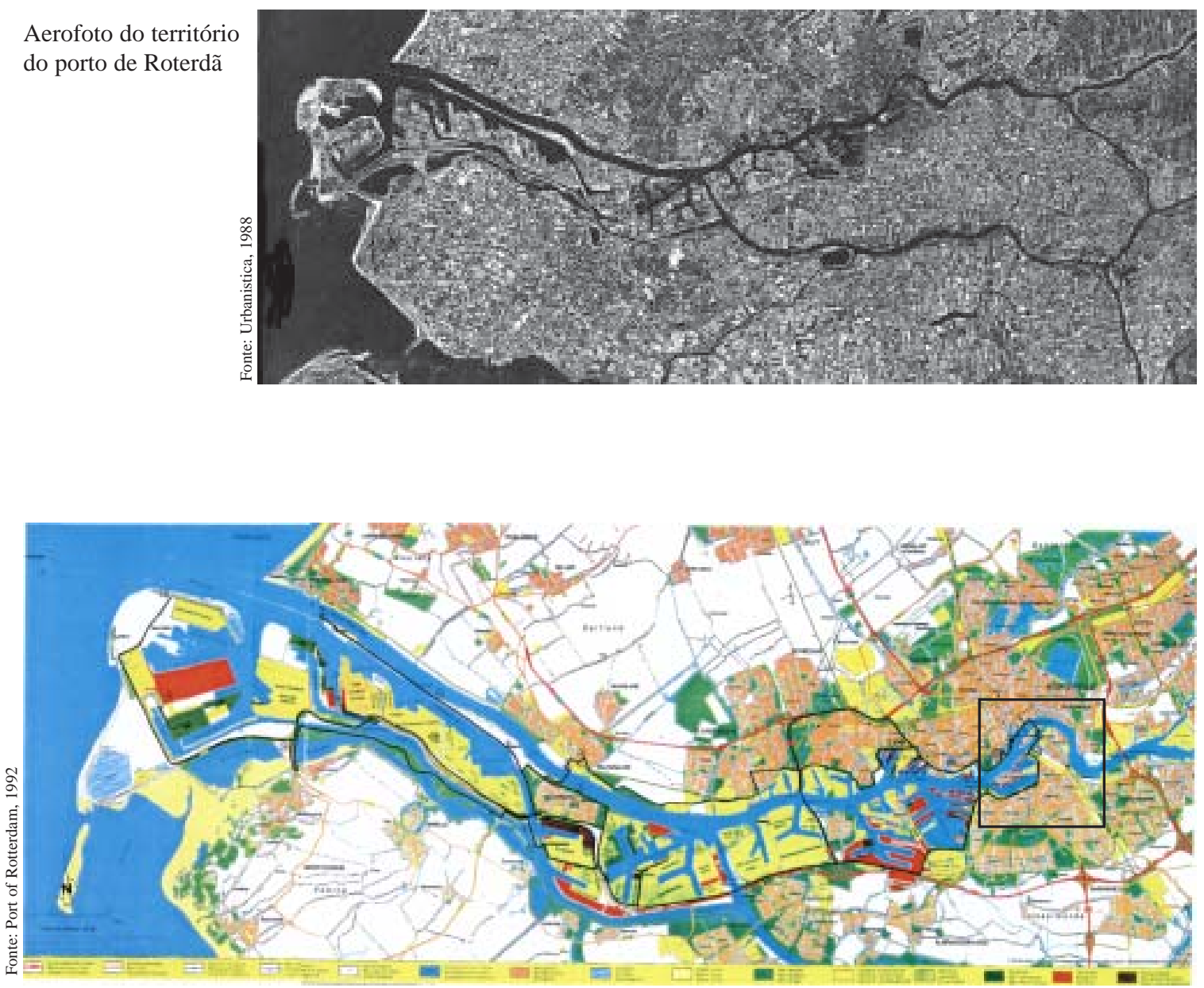

Esquema da expansão do porto de Roterdâ: no quadrado, a localização de Kop van Zuid 
Elementos estruturais do Plano de reconversão da Waterstad

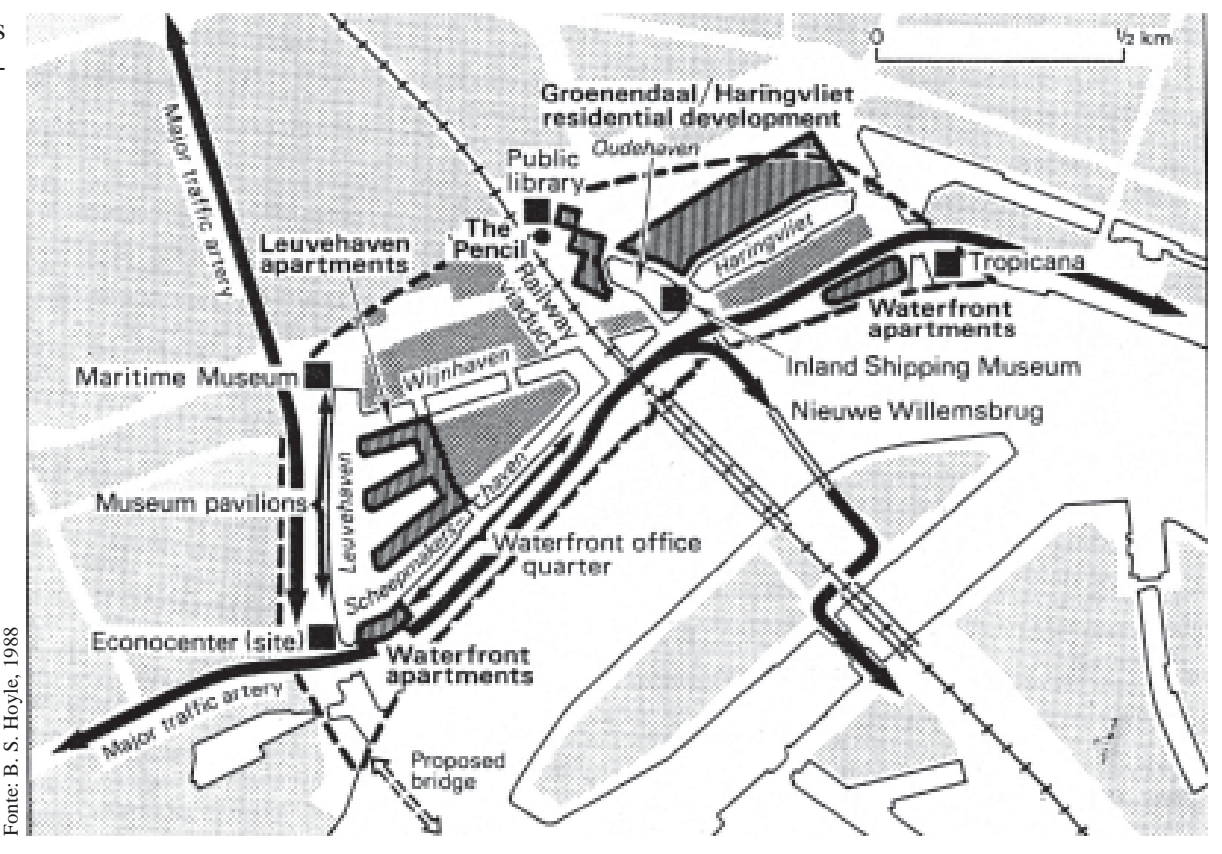

Revitalização do waterfront além da Waterstad, indicando os investimentos públicos e privados em habitação

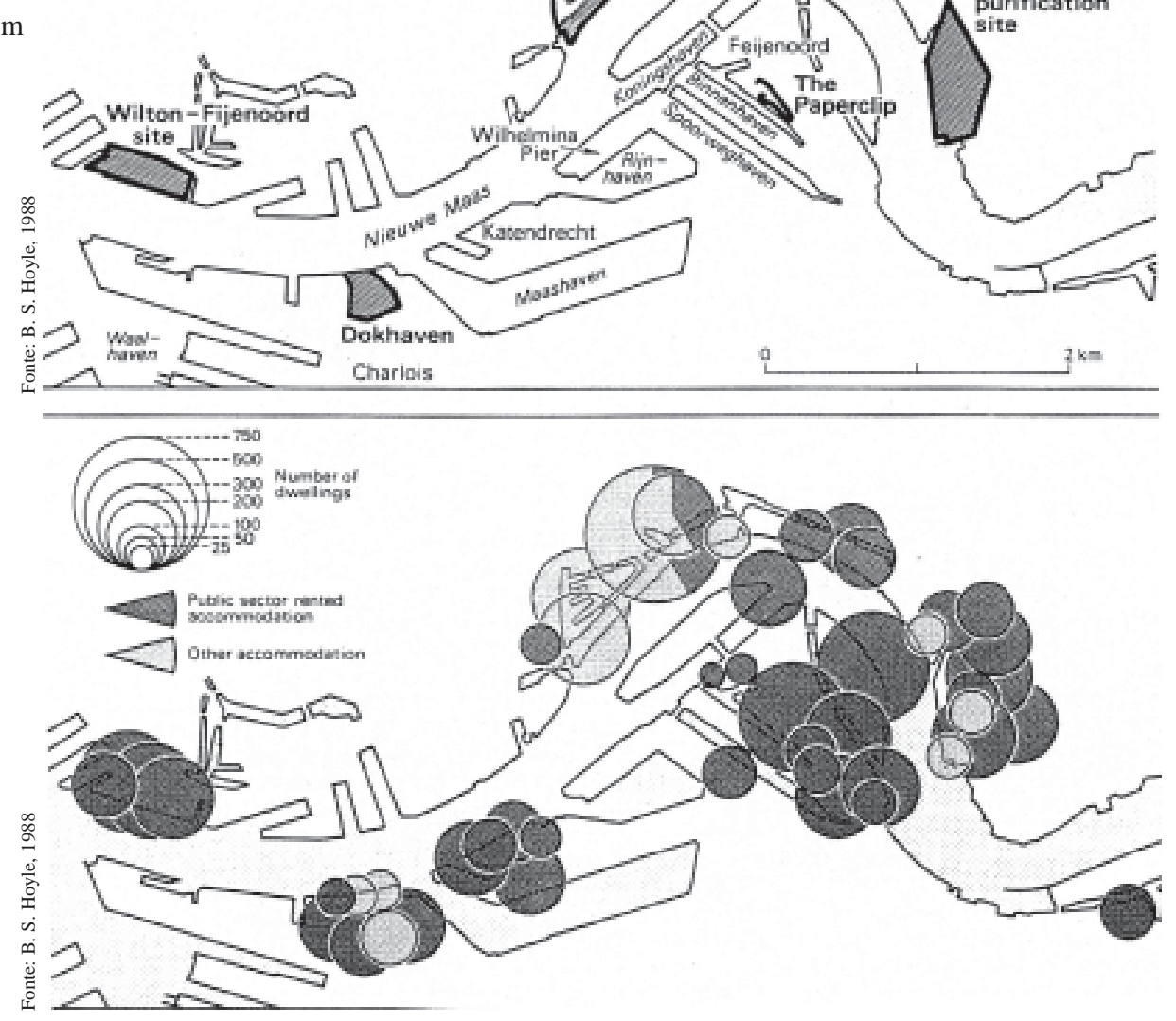



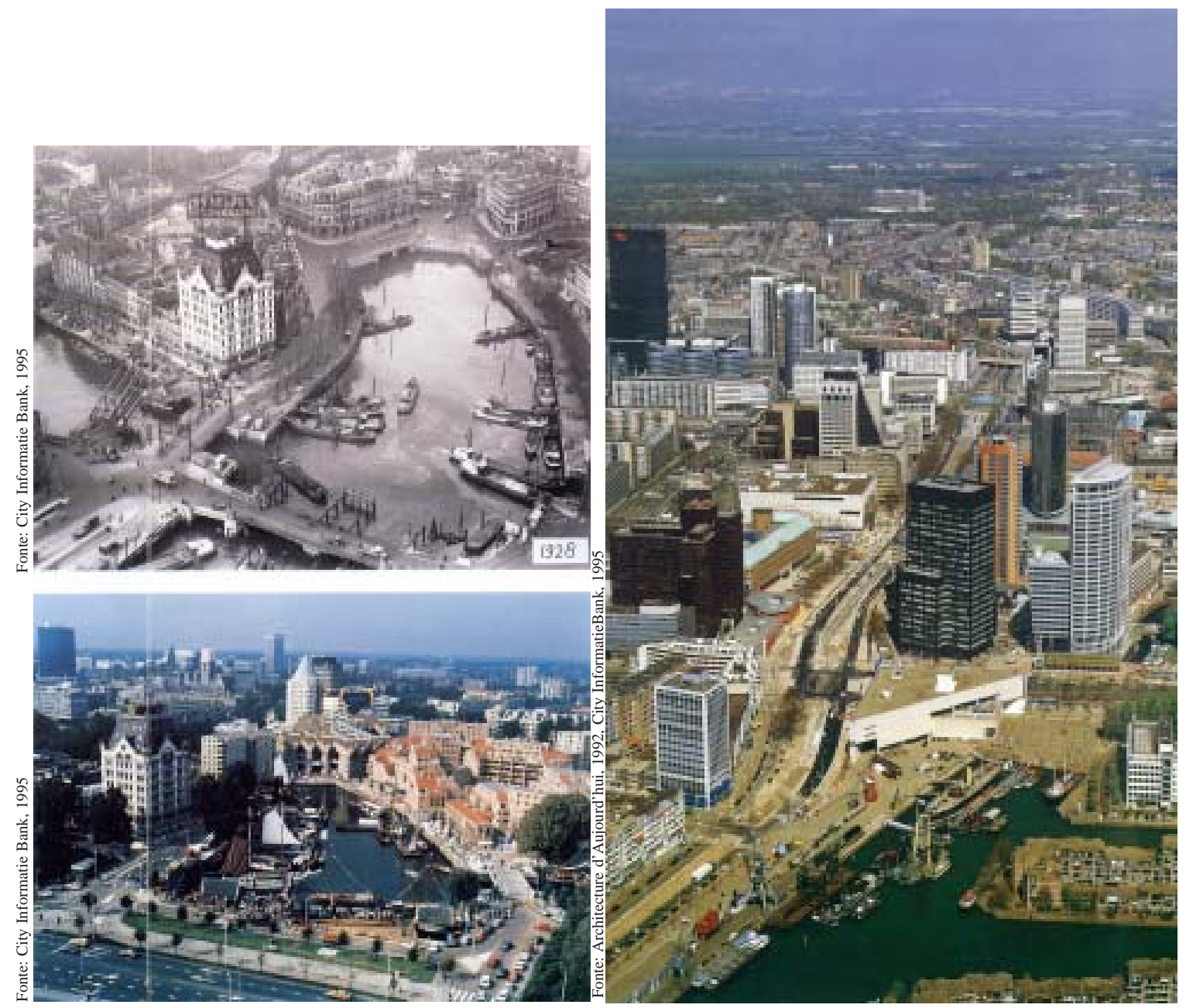

Oude Haven: recon-versão urbanística da antiga bacia por- Vista da Waterstad: residência e museu marítimo, nos prituária (1978-1984) meiros planos, arrematando, na margem direita, o eixo central de desenvovlimento

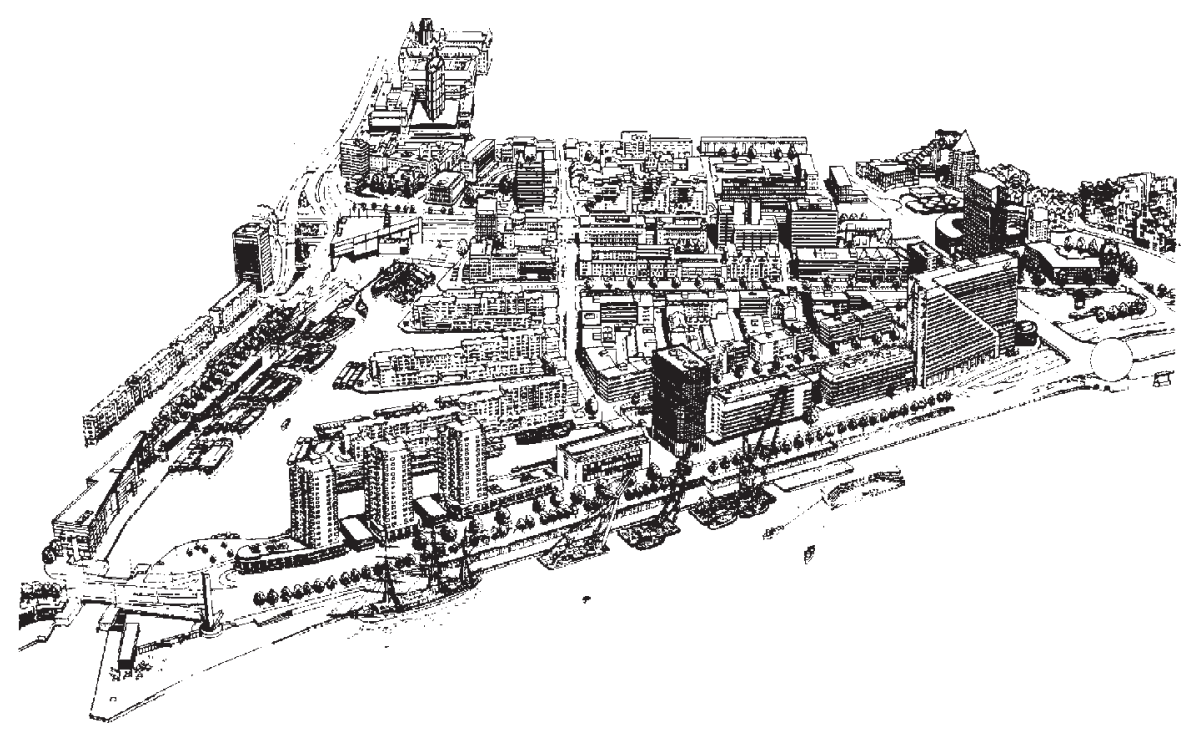




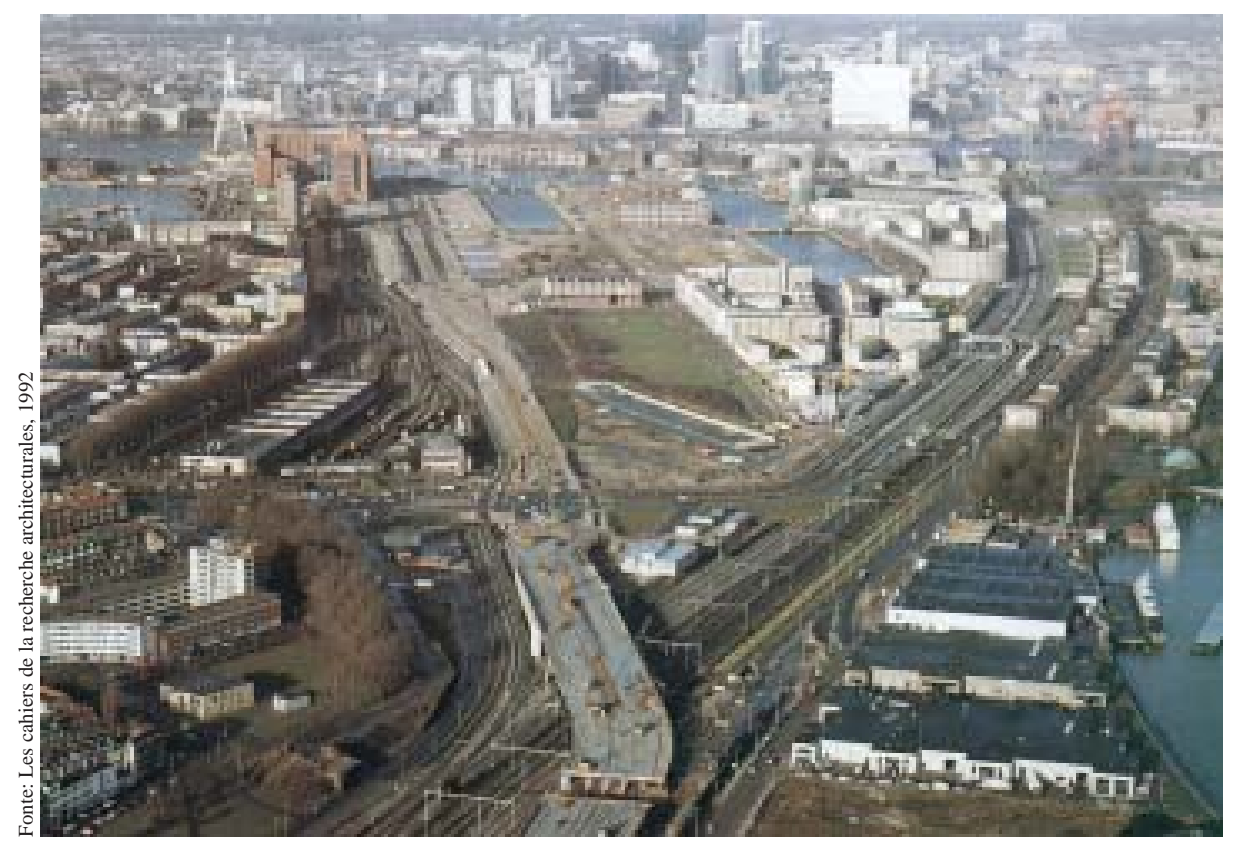

Vistas da antiga área portuária de Kop van Zuid.

À direita da imagem o conjunto Pepperclip

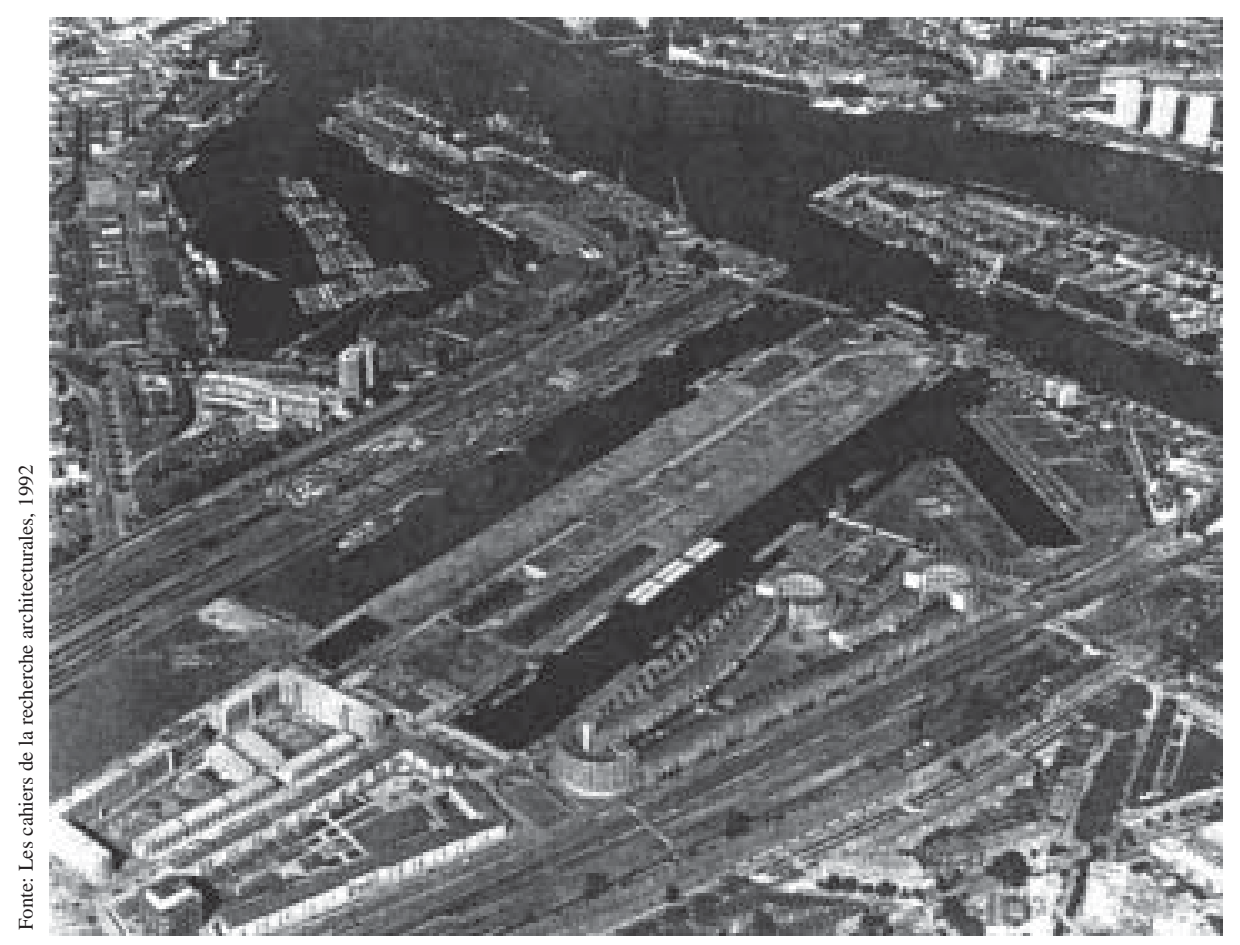


OPlano Teun Koolhaas, 1987: 1) nova ponte interligando o centro da cidade com Kop van Zuid; 2) Wilhelmina Pier: centro de negócios, 3)desenvolvimento residencia de máedia densidade

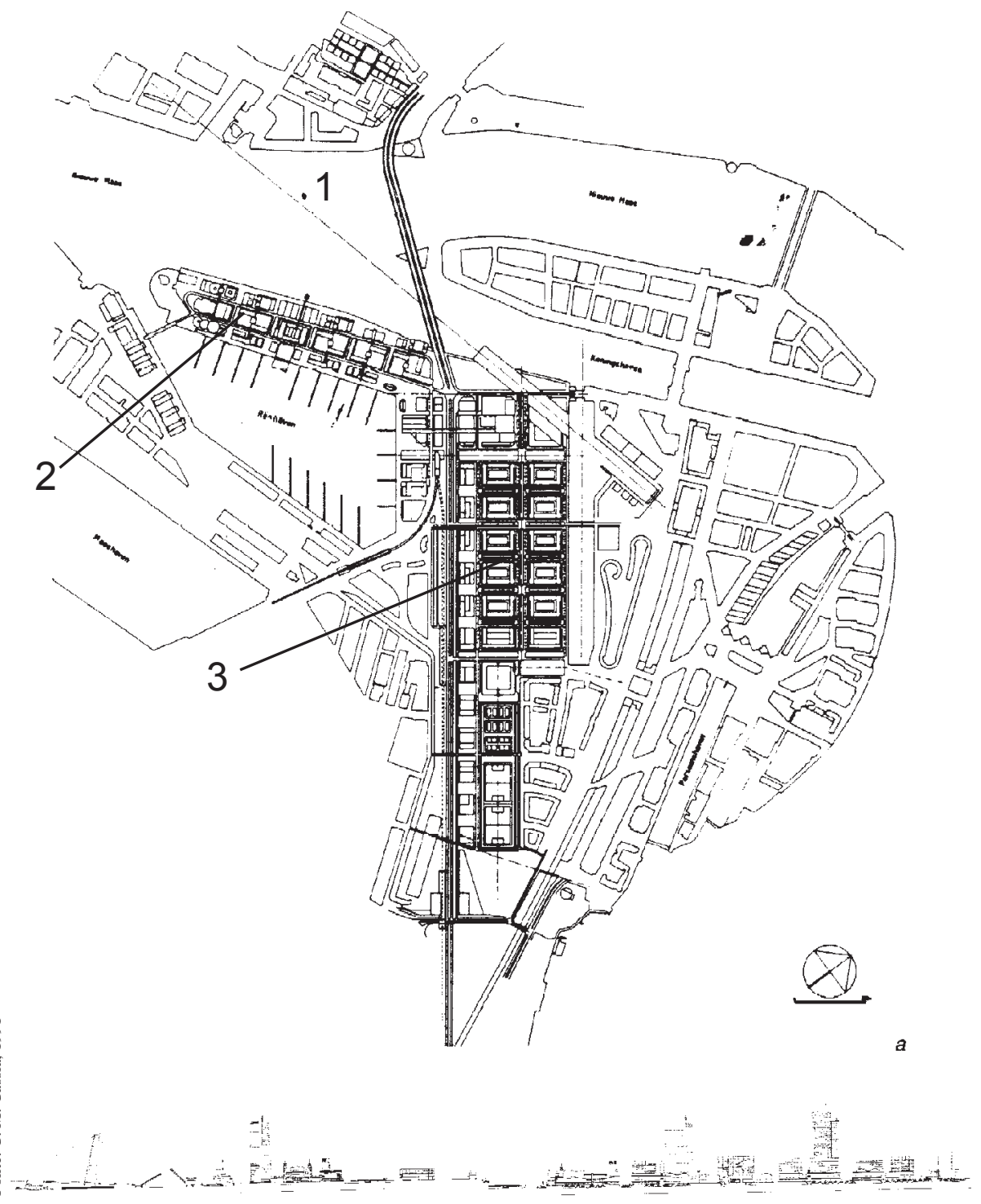

Cortes esquemáticos do Plano Koolhaas: a nova ponte sobre o rio constitui elemento fundamental de inte-gração com o centro
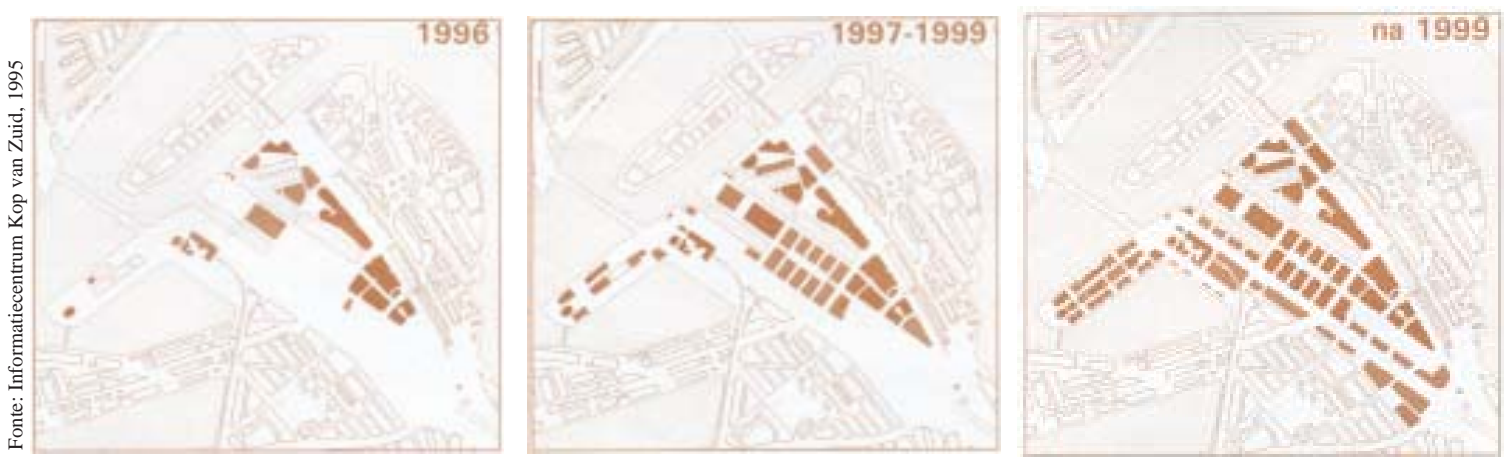

Etapas de implantação de Kop van Zuid 


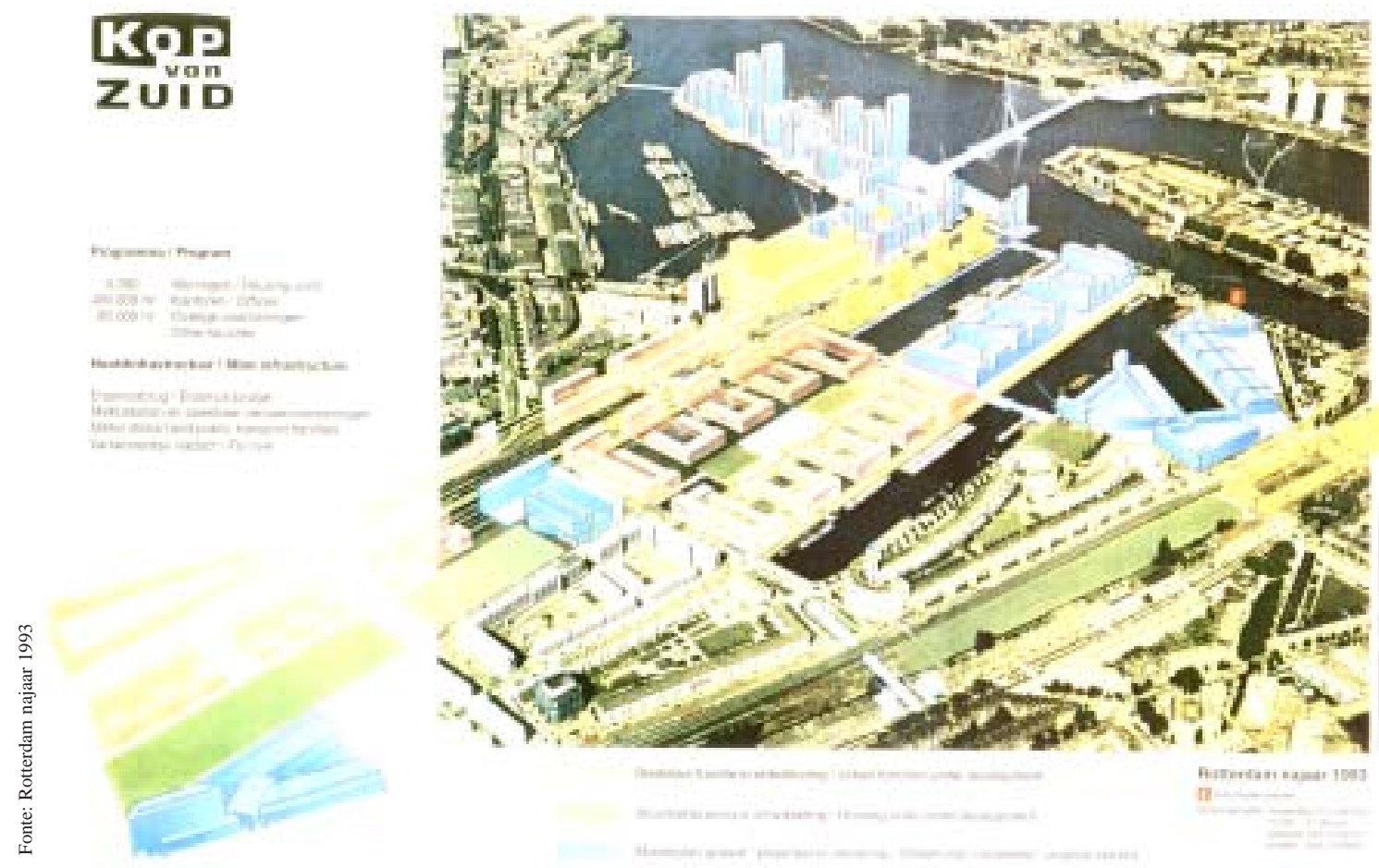

Perspectiva e programa de desenvovlimento: serviços (amarelo), centro comercial e residencial — obras iniciadas — (azul), unidades residenciais em projeto (rosa)

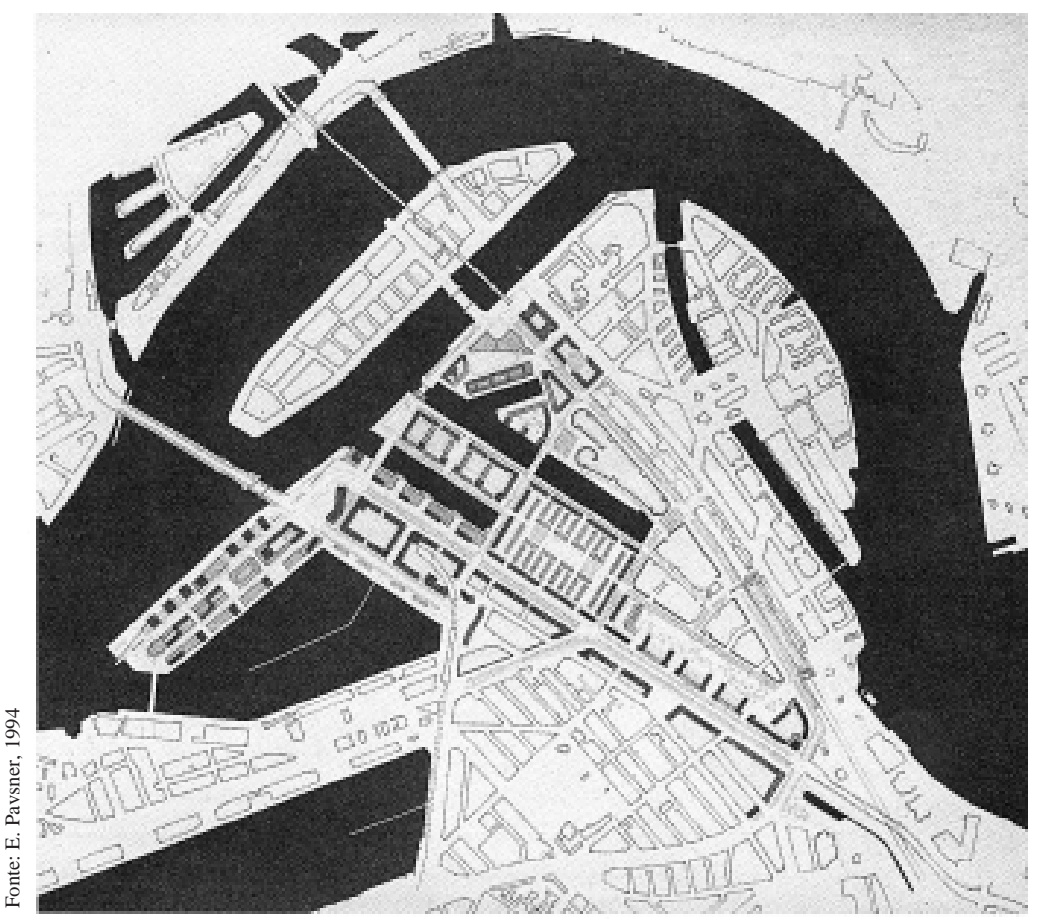

Planimetria do projeto Koolhaas 
A nova ponte como elemento "chave" do projeto: integração de setores e o rio como centro simbólico da cidade

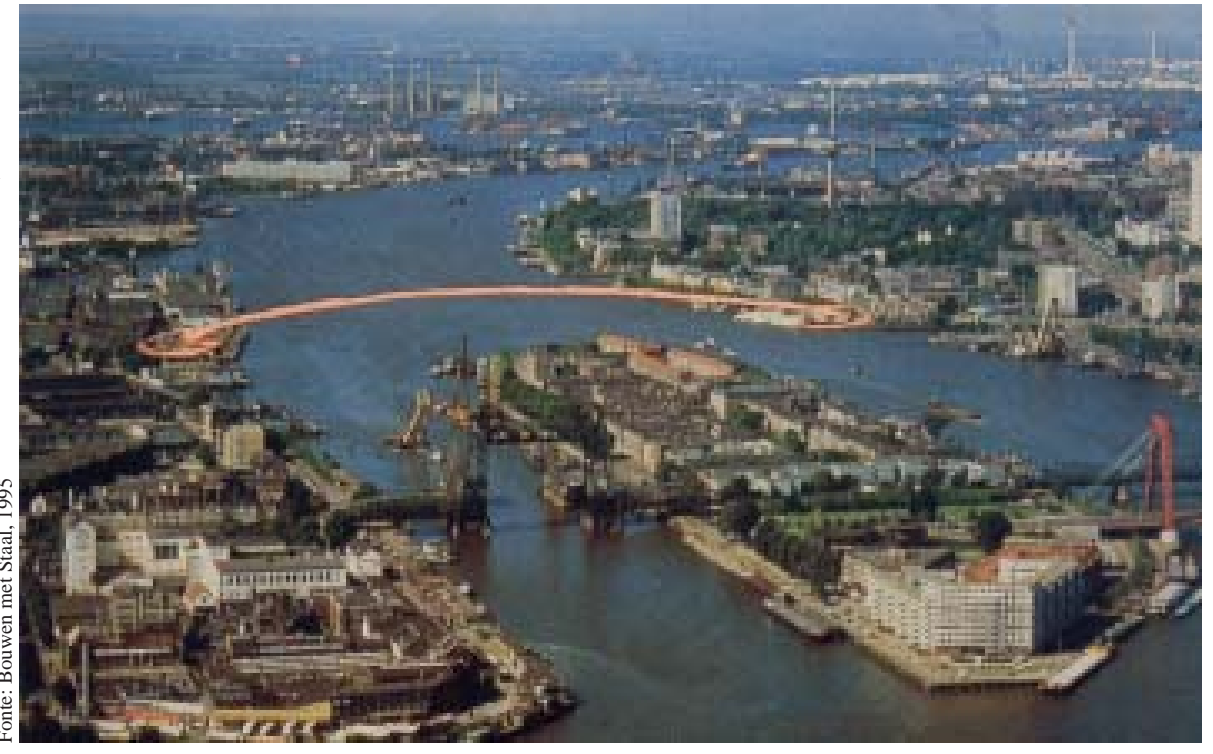

$\mathrm{Na}$ imagem à esquerda, a ponte Erasmusbrug, projeto de Van Berkel, em construção: ao fundo, a Waterstad e a nova configuração da orla. Vista da ilha de Kaatendrecht e da construção de Kop van Zuid
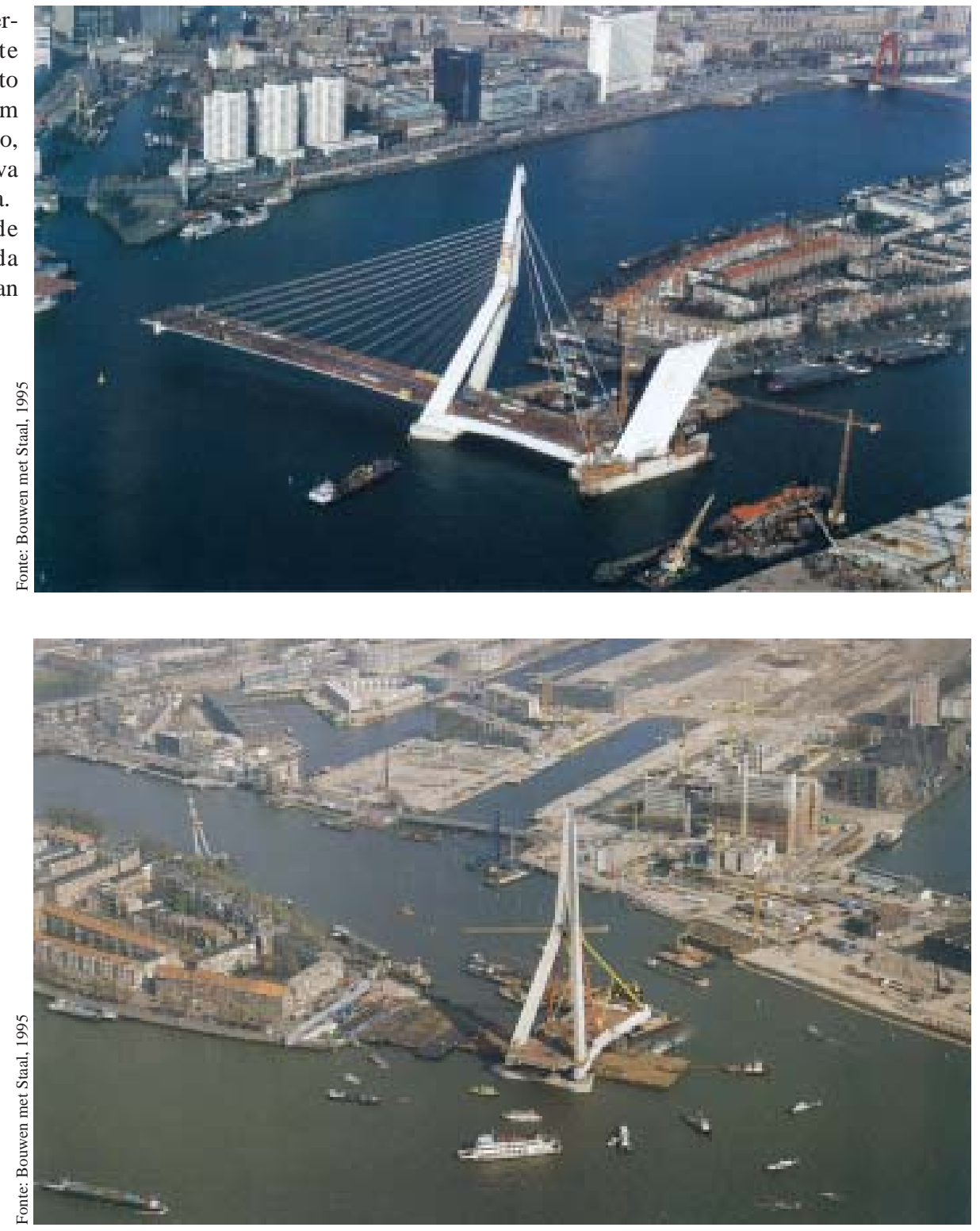

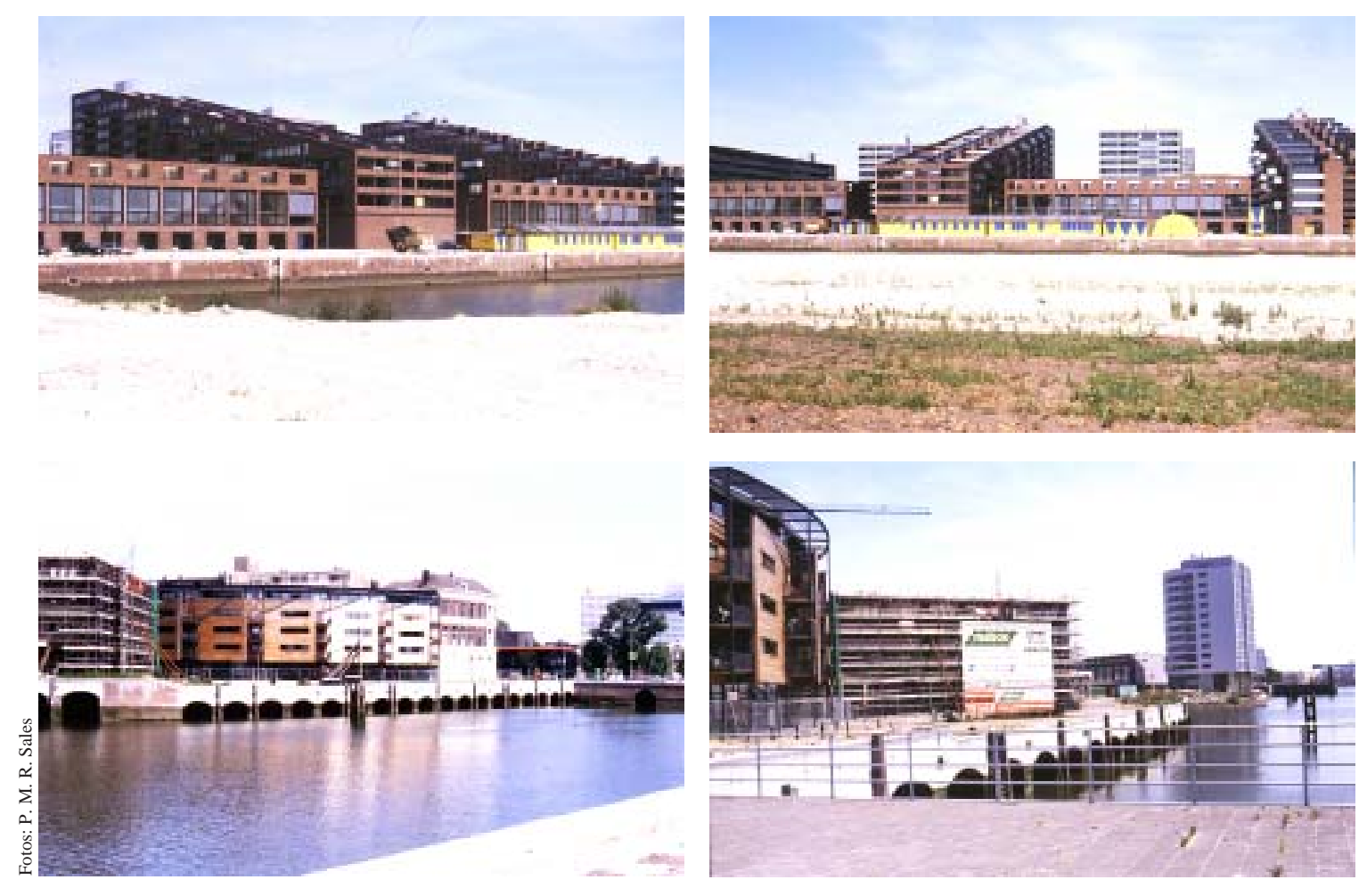

Unidades residenciais em Binnehaven
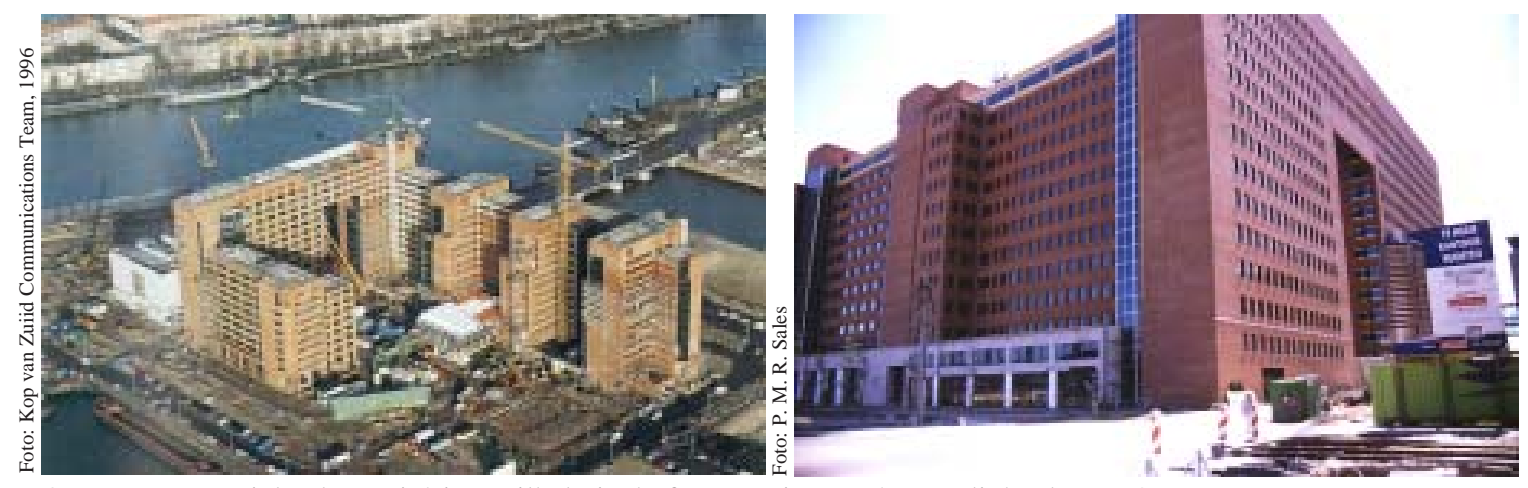

$\mathrm{O}$ centro comercial e de escritórios Wilhelminahof: acesso interno à nova linha de metrô
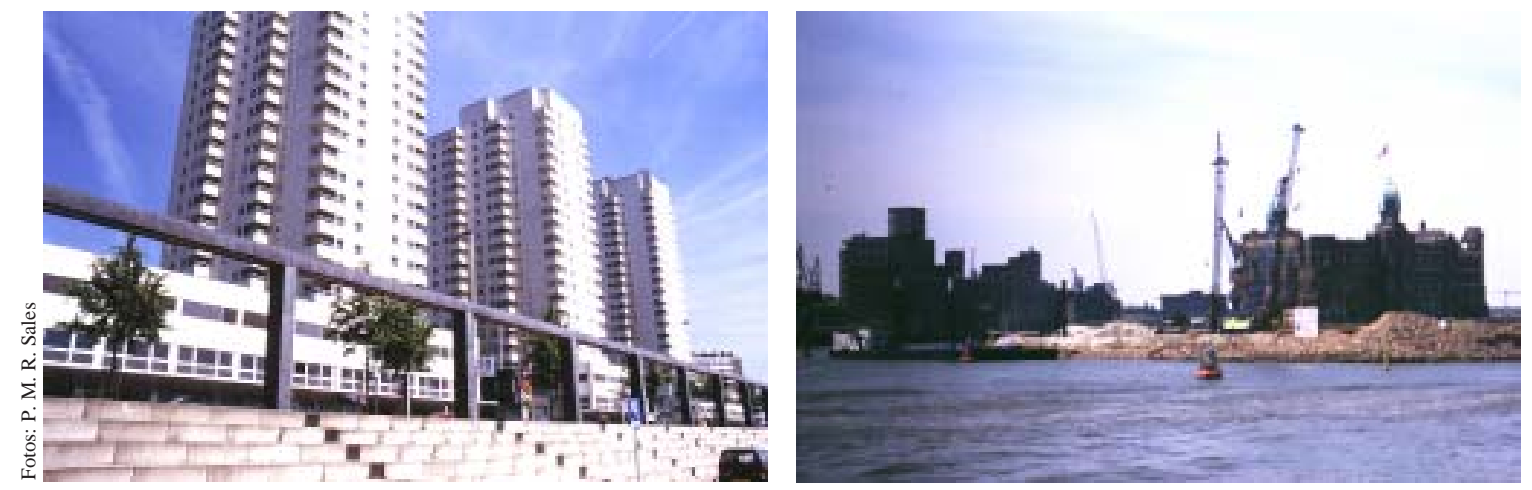

A linha de edifícios da margem direita do Maas e Americanlijn — antigas instalações portuárias convertidas em hotel, na ponta oeste de Wilhelmina Pier 
${ }^{1}$ Peter Hall. Op. cit.

${ }^{2}$ Han Meyer. "The discreet charm of port and city, a seductive combination" in Jef van Reusel (ed) Antwerp. Reshaping a city. Blondé Artprinting International Association with The City and the River Project, Antuérpia, 1990.

${ }^{3}$ Joan Busquets e Joan Alemany. Plan Estratégico del Antiguo Puerto Madero. Consultores Europeus Associados, Ayuntament de Barcelona, Municipalidad de Buenos Aires, Buenos Aires, 1990, pp. 6 - 7.

${ }^{4}$ Christopher M. Law. "Global revitalisation, public policy and the redevelopment of redundant port zones: lessons from Baltimore and Manchester" in B. S. Hoyle et al. Revitalising the waterfront: international dimensions of dockland redevelopment. Belhaven Press, Londres, 1988

${ }^{5}$ Seriam basicamente três os modos da relação porto-cidade:

1.imbricação possível mas não direta (ex: Roterdã, Amsterdã, Sevilha)

2.frente marítima natural (ex: Nápoles, Baltimore, Puerto Madero-Buenos Aires, Barcelona, Gênova, Marseille, Antuérpia).

3.peça à parte da cidade (ex: Docklands, Glasgow).

De qualquer maneira, independente da distância à água, a questão da acessibilidade à área geralmente é bastante dificultada pela existência de pesadas infra-estruturas, sejam ferroviárias ou rodoviárias

${ }^{6}$ A forma do porto:

- $\quad$ diques perpendiculares (ex: Manhattan, Boston, Gênova, Barcelona, São Francisco)

- $\quad$ recintos de água ou bacias (ex: Puerto Madero, Roterdã, Antuérpia, Docklands)

- ilhas artificiais (ex: Osaka, Kobe e grande parte dos portos asiáticos)

Aqui haveria que se incluir as docas construídas em linha ao longo de toda a extensão do waterfront, como é o caso do estuário de Santos, ou mesmo a estrura costeira de Nova York, que não conferem um foco óbvio de referência para novos desenvolvimentos, como por exemplo os casos de Marseille ou Baltimore o demonstram.

${ }^{7}$ J. Busquets. Quanto aos mecanismos de gestão:

- gestão fragmentária -conjunto de transformações de pequenas escalas

- gestão inicial unitária e desenvolvimento por partes - grandes operações de renovação geridas por agências específicas como é o caso da London Docklandas Development Company, Port 2000 em Barcelona, Kop van Zuid em Roterdã

${ }^{8}$ Ibid.

${ }^{\ominus}$ Como sugere Meyer (Op. cit., 97) não só pela segregação imposta por uma via elevada como pela própria uniformidade de seu desenho e pela homogeneidade de seus usos.

${ }^{10}$ Além das funções citadas nos caos de Boston e Baltimore, que se difundiriam largamente em outras operações de waterfronts, são recorrentes as destinações de uso interessadas à criação de novas centralidades, ao aproveitamento das qualidades ambientais, proporcionadas pela presença da água (presença essa com efeitos de mais-valia sobre os preços dos terrenos à sua borda). Dessa maneira, segundo estudo da AIVP, sucedem-se empreendimentos destinados a criar Entrepises Zones e segundas Cities (Londres), parques urbanos (Boston, Hong Kong), complexos de serviços pessoais (Sothampton), aquários (Sidney, Baltimore), marinas (Toronto, Barcelona), estações marítimas (Quebec, Bordeaux), atividades científicas, de pesquisa e de ensino superior (Le Havre, Dunquerque), pólos tecnológicos ou teleportos (Osaka, Tokio), centros administrativos (Dunquerque), World Trade centers (Baltimore, Le Havre, Barcelona), centros comerciais e residenciais.

"P. Malone, City, capital and water, Routledge, 1996, 263.

${ }^{12}$ Ibid., p. 123.

${ }^{13} \mathrm{O}$ que revela a alta densidade da cidade, talvez uma das maiores da Europa.

${ }^{14}$ Pep Subirós. "The meaning of the city" in Rassegna, março 1989, p.33.

${ }^{15} \mathrm{~F}$. Sagarra y Trias, "Barcelone, la dynamique olympique et le projet urbain" in Metropoles Portuaries en Europe. Les Cahiers de la Recherche Architecturale, nº 30/31, 1992, p.24.

${ }^{16}$ Pep Subirós. Op. cit., p.34.

${ }^{17} \mathrm{Joan}$ Alemany, El puerto de Barcelona. Historia y actualidad, Puerto Autonomo de Barcelona, Barcelona, 1984, p.40.

Ainda que já exploradas pelos romanos juntamente com o porto de Tarrago(na) há dois mil anos atrás, as condições naturais e físicas fizeram com que muito tempo depois "as mercadorias das naus e embarcações de grande capacidade que não podiam aproximar-se da praia fossem desembarcadas por meio de "lleny, barques de ribu o llagun". A responsabilidade do transporte e manipulação tanto em mar como em terra eram reguladas por códigos de ordenanças e pelos 
grêmios"(p. 45)... Além do mais havia uma proibição real em 1234 a qualquer tipo de construção em um amplo setor da costa dedicado às "Drassanes" (docas) ou para reparar embarcações .

${ }^{18}$ Ibid., p. 41.

${ }^{19}$ Ibid., p. 49.

"Ainda que simplificando excessivamente uma situação e umas relações muito complexas, podese considerar que o elemento central da crise foi a excessiva dependência da economia catalã do comércio exterior: o setor chave de um crescimento econômico muito rápido que não conseguiu consolidar uma estrutura econômica bastante sólida converte-se no setor que vai ter uma incidência maior na crise".

${ }^{20}$ Manoel Solá-Morales, "La ciudad y el puerto: la historia continua" in Revista U.R, nº 4, p.56.

${ }^{21}$ Destacando-se o "gótico" de Santa Maria del Mar construído com a participação de marinheiros e representando o símbolo triunfante do antigo império marítimo de Barcelona.

${ }^{22}$ Prat, J. "El sistema ferroviario en la configuración de la región de Barcelona" in La xarxa ferroviaria: encaix urbá I impacte territorial. Institute de Estudis Metropolitans de Barcelona, Barcelona, 1994.

A construção das primeiras linhas férreas na "província" de Barcelona, muito intensa no período 1848-1882, estabelece de forma definitva os principais eixos de transporte ferroviário: é o conhecido "vuit" (oito) catalão hoje de competência da Renfe (Rede Nacional de Ferrocarriles). Na época, além de símbolo de progresso, constituía meio fundamental de transporte de passageiros e sobretudo de matérias primas e produtos manufaturados, consolidadando pela relação com Barcelona e seu porto, uma série de núcleos distantes e relativamente autônomos.

${ }^{23}$ Joan Busquets, Barcelona -Evolución Urbanistica de una Capital Compacta, (2 $\left.{ }^{\mathrm{a}} \mathrm{ed}\right)$. Editorial Mapfre, Madri, 1994 p. 256

${ }^{24}$ Soledad Garcia, "La modernisation de Barcelone", in Metropoles portuaires en Europe - Cahiers de la Recherche Architecturale, n 30/31, 1992, pp 13 -14.

"No caso de Barcelona, o porto tem uma importância menor que em outras cidades portuárias. Apesar da forte presença física na estrutura urbana, sempre esteve debilmente integrado à cidade tanto em termos econômicos, como sociais e espaciais Se o porto foi a ator econômico maior nos séculos XVIII e XIX, seu papel se dilui nos primeiros decênios deste século. Ainda que recebendo uma grande parte das importações necessárias à economia da região e sendo um dos principais portos espanhóis, seu papel internacional é limitado. Apesar do crescimento de seu tráfego nos anos 70 e 80, sua articulação com a ferrovia é muito insuficiente: esta assegura o transporte de somente $3 \%$ da carga destinada ao porto". E "o emprego nas atividades portuárias, já limitado, diminuiu ao longo dos últimos anos. Em 1983, somente 1\% da população ativa de Barcelona está empregada pelo porto, e menos de $3 \%$ nas empresas conexas. (Além do mais) a disperção dos trabalhadores do porto em diferentes bairros da cidade também provocou uma erosão de identidades comunitárias tradicionais."

${ }^{25}$ Ajuntament de Barcelona/Àrea de Urbanisme I Obres Publiques Àrees de nova centralitat. (2 ${ }^{\mathrm{a}}$ ed) Ajuntament de Barcelona, Barcelona, 1991

${ }^{26}$ Bohigas, O. Reconstrucción de Barcelona. Dirección General de Arquitectura e EdificaciónMinisterio de Obras Publicas e Urbanismo, Madrid, 1989.

${ }^{27}$ Ibid., p.7.

${ }^{28}$ Ibid., p.8.

${ }^{29}$ Os critérios estabelecidos para este ajuste são os seguintes:

- compromisso com soluções formais e programas de realização a curto e médio prazos

- prioridades de soluções particulares como matriz indispensável para as soluções gerais, privilegiando aquelas referentes à dotação de equipamentos e à reconsideração do espaço público como elemento gerador de requalificação e reabilitação setoriais

- busca de equilíbrio de significados e usos e respeito às bases históricas da dualidade centroperiferia e, também, dos traçados entendendo a cidade como a soma de entidades relativamente autônomas, corrigindo as diferenças da qualidade de vida da periferia

- eliminação e suavização dos traçados viários de circulação rápida e segregada, privilegiando assim a rua, o passeio, o jardim (O. Bohigas, op. cit., p.29).

${ }^{\text {зо }}$ Busquets, J. Op. cit., p.324.

${ }^{31}$ Infussi, F. Bracellona: La Vila Olimpica e la modificazione della cittá in Cassia C. Machi, Il grande progetto urbano. La Nuova Italia Scientifica, Roma, 1991.

${ }^{32}$ Segarra y Trias, F. Op. cit, p 24.

${ }^{3}$ Bohigas, O. Op. cit., p. 217.

${ }^{34}$ Grupo de Artistas y Técnicos Españoles para la Promoción de la Arquitectura Contemporánea.

${ }^{35}$ M. Solá-Morales, J. Busquets, A. Font et al. Barcelona: Remodelación Capitalista o Desarrollo 
Urbano. Barcelona, Editorial Gustavo Gili S.A, 1974.

${ }^{36}$ Busquets, J. Op.cit., p. 304.

${ }^{37}$ Iates e barcos de clubes náuticos, instalações de escolas náuticas e de investigação científica do mar, porto de pesca, raias de competição de remo ou natação, entrada e saída de navio de passageiros, transatlânticos, recepções oficiais por mar, festivais aquáticos,circuitos turísticos, golondrinas, etc.

${ }^{38}$ Busquets, J. Op cit., p.347.

${ }^{39}$ La Vanguardia, 19/2/1995, p.42.

${ }^{40}$ Semerani, L. Architettura sul limite in $U R$ n6, p.80.

Constituem ainda elementos do desenho, - arcadas ritmadas, cadência de luminárias e palmeiras, revestimento de pedra rústica, pontes e rampas.

${ }^{41}$ Em uma cidade como Barcelona a habitaçao para baixa renda constitui agora um grande problema a ser enfrentado sob o risco de perda de população e sobretudo de envelhecimento da mesma, já que a única alternativa para os mais jovens e para a baixa classe média em geral é residir fora da cidade, na região metropolitana.

${ }^{42}$ La Vanguardia, 14/3/95, p.24.

${ }^{43}$ A. M. J. Kreukels. "Rotterdam, le Port englobe la Ville -une estrategie d'expansion", in Metropoles Portuaries en Europe. Les Cahiers de la Recherche Architecturale, nº 30/31, 1992.

Onde se menciona a contribuição, no período da reconstrução, da forte tradição da engenharia hidráulica do Instituto Técnico de Delft que permitiu colocar em ação "um sistema de guidage de navios (que) dota o porto de Rotterdam de uma acessibilidade aos navios que vêm do mar que é, ainda hoje, excepcional”, (p. 24).

${ }^{44} \mathrm{~A}$ recuperação econômica da Europa nos anos 50 e 60 bem como o incremento do fluxo em direção à Alemanha, levaram o Conselho Municipal a adotar o Plano Europort que visava tornar Rotterdam o porto cujo hinterland seria não mais apenas os Países Baixos, mas o continente inteiro. ${ }^{45}$ A.M.J. Kreukels. Op. cit., p. 166.

Tudo isso seria favorecido, em grande medida, pela própria destruição que permitiu à cidade adaptarse, mais facilmente que as outras, às necessidades, funções e atividades diretamente ligadas ao porto.

${ }^{46}$ Ibid. p.24.

${ }^{47} \mathrm{~J}$. Nycolaas. Hay que 1 che disegni, in Urbanística $\mathrm{n}^{\circ} 93, \mathrm{p} .44$

${ }^{48}$ M. Fosso, "Rotterdam, Rivitalizzacioni e Nuove Centralitá", in Urbanistica, no 93.

${ }^{49}$ J. Nycolaas. Op. cit., p.45.

${ }^{50}$ A. M. J. Kreukels. Op. cit.,p. 24.

${ }^{51}$ J. Nycolaas. Op. cit., p. 46.

${ }^{52}$ A.M.J. Kreukels. Op. cit., pp. 26-27.

"Está previsto assim, reforçar o setor comercial e de serviços, direta ou indiretamente ligados ao porto. Isto significa que no futuro deveer-se-á conceder muito mais atenção ao valor agregado referente às atividades portuárias que à tonelagem de carga. Esta preferência dada ao valor agregado em combinação com as atividades produtivas e distributivas, é o elemento mais importante do "Plano 2010". De um lado isto implica, como os investimentos realizados mostram, na conteneirização e no tráfego "ro-ro", e de outro, na consolidação das novas modalidades de organização da "logística, da distribuição e da produção em setores diferenciados da economia, ligados à pesquisa de custos de transporte mínimos (articulando economias de campo e de escala).

${ }^{53}$ J. Van Teffelen. "Program Scenarios", in Vários, Kop van Zuid, p. 37.

${ }^{54}$ Pinder D, Rosing, K. "Public Policy and Planning of Rotterdam Waterfront: a tale of two cities" in Hoyle, B.S., Pinder, D.A., Husain, M.S. Revitalizing the waterfront: international dimensions of dockland redevelopment, Belhaven Press, Londres, 1988 p. 120.

${ }^{55}$ Ibid, p. 121 .

${ }^{56} \mathrm{O}$ soterramento deste tramo, ditado pelas necessidades técnicas de modernização da ferrovia, deve permitir um melhor reaproveitamento de uma extensa faixa de terra que liga o waterfront à estação, ainda que com a polêmica perda de um elemento significativo da memória da cidade.

${ }^{57}$ M. Fosso. "Rotterdam: Kop van Zuid e la cittá como insieme unitario", in C. M. Cassia, Il Grande Progetto Urbano, p. 117.

${ }^{58}$ J. Nycolaas. "La Randstad esiste" in Triennale 1988: Le Cittá del Mondo e il Futuro della Metrópoli, Electa, Milão, 1988, p. 166.

${ }^{59}$ City by the River Maas -Intervista con Mr. Rick Baker, direttore dell'Uficio di Piano"., in Urbanistica, $\mathrm{n}^{\circ} 93$, p. 49.

${ }^{60}$ Ibid. 
${ }^{61} \mathrm{~J}$. van Teffelen, Op. cit.

${ }^{62}$ Vide J. Nycolaas. Op. cit. e M. Fosso. Op. cit.

${ }^{63} \mathrm{~J}$. Nycolaas, ibid

A exigência de encontrar novos conteúdos disciplinares, novos métodos de trabalho e novos instrumentos do plano amadurece o reconhecimento (como desenvolvimento de uma cultura urbanística própria de Rotterdã) de que "o atual projeto urbano não pode senão sustentar-se sobre a individualização de partes definidas da cidade e sobre a cidade no seu conjunto. Quanto mais se avança na explicação da cidade como fenômeno político, cultural e econômico considerando as respectivas instâncias físicas e espaciais, menos adequado apresenta-se o tipo de planejamento e os argumentos técnico-"planeológicos" que suportaram os precedentes modelos estruturais de plano."Neste sentido, a pesquisa projetual tendo por fim constituir uma imagem para "tornar manipulável" para os projetistas a estrutura física e funcional da cidade, enfatizou os seguintes temas:

-estudo da estrutura da paisagem e sua relação com a forma urbana;

-estudo das linhas de longo percurso que atravessam a cidade e geram mobilidade;

-estudo tipológico dos quarteirões urbanos (morfologia/densidade/mescla de funções);

-análise dos pontos fortes e débeis da cidade, potencialidades e riscos;

Quanto ao estudo específico para Kop van Zuid:

-análise do processo de urbanização da margem esquerda do Maas, através da documentação histórico-topográfica busca-se evidenciar a estrutura fundiária e a construção da cidade;

-análise dos planos de Rotterdã-sul dos últimos cem anos evidenciando a mudança do caráter da forma urbana;

-análise da estrutura espacial da atual Rotterdã onde se evidencia a ligação da morfologia urbana (blocos, parcelamento, elementos de grande escala) aos sistemas de diques, viário e de verde; -análise da estrutura funcional, classificando-se os setores segundo as características da população residente, ocupada e dos serviços.

${ }^{64} \mathrm{H}$. Tilman. "Kop van Zuid from an international perspective", in, p. 16

${ }^{65}$ J. van den Bout. "Directing an urban planning design", in Kop van Zuid, p.19

${ }^{66}$ E. Pasveer. Op. cit., p.78

"The Hef is a prime example of the pure art of engineering, an impressive symbol of Rotterdam in the era of expendiency, efficient labor, and mechanical movement, conducted by the rythm of the port and the railroad."

${ }^{67}$ E. Pasver. "Rotterdam, City on the Maas". Op, cit., p.76

${ }^{68}$ Vide Kop van Zuid, Op. cit., ps 20 e 90, e Il Grande Progetto Urbano, Op. cit., p. 121

${ }^{69} \mathrm{~J}$. van den Bout. Op. cit., p. 21.

${ }^{7 \circ} \mathrm{M}$. Fosso. Op. cit., p.121.

${ }^{7} J$. Nycolaas, "Kop van Zui e il futuro de Rotterdam-sud", in Urbanistica n ${ }^{\circ}$ 93, p.57

${ }^{72}$ M. Fosso. Op. cit., p.119.

${ }^{73}$ E. Pasveer. Op. cit., p.77.

${ }^{74} \mathrm{~J}$. van den Bout. Op. cit., p.23.

${ }^{75}$ Ibid.

${ }^{76} \mathrm{Ibid}$.

${ }^{\pi}$ Como referência inclusive para a atuação do "Quality Team", uma equipe de técnicos internacionais foram contratados para fazer o acompanhamento e verificação do desenvolvimento do projeto.

${ }^{78}$. Kop van Zuid as key project, in Kop van Zuid, p.61.

${ }^{79}$ Pinder,D., Rosing, K. Op. cit., p. 116.

${ }^{80} \mathrm{P}$. Thondenberg. Op. cit., p. 62.

PPP, ou seja "Public-Private Patternership", que na verdade, é uma tradição em Rotterdã: desenvolvimento do porto, reconstrução do pós-guerra, regeneração do centro da cidade. "Esta tradição caracteriza-se pela não renúncia por parte da administração de seu papel na supervisão do processo, mesmo participando em uma posição de igualdade."

${ }^{8}$ M. Fosso. Op. cit., p.119.

${ }^{82}$ E. Pasveer. Op. cit., p.73.

${ }^{83}$ Ibid., p.78.

${ }^{84} \mathrm{~J}$. van den Bout. Op. cit., p. 22.

${ }^{85}$ J. Busquets. "Il spazio tra i ponti" in Lotus Internatinal, $\mathrm{n}^{\circ} 64$.

${ }^{86}$ Trading Association, Portgebouw, Five Continent's Entrepôt, os armazéns de Rinjhaven e o hall de embarque da Holland American Line.

${ }^{87}$ Kop van Zuid: una picolla Manhattan in. in Hall, Peter (org), “Aree portuali: nuovi approdi del 
progetto". Casabella, n 589, abril/1993. p. 38/39.

${ }^{88} \mathrm{~A}$ própria localização do projeto é criticada : a escala territorial da macro-região e da rede européia de cidades e aeroportos vinculados ao TGV imporia, segundo Tzonis, a escolha de um lugar nodal (não um "ponto morto") mais próximo à estação e ao centro existente.

${ }^{89} \mathrm{H}$. Meyer. "Monumental and informal", in Kop van Zuid, p.107.

${ }^{90}$ F. Belderbos. "Social Return", in Kop van Zuid, p. 51.

${ }^{9}$ A.M.J. Kreukels. Op. cit., p. 28 .

${ }^{92}$ Pinder D, Rosing, K. Op. cit. 


\section{BIBLIOGRAFIA}

ALEMANY, Joan, El puerto de Barcelona. Historia y actualidad, Barcelona, Puerto autonomo de Barcelona, 1984

ANDRADE, Carlos Roberto M. A peste e o plano: o urbanismo sanitarista do engenheiro Saturnino de Brito. Dissertação (Mestrado), FAU, USP, São Paulo, 1992

ANDRADE, Wilma Therezinha F.. O discurso do progresso: a evolução urbana de Santos 1870-1930. Tese (Doutorado), FFLCH, USP, São Paulo, 1989

ARAÚJO Filho, José Ribeiro. Santos: o porto do café. Rio de Janeiro, IBGE, 1969

ARENAS, M, XAVIER, B., GAUSA, M., RUANO, M. Barcelona Transfer. Sant Andreu. La Sagrera. 1884.1994. Barcelona, Actar, 1995.

ASSOCIATION INTERNATIONALE VILLES ET PORTS. Ciudad y puerto, mutación y recomposición. www.aivp.com, 1997

AYMONINO, Carlo. El significado de las ciudades. Madri, Hermann Blume Ediciones, 1981

BALBO, Pier Paolo. Il progetto urbano. Roma, Gangemi Editore, 1992

BARBIERI, Uberto. "Il Concurso AIR a Rotterdam". Casabella, n487/8, janeiro/fevereiro/1983

BARCELONA Ajuntament/Àrea de Urbanisme I Obres Publiques Àrees de nova centralitat. $2^{\mathrm{a}}$ ed. Barcelona, Ajuntament de Barcelona, 1991

BELLOTTO, Heloísa Liberali. Autoridade e conflito no Brasil colonial: o governo do Morgado de Mateus em São Paulo. São Paulo, Secretaria do Estado da Cultura, São Paulo, 1979

BERTOLINI, L. SPIT, T. Cities on rails - The redevelopment of railway station areas. Londres/Nova York, Routledge, 1998

BLOCH, Ernst. El principio esperanza. Tomo I. Madri, Aguilar SA de ediciones, 1970

BOHIGAS, O. Reconstrucción de Barcelona. Madri, Dirección General de Arquitectura e Edificación- Ministerio de Obras Publicas e Urbanismo, 1989

BOHIGAS, O., PUIGDOMENECH A., ACEBILLO, J.. Plans i projectes per a Barcelona 1981/1982. 2a ed. Barcelona, Ajuntament de Barcelona, Area d'Urbanisme, 1983

BONE, Kevin (ed.) The New York Waterfront - evolution and building culture of the port and the harbor. Nova York, The Monacelli Press, 1997

BONILLO, Jean-Lucien. Marseille, ville \& port. Marseille, Parenthèses, 1991

BRASIL, Governo do. III Plano Nacional de Desenvolvimento (Pnd) 1980/ 85. Brasilia, S.N, 1980

BRASIL, Republica Federativa do. II Plano Nacional de Desenvolvimento (1975-1979). Ed. Republica Federativa do Brasil, Brasilia 1974.

BRITO, Francisco Saturnino R. A planta de Santos, São Paulo, Typ. Bugil de Rothschild \& Co., 1915

BRUTOMESSO, Rínio (ed.). Waterfronts. A new frontier for cities on water. Veneza, International Centre Cities on the Water, 1993

BUSQUETS GRAU, Joan. Barcelona. Evolución urbanística de una capital compacta. ( ${ }^{\circ}$ ed.) Madri, Editorial Mapfre, 1994

BUSQUETS I Grao, Joan. "Anvers, Barcelona et Buenos Aires -quand les villes s'occupent de leurs ports”, in Les annales de la Recherche Urbaine, $\mathrm{n}^{\circ}$ 55/ 56

BUSQUETS, J. e A., Joan. Plan estratégico de Antiguo Puerto Madero. Buenos Aires, Consultores Europeus Asociados, Ajuntament de Barcelona, Municipalidad de Buenos Aires, 1990 
BUSQUETS, Joan et al. "Spazio tra i ponti" in Lotus International, n ${ }^{\circ}$ 64, abril/1989

BUSSINGER F., Reformas e regulação portuária. IPEA, s.d., mimeo

CAIADO, Aurílio Sérgio C. "Desenvolvimento regional: novos requisitos para a localização industrial em São Paulo" in São Paulo em perspectiva, vol 10, n². abril-junho 1996

CANO Wilson. “O processo de urbanização paulista no período 1970-89” in SEADE. São Paulo no limiar do século XXI, 1992

CANO, Wilson et al. A interiorização do desenvolvimento econômico no Estado de São Paulo (1920-1980). Vol 1, no 1 e n², São Paulo, SEADE, 1988

CARVALHO, Maria Conceição V.. Santos e a geografia humana do litoral. Tese (Doutorado), FFLCH, USP, São Paulo, 1944

CASSIA, C. M., Il grande progetto urbano

CASSIA, C.M., "Le procedure del Documento direttore", in Edilizia Popolare, $\mathrm{n}^{\circ} 185$

CODESP, Plano de desenvolvimento e zoneamento portuário. Santos, CODESP, 1996

COLQUHOUN, Ian. Urban regeneration - an international perspective. Londres, B.T. Batsford Ltd, 1995

CORPORACIÓ METROPOLITANA DE BARCELONA. Plan de costas.

Propuesta de ordenación de la zona costera metropolitana de Barcelona. Barcelona, Corporació Metropolitana de Barcelona, 1987

CROTTI, Sergio. "Scale, criteri e temi del mutamento a Milano", in

Urbanistica, $\mathrm{n}^{\circ} 89$

D’ALINCOURT, Luiz. Memória sobre a viagem do porto de Santos à cidade de Cuiabá. Belo Horizonte/São Paulo, Ed. Itatiaia/Ed. da Universidade de São Paulo, 1975

DEAN, Warren. A industrialização de São Paulo. (1880-1945). 4ª ed. Ed. Bertrand do Brasil, Rio de Janeiro, 1991

DEMATTEIS, Giuseppe. "Contesti e situazioni territoriali in Piemonte.

Abbozzo di una geografia regionale dei possibili" in Urbanistica, $\mathrm{n}^{\circ}$ 96, outubro 1989

DEMATTEIS, Giuseppe. Progetto implicito. Il contributo della geografia umana alle scienze del territorio. Milão, Franco Angeli, 1996

DERSA. Análise das alternativas para ligação Santos-Guarujá. São Paulo mimeo., s.d.

DUPART, M. C., CHALINE, C. (dir). Le port, cadre de ville. Paris, Ed. Harmattan, 1993

ECIPLAN, GPI. Estudo de viabilidade do distrito industrial de Santos. Santos, PRODESAN, 1967

FIGUEIREDO FERRAZ. Ligação rodoviária. Margem direita e esquerda do porto de Santos. Relatório técnico e econômico. Vol. 1/2 Santos, Codesp, 1997

FLORENCE, Hercules. Viagem fluvial do Tietê ao Amazonas: 1825 a 1829. São Paulo, Cultrix/Edusp, 1977

FONT A., CALVET L., ROCA E. (ed.) Infraestructuras de transporte y forma urbana. Exploraciones proyectuales para la ordenación urbana de Figueres. Fundación Politècnica de Catalunya-UPB, Barcelona, 1995

FOSSO, Mario (org). "Rotterdam: rivitalizzacioni e nuove centralitá" in Urbanistica $\mathrm{n}^{\circ}$ 93, novembro 1988

GAJA, Fernando. "Los paradigmas urbanísticos y su influencia en la enseñanza del urbanismo en las Escuelas Técnicas Superiores de Arquitectura del Estado", in Ciudades no 2, Instituto de Urbanística de Valladolid, 1995

GARCIA, Soledad, "La modernisation de Barcelone", in Metropoles portuaires en Europe - Cahiers de la Recherche Architecturale, no 55-56, 1993

GASPARRINI, Carlo. L'attuallità dell'urbanistica. Etsalibri, Milano, 1994

GAZAL, Fernado. "Os terminais multi-uso" in Portos e Navios, janeiro 1989 
GAZAL, Fernando. "A indústria da conteneirização: um impacto ambiental" in Portos e Navios, agosto 1989

GAZAL, Fernando. "Os modernos terminais portuários" in Portos e Navios, maio 1989

GITAHY, Maria Lúcia C. Ventos do mar. São Paulo, Ed. Unesp, 1992

GOLDSTEIN, L., CARVALHAES, S. G., “Avaliação política da

descentralização industrial: a experiência do complexo industrial da baixada santista" in Espaço \& Debates n 13, São Paulo, 1984

GOLDSTEIN, Léa. A industrialização da Baixada Santista - estudo de um centro industrial satélite. Tese (Doutoramento) Instituto de Geografia, USP, São Paulo, 1972

GONÇALVES, O. C., SOUZA H. F. Plano Diretor Físico - Problemática econômica e social. Santos, Prodesan, 1967

GONÇALVES, O. C., SOUZA, H. F. Plano Diretor Físico - Problemática econômica e social. 2 vol., Santos, PRODESAN, 1967

GREGOTTI, Vittorio. La cittá visible. Turim, Einaudi, 1993

GREGOTTI, Vittorio., "L'architettura del piano”, in Casabella , no 487/488,

HALL, Peter (org), "Aree portuali: nuovi approdi del progetto" in Casabella, no 589, abril/1993

HALL, Peter. "Planning and urban design in the 1990's" in Urban Design Quaterly $\mathrm{n}^{\circ} 56$

HALL, Peter. Cidades do amanhã. Uma história intelectual do planejamento e do projeto urbano no século XX. Editora Perspectiva, São Paulo, 1995

HARDING, Alan. "Rotterdam, croissance ou development", in Metropoles Portuaires en Europe. Les Cahiers de la Recherche Architecturale, n 30/31, 1992

HARVEY, D., DEMATTEIS, G. et alli. Le cittá del mondo e il futuro dellle metropoli. Milão, Electa/XVII Triennale, 1988

HARVEY, David. A condição pós-moderna. São Paulo, Edições Loyola, 1989

HONORATO, Cezar. O polvo e o porto: A Cia. Docas de santos (1888-1914). São Paulo/Santos Hucitec/Prefeitura Municipal de Santos, 1996

HOYLE, B. S., PINDER, D. A., HUSAIN, M. S. Revitalizing the waterfront: international dimensions of dockland redevelopment. Londres, Belhaven Press, 1988

INDOVINA, Francesco (ed). El despilfarro inmobiliario, Editorial Gustavo Gili, Barcelona, 1977

KIDDER, Daniel P. Reminiscências de viagem e permanências no Brasil (Rio de Janeiro e Província de São Paulo). Belo Horizonte/São Paulo, Ed. Itatiaia/Ed. da Universidade de São Paulo, 1980

KREUKELS, Anton M. J. "Rotterdam, le port englobe la ville: une estrategie d'expansion", in Grandes Villes et Ports de Mer. Les Annales de La Recherche Urbaine, n55/56, setembro de 1992 (difusão) março/1993

KREUKELS, Anton M. J. "Ville, port, region, la rupture d'echelle”, in Metropoles Portuaries en Europe. Les Cahiers de la Recherche Architecturale, no 30/31, 1992

LAMBERT, Donald. "Rotterdam, recoller les fragments". Architecture d'Aujourd'hui, nº589, abril/1992

LANNA, Ana Lúcia D. Uma cidade na transição - Santos: 1870-1913. São Paulo Ed Hucitec, 1996

LEFEBVRE, Henry. La prodution de l'espace. Paris, Editions Anthropos, 1974

Legislação Portuária Geral - 1828 à 1937, Rio de Janeiro, Typ. Do "Jornal do Comércio", Rodrigues \& Cia., 1938.

LISBOA, Alfedo. Portos do Brasil, $2^{\mathrm{a}}$ ed. Rio de Janeiro, Imprensa Nacional, 1926 
LOBO, Helio - Legislação relativa ao porto de Santos. Precedida da da Legislação Portuária Geral - 1828 à 1937. Rio de Janeiro, Typ. Do "Jornal do Comércio", Rodrigues \& Cia., 1938.

LOBO, Hélio. Docas de Santos. Suas origens, lutas e realizações. São Paulo, Typ. Jornal do Comércio, 1936

MACCHI CASSIA, Cesare Il grande progetto urbano. La forma della cittá e $i$ desideri dei cittadini. Roma, La Nuova Italia Scientifica, 1991

MACMILLEN, D. A.. A solução do problema dos transportes de S. Paulo ao litoral, São Paulo. Companhia Graphico-Editora Monteiro Lobato, 1925

MAIA, Francisco Prestes. O Plano regional de Santos. Oficinas Gráficas de Saraiva S.A., São Paulo, 1950

MALONE, Patrick. City, capital and water. Nova York/Londres, Routledge, 1996

MATOS, Odilon Nogueira. Café e ferrovias. São Paulo, Ed. Arquivo do Estado, 1981

MILLIET, Sérgio. Roteiro do café e outros ensaios. São Paulo, BIPA Editora 1946

MONBEIG, Pierre. Novos estudos de geografia humana brasileira, São Paulo, Difusão Européia do Livro 1957

MOREIRA, A.Filho - Legislação relativa ao porto de Santos - 1938 à 1964. vol. II à VI, Rio de janeiro Baptista de Souza \& Cia., 1938/1964.

MOREIRA, A.Filho Colletanea das leis, decretos, outros actos officiais e informes referentes ao Porto de Santos. Rio de Janeiro, Pap. Americana, 1926.

MORIN, Edgar. Introducción al pensamento complejo. Barcelona, Gedisa Editorial, 1995

NYCOLAAS, Jacques. "Hay chel que disegni" in Urbanistica $\mathrm{n}^{\circ}$ 93, novembro/1988

NYCOLAS, Jacques. "Kop van Zuid e il Futuro de Rotterdam-sud" in Urbanistica $n^{\circ}$ 93, novembro/1988

PANERAI P., DEPAULE, J. C,, DEMORGEN, M., VEYRENCHE M.. Elementos de análisis urbano. Madri, Instituto de Estudios de Administración Local, 1983

PASVEER, E., BOUT, J. (ed.). Kop van Zuid. Roterdã, Uitgverij 010 Publishers, 1994

PENTEADO Theodor, "As grandes obras rodoviárias de S. Paulo" in Engenharia, São Paulo, outubro 1942

PEREIRA, Maria Aparecida F. O comissário de café no porto de Santos (1870-1920). Dissertação (Mestrado), FFLCH, USP, São Paulo, 1980

PETRONE, Maria Thereza S. A lavoura canaviera em São Paulo. São Paulo, Difusão Européia do Livro, 1968

PETRONE, Pasquale "Povoamento e caminhos no século XVIII e primeira metade do século XIX" in A Baixada Santista, aspectos geográficos, vol II., Editora da Universidade de São Paulo, São Paulo, 1965

PETRONE, Pasquale. "Povoamento e caminhos nos séculos XVI e XVII" in $A$ Baixada Santista - Aspectos geográficos. vol II, São Paulo, Ed. da Universidade de São Paulo, 1965

PINTO, Adolpho Augusto. História da viação pública de São Paulo. São Paulo, Typographia e Papelaria de Vanorden \& Cia, 1903

POZUETA, Julio. "Puertos urbanos: transformación de espacios portuarios en areas urbanas" in Urbanismo COAM n ${ }^{\circ} 27$, fev. 1996

PRADO Jr., Caio. Evolução política do Brasil e outros estudos. São Paulo, Brasiliense, 1961

PRODESAN, Plano Diretor de Desenvolvimento Integrado - PPDI 1976, Santos, Prefeitura Municpal de Santos, 1976

PRODESAN. Plano Diretor de Desenvovimento Integrado de Santos - PPDI 78. Santos, Prefeitura Municipal de Santos, 1978 
REIS Filho, Nestor Goulart. São Paulo e outras cidades. Produção social e degradação dos espaços urbanos. São Paulo, Hucitec, 1994

REIS, Nestor Goulart. Memória do transporte rodoviário. Desenvolviemnto das atividades rodoviárias de São Paulo, São Paulo, CPA Consultoria de Projetos e Artes Ltda, 1996

RIBAS i P., M.; SOLÉ i L., J.; POU I V. Teoría de las area metropolitanas. Barcelona, Escola Técnica Superior d'Arquitectura de Barcelona, 1979

RODRIGUES, J. C., ARAÚJO Filho, J C., RODRIGUES, L. M. et alli. A Baixada Santista - Aspectos geográficos vol 1. São Paulo Ed. da Universidade de São Paulo, 1956

ROSS, J. L. S., MOROZ, I. C. Mapa geomorfológico do Estado de São Paulo, São Paulo, FFLCH-USP/FAPESP/IPT, 1997

RUSEL, J. Van (ed.). Antwerp. Reshaping a city. Antuérpia Blonde Artprinting/ International Association The River and the City Project, 1990

RUSSO, Michelangelo. Aree dismesse. Forma e risorsa della cittá esistente. Napoli, Ed. Scientifiche Italiane, 1998

S.A.G.M.A.C.S. Problemas de desenvolvimento: necessidades e possibilidades do Estado de São Paulo. São Paulo, Comissão Interestadual da Bacia PranáUruguai, 1954

SAEZ, Flávio A. M A grande empresa de serviços públicos na economia cafeeira (um estudo sobre o desenvolvimento do grand capital em São Paulo). Tese (Doutorado), FEA, USP, São Paulo, 1979

SAEZ, Flávio A. M. As ferrovias de São Paulo 1870-1940. São Paulo, Hucitec/INL-MEC, 1981

SAGARRA y Trias, F. "Barcelone, la dynamique olympique et le projet urbain" in Le cahiers de la recherche archicteturel $n^{\circ}$ 30-31, 1992

SANTOS (Prefeitura Municipal). "Lei complementar no 311 de 23 de novembro de 1998" in Diário Oficial de Santos. Santos, Prefeitura Municipal de Santos, 24 novembro 1998

SANTOS (Prefeitura Municipal). Plano Diretor de Santos 1995 - Manual do Propietário. Santos, Prefeitura Municipal de Santos, 1995

SANTOS, M., SOUZA, M. A., SILVEIRA, M. L (org). Território globalização e fragmentação. São Paulo, Editora Hucitec/ANPUR, 1994

SANTOS, Marli Alves S. Urbanização Baixada Santista - Relatório parcial. São Paulo, FECAMP/SRL Projetos, 1990

Santos, Milton. Metrópole corporativa e fragmentada - O caso de São Paulo. São Paulo, Livraria Nobel, 1990

SANTOS, Milton. A urbanização Brasileira. São Paulo, Ed. Hucitec, 1993

SÃO PAULO (Associação Comercial de). A solução das crises do porto de Santos. São Paulo, Editora Limitada, 1927

SAO PAULO (Estado). Departamento Hidroviário. Estudo de viabilidade econômica do Porto de Sao Sebastião. 4 vol. Brasconsulti Engenharia de Projetos, São Paulo. 1972

SÃO PAULO (Estado). Plano metropolitano da Grande São Paulo. 19932010, São Paulo, SPG/Emplasa, 1994

São Paulo (Governo do Estado). Plano de ação 1959-1963. Administração estadual e desenvolvimento sócio-econômico, São Paulo, IOE, 1959

SÃO PAULO (Governo), Secretraia de Economia e Planejamento. Padrões funcionais e espaciais da rede urbana deo Estado de São Paulo, São Paulo, 1975

SÃO PAULO (Goverrno do Estado). $1^{a}$ Região Administrativa Diagnóstico. São Paulo, Secretaria de Economia e Planejamento . Coordenadoria de Ação regional, 1973

SÃO PAULO (Goverrno do Estado). $2^{a}$ Região Administrativa Diagnóstico. São Paulo, Secretaria de Economia e Planejamento . Coordenadoria de Ação regional, 1972 
SÃO PAULO (Governo do Estado). $5^{a}$ Região Administrativa Diagnóstico. $2^{a}$ imp.. São Paulo, Secretaria de Economia e Planejamento . Coordenadoria de Ação Regional, 1973

SÃO PAULO, Associação Commercial. A solução das crises do porto de Santos. São Paulo, SEP Ed. Limitada, 1927

SÃO PAULO, Associação Commercial. Crise do Porto de Santos: Estudo

Preliminar elaborado pela Associação Commercial de São Paulo. s.l., s.n., 1925.

SÃO PAULO, Governo Plano Regional do Litoral, 1978. São Paulo, SEP-CAR, Serete SA, 1978

SÃO PAULO, Governo. Plano Regional de Campinas. São Paulo, SEP-CAR, 1978

SÃO PAULO. SEP. CAR. Política de desenvolvimento urbano e regional do Estado de São Paulo. São Paulo, SEP, 1976

SASSEN, Saskia. As cidades na economia mundial, São Paulo, Studio Nobel, 1998

SEABRA, Odete C. L.. A muralha que cerca o mar. Dissertação de Mestrado. São Paulo, FFLCH-USP, 1979

SEADE. São Paulo no limiar do século XXI, 1992

SECCHI, Bernardo (org.) Analisis de las estructuras territoriales. Barcelona, Editora Gustavo Gili, 1968

SECCHI, Bernardo "Disegnare il piano". in Urbanistica n ${ }^{\circ} 89$

SECCHI, Bernardo "La riduzione fertile" in Urbanistica, $\mathrm{n}^{\circ}, 90$

SECCHI, Bernardo "Nuove forme de razionalitá" in Urbanistica, no 91

SECCHI, Bernardo "Ridurre la complessitá" in Urbanistica $\mathrm{n}^{\circ}, 84$

SECCHI, Bernardo. "Ridurre la complessitá", in Urbanistica n ${ }^{\circ} 85$

SECCHI, Bernardo. Un progetto per l'urbanistica. Turim, Giulio Einaudi

Editore, 1989

SEMEGHINI, Ulysses Cidade. Urbanização - Campinas. Relatório parcial.

São Paulo, FECAMP/SRL Projetos, 1990

SEMERANI, L. "Architettura sul limite" in UR-Urbanismo Revista $\mathrm{n}^{\circ} 6$

SENNETT, Richard. The conscience of the eye: the design and social life of cities. Londres, Faber and Faber, 1991

SERRANO, Fábio Eduardo. "O Plano Regional de Santos, de Francisco Prestes Maia" in Leopoldianum $\mathrm{n}^{\circ}$ 64, Santos, 1997

SINGER, Paul. Desenvolvimento econômico e evolução urbana. São Paulo,

Ed. Nacional/Edusp, 1968

SODRE, Nelson Werneck. "O pôrto de Santos" in O Observador Econômico e Financeiro, ano XII, $\mathrm{n}^{\circ}$ 135, 136, 137. São Paulo, 1947

SOLÁ-MORALES I Rubió, M., BUSQUETS, J. e FONT, A.. La enseñanza del Urbanismo. Perspectiva española 1979-80 (1). La situación en otros países.

Laboratorio de Urbanismo de Barcelona, Barcelona, 1973

SOLÁ-MORALES I Rubió, Manuel de, e GOMEZ Ordoñez, José Luiz.

"Crescimiento urbano como inversió de capital fixo" in Ciudad y Territorio, $\mathrm{n}^{\circ} 2$, 1977

SOLÁ-MORALES I Rubió, Manuel de, e GOMEZ Ordoñez, José Luiz. La enseñanza del urbanismo. Perspectiva española 1970-80. Reedição LUB, Barcelona, 1974

SOLÁ-MORALES I Rubió, Manuel de, e PARCERISA, Josep. "La forma d'un pais". in Quaderns. 1981

SOLÁ-MORALES I Rubió, Manuel de, GOMEZ Ordoñez, J. L.. La enseñanza del urbanismo II. Laboratorio de Urbanismo, E.T.S.A.B., Bracelona, 1974

SOLÁ-MORALES I Rubió, Manuel de. "La segunda historia del proyecto urbano" in UR-Urbanismo Revista, $\mathrm{n}^{\circ} 5$

SOLÁ-MORALES I Rubió, Manuel de. "Reconexeiment comarcal i ordenació del Territori”. in Quaderns, 1981, p.59 
SOLÁ-MORALES I Rubió, Manuel de. Sobre metodologia urbanística , Barcelona, Laboratorio de Urbanismo, ETSAB, 1969

SOLÁ-MORALES, Manoel, "La ciudad y el puerto: la historia continua" in $U R$

- Urbanismo Revista $\mathrm{n}^{\circ}$ 2, Barcelona

SOLÁ-MORALES, Mauel. Les formes de creixement urbá. Barcelona, Edicions UPC, 1993

SOUZA, Alberto. Os Andradas. 3 vol. São Paulo, Typ. Piratininga, 1922

SUBIRÓS, Pep. "The meaning of the city" in Rassegna, marco 1989

TAUNAY, Afonso D'Esacragnole. Colletanea de Mappas da Cartographia Paulista antiga, vol I, São Paulo, Companhia Melhoramentos de São Paulo, 1922

TSCHUDI, J. J. von. Viagens às províncias do Rio de Janeiro e São Paulo. Belo Horizonte/São Paulo, Ed. Itatiaia/Ed. da Universidade de São Paulo, 1980

TZONIS, Alexander. "Kop van Zuid: una píccola Manhanttam”, in Casabella, $n^{\circ} 589$, abril 1993

VÁRIOS. "Grandes villes et ports de mer" Les Annales de la Recherche urbaine, $\mathrm{n}^{\circ}$ 55-56, 1993

VÁRIOS. "Metropoles Portuaires en Europe". Les Cahiers de la Recherche Architecturale, no 30/31, 1992

VÁRIOS. Hacia una visión estratégica de las infraestructuras como herramienta de integración. El caso de Iberoamérica en el contexto internacional. Seminário Internacional. Barcelona, Fundació Narcís Monturiol/Capítulo Español del Club de Roma, 1995

VÁRIOS. La xarxa ferroviàri: encaix urbà i impacte territorial . Barcelona, Institut d'Estudis Metropolitans de Barcelona, 1994

VÁRIOS. Le cittá imaginate. Un viaggio in Italia: nove progetti per nove cittá. Milão, Electa Triennale di Milano, 1987

VÁRIOS. O porto de Santos e sua história -Edição comemorativa dos 100 anos do porto. São Paulo, Alomo Transportes Ltda, 1992,

VENUTI, Giuseppe Campos. La terza generazione dell'urbanistica. Milão, Franco Angeli, 1989

VILLAÇA, Fávio. A estrutura territorial da metrópole sul-brasileira: áreas residenciais e comerciais. Tese (Doutorado). FFLCH, USP, São Paulo, 1978

Revistas

Exame $n^{\circ} 26$, novembro 1998

Papers $n^{\circ} 28$, janeiro 1997

Jornais

A Cidade de Santos 13/5/1978

A Cidade de Santos 15/8/1980

A Cidade de Santos 20/12/1898

A Cidade de Santos 8/10/1982

A Tribuna 16/12/1997

A Tribuna 18/3/1999

A Tribuna 26/1/1989

A Tribuna 26/11/1989

A Tribuna 26/6/1982

A Tribuna 28/2/1999

A Tribuna 3/8/1998

A Tribuna 31/1/1988

A Tribuna $8 / 11 / 1975$

A Tribuna 9/3/1999

Diário de Santos 3/6/1908

Diário de Santos 9/7/1904

Diário Oficial de Santos 7/7/1993 (encarte D. O. urgente)

Diário Oficial de Santos 30/81995 (encarte D. O. urgente) 
Diário Oficial de Santos 24/11/1998

Folha de São Paulo 2/5/1999

Folha de São Paulo 20/5/1991

O Estado de São Paulo 12/5/1999 (suplemento Marinha Mercante)

O Estado de São Paulo 9/8/1998

O Estado de São Paulo 7/7/1999 (suplemento Marinha Mercante)

Legislação

Imperial e republicana

Lei $\mathrm{n}^{\circ} 1746$ de 1869

Lei $\mathrm{n}^{\circ} 3.348$, de 20 de outubro de 1887

Lei $n^{\circ} 8.630$ de 25/2/1993

Decreto $n^{\circ} 9979$ de 12/7/1888

Decreto $n^{\circ} 4.228$ de $6 / 11 / 1901$

Decreto $\mathrm{n}^{\circ} 1.746$, de $13 / 10 / 1869$

Decreto $n^{\circ} 4.105$ de 22/2/1868

Decreto $n^{\circ} 64.359$ de17/04/1969

Decreto $n^{\circ} 790$ de $8 / 4 / 1892$

Decreto $n^{\circ} 942$ de 15/5/1892

Estadual

Lei complementar $n^{\circ} 815$ de 30/7/1996

Decreto $n^{\circ} 369$ de 28/12/1912

Municipal

Lei $n^{\circ} 403$ de 15/9/45

Lei $n^{\circ} 1316$ de 27/12/1951

Lei $\mathrm{n}^{\circ} 1831$ de $9 / 4 / 1956$

Lei $\mathrm{n}^{\mathrm{o}} 3.529$ de 16 de abril de 1968

Lei complementar $n^{\circ} 53$ de 15/5/1992

Lei complentar $n^{\circ} 54$ de 9/6/1992

Lei complementar $n^{\circ} 311$ de 23 de novembro de 1998 